\title{
PAINÉIS DE VEDAÇÃO DE CONCRETO MOLDADOS IN LOCO: AVALIAÇÃO DE DESEMPENHO TÉRMICO E DESENVOLVIMENTO DE CONCRETOS
}

Dissertação apresentada ao Departamento de Arquitetura e Urbanismo da Escola de Engenharia de São Carlos da Universidade de São Paulo, como parte dos requisitos para obtenção de título de Mestre em Arquitetura e Urbanismo.

Área de Concentração:

Arquitetura, Urbanismo e Tecnologia.

Orientador:

Prof. Dr. JOÃO ADRIANO ROSSIGNOLO 


\section{FOLHA DE JULGAMENTO}

Candidata: Arquiteta e Urbanista HELENICE MARIA SACHT

Dissertação defendida e julgada em 28/08/2008 perante a Comissão Julgadora-
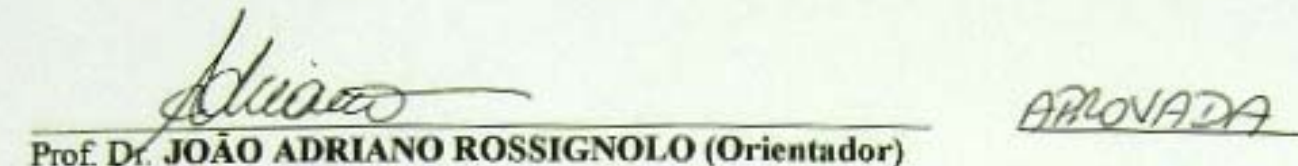

(Escola de Engenharia de São Carlos/USP)

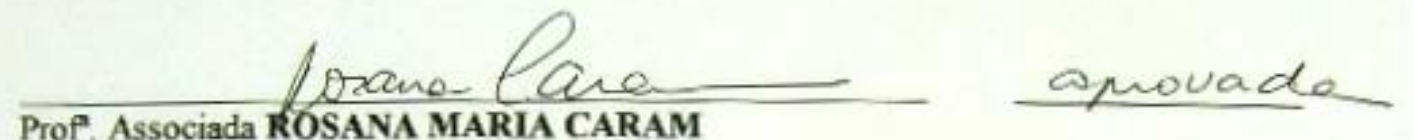

(Escola de Engenharia de São Carlos/USP)
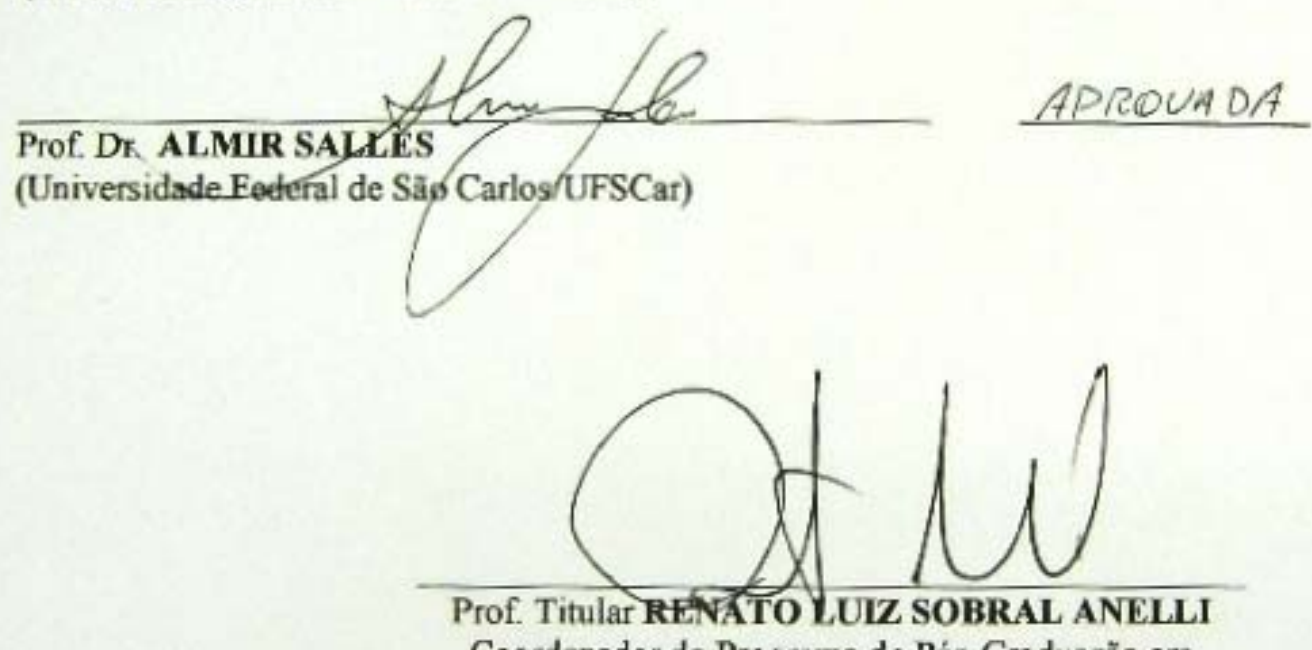

Coordenador do Programa de Pós-Graduaçăo em Arquitetura e Urbanismo

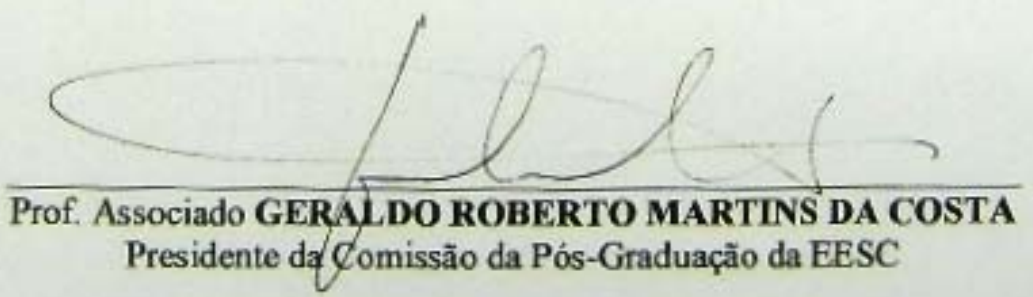


Dedico aos meus pais, Arnaldo Sacht e Dilma R. M. Sacht, Pelo amor e exemplo de vida, na sua simplicidade e humildade, fonte de sabedoria, fé e perseverança. Os Grandes incentivadores para todas as minhas conquistas. 


\section{AGRADECIMENTOS}

Agradeço primeiramente a Deus,

À minha família que mesmo distante sempre se fez presente me incentivando, em especial minhas irmãs Ida e Leiliani e meus sobrinhos Patrick e Pablo.

Meus profundos agradecimentos ao professor Doutor João Adriano Rossignolo, pela valiosíssima orientação, amizade e incansável incentivo, ao longo da realização do mestrado, fundamentais para minha formação pessoal e acadêmica.

À Fundação de Amparo à Pesquisa do Estado de São Paulo (FAPESP), pelo financiamento desta pesquisa. Aos meus fiéis amigos desde a Universidade Federal de Viçosa, Daniela, Juliana, Fabrícia, Joseane, Carolina, Luana e Rafaella, e com carinho aos mais novos amigos e companheiros de São Carlos, em especial Carol, Sofia, Ana Paula e

A meu alicerce Vitor, companheiro de todas as fases de realização deste trabalho.

Ao Engenheiro Civil Francisco Hermes Lopes, pelas primeiras oportunidades de crescimento profissional e aos demais funcionários da Casa Engenharia e Projetos Ltda.

Aos Professores Rosana Caram, Wilson Nunes dos Santos e Almir Sales pela valiosa contribuição a esta pesquisa.

Meus sinceros agradecimentos aos funcionários do Laboratório de Construção Civil (LCC) em especial Paulo Pratavieira, Paulo Alberto e Sérgio Trevelin e aos demais funcionários do Departamento de Arquitetura e Urbanismo da EESC-USP; ao NETEF da Escola de Engenharia de São Carlos pelo apoio na confecção dos termopares.

A todos que contribuíram de forma direta ou indireta para a realização deste trabalho, os meus sinceros agradecimentos. 
"Cada qual vê o que quer, pode ou consegue enxergar.

Porque eu sou do tamanho do que vejo.

E não do tamanho da minha altura."

Fernando Pessoa

"O arquiteto tem que fazer da luz, do sol e do calor, um problema seu."

Louis Kahn 


\section{RESUMO}

SACHT, H. M. Painéis de vedação de concreto moldados in loco: avaliação de desempenho térmico e desenvolvimento de concretos. 229p. + anexos. Dissertação (Mestrado) - Escola de Engenharia de São Carlos, Universidade de São Paulo. São Carlos, 2008.

A carência habitacional é atualmente um dos maiores desafios urbanos para as políticas públicas das cidades brasileiras e deve impulsionar a busca de soluções tecnológicas para o desenvolvimento de habitações com baixo custo e desempenho satisfatório. Nesse contexto se insere o sistema construtivo de painéis monolíticos de concreto moldados in loco. Nesta pesquisa apresenta-se uma proposta de desenvolvimento de concretos destinados ao sistema construtivo de painéis monolíticos moldados in loco, tendo como referencial, além dos requisitos técnicos de trabalhabilidade, resistência mecânica e durabilidade, a influência dos painéis no desempenho térmico das habitações. Com isso, o desenvolvimento dos concretos assim como a definição de espessura do painel de vedação foi realizado, considerando as particularidades das oito diferentes zonas bioclimáticas brasileiras e as tipologias construtivas adotadas pela Companhia de Desenvolvimento Habitacional e Urbano (CDHU) e Caixa Econômica Federal (CEF). Por meio de simulações computacionais do desempenho térmico de edificações térreas (com laje plana, com laje inclinada e sem laje) e multipavimentos (cobertura e segundo pavimento), avaliaram-se as espessuras dos painéis $(8,10$ e $12 \mathrm{~cm})$ e as massas específicas dos concretos (1600, 1800, 2000, 2200 e $2400 \mathrm{~kg} / \mathrm{m}^{3}$ ) adequadas em relação às características climáticas das localidades analisadas, utilizando como parâmetro a norma "NBR 15575 Edifícios habitacionais de até cinco pavimentos - Desempenho" da Associação Brasileira de Normas Técnicas. A partir da avaliação do desempenho térmico das tipologias selecionadas, dentre os concretos e as espessuras de painéis analisadas, observou-se que as tipologias com painéis de concreto com massa específica de $2400 \mathrm{~kg} / \mathrm{m}^{3}$ e com espessura de $12 \mathrm{~cm}$ foram as que apresentaram os melhores resultados para as oito regiões bioclimáticas analisadas.

Palavras-chave: Paredes de concreto. Habitação de interesse social. Desempenho térmico. Conforto ambiental. 


\section{ABSTRACT}

SACHT, H. M. Cast-in-place monolithic panels of concrete: evaluation of thermal performance and development of concrete. 229p. + appendix. Dissertation (Master's degree) - Engineering School of São Carlos, University of São Paulo. São Carlos, Brazil, 2008.

Nowadays, the lack of housing has been one of the biggest urban challenges to the Brazilian public policies and should impel the search for technological solutions by the development of housings with low-cost and satisfactory performance. In this context is the constructive system of cast-in-place monolithic panels of concrete. This dissertation presents a proposal for the development of concretes destined to the system having the technical requirements of workability, mechanical resistance and durability, and the influence of the panels' peculiarities on the thermal performance of the housings as reference. Herewith, the development of concretes as well as the panels' thicknesses definition has been realized, considering the particularities of the eight different Brazilian climate zones, and the constructive typologies used by the Companhia de Desenvolvimento Habitacional e Urbano do Estado de São Paulo (CDHU) and Caixa Econômica Federal (CEF). By means of computational simulations of thermal performance of one-storey (with plane and inclined slabs, and without slab) and multi-storey (last and second floors) constructive typologies, the suitable panels' thicknesses (8, 10 and $12 \mathrm{~cm}$ ) and concretes' densities (1600, 1800, 2000, 2200 and $2400 \mathrm{~kg} / \mathrm{m}^{3}$ ) in relation to the climatic characteristics of the analyzed places were determined, having the standard "NBR 15575 Residential buildings up to five storied Performace" of the Associação Brasileira de Normas Técnicas as parameter. Starting from the evaluation of the thermal performance of the selected typologies, among concretes and panels' thickness analyzed, the use of concrete's panels with densities of $2400 \mathrm{~kg} / \mathrm{m}^{3}$ and thicknesses of $12 \mathrm{~cm}$ has been presented better results for the eight Brazilian climate zones.

Key words: Concrete walls. Low-cost housing. Thermal performance. Thermal comfort. 


\section{USTADE ILUSTRAÇÕES}

Figura 1. Casa operária para nove pessoas, Glasgow, Escócia

Figura 2. Complexo de cortiços de São Paulo da primeira metade da década de 20 onde em 1940 foi implantado o viaduto Jacareí.

Figura 3. Modelo de moradia operária proposto pela Comissão de Exame e Inspeção dos cortiços em 1893

Figura 4. Em grandes eventos a campanha de vacinação reunindo multidões .35

Figura 5. O presidente Costa e Silva sendo vacinado .35

Figura 6. Conjunto Residencial do Realengo construído nos anos 40. Arquiteto Carlos Frederico Ferreira. Rio de Janeiro, décadas de 30 e 40.

Figura 7. Conjunto Residencial Pedregulho, Arquiteto Afonso Eduardo Reidy. Rio de janeiro, décadas de 40 e 50 .

Figura 8. Conjunto Residencial da Moóca, Arquiteto Paulo Antunes Ribeiro. São Paulo, década de 40 .

Figura 9. Conjunto Residencial Vila Guiomar, Arquiteto Carlos Frederico Ferreira. Santo André, SP, década de 40

Figura 10. Favela Várzea do Penteado, junto à Avenida do Estado provavelmente a primeira de São Paulo, 1942.

Figura 11. Favela na área reservada ao parque do Ibirapuera. São Paulo, 1951

Figura 12. Conjuntos Habitacionais produzidos pelo BNH em Minas Gerais e Espírito Santo, 1979

Figura 13. Exemplo de tipologia executada pela $\mathrm{CDHU}$..................................................45

Figura 14. Exemplo de tipologia executada pela CEF

Figura 15. Distribuição do Déficit Habitacional Urbano, segundo Grandes Regiões Brasil 2005 
Figura 16. Distribuição Percentual do Déficit Habitacional, segundo Grandes Regiões Brasil $-2000-2004-2005$ .48

Figura 17. INPAR - Edifício multipavimentos, escoramento e posicionamento das fôrmas ....54

Figura 18. INPAR - Edifício multipavimentos, após a retirada das fôrmas. .54

Figura 19. SERGUS - Vista da execução de um pavimento-tipo .54

Figura 20. SERGUS - Edifício padrão dois dormitórios (PP2D48) .54

Figura 21. GETHAL - Sistema com formas de madeira para habitações térreas .54

Figura 22. RODOBENS - Habitações térreas executadas com sistema de moldes ..... .54

Figura 23. FORSA FORMALETAS - Montagem das fôrmas e armaduras 55

Figura 24. FORSA FORMALETAS - Montagem das fôrmas. .55

Figura 25. Execução da fundação em radier: fôrmas. Analândia-SP. .55

Figura 26. Fundação em radier: detalhe do rebaixo do banheiro e das tubulações. Analândia-SP .55

Figura 27. Fundação em radier. Analândia-SP .56

Figura 28. Fundação em radier concretada. Analândia-SP .56

Figura 29. Fôrmas metálicas sendo montadas no local de implantação. Analândia-SP. .56

Figura 30. Fechamento das fôrmas metálicas. Analândia-SP .56

Figura 31. Visão geral das fôrmas das vedações montadas. Analândia-SP 56

Figura 32. Fôrmas dos painéis de uma edificação térrea posicionadas, detalhe das instalações elétricas embutidas Analândia-SP

Figura 33. Detalhe dos espaçadores e das armaduras, neste caso tela eletrosoldada. Analândia-SP 58

Figura 34. Espaçadores utilizados nas armaduras. Analândia-SP 58

Figura 35. Painel metálico com tubulação elétrica já fixada. Analândia-SP. 58

Figura 36. Instalações hidráulicas fixadas nos painéis metálicos. Analândia-SP .58

Figura 37. Painel com esquadrias fixadas. Analândia-SP. 59

Figura 38. Detalhe de esquadria após desforma. Analândia-SP 59

Figura 39. Guindaste utilizado na concretagem. Monte Mor-SP .59

Figura 40. Concretagem por bombeamento. Analândia-SP. .59

Figura 41. Vedações após a desforma. Santa Maria da Serra-SP .60

Figura 42. Vista geral do sistema produtivo. Analândia-SP 60 
Figura 43. Habitação com laje inclinada. Monte Mor-SP ................................................60

Figura 44. Habitações com cobertura em telha cerâmica. Analândia-SP .............................60

Figura 45. Detalhe do telhado com telhas cerâmicas. Analândia-SP ...................................60

Figura 46. Habitação em Monte Mor-SP ...................................................................61

Figura 47. Habitações em Analândia-SP ................................................................... 61

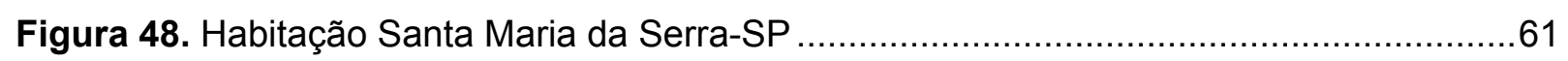

Figura 49. Edifício de múltiplos andares executados com sistema de painéis monolíticos.

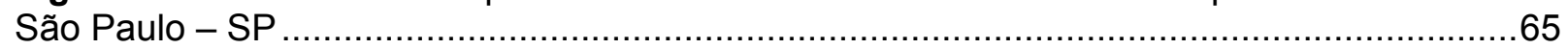

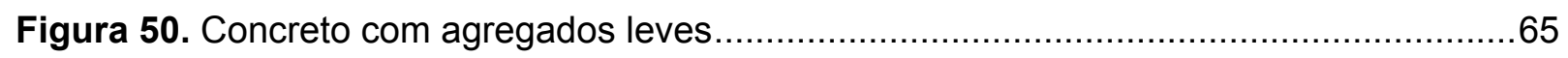

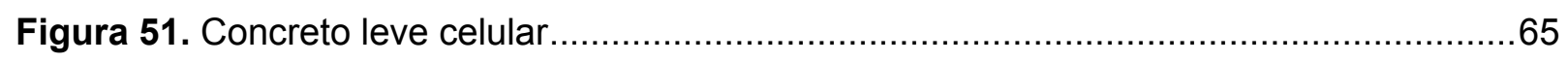

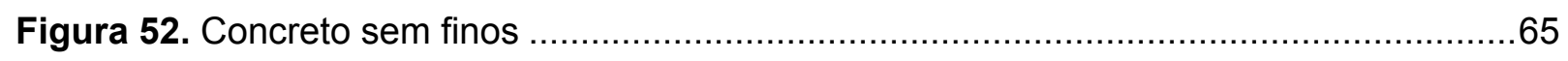

Figura 53. Concreto: durabilidade, influência do conteúdo de ar .....................................67

Figura 54. Intervalos típicos de valores de massa específica de concretos com agregados leves 69

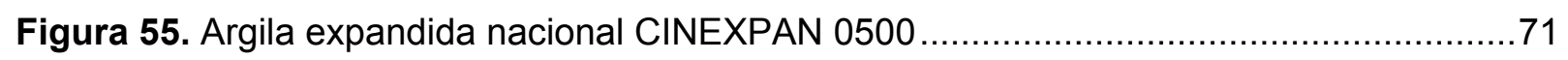

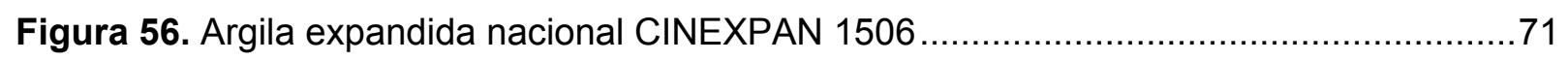

Figura 57. Presença de bolhas de ar ao redor do agregado leve devido à alta absorção de água

Figura 58. Forma de ruptura de concretos com agregados leves e com agregados tradicionais .76

Figura 59. Relação entre resistência à compressão a massa específica do concreto leve com argila expandida nacional. .78

Figura 60. Relação entre resistência à compressão do concreto leve e a dimensão máxima característica do agregado leve nacional. .78

Figura 61. Relação entre resistência à compressão e a massa específica do concreto leve com argila expandida nacional. .79

Figura 62. Relação entre a resistência à compressão e a massa específica do concreto leve com argila expandida nacional. .79

Figura 63. Comportamento da curva tensão-deformação dos concretos leves .83

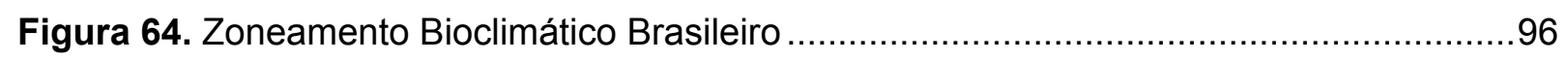

Figura 65. Tabela - Ganhos e perdas de calor de acordo com as horas do dia 105

Figura 66. Tabela - Distribuição de ganhos e perdas de calor de acordo com as horas do dia e os componentes. 
Figura 67. Modelo de tela do software Arquitrop 3.0 para inserção ou modificação de dados do projeto 105

Figura 68. Gráfico - Estimativa da variação horária das temperaturas 107

Figura 69. Gráfico - Distribuição do fluxo térmico (watts) no ambiente 107

Figura 70. Detalhe do dormitório - Projeto CDHU - Padrão Habitacional TI24A. 113

Figura 71. Detalhe do dormitório - Projeto CEF - Padrão Habitacional HM5 . 113

Figura 72. Tipologia TI24A-CDHU com cobertura de telha cerâmica 114

Figura 73. Tipologia TI24A-CDHU com cobertura de telha cerâmica e laje plana 114

Figura 74. Tipologia TI24A-CDHU com cobertura de telha cerâmica e laje inclinada 114

Figura 75. Detalhe do dormitório - Projeto CDHU - Padrão Habitacional V052H-01 (Antiga VI22B-V2)...

Figura 76. Corte AB - Projeto CDHU - Padrão Habitacional V052H-01 (Antiga VI22B-V2) .115

Figura 77. Arranjo dos corpos-de-prova: técnica do fio quente paralelo 120

Figura 78. Diagrama esquemático do Método do Fio Quente Paralelo 121

Figura 79. Corpo-de-prova sendo ensaiado 122

Figura 80. Aparelhagem para aquisição dos dados 122

Figura 81. Número de Pessoas por Quarto (Casal) 126

Figura 82. Número de Pessoas por Quarto 126

Figura 83. Período de Ocupação 127

Figura 84. Duração de Ocupação 127

Figura 85. Período de Ventilação 128

Figura 86. Duração da Ventilação . 128

Figura 87. Orientação Padrão Habitacional TI24A (Tipologia Térrea) - Inverno 130

Figura 88. Orientação Padrão Habitacional TI24A (Tipologia Térrea) - Verão. 130

Figura 89. Orientação Padrão Habitacional V052H-01 (Tipologia Multipavimentos) Inverno 130

Figura 90. Orientação Padrão Habitacional V052H-01 (Tipologia Multipavimentos) Verão. 130

Figura 91. Curva Granulométrica da Areia Natural Quartzosa..... 133

Figura 92. Ilustração do preparo dos concretos - betoneira utilizada. 136 
Figura 93. Ilustração do preparo dos concretos - materiais 136

Figura 94. Adensamento em mesa vibratória 137

Figura 95. Corpos-de-prova sob cura úmida. 137

Figura 96. Relação entre condutividade térmica e massa específica dos concretos analisados 140

Figura 97. a-b. Tipologia Térrea - Temperaturas Internas - Zona Bioclimática 1 (Caxias do Sul) - a. Inverno. b. Verão 142

Figura 98. a-b. Tipologia Multipavimentos - Temperaturas Internas - Zona Bioclimática 1 (Caxias do Sul) - a. Inverno. b. Verão.

Figura 99. a-b. Tipologia Térrea - Temperaturas Internas - Zona Bioclimática 2 (Ponta Grossa) - a. Inverno. b. Verão 148

Figura 100. a-b. Tipologia Multipavimentos - Temperaturas Internas - Zona Bioclimática 2 (Ponta Grossa) - a. Inverno. b. Verão 151

Figura 101. a-b. Tipologia Térrea - Temperaturas Internas - Zona Bioclimática 3 (São Paulo) - a. Inverno. b. Verão 154

Figura 102. a-b. Tipologia Térrea - Temperaturas Internas - Zona Bioclimática 3 (Florianópolis) - a. Inverno. b. Verão...... 155

Figura 103. a-b. Tipologia Multipavimentos - Temperaturas Internas - Zona Bioclimática 3 (São Paulo) - a. Inverno. b. Verão. 159

Figura 104. a-b. Tipologia Multipavimentos - Temperaturas Internas - Zona Bioclimática 3 (Florianópolis) - a. Inverno. b. Verão. 160

Figura 105. a-b. Tipologia Térrea - Temperaturas Internas - Zona Bioclimática 4 (São Carlos) - a. Inverno. b. Verão. 164

Figura 106. a-b. Tipologia Térrea - Temperaturas Internas - Zona Bioclimática 4 (Brasília) a. Inverno. b. Verão 165

Figura 107. a-b. Tipologia Multipavimentos - Temperaturas Internas - Zona Bioclimática 4 (São Carlos) - a. Inverno. b. Verão 169

Figura 108. a-b. Tipologia Multipavimentos - Temperaturas Internas - Zona Bioclimática 4 (Brasília) - a. Inverno. b. Verão 170

Figura 109. a-b. Tipologia Térrea - Temperaturas Internas - Zona Bioclimática 5 (Santos) a. Inverno. b. Verão. 174

Figura 110. a-b. Tipologia Multipavimentos - Temperaturas Internas - Zona Bioclimática 5 (Santos) - a. Inverno. b. Verão .

Figura 111. a-b. Tipologia Térrea - Temperaturas Internas - Zona Bioclimática 6 (Presidente Prudente) - a. Inverno. b. Verão. 180

Figura 112. a-b. Tipologia Multipavimentos - Temperaturas Internas - Zona Bioclimática 6 (Presidente Prudente) - a. Inverno. b. Verão 
Figura 113. a-b. Tipologia Térrea - Temperaturas Internas - Zona Bioclimática 7 (Teresina) a. Inverno. b. Verão. 186

Figura 114. a-b. Tipologia Multipavimentos- Temperaturas Internas - Zona Bioclimática 7 (Teresina) - a. Inverno. b. Verão 189

Figura 115. a-b. Tipologia Térrea - Temperaturas Internas - Zona Bioclimática 8 (Belém) - a. Inverno. b. Verão 192

Figura 116. a-b. Tipologia Multipavimentos - Temperaturas Internas - Zona Bioclimática 8 (Belém) - a. Inverno. b. Verão .195

Figura 117. Comportamento do consumo de cimento dos concretos em função de $\mathrm{m}$ (agregados secos/cimento em massa) ..... 202

Figura 118. Comportamento de $m$ (relação agregados secos/cimento em massa) em função da relação água/aglo efetiva 202

Figura 119. Ensaio de abatimento de tronco de cone .203

Figura 120. Execução do ensaio de resistência à compressão 204

Figura 121. Comportamento da resistência à compressão às 12 horas dos concretos em função da relação a/aglo efetiva 205

Figura 122. Comportamento da resistência à compressão a 1 dia dos concretos em função da relação a/ aglo efetiva 206

Figura 123. Comportamento da resistência à compressão aos 7 dias dos concretos em função da relação a/aglo efetiva 206

Figura 124. Comportamento da resistência à compressão aos 28 dias dos concretos em função da relação a/aglo efetiva

Figura 125. Comportamento da resistência à compressão (todas as idades) dos concretos com CPII E 32 em função da relação a/aglo efetiva 207

Figura 126. Comportamento da resistência à compressão (todas as idades) dos concretos com CPIII 40 RS em função da relação a/aglo efetiva... 208

Figura 127. Execução do ensaio de resistência à tração por compressão diametral .... 208

Figura 128. Comportamento da resistência à tração por compressão diametral dos concretos com CPII E 32 e CPIII 40 RS em função da resist. à compressão aos 28 dias ...209

Figura 129. Comportamento da resistência à compressão aos 28 dias em relação ao módulo de elasticidade para os concretos com CPII E 32 .

Figura 130. Comportamento da resistência à compressão aos 28 dias em relação ao módulo de elasticidade para os concretos com CPII 40 RS .

Figura 131. Ensaio de absorção de água por imersão e índice de vazios - Pesagem do corpo-de-prova saturado

Figura 132. Comportamento da absorção de água por imersão (28 dias) dos concretos com CPII E 32 e CPIII 40 RS em função da resistência à compressão aos 28 dias .... 


\section{USTA DETABELAS}

Tabela 1. Déficit Habitacional e Percentual em Relação aos Domicílios Permanentes por

Situação do Domicílio - Brasil e Grandes Regiões - 2005.

Tabela 2. Relações entre a resistência à compressão e as resistências à tração por compressão diametral e à tração na flexão dos concretos leves.

Tabela 3. Equações para cálculo do módulo de deformação ...............................................82

Tabela 4. Propriedades térmicas dos concretos leves ..................................................... 85

Tabela 5. Síntese dos Concretos utilizados para o sistema construtivo em questão..............86

Tabela 6. Temperaturas (limites máximos e mínimos) e umidade (limites máximos e mínimos) de diferentes Metodologias

Tabela 7. Valores da condutividade térmica de acordo com a NBR 15220 (ABNT, 2005) ...117

Tabela 8. Características dos agregados. 119

Tabela 9. Tabela quantitativa dos materiais utilizados para $1 \mathrm{~m}^{3}$ de concreto 120

Tabela 10. Características e Propriedades do CPII E 32 131

Tabela 11. Características e Propriedades do CPIII 40 RS

Tabela 12. Características e Propriedades do Metacaulim HP 132

Tabela 13. Características da Areia Natural 133

Tabela 14. Características e Propriedades da Brita Basáltica. 134

Tabela 15. Características do Aditivo Superplastificante 134

Tabela 16. Traços teóricos para concreto tradicional com CPII E $32\left(1 \mathrm{~m}^{3}\right)$ 135

Tabela 17. Traços teóricos para concreto tradicional com CPIII 40 RS $\left(1 \mathrm{~m}^{3}\right)$. 135

Tabela 18. Valores de $m$ (relação agregados secos/cimento em massa) para o concreto tradicional com CPII E $32\left(1 \mathrm{~m}^{3}\right)$. 
Tabela 19. Valores de $\mathrm{m}$ (relação agregados secos/cimento em massa) para concreto tradicional com CPIII $40 \mathrm{RS}\left(1 \mathrm{~m}^{3}\right)$. 136

Tabela 20. Valores da condutividade térmica, massa específica e teor de umidade 139

Tabela 21. Dosagem para concreto tradicional com CPII E $32\left(1 \mathrm{~m}^{3}\right)$ 201

Tabela 22. Dosagem para concreto tradicional com CPIII $40 \mathrm{RS}\left(1 \mathrm{~m}^{3}\right)$ 202

Tabela 23. Valores da massa específica fresca e do teor de ar incorporado dos concretos.204

Tabela 24. Valores da resistência à compressão dos concretos com CPII E 32 205

Tabela 25. Valores da resistência à compressão dos concretos com CPIII 40 RS 205

Tabela 26. Valores da resistência à tração por compressão diametral 209

Tabela 27. Módulo de Deformação Concretos com CPII E 32 210

Tabela 28. Módulo de Deformação concretos com CPIII 40 RS 210

Tabela 29. Valores de absorção de água por imersão e índice de vazios, concretos com CPII E 32

Tabela 30. Valores de absorção de água por imersão e índice de vazios, concretos com CPIII 40 RS

Tabela 31. Dosagens recomendadas para aplicação $\left(1 \mathrm{~m}^{3}\right)$

Tabela 32. Propriedades dos Concretos 


\section{USTADEQUADROS}

Quadro 1. Sistema construtivo de painéis monolíticos moldados in loco. Vantagens e Desvantagens

Quadro 2. Zonas Bioclimáticas e diretrizes para habitações ............................................97

Quadro 3. Níveis de desempenho das edificações no inverno ..........................................98

Quadro 4. Níveis de desempenho das edificações no verão ...........................................98

Quadro 5. Procedimentos para utilização do ARQUITROP 3.0 ......................................... 105

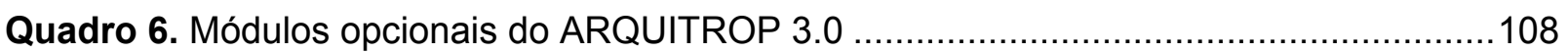

Quadro 7. Cidades adotadas para simulação do desempenho térmico das habitações ......123

Quadro 8. Diretrizes para Simulação Computacional .................................................... 124

Quadro 9. Dados para Simulação Computacional ...........................................................129

Quadro 10. Procedimentos experimentais normalizados................................................138

Quadro 11. Níveis de desempenho das edificações no inverno .......................................141

Quadro 12. Níveis de desempenho das edificações no verão ............................................141

Quadro 13. Quadro resumo dos resultados das simulações computacionais para a tipologia térrea

Quadro 14. Quadro resumo dos resultados das simulações computacionais para a tipologia multipavimentos 


\section{SUMÁRIO}

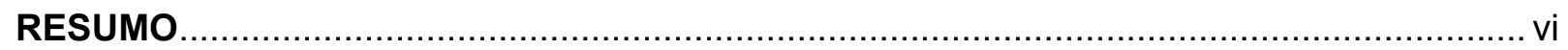

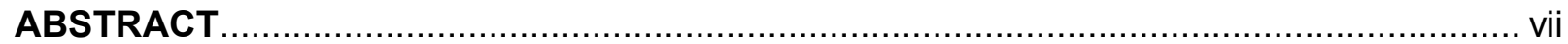

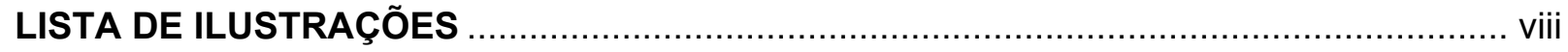

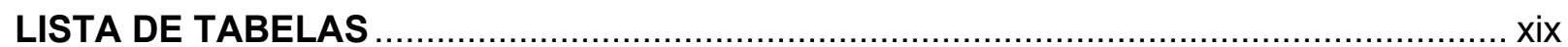

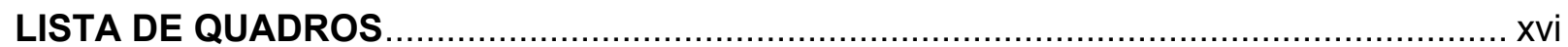

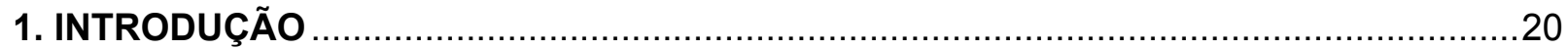

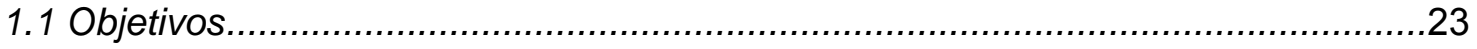

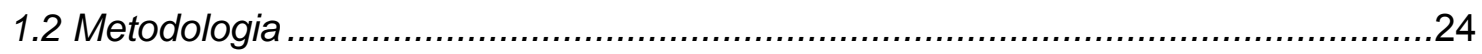

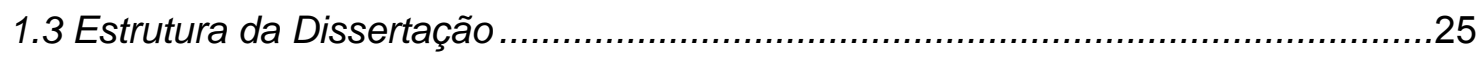

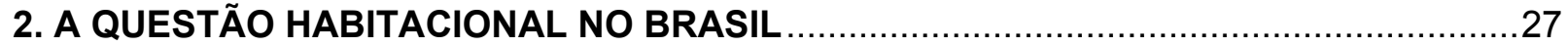

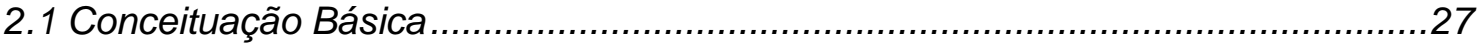

2.2 Evolução da Habitação de Interesse Social: Problemas e Iniciativas ...................29

2.3 Déficit Habitacional e Atualidades .......................................................................46

3. SISTEMA CONSTRUTIVO DE PAINÉIS MONOLÍTICOS DE CONCRETO

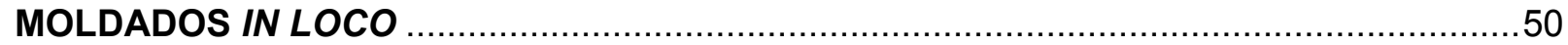

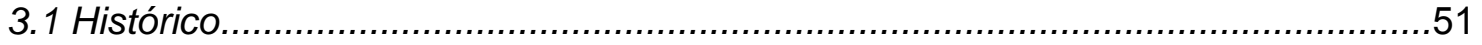

3.2. Descrição do Sistema Construtivo de Painéis Monolíticos Moldados

in LOCO

4. CONCRETOS UTILIZADOS NOS PAINÉIS MONOLÍTICOS MOLDADOS IN LOCO

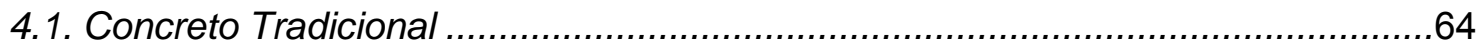

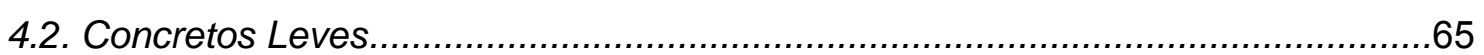

4.2.1 Concreto Leve Celular .........................................................................6 66

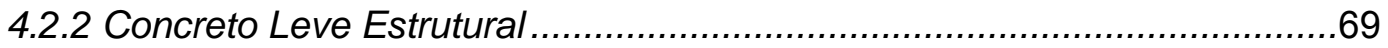




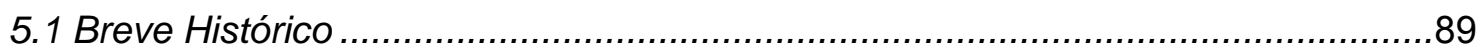

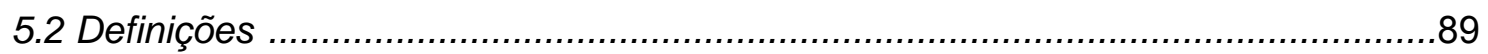

5.3 Vedações Verticais e o Conforto Térmico ........................................................ 91

5.4 Normalização em Conforto Térmico ................................................................ 92

5.5 Software como Ferramenta para Avaliação de Desempenho na Fase de

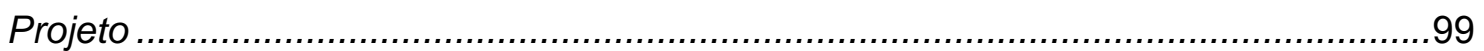

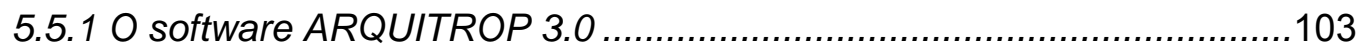

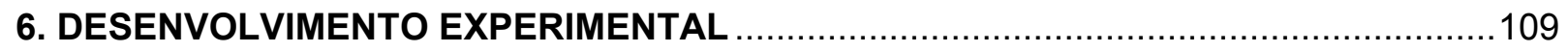

6.1. Definição dos Critérios Iniciais de Estudo ...................................................... 112

6.1.1. Definição das tipologias habitacionais térrea e multipavimentos..........112

6.1.2. Características dos Painéis de Referência .........................................116

6.1.3. Características dos Painéis de Concreto........................................116

6.1.4. Cidades determinadas para Execução das Simulações Computacionais

6.2. Avaliação do Desempenho Térmico das Edificações por meio de

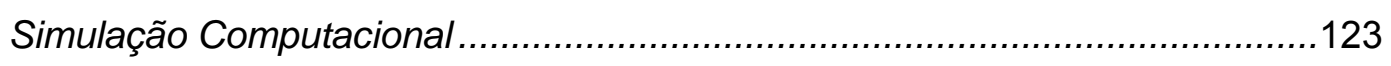

6.2.1. Diretrizes para a Simulação Computacional (ABNT, 2008)................. 124

6.2.2. Simulação Computacional da Tipologia Térrea e Multipavimentos ...... 124

6.3. Desenvolvimento de Concretos.............................................................. 131

6.3.1. Caracterização dos Materiais Constituintes...................................... 131

6.3.2. Dosagem dos Concretos ............................................................... 134

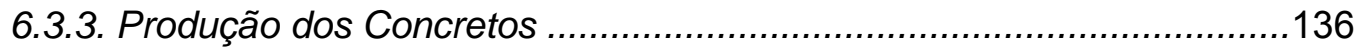

6.3.4. Caracterização das Propriedades dos Concretos ............................. 137

7. APRESENTAÇÃO E ANÁLISE DOS RESULTADOS …..................................... 139

7.1. Resultados do Ensaio de Condutividade Térmica..........................................139

7.2. Resultados das Simulações Computacionais - Tipologia Térrea e Multipavimentos.............................................................................. 140

7.2.1. Zona Bioclimática 1 - Caxias do Sul .................................................. 142

7.2.2. Zona Bioclimática 2 - Ponta Grossa...............................................148

7.2.3. Zona Bioclimática 3 - São Paulo e Florianópolis................................ 154

7.2.4. Zona Bioclimática 4 - São Carlos e Brasília........................................164

7.2.5. Zona Bioclimática 5 - Santos .......................................................... 174

7.2.6. Zona Bioclimática 6 - Presidente Prudente.......................................180

7.2.7. Zona Bioclimática 7 - Teresina.......................................................... 186

7.2.8. Zona Bioclimática 8 - Belém .......................................................... 192

7.2.9 Análise Geral do Desempenho Térmico das Tipologias...................... 197 


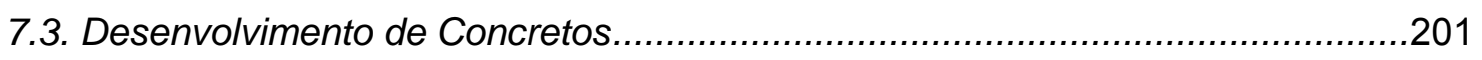

7.3.1. Propriedades no Estado Fresco ....................................................203

7.3.2. Propriedades no Estado Endurecido ...............................................204

7.3.3. Especificação da dosagem de concretos para aplicação nos painéis moldados in loco..............................................................213

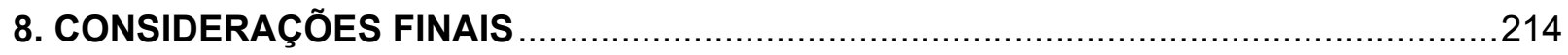

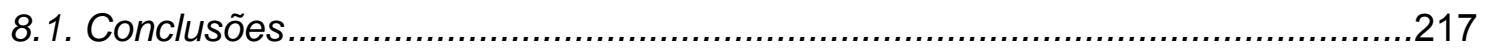

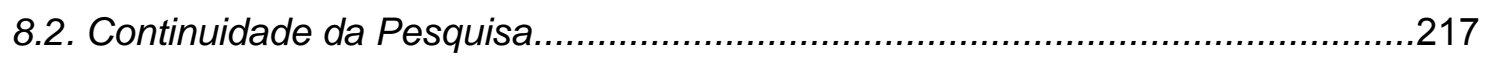

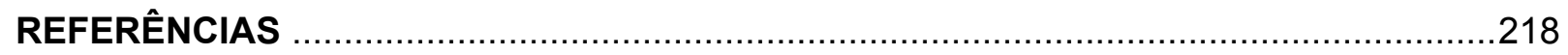

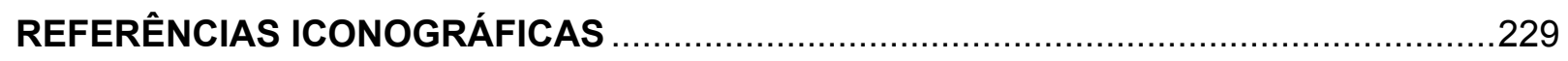

APÊNDICES

Apêndice 1. Questionário Ocupação e Ventilação ..............................................231

Apêndice 2. Tabelas - Resultados das Simulações Térreas...................................... 232

Apêndice 3. Tabelas - Resultados das Simulações Multipavimentos .........................254

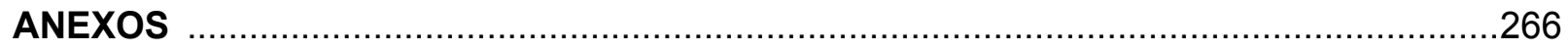

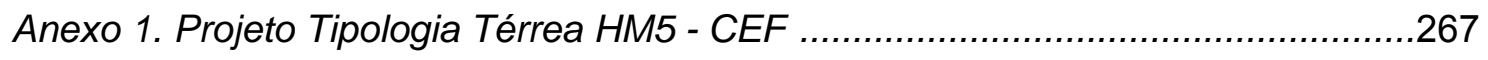

Anexo 2. Projeto Tipologia Térrea TI24A - CDHU …...............................................268

Anexo 3. Projeto Tipologia Multipavimentos V052H-01 (Antiga VI22B-V2) - CDHU .272

Anexo 4. Características dos Painéis e Tipos de Cobertura ....................................27

Anexo 5. Avaliação do Teor Ótimo de Aditivo Superplastificante ..............................285 


\section{INIRODUÇÃO}

Desde a pré-história a célula habitacional sempre foi indispensável ao ser humano. Todos os aspectos, a relação ergonômica (forma, espaço e corpo humano), materiais e técnicas construtivas, foram evoluindo e adequando-se de acordo com as necessidades dos usuários e o padrão de vida (SEGRE, 1991). Para designar a célula habitacional podem ser empregados três diferentes termos, esses três elementos são os conceitos de casa, moradia e habitação. Para este projeto especificamente o termo adotado foi Habitação de Interesse Social (HIS), que define uma série de soluções de moradia voltada à população de baixa renda podendo ser produzida e financiada por iniciativa pública ou privada.

No Brasil atualmente devido a constante perda de poder aquisitivo, pode-se considerar uma renda familiar de até 5 salários mínimos como referencial para a maioria das famílias que moram em habitações de interesse social, sejam elas produzidas por iniciativas públicas ou privadas (ORNSTEIN, 1992).

A habitação é definida na constituição federal como um dos direitos do cidadão e deve atender a uma série de anseios materiais e psicológicos dos seus ocupantes, além de reunir as qualidades necessárias ao atendimento das condições básicas de segurança, saúde, higiene e bem-estar dos moradores (ABNT, 2008). Porém, grande parcela da população brasileira não tem acesso à moradia própria.

Um estudo elaborado pela Fundação João Pinheiro em 2005, em parceria com a Secretaria Nacional de Habitação, do Ministério das Cidades, gerou informações sobre o déficit habitacional e a inadequação dos domicílios no Brasil. Os números apontados pelo IBGE na Pesquisa Nacional por Amostra de Domicílios - PNAD 2005 mostram que o déficit habitacional no Brasil passou de 7.223 milhões em 2004 para 7.903 milhões de domicílios em 2005 (DÉFICIT, 2006). A demanda por habitações nas cidades brasileiras cresce cada vez mais devido aos complexos mecanismos sócio-econômicos e culturais, que incluem o crescimento vegetativo, a migração rural, os mercados de trabalho, a distribuição de renda, o desenvolvimento industrial, a importação de tecnologias entre outros. 
Diante desse cenário mostra-se urgente em nosso país além de um maior número de iniciativas por parte do governo, o aperfeiçoamento dos sistemas construtivos disponíveis para habitação de interesse social, assim como o desenvolvimento de novos sistemas, com a finalidade de contribuir para a produção de habitações com baixo custo e que atendam plenamente às exigências dos usuários (ABNT, 2005). A redução do déficit habitacional brasileiro deve ser resultado, além de políticas públicas adequadas, de projetos para desenvolvimento de habitações com baixo custo e desempenho satisfatório (ABNT, 2008), devem ser priorizados aspectos como durabilidade do imóvel; infra-estrutura e serviços; conforto e segurança para o morador; redução de impacto ambiental e a utilização de tecnologias construtivas adequadas, as quais têm um papel fundamental na viabilização de habitações com baixo custo e níveis satisfatórios de desempenho (IPT, 1998; ABCP, 2007). A busca de soluções tecnológicas, econômicas e ambientalmente apropriadas para atender à carência habitacional é atualmente um dos maiores desafios urbanos para as políticas públicas das cidades brasileiras (ARRUDA, 2000).

Dentre os vários sistemas construtivos empregados atualmente na execução de habitações de interesse social no Brasil, destaca-se o sistema construtivo em painéis monolíticos de concreto armado moldados in loco, utilizado no Brasil desde os anos 80, que pode ser empregado tanto em edificações térreas como de múltiplos pavimentos (IPT, 1998; CEF, 2003).

Nesse sistema construtivo as vedações das edificações possuem função estrutural e são executadas no local de utilização empregando o concreto armado. Na execução das vedações utiliza-se fôrma dupla (madeira, metálica ou mista), na conformação desejada dos painéis, com as esquadrias e parte dos sistemas elétrico e hidráulico, como tubulações, quadros, registros e caixas de passagem, já posicionados no local de utilização no interior da fôrma. Esse sistema apresenta alta produtividade, baixo índice de perdas, rapidez na execução; economia no uso de revestimentos, ou mesmo a eliminação do revestimento de regularização; diminuição da mão-de-obra e necessidade de maior planejamento (LORDSLEEM JUNIOR et al., 1998).

O concreto tem um papel fundamental na execução e no desempenho dos painéis de vedação desse sistema construtivo. Usualmente são empregados o concreto tradicional e o concreto leve celular (NBR 12646, 1992 e ACl 332R04, 2004). O concreto tradicional, composto por cimento Portland, brita, areia e água, é empregado com mais frequência no sistema construtivo de painéis monolíticos de edifícios de múltiplos andares, por apresentar valores de resistência à compressão acima de $20 \mathrm{MPa}$.

Entretanto, especificamente com relação às habitações térreas, há uma recomendação de alguns órgãos governamentais brasileiros, como a Companhia de Desenvolvimento Habitacional e Urbano do Estado de São Paulo (CDHU) e a Caixa 
Econômica Federal (CEF), para a utilização de concretos leves, com massa específica em torno de $1700 \mathrm{~kg} / \mathrm{m}^{3}$, e espessura dos painéis entre 9 e $12 \mathrm{~cm}$, com a finalidade da melhoria do desempenho térmico dos painéis. Contudo, essas recomendações não consideram a influência da tipologia construtiva, assim como não incluem as especificidades climáticas regionais. No Brasil, usualmente, emprega-se o concreto leve do tipo celular na execução de habitações térreas utilizando esse sistema construtivo (NBR 12646; CEF, 2003; IPT, 1998; TCA, 2000; TCA, 2004a e 2004b).

O concreto leve celular é constituído de cimento Portland, areia, brita, água e espuma ou agentes incorporadores de ar. As bolhas de ar incorporadas na matriz de cimento ocasionam a redução da massa específica do concreto para valores entre $1200 \mathrm{e}$ $2000 \mathrm{~kg} / \mathrm{m}^{3}$. Entretanto, o ar incorporado à matriz de cimento aumenta significativamente a permeabilidade do concreto, assim como reduz sua resistência mecânica. Esse tipo de concreto apresenta valores de resistência à compressão abaixo de $6 \mathrm{MPa}$ e baixa durabilidade devido ao rápido ataque à armadura interna do concreto por ação, por exemplo, de íons cloreto e da carbonatação, que ocorre devido à alta porosidade do concreto. Esse tipo de concreto quando aplicado no sistema construtivo exige cuidados adicionais para garantir a durabilidade das vedações, como a impermeabilização e barrados protetores, itens que reduzem a produtividade e aumentam o custo do processo.

O concreto leve estrutural (com agregados leves) apresenta-se como um material alternativo para aplicação no sistema construtivo de painéis monolíticos, apresentando massa específica, isolamento térmico e acústico compatível com o obtido em concretos celulares e desempenho das propriedades relativas à resistência mecânica e à durabilidade semelhante a dos concretos tradicionais, para as mesmas características de dosagem. Esse tipo de concreto tem sido utilizado desde o início do século passado, para fins estruturais e de vedação, com excelentes resultados. A partir de 1980, foram realizadas rigorosas pesquisas sobre os concretos leves, em todo o mundo, demonstrando o grande potencial do uso desse material nas mais diversas áreas da construção civil, por apresentar baixa massa específica, elevada resistência mecânica e alta durabilidade (SLATE et al., 1986; BERNER, 1991; ZHANG e GJ\$RV, 1991; ROSSIGNOLO et al., 2001; ROSSIGNOLO e AGNESINI, 2001, 2002a e 2004).

Estudos realizados no Laboratório de Construção Civil (LCC) da Escola de Engenharia de São Carlos (USP) no fim de 2004 indicaram que o concreto leve com argila expandida nacional apresenta grande potencial de utilização no sistema construtivo de painéis monolíticos, principalmente por apresentar trabalhabilidade adequada ao bombeamento e a moldagem (slump acima de $160 \mathrm{~mm}$ ); condições favoráveis de produção e cura; valores de resistência à compressão às 12 horas de idade acima de $2 \mathrm{MPa}$, favorecendo a rápida desforma dos painéis, e aos 28 dias acima de $30 \mathrm{MPa}$; massa 
específica seca abaixo de $1700 \mathrm{~kg} / \mathrm{m}^{3}$ aos 28 dias (cerca de $35 \%$ inferior a dos concretos tradicionais); e absorção de água por imersão aos 28 dias de idade abaixo de 2,5\%.

Desde 1998 são realizados estudos no Laboratório de Construção Civil (LCC) do Departamento de Arquitetura e Urbanismo (EESC/USP) com o objetivo de desenvolver concretos especiais destinados à construção civil (AGNESINI e GOMES NETO, 1998, ROSSIGNOLO e AGNESINI, 2002a 2002b, 2004 e 2005). Este projeto, portanto é um subprojeto com a participação de outros três pesquisadores, sendo eles os estudantes de Iniciação Científica: José Irail de Rezende Neto ${ }^{1}$ (tipologia térrea), Fernanda Faria Graçon ${ }^{2}$ (tipologia multipavimentos) e Bruno Ferrari Brandão da Silva ${ }^{3}$ (desenvolvimento de concreto leve para esse sistema construtivo utilizando agregado de pneus inservíveis).

A partir dos estudos desenvolvidos no LCC-USP e da execução de sete unidades habitacionais na cidade de Monte Mor - SP e 25 unidades em Santa Maria da Serra - SP em 2006, a diretoria técnica da CEF e da CDHU aprovou, de forma provisória, a utilização do concreto com agregados leves para execução de painéis monolíticos de habitações de interesse social. Portanto, mostra-se relevante a continuidade dos estudos, enfocando no desempenho global da edificação, especialmente na especificação correta da espessura da vedação assim como da massa específica do concreto tendo como referência as características bioclimáticas regionais (ABNT, 2008 e ABNT, 2005).

\subsection{Objetivos}

O objetivo geral desta pesquisa foi desenvolver concretos destinados ao sistema construtivo de painéis monolíticos moldados in loco, tendo como referencial, além dos requisitos técnicos de trabalhabilidade, resistência mecânica e durabilidade, a influência das características dos painéis no conforto térmico das habitações.

\footnotetext{
${ }^{1}$ Projeto de pesquisa de Iniciação Científica: "Avaliação de desempenho térmico de painéis de vedação de concreto moldados in loco para habitações de interesse social: edificações térreas". Processo FAPESP $n^{\circ}$. 2006/56263-6.

${ }_{2}$ Projeto de pesquisa de iniciação científica: "Avaliação de desempenho de painéis de vedação de concreto moldados in loco para habitações de interesse social: edificações assobradadas e de múltiplos pavimentos".

${ }^{3}$ Projeto de pesquisa de iniciação científica: "Desenvolvimento de concreto leve com agregados de pneus inservíveis destinados à produção de painéis e vedação de habitações de interesse social". Processo PIBIC/ CNPq.
} 


\subsection{Metodologia}

Essa pesquisa, ao abordar o desenvolvimento de concretos para o sistema construtivo de painéis monolíticos moldados in loco, seguiu a seguinte metodologia:

a) Definição dos critérios iniciais de estudo, sendo eles: a definição das tipologias habitacionais a serem analisadas, tendo como referência as tipologias adotadas pelo CDHU e CEF; a definição da faixa de variação da espessura dos painéis de vedação; a definição da faixa de variação da massa específica dos concretos empregados; a definição dos painéis de referência (alvenaria de blocos cerâmicos e de blocos de concreto) e suas características;

b) Execução do ensaio de determinação da condutividade térmica dos concretos pelo método do fio quente paralelo e levantamento de dados comportamentais de moradores de habitação de interesse social;

c) Avaliação do desempenho das tipologias habitacionais térrea e multipavimentos, utilizando software de simulação computacional Arquitrop 3.0, para as oito zonas bioclimáticas do Brasil (ABNT, 2008 e ABNT, 2005), tendo como variáveis a espessura do painel e a massa específica do concreto empregado;

d) Definição da espessura do painel e da faixa de variação da massa específica do concreto adequadas de acordo com a região bioclimática analisada (ABNT, 2008; ABNT, 2005);

e) Especificação e caracterização dos materiais utilizados na dosagem dos concretos;

f) Dosagem dos concretos destinados a uma das tipologias de habitação térrea analisadas, com valores de massa específica definidas no item "d", atendendo os seguintes requisitos: relação a/c abaixo de 0,60 (Classe de agressividade II, em área urbana - NBR 6118); abatimento do tronco de cone (slump test) acima de $150 \mathrm{~mm}$; e resistência à compressão aos 28 dias acima de $25 \mathrm{MPa}$ (Classe de agressividade II - NBR 6118).

g) Análise da produção do concreto: mistura, transporte, adensamento e cura;

h) Avaliação da resistência à compressão de corpos-de-prova das dosagens obtidas nas idades de 12 horas, 1,7 e 28 dias;

i) Análise do módulo de deformação de corpos-de-prova das dosagens obtidas na idade de 28 dias. 


\subsection{Estrutura da Dissertação}

A estrutura deste trabalho encontra-se dividida em oito capítulos. No primeiro capítulo apresenta-se uma introdução, as justificativas e os objetivos deste projeto.

No Capítulo 2 é abordada a questão habitacional no Brasil, pois trata-se de um assunto diretamente ligado ao tema desta dissertação. Este Capítulo foi elaborado de forma a mostrar a evolução da problemática da habitação social no Brasil e atualidades. Estes dados apontam para a necessidade de iniciativas na área, tanto por parte do governo, quanto em relação à tecnologia, como por meio do aperfeiçoamento dos sistemas construtivos disponíveis e o desenvolvimento de novos sistemas, com o objetivo de contribuir para a produção de habitações com baixo custo e desempenho satisfatório.

No Capítulo 3 é apresentada uma caracterização do sistema construtivo de painéis monolíticos moldados in loco, no qual esta pesquisa se concentra. Trata-se de um sistema construtivo racionalizado que apresenta inovações na execução da vedação, dos sistemas prediais e no posicionamento das esquadrias.

No Capítulo 4 são apresentados os tipos de concretos geralmente empregados no sistema construtivo de painéis de concreto moldados in loco. Nesse sistema construtivo o concreto tem um papel fundamental na execução e no desempenho dos painéis de vedação e usualmente são utilizados o concreto tradicional e o concreto leve celular, porém nesta pesquisa procurou-se apresentar alternativas aos concretos anteriormente citados.

No Capítulo 5 trata-se especificamente sobre o assunto conforto térmico de edificações e suas definições, pois a avaliação de desempenho realizada nesta pesquisa abrange esse aspecto, incluindo a normalização na área, da qual foram utilizados os parâmetros de avaliação; esse capítulo inclui também o assunto softwares de simulação computacional para conforto térmico utilizados nesse caso como ferramenta de avaliação de desempenho térmico.

O Capítulo 6 detalha os procedimentos adotados para o estudo da influência do tipo de concreto e da espessura dos painéis das vedações verticais no conforto térmico das habitações de interesse social térreas e multipavimentos, bem como os procedimentos experimentais realizados para caracterização dos concretos estudados, sendo eles caracterização dos materiais constituintes; dosagem dos concretos; produção dos concretos e caracterização das propriedades dos concretos.

No Capítulo 7 são apresentados os resultados e as análises dos dados obtidos no ensaio de determinação da condutividade térmica dos concretos, os resultados das simulações computacionais para a tipologia térrea e multipavimentos, além da última etapa com os resultados dos ensaios realizados com o concreto tradicional $\left(2400 \mathrm{~kg} / \mathrm{m}^{3}\right)$. 
O Capítulo 8 contém as considerações finais em relação a esta pesquisa. 


\section{AQUESTÃO HABITACIONAL NOBRASIL}

\subsection{Conceituação Básica}

A célula habitacional desde a pré-história sempre foi indispensável ao ser humano. Todas as características, a relação ergonômica (forma, espaço e corpo humano), a base material e construtiva, foram evoluindo e se adequando de acordo com as necessidades dos usuários e o padrão de vida. Pouco a pouco se formou uma imagem universal da célula: "volume retangular com pórtico e teto de duas águas" (SEGRE, 1991).

Para designar a célula habitacional podem ser utilizados três elementos diferentes, os quais possuem significados também diferentes, mesmo que muitas vezes pareça induzir a um mesmo entendimento. Esses três elementos são os conceitos de casa, moradia e habitação. Pode-se dizer inicialmente que o setor de construção civil produz a casa, baseado nos parâmetros e requisitos de uma moradia, porém o que entra no mercado para a venda é a habitação (grifo nosso).

"A casa é a casca protetora, o invólucro que divide tanto espaços internos como espaços externos, é o ente físico". A moradia possui uma ligação muito mais forte com os elementos que permitem o funcionamento da casa, ou seja, os "hábitos de uso" da casa. Para que uma casa se caracterize como moradia é necessário que a mesma se identifique com o "modo de vida" dos usuários. O mesmo invólucro, o mesmo ente físico se transforma em moradias diferentes, com características distintas, cujos hábitos de uso dos moradores ou usuários são a tônica da mudança. Já a habitação, inegavelmente se remete aos elementos que caracterizam tanto a casa quanto a moradia, entretanto não mais de uma forma isolada, mas sim com um sentido mais amplo; a habitação deve ser entendida do ponto de vista conceitual como a casa e a moradia integrada ao espaço urbano; deve ser considerada e analisada através do conceito de "habitat", integrando o interno (privado) com o externo (público) (MARTUCCI, 1999). 
Para Bonduki (1998) o termo habitação social significa a habitação produzida e financiada por órgãos estatais destinada à população de baixa renda, mas num sentido mais amplo que inclui a regulamentação estatal da locação habitacional e incorporação, como um problema do estado, da falta de infra-estrutura urbana gerada pelo loteamento privado.

Segundo Folz (2003) quando se fala em "habitação popular" refere-se à habitação para a classe trabalhadora que vive na cidade e que possui uma renda familiar baixa. Devido a constante perda de poder aquisitivo desta classe, pode-se considerar hoje, aqui no Brasil, uma renda familiar de até 5 salários mínimos como referencial para a maioria das famílias que moram nessas habitações, sejam elas produzidas por iniciativa pública ou privada. A habitação é um bem de consumo de características únicas, sendo um produto potencialmente muito durável onde muito freqüentemente são observados tempos de vida útil superior a 50 anos (ORNSTEIN, 1992).

O termo Habitação de Interesse Social (HIS) define uma série de soluções de moradia voltada à população de baixa renda. Esse termo tem prevalecido nos estudos sobre gestão habitacional e vem sendo utilizado por várias instituições e agências, ao lado de outros termos equivalentes, como: Habitação de Baixo Custo (low-cost housing), termo que designa habitação barata sem que isto signifique necessariamente habitação para população de baixa renda; Habitação para População de Baixa Renda (housing for lowincome people), é um termo mais adequado que o anterior, esse possui a mesma conotação que habitação de interesse social; e Habitação Popular termo genérico que envolve todas as soluções destinadas ao atendimento de necessidades habitacionais (ABIKO, 1995 apud LARCHE, 2005, grifo nosso).

A junção das células habitacionais e de todos os elementos que circunscrevem a vida social (espaços públicos; vias de acesso; edifícios para saúde, cultura e educação, etc.) formam o "habitat" cujo conceito está intimamente ligado com os conceitos de habitação e habitabilidade (possibilidade de ser habitado). A relação entre habitação e habitabilidade deve ser de forma a propiciar qualidade de vida. A organização do espaço arquitetônico e urbanístico (aspectos construtivos, tecnológicos, de infra-estrutura urbana, de integração das atividades e das funções dos espaços internos e externos da habitação) interfere na qualidade do habitat, assim como os aspectos culturais e sociais (SEGRE, 1991).

O aspecto principal que justifica iniciativas na área de habitação define-se por necessidades habitacionais. De acordo com a metodologia desenvolvida pela Fundação João Pinheiro a partir do conceito mais amplo de necessidades habitacionais, pode-se utilizar dois segmentos distintos: o déficit habitacional e a inadequação de moradias. Sobre o déficit habitacional, a noção mais imediata e intuitiva se reporta à necessidade de construção de novas moradias para a solução de problemas sociais e específicos de 
habitação detectados em certo momento; o mesmo é composto por habitação precária, coabitação familiar e o ônus excessivo com aluguel (DÉFICIT, 2006, grifo nosso).

A habitação precária inclui os domicílios rústicos e os improvisados. A componente coabitação familiar compreende a soma das famílias conviventes secundárias ${ }^{4}$ às que vivem em cômodos (exceto os cedidos por empregador), e o ônus excessivo com aluguel corresponde ao número de famílias urbanas, com renda familiar de até três salários mínimos, que moram em habitações térreas ou multipavimentos (domicílios urbanos duráveis) e que despendem mais de $30 \%$ de sua renda com aluguel.

$\mathrm{O}$ conceito de déficit habitacional utilizado está ligado diretamente às deficiências do estoque de habitação e engloba aquelas sem condições de habitabilidade devido à precariedade das construções ou em virtude de desgaste da estrutura física. No caso de precariedade existe a necessidade reposição e existe também devido à coabitação familiar ou à moradia em imóveis construídos com fins não residenciais a necessidade de incremento do estoque. O déficit habitacional pode ser entendido, portanto, como "déficit por incremento de estoque" e como "déficit por reposição do estoque". O déficit por reposição do estoque refere-se aos domicílios rústicos acrescidos de uma parcela devida à depreciação dos domicílios existentes. O déficit por incremento de estoque contempla os domicílios improvisados e a coabitação familiar (DÉFICIT, 2006).

As habitações inadequadas são aquelas que não proporcionam condições desejáveis de habitabilidade, o que não implica, contudo, em necessidade de construção de novas unidades. Como inadequados são classificados os domicílios com carência de infraestrutura, com adensamento excessivo de moradores, com problemas de natureza fundiária, em alto grau de depreciação ou sem unidade sanitária domiciliar exclusiva (grifo nosso).

\subsection{Evolução da Habitação de Interesse Social: Problemas e Iniciativas}

A primeira crise habitacional surgiu nos paises pioneiros da revolução industrial, Inglaterra e França, no final do século XIII, quando grandes levas da população rural foram atraídas para a cidade formando as novas camadas do proletariado ${ }^{5}$ urbano (FOLZ, 2003). $\mathrm{Na}$ Europa o início da produção de habitações de interesse social procurava atender à demanda gerada por famílias com baixa renda, remonta ao movimento funcionalista do século XVIII, isso em resposta à situação das classes trabalhadoras (MAGNAVITA, 1994). As moradias dos trabalhadores das indústrias não atendiam aos requisitos mínimos de qualidade, tanto no aspecto construtivo quanto às condições de higiene, gerando muitas

\footnotetext{
${ }^{4}$ Famílias conviventes secundárias são famílias que vivem junto a uma outra em um mesmo domicílio (DÉFICIT, 2006).

${ }^{5}$ Proletário- Homem de nível de vida relativamente baixo, e cujo sustento depende da remuneração recebida pelo trabalho que exerce em ofício ou profissão manual ou mecânica (operário, trabalhador). Fonte: AURÉLIO: dicionário eletrônico. Rio de Janeiro: Positivo Informática, 2004. 1 cd-rom.
} 
vezes, a ocorrência de epidemias de cólera, peste bubônica e tifo, que dizimaram parcela considerável das populações dos grandes centros (FINEP/GAP, 1985; FOLZ, 2003). As epidemias se alastravam não somente devido às condições precárias das moradias, mas, sobretudo pela falta de infra-estrutura nas cidades (Figura 1) (FOLZ, 2003).

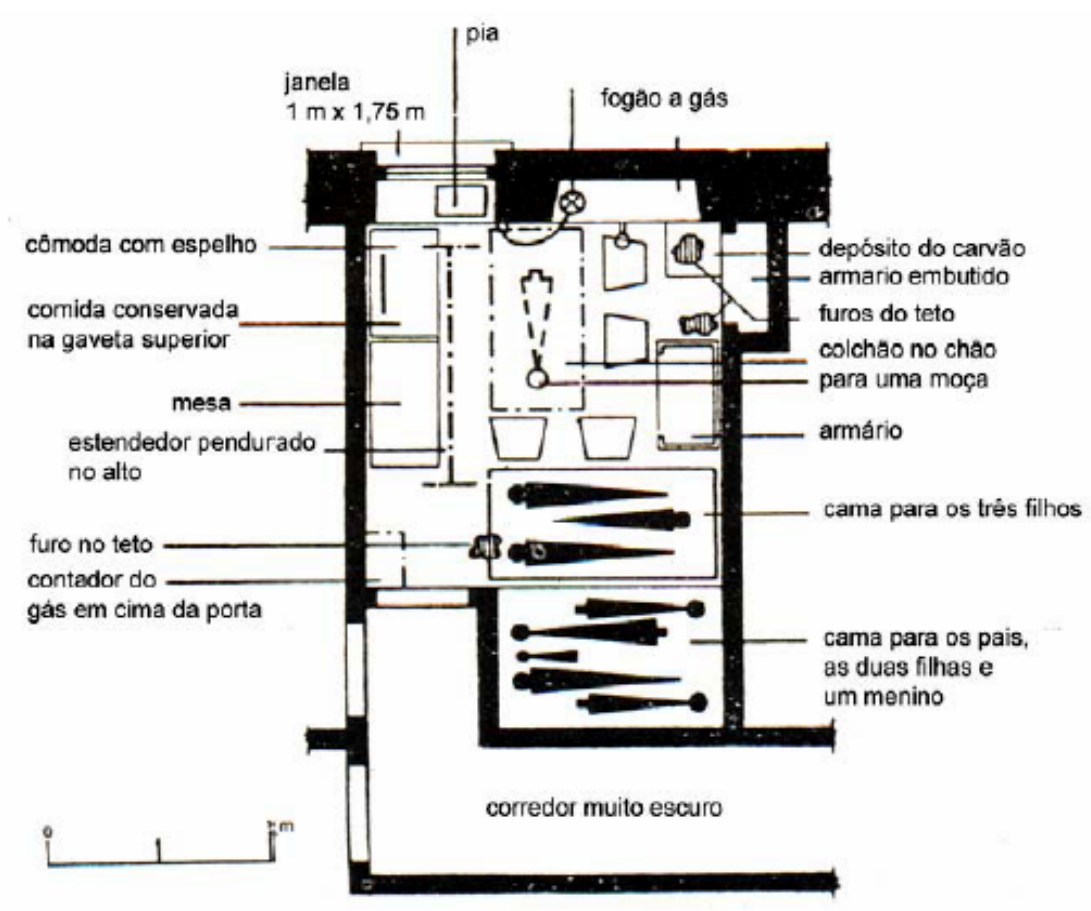

Figura 1. Casa operária para nove pessoas, Glasgow, Escócia.

Fonte: FOLZ, 2003.

Problemas semelhantes aos surgidos nas grandes metrópoles industriais européias se repetiram aqui no Brasil, principalmente nas grandes cidades como Rio de Janeiro e São Paulo (FOLZ, 2003). Igualmente à Europa o início da produção habitacional brasileira se relaciona à classe trabalhadora. Por volta de 1886 a falta de moradias adequadas passou a ser considerada um problema principalmente na capital paulista, quando as atividades urbanas tornaram-se intensas devido à expansão da atividade cafeeira. Antes disso, a maioria dos trabalhadores era escravo e, portanto, não havia preocupação com sua moradia, uma vez que a função da senzala era mais impedir a fuga dos negros para os quilombos do que abrigá-los (CORREIA, 2004).

Com a abolição da escravatura em 1888 uma grande massa de trabalhadores se transferiu para a cidade, sendo na maioria negros libertos ou imigrantes insatisfeitos com as condições das lavouras. Os problemas relacionados com a habitação se agravaram nesse período marcado por intensas mudanças decorrentes da explosão das forças progressistas e do florescimento das atividades comerciais e industriais, no qual as cidades começaram a converter-se no principal centro de atividades econômicas (FINEP/GAP, 1985). Com esse 
aumento da população dos centros urbanos gerado pelo capitalismo através dos chamados "homens livres" que migravam para as principais capitais em busca de melhores condições de vida, a habitação começou lentamente a assumir forma de mercadoria, juntamente com os demais bens necessários para atender às necessidades humanas (BONDUKI, 1998).

Segundo Werna (2001), numa cidade que ainda procurava adequar-se aos novos moldes de uma verdadeira cidade industrial, não havia habitação adequada para todos, o que exigia que fossem providenciadas rapidamente novas habitações, pois se pensava que essa carência poderia ser um obstáculo a um crescimento ainda maior da cidade, caso a crescente oferta de mão-de-obra fosse interrompida por não haver habitação.

Desde o surgimento do problema habitacional em São Paulo no final do século XIX até a década de 1930, surgiram várias modalidades de moradia para alojar os setores de baixa e média renda, todas construídas pela iniciativa privada. As mais difundidas entre elas foram o cortiço-corredor, o cortiço-casa de cômodos, os vários tipos de vilas e as casas geminadas (Figura 2) (BONDUKI, 1998).

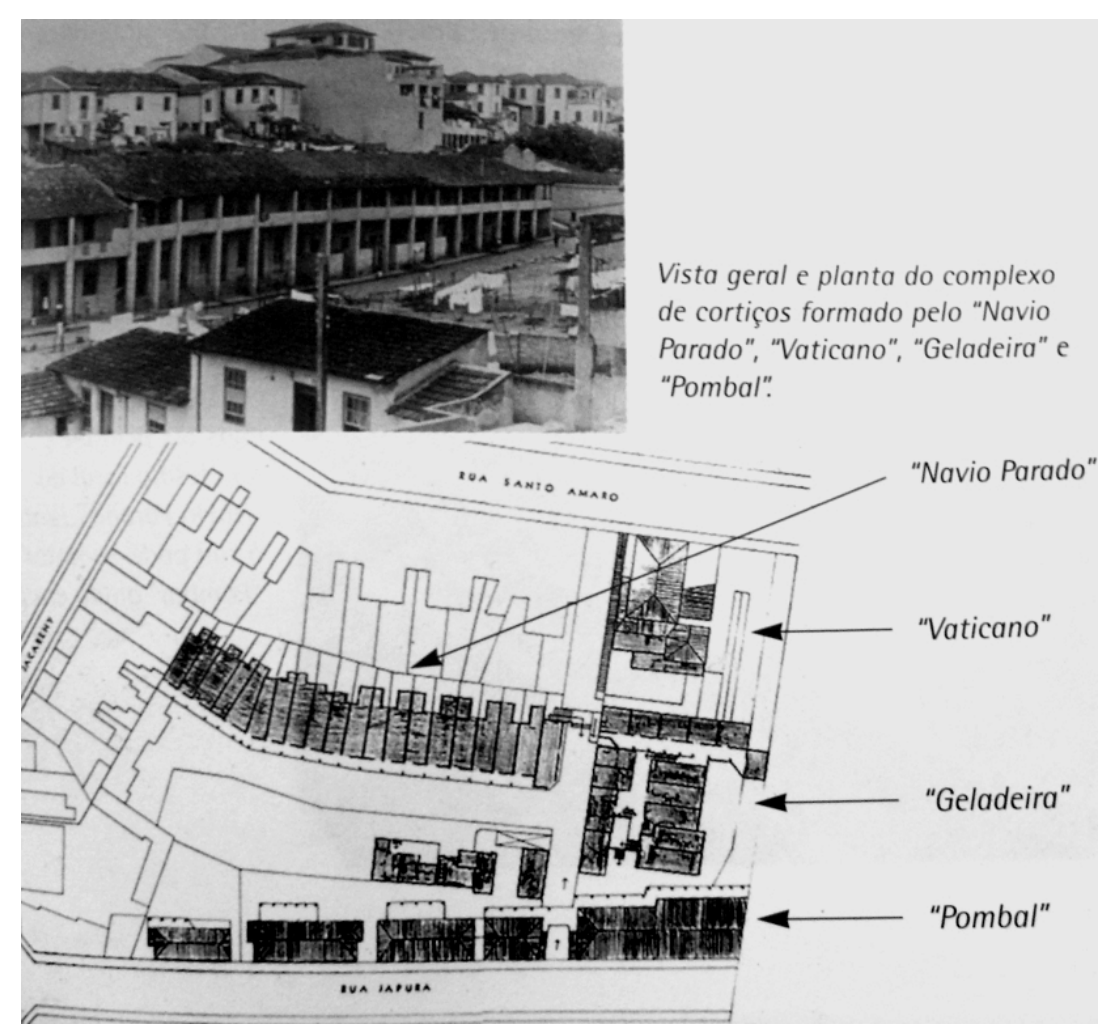

Figura 2. Complexo de cortiços de São Paulo da primeira metade da década de 20 onde em 1940 foi implantado o viaduto Jacareí

Fonte: BONDUKI, 1998.

$\mathrm{Na}$ mesma época, as tipologias de alojamento existentes para abrigar os trabalhadores eram os hotéis-cortiços, para operários ${ }^{6}$ sem família; os cômodos de fundo de

\footnotetext{
${ }^{6}$ Operário - Trabalhador manual ou mecânico das grandes indústrias, nesse sentido proletário (AURÉLIO, 2004).
} 
lote, que eram alugados por famílias e considerados os piores por ficarem próximos a estábulos e depósitos insalubres; as casas de cômodos, que eram antigas casas e sobrados transformados em cortiços; o cortiço-pátio, no interior de quarteirões, trata-se de habitações precárias que se desenvolvem ao redor de um pátio, havendo sempre uma pequena mercearia para abastecer os moradores; e ainda as casinhas, que embora voltadas para a rua não atendiam às questões de higiene e iluminação adequadas, semelhantes às moradias das vilas operárias, que seriam os primórdios dos conjuntos habitacionais (Figura 3).

Acreditava-se que as habitações precárias e insalubres consistiam em ameaça social para o trabalhador deixando-o cansado e, portanto, ineficiente, além de propiciar a promiscuidade, o vício, as doenças e as epidemias. A umidade presente nas habitações era vista como a grande causadora de surtos epidêmicos, portanto sendo necessário a ventilação e luz e para isso foram previstos na época os porões, que afastavam a habitação do solo; os recuos laterais, que mais tarde se transformarão em jardins; e os recuos frontais surgirão posteriormente (CORREIA, 2004).

Os problemas relacionados à moradia como infra-estrutura e principalmente a vinda de imigrantes, que viajavam nos navios em condições subumanas, trazendo vários tipos de doenças fez com que na capital paulista surgisse o medo de um surto epidêmico, exigindo assim do Estado providências urgentes. Estas providências seriam possíveis por meio do controle sanitário das moradias, de uma legislação que abrangesse as novas necessidades da cidade e da atuação direta sobre a infra-estrutura: rede de água e esgoto, drenagem e urbanização do centro (CORREIA, 2004).

O Estado teve dificuldades em prover a cidade de todos os itens necessários à sua expansão, mas houve uma grande preocupação com as questões referentes à higiene e pode-se dizer que a ação estatal sobre a habitação popular se origina e permanece na Primeira República voltada quase que apenas para esse problema. Os chamados engenheiros sanitaristas visitavam as moradias dos trabalhadores e faziam relatórios a respeito de suas condições, obtendo informações sobre as habitações, as quais estavam inseridas nos lugares menos favorecidos da cidade, enquanto que a elite vivia uma aparência européia nas melhores partes da cidade, sendo que as construções da elite foram as mais documentadas do período (Figura 3). Nos últimos quinze anos do século XIX higienistas, médicos e engenheiros já começaram a clamar pela criação de leis e serviços sanitários similares aos existentes na Europa, e como obtiveram apoio da opinião pública, conseguiram fazer com que o estado desse prioridade à questão (BONDUKI, 1998).

Essa estratégia de visitas domiciliares e desinfecções adotada pelos sanitaristas em nada contribuiu para melhorar as condições de moradia e saúde, ou eliminar os problemas: pobreza, superexploração (baixos salários), subnutrição, falta de saneamento e moradias 
dignas. Essa visão moralista, onde a própria moradia era a origem de todos os males orientou a intervenção estatal em São Paulo até a década de 40 (BONDUKI, 1998).

No século XIX, o Estado passou a intervir na habitação através de medidas sanitárias, na tentativa de controle das epidemias. Ocorreu a criação da legislação urbanística (Código de Postura e Obras, Código de Loteamentos e Código de Zoneamentos) pouco utilizada e que pouco ou nada influenciou sobre as condições da população urbana brasileira. O Código de Posturas de 1886 determinava regras próprias para a habitação operária, entre elas: área mínima de $5 \mathrm{~m}^{2}$ para cada cômodo, afastamentos de pelo menos 5 metros entre as linhas de cortiços, existência de poço com água, tanque e uma latrina para cada duas habitações. Posteriormente o Código Sanitário de 1894, regulamentava a construção de moradias operárias e indicava, indiretamente, a sua implantação fora da área central e dos locais onde vivia a elite da cidade; proibia terminantemente a construção de cortiços e atribuía à municipalidade a responsabilidade de fechar os existentes. (BONDUKI, 1998). Posturas semelhantes foram adotadas no município de São Paulo, como a Lei 38 de 1893, estabelecendo a necessidade de uma planta aprovada para construção e a Lei 375 de 1898, que determinava a proibição de cortiços e que os mesmos deveriam ser demolidos ou reconstruídos conforme padrão municipal. Em 1900 a Lei 493 veio como reforço às leis anteriores, em relação à proibição de habitações coletivas na forma de cortiços.

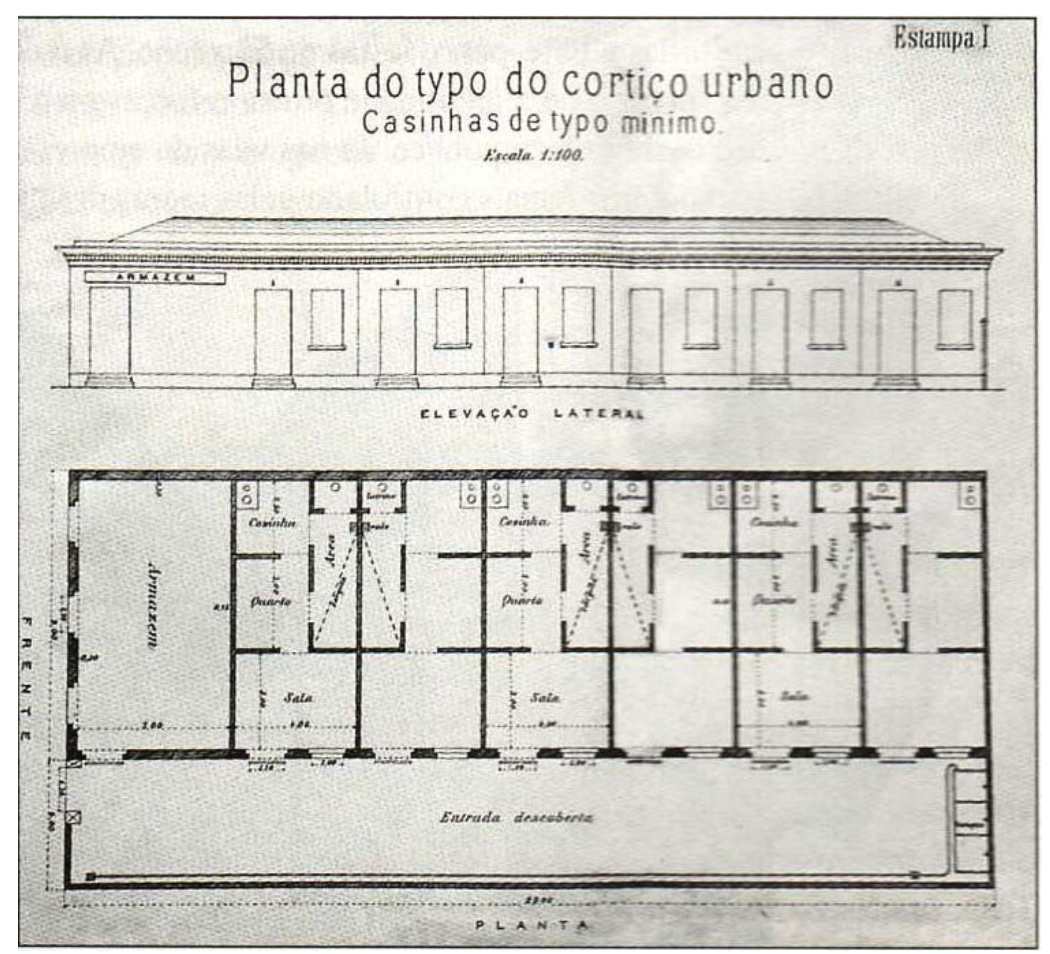

Figura 3. Modelo de moradia operária proposto pela Comissão de Exame e Inspeção dos cortiços em 1893.

Fonte: BONDUKI, 1998. 
Apesar de exercer grande controle sobre as habitações, por meios dos códigos e leis, o Estado não estava disposto a construir moradias adequadas aos trabalhadores isoladamente, o que rendeu a concessão desse serviço ao setor privado. No Brasil, a partir da década de 1890, indústrias, empresas de mineração, companhias ferroviárias e empresas imobiliárias estiveram envolvidas na construção de habitações salubres e baratas para proletários. O poder público incentivou por meio de benefícios diversos como isenção de impostos e direitos de desapropriação de terrenos, a presença de empreendedores imobiliários (CORREIA, 2004).

A produção de habitações aos trabalhadores muitas vezes servia como intermediação no vínculo entre trabalhador e fábrica, algumas causas para esses investimentos podem ser citadas, entre elas: manter proximidade constante e controle dos trabalhadores; manter o pessoal de manutenção sempre próximo ao local de trabalho, de forma que pudessem ser convocados eventualmente; a intenção do empresário de conseguir vantagens adicionais, negociando uma redução nos aluguéis em troca de salários menores, exigindo que outros membros da família se empregassem na empresa, contando com a relutância do trabalhador a buscar um novo emprego melhor remunerado, pois a demissão implicaria na perda da casa (BONDUKI, 1998). Essa produção de habitações era uma fonte de rendimentos, uma mercadoria como qualquer outra aos olhos de investidores capitalistas. Era uma forma de investir os volumosos ganhos com a atividade cafeeira, pois pouco se podia investir na indústria ainda nascente que produzia basicamente bens de consumo. Como grande parte das moradias era para aluguel, já que não havia programas de financiamento e levaria anos até um trabalhador ganhar o suficiente para comprar sua casa própria, a construção habitacional tornou-se muito atraente àqueles que queriam investir seus ganhos em algo rentável (BLAY, 1985). Tais condições onde cerca de $80 \%$ dos edifícios eram destinados ao aluguel não foram características exclusivas do período de 1900 a 1920, perduraram mesmo depois de 1930.

Devido ao fato do aluguel absorver grande parte do salário dos operários, alguns preferiam adquirir seus próprios terrenos, localizados nas periferias, desprovidos de qualquer infra-estrutura. Eles construíam ao longo de anos a sua casa gastando muito mais do que os investidores nas casas de aluguel, pois não tinham uma visão rentista e muitas vezes produziam habitações tão precárias que o Estado viria a interditá-las ou destruí-las nas suas buscas por focos de doenças.

A reconstrução do centro do Rio de Janeiro efetuada durante o governo de Pereira Passos entre os anos 1903 e 1907 é apresentada como o exemplo mais conhecido de demolições feitas pelo governo (FINEP/GAP, 1985). Incorporando o serviço de polícia sanitária das habitações, foi aprovada em 1904 no município uma lei de combate à febre amarela, que concedia plenos poderes às autoridades para demolirem edifícios 
considerados insalubres. Nessa mesma época as chamadas "brigadas sanitárias" da saúde pública realizam 512 mil visitas domiciliares na cidade, distribuindo intimações que obrigavam a implementação de melhorias nas edificações. Devido às más condições de higiene, quase três mil prédios foram condenados e seus moradores notificados a deixá-los. Nesse momento, a imprensa anuncia um recrudescimento da epidemia de varíola, sendo aprovada a lei da vacina obrigatória contra a doença em todo o território da República, ocasionando, em seguida, a chamada Revolta da $\mathrm{Vacina}^{7}$, que ganhou fôlego ao final de 1904 (Figuras 4 e 5) (RABHA, 2007).

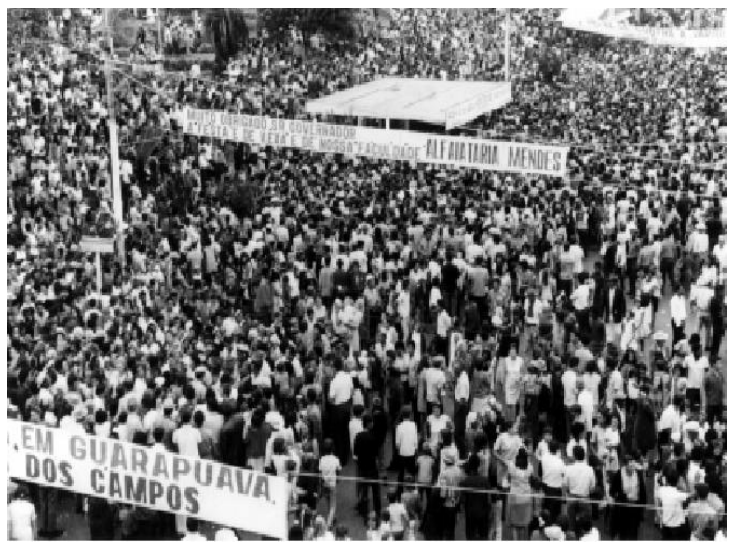

Figura 4. Em grandes eventos a campanha de vacinação reunindo multidões.

Fonte: PÔRTO; PONTE, 1998.

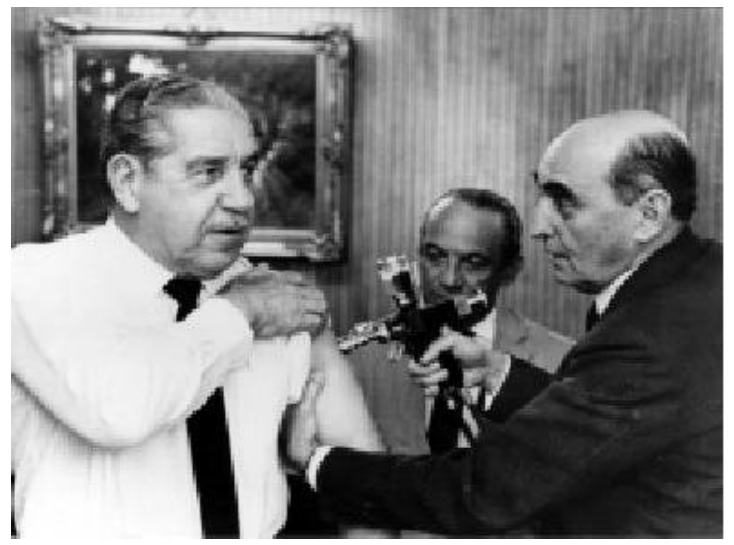

Figura 5. O presidente Costa e Silva sendo vacinado.

Fonte: PÔRTO; PONTE, 1998.

As antigas moradias destruídas não foram substituídas por novas e a população pobre, varrida do centro da cidade, encontraria refúgio nos pontos mais distantes da periferia ou ocuparia os morros, então quase desabitados, para dar início os barracos das primeiras favelas (FINEP/GAP, 1985). Iniciam-se então as autoconstruções ${ }^{8}$ e favelas $^{9}$ e o comércio passou a se localizar nas áreas com maior possibilidade de lucro, gerando assim um crescimento urbano sem regulamentação, sem zoneamento e desprovido de infraestrutura.

Entre 1908 e 1914, a produção de novas edificações acelerou-se, resultando numa superabundância de edificações no ano seguinte. A partir de 1914 a crise econômica e a Primeira Guerra provocaram uma acentuada queda no ritmo das construções, entre 1914 e 1918 foram construídos menos de 6 mil prédios.

\footnotetext{
${ }^{7}$ Considerada como um dos maiores levantes populares ocorridos no Brasil durante o século XX, a Revolta da Vacina tem sido, muitas vezes, interpretada como um movimento originário, quase que exclusivamente, de manipulações políticas engendradas por segmentos da elite brasileira descontentes com os rumos assumidos pela República. Entretanto, não há como negar que a obrigatoriedade da vacinação por si só trazia força suficiente para provocar reações violentas em defesa da privacidade e da livre determinação (PORTO; PONTE, 2003).

${ }^{8}$ Autoconstrução- processo de produção de moradias de baixo custo, pela população de baixa renda, mediante o seu próprio trabalho (AURÉLIO, 2004).

${ }_{9}$ Favela- conjunto de habitações populares construídas de forma malfeita (por via de regra em morros) e com recursos higiênicos deficientes (AURÉLIO, 2004).
} 
Do final do século XIX até a 1930 aproximadamente, o foco da ação de construção de habitações era os trabalhadores, mas as novas moradias acabavam por adquirir diferentes padrões, que atenderam à demanda não só por parte dos operários, mas também dos setores mais abastados. Desta forma surgiram as vilas operárias, havendo basicamente dois tipos: as vilas de empresas, construídas pela própria indústria para abrigar seus trabalhadores, e as vilas de particulares, que eram construídas para ser fonte de renda através do aluguel. As primeiras eram construídas próximo às fábricas e ferrovias e muitas delas eram verdadeiras cidades, abrigando além das moradias, uma série de equipamentos como escolas, igreja, mercearia e clube. Já as vilas particulares faziam uso de toda racionalidade capitalista na produção das habitações, o que as tornava mais baratas, tanto para o capitalista quanto para o futuro morador, além de muito rentáveis em relação ao que se gastava na sua produção. Essas vilas não eram construídas somente por investidores individuais, mas também por empresas (BONDUKI, 1998).

O governo Epitácio Pessoa em 1920 deu início à política oficial de construção de habitação de aluguel para operários e proletários, a provisão de habitação para a força de trabalho teve um novo estímulo com o estabelecimento um programa oficial para a construção de acomodações para locação (WERNA et al., 2001). Em 1923, sob o governo de Arthur Bernardes, foi criada uma Caixa de Aposentadoria e Pensão para os funcionários das Estradas de Ferro do país, mais tarde seguida pela criação de Caixas para outras categorias. Em 1930 já havia 47 Caixas, contando com cerca de 140 mil associados. A partir de 1933 elas foram gradualmente substituídas pelos Institutos de Aposentadoria e Pensão (IAP's), cada setor trabalhista se enquadrando num IAP, havendo, por exemplo, o IAPI industriários; o IAPC - comerciários; o IAPB - bancários, entre outros (FINEP/GAP, 1985; WERNA et al., 2001). Ressalta-se a importância desses órgãos na atuação do Estado na produção direta de conjuntos habitacionais e no financiamento de habitações para trabalhadores durante o período populista principalmente. Durante a década de 30 , os IAPs construíram unidades horizontais isoladas e/ou semi-isoladas, similarmente aos programas anteriores. Na década seguinte, tais políticas passaram a construir conjuntos de edifícios, especialmente no caso do Instituto para Aposentadoria e Pensão dos Industriários (IAPI) (WERNA et al, 2001).

Em 1930 no início do governo Vargas foi adotada outra estratégia na produção de habitações de interesse social, que no momento significava basicamente abrigar o proletariado. O tema habitação social passou a ter muita importância, seguindo o projeto nacional-desenvolvimentista. O Estado fez intervenções nas situações habitacionais através de leis, como a Lei do Inquilinato de 1942, e da polícia sanitária. Por se tratar de uma ditadura, o governo via-se responsável por todas as questões econômicas e sociais, o que envolvia obviamente a produção das habitações operárias. A questão sanitária foi 
inicialmente deixada em segundo plano e o modelo adotado até então, a produção pelo setor privado, foi questionado pelo Estado, que logo pôs fim aos privilégios garantidos aos investidores, e passou ele próprio a pensar a produção de habitações, buscando a sua racionalização de modo a comercializá-las por um preço mais acessível e a privilegiar a autoconstrução de casas pelos trabalhadores na periferia (BONDUKI, 1985).

A classe operária deveria possuir todas as condições necessárias à sua sobrevivência e reprodução, pois passou a ser vista como a base para a industrialização do país. Houve então o fortalecimento dos órgãos estatais responsáveis pela produção habitacional (BONDUKI, 1998), as Carteiras Prediais dos Institutos de Aposentadoria e Pensões (IAP's), que no início da década de 40, já atuavam de forma significativa, como na construção do Realengo (Figura 6), o primeiro grande conjunto habitacional do país, além do Conjunto Residencial de Pedregulho de grande destaque na arquitetura brasileira (Figura 7) além de outros conjuntos como o Conjunto Residencial da Moòca e o Conjunto Residencial Vila Guiomar (Figuras 8 e 9).

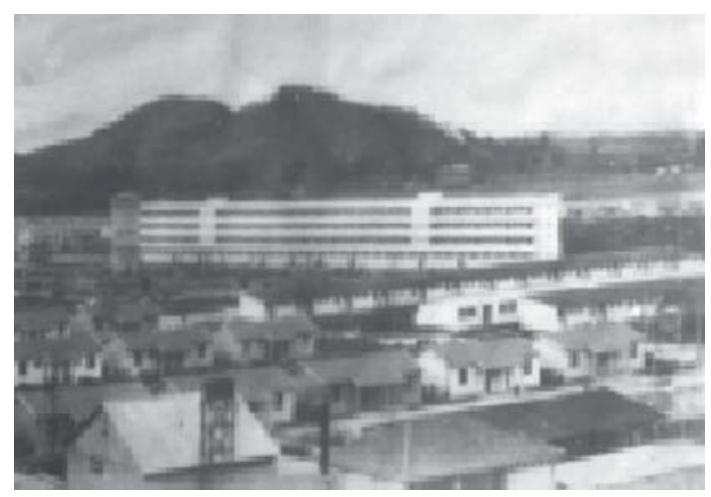

Figura 6. Conjunto Residencial do Realengo construído nos anos 40. Arquiteto Carlos Frederico Ferreira. Rio de Janeiro, décadas de 30 e 40.

Fonte: BONDUKI, 1998.

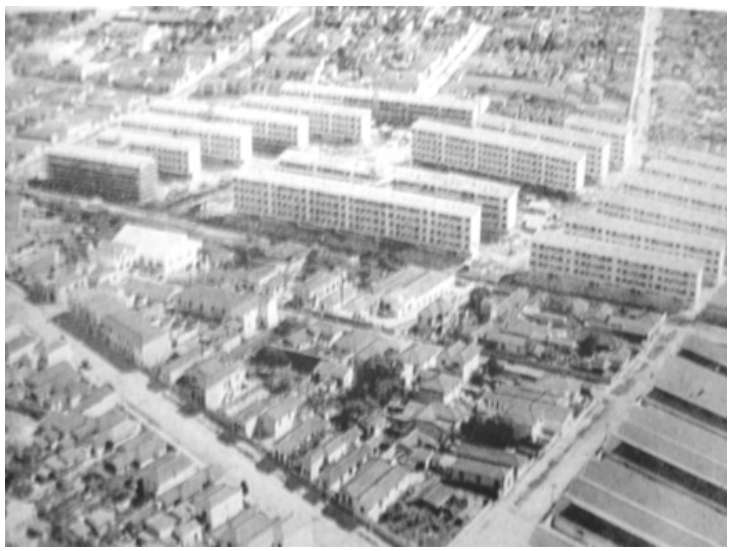

Figura 8. Conjunto Residencial da Moóca, Arquiteto Paulo Antunes Ribeiro. São Paulo, década de 40.

Fonte: BONDUKI, 1998.

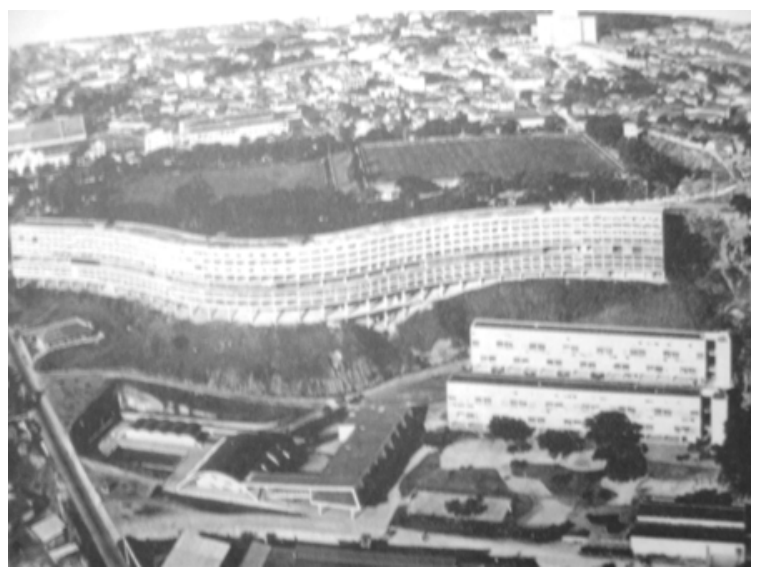

Figura 7. Conjunto Residencial Pedregulho, Arquiteto Afonso Eduardo Reidy. Rio de janeiro, décadas de 40 e 50.

Fonte: BONDUKI, 1998.

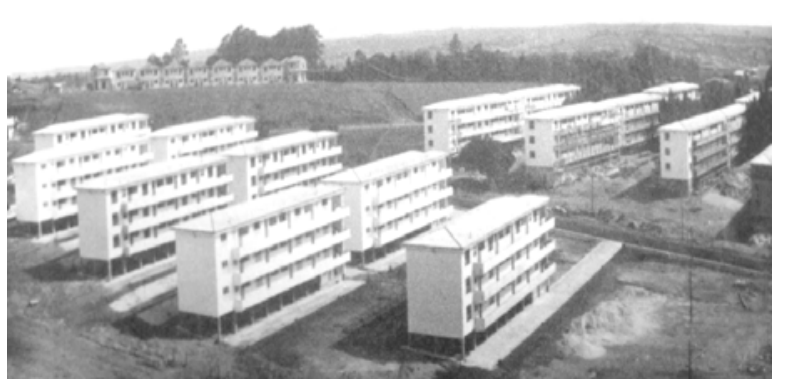

Figura 9. Conjunto Residencial Vila Guiomar, Arquiteto Carlos Frederico Ferreira. Santo André, SP, década de 40.

Fonte: BONDUKI, 1998. 
O Instituto de Organização Racional do Trabalho (IDORT) atuou a partir de 1932 difundindo métodos organizados de construir, promovendo o taylorismo: "produzir mais e melhor em um menor tempo era o objetivo básico da racionalização do trabalho" (CORREIA, 2004).

Com a Segunda Guerra Mundial as transações imobiliárias aumentaram, assim como os valores dos imóveis, tornando o setor um foco de investimentos. As possibilidades tornaram-se ainda maiores com a reorganização das Caixas Econômicas, criadas ainda no período de Regência e principalmente durante o Segundo Reinado, que destinavam cerca de $60 \%$ dos empréstimos ao crédito imobiliário. O destino desses imóveis, porém, não era a habitação para trabalhadores, mas sim para a classe mais alta, como edifícios de apartamentos para venda, constituindo parte do projeto de modernização de cidades como São Paulo e Rio de Janeiro, simbolizada pelo automóvel, pelas grandes avenidas e arranhacéus, enfim, aqueles que norteavam os discursos modernistas de arquitetos como Le Corbusier. Os investidores agora pouco atuavam em vilas operárias, contribuindo para a falta de moradias, desencadeando assim outra crise habitacional (BONDUKI, 1998).

O Estado por sua vez, passou por meio de uma série de medidas, a dificultar o crédito imobiliário empenhado que estava em fazer crescer a indústria brasileira, considerando que as empresas privadas pouco investiam no setor industrial, pois destinavam seu capital ao setor imobiliário, então bastante lucrativo. A população menos favorecida sofreu as conseqüências, mais uma vez surgiram dificuldades para obter financiamentos habitacionais e a falta de opções da classe média fez com que os novos aluguéis aumentassem, sendo esse aumento também repassado para a classe trabalhadora (BONDUKI, 1998).

Em 1942, o governo promulgou a Lei do Inquilinato, que congelava os preços de todos os aluguéis, isso porque ainda existiam as vilas operárias privadas, cujos aluguéis podiam prejudicar a tática do Estado de liberação do salário do trabalhador para atividades além do pagamento de sua moradia. No início, a população operária se beneficiou amplamente, pois era possível guardar parte de seus rendimentos, antes logo absorvidos pelos aumentos dos aluguéis. No momento seguinte, porém, observou-se o desinteresse do capital privado em investir no setor, que já não era mais tão rentável, primeiro pela menor oferta de alguns materiais, ocasionada pela Segunda Guerra Mundial e depois por não possuírem mais as isenções fiscais com as quais contavam antes do período Vargas. Mesmo os IAP's viram-se numa situação complicada com o congelamento dos aluguéis, pois isso implicava num menor rendimento para os seus próprios fundos (BONDUKI, 1998).

A Lei do Inquilinato prejudicou amplamente os trabalhadores e fez a elite acompanhar de perto a formação de favelas no centro da cidade. Como não era permitido aumentar os valores dos aluguéis, os investidores procuraram outros meios de obter lucro, 
meios às vezes legais, mas outras vezes ilegais e violentos, entre eles ameaça de despejo, que alguns proprietários conseguiam legalizar com a ajuda de advogados especializados. Depois que conseguiam livrar-se dos inquilinos, os locadores colocavam novamente o imóvel no mercado, mas desta vez cobravam luvas ${ }^{10}$ para alugar as residências, o que até então era feito somente para prédios comerciais. A grande maioria dos trabalhadores, uma vez despejados, não encontravam outra moradia, pois não tinham posses suficientes para pagar as luvas e aluguéis mais caros e como conseqüência muitos imóveis ficavam vazios. Muitas das antigas vilas operárias, cortiços e casinhas, quando não demolidos, eram destinados a outros usos, como fábricas e armazéns (BONDUKI, 1998).

No final do Estado Novo, o país teve a ponto de elaborar uma política habitacional consistente, que não se concretizou devido ao predomínio dos interesses econômicos ou corporativos, como o fortalecimento da estrutura dos IAP's nos governos seguintes. O fim do Governo Vargas interrompeu em 1945, um processo institucional que se encaminhava para a criação de uma política habitacional para o país, que na época contava com recursos vultuosos, reestruturação dos IAP's, criação de uma "superagência habitacional", capacitação técnica, reconhecimento pela sociedade e vontade política do governo. Esses interesses contraditórios presentes nos governos populistas, descontinuidade administrativa e falta de prioridade impedirão a implementação de uma política de habitação social de maior alcance até 1964 (BONDUKI, 1998).

Em 1946 Eurico Gaspar Dutra cria a Fundação da Casa Popular a qual, nunca funcionou da maneira esperada, produzindo ao longo de seu funcionamento menos unidades habitacionais que os IAP's, cuja função não era especificamente preocupar-se com a habitação popular, o que fazia pelo apelo social manifestado por seus integrantes (BONDUKI, 1998).

Como o Estado não parecia interessado em produzir ou estimular a produção de moradias de aluguel, a grande aspiração dos trabalhadores passou a ser a casa própria, mesmo que localizada na periferia onde as condições eram precárias. Muitos, porém, como forma de resistência se recusavam a mudar para a periferia, longe do seu local de emprego, e foram ocupar os terrenos vazios, essa ocupação contribuiu para o aumento das favelas.

Como já falado anteriormente, no Rio de Janeiro as favelas já existiam desde o início do século (1903 e 1907), mas em São Paulo, a crise habitacional da década de 40 fez com que elas surgissem. Os governos das cidades impulsionados pela expansão das favelas e pressionados pela elite, iniciaram a construção de alojamentos provisórios para alojar seus moradores, construídos muitas vezes no próprio terreno invadido por eles. As práticas de repressão e remoção dos desabrigados seguiram-se por mais três décadas (até os anos 70) em São Paulo. Devido a esse tipo de atuação, as favelas foram realmente contidas,

\footnotetext{
${ }^{10}$ Soma paga pelo inquilino ao locador na ocasião da assinatura do contrato de locação (AURÉLIO, 2004).
} 
abrigando uma parcela muito pequena da população. Relaciona-se a isso o fato de que nesse período aqueles que viviam nas favelas eram praticamente do mesmo nível sócioeconômico da população que construíra suas casas na periferia, assim, logo que fosse possível comprar um terreno muitos acabavam mudando-se para casas próprias longe do centro (Figuras 10 e 11) (BONDUKI, 1998).

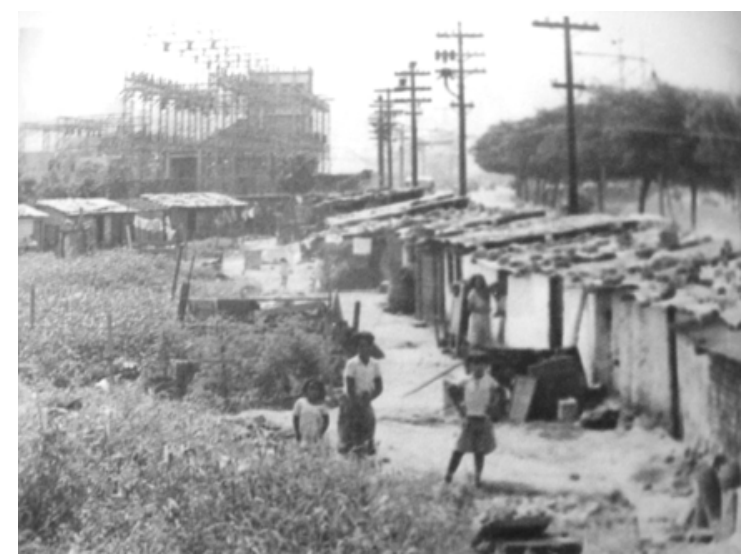

Figura 10. Favela Várzea do Penteado, junto à Avenida do Estado provavelmente a primeira de São Paulo, 1942.

Fonte: BONDUKI, 1998.

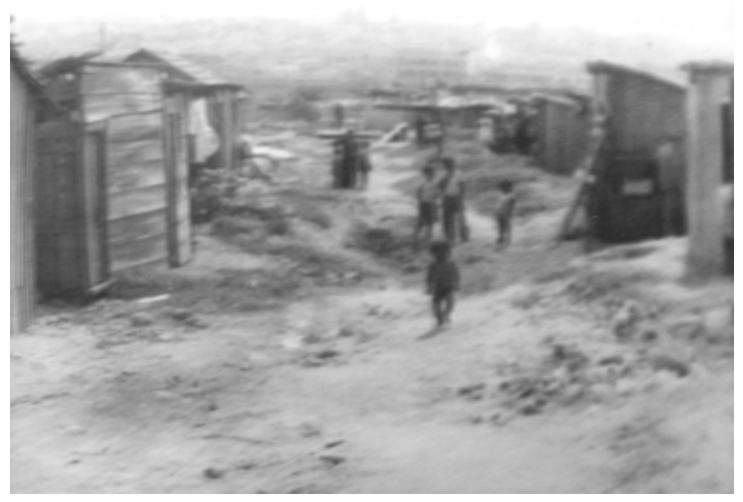

Figura 11. Favela na área reservada ao parque do Ibirapuera. São Paulo, 1951.

Fonte: BONDUKI, 1998.

De 1930 a 1955 houve uma crescente intervenção do Estado na economia, com ênfase numa política industrial de substituição de importações. O processo de urbanização intensificou-se, e havia um substancial aumento no número de favelas e outras formas de submoradias. A intervenção do Estado no setor habitacional foi inicialmente marcada por um refortalecimento do programa de caixas de aposentadoria e pensão (WERNA et al, 2001).

Em 1962 a habitação passou a ser problema de ordem maior e chegava a configurar uma crise. Em 1963, o presidente Jânio Quadros estabeleceu o Plano de Assistência Habitacional (PAH) com o intuito de construir 100.000 unidades em 18 meses. Houve uma tentativa de estabelecer o Instituto Brasileiro de Habitação (IBH) como um substituto para a Fundação da Casa Popular. Entretanto, nem a meta de produção habitacional, nem mesmo o estabelecimento do IBH foram bem-sucedidos (WERNA et al, 2001).

Em 1964 o déficit habitacional era de cerca de 8 milhões de unidades. Nesse mesmo ano, o golpe militar tirou João Goulart do poder. Uma das primeiras ações do novo governo ditatorial, que perdurou até 1986, foi a criação do Banco Nacional de Habitação, o BNH, que teve por meta instituir uma forte presença estatal no processo de provisão habitacional, que era também uma das áreas prioritárias naquele regime recém - instituído (WERNA et al., 2001). Criado com o objetivo de construir conjuntos habitacionais para eliminar as favelas, o BNH possuía outros objetivos, como o uso da casa própria para promover a acumulação de 
renda e atender à pressão das massas, podendo até ser investigada a hipótese de servir para atender aos interesses do setor pesado da construção civil (BONDUKI, 1998) e fortalecer a indústria da construção (MARICATO, 1987; MAUTNER, 1991 apud WERNA et al, 2001).

O BNH era o órgão gestor do Fundo de Garantia por Tempo de Serviço (FGTS), e regulava o Sistema Brasileiro de Poupança e Empréstimo (SBPE), que compunham juntos o Sistema Financeiro da Habitação (SFH) (WERNA et al., 2001). O FGTS era o que se destinava à produção de moradias para a população de baixa renda. O governo procurou também regulamentar o mercado de aluguéis através de leis federais e, em 1964, pôs fim ao congelamento dos preços. Havia ainda no BHN, a intenção de fazer crescer o mercado da construção civil.

Em 1965 o BNH passou a atuar dentro de um novo programa, os Institutos de Orientação a Cooperativas Habitacionais, que se desdobram a nível estadual nas Companhias de Habitação Popular (COHAB's). A partir da metade da década de 70 até o início da década seguinte, as COHAB's, viriam a produzir habitações para atender preferivelmente as famílias com renda superior a três salários mínimos. A produção de habitação tanto para o mercado de baixa renda quanto para o de média e alta renda, ficou a cargo de empresas privadas e o Estado atuava apenas como regulador.

Em 1976 inicia-se uma nova política no BNH tornando-se necessárias estratégias para quantificar e qualificar a escassez de moradias no país, de modo que o governo pudesse solucionar adequadamente o problema com políticas habitacionais que respondessem à demanda. Além do sistema convencional, em que eram produzidas unidades em larga escala surgiram os Planos de desenvolvimento Integrado do Serviço Federal de Habitação e Urbanismo (SERFHAU) (FINEP/GAP, 1985). Notou-se, porém, que a maior parte dos recursos do projeto era utilizada para atender às classes média e alta, a partir dessa informação foram criados programas para atender a população de baixa renda, quem realmente necessitava. Foram criados o Programa de Financiamento de Lotes Urbanizados (PROFILURB), o Financiamento para Construção, a Ampliação e Melhoria (FICAM), o Programa de Erradicação de Subhabitação (PROMORAR) e também um programa de ajuda assistida, o João-de-Barro (WERNA et al., 2001). Nessas iniciativas foram utilizados métodos construtivos baratos, através da importação de tecnologias, adequando-as às características socioeconômicas do país (Figura 12). Os processos construtivos utilizados variaram ao longo dos anos, com o predomínio dos sistemas construtivos tradicionais (entre 1965 e 1976) e da utilização de sistemas construtivos racionalizados (entre 1976 e 1986). Após os anos 80 há a predominância da alvenaria estrutural. Algumas tecnologias acarretaram mudanças na construção de habitações de interesse social na época, dentre elas destacam-se: em 1976, surgimento das fôrmas 
metálicas (sistema Túnel); em 1977 e 1978 utilização de alvenaria estrutural de blocos de concreto e sílico-calcário; e em 1980 inicia-se o uso de elementos pré-moldados de concreto (MAGNAVITA, 1994).
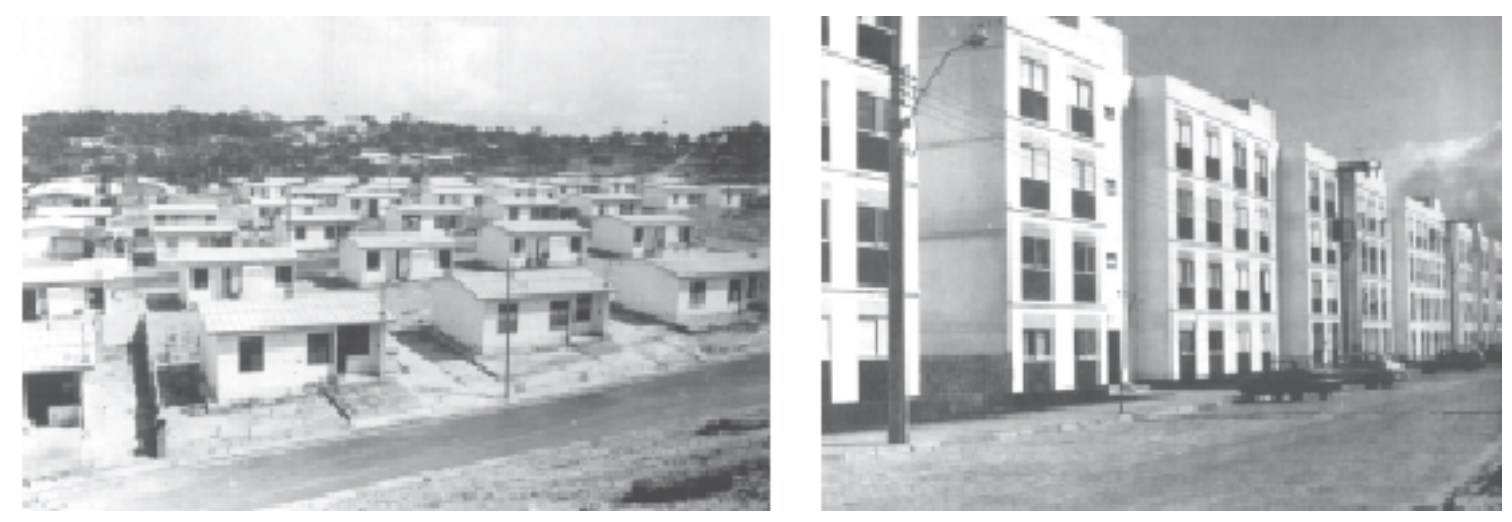

Figura 12. Conjuntos Habitacionais produzidos pelo BNH em Minas Gerais e Espírito Santo, 1979.

Fonte: FOLZ, 2003.

Paralelamente à oposição ao governo autoritário, nos anos 80 surgiram críticas às ações federais no campo da habitação. Foram apresentadas propostas alternativas de políticas urbanas e habitacionais na imprensa, nas universidades, nas organizações e movimentos comunitários (ARRUDA, 2000). A impossibilidade do Sistema se auto-sustentar devido à crise e à falta de retornos levaram à falência do BNH em 1986.

Após a extinção do BNH que até 1985 era subordinado ao Ministério do Interior e depois ao Ministério do Desenvolvimento Urbano e Meio Ambiente, em 1986 a Caixa Econômica Federal (CEF), assume suas funções. As questões habitacionais ficaram a cargo de diferentes secretarias e ministérios ao longo dos anos (1986 a 1990), passando por diversos ministérios e secretarias. Em 1993 foi subordinada ao Ministério da Ação Social, que é renomeado Ministério do Bem-Estar Social e cria-se então o Fundo Especial de Habitação Popular. Foram criados vários programas habitacionais que visavam atender à população de baixa renda sempre sob a supervisão da Caixa Econômica Federal, baseando-se principalmente em financiamentos, aos construtores ou aos próprios moradores. Ocorre também neste período associações com ONG's e universidades, buscando novas e melhores formas de produzir habitações (WERNA et al., 2001).

Em 1990, a Secretaria de Habitação e a de Saneamento eram subordinadas ao Ministério da Ação Social, que em 1993 passou a se chamar Ministério do Bem-Estar Social. Foi então criado o Fundo Especial de Habitação Popular e lançados os Programas "Habitar Brasil" e "Morar Município". Em 1995, foram criados os Departamentos de Habitação, de Saneamento, e de Programas e Projetos Especiais, atrelados à Secretaria de Política Urbana, no âmbito do Ministério do Planejamento e Orçamento. Neste mesmo ano, foram 
implementados os Programas "Pró-Moradia", "Pró-Saneamento" e "Carta de Crédito" (MPO, 1996 apud WERNA et al, 2001).

Segundo estudo da Fundação João Pinheiro, dentre as unidades construídas no país nos anos 80 e 90, a maioria não contou com as linhas de crédito governamentais, predominando a autoconstrução (FUNDAÇÃO JOÃO PINHEIRO, 2001). A função do Estado, na oferta de serviços e bens em geral, e da habitação em particular, tem sofrido profundas alterações. Ocorre uma tendência clara de redução da intervenção direta dos agentes públicos no processo de provisão da habitação e de se estimular a participação de agentes não-públicos, tais como o setor privado, as ONG's e a própria comunidade (WERNA et al., 2001).

Existe a participação das Organizações Não-Governamentais (ONG's), cujas ações se fazem junto aos movimentos de moradia, através de pontes entre a população e a assessoria técnica, como escritórios de arquitetura. Os recursos das ONG's geralmente são provenientes de doações, e às vezes do próprio Estado. Essas trabalham diretamente junto às comunidades e por isso sabem suas reais necessidades, oferecem assistência aos moradores de favelas e cortiços, e auxílio aos mutirões (WERNA et al., 2001).

Segundo Werna (2001) os pequenos construtores informais são uma ramificação do setor privado com presença significativa nessa área. Atuam juntamente com o processo de autoconstrução que sem dúvidas é responsável pela maior parte da produção de moradias de baixa renda. Provavelmente devido a pouca lucratividade que a produção de habitação para baixa renda oferece, as grandes empresas parecem não investir, em detrimento dos altos preços que podem ser cobrados de moradias para as classes média e alta. De qualquer forma, a atuação do governo junto aos pequenos construtores é sempre de grande utilidade, seja na isenção de impostos, na doação de terrenos ou na redução de juros bancários.

Com base em dados levantados em meados de 1997, em especial relativos aos modos de intervenção atuantes na Região Metropolitana de São Paulo destacam-se ações estaduais, como a Companhia de Desenvolvimento Habitacional e Urbano (CDHU), que atua no estado de São Paulo, cujos recursos provêm do ICMS - Imposto sobre Circulação de Mercadorias e Serviços, estatal. As unidades são produzidas pela CDHU dentro de diversos programas, com auxílio a mutirões, construção de unidades, além de programas que contam com o apoio de empresas privadas. Segundo Werna et al (2001), a CDHU é a instituição que mais produz habitações de interesse social no estado de São Paulo. A instituição também atua junto a assentamentos irregulares e áreas de riscos, buscando realojar adequadamente a população que necessita ser deslocada, investindo também em melhorias de infra-estrutura, tanto das habitações quanto das regiões escolhidas e em ações sociais de diferentes gêneros (CDHU, 2006). 
A Caixa Econômica Federal (CEF), banco estatal com programas de âmbito nacional que utiliza rendimentos de diferentes Fundos para a área habitacional. Substituiu o Banco Nacional de Habitação - BNH - extinto em 1986, como órgão a nível federal financiador de programas habitacionais. Embora a Caixa tenha assumido as atribuições do então $\mathrm{BNH}$, a fragmentação institucional e a redução dos recursos disponibilizados para investimentos, tem refletido na baixa atuação deste banco em programas que financiem a construção de habitações para a população de baixa renda (FOLZ, 2004).

A CDHU é o órgão executor da política estadual de habitação traçada pela Secretaria de Habitação do Governo do Estado para atender famílias com renda mensal na faixa de 01 a 10 salários mínimos. Além da área habitacional, ela atua também em projetos de desenvolvimento urbano. Já a Caixa Econômica Federal apresenta como grande problema subsidiar o financiamento de habitações para uma população com renda familiar até cinco salários mínimos. Esse problema torna-se mais sério quando a renda cai para três Salários Mínimos, faixa onde se insere $84 \%$ do déficit habitacional brasileiro (FOLZ, 2004).

Com relação aos projetos das habitações implantados pela CDHU (Figura 13), existe um Caderno de tipologias desta Companhia, com projetos prontos para serem implantados independentemente de sua localização no estado de São Paulo. Nele as tipologias se repetem, inclusive não importando se serão construídas por empreitada ou por mutirão. As exigências para projetos habitacionais feitas pela Caixa é que as unidades possuam área útil mínima de $37 \mathrm{~m}^{2}$, apresentando pelo menos dois quartos, sala, cozinha e banheiro (Figura 14). As demais exigências tratam do nível de acabamento que o imóvel precisa apresentar na sua entrega. Com base nas características das tipologias da CDHU nota-se que uma área de $45 \mathrm{~m}^{2}$ está tornando-se a área máxima de uma unidade habitacional, isso se comparada com a área exigida pela CEF, onde existe a exigência de que a unidade apresente dois dormitórios mesmo com $37 \mathrm{~m}^{2}$, de área somente. Portanto pode-se questionar se essa diminuição de área é justificada pela diminuição das famílias e se realmente atende às suas necessidades. Além destas duas instituições existem ações de âmbito municipal que procuram produzir moradias econômicas, como é o caso de algumas COHABs, remanescentes do período $\mathrm{BNH}$, assim como outros órgãos municipais que executam suas políticas habitacionais para atender a demanda da cidade (FOLZ, 2004).

Segundo Werna et al (2001) a população que vive em conjuntos habitacionais produzidos pelo Estado ou por empresas privadas, está medianamente satisfeita com a sua moradia. Entretanto, sabe-se que o número de unidades habitacionais produzidas anualmente é insuficiente para atender a quantidade de famílias com baixa renda. Muitas dessas famílias não têm condições sequer de adquirir as moradias vendidas nos conjuntos habitacionais. Esse pode ser uma solução arquitetônica e urbanística para responder à realidade de escassez de moradias apropriadas para o grande número de famílias sem 
condições financeiras de construir ou adquirir sua própria habitação. É preciso solucionar não só a questão que propriamente se refere à falta de habitações, mas também atender aos requisitos de segurança, conforto, ambientais, econômicos e higiênicos.
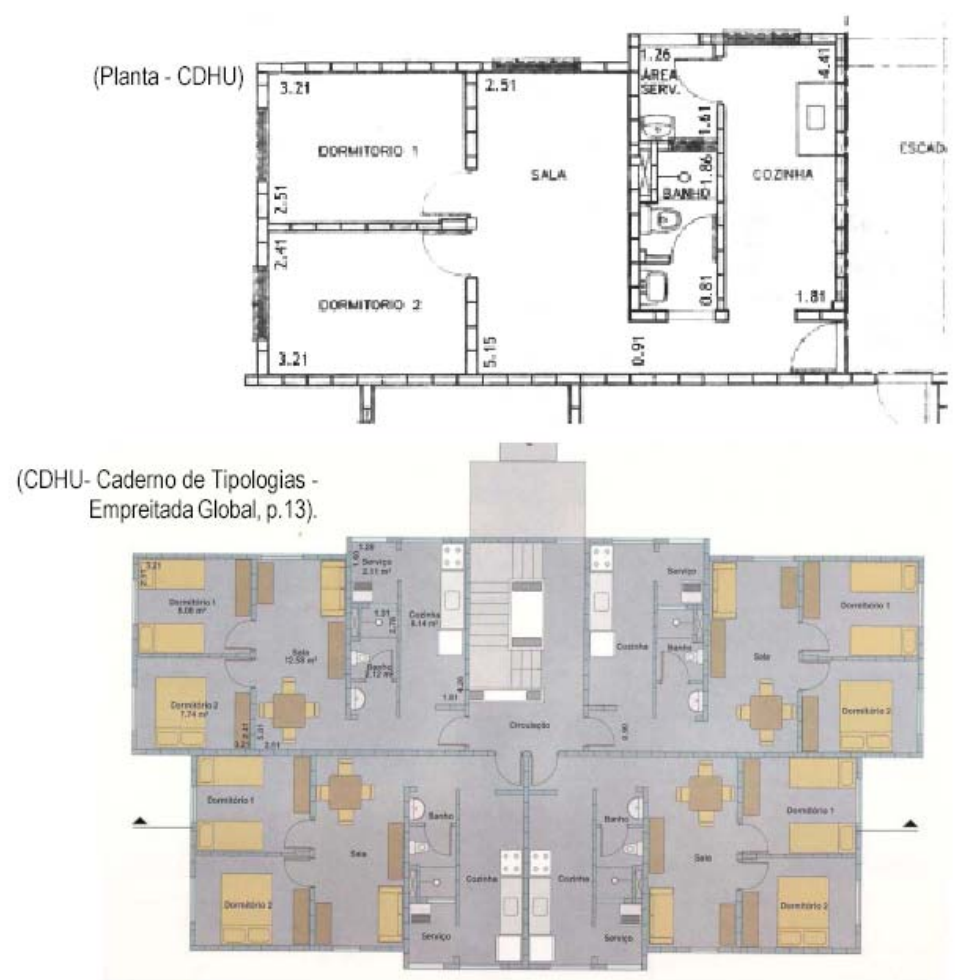

Figura 13. Exemplo de tipologia executada pela CDHU

Fonte: FOLZ, 2004.

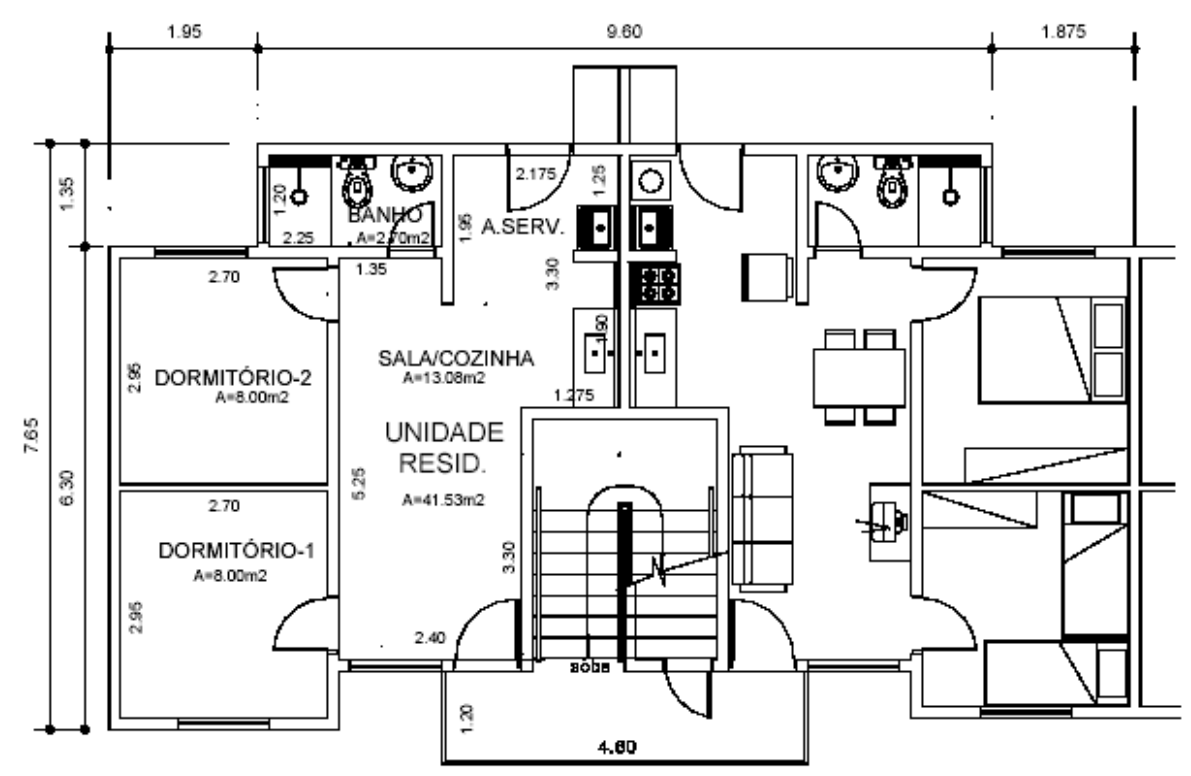

Figura 14. Exemplo de tipologia executada pela CEF.

Fonte: FOLZ, 2004. 


\subsection{Déficit Habitacional e Atualidades}

Em 2006 o Ministério das Cidades lançou o livro "Déficit Habitacional no Brasil: 2005". Esse livro contém um estudo realizado pela Fundação João Pinheiro, elaborado em parceria com a Secretaria Nacional de Habitação, do Ministério das Cidades. Por intermédio deste estudo sobre o déficit habitacional e a inadequação dos domicílios, é possível traçar a evolução dos indicadores nos anos de 1991, 2000, 2004 e 2005. Nesses números, apontados pelo IBGE na Pesquisa Nacional por Amostra de Domicílios - PNAD 2005, o déficit habitacional passou de 7.223 milhões em 2004 para 7.903 milhões de domicílios em 2005 (DÉFICIT, 2006).

De acordo com os dados estima-se o total das carências habitacionais no país em 7.902.699 moradias, o que significa $14,9 \%$ do total do estoque de domicílios. Desse total, $28,9 \%$ se situam nas regiões metropolitanas (Belém, Fortaleza, Recife, Salvador, Belo Horizonte, Rio de Janeiro, São Paulo, Curitiba e Porto Alegre). Em números absolutos, o déficit habitacional está predominantemente concentrado nas áreas urbanas, 6.414.143 domicílios. O déficit representa $14,3 \%$ do total dos domicílios urbanos e nas áreas rurais chega a 18,2\%, devido principalmente à presença de habitações em condições precárias, mais especificamente os domicílios rústicos (Tabela 1) (DÉFICIT, 2006).

Tabela 1. Déficit Habitacional* e Percentual em Relação aos Domicílios Permanentes por Situação do Domicílio - Brasil e Grandes Regiões - 2005.

\begin{tabular}{|c|c|c|c|c|c|c|c|c|}
\hline \multirow{3}{*}{ Especificação } & \multicolumn{4}{|c|}{ Déficit Habitacional } & \multicolumn{4}{|c|}{ Percentual dos Domicílios (\%) } \\
\hline & \multirow[b]{2}{*}{ Total } & \multirow[b]{2}{*}{ Urbano } & \multicolumn{2}{|c|}{ Rural } & \multirow[b]{2}{*}{ Total } & \multirow[b]{2}{*}{ Urbano } & \multicolumn{2}{|c|}{ Rural } \\
\hline & & & Total & $\begin{array}{c}\text { Extensão } \\
\text { Urbana }\end{array}$ & & & Total & $\begin{array}{c}\text { Extensão } \\
\text { Urbana }\end{array}$ \\
\hline Norte & 850.355 & 614.573 & 235.782 & 3.512 & 22,9 & 22,0 & 25,9 & 11,5 \\
\hline Nordeste & 2.743 .147 & 1.844 .068 & 899.079 & 5.508 & 20,6 & 18,9 & 25,1 & 7,8 \\
\hline Sudeste & 2.898 .928 & 2.725 .205 & 173.723 & 13.415 & 12,2 & 12,4 & 9,80 & 8,6 \\
\hline Sul & 873.708 & 755.589 & 118.119 & - & 10,4 & 10,8 & 8,50 & - \\
\hline Centro-Oeste & 536.561 & 474.708 & 61.853 & 420 & 14,0 & 14,4 & 11,5 & 6,1 \\
\hline Brasil & 7.902 .699 & 6.414 .143 & 1.488 .556 & 22.855 & 14,9 & 14,3 & 18,2 & 8,4 \\
\hline
\end{tabular}

Fonte: Elaborada a partir da tabela Dados Básicos Instituto Brasileiro de Geografia e Estatística (IBGE), Pesquisa Nacional por amostra de domicílios (PNAD), 2005.

* Não inclui a parcela de déficit por depreciação do imóvel.

Em termos da distribuição regional, as regiões Sudeste e Nordeste são responsáveis por $71,4 \%$ das carências habitacionais. Todavia, enquanto a maioria das deficiências do setor concentra-se na área urbana da primeira, no Nordeste a área rural tem papel de destaque. A distribuição do déficit urbano nas regiões pode ser visualizada na Figura 15.

De acordo com os dados do mesmo estudo, na região Sudeste se destacam os estados de São Paulo, Minas Gerais e o Rio de Janeiro. Na região Nordeste, o destaque é para Bahia, Maranhão, Pernambuco e Ceará. Quanto às demais unidades da Federação 
sobressaem apenas o Pará e Amazonas, na região Norte, Rio Grande do Sul e Paraná, na região Sul e Goiás na região Centro-Oeste. A análise em termos percentuais revela um padrão de comportamento bastante diferenciado entre as regiões. Na Norte e na Nordeste, a participação do déficit habitacional em relação ao total do estoque de domicílios é significativamente superior em relação às demais (DÉFICIT, 2006).

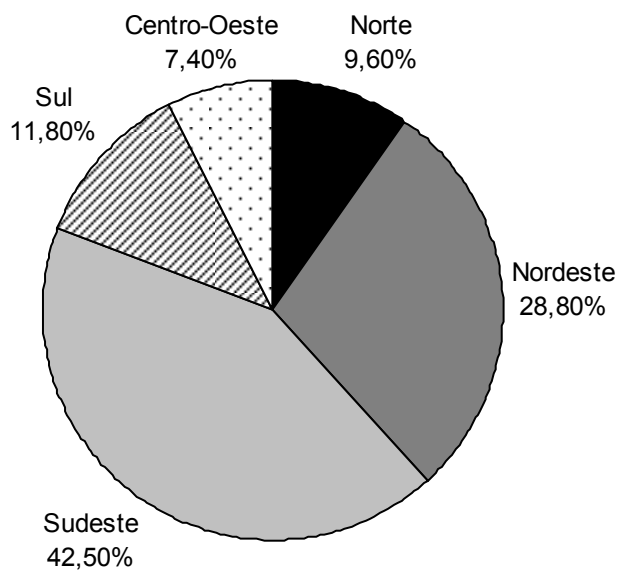

Figura 15. Distribuição do Déficit Habitacional Urbano, segundo Grandes Regiões Brasil - 2005

Fonte: Dados básicos: Instituto Brasileiro de Geografia e Estatística (IBGE), Pesquisa Nacional por Amostra de Domicílios (PNAD), 2005. (DÉFICIT, 2006).

A Figura 16 apresenta as estimativas do déficit habitacional no período considerado pelo estudo. Na evolução do déficit habitacional no intervalo de 2000 a 2005 é verificado um acréscimo, em termos absolutos, de cerca de 680 mil domicílios. As estimativas apontam para certa estabilidade entre 2004 e 2005 em todas as regiões. Na região norte de 2000 a 2005 a variação do déficit foi de 11,80 para $10,8 \%$, ou seja, ocorreu uma diminuição de $1 \%$. No nordeste observa-se a maior queda, de 39,5\% em 2000 para 35\% em 2005. A região sudeste apresentou o aumento mais significativo, de 32,4\% em 2000 para 36,7\% em 2005. Na região sul a variação foi de 9,4\% (2000) para 11,10\%(2005). Já a região Centro-Oeste permaneceu como déficit habitacional praticamente estável, cerca de 7,0\% (DÉFICIT, 2006). A região sudeste lidera os números do déficit nos anos de 2004 e 2005, perdendo somente em 2000 para o nordeste.

Apesar da existência de iniciativas o déficit de moradias no Brasil é extremamente elevado e caso não for combatido existe um sério risco de se confirmarem as projeções feitas pela ONU (Organizações das Nações Unidas) no Habitat (programa voltado para habitação realizado no Quênia, África Oriental), segundo as quais, no final da próxima década 1 em cada 4 brasileiros poderá estar vivendo em favelas. Essa advertência feita em 2005 continua a incomodar as autoridades brasileiras da área habitacional. No Habitat, 
participantes informaram que o número de favelados no mundo pode triplicar até 2050 , chegando até a casa de 3 bilhões de pessoas, caso não haja um significativo aumento dos investimentos públicos nesse setor (MAWAKDIYE, 2006).

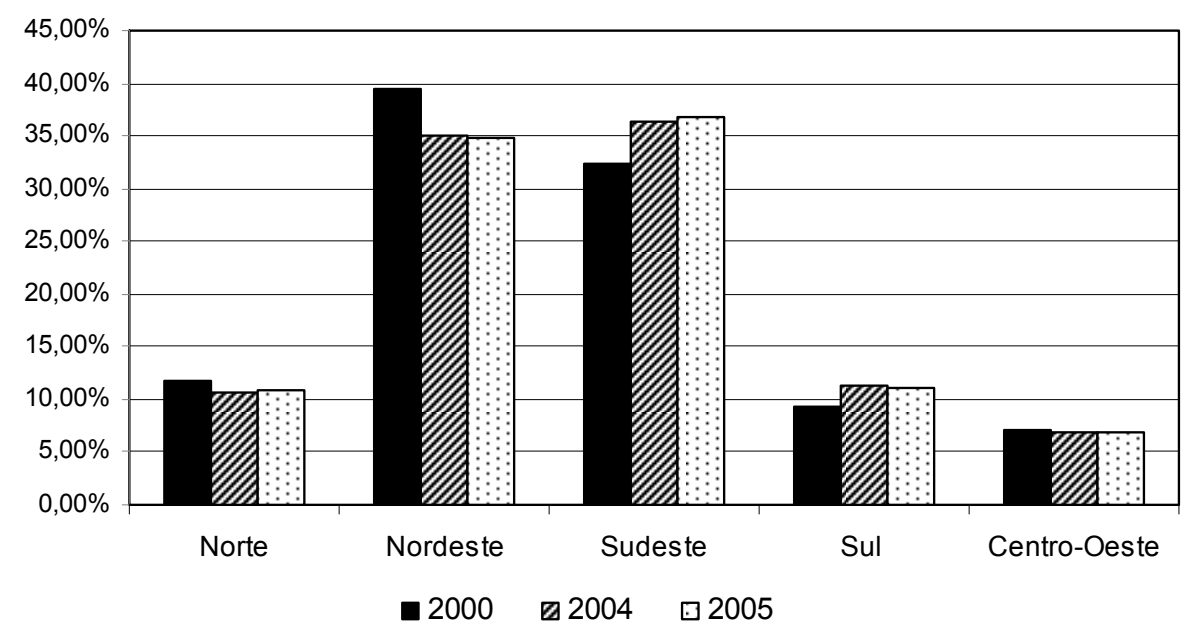

Figura 16. Distribuição Percentual do Déficit Habitacional, segundo Grandes Regiões Brasil - 2000-2004-2005

Fontes: Dados básicos: Instituto Brasileiro de Geografia e Estatística (IBGE), Pesquisa Nacional por Amostra de Domicílios (PNAD), 2004-2005 - Fundação João Pinheiro (FJP), Déficit Habitacional no Brasil 2000; Déficit Habitacional no Brasil, municípios selecionados e microrregiões geográficas (DÉFICIT, 2006).

A população que mora em habitações improvisadas corresponde a $20 \%$ do total de habitantes do Rio de Janeiro e de Belo Horizonte, 22\% em São Paulo, 31\% em Fortaleza e 46\% em Recife. Em São Paulo, onde vivem 11 milhões de pessoas, mais de 2 milhões estão nas favelas. Outro 1,5 milhão encontra-se em cortiços ou quintais. Para minimizar essa carência, é necessário que o país invista em habitação social cerca de $\mathrm{R} \$ 40$ bilhões entre 2007 e 2010, de acordo com projeção feita pela Fundação Getúlio Vargas (FGV); sendo $\mathrm{R} \$ 22,8$ bilhões para zerar o déficit e $\mathrm{R} \$ 17,9$ bilhões em novas unidades para atender ao crescimento vegetativo. Trata-se de uma meta considerada pelo governo como difícil de ser alcançada. Esse investimento nos últimos anos não ultrapassou $\mathrm{R} \$ 5$ bilhões anuais, por simples falta de recursos. Analisando a evolução da questão habitacional ao longo da história, percebe-se que a situação chegou a esse ponto problemático devido à ampliação do déficit que foi acumulando-se com o passar dos anos (MAWAKDIYE, 2006).

O problema habitacional entendido dentro de uma perspectiva sociológica reflete o dinamismo e a complexidade de uma determinada realidade socioeconômica. Desta forma, as necessidades do habitat não se reduzem exclusivamente a um instrumento material "mas dependem da vontade coletiva e articulam-se às condições culturais e a outros aspectos da dimensão individual e familiar" (BRANDÃO, 1984 apud DÉFICIT, 2006). Em suma, as demandas habitacionais não são apenas diferentes para os diversos setores sociais. 
Também variam e se transformam com a própria dinâmica da sociedade. Segundo Arruda (2000) a busca de soluções tecnológicas, econômicas e ambientalmente apropriadas para atender à carência habitacional é atualmente um dos maiores desafios urbanos para as políticas públicas das cidades brasileiras.

Diante desse cenário mostra-se urgente em nosso país além de um maior número de iniciativas por parte do governo, o aperfeiçoamento dos sistemas construtivos disponíveis para habitação de interesse social, assim como o desenvolvimento de novos sistemas, com a finalidade de contribuir para a produção de habitações com baixo custo e que atendam plenamente às exigências dos usuários (ABNT, 2005).

Tendo em vista a importância do sistema construtivo para a execução de habitações de interesse social, no próximo capítulo será abordado especificamente, dentre os vários sistemas construtivos empregados atualmente no Brasil, o sistema construtivo em painéis monolíticos de concreto armado moldados in loco, abordado neste trabalho. Esse sistema é empregado atualmente no Brasil tanto em habitações térreas como em edificações de múltiplos pavimentos. É considerado pelos pesquisadores e construtores da área de construção civil, como um sistema construtivo promissor para habitações de interesse social (IPT, 1998; CEF, 2003a). 


\section{SISTEMA CONSTRUTIVO DE PAINÉS 3.NOUÚTICOS DE CONCRETO MOLDADOS IN LOCO}

Os sistemas construtivos representam, dentro do quadro da construção de edificações, um determinado estágio tecnológico, que induz a forma de executar as construções, ou seja, sintetizam o conjunto de conhecimentos técnicos e organizacionais, possíveis de ser combinados. Este estágio acompanha o grau de desenvolvimento tecnológico em que se encontram a indústria de materiais de construção e a indústria de máquinas, equipamentos e ferramentas para a construção civil. Os Sistemas construtivos podem ser subdivididos em vários subsistemas, os quais são definidos segundo suas características e funções técnicas em relação ao edifício como um todo. É necessário ao iniciar a elaboração de um projeto de uma edificação habitacional ter em mente a infinidade de situações possíveis de serem propostas em termos de sistemas construtivos (MARTUCCI, 1999).

Atualmente são vários os sistemas utilizados no Brasil para a construção de habitações de interesse social. Dentre eles estão os sistemas convencionais, cujos principais elementos são executados no canteiro de obras e suas técnicas construtivas e materiais são tradicionais; os sistemas construtivos racionalizados, onde parte dos elementos são pré-fabricados e a montagem ocorre no local da obra, utilizando técnicas convencionais (sistemas em alvenaria estrutural, painéis de concreto ou painéis monolíticos moldados in loco); além dos sistemas industrializados, nos quais grande parte dos elementos são transportados da fábrica para o local da obra, onde ocorre somente sua montagem e acabamento (habitações pré-fabricadas em concreto, madeira e aço).

Os sistemas construtivos utilizados na produção das vedações na maioria das obras brasileiras apresentam um elevado desperdício de mão-de-obra, componentes e materiais, devido ao emprego de técnicas não racionalizadas. Além da função de dividir o ambiente em compartimentos, as vedações de um sistema construtivo deve também protegê-lo, servir de 
suporte e proteção às instalações do edifício, aos equipamentos de utilização do edifício, criar condições de habitabilidade e suprir a função estrutural ou parte da mesma (LORDSLEEM JÚNIOR, 1998).

Esta pesquisa se concentra no sistema construtivo racionalizado de painéis monolíticos de concreto moldado in loco. O sistema construtivo de painéis monolíticos de concreto moldado in loco apresenta inovações na execução da vedação, dos sistemas prediais e no assentamento das esquadrias. Nesse sistema construtivo as vedações de concreto armado, que possuem também função estrutural, são moldadas in loco utilizando fôrma dupla e podem incorporar, durante o processo de produção, parte das instalações dos sistemas prediais e esquadrias.

Segundo Lordsleem Junior (1998), o sistema de painéis monolíticos moldados in loco quando comparado à alvenaria tradicional apresenta desempenho semelhante, porém com vantagens potenciais em relação ao aumento de velocidade de produção, redução de custos de mão-de-obra e reduzida geração de entulho. Porém a questão relacionada ao desempenho precisa de maiores estudos, principalmente em relação ao conforto térmico e a durabilidade, que pode ser inclusive superior à alvenaria tradicional.

O painel maciço monolítico moldado in loco pode ser definido como um elemento do subsistema vedação de formato laminar, obtido por moldagem no seu local definitivo de utilização. Caracteriza-se ainda por ser monolítico, ou seja, quando solicitado tem capacidade de distribuir os esforços por toda parede e, além de ser contínuo, pois não apresenta juntas de dilatação aparentes (LORDSLEEM JUNIOR et al, 1998 a)

\subsection{Histórico}

Em 1966 a criação do Banco Nacional da Habitação - BNH fez despontar grandes programas habitacionais na década de 70 . Seguindo a filosofia de "industrialização", o setor de construção civil teve grande expansão até o início dessa década, começando a dar sinais de queda a partir do final desse período. Nos anos $80 \mathrm{com}$ a extinção do BNH e redirecionamento da política habitacional houve uma nova postura no mercado de edificações. Ocorreu a importação de novas tecnologias e o interesse crescente de construtoras e fabricantes de materiais pelos processos construtivos não convencionais. As empresas iniciaram então uma busca pela racionalização da produção de edifícios, por meio da otimização das atividades da obra, diminuição de prazos, minimização de custos, sem implicar na ruptura da base produtiva que caracteriza esse subsetor (LORDSLEEM JUNIOR, et al., 1998 b). A crise no setor se intensificou e devido à retração do mercado, a racionalização da produção de edifícios passa a ser uma das estratégias de ação das empresas construtoras para enfrentar a concorrência (BARROS, 1998). 
Dentre os sistemas construtivos desenvolvidos nesse período, destaca-se o sistema construtivo de painéis monolíticos moldados in loco ${ }^{11}$ (COHABS..., 1977 apud LORDSLEEM JUNIOR, et al., 1998 a). Desses processos construtivos que se consolidaram na década de 80 , somente a alvenaria estrutural e o sistema Outinord mostraram um potencial de avanço (TAUIL, 1987 apud LORDSLEEM JUNIOR, et al., 1998). Diante da modernização que o subsetor de construção de edifícios necessitava desde a década de 80, uma das alternativas foi a racionalização das vedações verticais por meio do aprimoramento do sistema de painéis monolíticos moldados in loco (LORDSLEEM JUNIOR, 1998 a).

De acordo com o sistema de fôrmas utilizado na execução e do tipo de material empregado o processo de produção pode diferir substancialmente. A tecnologia de produção desse sistema construtivo depende do tipo de fôrma empregado, sendo que atualmente no mercado estão disponíveis os sistemas de fôrmas tipo túnel com fôrmas metálicas; o tipo mesa/parede e o tipo parede; os dois últimos podendo ser metálicas ou mistas (metálicas e madeira). Nos sistema de fôrmas tipo túnel ocorre a execução simultânea de paredes e lajes; no sistema tipo mesa/parede ocorre a execução das lajes numa fase posterior à das paredes e o sistema tipo parede ocorre somente a execução de paredes (LORDSLEEM JUNIOR, et al., 1998 b)

O primeiro registro da utilização desse sistema construtivo no Brasil foi em 1979, utilizado pela COHAB-MG na cidade de Santa Luzia - MG, na execução de 46 unidades habitacionais no Conjunto Habitacional Carreira Comprida. Foram empregadas na época fôrmas metálicas (alumínio) e concreto celular. O peso final do produto acabado foi consideravelmente menor que o da alvenaria convencional, o que acarretou economia nas fundações. As características consideradas importantes do sistema foi não necessitar a quebra de paredes para instalações hidro-sanitárias e elétricas, além do bom desempenho em relação ao conforto térmico e acústico, em função das características do concreto celular. Pode-se ainda, acrescentar a essas vantagens a facilidade de instalação dos caixilhos.

As habitações construídas em Santa Luzia-MG receberam pintura direta sobre as paredes, não necessitaram de revestimento, pois apresentaram acabamento superficial de boa qualidade. Toda a execução da alvenaria, que incluiu montagem, concretagem e desmoldagem de cada unidade, levou em média 20 horas. No entanto alguns problemas constatados na obra fizeram com que o custo final excedesse em muito o planejado. Algumas edificações apresentaram patologias, dentre elas a presença de trincas e infiltrações na junção das telhas com a alvenaria em pontos específicos da casa. Após a conclusão das habitações, foram observadas algumas dificuldades na realização da ampliação, por exemplo, na execução de aberturas de portas e janelas, que poderia diminuir

\footnotetext{
${ }^{11}$ Sistema Outinord de fôrmas metálicas; e os sistemas de fôrmas metálicas e de madeira Geo-sistem e Preford.
} 
a resistência das paredes, assim como a presença de armadura nas mesmas (HABITAR, $1979)^{12}$.

Em 1980 este sistema foi utilizado pela COHAB-MG na construção do Conjunto Habitacional Dr. Pedro Afonso Junqueira em Poços de Caldas - MG. Nesse exemplo de emprego do sistema foi utilizado concreto tradicional com teor de cimento de $200 \mathrm{~kg} / \mathrm{m}^{3}$, com substituição de $10 \%$ de pozolana e a mesma porcentagem de cal. As habitações receberam cal lisa nas paredes externas e internas e nas áreas úmidas foi executada impermeabilização. Segundo a fonte pesquisada, as casas construídas possuíam laje inclinada de concreto, com o objetivo de criar um sistema de cobertura com bom desempenho térmico e acústico. Nesse caso a ampliação das residências tornou-se possível, pois as paredes não eram armadas. Houve uma considerável redução da mão-deobra, em função da maior produtividade do sistema, as vedações completas de uma habitação era construída em até 6 horas (HABITAR, 1980) ${ }^{13}$.

Nos anos 80 esse sistema também foi utilizado para a construção de habitações de interesse social nas cidades de Natal (RN) e Manaus (AM) (ABCP, 2002). No início da década de 90 novamente foram construídos edifícios de múltiplos pavimentos utilizando esse sistema em Manaus-AM, devido à escassez de componentes de alvenaria de boa qualidade no local. O concreto celular espumoso foi utilizado inicialmente devido à sua fluidez e a alta trabalhabilidade e por permitir a utilização de equipamentos convencionais na execução (mistura, transporte e lançamento) (LORDSLEEM JUNIOR, 1998).

Algumas empresas atuam no mercado com esse sistema, dentre elas: a INPAR (São Paulo-SP, Rio de Janeiro-RJ) que utiliza essa tecnologia em construções habitacionais multipavimentos (Figuras 17 e 18); a SERGUS (Barueri-SP) que utiliza esse sistema construtivo para a construção de edifícios habitacionais multipavimentos, com até 15 pavimentos-tipo (Figuras 19 e 20); a GETHAL (São Paulo-SP) que executa habitações térreas e multipavimentos (Figura 21); a empresa americana OUTINORD (Flórida, EUA) que utiliza esse sistema com fôrmas do tipo túnel para habitações térreas e outros tipos de construções, porém não atua no Brasil. As empresas IHL DO BRASIL, PRECISE FORMS (Missouri, USA) e a FORSA FORMALETAS (Cali, CO) atuam no mercado na confecção de fôrmas para esse sistema construtivo (Figuras 23 e 24).

Atualmente, com a expectativa de um aumento na escala de construção de habitações de interesse social, outras construtoras como a RODOBENS, a ROSSI e a BAIRRO NOVO estão utilizando esse sistema construtivo para dar mais rapidez à execução da obra (BOECHAT, 2008; TODESCHINI e BETTI, 2008) (Figura 22).

\footnotetext{
${ }^{12}$ SISTEMA COHAB - Forma Metálica/ Concreto Celular

${ }^{13}$ COHAB-MG - Sistema Industrializado
} 


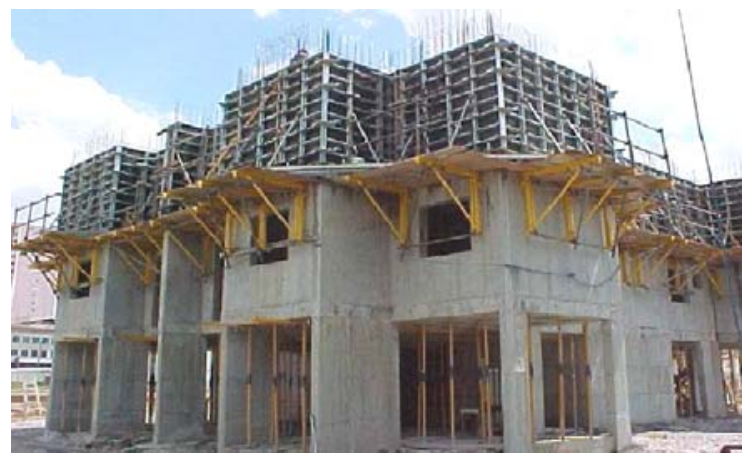

Figura 17. INPAR - Edifício multipavimentos, escoramento e posicionamento das fôrmas.

Fonte: INPAR, 2007.

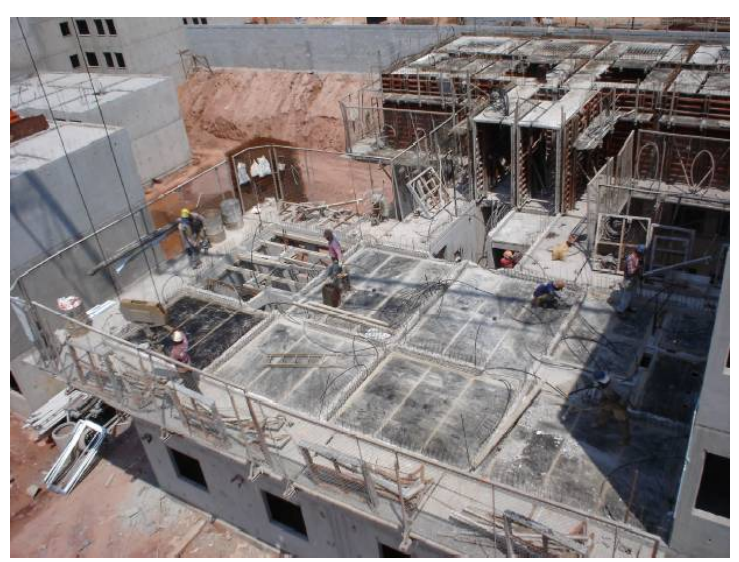

Figura 19. SERGUS - Vista da execução de um pavimento-tipo.

Fonte: IPT, 2007.

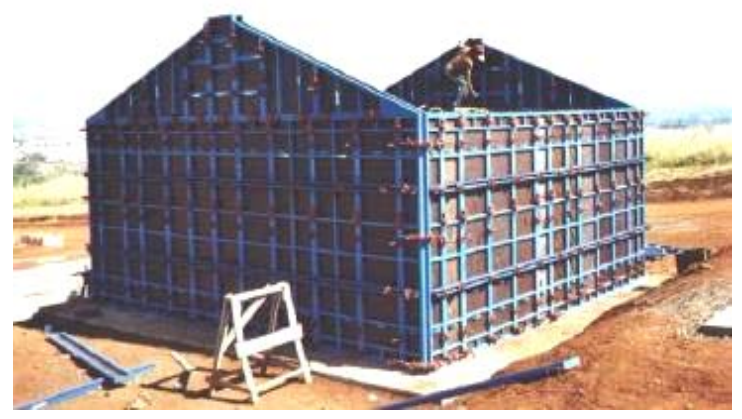

Figura 21. GETHAL - Sistema com formas de madeira para habitações térreas.

Fonte: GETHAL, 2006.

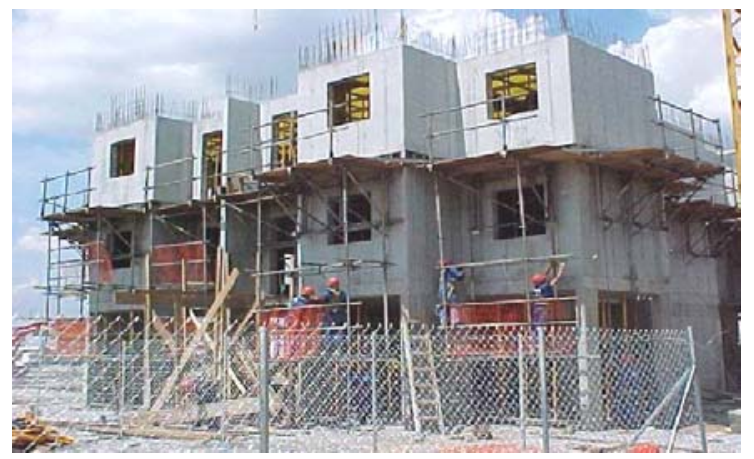

Figura 18. INPAR - Edifício multipavimentos, após a retirada das fôrmas.

Fonte: INPAR, 2007.

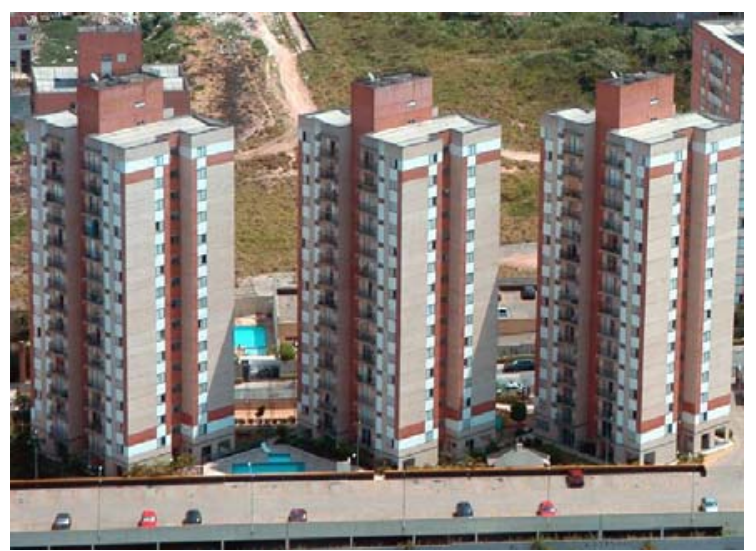

Figura 20. SERGUS - Edifício padrão dois dormitórios (PP2D48).

Fonte: IPT, 2007.

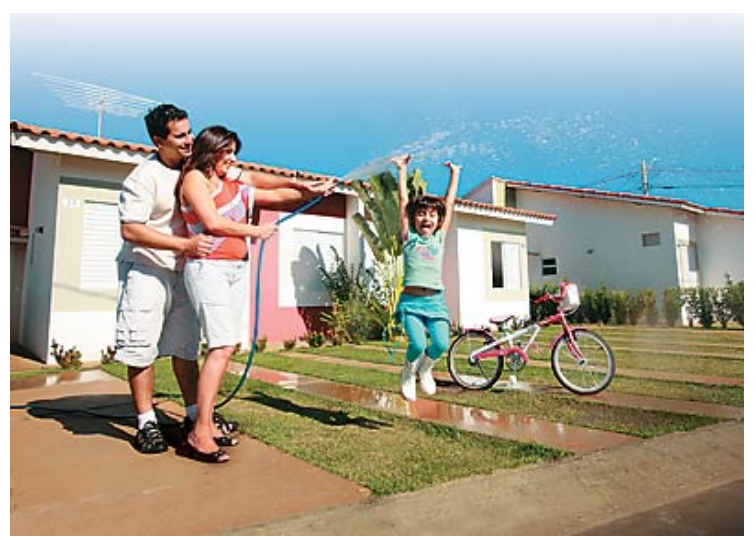

Figura 22. RODOBENS - Habitações térreas executadas com sistema de moldes.

Fonte: TODESCHINI e BETTI, 2008. 


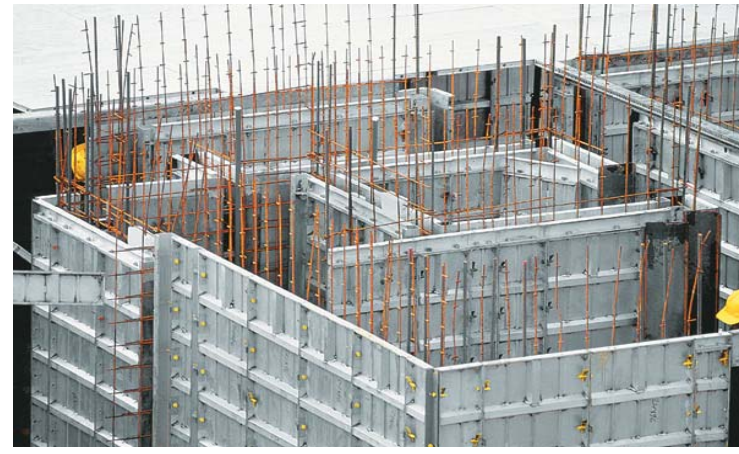

Figura 23. FORSA FORMALETAS Montagem das fôrmas e armaduras.

Fonte: FORSA FORMALETAS, 2007.

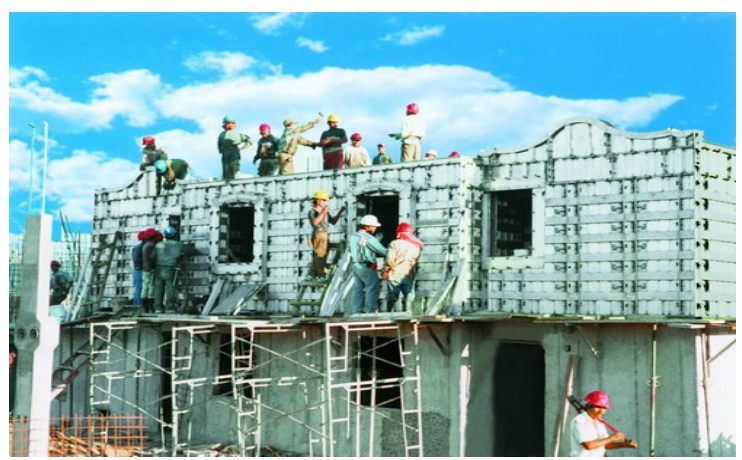

Figura 24. FORSA FORMALETAS Montagem das fôrmas.

Fonte: FORSA FORMALETAS, 2007.

\subsection{Descrição do Sistema Construtivo de Painéis Monolíticos Moldados in loco}

Nesse sistema construtivo a estrutura de fundação é usualmente do tipo radier para as habitações térreas, porém pode variar de acordo com o terreno em questão (Figuras 25 a 28). A fundação tipo radier tem a vantagem de proporcionar uma base de trabalho apropriada para as ações das equipes de montagem das fôrmas e instalações, além de permitir o posicionamento das instalações de entrada e saída pelo piso, tais como as redes de esgoto (ABCP, 2002).

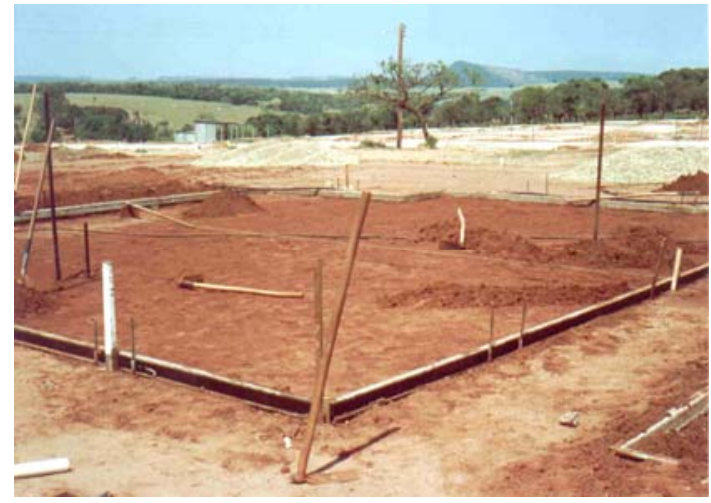

Figura 25. Execução da fundação em radier: fôrmas. Analândia-SP.

Fonte: ROSSIGNOLO, 2005.

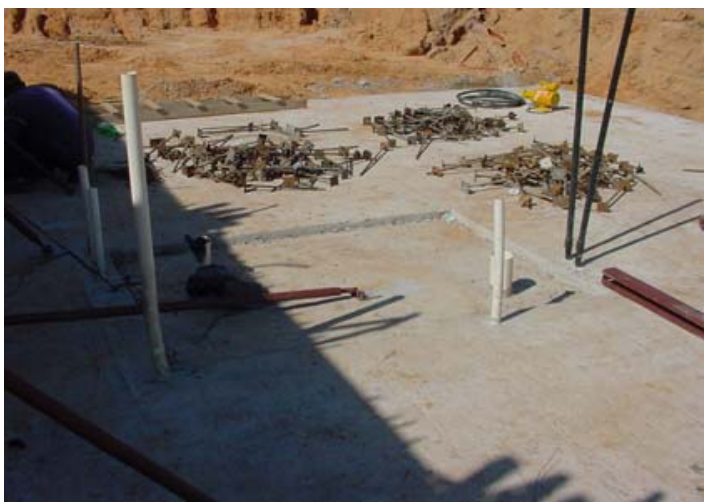

Figura 26. Fundação em radier: detalhe do rebaixo do banheiro e das tubulações. Analândia-SP.

Fonte: ROSSIGNOLO, 2005. 


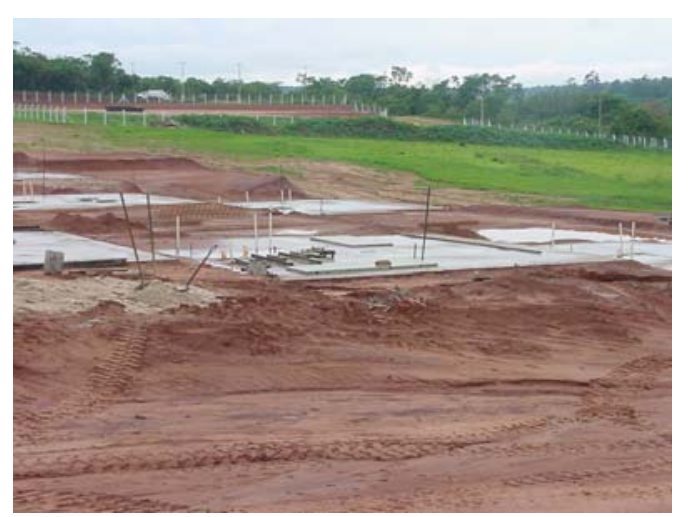

Figura 27. Fundação em radier. Analândia-SP.

Fonte: ROSSIGNOLO, 2005.

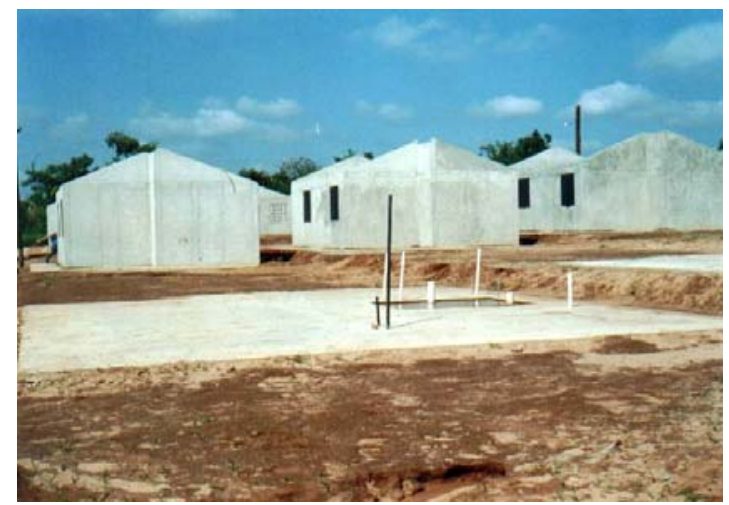

Figura 28. Fundação em radier concretada. Analândia-SP.

Fonte: ROSSIGNOLO, 2005.

Na execução das vedações utilizam-se fôrmas na conformação desejada dos painéis (Figuras 29 a 32).

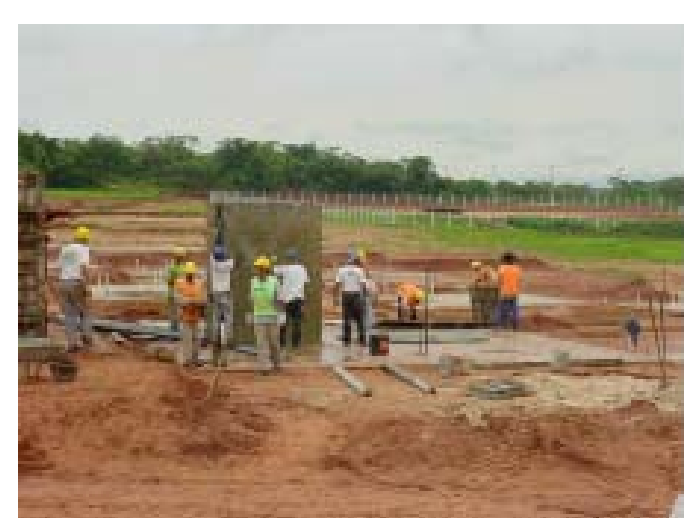

Figura 29. Fôrmas metálicas sendo montadas no local de implantação. Analândia-SP.

Fonte: ROSSIGNOLO, 2005.

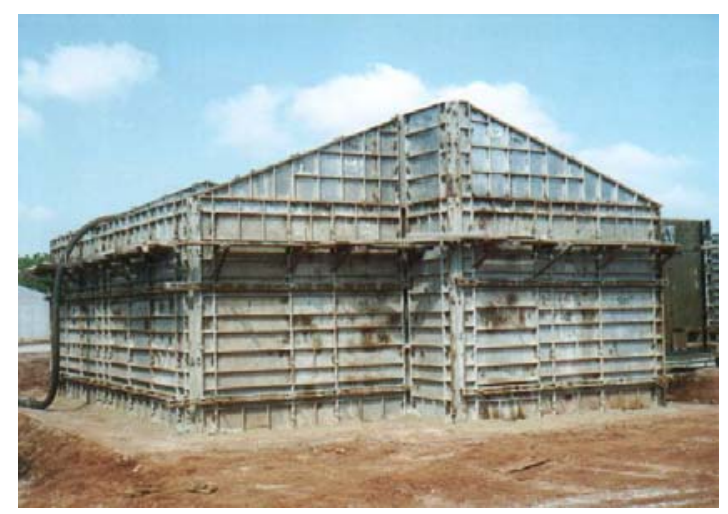

Figura 31. Visão geral das fôrmas das vedações montadas. Analândia-SP.

Fonte: ROSSIGNOLO, 2005.

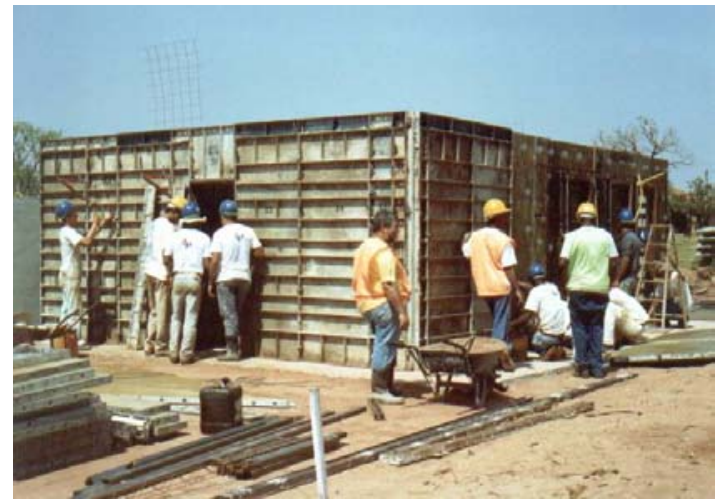

Figura 30. Fechamento das fôrmas metálicas. Analândia-SP.

Fonte: ROSSIGNOLO, 2005.

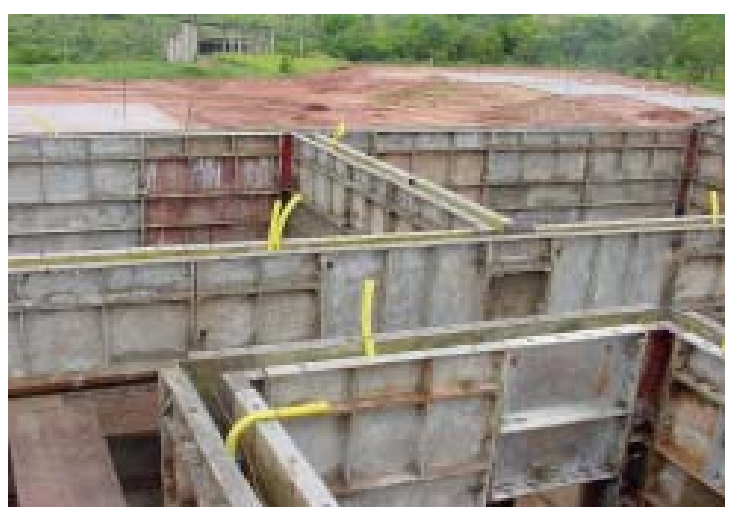

Figura 32. Fôrmas dos painéis de uma edificação térrea posicionadas, detalhe das instalações elétricas embutidas Analândia-SP.

Fonte: ROSSIGNOLO, 2005. 
Atualmente para esse sistema construtivo estão disponíveis no mercado três sistemas de fôrmas, sendo eles:

Sistemas de fôrmas de madeira tradicional e racionalizado: os elementos constituintes das fôrmas (molde, estrutura do molde, escoramento e acessórios) são compostos basicamente por peças de madeira, montados e desmontados individualmente, ocasionando um grande consumo e desperdício de material e mão-de-obra. No sistema racionalizado também ocorre o uso de madeira, porém existe a preocupação com a criação de módulos e ciclos de utilização, o que resulta em maior produtividade (LORDSLEEM JUNIOR, et al., 1998);

Sistema de fôrmas metálicas: nesse caso os componentes são metálicos e foram desenvolvidos com o objetivo de multiplicar o número de usos de um mesmo painel, racionalizando a utilização de fôrmas. Basicamente, hoje são utilizadas fôrmas de aço ou alumínio, que apresentam vantagens como rapidez na montagem.

Sistema de fôrmas mistas: nesse sistema chapas de madeira compensada compõem o molde, enquanto a estrutura do molde incorpora componentes metálicos. $O$ objetivo nesse caso definição de um módulo, com dimensões tais que permitam o reaproveitamento e que possam ser deformados íntegros, além da utilização de dispositivos de união ou encaixe metálicos em substituição de peças usualmente pregadas.

As fôrmas podem ser ainda classificadas de acordo com peso como leves (transportáveis sem equipamento por um ou dois operários) ou pesadas (necessitam de equipamento para serem transportadas). Essa classificação é importante para o planejamento das operações de montagem e escolha do sistema de fôrmas. Em função do material com os quais são constituídas as paredes monolíticas moldadas in loco podem ser de solo não-estabilizado, de solo-cimento, de concreto tradicional, de concreto com agregados leves, de concreto celular ou argamassa celular (LORDSLEEM JUNIOR, et al., 1998 a).

Os painéis verticais de vedação geralmente possuem função estrutural, são executados no local utilizando concreto armado. Nesse sistema construtivo, todos os painéis de uma edificação são produzidos de uma só vez e apresentam geralmente espessura variando entre 8 e $12 \mathrm{~cm}$. As aberturas de portas são mantidas para permitir a circulação dos operários durante a execução da montagem das formas. Os módulos das formas para o sistema convencional são produzidos de modo que possam ser carregados por uma ou duas pessoas e são fixados de acordo com as exigências do projeto (ABCP, 2002). No caso da forma tipo túnel existe a necessidade de grua tanto para a movimentação das fôrmas do concreto e de outros insumos.

As armaduras nesse sistema têm a função de resistir às tensões iniciais geradas pela retração do concreto, provocada pela perda de água nas primeiras idades (Figura 33), 
além de servir também para resistir a esforços de flexo-torção nas paredes por ações externas e esforços devidos à variação da temperatura externa (ABCP, 2002). Devem ser utilizados espaçadores (Figura 34) para garantia de posicionamento das armaduras e dos painéis em de acordo com o projeto, especialmente alinhamentos e espessura (ABCP, 2002).

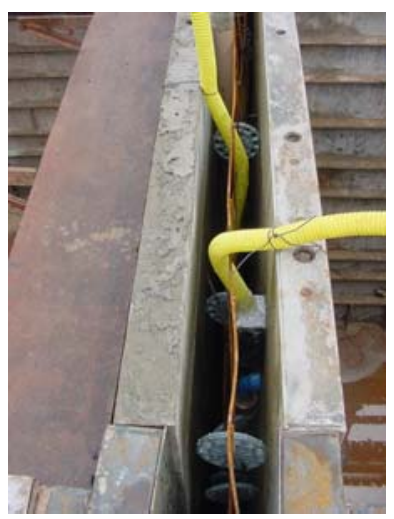

Figura 33. Detalhe dos espaçadores e das armaduras, neste caso tela eletrosoldada. Analândia-SP.

Fonte: ROSSIGNOLO, 2001

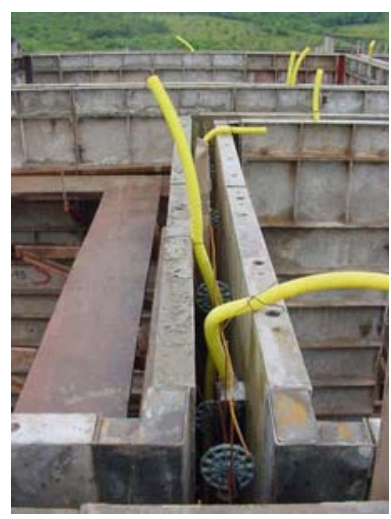

Figura 34. Espaçadores utilizados nas armaduras. Analândia-SP.

Fonte: ROSSIGNOLO, 2001.

As esquadrias e parte dos sistemas elétrico e hidráulico, como tubulações, quadros, registros e caixas de passagem já podem ser posicionados no interior da fôrma nos locais previstos em projeto antes da concretagem. Assim, após o término da concretagem são obtidas todas as vedações da edificação com as esquadrias e parte dos sistemas elétrico e hidráulico já instalados (Figuras 35 e 36).

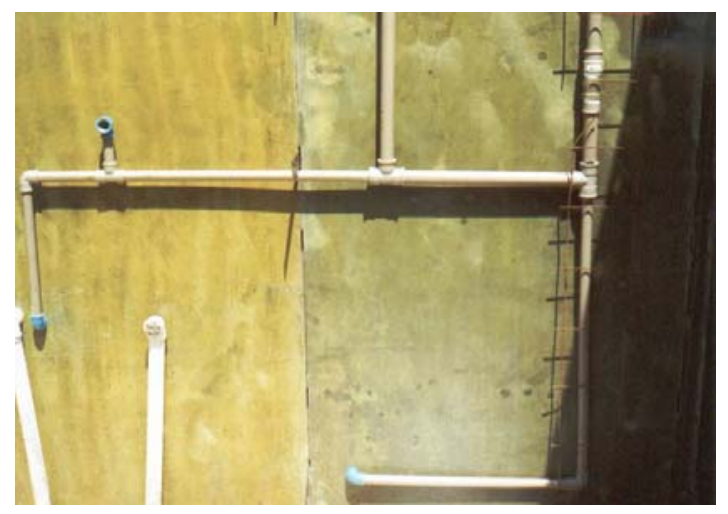

Figura 35. Painel metálico com tubulação elétrica já fixada. Analândia-SP.

Fonte: ROSSIGNOLO, 2005.

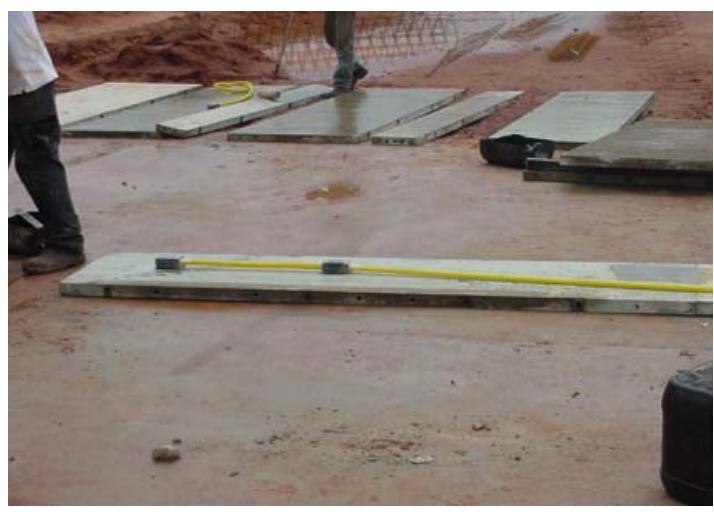

Figura 36. Instalações hidráulicas fixadas nos painéis metálicos. Analândia-SP.

Fonte: ROSSIGNOLO, 2005.

As esquadrias são fixadas por meio de um dos seguintes processos: colocação prévia de contramarcos pré-fabricados em madeira, aço ou concreto diretamente no interior das fôrmas e encaixe das esquadrias após desforma; e a colocação da esquadria completa, 
devidamente vedada, na sua posição definitiva, dotada de grapas para garantir fixação após a concretagem (ABCP, 2002). As esquadrias podem ser de madeira ou metálicas e sua estrutura deve resistir aos esforços da concretagem por meio de sua rigidez ou de contraventamentos que são removidos após desmoldagem (Figura 37 e 38).

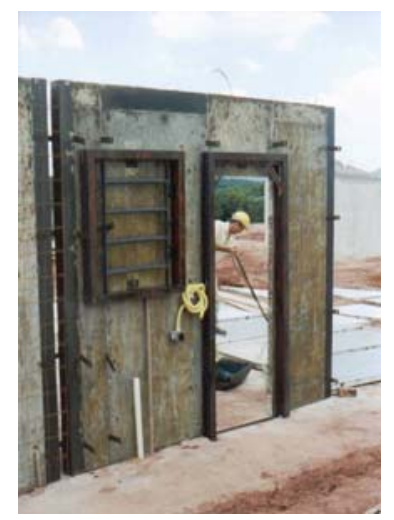

Figura 37. Painel com esquadrias fixadas. Analândia-SP.

Fonte: ROSSIGNOLO, 2005.

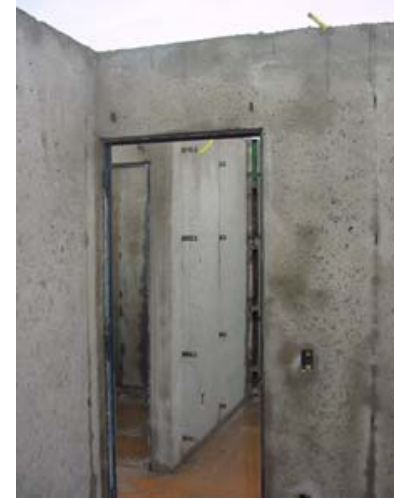

Figura 38. Detalhe de esquadria após desforma. Analândia-SP.

Fonte: ROSSIGNOLO, 2001.

Usualmente, o lançamento do concreto nas fôrmas pode ser feito utilizando caçambas içadas por guindastes ou utilizando bombeamento (Figuras 39 e 40). É necessário nos dois casos que o concreto apresente trabalhabilidade adequada para 0 lançamento. O abatimento do tronco-de-cone (NBR NM 67) deve estar em torno de $160 \pm 10$ mm (Figuras 41 e 42).

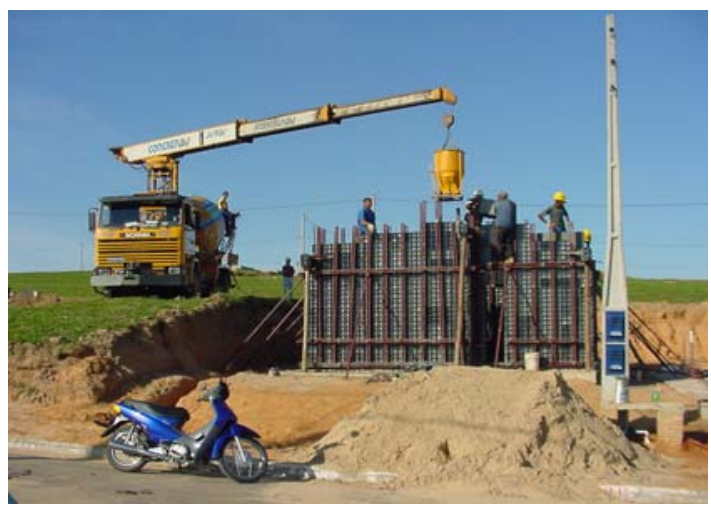

Figura 39. Guindaste utilizado na concretagem. Monte Mor-SP.

Fonte: ROSSIGNOLO, 2006.

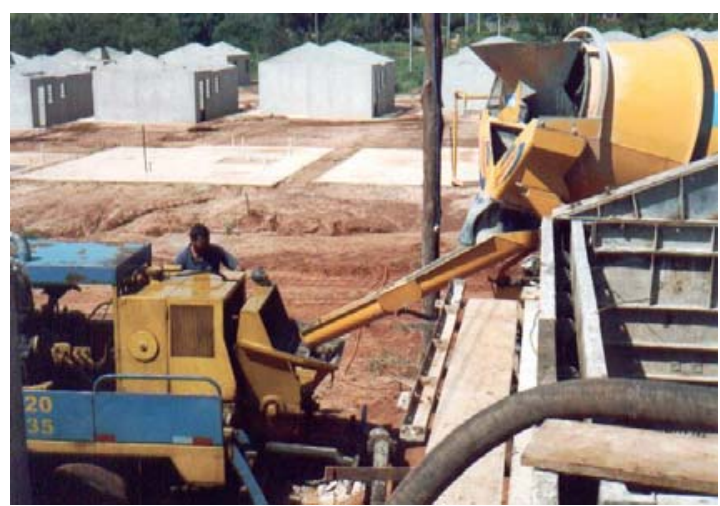

Figura 40. Concretagem por bombeamento. Analândia-SP.

Fonte: ROSSIGNOLO, 2005. 


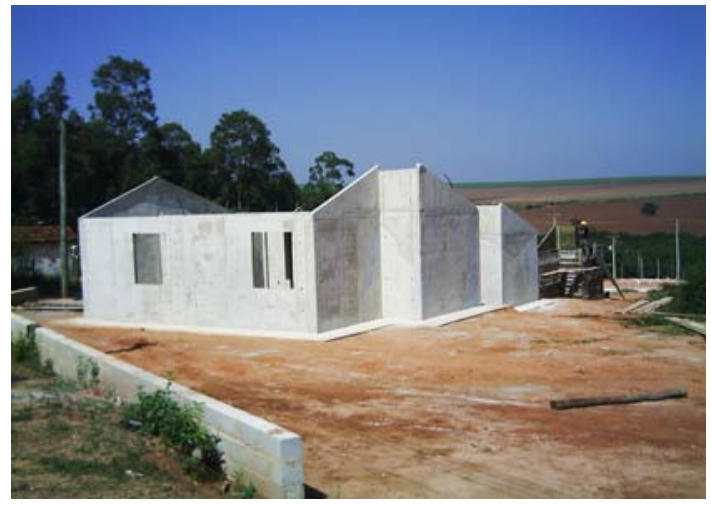

Figura 41. Vedações após a desforma. Santa Maria da Serra-SP.

Fonte: ROSSIGNOLO, 2006.

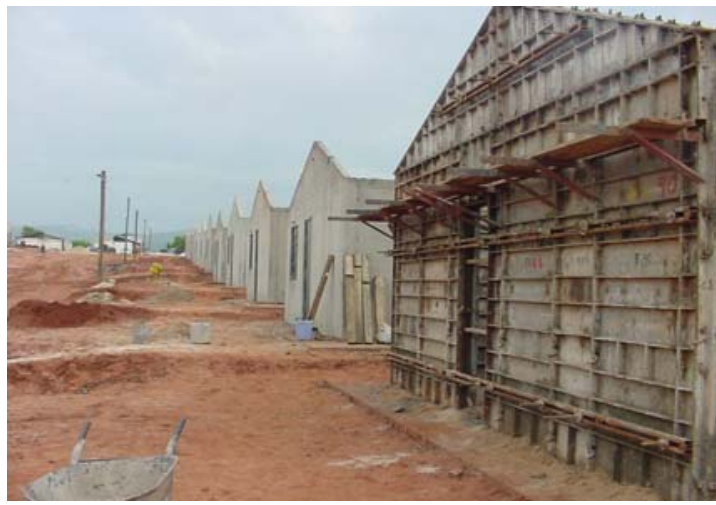

Figura 42. Vista geral do sistema produtivo. Analândia-SP.

Fonte: ROSSIGNOLO, 2005.

Para as habitações térreas a cobertura pode ser feita com a utilização de telhas de concreto, cerâmicas ou metálicas (Figuras 43, 44 e 45), e a estrutura pode ser de madeira, ou pré-fabricada, acelerando o processo de execução.

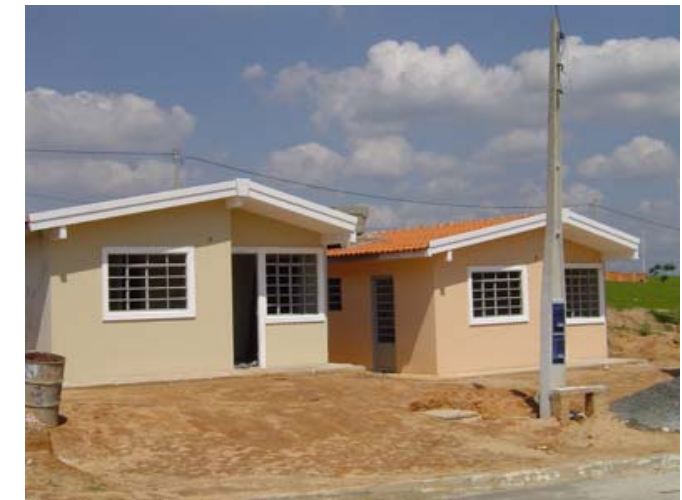

Figura 43. Habitação com laje inclinada. Monte Mor-SP.

Fonte: ROSSIGNOLO, 2005.

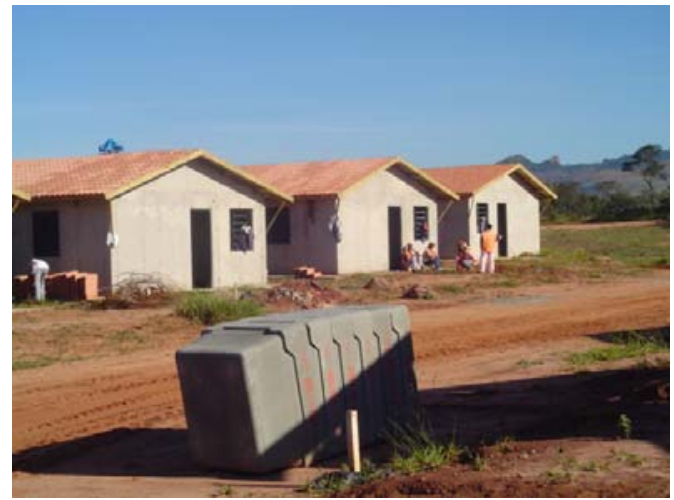

Figura 44. Habitações com cobertura em telha cerâmica. Analândia-SP.

Fonte: FERRARI, 2005.

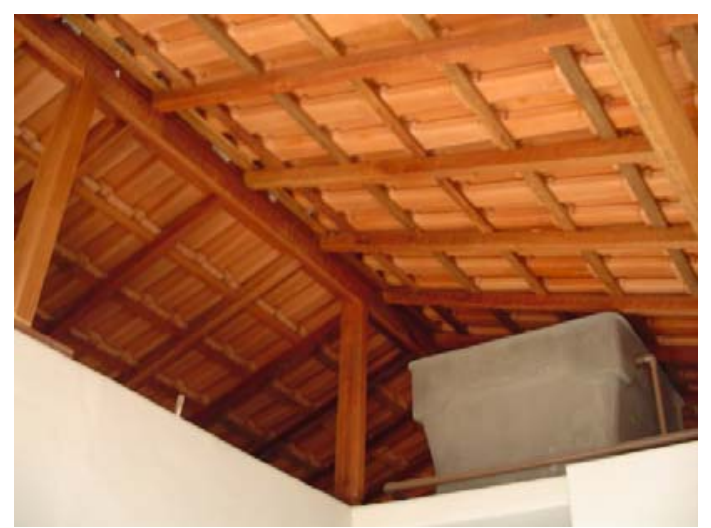

Figura 45. Detalhe do telhado com telhas cerâmicas. Analândia-SP.

Fonte: ROSSIGNOLO, 2005. 
Existe também a possibilidade de utilizar nesse sistema as lajes normalmente empregadas nos sistemas tradicionais, como a laje mista (vigas pré-fabricas de concreto com elementos de enchimento (cerâmico ou EPS) e com cobrimento de concreto ou a laje pré-fabricada de concreto. As lajes quando do tipo inclinadas, possibilitam a aplicação das telhas diretamente sobre as ripas fixadas nas lajes, possibilitando desta forma a redução da estrutura do telhado.

De acordo com a complexidade do projeto e da equipe disponível, a montagem de todos os painéis (montagem de fôrmas, armaduras, instalações e concretagem) pode ocorrer em apenas 24 horas em média. É possível que para cada conjunto de fôrmas seja executada todas as vedações, com instalações elétricas e hidráulicas embutidas e todas as esquadrias instaladas. Isso considerando que a desforma ocorra já nas primeiras horas do dia seguinte de acordo com as condições climáticas do local. Logo após a desmoldagem procede-se a correção de possíveis imperfeições nas paredes, caso existam, isso antes de aplicar o acabamento final dos painéis. Nas Figuras 46 a 48 são mostradas alguns exemplos habitações prontas construídas utilizando esse sistema construtivo, executadas nas cidades de Monte Mor, Analândia e Santa Maria da Serra do estado de São Paulo utilizadas nas ilustrações deste trabalho.

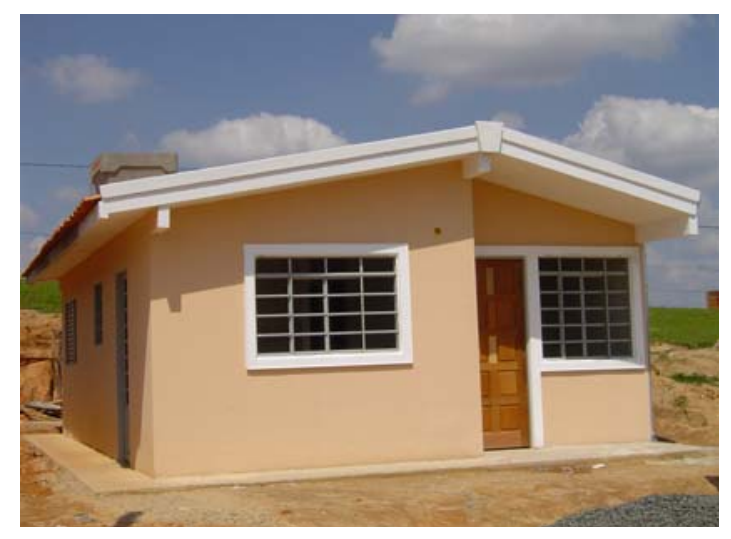

Figura 46. Habitação em Monte Mor-SP. Fonte: ROSSIGNOLO, 2005.

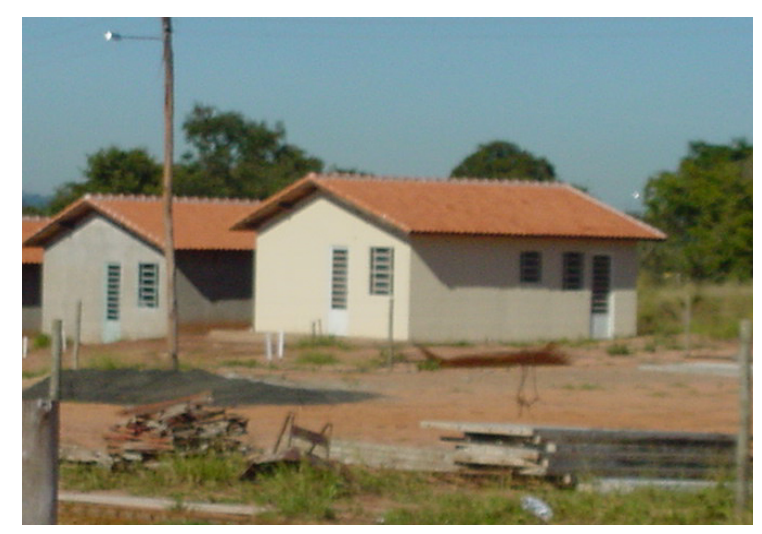

Figura 47. Habitações em Analândia-SP.

Fonte: ROSSIGNOLO, 2005.

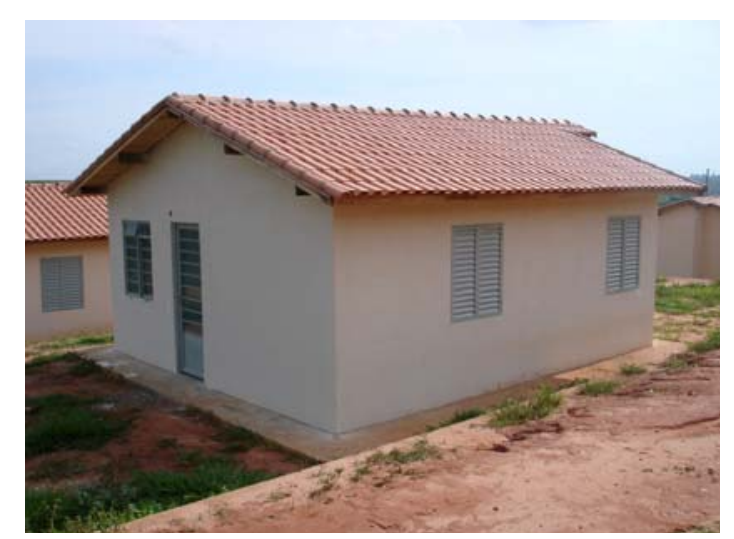

Figura 48. Habitação Santa Maria da Serra-SP.

Fonte: ROSSIGNOLO, 2005. 
Após apresentar as características e particularidades do sistema, a seguir (Quadro 1) são citados alguns benefícios e desvantagens de sua utilização quando comparados aos sistemas normalmente empregados para construção habitacional, segundo Lordsleem Junior et al (1998 a, b).

Como citadas anteriormente, as características do concreto empregado nesse sistema construtivo, principalmente a trabalhabilidade tem um papel fundamental na execução e no desempenho dos painéis de vedação. Geralmente utiliza-se o concreto tradicional para edifícios de múltiplos andares e o concreto leve celular para edificações térreas. Para a utilização nesse sistema construtivo o concreto deve apresentar trabalhabilidade adequada para moldagem (abatimento do tronco-de-cone geralmente acima de $150 \mathrm{~mm}$ ); resistência à compressão entre 8 e 12 horas acima de 1,0 MPa para possibilitar a desforma sem causar danos aos painéis; resistência à compressão aos 28 dias de acordo com projeto estrutural e com o ambiente de exposição; assim como deve apresentar durabilidade em conformidade com a tempo de vida útil de projeto.

Em 2004 após a realização de estudos no Laboratório de Construção Civil (LCC) da Escola de Engenharia de São Carlos (EESC - USP) observou-se que o concreto leve (com agregados leves) apresenta grande potencial de utilização nesse sistema. Isso por apresentar resistência à compressão compatível com o concreto tradicional, porém com menor massa específica; além de características relacionadas ao conforto térmico compatíveis com o concreto celular, apresentando maior durabilidade que o mesmo. Além disso, apresenta trabalhabilidade adequada ao bombeamento e a moldagem (abatimento do tronco-de-cone em torno $160 \pm 10 \mathrm{~mm}$ ) e condições favoráveis de produção e cura.

Apesar desse sistema construtivo apresentar maior produtividade e menor desperdício, para a consolidação da utilização do mesmo ainda são necessários alguns estudos sobre as suas propriedades, como a massa específica do concreto e a espessura do painel a ser utilizado de acordo com o local a ser empregado. Essas características estão ligadas diretamente às questões de desempenho térmico. Existe algumas recomendações de órgãos governamentais brasileiros como a Caixa Econômica Federal (CEF) e Companhia de Desenvolvimento Habitacional e Urbano (CDHU), segundo as quais deve-se a utilizar para esse sistema concretos leves com massa específica em torno de $1700 \mathrm{~kg} / \mathrm{m}^{3}$, e espessura dos painéis de vedação variando entre 8 e $12 \mathrm{~cm}$, com a finalidade de melhorar o desempenho térmico dos painéis. 
Quadro 1. Sistema construtivo de painéis monolíticos moldados in loco. Vantagens e Desvantagens.

\begin{tabular}{l} 
VANTAGENS \\
\hline Racionalização da produção das vedações, com alta \\
produtividade, baixo índice de perdas e mão-de-obra \\
reduzida; \\
Ocorre o aumento da produtividade, devido a \\
existência de uma seqüência definida de tarefas \\
(locação, montagem das fôrmas, posicionamento das \\
instalações, fixação dos negativos das esquadrias, \\
com possibilidade dos batentes na própria fôrma, \\
resultando na redução do custo global da obra);
\end{tabular}

Aumento da qualidade tanto nos serviços de execução quanto no acabamento superficial (final da parede);

As fôrmas são reutilizáveis e cada conjunto produz os painéis de vedação de uma habitação em 24 horas, podendo incluir a laje na cobertura;

Existe por meio do sistema a possibilidade da vedação exercer função estrutural, onde as paredes são adotadas para distribuir o carregamento;

A uniformidade da parede que permite a utilização de revestimento de pequena espessura, sem necessidade de regularização, ou mesmo a eliminação do revestimento de regularização, como argamassas e pastas, antes da aplicação da pintura;

As atividades independem da habilidade do operário, não exigindo qualificação, apenas treinamento. O consumo de mão-de-obra é reduzido quando comparado ao processo construtivo tradicional;

Existe uma seqüência ordenada de trabalho, que permite uma simplificação das tarefas;

O emprego desse sistema construtivo exige organização e maior planejamento do processo de construção, as soluções devem ser tomadas previamente à execução;

Proporciona o aumento da área útil da habitação, quando comparado aos sistemas convencionais com paredes com espessura acima de $15 \mathrm{~cm}$, pois os painéis de concreto usualmente apresentam espessura final entre 8 e $12 \mathrm{~cm}$.

\section{DESVANTAGENS}

Elevado custo das fôrmas que deve ser reduzido em diversas utilizações. Essa necessidade de alta reutilização ocorre apenas quando se tem uma demanda constante e uma tipologia habitacional definida e ainda é viável para um número de unidades superior a 50 ;

Há na maioria dos casos necessidade de equipamentos de grande porte para o emprego das fôrmas metálicas, que são geralmente pesadas e de grandes dimensões, os mesmo são necessários para o transporte das fôrmas ou do volume de concreto requerido;

$\mathrm{Na}$ execução com paredes monolíticas moldadas in loco, algumas limitações podem ser apontadas em relação ao projeto principalmente em relação à modificações devido à função estrutural;

No emprego de fôrmas tipo túnel e mesa/parede, há restrições quanto ao emprego de lajes com diferentes níveis, devido ao deslocamento de fôrmas em cada andar nos ciclos da produção;

No emprego das fôrmas tipo túnel e mesa/parede, há paredes com função de vedação que não são determinadas pelo método construtivo e quando ocorre o emprego de alvenaria de blocos, não conseguem acompanhar a velocidade com que são executadas as paredes estruturais;

As patologias, principalmente as fissuras, a umidade e o desempenho insatisfatório decorrentes do inadequado emprego do passado contribuem para a pouca utilização no presente.

Fonte: Elaborado a partir de Lordsleem Junior et al. (1998).

No entanto, essas recomendações não consideram a influência da tipologia construtiva (tipo de cobertura, por exemplo, que é a grande responsável pela maior parte das trocas térmicas) assim como não incluem as particularidades de acordo com as condições climáticas regionais. Por esse motivo no próximo capítulo será apresentada uma discussão sobre os concretos usualmente empregados nesse sistema construtivo, assim como sobre a utilização do concreto estrutural leve (com agregados leves) como alternativa aos concretos anteriormente citados. 


\section{CONCRETOS UTLZADOS NOS PAINÉS 4 MONOÚTICOS MOLDADOS IN LOCO}

O concreto tem um papel fundamental na execução e no desempenho dos painéis de vedação e usualmente são utilizados o concreto tradicional e o concreto leve celular no sistema construtivo de painéis de concreto moldados in loco (ABNT, 1992 e ACl, 2004). Além desses dois tipos de concretos, serão apresentadas também nesse capítulo as características e propriedades do concreto com agregados leves, apresentado nesta pesquisa como alternativa aos concretos anteriormente citados.

\subsection{Concreto Tradicional}

O concreto tradicional, composto por cimento Portland, brita, areia e água, é empregado no Brasil atualmente pela empresa INPAR para execução de edifícios de múltiplos pavimentos utilizando o sistema construtivo de painéis monolíticos moldados in loco (Figura 49), especialmente por apresentar valores de resistência à compressão acima de $20 \mathrm{MPa}$. Porém algumas aplicações para habitações térreas foram observadas na década de 80 em Santa Luzia - MG.

Esse tipo de concreto, apesar de atender aos requisitos estruturais, pode apresentar algumas deficiências para aplicação nos painéis de vedação, em relação aos concretos leves, por exemplo, pode ocorrer um aumentando as cargas na fundação e na estrutura da edificação, além de apresentar isolamento térmico e acústico inferior ao obtido para os concretos leves (MEHTA e MONTEIRO, 1994). O desempenho térmico dependerá também da espessura dos painéis. 


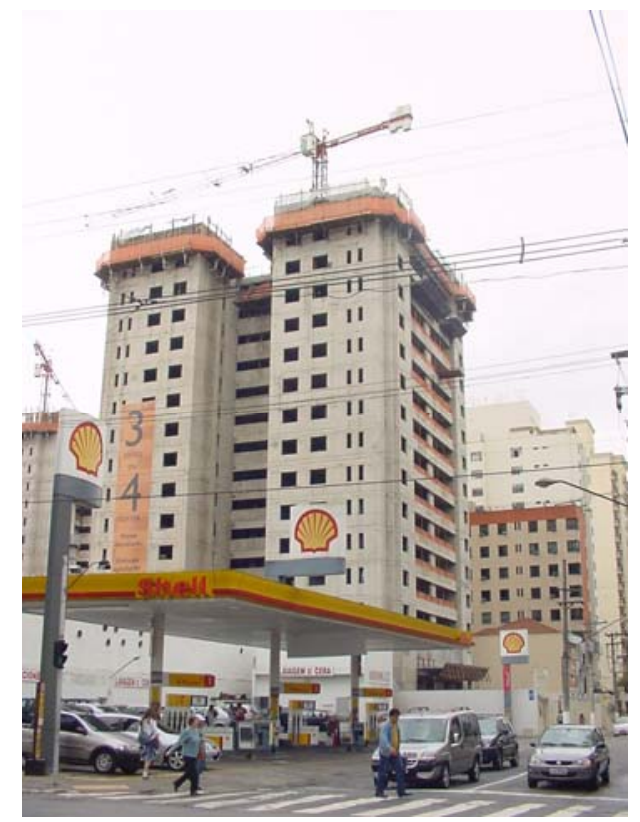

Figura 49. Edifício de múltiplos andares executados com sistema de painéis monolíticos. São Paulo - SP.

Fonte: ROSSIGNOLO, 2005.

\subsection{Concretos Leves}

A definição usual de concreto leve identifica concretos com menor massa específica do que os concretos com agregados convencionais. Essa diminuição da massa específica ocorre pela substituição de componentes sólidos da mistura por ar, que pode ser obtida pela substituição dos agregados tradicionais por agregados leves, pela incorporação de ar, no caso dos concretos celulares, ou pela retirada dos finos (ROSSIGNOLO e AGNESINI, 2005).

Se classificam em: concreto com agregados leves (Figura 50), concreto leve celular (Figura 51) e concreto sem finos (Figura 52).

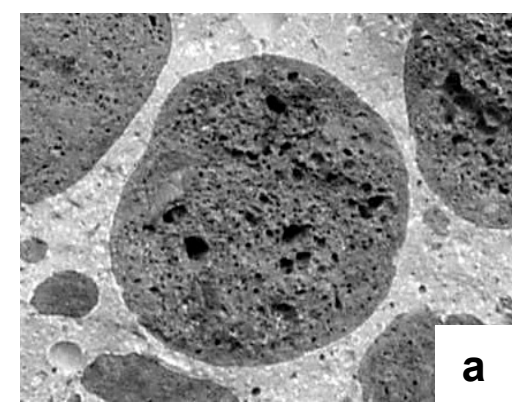

Figura 50. Concreto com agregados leves.

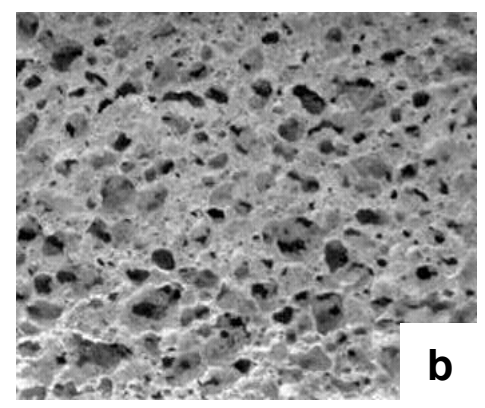

Figura 51. Concreto leve celular

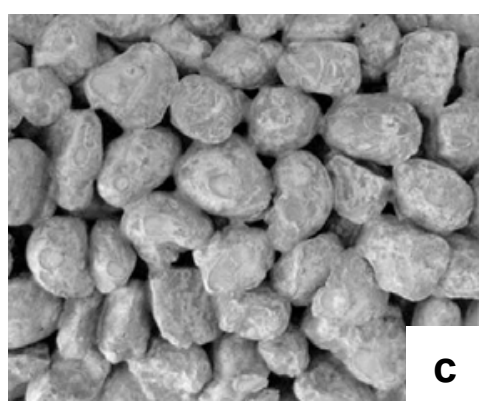

Figura 52. Concreto sem finos.

Fonte: ROSSIGNOLO e AGNESINI, 2005. 
Dentre esses três tipos de concretos, desde a década de 80 o concreto leve celular encontra aplicação nos painéis de vedação de edificações térreas e o concreto com agregados leves apresenta-se como uma alternativa ao concreto leve celular, com isso serão discutidas as características dos mesmos. Já sobre os concretos sem finos não serão analisados maiores detalhes, pois o mesmo não se aplica a esse sistema construtivo em questão.

\subsubsection{Concreto Leve Celular}

Há alguns anos o concreto celular é utilizado no Brasil na produção de vedações verticais, como painéis monolíticos e blocos de alvenaria. Existem dois grupos de concreto celular, divididos de acordo com a sua produção. Há o tipo gasoso, no qual a partir da inclusão de aditivos à mistura, ocorre uma reação química que produz gás, incorporando ar ao concreto. Há, ainda, o concreto celular espumoso, no qual a espuma é incorporada ao concreto, sendo responsável pela formação dos poros no material. Nesse tipo de concreto, a incorporação de ar normalmente ultrapassa $25 \%$ do volume do concreto (BOTTURA et al, 1986).

O concreto celular é definido, segundo a norma NBR 12646 (ABNT, 1992 b) como:

[...] concreto leve obtido pela introdução em argamassa de bolhas de ar, com dimensões milimétricas, homogêneas, uniformemente distribuídas, estáveis, incomunicáveis e indeformadas ao fim do processo, cuja densidade de massa aparente no estado fresco deve estar compreendida entre $1300 \mathrm{~kg} / \mathrm{m}^{3}$ e $1900 \mathrm{~kg} / \mathrm{m}^{3}$ (ABNT, $1992 \mathrm{~b}$ ).

O concreto leve celular é constituído de cimento Portland, areia, brita, água, espuma ou agentes incorporadores de ar. Por meio da adição de bolhas de ar na matriz de cimento ocorre uma redução da massa específica do concreto para valores entre 1300 e $1900 \mathrm{~kg} / \mathrm{m}^{3}$. Porém, o ar incorporado à matriz de cimento aumenta significativamente a permeabilidade do concreto, além de reduzir sua resistência mecânica. Possui também baixa durabilidade devido ao rápido ataque à armadura interna por ação de íons cloreto e da carbonatação, por exemplo, que ocorre devido à alta porosidade do concreto.

$\mathrm{Na}$ Figura 53 são apresentadas as relações entre a porosidade, a durabilidade e a resistência à compressão dos concretos. Observa-se uma relação linear entre a resistência à compressão e o teor de ar incorporado, ocorre uma diminuição da resistência com o aumento do teor de ar. Em relação à durabilidade, observa-se que a partir de certo limite ótimo de teor de ar incorporado, algo em torno de $4 \%$, a porosidade reduz significativamente 
o desempenho e durabilidade dos concretos. Com isso, a aplicação estrutural do concreto celular requer cuidados especiais para a proteção da armadura (NEVILLE, 1997).

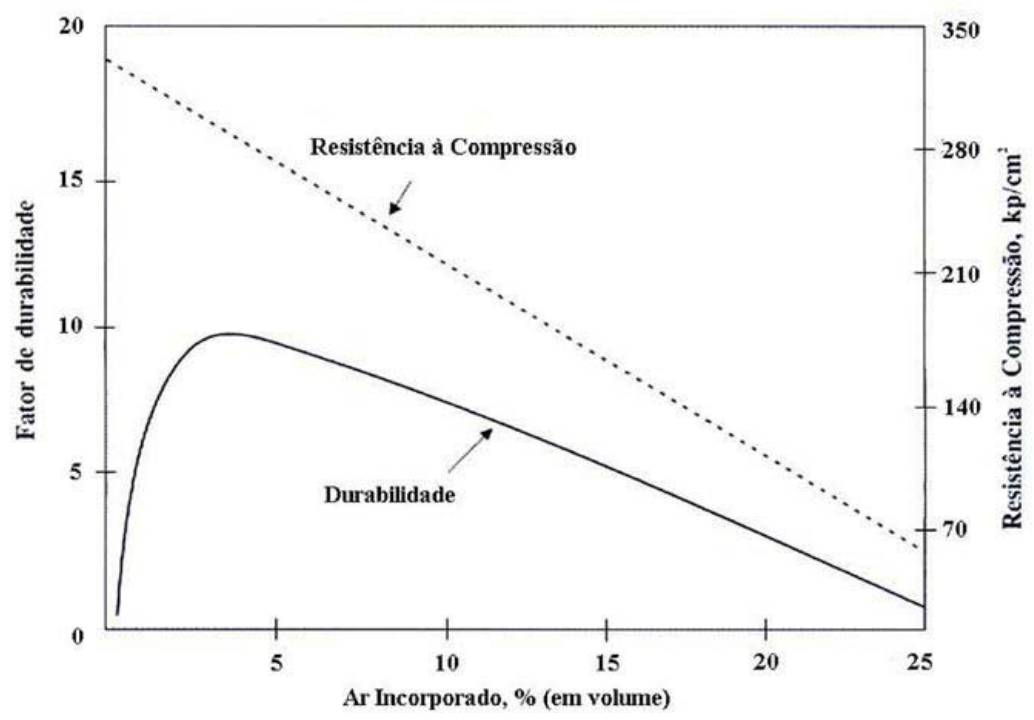

Figura 53. Concreto: durabilidade, influência do conteúdo de ar.

Fonte: MARTIN, 2005.

Esse tipo de concreto, quando aplicado para execução de painéis monolíticos moldados in loco, usualmente apresenta massa específica em torno de $1700 \mathrm{~kg} / \mathrm{m}^{3}$, o que representa valores de incorporação de ar em torno de $30 \%$. Com isso, apresenta valores de resistência à compressão abaixo de $6 \mathrm{MPa}$ e exige cuidados adicionais para garantir sua durabilidade, como pinturas especiais ou impermeabilização, fazendo com que a produtividade diminua e aumente o custo do processo. Em função dos baixos valores de resistência à compressão, é utilizado normalmente apenas em edificações térreas (CEF, 2003).

As recomendações e os critérios técnicos para a utilização do concreto celular espumoso no sistema construtivo de painéis monolíticos moldados in loco são abordados nas normas NBR 12645- Execução de paredes de concreto celular espumoso moldadas no local" e NBR 12646 - Paredes de concreto celular espumoso moldadas no local (ABNT, 1992 a e ABNT, 1992 b).

Em 2003 a Caixa Econômica Federal (CEF) divulgou um documento técnico ${ }^{14}$ complementar a essas normas, realizado sob a coordenação do Departamento de Apoio e Controle Técnico de FURNAS e em conjunto com a Associação Brasileira de Cimento Portland $(\mathrm{ABCP})$, contendo os critérios e requisitos mínimos a serem observados quando da execução de painéis de concreto celular moldados in loco. Esse trabalho analisou o desempenho de unidades habitacionais de um pavimento de diferentes conjuntos

\footnotetext{
${ }^{14}$ Trata-se do Relatório DCT.T.15.005.2003 - R1 - Avaliações de Sistemas Construtivos e Estabelecimento de Requisitos para Edificações Térreas com Paredes de Concreto Celular. Departamento de Apoio e Controle Técnico de FURNAS Centrais Elétricas S. A., Brasília/ DF, 2003.
} 
Capítulo 4. Concretos Utilizados nos Painéis Monolíticos Moldados In Loco 68

habitacionais, produzidas com o sistema de painéis monolíticos moldados in loco em todo o país. Esse documento ressalta inicialmente a importância de evitar a aplicação do concreto leve celular em ambientes marítimos, devido à sua alta porosidade, que confere baixa proteção ao ataque de cloretos à armadura dos painéis. Constatou-se também que detalhes do projeto arquitetônico, como beirais e revestimentos impermeabilizantes, são muito importantes para garantir o bom desempenho e a durabilidade dos painéis executados com esse tipo de concreto.

As habitações analisadas pela CEF foram executadas no sistema construtivo de painéis monolíticos moldados in loco com o emprego de concreto celular espumoso, cujas características foram: consumo de cimento entre 280 e $320 \mathrm{~kg} / \mathrm{m}^{3}$; massa específica em torno de $1500 \mathrm{~kg} / \mathrm{m}^{3}$; índice de vazios entre 35 e 45\%; absorção de água por imersão entre 22 e $28 \%$, em massa; resistência à compressão aos 28 dias acima 2,5 MPa (ABNT, 1992 b); e módulo de elasticidade aos 28 dias de idade entre 5 a $6 \mathrm{GPa}$. Em decorrência da alta permeabilidade do concreto celular, observada nos índices de absorção de água, o relatório emitido pela CEF recomenda a execução de um sistema de revestimento impermeável nos painéis como forma de aumentar a proteção da armadura dos painéis.

Por meio da análise desse relatório é visível a possibilidade de rápida degradação dos painéis de concreto celular caso haja falhas no sistema construtivo ou no processo de manutenção, como a ausência de acabamento impermeável, infiltração acidental não solucionada rapidamente ou problemas com a impermeabilização da fundação em solos com pouca drenagem. Recomenda-se que para garantia de desempenho estrutural dos painéis de concreto celular ao longo da vida útil da edificação, deve ser aplicado um revestimento impermeabilizante após a desforma, com uma mistura de cimento, areia e polímeros, em toda a superfície dos painéis, assim como executar uma barra impermeável de aproximadamente $60 \mathrm{~cm}$ de altura nas paredes externas, com argamassa impermeável. Com isso, a característica de alta produtividade do sistema construtivo em questão pode ser prejudicada pelas etapas adicionais de impermeabilização dos painéis.

A Caixa Econômica Federal (CEF) e a Companhia de Desenvolvimento Habitacional e Urbano (CDHU) indicam a utilização de concretos leves na execução de habitações de interesse social utilizando sistema construtivo de painéis monolíticos, com a intenção de melhorar o desempenho térmico das edificações, sendo o concreto leve celular o mais utilizado. Porém o mesmo apresenta as desvantagens citadas acima, criando a necessidade de estudos sobre a utilização de outros tipos de concreto leves assim como sobre os valores ideais de massa específica do concreto e da espessura do painel.

Diante disso, uma alternativa para eliminar as etapas de impermeabilização e assegurar o desempenho adequado dos painéis ao longo da vida útil da habitação é a utilização do concreto leve estrutural (com agregados leves). 


\subsubsection{Concreto Leve Estrutural}

O concreto leve estrutural, com agregados leves, apresenta-se como um material alternativo para aplicação no sistema construtivo de painéis monolíticos moldados in loco, pois possui massa específica e isolamento térmico e acústico compatível com o obtido em concretos celulares, além de resistência mecânica e durabilidade semelhante a dos concretos tradicionais, para as mesmas características de dosagem. Esse tipo de concreto tem sido utilizado desde o início do século passado, para fins estruturais e de vedação, com excelentes resultados (SLATE et al., 1986; BERNER, 1991; ZHANG e GJ $\phi R V, 1991$; ROSSIGNOLO et al., 2001; ROSSIGNOLO e AGNESINI, 2001, 2002 a e 2004).

Com a substituição total ou parcial dos agregados tradicionais por agregados leves (Figura 54) são obtidos concretos leves estruturais, os quais se caracterizam por apresentarem massa específica seca abaixo de $2000 \mathrm{~kg} / \mathrm{m}^{3}$ (ROSSIGNOLO e AGNESINI, 2005).

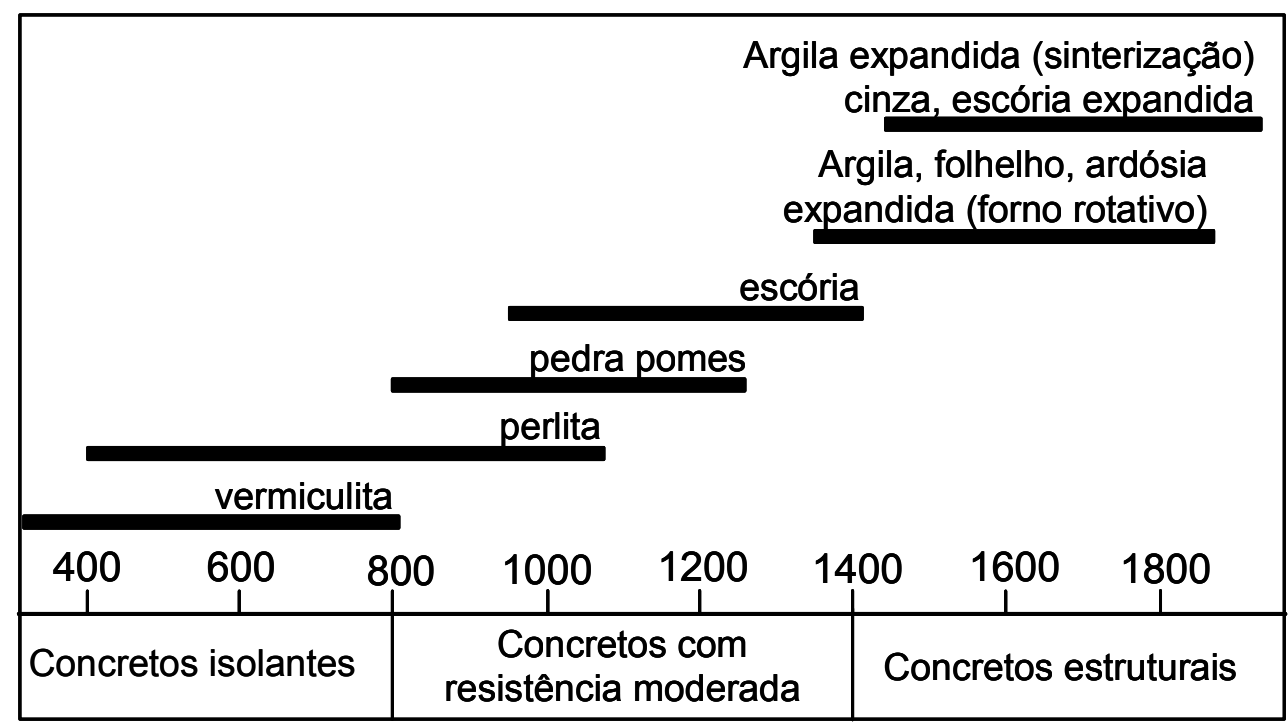

Figura 54. Intervalos típicos de valores de massa específica de concretos com agregados leves.

Fonte: ROSSIGNOLO e AGNESINI, 2005.

O concreto com agregados leves, também denominado de concreto leve estrutural (CLE), vem sendo largamente aplicado em todo o mundo em diversas áreas da construção civil, como em pontes, plataformas marítimas e componentes pré-fabricados (ROSSIGNOLO e AGNESINI, 2005). Esse tipo de concreto caracteriza-se pela substituição total ou parcial dos agregados tradicionais por agregados leves e pelo valor de sua massa específica, que deve ser inferior a $2000 \mathrm{~kg} / \mathrm{m}^{3}$ (ABNT, 2004). O Guia do Concreto Estrutural com Agregados Leves do $(\mathrm{ACl}, 1995)$ aponta que o concreto leve estrutural deve apresentar resistência à compressão acima de 17,2 MPa. De acordo com a NM 35 (ABNT, 1995), os agregados 
leves, utilizados na produção do CLE, não devem apresentar massa unitária no estado seco e solto acima de $1120 \mathrm{~kg} / \mathrm{m}^{3}$, para agregados miúdos; e $880 \mathrm{~kg} / \mathrm{m}^{3}$, para agregados graúdos.

Após a realização de estudos no Laboratório de Construção Civil (LCC) da Escola de Engenharia de São Carlos (USP) no fim de 2004, observou-se que o concreto leve com argila expandida nacional apresenta grande potencial de utilização no sistema construtivo de painéis monolíticos, devido, aos seguintes fatores: trabalhabilidade adequada ao bombeamento e a moldagem (slump acima de $150 \mathrm{~mm}$ ), condições favoráveis de produção e cura; valores de resistência à compressão às 12 horas de idade acima de $2 \mathrm{MPa}$, favorecendo a rápida desforma dos painéis, e aos 28 dias acima de $30 \mathrm{MPa}$; massa específica seca abaixo de $1700 \mathrm{~kg} / \mathrm{m}^{3}$ aos 28 dias (aproximadamente $35 \%$ inferior a dos concretos tradicionais); e absorção de água por imersão aos 28 dias de idade abaixo de $2,5 \%$, indicando, assim, a baixa permeabilidade à agentes agressivos desse material (ROSSIGNOLO et al., 2005).

Em 2005 tendo como referência os estudos desenvolvidos no LCC-USP e o desenvolvimento de um protótipo, a diretoria técnica da CEF aprovou, de forma provisória, a utilização de concreto com agregados leves para execução de painéis monolíticos de habitações de interesse social. Nesse mesmo ano foi iniciada a execução de conjuntos habitacionais utilizando esse material, o primeiro com 25 unidades habitacionais foi construído em Santa Maria da Serra-SP, nas proximidades de Piracicaba. Com isso, o concreto com agregados leves mostra-se como um material alternativo para aplicação na produção dos painéis monolíticos moldados in loco. A seguir serão apresentadas mais informações sobre os agregados para esse tipo de concreto.

\section{Agregados Leves}

O termo geral agregados leves engloba uma grande variedade de produtos, que vão desde os naturais aos sintéticos, passando pelos subprodutos e rejeitos industriais. Em função dessa variedade, é necessário o conhecimento de suas propriedades e de suas características de melhor desempenho (DANTAS, 2003). Para a dosagem e produção dos concretos leves estruturais, é fundamental que se conheçam as propriedades dos agregados leves utilizados, que podem variar significativamente, em função da matériaprima utilizada e do processo de fabricação. Os agregados leves podem ser classificados em naturais ou artificiais. Os primeiros são obtidos por meio da extração direta em jazidas, seguida de classificação granulométrica. Esse tipo de agregado, entre os quais está a pedra-pomes, tem pouca utilização na produção de concretos leves estruturais em decorrência da variação de suas propriedades.

Os agregados leves artificiais são obtidos industrialmente e, em geral, são classificados em função da matéria-prima utilizada e do processo de fabricação. Como 
exemplo, têm-se as argilas (Figura 55 e 56), que são mais utilizadas no Brasil; folhelhos e escórias expandidas. Esses agregados leves apresentam valores de massa específica inversamente proporcional ao diâmetro, sendo, na maioria dos processos de fabricação, obtidas partículas com diâmetro entre 1 e $25 \mathrm{~mm}$. Especificamente na produção de concretos estruturais são utilizados agregados com dimensão máxima característica abaixo de 19 mm (ROSSIGNOLO e AGNESINI, 2005).

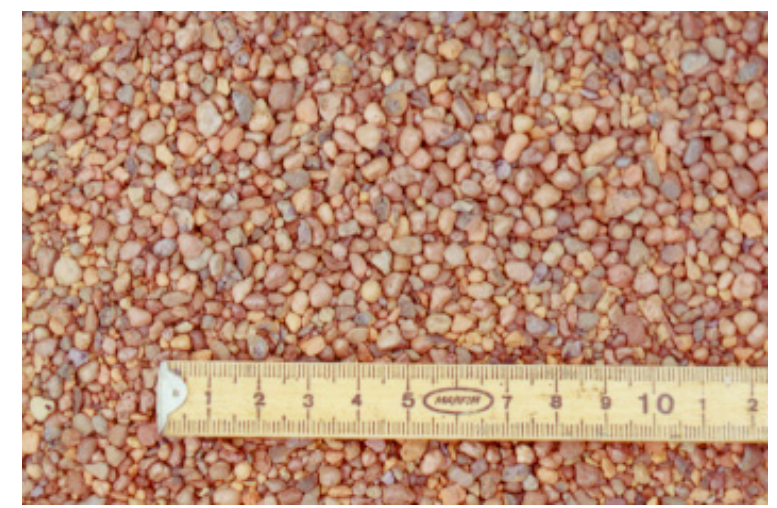

Figura 55. Argila expandida nacional CINEXPAN 0500.

Fonte: ROSSIGNOLO e AGNESINI, 2005.

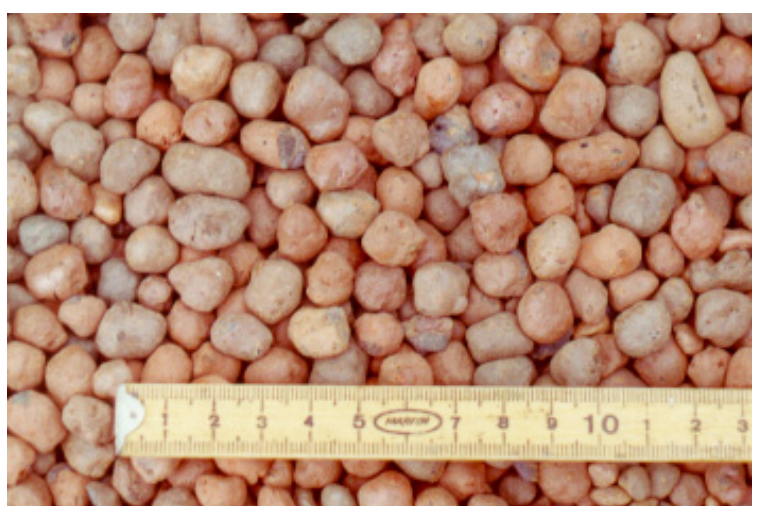

Figura 56. Argila expandida nacional CINEXPAN 1506.

Fonte: ROSSIGNOLO e AGNESINI, 2005.

A produção dos agregados leves artificiais pode ser feita por dois processos diferentes, sinterização e forno rotativo. Na sinterização a matéria prima é misturada a certa quantidade de combustível e em seguida é submetida a altas temperaturas, que causam a sua expansão devido à formação de gases (GOMES NETO, 1998). Esse agregado apresenta superfície altamente rugosa, que confere boa aderência à pasta de cimento, mas os poros abertos e sem recobrimento implicam em valores altos de absorção de água e na penetração da pasta de cimento nos poros externos, o que aumenta o consumo de cimento e a massa específica do concreto. Além disso, possui arestas que necessitam de britagem para atender a todas as granulações necessárias à produção dos concretos leves e devido ao fato de ser anguloso aumentam a quantidade de água necessária para obtenção da trabalhabilidade desejada (ROSSIGNOLO e AGNESINI, 2005).

Os agregados produzidos no forno rotativo caracterizam-se por uma massa esponjosa micro-celular, envolta por uma camada vitrificada, que confere baixa permeabilidade, o que possibilita a obtenção de boa trabalhabilidade com baixas relações água/cimento. Geralmente têm granulometria variada, mas seu formato é regular e arredondado, possuindo maior facilidade de segregação do que os produzidos por sinterização (CEB/FIP, 1977).

Para a mesma matéria-prima e processo de fabricação, agregados com estrutura bastante porosa são menos resistentes do que os agregados com estrutura pouco porosa. $A$ estrutura interna tem um efeito importante na resistência mecânica e no módulo de 
deformação dos agregados leves. O tamanho e a distribuição dos poros também são decisivos na resistência mecânica dos agregados leves. Para um mesmo grau de porosidade é interessante que haja uma distribuição uniforme de pequenos poros, ao invés de poucos poros de grande diâmetro. (ROSSIGNOLO e AGNESINI, 2005).

Segundo Rossignolo e Agnesini (2005), quanto maior a diferença entre o módulo de deformação do agregado e da matriz de cimento, maior será a diferença entre a resistência à compressão da matriz de cimento e do concreto. O aumento do módulo de deformação do agregado leve aumenta também os valores da resistência à compressão e o do módulo do concreto.

As características absorventes de um determinado agregado leve são muito importantes, principalmente se o objetivo é a produção de concreto leve de alto desempenho (ZHANG e GJ $\phi R V$, 1991). Caso o agregado seja muito absorvente, pode ser problemático do ponto de vista reológico, pois pode gerar resistências à compressão relativamente altas e massas específicas baixas. A absorção de um agregado leve tem um efeito direto no controle do abatimento e da trabalhabilidade de um concreto leve.

O estado do agregado (seco, pré-saturado ou outro estado intermediário) também é de grande importância. Para alguns pesquisadores, os agregados leves devem estar completamente secos, levando em consideração a quantidade de água que irão absorver durante a mistura e o transporte. Porém Novokshchenov e Whitcon (1990) apud Aïtcin (2000) consideram que isto pode ser feito excepcionalmente, com agregados leves de baixa absorção. Já Malhotra (1990), Hoff e Elimov (1995) apud Aïtcin (2000), preferem agregados encharcados em água, de tal forma que não absorvam nenhuma água da mistura. Essa água absorvida pode ser considerada como um suprimento para hidratação tardia em traços com relação água/cimento muito baixa, o que diminui significativamente a retração autógena.

\section{Produção dos Concretos Leves}

\section{Mistura e teor de umidade dos agregados}

Devem ser tomados alguns cuidados no momento da mistura dos materiais na produção dos concretos leves, para evitar que a absorção de água dos agregados leves prejudique algumas propriedades dos concretos, principalmente, no estado fresco (HOLM e BREMNER, 2000).

Pode ser adotado o método de mistura utilizado para os concretos tradicionais e utilizar os agregados nas condições ambientais de umidade, isto é, sem saturação prévia caso o concreto for produzido com agregados leves com baixa absorção de água, valores abaixo de 10\%, em massa, após 24 horas de imersão. Alguns tipos de agregados leves, 
mesmo nessas condições, apresentam alta absorção de água (Figura 57), nos primeiros minutos, seguido de estabilização. Nesses casos, deve-se adicionar os materiais sólidos e a água juntos no misturador e em seguida, os agregados leves (HOLM e BREMNER, 2000)

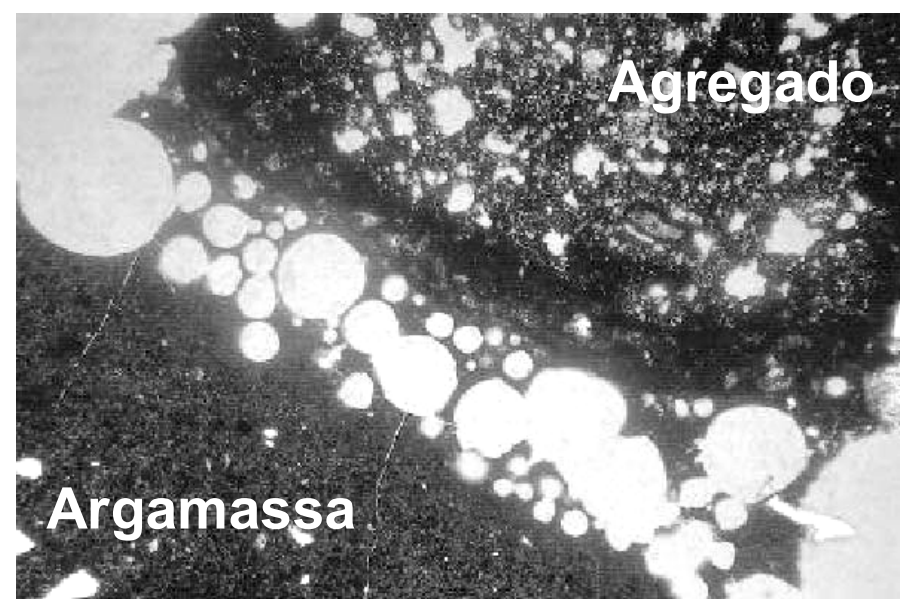

Figura 57. Presença de bolhas de ar ao redor do agregado leve devido à alta absorção de água.

Fonte: ROSSIGNOLO e AGNESINI, 2005.

Caso o agregado leve utilizado apresente altos valores de absorção de água após 24 horas de imersão, acima de 10\%, em massa, recomenda-se que seja realizada a présaturação desses agregados. Se esse procedimento não for realizado, haverá dificuldade em manter a trabalhabilidade adequada do material durante o lançamento (HOLM e BREMNER, 2000; ZHANG e GJ $\phi R V$, 1991).

\section{Transporte, lançamento e adensamento}

Durante o transporte dos concretos leves existe uma tendência à segregação devido aos baixos valores da massa específica dos agregados. Esse fenômeno pode ser evitado ou reduzido, com a dosagem de concretos com coesão e consistência adequados, por meio da adequação da relação água/cimento e do teor dos agregados miúdos e da utilização de adições minerais, como a sílica ativa (ROSSIGNOLO e AGNESINI, 2005).

As características de umidade e a granulometria dos agregados leves assumem grande importância para o bombeamento do concreto. O pré-umidecimento do agregado leve mostra-se importante para prevenir a perda brusca de trabalhabilidade no estado fresco, que pode provocar o entupimento dos dutos durante o lançamento. Recomenda-se, ainda, que o agregado miúdo tenha altos teores de partículas com diâmetro inferior a 0,3 mm (EUROLIGHTCON, 2000).

Os esforços transmitidos às formas, durante o lançamento são inferiores aos observados para os concretos tradicionais, isso em decorrência dos menores valores da 
massa específica dos concretos leves. Em contrapartida, normalmente os concretos leves exigem maior energia de vibração do que os concretos tradicionais, fazendo com que ocorra um aumento dos esforços e deformações nas formas durante o adensamento.

As técnicas usuais de adensamento podem ser adotadas para os concretos leves, entretanto esses concretos exigem uma energia maior de vibração do que os concretos tradicionais. O raio de ação no caso específico dos vibradores de imersão é adotado como a metade dos utilizados nos concretos tradicionais. Os concretos leves devem apresentar coesão adequada para evitar a segregação, isso devido a energia de vibração utilizada nos concretos leves ser maior do que a utilizada para os concretos tradicionais. (CEB/FIP, 1977; HOLM e BREMNER, 2000). É possível também a utilização de concretos leves autoadensáveis, de forma a evitar a formação de vazios ao redor do agregado leve.

\section{Cura}

Pode ser adotado o mesmo processo de cura dos concretos convencionais para os concretos com agregados leves, tomando-se cuidados especiais com a temperatura do concreto (HOLM e BREMNER,1994).

O calor liberado durante o processo de hidratação do cimento acarreta uma elevação maior na temperatura dos concretos leves do que nos concretos convencionais, em função da baixa condutibilidade térmica dos agregados leves. Recomenda-se adiar a retiradas das formas, ou cobrir o concreto com mantas isolantes de modo a evitar a formação de fissuras térmicas, em ambientes com baixas temperaturas. Quando for utilizado o processo de cura térmica, deve-se adotar um período maior de cura ou uma velocidade de elevação de temperatura menor (EUROLIGHTCON, 1998).

Nos concretos com agregados leves ocorre um fenômeno, denominado "cura interna", o qual os torna menos sensíveis às variações do processo de cura nas idades iniciais (AL-KHAIAT e HAQUE,1998). O agregado leve beneficia o processo de hidratação do cimento, pois durante o processo de mistura dos materiais, retém uma parcela de água que será transferida para a matriz de cimento ao longo do período de hidratação, garantindo assim a presença de parte da água necessária para as reações químicas desse processo, independentemente do rigor das condições ambientais externas. 


\section{Propriedades do Concreto com Agregados Leves}

\section{Trabalhabilidade}

As propriedades dos concretos leves no estado fresco e os fatores que as afetam são essencialmente os mesmos observados nos concretos tradicionais. Entretanto, devido à baixa massa específica e à alta absorção de água dos agregados leves, as propriedades relacionadas à trabalhabilidade dos concretos leves necessitam de uma atenção especial.

A trabalhabilidade do concreto pode ser definida como a propriedade que determina o esforço necessário para manipular uma quantidade de concreto fresco, com perda mínima de homogeneidade. O termo manipular inclui as operações das primeiras idades como lançamento, adensamento e acabamento. Considera-se o índice de consistência, medido pelo abatimento do tronco de cone ou pela mesa de espalhamento, um dos parâmetros mais adequados para a verificação das características associadas à trabalhabilidade dos concretos no estado fresco (MEHTA e MONTEIRO, 1994; ASTM C 125, 1993)

A faixa de variação dos valores de abatimento dos concretos leves mostra-se normalmente menor do que a utilizada para os concretos tradicionais, tendo a absorção de água dos agregados grande influência na manutenção da trabalhabilidade do concreto após a mistura. Durante o processo de determinação dos valores de abatimento para os concretos leves, deve ser considerado o valor da massa específica do agregado leve. Os concretos leves com altos valores de índice de consistência apresentam grandes possibilidades de segregação dos agregados e por outro lado, concretos leves com baixos valores de índice de consistência apresentam dificuldades no adensamento.

No caso do abatimento do tronco de cone (slump test), os concretos leves apresentam valores de abatimento menores do que os obtidos para os concretos tradicionais, produzidos nas mesmas condições de dosagem, devido essencialmente à diferença dos valores da massa específica dos agregados. Com isso, concretos leves com abatimento de $80 \mathrm{~mm}$, por exemplo, podem apresentar trabalhabilidade similar a dos concretos tradicionais com abatimento de $100 \mathrm{~mm}$ (ROSSIGNOLO e AGNESINI, 2005).

A vibração excessiva, os altos valores de índice de consistência e a baixa coesão são, normalmente, os fatores responsáveis pela segregação e exsudação nos concretos leves, afetando, desfavoravelmente, a manipulação do material, podendo em alguns casos alterar o desempenho de algumas propriedades no estado endurecido (MEHTA e MONTEIRO, 1994). Porém a segregação pode ser evitada ou minimizada tomando-se alguns cuidados no processo de dosagem, como granulometria adequada dos agregados, substituição total ou parcial do agregado miúdo por areia natural e utilização de adições minerais. 


\section{Resistência à compressão e massa específica}

A resistência à compressão e a massa específica são as propriedades mais utilizadas na caracterização dos concretos leves estruturais e estão diretamente relacionadas com o tipo e a granulometria do agregado leve utilizado, pois o valor da massa específica dos agregados leves é inversamente proporcional à sua dimensão. $\mathrm{O}$ valor da massa específica dos concretos leves apresenta variação progressiva, desde sua condição inicial até uma condição mais estável, que depende das condições de exposição. Para a estimativa das cargas a serem suportadas pelas formas e escoramentos, recomenda-se utilizar o valor de massa específica do concreto leve no estado fresco e para estimativa do peso próprio deve ser considerado o valor da massa específica do concreto leve seco ao ar, ligeiramente superior à do concreto seco em estufa (ROSSIGNOLO e AGNESINI, 2005).

Devido ao fato dos agregados leves possuírem baixa resistência mecânica, quando comparados aos agregados tradicionais, a resistência mecânica da matriz de cimento é de suma importância na resistência mecânica do concreto.

Nos concretos leves, utiliza-se, mais eficientemente, a resistência mecânica potencial da matriz de cimento do que nos concretos tradicionais, em função da similaridade entre os valores dos módulos de deformação do agregado e da matriz e da excelente qualidade da zona de transição agregado-matriz. Com isso, os concretos leves, normalmente, não rompem devido à diferença entre as deformações dos agregados e da matriz de cimento, mas, sim, devido ao colapso da argamassa, que, normalmente, ocorre na região ao redor do agregado. No colapso dos concretos leves, a linha de fratura atravessa os agregados, como ocorre nos concretos de alta resistência com massa específica normal, diferentemente do que ocorre nos concretos tradicionais, em que a ruptura do material ocorre pelo colapso da argamassa e a separação entre as fases, resultando uma linha de fratura ao redor do agregado (Figura 58) (ZHANG e GJ $\phi R V$, 1991a; EUROLIGHTCON, 1998).
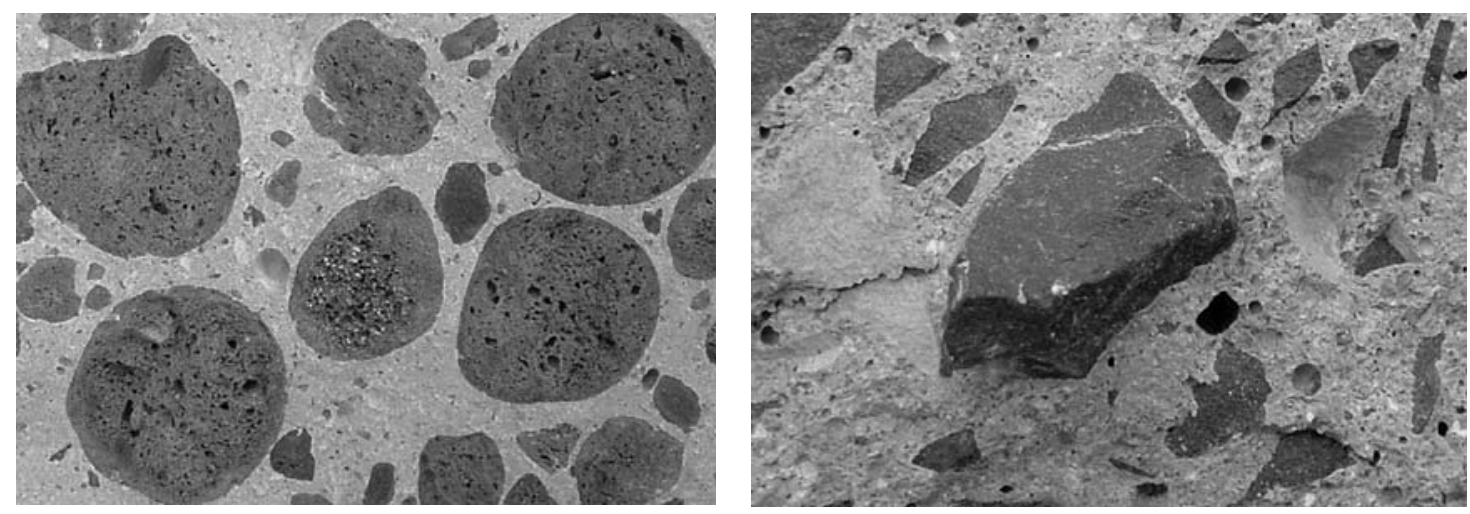

Figura 58. Forma de ruptura de concretos com agregados leves e com agregados tradicionais.

Fonte: ROSSIGNOLO e AGNESINI, 2005. 
Os concretos leves têm valores finais de resistência à compressão estabilizados mais rapidamente do que os concretos tradicionais. Em geral, aos 7 dias já apresentam $80 \%$ da resistência à compressão observada aos 28 dias de idade. Esse efeito pode ser atribuído à baixa resistência mecânica dos agregados leves, principal limitante da resistência mecânica dos concretos leves (EUROLIGHTCON, 1998).

Para aumentar o valor da resistência à compressão do concreto leve, existe um limite máximo para o teor de cimento. Atingindo esse limite, o agregado leve mostra-se como o material determinante na resistência à compressão do concreto, e o aumento da resistência à compressão da pasta de cimento já não contribui para o aumento da resistência à compressão do concreto. O consumo de cimento dos concretos leves de alto desempenho normalmente varia entre 400 e 600 kg/m³ (AÏTICIN, 2000).

Em alguns casos, seria difícil produzir um concreto tendo massa específica menor que $2000 \mathrm{~kg} / \mathrm{m}^{3}$ e uma resistência à compressão de $50 \mathrm{MPa}$, enquanto em outros casos, com um agregado leve de "bom desempenho", seria possível produzir um concreto com resistência à compressão de cerca de $100 \mathrm{MPa}$ e massa específica, enquanto fresco, de $1865 \mathrm{~kg} / \mathrm{m}^{3}$. Obviamente, quanto mais elevada for a massa unitária de um agregado, mas alta será a sua resistência à compressão (ZHANG e GJ $\phi R V, 1990)$. No presente estado da arte, $102 \mathrm{MPa}$ representa o limite superior de resistência à compressão para concretos leves. Esse valor foi obtido por Zhang e Gj申rv (1991) para concretos leves com massa específica de $1735 \mathrm{~kg} / \mathrm{m}^{3}$, o que representa um fator de eficiência de $58,7 \mathrm{MPa} \cdot \mathrm{dm}^{3} / \mathrm{kg}$.

De acordo com estudos realizados com concretos leves com argila expandida nacional, é possível observar as relações entre a resistência à compressão e a massa específica do concreto leve (Figura 59) e entre a resistência à compressão do concreto leve e a dimensão máxima característica do agregado leve (Figura 60). Nesses estudos foram utilizados agregados com dimensão máxima característica de 9,5 e 12,5 mm e o consumo de cimento dos concretos leves foi de $500 \mathrm{~kg} / \mathrm{m}^{3}$ (EVANGELISTA et al,1996). 


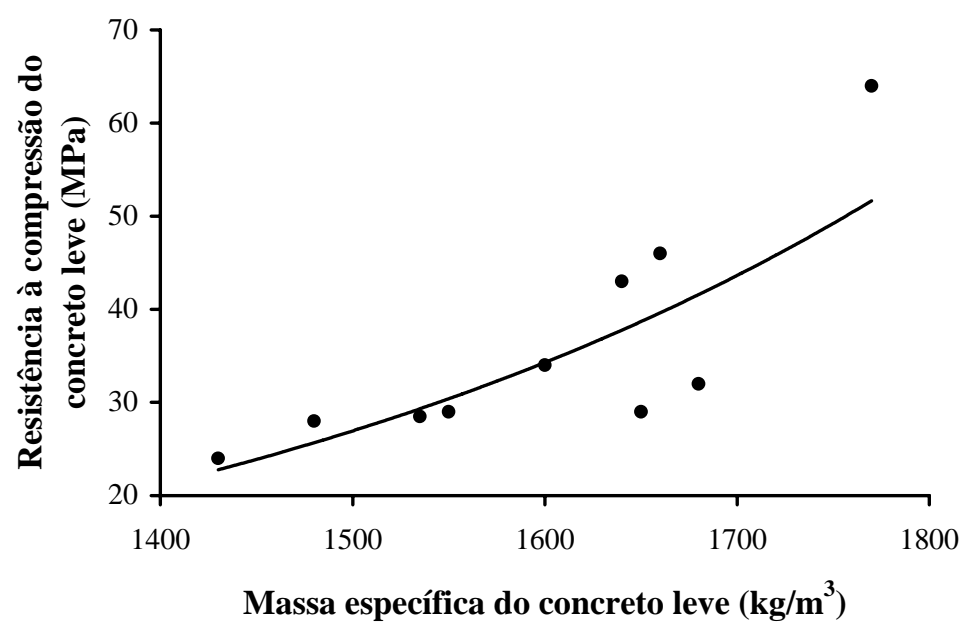

Figura 59. Relação entre resistência à compressão a massa específica do concreto leve com argila expandida nacional.

Fonte: EVANGELISTA et al., 1996.

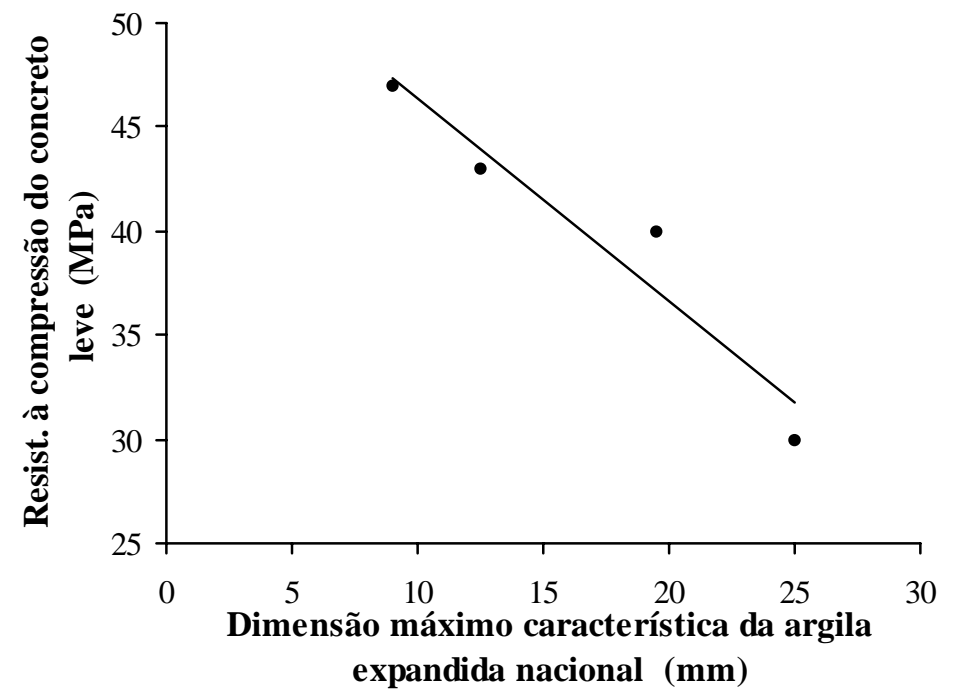

Figura 60. Relação entre resistência à compressão do concreto leve e a dimensão máxima característica do agregado leve nacional.

Fonte: EVANGELISTA et al., 1996.

Outro estudo da relação entre a resistência à compressão e a massa específica dos concretos com agregados leves nacionais pode ser observado na Figura 61. Nesse caso utilizou-se agregado leve nacional com dimensão máxima característica de 6,3 $\mathrm{mm}$ e o consumo de cimento dos concretos leves variou entre 450 e $1300 \mathrm{~kg} / \mathrm{m}^{3}$ (GOMES NETO, 1998) 


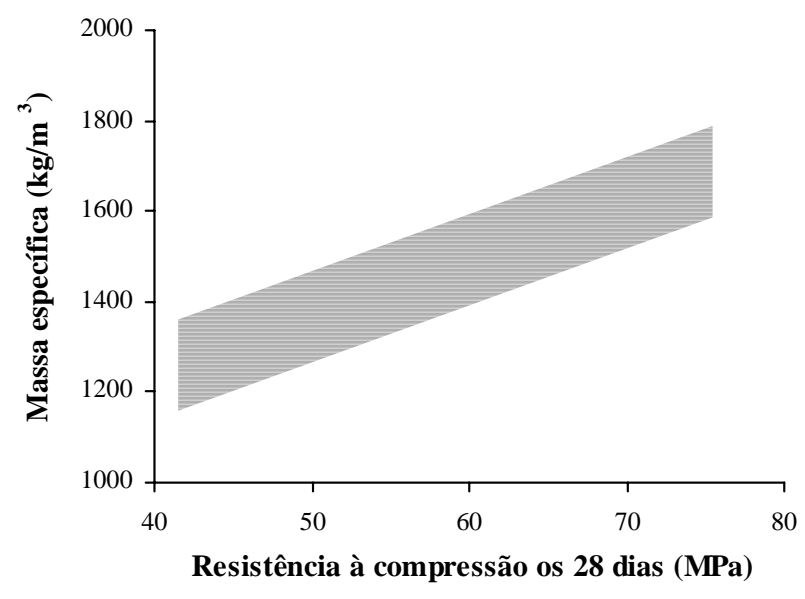

Figura 61. Relação entre resistência à compressão e a massa específica do concreto leve com argila expandida nacional.

Fonte: GOMES NETO, 1998.

A Figura 62 apresenta a síntese dos resultados das três pesquisas realizadas sobre a relação entre a resistência à compressão e a massa específica dos concretos com argila expandida nacional.

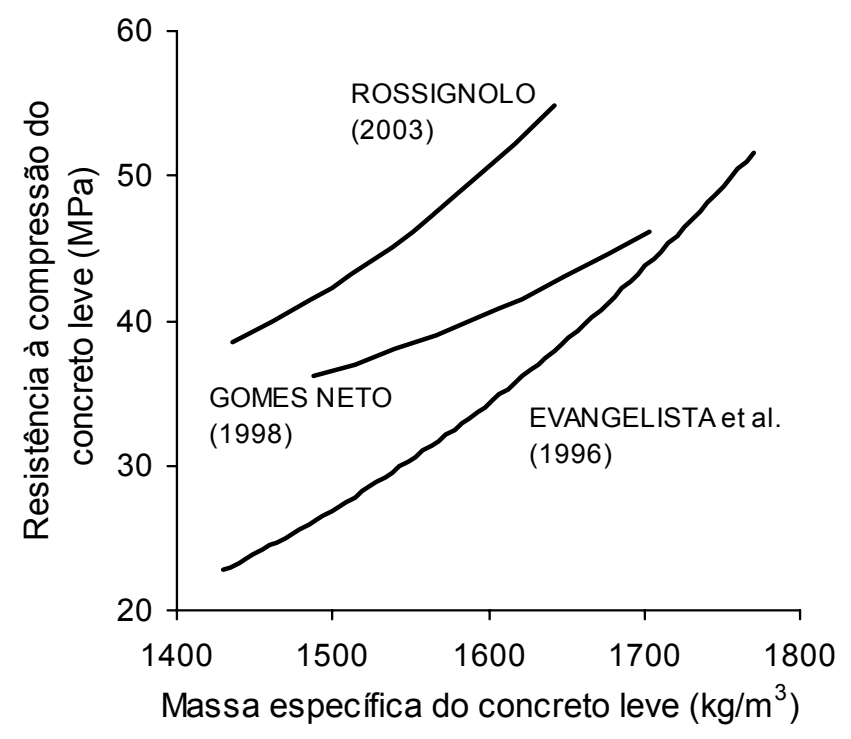

Figura 62. Relação entre a resistência à compressão e a massa específica do concreto leve com argila expandida nacional.

Fonte: ROSSIGNOLO e AGNESINI, 2005. 


\section{Resistência à tração}

Um relatório elaborado pelo EUROLIGHTCON (1998), com relação à propriedade de resistência à tração, apresenta as principais diferenças entre os concretos leves e os tradicionais, que se resumem: no tipo de fratura, pois nos concretos leves, a fratura ocorre através do agregado e não ao redor do agregado; na zona de transição agregado-matriz, como ocorre nos concretos tradicionais; no teor de umidade do concreto, que pode ser maior nos concretos leves do que nos tradicionais nas mesmas condições de cura e pode causar uma redução significativa no valor da resistência à tração; e na resistência à tração na flexão, que nos concretos leves, é mais afetada do que a resistência à tração na compressão diametral.

Os valores da resistência à tração dos concretos leves, tanto na compressão diametral, como na flexão, são ligeiramente inferiores aos observados nos concretos com massa específica normal para o mesmo nível de resistência à compressão, isso ocorre em função do grande volume de vazios dos agregados leves, que pode chegar a $50 \%$ do volume total para as argilas expandidas (HOLM e BREMNER, 1994).

A relação entre os valores das resistências à compressão e à tração por compressão diametral dos concretos leves, normalmente, varia entre 5 e 15\% para concretos com resistência à compressão acima de $20 \mathrm{MPa}$ e depende, essencialmente, da qualidade do concreto. Num estudo com concretos leves de alto desempenho, foi observado que o valor de resistência à tração na compressão diametral variou entre 6 e $6,5 \%$ do valor da resistência à compressão. Nesse mesmo estudo, foram observados também, valores de resistência à tração na flexão dos concretos leves, variando entre 9,8 e 10,5\% da resistência à compressão (ROSSIGNOLO, 2003).

Para o caso específico dos concretos produzidos com agregados leves nacionais, observam-se valores de resistência à tração por compressão diametral variando entre $6 \mathrm{e}$ 9\% da resistência à compressão (TEZUKA, 1973; EVANGELISTA et al., 1996; GOMES NETO, 1998).

São apresentadas na Tabela 2 algumas expressões de documentos normativos internacionais para a estimativa dos valores das resistências à tração por compressão diametral e à tração na flexão dos concretos leves em função da resistência à compressão. Observa-se pela análise dessas relações que para os concretos leves com resistência à compressão variando entre 20 e $50 \mathrm{MPa}$, a relação entre os valores da resistência à tração na compressão diametral e da resistência à compressão varia entre 6 e 10\% e que a relação entre os valores da resistência à tração na flexão e da resistência à compressão varia entre 7,5 e 12\%. Observa-se, também, a redução dos valores das relações entre os valores das resistências à tração e à compressão com o aumento dos valores da resistência à compressão dos concretos leves. 
Tabela 2. Relações entre a resistência à compressão e as resistências à tração por compressão diametral e à tração na flexão dos concretos leves.

\begin{tabular}{|c|c|c|c|}
\hline \multirow{2}{*}{ Referência } & \multicolumn{2}{|c|}{ Resistência à tração (MPa) } & \multirow{2}{*}{ Observações } \\
\hline & $\begin{array}{l}\text { Compressão } \\
\text { diametral }\left(f_{\mathrm{tD}}\right)\end{array}$ & Flexão $\left(\mathrm{f}_{\mathrm{ctM}}\right)$ & \\
\hline SLATE et al. (1986) & $0,42 \cdot f_{C}{ }^{0,5}$ & $0,54 \cdot f_{c}^{0,5}$ & $\begin{array}{c}62 \geq f_{c} \geq 21 \\
\text { Apenas agregado leve }\end{array}$ \\
\hline ZHANG e GJ $\phi R V$ (1991a) & $0,23 . f_{\mathrm{cu}}^{0,67}$ & $0,73 . f_{\mathrm{cu}}^{0,5}$ & - \\
\hline HOFF (1991) & $0,49 \cdot f_{c}{ }^{0,5}$ & - & - \\
\hline CEB/FIP (1977) & $0,23 \cdot f_{\mathrm{cu}}{ }^{0,67}$ & $0,46 . f_{\mathrm{cu}}^{0,67}$ & - \\
\hline ACI 318 (1992) & $0,42 \cdot f_{c}{ }^{0,5}$ & $0,46 . f_{c}{ }^{0,5}$ & Apenas agregado leve \\
\hline ACl 318 (1992) & $0,48 \cdot f_{c}{ }_{c}^{0,5}$ & $0,53 \cdot f_{c}{ }_{c}^{0,5}$ & Areia e agregado leve \\
\hline
\end{tabular}

Fonte: ROSSIGNOLO e AGNESINI, 2003.

Sendo:

$\mathrm{f}_{\mathrm{C}}=$ Resistência à compressão em corpos-de-prova cilíndricos (MPa);

$\mathrm{f}_{\mathrm{cu}}=$ Resistência à compressão em corpos-de-prova cúbicos (MPa).

\section{Módulo de deformação e o comportamento da curva tensão-deformação}

O módulo de deformação dos concretos leves está diretamente relacionado ao tipo e à quantidade de agregado leve utilizado. O módulo de deformação depende dos valores do módulo dos componentes individuais, da proporção dos materiais e da qualidade da zona de transição entre o agregado e a matriz de cimento. Por se utilizar altos teores de agregados no concreto leve, que apresentam valores de módulo de deformação significativamente inferiores aos observados nos agregados tradicionais, esse tipo de concreto também apresenta valores de módulo de deformação inferiores aos observados nos concretos tradicionais (ROSSIGNOLO e AGNESINI, 2005).

O valor do módulo de deformação do concreto leve normalmente varia entre $30 \mathrm{e}$ $70 \%$ do valor do módulo de deformação do concreto com massa específica normal, para um mesmo nível de resistência à compressão. Quanto mais próximos forem os valores do módulo de deformação do agregado e da matriz de cimento, melhor será o comportamento do concreto no regime elástico. (CEB/FIP, 1977 apud ROSSIGNOLO e AGNESINI, 2003). Para concretos leves com resistência à compressão acima de $60 \mathrm{MPa}$ o valor do módulo de deformação mostra-se cerca de 20 a $30 \%$ inferior ao observado nos concretos com agregados tradicionais, para o mesmo nível de resistência (SMEPLASS,1992 apud EUROLIGHTCON, 1998). 
Em alguns estudos observou-se que o módulo de deformação do concreto leve está diretamente relacionado com a resistência e com a quantidade de agregado, assim como com a qualidade da zona de transição agregado-matriz (ZHANG e GJ $\phi R V, 1991$ )

Abaixo são apresentadas algumas expressões mencionadas em documentos normativos internacionais que relacionam o módulo de deformação do concreto leve com sua respectiva resistência à compressão e massa específica. A expressão do $\mathrm{ACl} 318$ (1992), (Tabela 3), que relaciona o módulo de deformação do concreto leve com a resistência à compressão e a massa específica mostra-se bastante adequada para a estimativa do valor do módulo de deformação dos concretos com agregado leve nacional, conforme os estudos realizados por TEZUKA (1973), ARMELIN et al. (1994), EVANGELISTA et al. (1996) e GOMES NETO (1998).

Tabela 3. Equações para cálculo do módulo de deformação

\begin{tabular}{|c|c|c|}
\hline Referência & Equação * & Observações \\
\hline NS 3473 (1992) & $\mathrm{E}_{\mathrm{c}}=9.5 \cdot \mathrm{f}_{\mathrm{cck}}^{0,3} \cdot(\gamma / 2400)^{1,5}[\mathrm{GPa}]$ & $\mathrm{f}_{\mathrm{cck}}<85 \mathrm{Mpa}$ \\
\hline ACI 318 (1992) & $E_{c}=0,043 \cdot \gamma^{1,5} \cdot f_{c}^{0,5}[\mathrm{MPa}]$ & $\mathrm{f}_{\mathrm{c}}<41 \mathrm{Mpa}$ \\
\hline BS 8110 Part.2 (1985) & $\mathrm{E}_{\mathrm{c}}=1,7 \cdot(\gamma / 1000)^{2} \cdot \mathrm{f}_{\mathrm{ck}}^{0,3}[\mathrm{GPa}]$ & - \\
\hline CEB (1978) & $E_{c}=1,6 \cdot \gamma^{2} \cdot\left(f_{c c k}+8\right)^{0,33} \cdot 10^{-6}[\mathrm{GPa}]$ & - \\
\hline
\end{tabular}

Fonte: ROSSIGNOLO e AGNESINI, 2005.

Nos concretos leves a curva tensão-deformação, normalmente caracteriza-se por apresentar maior linearidade do trecho ascendente, maior valor da deformação última e maior inclinação no trecho descendente da curva após a ruptura, quando comparada à observada para o concreto tradicional. Isso ocorre devido à maior compatibilidade entre os valores do módulo de deformação da matriz de cimento e do agregado e a melhoria da qualidade da matriz de cimento na zona de transição entre o agregado e a matriz de cimento (AÏTCIN, 2000; GRIMER e HEWITT, 1969).

Segundo estudos de Zhang e Gjфrv (1991), observou-se que a parte ascendente da curva tensão-deformação dos concretos leves torna-se mais linear à medida que a resistência do concreto cresce, enquanto a parte descendente da curva, após a ruptura, torna-se mais íngreme.

A Figura 63 apresenta uma representação esquemática do comportamento da curva tensão-deformação dos concretos leves segundo sua classe de resistência à compressão (CARRASQUILO et al,1981). 


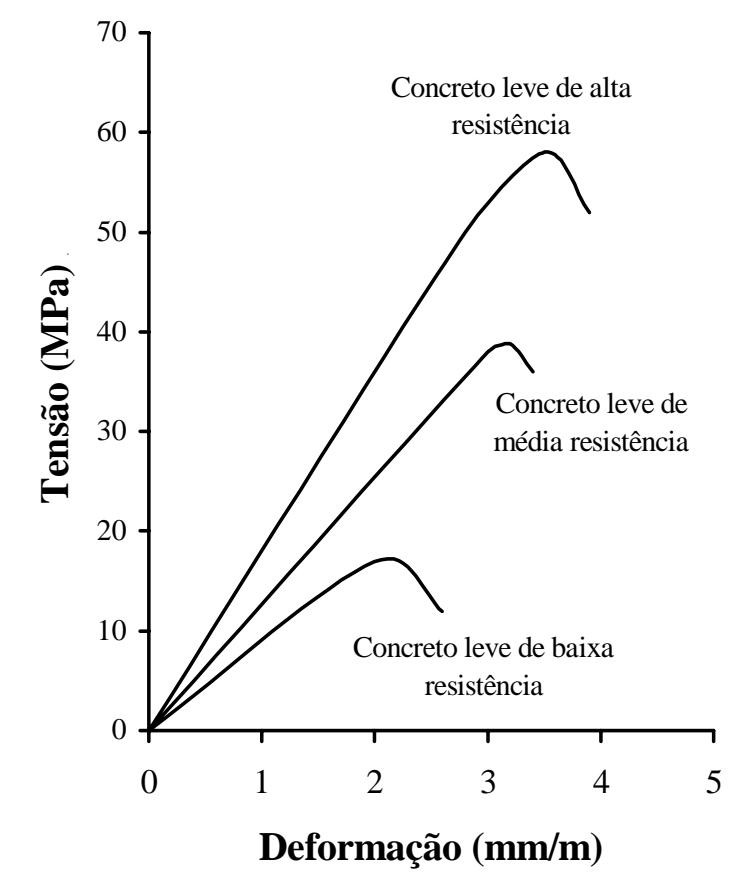

Figura 63. Comportamento da curva tensãodeformação dos concretos leves

Fonte: CARRASQUILO et al. (1981). In: ROSSIGNOLO e AGNESINI, 2005

A partir do mesmo trabalho de Zhang e Gjфrv (1991), são feitas algumas observações importantes a respeito da curva tensão-deformação, são elas: a deformação última decresce com o aumento do consumo de cimento; os concretos com sílica ativa apresentam curva tensão-deformação mais linear quando comparados aos concretos sem sílica ativa, provavelmente devido à melhoria de desempenho da zona interfacial entre o agregado e a matriz de cimento; o efeito da substituição parcial do agregado leve miúdo pela areia natural não influi no comportamento da curva tensão-deformação; e por último que o comportamento da curva tensão-deformação depende muito das propriedades dos agregados leves, pois houve grande variação do comportamento da curva para os diversos tipos de agregados utilizados.

\section{Permeabilidade}

A durabilidade dos concretos depende essencialmente de sua permeabilidade. No caso dos concretos leves, os agregados apresentam grande influência na permeabilidade dos concretos caso existam poros interligados, pois isso facilita o fluxo de líquidos e gases e conseqüentemente, de agentes agressivos no concreto. Agregados artificiais, como as argilas expandidas, mesmo com grande porosidade, geralmente apresentam baixa permeabilidade pelo fato de seus poros não serem comunicáveis. Além disso, a permeabilidade dos concretos depende, também, da ocorrência de fissuras internas, 
ocasionadas, principalmente, pela concentração de tensões devido à diferença dos valores do módulo de deformação do agregado e da matriz de cimento (CEB/FIP, 1977; HOLM e BRENMER, 1994)

As propriedades relativas à porosidade e absorção de água dos agregados alteram as propriedades do concreto no estado fresco e o processo de hidratação do cimento. $A$ velocidade e a quantidade de água absorvida pelos agregados variam de acordo com a porosidade total, a conectividade entre os poros, as características da superfície do agregado e a umidade do agregado antes da mistura (NEVILLE, 1997; EUROLIGHTCON, 1998). Além de fatores como o uso de aditivos à mistura, a temperatura e a pressão de bombeamento, no caso do concreto ser bombeado, pois a absorção de água dos agregados é proporcional à consistência do concreto, que varia na ocorrência de alguns desses fatores.

Os concretos leves estruturais de modo geral apresentam permeabilidade a líquidos e gases semelhante ou inferior à observada nos concretos tradicionais, isso para o mesmo nível de resistência à compressão. Isso deve-se aos baixos valores da relação água/cimento dos concretos leves, comparado aos concretos tradicionais; à diminuição das fissuras internas do concreto leve pela maior proximidade dos valores dos módulos de deformação do agregado e da matriz de cimento e à melhoria da qualidade da matriz, na zona de transição agregado-matriz (ROSSIGNOLO e AGNESINI, 2005).

\section{Resistência à penetração de cloretos e a carbonatação}

A durabilidade de estruturas em concreto armado próximas de ambientes marinhos devido à presença de íons cloreto é considerada fator de preocupação, porém estudos revelam valores semelhantes de difusão de íons cloreto em concretos com agregados leves e tradicionais, demonstrando a baixa influência do agregado na resistência do concreto leve à penetração e difusão de íons cloretos. A velocidade e a quantidade de íons cloreto que penetram no concreto dependem, essencialmente, das propriedades da matriz de cimento (EUROLIGHTCON, 1998)

O desempenho das propriedades relacionadas à durabilidade dos concretos leves pode aumentar significativamente com o uso de adições minerais pozolânicas, tais como a sílica ativa e a argila calcinada (metacaulin). As adições reduzem a porosidade da matriz de cimento e melhoram a qualidade da zona de transição agregado-pasta, aumentando a proteção da armadura contra a ação dos agentes agressivos, como a carbonatação e os íons cloreto (ROSSIGNOLO e AGNESINI, 2005).

Para os mesmos valores de resistência à compressão, os concretos leves geralmente apresentam uma relação água/cimento menor que a dos concretos tradicionais, o que torna a sua matriz de cimento menos porosa e, portanto menos propensa à ação da carbonatação que a de um concreto convencional (EUROLIGHTCON, 1998) 
Uma avaliação realizada em uma embarcação produzida com concreto leve durante a Primeira Guerra Mundial, demonstrou que após oito décadas, os concretos leves apresentavam espessura média de carbonatação de $2 \mathrm{~mm}$ e não apresentavam carbonatação na interface entre o concreto e a armadura (HOLM e BREMNER, 1994). Um estudo realizado no Japão demonstrou também, que concretos leves com 19 anos de idade apresentaram profundidade de carbonatação similar à apresentada pelos concretos tradicionais, com as mesmas condições de dosagem (OCHUCHI et al., 1984 apud EUROLIGHTCON, 1998).

\section{Propriedades Térmicas}

As propriedades térmicas dos concretos leves são significativamente diferentes das observadas nos concretos tradicionais, principalmente devido ao ar aprisionado na estrutura celular dos agregados leves que reduz a transferência e a absorção de calor em relação aos agregados tradicionais, alterando assim as propriedades térmicas dos concretos, por exemplo, a redução da condutividade térmica. Devido a esse fator o concreto leve é utilizado em algumas edificações como vedação das fachadas e na cobertura, com o objetivo de reduzir a absorção e a transferência para o ambiente interno do calor proveniente da radiação solar (CEB/FIP, 1977; EUROLIGHTCON, 1998; HOLM e BREMNER, 2000). A Tabela 4 apresenta uma comparação entre os valores de condutividade térmica, expansão térmica, difusão térmica e calor específico entre o concreto leve e o concreto tradicional.

Tabela 4. Propriedades térmicas dos concretos leves

\begin{tabular}{lcc}
\multicolumn{1}{c|}{ Propriedades } & Concreto Leve & Concreto Normal \\
\hline Massa específica $\left(\mathrm{kg} / \mathrm{m}^{3}\right)$ & 1850 & 2400 \\
\hline Resistência à compressão $(\mathrm{MPa})$ & $20-50$ & $20-70$ \\
\hline Calor específico $\left(\mathrm{cal} / \mathrm{g}^{\circ} \mathrm{C}\right)$ & 0,23 & 0,22 \\
\hline Condutividade térmica $(\mathrm{W} / \mathrm{mK})$ & $0,58-0,86$ & $1,4-2,9$ \\
\hline Difusão térmica $\left(\mathrm{m}^{2} / \mathrm{h}\right)$ & 0,0015 & $0,0025-0,0079$ \\
\hline Expansão térmica $\left(\mathrm{microstrain} .10^{-6} /{ }^{\circ} \mathrm{C}\right)$ & 9 & 11 \\
\hline
\end{tabular}

Fonte: HOLM e BREMNER, 2000.

Os concretos leves geralmente apresentam maior resistência ao fogo do que os concretos tradicionais. Isso pode ser atribuído à combinação dos seguintes fatores: menor condutividade térmica, menor coeficiente de expansão térmica e maior estabilidade dos agregados leves quando expostos à altas temperaturas (EUROLIGHTCON, 1998; NOUMOWÉ et al., 2000). 
Segundo Berra e Ferrara (1990) apud Dantas (2003) as propriedades térmicas (coeficiente de dilatação térmica, condutividade térmica e difusidade térmica) são aproximadamente a metade das propriedades correspondentes dos concretos de massa específica normal e composição similar. Por sua vez, Novokshchenov e Whitcomb (1990) observaram que o coeficiente de condutividade térmica aumenta drasticamente com o aumento da resistência do concreto leve.

Segundo Dantas (2003), concretos com massa específica variando de 250 a 800 $\mathrm{kg} / \mathrm{m}^{3}$, apresentam baixa resistência mecânica e ótimo isolamento térmico; concretos com massa específica variando de 800 a $1400 \mathrm{~kg} / \mathrm{m}^{3}$ apresentam média resistência mecânica e adequado isolamento térmico; e os concretos cuja massa específica está entre 1400 a 2100 $\mathrm{kg} / \mathrm{m}^{3}$ apresentam boa resistência mecânica e limitado isolamento térmico.

A partir do que foi apresentado anteriormente, a Tabela 5 mostra uma síntese das características dos concretos que podem ser utilizados no sistema construtivo de painéis monolíticos de concreto moldados in loco.

Tabela 5. Síntese dos Concretos utilizados para o sistema construtivo em questão.

\begin{tabular}{|c|c|c|c|c|}
\hline \multicolumn{5}{|c|}{ Características dos Concretos Empregados no Sistema Construtivo } \\
\hline Tipo de Concreto & Composição & $\begin{array}{c}\text { Massa } \\
\text { Específica }\end{array}$ & $\begin{array}{c}\text { Resistência à } \\
\text { Compressão }\end{array}$ & Observações \\
\hline Tradicional & $\begin{array}{l}\text { Cimento Portland, } \\
\text { brita, areia e água. }\end{array}$ & $2400 \mathrm{~kg} / \mathrm{m}^{3}$ & $\begin{array}{l}\text { Em torno de } \\
20 \mathrm{MPa}\end{array}$ & $\begin{array}{l}\text { - Podem ocorrer aumento das } \\
\text { cargas na fundação e na } \\
\text { estrutura; } \\
\text { - Desempenho térmico e } \\
\text { acústico inferior ao concreto leve } \\
\text { (depende da espessura do } \\
\text { painel). }\end{array}$ \\
\hline Leve Celular & $\begin{array}{l}\text { Cimento Portland, } \\
\text { areia, brita, água, } \\
\text { espuma ou agentes } \\
\text { incorporadores de ar. }\end{array}$ & $\begin{array}{c}1300 \mathrm{a} \\
1900 \mathrm{~kg} / \mathrm{m}^{3}\end{array}$ & $\begin{array}{c}\text { Em torno de } 6 \\
\mathrm{MPa}^{15}\end{array}$ & $\begin{array}{l}\text { - Aumento da permeabilidade do } \\
\text { concreto; } \\
\text { - Diminuição da resistência } \\
\text { mecânica e durabilidade; } \\
\text { - Desempenho Térmico e } \\
\text { Acústico Satisfatório; } \\
\text { - Ataque à armadura - íons } \\
\text { cloreto e carbonatação; } \\
\text { - Menor produtividade; } \\
\text { - Aumento do custo, necessidade } \\
\text { de pinturas especiais ou } \\
\text { impermeabilização; } \\
\text { - Somente para edificações } \\
\text { térreas. }\end{array}$ \\
\hline Leve Estrutural $^{16}$ & $\begin{array}{l}\text { Cimento Portland, } \\
\text { areia, brita, argila } \\
\text { expandida e água. }\end{array}$ & $1700 \mathrm{~kg} / \mathrm{m}^{3}$ & $\begin{array}{l}\cdot 12 \text { horas de idade } \\
\text { em torno de } 2 \mathrm{MPa} \\
\cdot 28 \text { dias de idade } \\
\text { acima de } 30 \mathrm{MPa}\end{array}$ & $\begin{array}{l}\text { - Trabalhabilidade (bombeamento } \\
\text { e moldagem), slump em torno de } \\
150 \mathrm{~mm} ; \\
\text {-Permeabilidade aos } 28 \text { dias } \\
\text { diminuição de } 2,5 \% \text {, diminuição } \\
\text { da ação de agentes agressivos; } \\
\text {-Isolamento térmico e acústico } \\
\text { compatível à concretos celulares. }\end{array}$ \\
\hline
\end{tabular}

Fonte: Produzida a partir dos dados anteriormente discutidos.

\footnotetext{
${ }^{15}$ Sendo esse valor de resistência à compressão para a massa específica de $1700 \mathrm{~kg} / \mathrm{m}^{3}$.

${ }^{16}$ Resultados obtidos em estudo preliminar realizado no Laboratório de Construção Civil (LCC) da Escola de Engenharia de São Carlos (USP) no fim de 2004, indicando que o concreto leve com argila expandida nacional apresenta grande potencial de utilização no sistema construtivo de painéis monolíticos moldados in loco.
} 
Tendo como referência o desempenho global da edificação (ABNT, 2008 e ABNT, 2005), mostram-se relevantes estudos sobre o desenvolvimento de concretos alternativos ao concreto celular e ao tradicional para aplicação no sistema construtivo de painéis monolíticos moldados in loco que atendam aos requisitos técnicos de trabalhabilidade, resistência mecânica e durabilidade, além dos requisitos relacionados ao desempenho térmico da habitação, como os concretos com agregados leves.

Após a análise detalhada das características e propriedades dos concretos leves, principalmente em relação à durabilidade é possível perceber a importância do estudo desses aspectos para o seu correto emprego. O desempenho térmico da edificação neste estudo é igualmente de grande importância, especialmente para a especificação correta da espessura das vedações assim como da massa específica do concreto, tendo como referência as zonas bioclimáticas regionais e a tipologia construtiva. Com isso no próximo capitulo será abordado o assunto conforto térmico, diretamente relacionado a este projeto. 


\section{CONFORTO TÉRMCO DE EDIRCAÇÕES}

\subsection{Breve Histórico}

O conforto térmico tem sido analisado internacionalmente há cerca de 150 anos, inicialmente nas minas de carvão da Inglaterra ou com interesses militares. Outras áreas de interesse, visando diferentes aplicações foram: rendimento nos trabalhos físico e intelectual, sobrevivência humana em condições de exposição curta ou prolongada a climas agressivos, obtenção de parâmetros para projeto e desempenho de sistemas de ventilação e climatização natural ou artificial de ambientes (PIETROBON, 2001). A preocupação para a obtenção de conforto térmico de uma edificação tem sido discutida com maior freqüência nas últimas décadas do século XX e tem aumentado nos últimos anos.

Até a década de 60 , os trabalhos na área de conforto térmico no Brasil podem ser considerados incipientes quando comparados ao contexto internacional, com exceção dos trabalhos do antigo Instituto de Higiene da Universidade de São Paulo. Anteriormente foram realizados trabalhos no Instituto Nacional de Tecnologia no Rio de Janeiro, tendo destaque o trabalho de Paulo Sá, desenvolvido em 1938 e publicado por meio do Departamento de Estatística e Publicidade do Rio de Janeiro (BARBOSA, 1997).

A partir da década de 90 destacam-se os trabalhos da ANTAC (Associação Nacional de Tecnologia do Ambiente Construído), organizando eventos na área de conforto ambiental, contribuindo para o fortalecimento do conhecimento na área e promovendo a interação entre grupos de pesquisa consolidados com grupos emergentes. Destacam-se também grupos de pesquisas em nível acadêmico como o Laboratório de Conforto Ambiental e Eficiência Energética (LABAUT), do Departamento de Tecnologia da FAU/USP que opera há quatro anos e o Laboratório de Eficiência Energética em Edificações (LABEEE) que está vinculado ao Departamento de Engenharia Civil da Universidade Federal de Santa Catarina. 


\subsection{Definições}

O conforto térmico pode ser considerado um estado de espírito que reflete satisfação com o ambiente térmico que envolve o ser humano (ASHRAE, 1992). Se o balanço de todas as trocas de calor a que está submetido o corpo for nulo e a temperatura da pele e suor estiverem dentro de certos limites, pode-se dizer que o homem sente conforto térmico. $A$ sensação de conforto térmico implica em considerações fisiológicas e psicológicas variáveis por pessoa, porém pode ser melhorada e qualificada (CARDOSO, 2002).

O conforto pode ser definido especificamente, em função da relação que o homem estabelece com ambiente e de acordo com o que o ambiente construído possibilita ao indivíduo sob o aspecto bio-ambiental, em termos de luz, som, calor, uso do espaço, de acordo com as experiências de cada pessoa. As bases da relação entre o homem e o ambiente construído residem no campo da psicofisiologia, cujas leis dizem respeito exatamente às sensações humanas com os estímulos físicos. A psicofisiologia orienta o projetista com relação aos principais problemas da percepção humana para se estabelecer as necessidades do usuário e possibilitar as respostas mais adequadas por meio da intervenção do projetista no meio ambiente (PIETROBON, 2001).

Segundo Roriz (1987) o conforto térmico mostra-se como um dos requisitos básicos para que os ambientes apresentem o melhor nível possível de habitabilidade e sua importância está ligada não só à sensação de conforto dos seus usuários, como também ao seu desempenho no trabalho e à sua saúde. O mesmo autor cita como fundamental para determinação da condição de conforto elementos como o clima (temperatura do ar, umidade relativa, movimento do ar e radiação), a vestimenta, e outros, de caráter subjetivo (aclimatação, forma e volume do corpo, cor, metabolismo, etc.). O efeito conjugado desses parâmetros, quando produz sensações térmicas agradáveis denomina-se zona de conforto. Seu estudo é de suma importância para o condicionamento térmico natural das edificações, ou arquitetura bioclimática. As zonas de conforto térmico (parâmetros e índices) colaboram na definição das cartas bioclimáticas a serem adotadas, as quais devem conter as seguintes informações: comportamento climático do entorno e previsão de estratégias indicadas para a correção desse comportamento climático por meio de desempenho esperado na edificação.

O conforto térmico depende de um conjunto de parâmetros relacionados aos processos de troca de calor entre a edificação e o ambiente externo, tais como as propriedades higrotérmicas e inércia térmica dos materiais e componentes; a insolação; a ventilação e deve ser considerada, ainda, as condições climáticas da região, o entorno e as atividades previstas. Tudo isso deve ser inserido no processo de projeto, nem sempre de forma sistemática, devido à complexidade dos fenômenos envolvidos (CARDOSO, 2002). 
Procura-se por meio desses parâmetros e índices estabelecer o bem-estar dos usuários de um edifício, num sentido mais amplo, pois o edifício, projetado pelo arquiteto para o homem deve atender aos requisitos de conforto psicológico dos usuários; sem esquecer outros aspectos não menos importantes, como os funcionais, construtivos, estéticos e até simbólicos da obra arquitetônica, além da salubridade (PIETROBON, 2001). Para a obtenção de uma metodologia que possa ser aplicada a projetos de edificação, em relação à Bioclimatologia, deve-se estudar e aperfeiçoar os sistemas bioclimáticos, bem como estabelecer parâmetros de avaliação térmica do ambiente construído (CARDOSO, 2002).

Segundo Lamberts (2005) as variáveis de conforto térmico estão divididas em variáveis ambientais e variáveis humanas. As variáveis humanas são, o metabolismo gerado pela atividade física e a resistência térmica oferecida pela vestimenta. As variáveis ambientais são a temperatura do ar; a temperatura radiante média; a velocidade do ar e a umidade relativa do ar. Além disso, variáveis como sexo, idade, raça, hábitos alimentares, peso, altura entre outros podem exercer influência nas condições de conforto de cada pessoa e devem ser consideradas.

Atualmente o tema conforto ambiental consiste em uma visão integrada de um conjunto de condições e situações que antes eram tratadas de forma estanque e fragmentada por especialistas, os quais em sua maioria não dialogavam entre si (KOWALTOWSKI et al, 1998). Isso, focado em arquitetura, remete ao desafio da atuação dos projetistas no sentido de harmonizar esses diferentes critérios e indicadores de conforto na busca de uma melhor solução para o projeto arquitetônico.

Temos como exemplo na área de conforto ambiental para habitações o trabalho Kowaltowski et al (1998), que propôs o estabelecimento de diretrizes de implantação de conjuntos habitacionais de interesse social construídos pela Companhia de Desenvolvimento Habitacional e Urbano do Estado de São Paulo (CDHU). A ênfase nesse caso foi nos aspectos de sustentabilidade e qualidade de vida (KOWALTOWSKI et. al., 1998). Pietrobon (1990) propôs em seu trabalho o projeto de uma casa hipotética de 49,84 $\mathrm{m}^{2}$ para a cidade de Maringá, com o objetivo de buscar condições de conforto higro-térmico por meio de soluções passivas com mínimo aporte energético, isso garantindo conforto térmico em $80 \%$ do ano e apontando mecanismos e estratégias simples de climatização natural (CARDOSO, 2002).

Em termos de atuação profissional, exige-se do profissional de projetos a análise em relação à iluminação, ao conforto térmico e acústico, à funcionalidade e ergonometria, oriundos da pesquisa científica, porém grande parte dos exemplos presentes nas pesquisas científicas, não se adapta ao projeto real com facilidade. Cada aspecto do projeto 
arquitetônico necessita de tradução de conceitos específicos e de indicadores em imagens gráficas adequadas ao processo de projeto (KOWALTOWSKI et. al., 1998).

O interesse quanto ao condicionamento térmico natural não deve ser somente por razões de conforto, mas também de eficiência energética, pois importante parcela do consumo total de energia elétrica em um edifício se deve aos equipamentos de climatização, seja para o aquecimento ou para a refrigeração dos ambientes. Enquanto que para a população de classe média e alta a falta de habitabilidade das edificações significa aumento de consumo energético com climatização artificial, para a população menos favorecida a inadequação térmica das habitações significa desconforto (VIEIRA, 2005).

\subsection{Vedações Verticais e o Conforto Térmico}

Como o objeto de estudo em questão neste trabalho são as vedações verticais, devem ser mostradas algumas características importantes a serem observadas nas mesmas e sua influência em relação ao conforto térmico.

As trocas de energia, luz e calor entre os meios externos e internos, têm como fator principal o "envelope construtivo", ou seja, as vedações. Para analisá-la devem ser considerados todos os fatores que intervêm no problema, dentre eles a radiação solar, diante da qual os materiais se comportam de maneira distinta. O envelope construtivo se divide em dois tipos, que são: fechamentos opacos e fechamentos transparentes. A principal diferença entre eles é justamente sua capacidade (transparentes) ou incapacidade (opacos) de transmitir a radiação solar para o ambiente interno (LAMBERTS, 1997).

Outra característica importante a ser observada nos fechamentos é a inércia térmica. À inércia térmica estão relacionados dois fenômenos de grande significado para o comportamento térmico do edifício: o amortecimento e o atraso da onda de calor, devido ao aquecimento ou ao resfriamento dos materiais. A inércia térmica depende das características térmicas da envolvente e dos componentes construtivos, e é função da densidade, da condutividade térmica e da capacidade calorífica das vedações (FROTA, 1995).

Uma vedação construída com materiais inadequados pode funcionar como um painel radiante em horários indesejáveis. Um importante parâmetro para a tomada de decisões sobre a escolha de vedações e cobertura é a transmitância térmica. Devem ser feitas análises que considerem a variação periódica dos parâmetros climáticos externos e a capacidade de armazenamento térmico de coberturas e vedações, fazendo uso dessa energia armazenada nos horários oportunos (GRANJA e LABAKI, 2004). No estudo de Granja e Labaki (2004), por exemplo, foi observado que fechamentos mais leves tendem a adiantar sensivelmente o pico de carga térmica para dentro do cômodo em relação a 
fechamentos de massa mais elevada. Os dois tipos de fechamentos analisados, concreto tradicional $\left(\rho=2.200 \mathrm{~kg} / \mathrm{m}^{3}, \lambda=75 \mathrm{~W} / \mathrm{m} \mathrm{K}, \mathrm{c}=1,00 \mathrm{~kJ} / \mathrm{kg} \mathrm{K}\right.$ ) e concreto com argila expandida ( $\rho=500 \mathrm{~kg} / \mathrm{m}^{3}, \lambda=0,20 \mathrm{~W} / \mathrm{m} \mathrm{K}, c=1,00 \mathrm{~kJ} / \mathrm{kgK}$ ) apresentaram comportamento distinto relativos à onda térmica, relativos à massa de cada um o que pode gerar graus de desconforto ao usuário em diferentes horas do dia, segundo a adoção de um sistema de parede com maior ou menor massa. Nesse trabalho observou-se que a concepção dos sistemas de vedações deve levar em conta também o período de utilização da edificação, e que o adiantamento dos picos da onda térmica, causado por uma parede mais leve em relação a uma de maior massa, pode ser justificável sob o ponto de vista do período de uso do cômodo; o mesmo raciocínio vale para justificar o uso do maior atraso térmico das paredes de maior massa.

\subsection{Normalização em Conforto Térmico}

No cenário internacional, o uso de diretrizes e normas tem sido efetivo no estabelecimento de medidas de eficiência energética em edificações. Muitas organizações independentes têm desenvolvido requerimentos energéticos para construções residenciais nos Estados Unidos, assim como o Model Energy Code, o Energy-Efficient Design of Lowrise Residential Buildings, aprovados pela ASHRAE (American Society of Heating, Refrigerating and Air), e as normas desenvolvidas pelo Departamento de Energia dos Estados Unidos. Esses requerimentos podem ser usados junto com códigos para incentivar construtores a encontrar métodos inovadores que excedam os padrões mínimos. Além disso, os resultados obtidos e o uso de programas da certificação podem adicionar valor à edificação, estimulando a indústria da construção (MACIEL, 2006).

A União Européia estabeleceu uma diretriz orientadora no desempenho energético de edificações em 2002. Essa diretriz orientadora está de acordo com o procedimento colocado no artigo 251 do tratado que estabelece a Comunidade Européia. Essa diretriz orientadora tem como objetivo promover a melhoria do desempenho energético de edificações dentro da comunidade, considerando as condições climáticas externas locais, assim como as exigências climáticas internas e o custo-benefício (MACIEL, 2006).

Segundo Romero (1998) apesar de parâmetros diferentes para normalização nesse campo, as normas e os códigos europeus são bons indicadores e pontos de partida para implantação de regulamentos energéticos no Brasil, pois há neles a preocupação em garantir a qualidade dos envolventes dos edifícios sem dificultar a criatividade dos projetistas.

Não se trata apenas de seguir a normalização deve haver a preocupação, por parte dos profissionais da área da construção civil, com soluções arquitetônicas e sistemas 
construtivos que promovam mais eficiência ao sistema final, incluindo a busca do aproveitamento máximo dos recursos naturais disponíveis, a serem considerados desde a fase inicial dos projetos. Essas soluções devem se basear, evidentemente, em dados climatológicos e demais características da região na qual se localizará a edificação (CARDOSO, 2002).

Um aspecto de grande importância, diretamente relacionado à normalização em conforto térmico é o estabelecimento de parâmetros para determinação das condições de conforto. Roriz e Basso (1991), por exemplo, estudaram dez métodos que determinam sob quais condições um ambiente se torna termicamente agradável. Foram aplicados nesse estudo, para cada um dos dez métodos estudados, as mesmas condições climáticas, comparando os resultados. Observando-se que as divergências são muitas nos aspectos de conceitos, variáveis e abordagens, tornou-se necessário fazer algumas adaptações para viabilizar a comparação. Nesse estudo, as condições climáticas escolhidas se referiram aos dias típicos de verão e inverno para Porto Alegre, ambos com probabilidade definida em 2,5\%, (condições rigorosas). Os dez métodos estudados por Roriz e Basso (1991) foram: 1Evans (Argentina); 2-Fanger (Dinamarca); 3 - Givoni (Israel); 4-Humphreys (Inglaterra); 5Lotersztain e Murature (Argentina); 6- Mahoney (Inglaterra); 7-Olgyay (USA); 8-Rivero (Uruguai); 9-Szokolay (Austrália); e 10-Vogt e Miller Chagas (França). Ao final do trabalho chegou-se à conclusão que os diversos métodos estudados não divergem quanto às condições extremas (no caso do inverno em Porto Alegre) porque são óbvias, todavia, quanto aos limites de conforto (durante o período de verão em Porto Alegre), existem divergências, pois os métodos não coincidem principalmente nos horários de transição entre dia e noite.

Em 1994 com o objetivo de selecionar um método para delimitação da zona de conforto a ser adotada ou adaptada para a realidade brasileira e considerando que o método de Fanger contempla todas as variáveis que afetam o conforto humano e o desempenho do ambiente construído, GOULART et al (1994) aplicaram a equação desse método para determinação do PMV (Voto Médio Estimado) e PPD (Porcentagem de Pessoas Insatisfeitas), nos pontos extremos que delimitam as zonas de conforto dos diagramas bio climáticos desenvolvidos por: OLGYAY para os USA; OLGYAY para climas quentes; OLGYAY para trópicos; GIVONI original (1969); GIVONI e MILNE (1979); GONZALEZ (1980); GIVONI (1992) países desenvolvidos; GIVONI (1992) países em desenvolvimento; SZOKOLAY (1987) para o clima de Florianópolis-SC; WATSON \& LABs. (1983); ASHRAE 55-74. (1974); ASHRAE 55-81 (1981); e ASHRAE 55-92 (1992). A Tabela 6 mostra as temperaturas (limites máximos e mínimos) e a umidade (limites máximos e mínimos) de acordo com a metodologia (BARBOSA, 1997). 
Tabela 6. Temperaturas (limites máximos e mínimos) e umidade (limites máximos e mínimos) de diferentes Metodologias.

\begin{tabular}{|c|c|c|c|c|c|}
\hline \multirow[b]{2}{*}{ METODOLOGIA } & \multicolumn{2}{|c|}{ TEMPERATURA } & \multicolumn{2}{|c|}{ UMIDADE } & \multirow{2}{*}{ OBSERVAÇÃO } \\
\hline & $\begin{array}{l}\text { Limite } \\
\text { Mínino }\end{array}$ & $\begin{array}{c}\text { Limite } \\
\text { Máximo }\end{array}$ & Limite Mínimo & Limite Máximo & \\
\hline ASHRAE 55-74 & $>20,0^{\circ} \mathrm{C} \mathrm{TE}^{*}$ & $<26,1^{\circ} \mathrm{CTE}^{*}$ & $>5 \mathrm{~mm} \mathrm{Hg}$ & $<14 \mathrm{~mm} \mathrm{Hg}$ & \\
\hline \multirow{3}{*}{ ASHRAE 55-81 } & & & $>4 \mathrm{~g} / \mathrm{kg}$ & $<12 \mathrm{~g} / \mathrm{kg}$ & \\
\hline & $>23^{\circ} \mathrm{CTE}^{*}$ & $<27^{\circ} \mathrm{C} \mathrm{TE}^{*}$ & & & Verão \\
\hline & $>20^{\circ} \mathrm{C} \mathrm{TE}^{*}$ & $<24^{\circ} \mathrm{C} \mathrm{TE}^{*}$ & & & Inverno \\
\hline \multirow{3}{*}{ ASHRAE 55-92 } & & & $>4,5 \mathrm{~g} / \mathrm{kg}$ e $30 \%$ & $<60 \%$ & \\
\hline & $>23^{\circ} \mathrm{C} \mathrm{TE}^{*}$ & $<26^{\circ} \mathrm{C} \mathrm{TE}^{*}$ & & & Verão \\
\hline & $>20^{\circ} \mathrm{C} \mathrm{TE}^{*}$ & $<23,5^{\circ} \mathrm{C} \mathrm{TE}^{*}$ & & & Inverno \\
\hline \multirow{3}{*}{ GIVONI original } & & & $>5 \mathrm{~mm} \mathrm{Hg}$ & $\begin{array}{c}<17 \mathrm{~mm} \mathrm{Hg} \mathrm{e} \\
80 \% \\
\end{array}$ & \\
\hline & $>21^{\circ} \mathrm{C}$ & $<26^{\circ} \mathrm{C}$ & & & baixa umidade \\
\hline & & $<25^{\circ} \mathrm{C}$ & & & altas umidades \\
\hline \multirow{3}{*}{ GIVONI e MILNE } & & & $>20 \%$ & $<80 \%$ & \\
\hline & $>22,7^{\circ} \mathrm{C}$ & $<27^{\circ} \mathrm{C}$ & & & verão \\
\hline & $>20^{\circ} \mathrm{C}$ & $<24^{\circ} \mathrm{C}$ & & & inverno \\
\hline GIVONI 92 & & & $>4 \mathrm{~g} / \mathrm{kg}$ & $<15 \mathrm{~g} / \mathrm{kg}$ e $80 \%$ & \\
\hline Países & $>20^{\circ} \mathrm{C}$ & $<27^{\circ} \mathrm{C}$ & & & verão \\
\hline Desenvolvidos & $>18^{\circ} \mathrm{C}$ & $<25^{\circ} \mathrm{C}$ & & & inverno \\
\hline GIVONI 92 & & & $>4 \mathrm{~g} / \mathrm{kg}$ & $<17 \mathrm{~g} / \mathrm{kg}$ e $80 \%$ & \\
\hline \multirow{2}{*}{$\begin{array}{c}\text { Países em } \\
\text { Desenvolvimento }\end{array}$} & $>25^{\circ} \mathrm{C}$ & $<29^{\circ} \mathrm{C}$ & & baixa umidade & $\begin{array}{c}\text { verão baixa } \\
\text { umidade }\end{array}$ \\
\hline & & $<26^{\circ} \mathrm{C}$ & & altas umidades & \\
\hline \multirow{5}{*}{ SZOKOLAY } & $>18^{\circ} \mathrm{C}$ & $<25^{\circ} \mathrm{C}$ & & & inverno \\
\hline & & & $>4 \mathrm{~g} / \mathrm{kg}$ & $<12 \mathrm{~g} / \mathrm{kg}$ & \\
\hline & $\begin{array}{l}\text { TMA } \pm 2 \mathrm{~K} \\
\mathrm{SET}\end{array}$ & & & & $\begin{array}{c}\text { limites variáveis } \\
\text { com o clima } \\
\text { local }\end{array}$ \\
\hline & $18,5^{\circ} \mathrm{C}$ & $28,5^{\circ} \mathrm{C}$ & & & \\
\hline & $\begin{array}{c}\text { TMM } \pm 1,75 \mathrm{~K} \\
\text { SET }\end{array}$ & & & & \\
\hline WATSON \& LABS & $20^{\circ} \mathrm{C} \mathrm{TE}{ }^{*}$ & $<25,6^{\circ} \mathrm{CTE}^{*}$ & $>5 \mathrm{~mm} \mathrm{Hg}<$ & $80 \%$ & \\
\hline
\end{tabular}

Fonte: GOULART et al (1994) In: BARBOSA (1997)

Barbosa e Lamberts (1997) realizaram uma análise de algumas normas sobre avaliação térmica e consumo de energia em edifícios de outros países, propondo uma linha a ser seguida por uma normatização brasileira nesse setor, voltada especialmente para edificações residenciais unifamiliares. Foi constatado que a maioria dessas normas combina exigências prescritivas e de desempenho, em seu projeto, sendo que a conservação de energia foi o objetivo principal na maioria dos paises. Quase todos possuem normas que incorporam prescrições para o envelope da edificação, as quais influenciam sobre a escolha de projeto para cobertura, paredes e janelas. Ainda, em uma menor extensão, prescrições mecânicas e de iluminação também são vistas (CARDOSO, 2002).

Nesse trabalho realizado no Núcleo de Pesquisa em Construção Civil da UFSC, por Barbosa e Lamberts (1997) foram desenvolvidos os seguintes itens para a norma brasileira, basicamente: Item 1 - Definição dos símbolos e unidades; Item 2 - Calculo de transmitância 
térmica desenvolvida; Item 3 - Procedimento para o tratamento de dados climáticos, estudados e sistematizados; Item 4 - Zoneamento bioclimático e Item 5 - Avaliação do desempenho térmico para edificações residenciais unifamiliares. Foi proposto, com base em revisões bibliográficas o desenvolvimento de itens básicos por zonas climáticas: soluções técnicas relacionadas à transmitância, sombreamento, ventilação, perdas e pacotes alternativos.

Até pouco tempo o Brasil equiparava-se em relação à normalização da energia em edifícios a outros países como Bangladesh, Botswana, Costa Rica, Djibouti e Venezuela, nos quais não se constatava normatização na área (BARBOSA, 1994). Porém a situação hoje está diferente, pois o Brasil aprovou em 2005 a norma NBR 15220 - Desempenho térmico de edificações e foi aprovada recentemente (maio de 2008) na ABNT a norma NBR - 15575 Edifícios habitacionais de até cinco pavimentos - Desempenho, que representam um grande avanço para a área de conforto térmico.

A Norma NBR 15220 - Desempenho Térmico de Edificações (ABNT, 2005), já efetivada é constituída de cinco partes, sendo: Parte 1: Definições, símbolos e unidades; Parte 2: Métodos de calculo de transmitação térmica, da capacidade térmica, do atraso térmico e do fator de calor solar de elementos e componentes de edificações; Parte 3 : Zoneamento bioclimático brasileiro e diretrizes construtivas para habitações unifamiliares de interesse social; Parte 4: Medição da condutividade térmica pelo principio da placa quente protegida e Parte 5: Determinação de resistência térmica e da condutividade térmica em regime estacionário, pelo método fluxométrico. A norma brasileira Desempenho térmico de edificações - Parte 3, de maior importância para este trabalho, divide o território brasileiro em oito zonas diferentes, apresenta uma relação de 330 cidades cujos climas foram classificados e foi adotada uma metodologia na determinação do zoneamento (Figura 64). 


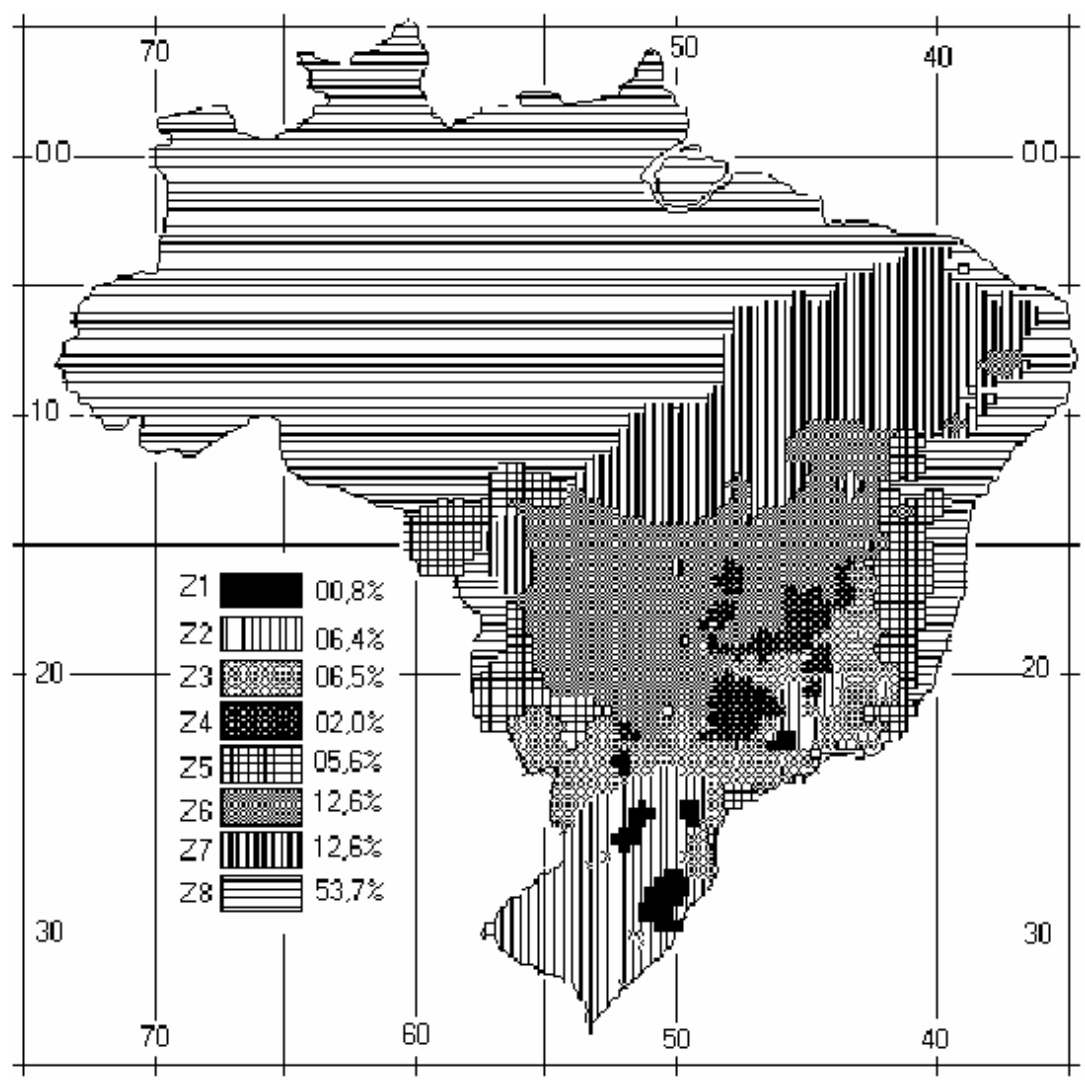

Figura 64. Zoneamento Bioclimático Brasileiro

Fonte: ABNT, 2005.

O zoneamento bioclimático brasileiro foi definido por meio de uma base de dados climáticos, obtida pela divisão do território brasileiro em 6500 células (quadrados cujo lado possui $36 \mathrm{~km}$ ), caracterizadas pela sua posição geográfica, bem como pelas médias mensais de temperaturas máximas e mínimas e das umidades relativas do ar. Foi adaptada uma carta bioclimática a partir da sugerida por Givoni (1992), para a Norma Brasileira de Desempenho Térmico em Edificações, Parte 3: Zoneamento Bioclimático Brasileiro e Diretrizes para Habitações Unifamiliares de Interesse Social. Com base nessas zonas relativamente homogêneas quanto ao clima, foram formuladas uma série de recomendações tecno-construtivas objetivando otimizar o desempenho térmico das edificações, através de sua melhor adequação climática (RORIZ et al.,1999).

Essa parte da norma estabelece alguns parâmetros construtivos relacionados à ventilação, entre eles o tamanho das aberturas; a necessidade ou não de proteção das aberturas; as vedações externas e internas; e o tipo de cobertura que as habitações devem possuir de acordo com a Zona Bioclimática na qual está inserida. Além disso, são indicadas estratégias de condicionamento térmico passivo para as edificações. Uma síntese dessas características é apresentada no Quadro 2. Assim como para a ventilação, a Parte 3 da NBR 15220 (ABNT, 2005) também apresenta diretrizes construtivas para aquecimento (solar, artificial, inércia térmica). 
Quadro 2. Zonas Bioclimáticas e diretrizes para habitações

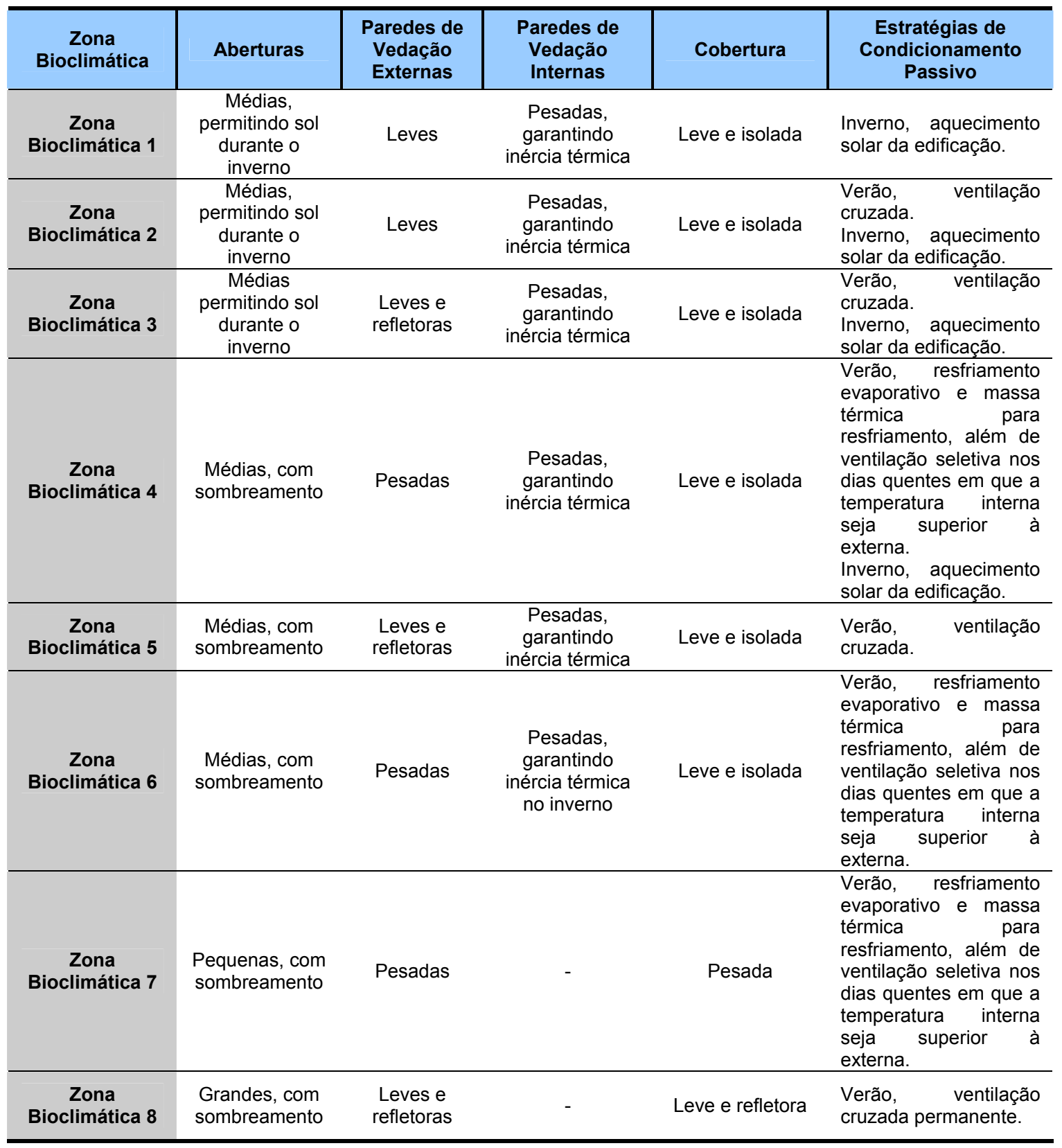

Fonte: Adaptado de ABNT, 2005.

A norma NBR 15575 Edifícios habitacionais de até cinco pavimentos - Desempenho (ABNT, 2008) é dividida em seis partes, sendo elas: Parte 1: Requisitos gerais; Parte 2: Requisitos para os sistemas estruturais; Parte 3: Requisitos para os sistemas de pisos internos; Parte 4: Sistemas de vedações verticais externas e Internas; Parte 5: Requisitos para sistemas de coberturas e Parte 6: Sistemas hidrossanitários. Nessa norma em relação à eficiência energética especificamente, destaca-se a Parte 1: requisitos gerais, na qual são estabelecidos parâmetros para avaliar as condições de conforto térmico e lumínico, além de diretrizes para execução de simulações computacionais de edifícios existentes e na fase de projeto de extrema importância para este trabalho. A restrição ao número de cinco 
pavimentos explica - se devido ao fato desta classificação abranger a grande maioria dos edifícios habitacionais do Brasil.

Outra característica de grande importância para este trabalho são os requisitos de conforto térmico apresentados pela NBR 15575-1 (ABNT, 2008) para as estações inverno (Quadro 3) e verão (Quadro 4). Esses níveis de desempenho são obtidos a partir dos resultados das temperaturas internas e externas das simulações computacionais. Tanto para as condições de inverno quanto para as condições de verão, o nível de desempenho deve ser entendido da seguinte maneira:

Nível de desempenho $M$ : atende às exigências mínimas do usuário. Deve ser obrigatoriamente atendido;

Nível de desempenho I: representa as exigências ideais do usuário, além das exigências mínimas, e não é obrigatório;

Nível de desempenho S: excede o nível mínimo I, atende além das exigências mínimas do usuário, não é obrigatório.

Quadro 3. Níveis de desempenho das edificações no inverno.

\begin{tabular}{|c|c|c|}
\hline \multirow{2}{*}{ Nível de Desempenho } & \multicolumn{2}{|c|}{ Critério } \\
\hline & Zonas Bioclimáticas 1 a $5^{1}$ & Zonas Bioclimáticas 6,7 e 8 \\
\hline M & $\mathrm{T}_{\mathrm{i}, \min } \geq\left(\mathrm{T}_{\mathrm{e}, \min }+3^{\circ} \mathrm{C}\right)$ & \multirow{3}{*}{$\begin{array}{l}\text { Nestas zonas, este critério não } \\
\text { precisa ser verificado. }\end{array}$} \\
\hline I & $\mathrm{T}_{\mathrm{i}, \min } \geq\left(\mathrm{T}_{\mathrm{e}, \min }+5^{\circ} \mathrm{C}\right)$ & \\
\hline $\mathbf{S}$ & $\mathrm{T}_{\mathrm{i}, \min } \geq\left(\mathrm{T}_{\mathrm{e}, \min }+7^{\circ} \mathrm{C}\right)$ & \\
\hline \multicolumn{3}{|c|}{$\begin{array}{l}\mathrm{T}_{\mathrm{i}, \text { min }} \text { é o valor mínimo diário da temperatura do ar no interior da edificação, em graus centígrados; } \\
\mathrm{T}_{\mathrm{e}} \text {, min é o valor mínimo diário da temperatura do ar exterior à edificação, em graus centígrados. } \\
\text { NOTA: Zonas Bioclimáticas de acordo com a ABNT NBR 15220-3. }\end{array}$} \\
\hline
\end{tabular}

Fonte: ABNT, 2008.

Quadro 4. Níveis de desempenho das edificações no verão.

\begin{tabular}{|c|c|c|}
\hline \multirow{2}{*}{ Nível de Desempenho } & \multicolumn{2}{|c|}{ Critério } \\
\hline & Zonas Bioclimáticas 1 a $7^{1}$ & Zona Bioclimática 8 \\
\hline M & $\mathrm{T}_{\mathrm{i}, \max } \leq \mathrm{T}_{\mathrm{e}, \max }$ & $\mathrm{T}_{\mathrm{i}, \max } \leq \mathrm{T}_{\mathrm{e}, \max }$ \\
\hline $\mathbf{I}$ & $\mathrm{T}_{\mathrm{i}, \max } \leq\left(\mathrm{T}_{\mathrm{e}, \max }-2^{\circ} \mathrm{C}\right)$ & $\mathrm{T}_{\mathrm{i}, \max } \leq\left(\mathrm{T}_{\mathrm{e}, \max }-1^{\circ} \mathrm{C}\right)$ \\
\hline $\mathbf{S}$ & $\mathrm{T}_{\mathrm{i}, \max } \leq\left(\mathrm{T}_{\mathrm{e}, \max }-4^{\circ} \mathrm{C}\right)$ & $\begin{array}{c}T_{i, \max } \leq\left(T_{e, \max }-2^{\circ} \mathrm{C}\right) \mathrm{e} \\
T_{\mathrm{i}, \min } \leq\left(\mathrm{T}_{\mathrm{e}, \min }+1^{\circ} \mathrm{C}\right)\end{array}$ \\
\hline \multicolumn{3}{|c|}{$\begin{array}{l}\mathrm{T}_{\mathrm{i}, \text { max }} \text { é o valor máximo diário da temperatura do ar no interior da edificação, em graus centígrados; } \\
\mathrm{T}_{\mathrm{e}, \text { max é e valor máximo diário da temperatura do ar exterior à edificação, em graus centígrados; }} \\
\mathrm{T}_{\mathrm{i}, \text { min é o valor mínimo diário da temperatura do ar no interior da edificação, em graus centígrados; }} \\
\mathrm{T}_{\mathrm{e}} \text { min é o valor mínimo diário da temperatura do ar exterior à edificação, em graus centígrados. } \\
\text { NOTA: Zonas Bioclimáticas de acordo com a ABNT NBR 15220-3. }\end{array}$} \\
\hline
\end{tabular}

Fonte: ABNT, 2008. 


\subsection{Software como Ferramenta para Avaliação de Desempenho na Fase de Projeto}

Atualmente verifica-se um uso generalizado de computadores, softwares e meios eletrônicos de comunicação. As novas tecnologias abrem uma série de desafios e possibilidades para as práticas de projeto. A crescente facilidade de manipular informações e automatização de cálculos permite a introdução crescente de simulações como ferramenta de projeto mesmo em fases avançadas de desenvolvimento (FABRíCIO e MELHADO, 2002).

Segundo Marsh (1997), o termo ferramenta de projeto é geralmente aplicado a uma quantidade grande de técnicas, variando de dados tabulados em planilhas e dos métodos manuais do cálculo a programas sofisticados de análise computacional. Entretanto, pode-se observar que embora sejam classificados por pesquisadores como ferramentas de projeto, a maioria focaliza mais a análise do projeto consolidado do que a tomada de decisão durante o projeto. É necessário compreender que a ferramenta estará baseada sempre em um modelo teórico, em que estimativas são feitas. Para identificar a ferramenta mais apropriada a seus objetivos é necessário observar a funcionalidade da ferramenta. Isto inclui os dados de entrada, o método do cálculo, as funções relacionadas à eficiência energética e ao projeto ambiental e o formato requerido para saída dos resultados (MACIEL, 2006).

As primeiras ferramentas computacionais para simulação de edificações em conforto ambiental foram desenvolvidas ainda na década de 70, em computadores do tipo mainframe, podendo-se citar como referência dessa tecnologia o programa NBSLD, desenvolvido nos Estados Unidos (EUA). Em seguida, surgiram as estações de trabalho (workstations), operando em ambiente Unix, sob o qual foram desenvolvidas algumas ferramentas computacionais utilizadas até hoje, entre elas: DOE-2, BLAST, RADIANCE e ESP-r; os três primeiros desenvolvidos nos EUA e o último desenvolvido na Escócia, Reino Unido (MENDES et al, 2005).

A partir da década de 90, com a popularização dos computadores pessoais, empresas e grupos de pesquisa se empenharam no desenvolvimento de interfaces para esses programas, compatíveis com o sistema operacional Windows. Com o avanço progressivo dos recursos computacionais, aumento de capacidade de processamento e memória, programas mais modernos e complexos puderam ser desenvolvidos, tais como o ENERGYPLUS, o FLUENT, o CFX e o PHOENICS. O primeiro adota os principais recursos do DOE-2 e do BLAST, e os outros já utilizam o conceito de Dinâmica dos Fluídos Computacional (CFD) para representar detalhadamente o fluxo de calor e o escoamento de ar em edificações. Mas por tratarem de fenômenos físicos complexos, essas ferramentas computacionais ainda são empregadas apenas em centros de pesquisas de universidades e 
institutos, com pouca transferência de tecnologia para o setor de projetos, ou seja, os escritórios de engenharia e arquitetura (MENDES et al, 2005).

Os softwares de simulação para as avaliações de desempenho ambiental na arquitetura já são uma prática consolidada no cenário europeu, de conhecimento e uso por parte de arquitetos, engenheiros e demais profissionais de projeto. Enquanto isso, no Brasil o uso ainda é restrito, e o conhecimento dessas ferramentas é encontrado em centros de pesquisa, sem o domínio de profissionais exclusivamente da prática de projeto (GONÇALVES, 2006).

Um levantamento executado na Holanda em 70 projetos de edificações verificou-se que cerca de $80 \%$ das medidas de eficiência energética adotadas são selecionadas com base na intuição ou experiências anteriores, sem a consideração de outras alternativas. A seleção da maioria dos conceitos ou componentes energeticamente eficientes é feita durante a fase conceitual do projeto e que as ferramentas de simulação, quando utilizadas, são adotadas após essa fase, apenas para verificar as expectativas em relação à economia de energia ou otimizar a alternativa selecionada. Entre as principais barreiras para integração da simulação durante o projeto os autores citam: a falta de confiança e clareza nos resultados fornecidos pelos programas; alto grau de experiência exigido para a correta utilização; e custos com simulação, especialmente em relação ao tempo envolvido no processo de modelagem (WILDE e VOORDEN, 2004 apud GOSCH, S. R.; WESTPHAL, F. S.; LAMBERTS, 2004).

Outro levantamento, realizado nos Estados Unidos e na Nova Zelândia, junto a escritórios que utilizam simulação computacional em seus projetos foi possível identificar as experiências desses usuários e suas necessidades em termos de aprimoramento das ferramentas existentes. Nesse estudo a maioria dos usuários identificou que o maior dispêndio de tempo no uso das ferramentas está no processo de modelagem da edificação. Cerca de $40 \%$ dos usuários sugeriram melhorias nas interfaces dos programas, principalmente em relação à existência de valores pré-definidos para dados de entrada e padrões de uso. Há uma necessidade de se desenvolver diferentes níveis de simulação para os diferentes estágios do projeto, além de ferramentas que possam garantir a modelagem rápida e expedita da edificação (DONN, 1997 apud GOSCH, S. R.; WESTPHAL, F. S.; LAMBERTS, 2004).

Desde a década de 80 o Brasil vem importando os programas de simulação desenvolvidos no exterior, onde os recursos financeiros para esse tipo de pesquisa são mais abundantes. Nesse período, alguns grupos de pesquisa do país se destacaram, empregando as ferramentas computacionais existentes ou desenvolvendo seus próprios códigos e algoritmos para promover o desenvolvimento de projetos de edificações mais eficientes (MENDES et al, 2005). 
Empresas de grande porte no cenário brasileiro, de origem pública e privada, vêm se destacando nos últimos anos por exigir estudos sobre o desempenho ambiental na elaboração de projetos de edificações, almejando também uma maior visibilidade internacional. Porém, antes do interesse das grandes empresas, uma série de propostas de menor escala e movidas por temas ambientais já permeavam a produção arquitetônica (GONÇALVES, 2006).

Nos últimos anos, diversas ferramentas computacionais foram desenvolvidas para auxiliar na análise térmica e energética de edificações e seus componentes. O Diretório de Ferramentas de Simulação Energética (Building Energy Tools Directory) do Departamento de Energia dos Estados Unidos apresenta mais de 340 programas de simulação desenvolvidos em diversos países, sendo apenas um deles software brasileiro. Trata-se de softwares destinados a avaliar a eficiência energética, a energia renovável, e a sustentabilidade nos edifícios ${ }^{17}$.

Essas ferramentas incluem bases de dados, análises de componentes e dos sistemas, e programas de simulação do desempenho global de energia no edifício. Apesar dessa quantidade de programas existentes, o emprego de simulação computacional nos escritórios de engenharia e arquitetura durante a elaboração do projeto arquitetônico apresenta-se pouco visível. Avaliar o desempenho energético de edificações mostra-se como uma tarefa complexa que envolve grande quantidade de variáveis interdependentes e conceitos multidisciplinares. $O$ advento do computador foi fundamental para 0 desenvolvimento dos modelos físicos que representam o comportamento térmico $\mathrm{e}$ energético de edificações, permitindo a simulação de diferentes cenários. Por meio dos programas de simulação, pode-se avaliar o desempenho térmico e energético de edificações para diferentes alternativas de projeto, sejam elas opções do desenho arquitetônico, componentes construtivos, sistemas de iluminação ou sistemas de condicionamento de ar. Além disso, pode-se estimar o consumo de energia, o custo desse consumo e até mesmo o impacto ambiental provocado pela alternativa de projeto antes mesmo de sua execução (MENDES et al, 2005).

É possível identificar quatro linhas principais de desenvolvimento; a maioria delas são ferramentas relacionadas ao projeto de proteções solares usando diagramas solares; vêm em seguida as ferramentas para a sistematização de dados climáticos; as ferramentas de ensino e disseminação de conceitos relacionados à arquitetura passiva e adequação climática e; finalmente, as ferramentas que associam características climáticas com as estratégias do projeto, geralmente através de cartas bioclimáticas. Algumas ferramentas visam também a integração de diretrizes práticas por meio de modelos da simulação. Por meio de sistemas especialistas o arquiteto é guiado pelo processo de tomada de decisão

\footnotetext{
${ }^{17}$ Fonte: http://apps1.eere.energy.gov/buildings/tools_directory/
} 
com a aplicação de diretrizes práticas e sempre que estas não podem ser aplicadas, o sistema orienta o projetista usando modelos de simulação com métodos precisos (MACIEL, 2006).

A grande quantidade de dados requeridos pela maioria das ferramentas de análise de desempenho conduz a tomada de decisões arbitrárias e prematuras para poder definir um modelo aceitável para a ferramenta. Essas exigências são inadequadas ao nível de informação ainda subjetivo e incipiente do processo inicial de projeto. Esse tipo de ferramenta também não permite uma análise conjunta das variáveis de desempenho e das alternativas propostas. Além disso, representa um acréscimo de tempo no processo de projeto. Conseqüentemente, estas ferramentas são usadas quase exclusivamente em estágios mais avançados do projeto, quando aspectos relevantes da arquitetura já foram definidos e assim há pouca possibilidade de alteração. Assim, os resultados de simulação são usados apenas para satisfazer o cliente, demonstrar o projeto ou para projetar sistemas auxiliares (MACIEL, 2006).

Tanto na prática como no ensino, a simulação computacional ainda apresenta-se como um ponto crítico. Os programas de simulação computacional com resultados gráficos avançados são complexos nos dados de entrada e na modelagem. Sem uma base sólida de trocas de calor e mecânica de fluidos, principalmente, o usuário não tem condições de interpretar corretamente os resultados. Nesses casos, a fidelidade da representação do fenômeno é ainda mais importante do que a fidelidade formal. Já os softwares mais simplificados, adotados pelos cursos de graduação, pressupõem uma simplificação formal que não atende às idéias de projeto (GONÇALVES, 2006).

A informática mostra-se como uma ferramenta importante no auxilio do projetista para analisar e aquilatar as variantes de conforto térmico em seus projetos. Atualmente como ferramentas para a ventilação natural têm-se o programa VENTO. Com relação às ferramentas para simulação de desempenho térmico em edificações, as mais recentes são aquelas que permitem a modelagem de elementos de sombreamento e obstruções externas, além de trabalhar com arquivos climáticos com dados horários anuais. $O$ programa COMFIE, por exemplo, permite uma análise para o ano inteiro, além da modelagem de elementos de sombreamento e obstruções externas; já o software ARQUITROP 3.0 limita-se ao cálculo de um só dia por simulação; o programa LUZ DO SOL 1.1 estima a quantidade de radiação e o efeito de dispositivos de proteção solar, entre vários outros softwares como POWER-DOE, SEMPRE, ENERGRAPH, ANALYSIS SOL-AR; SUNPATH; TRANSMITÂNCIA; DECLINAÇÃO MAGNÉTICA 2.0; AVALCON -RIO 1.0; e NETUNO. Porém, quase todos ainda carecem de uma melhor integração com o ambiente CAD e uma mais ampla adaptação a um casamento de todas as variáveis (CARDOSO, 2002). 
O uso de simulação de edificações no Brasil ainda está concentrado nas instituições de ensino e pesquisa, com pouca transferência da tecnologia para o setor privado, isso com raras exceções de utilização na área de certificação de edificações, na qual é utilizado principalmente o software Energy Plus. O mesmo padrão de comportamento é verificado em outros países, com exceção da Alemanha, onde escritórios de projeto vêm se destacando com a aplicação de ferramentas de simulação no desenvolvimento de edificações com alto nível de eficiência energética. A complexidade das ferramentas existentes e a falta de programas nacionais são as principais causas da fraca disseminação desse tipo de tecnologia no Brasil. Para disseminar o uso da simulação nos escritórios é imprescindível a elaboração de interfaces simplificadas, que reduzam o tempo gasto na modelagem e análise de diferentes alternativas ainda na etapa de anteprojeto, na qual são assumidos os conceitos principais, que poderão sofrer poucas alterações no decorrer do projeto. Programas mais recentes já adotam níveis diferentes de interface, de acordo com a etapa do projeto à qual a simulação está sendo aplicada (MENDES et al., 2005).

\subsubsection{O Software ARQUITROP 3.0}

O ARQUITROP 3.0 é um sistema integrado de programas computacionais e bancos de dados que simula o desempenho térmico e verifica a adequação climática de edificações visando otimizar o conforto ambiental e a economia de energia. Pode ser operado no microcomputador e coloca-se como um aplicativo de apoio às atividades de projeto em arquitetura e engenharia civil. Foi desenvolvido de modo a tornar-se acessível ao maior número possível de usuários, mesmo para os profissionais não especialistas nas técnicas de controle termo - ambiental dos edifícios. O software processa em poucos minutos, um grande conjunto de dados e modelos matemáticos cujo tratamento manual demandaria vários dias de especialistas (RORIZ e BASSO, 1989).

O ARQUITROP 3.0 foi utilizado neste trabalho mesmo não sendo um dos mais recentes da área (foi criado em 1989), principalmente em relação aos dados climáticos cuja maioria se refere ao período compreendido entre os anos de 1931 e 1960.

Apesar disso, o software apresenta algumas características favoráveis, como a simulação de apenas um dia, que faz parte das diretrizes da NBR 15575-1 (ABNT, 2008) ${ }^{18}$ para simulação de edificações na fase de projeto. As exigências para as simulações é a utilização dos dias considerados críticos para a estação de verão (22 de dezembro) e de inverno (22 de junho). Além disso como os projetos de edificações de interesse social selecionados para as simulações possuem os ambientes determinados para as mesmas com formas retangulares, não teria nenhum tipo de interferência em relação à forma, pois o

\footnotetext{
${ }^{18}$ Esse assunto será abordado posteriormente com maiores detalhes no item Diretrizes para a simulação computacional do capítulo Desenvolvimento Experimental.
} 
programa se limita quanto a esse aspecto. Outro fator decisivo foi a grande quantidade de simulações que seriam executadas, tornando necessário um programa com fácil usabilidade e entrada de dados, além de permitir o armazenamento das características do projeto, modificando apenas algumas variáveis.

O programa contém os principais dados climáticos de mais de 200 cidades brasileiras. Pode ser ampliado ou atualizado. Assim, procura suprir a dificuldade de acesso à informações sistematizadas sobre clima no Brasil. Esses dados permitem definir um conjunto de especificações de projetos que melhor atendam ao desempenho térmico dos sistema construtivos. Foram compilados principalmente dados do Instituto Nacional de Meteorologia do Ministério da Agricultura e da Diretoria de Rotas Aéreas do Ministério da Aeronáutica.

O banco de dados do programa armazena as seguintes informações climáticas: latitude, longitude e altitude da localidade; temperaturas máximas diárias absolutas, em graus centígrados; temperaturas mínimas diárias absolutas, em graus centígrados; amplitude das temperaturas absolutas (diferenças entre máximas e mínimas), em graus centígrados; médias das temperaturas máximas diárias, em graus centígrados; médias das temperaturas mínimas diárias, em graus centígrados; amplitudes médias das temperaturas, em graus centígrados; média mensal das umidades relativas, em porcentagem; média das precipitações pluviométricas totais do mês, em milímetros; média da nebulosidade mensal, em escala de 0 a 10; direção predominante dos ventos, em graus, a partir do Norte, no sentido horário; e velocidade predominante dos ventos, em metros por segundo.

O Quadro 5 mostra os procedimentos necessários para a execução de simulação computacional utilizando o software ARQUITROP 3.0. 
Quadro 5. Procedimentos para utilização do ARQUITROP 3.0

\begin{tabular}{|c|c|}
\hline \multicolumn{2}{|r|}{ Procedimentos para a utilização do software ARQUITROP 3.0} \\
\hline \multicolumn{2}{|r|}{ Dados sobre a Edificação } \\
\hline Título do Projeto & Contendo o máximo de vinte caracteres. \\
\hline $\begin{array}{l}\text { Número de } \\
\text { Pavimentos }\end{array}$ & Número total de pavimentos da edificação, incluindo o pavimento térreo. \\
\hline $\begin{array}{c}\text { Pavimento a ser } \\
\text { Avaliado }\end{array}$ & $\begin{array}{l}\text { O pavimento térreo é considerado o pavimento } 1 \text {. Essa informação é utilizada pelo sistema para } \\
\text { estimar a velocidade do vento em diferentes alturas do edifício. }\end{array}$ \\
\hline $\begin{array}{l}\text { Posição do } \\
\text { pavimento térreo em } \\
\text { relação ao solo }\end{array}$ & $\begin{array}{l}\text { No pavimento térreo será especificado se o piso está construído diretamente sobre o solo ou se } \\
\text { é elevado. }\end{array}$ \\
\hline Cor da Cobertura & $\begin{array}{l}\text { Se o pavimento considerado estiver diretamente sob a cobertura, o sistema solicitará a cor da } \\
\text { face superior, através de uma escala de } 1 \text { (clara) a } 5 \text { (escura). }\end{array}$ \\
\hline \multicolumn{2}{|r|}{ Dados sobre o Ambiente a ser Simulado } \\
\hline Pé Direito & $\begin{array}{l}\text { A distância, em metros, entre o piso e o forro, ou entre o piso e a laje, no caso de não existência } \\
\text { de forro ou laje, faz-se uma média das alturas do telhado. }\end{array}$ \\
\hline Número de fachadas & $\begin{array}{l}\text { Trata-se do número de paredes através das quais o ambiente se comunica com o exterior da } \\
\text { edificação. O sistema só aceita um número de fachadas igual ou menor que } 4 \text {. }\end{array}$ \\
\hline Área de ventilação & $\begin{array}{l}\text { É a soma de todas as áreas de aberturas para o exterior, em metros quadrados, considerar } \\
\text { ando apenas as áreas com efetiva possibilidade de serem abertas ao vento e descontando os } \\
\text { obstáculos como vidros, esquadrias, etc. }\end{array}$ \\
\hline $\begin{array}{l}\text { Período de } \\
\text { ventilação }\end{array}$ & $\begin{array}{l}\text { Hora em que as janelas serão abertas para a ventilação, e o tempo em que permanecerão } \\
\text { abertas em horas. }\end{array}$ \\
\hline $\begin{array}{l}\text { Orientação das } \\
\text { fachadas }\end{array}$ & $\begin{array}{l}\text { É o ponto cardeal para o qual a fachada está voltada, em graus e minutos, a contar do Norte } \\
\text { (verdadeiro e não magnético), considerando o sentido horário. Assim, uma fachada voltada para } \\
\text { Leste teria orientação } 90^{\circ} \text {, Sudeste } 135^{\circ} \text {, Oeste } 270^{\circ} \text {, etc. }\end{array}$ \\
\hline Área envidraçada & Para cada fachada, em metros quadrados e a espessura do vidro, em metros. \\
\hline $\begin{array}{l}\text { Dispositivos de } \\
\text { Proteção Solar }\end{array}$ & $\begin{array}{l}\text { Existência ou não de proteção contra radiação solar sobre as áreas envidraçadas, incluindo o } \\
\text { tipo, a cor e o número de vidros (caixilho simples ou duplo). }\end{array}$ \\
\hline $\begin{array}{l}\text { Dimensões do } \\
\text { ambiente }\end{array}$ & Comprimento e largura do ambiente a ser simulado em metros. \\
\hline Cores das fachadas & Na mesma escala adotada para as cores da cobertura. \\
\hline $\begin{array}{l}\text { Sobre a ocupação } \\
\text { do ambiente }\end{array}$ & $\begin{array}{l}\text { O número de pessoas ocupantes e o período de ocupação que compreende o início e a duração } \\
\text { da ocupação. }\end{array}$ \\
\hline $\begin{array}{l}\text { Existência de } \\
\text { Equipamentos } \\
\text { fontes de calor }\end{array}$ & $\begin{array}{l}\text { A intensidade total (soma das parcelas radiante e convectiva, em watts) dos equipamentos e } \\
\text { período principal de funcionamento. O sistema estimará a carga térmica proveniente da fonte de } \\
\text { calor. }\end{array}$ \\
\hline Materiais & Tipo de paredes, pisos e, quando for o caso, coberturas. \\
\hline Localização & A cidade onde a edificação será construída. \\
\hline Renovações de ar & Renovações de ar em Volumes/hora considerada para o ambiente simulado. \\
\hline
\end{tabular}

Fonte: Adaptado de RORIZ e BASSO (1989).

Por meio dos resultados das simulações computacionais são obtidas para a edificação com suas respectivas características, tabelas de variação horária de temperaturas (ganhos e perdas e estimativa de variação horária) (Figura 65); e a 
distribuição do fluxo térmico no ambiente (Figura 66), isso de acordo com o dia simulado, além de gráficos de variação horária de temperaturas e cargas térmicas. Após a inserção de dados o projeto pode ser armazenado e algumas características podem ser modificadas $A$ Figura 67 mostra um exemplo da entrada de dados de um projeto armazenado no banco de dados do ARQUITROP 3.0.

\begin{tabular}{rrrrrrrr}
\hline & & & & \\
\hline
\end{tabular}

Figura 65. Tabela - Ganhos e perdas de calor de acordo com as horas do dia.

Fonte: Software Arquitrop 3.0

\begin{tabular}{|c|c|c|c|c|c|c|}
\hline \multirow[b]{2}{*}{$\begin{array}{c}\text { ARQUIT ROP } \\
-- \text { hs } \\
2 \\
4 \\
6 \\
7 \\
8 \\
9 \\
19 \\
11 \\
12 \\
13 \\
14 \\
15 \\
16 \\
17 \\
18 \\
29 \\
21 \\
22 \\
24\end{array}$} & \multicolumn{2}{|c|}{$-{ }_{[}^{-} \begin{array}{l}\text { DISTRIBUICAO } \\
\text { Fachadas }\end{array}$} & $\begin{array}{l}\text { DE GANHOS E PERDAS } \\
\text { (orientacoes) }\end{array}$ & $\left\langle{ }_{1}^{\langle\text {Watt }\rangle}\right.$ & \multicolumn{2}{|c|}{$\begin{array}{l}\text { ATRAUES UEDACOES OPACAS } \\
\text { Piso Cobert }\end{array}$} \\
\hline & $\begin{array}{r}-36 \\
-53 \\
-69 \\
-75 \\
-79 \\
-81 \\
-78 \\
-72 \\
-60 \\
-43 \\
-23 \\
-4 \\
8 \\
15 \\
16 \\
9 \\
1 \\
-6 \\
-26\end{array}$ & $\begin{array}{r}-27 \\
-42 \\
-55 \\
-60 \\
-63 \\
-65 \\
-63 \\
-41 \\
-2 \\
16 \\
22 \\
21 \\
10 \\
15 \\
17 \\
19 \\
4 \\
-2 \\
-14\end{array}$ & 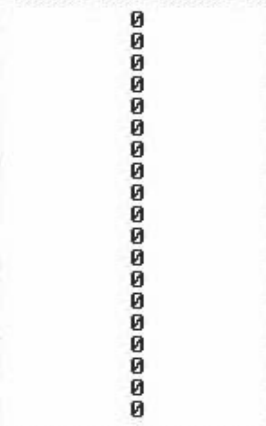 & 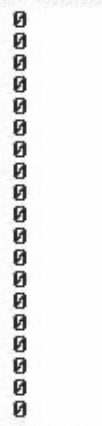 & 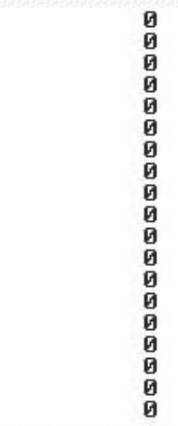 & $\begin{array}{r}-150 \\
-179 \\
-153 \\
-148 \\
-125 \\
-37 \\
72 \\
175 \\
255 \\
295 \\
297 \\
264 \\
206 \\
118 \\
42 \\
2 \\
-55 \\
-73 \\
-109\end{array}$ \\
\hline
\end{tabular}

Figura 66. Tabela - Distribuição de ganhos e perdas de calor de acordo com as horas do dia e os componentes.

Fonte: Software Arquitrop 3.0

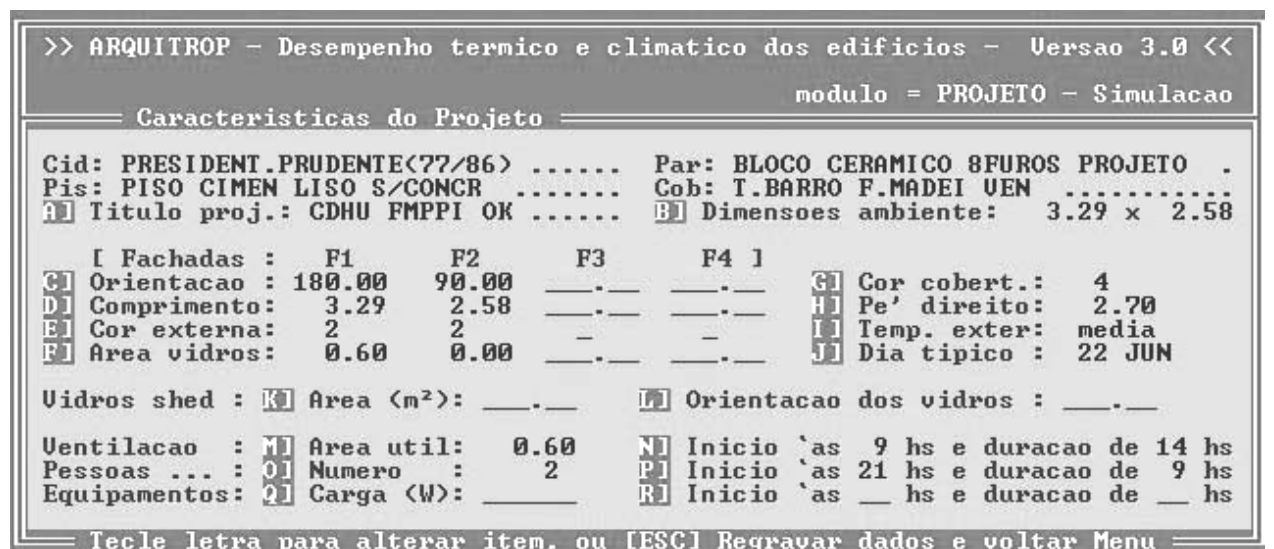

Figura 67. Modelo de tela do software Arquitrop 3.0 para inserção ou modificação de dados do projeto.

Fonte: Software Arquitrop 3.0 
Além das tabelas, são gerados gráficos que mostram uma estimativa da variação horária das temperaturas (Figura 68) e a distribuição do fluxo térmico (watts) no ambiente (Figura 69).

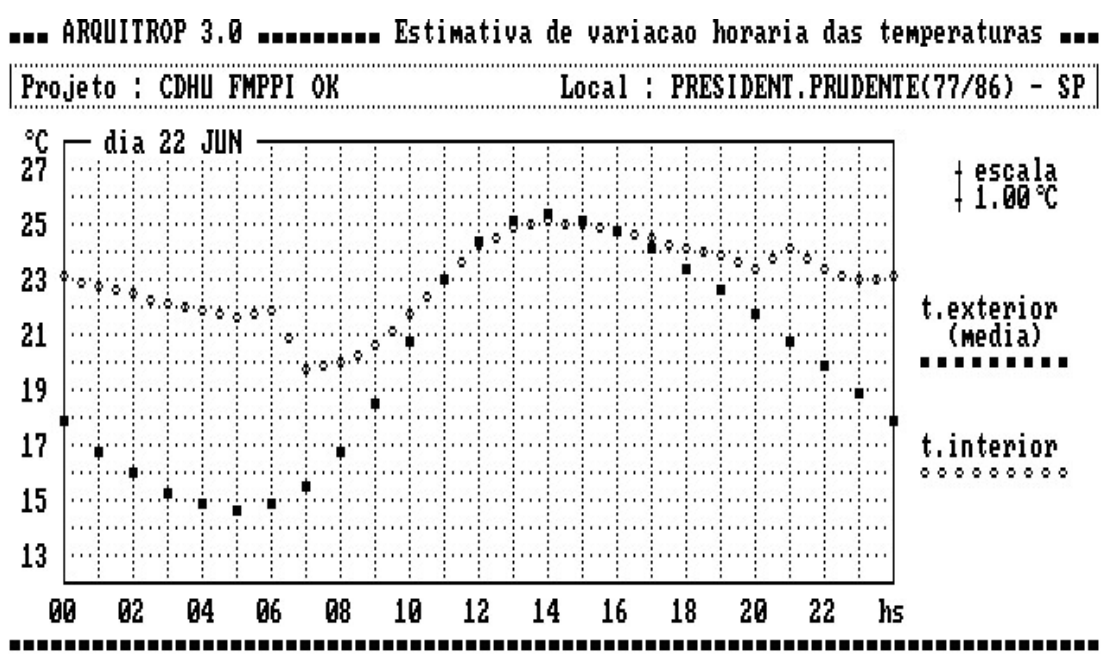

Figura 68. Gráfico - Estimativa da variação horária das temperaturas.

Fonte: Software Arquitrop 3.0

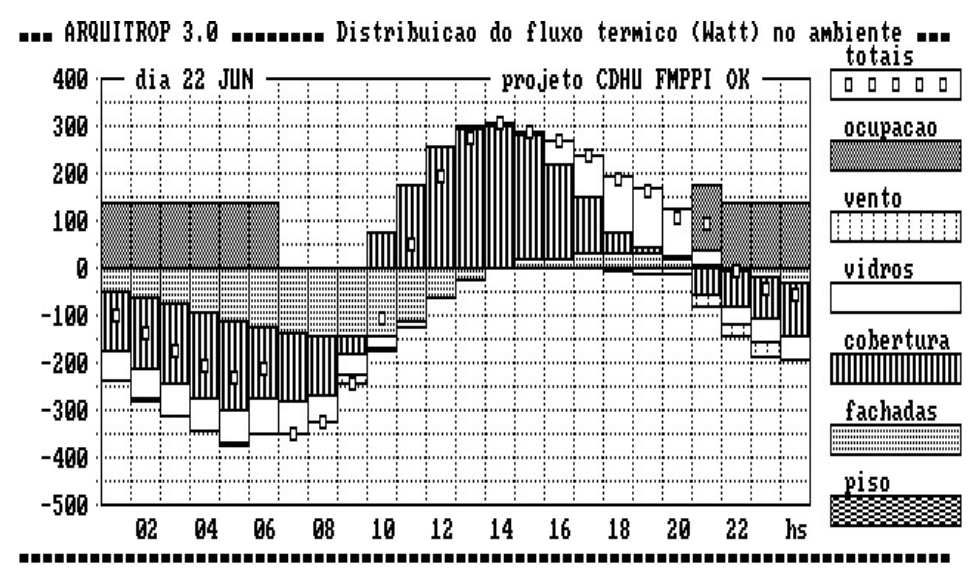

Figura 69. Gráfico - Distribuição do fluxo térmico (watts) no ambiente.

Fonte: Software Arquitrop 3.0

O software além das funções apresentadas, também possui alguns módulos opcionais que são mostrados no Quando 6. 
Quadro 6. Módulos opcionais do ARQUITROP 3.0

\section{Módulos Opcionais do Software ARQUITROP 3.0}

\section{Dados sobre a Edificação}

Trata-se do gráfico das órbitas aparentes do sol, que permite determinar, para qualquer latitude, para qualquer hora do dia e para todos os dias do ano, o ângulo de incidência dos raios solares sobre qualquer fachada. Esse recurso contribui tanto para o projeto de quebra sol quanto para o de iluminação natural.

Carta Solar Estimativa da intensidade horária da radiação solar, para qualquer dia do ano, em função da latitude e da nebulosidade média do mês.

\begin{tabular}{cl} 
Radiacão Solar & $\begin{array}{l}\text { Estimativa da intensidade horária da radiação solar, para qualquer dia do ano, em função da } \\
\text { latitude e da nebulosidade média do mês. }\end{array}$ \\
\hline $\begin{array}{c}\text { Condicionamento } \\
\text { Artificial }\end{array}$ & $\begin{array}{l}\text { Cálculo aproximado do consumo de energia (com refrigeração e/ou calefação) necessário para } \\
\text { manter o ambiente confortável }\end{array}$ \\
\hline $\begin{array}{c}\text { Temperaturas } \\
\text { Intermediárias }\end{array}$ & $\begin{array}{l}\text { Determina em função das temperaturas internas e externas e das resistências das camadas, as } \\
\text { temperaturas nas interfaces entre as camadas de distintos materiais que constituem uma parede } \\
\text { ou cobertura. }\end{array}$ \\
\hline $\begin{array}{c}\text { Avaliação } \\
\text { Complificada do }\end{array}$ & $\begin{array}{l}\text { Estima a variação horária do fluxo térmico através de componentes construtivos opacos, } \\
\text { considerando um "regime permanente" de transmissão de calor }\end{array}$ \\
\hline
\end{tabular}

Fonte: Adaptado de RORIZ e BASSO (1989).

No próximo capítulo apresentam-se os procedimentos utilizados nesta pesquisa para auxiliar na especificação dos valores da massa especifica do concreto e da espessura dos painéis de vedação para as habitações térreas e multipavimentos de interesse social, executadas com o sistema construtivo de painéis monolíticos de concreto moldados in loco, tendo como referencial o desempenho térmico das habitações. 


\section{DESENVOLYMENTOEXPERIMENTAL}

Este capítulo apresenta o detalhamento dos procedimentos adotados para o estudo da influência do tipo de concreto e da espessura dos painéis das vedações verticais no conforto térmico das habitações térreas e multipavimentos.

Inicialmente foi realizada uma pesquisa bibliográfica detalhada, abordando os temas: habitação de interesse social no Brasil; sistema construtivo de painéis monolíticos de concreto moldados in loco; concretos aplicados nesse sistema construtivo e o conforto térmico de habitações. Os materiais disponíveis referentes à revisão bibliográfica compreenderam livros técnicos; artigos técnicos em periódicos especializados; anais de seminários e congressos; boletins técnicos e publicações de Institutos de Pesquisa ( $A B C P$, IPT) e Universidades (USP, USP-EESC, UNICAMP e UFSC); dissertações de mestrado; teses de doutorado e conhecimentos disponíveis em redes de informação por computador. Essa revisão bibliográfica foi posteriormente complementada com os trabalhos e leituras realizadas durante as disciplinas cursadas.

Em seguida foi realizada a etapa de definição dos critérios iniciais de estudo para a obtenção dos dados utilizados nas simulações computacionais de desempenho térmico das habitações, sendo eles: definição das tipologias habitacionais, térrea e multipavimentos, tendo como referência as empregadas atualmente pela Companhia de Desenvolvimento Habitacional e Urbano do Estado de São Paulo (CDHU) e Caixa Econômica Federal (CEF); definição das características dos painéis de referência adotados para a análise comparativa de desempenho (alvenaria de blocos cerâmicos e de concreto); definição da faixa de variação da espessura dos painéis de vedação e da faixa de variação da massa específica do concreto; e por último a determinação das cidades a serem analisadas, representativas das 8 regiões bioclimáticas brasileiras de acordo com a NBR 15220 (ABNT, 2005).

$\mathrm{Na}$ concepção original deste projeto havia a indicação da avaliação do desempenho térmico das tipologias habitacionais utilizadas pela CDHU e pela CEF, porém ao realizar as simulações iniciais observou-se a semelhança de resultados e das características dos 
projetos. Com isso, optou-se por analisar um maior número de cidades utilizando apenas os projetos da CDHU.

O ambiente selecionado para as simulações de desempenho térmico foi o quarto, sendo que para a tipologia térrea foram considerados três tipos de cobertura (telhado com telha cerâmica, telhado com telha cerâmica e laje mista plana e telhado com telha cerâmica e laje mista inclinada) e para a tipologia multipavimentos, telhado com telha cerâmica e laje mista plana. Para a tipologia multipavimentos também foi analisado o comportamento do segundo pavimento. As duas tipologias e suas variações de tipo de cobertura foram simuladas para as vedações de referência (alvenaria de bloco cerâmico e de bloco de concreto) e para vedações executadas em concreto. Definiu-se para as habitações com vedações em concreto a massa específica variando entre 1600 e $2400 \mathrm{~kg} / \mathrm{m}^{3}$ e as espessuras do painel variando entre 8 e $12 \mathrm{~cm}$.

Para as simulações foram selecionadas 10 cidades representativas das oito zonas bioclimáticas brasileiras. A escolha por mais de oito cidades se justifica pela especificidade de algumas delas que mesmo inseridas na mesma zona bioclimática apresentam diferenças climáticas consideráveis.

$\mathrm{Na}$ definição dos critérios iniciais de estudo observou-se a necessidade de obter os valores de condutividade térmica dos concretos com massa específica entre 1600 e 2400 $\mathrm{kg} / \mathrm{m}^{3}$, para proporcionar maior precisão na análise do desempenho térmico das habitações em relação aos valores apresentados pela NBR 15220 (ABNT, 2005). Essa análise, que não estava prevista no projeto original, foi executada em parceria com o Departamento de Engenharia de Materiais (DEMa) da Universidade Federal de São Carlos (UFSCar), com o apoio do Prof. ${ }^{\circ}$ Dr. Wilson Nunes dos Santos.

Em seguida foram executadas as simulações computacionais de desempenho térmico das habitações de interesse social térreas e multipavimentos. A realização dessas análises contou com a participação dos estudantes de Iniciação Científica José Irail de Rezende Neto ${ }^{19}$ (tipologia térrea) e Fernanda Faria Graçon ${ }^{20}$ (tipologia multipavimentos), sob a coordenação da mestranda deste projeto.

No início das simulações computacionais observou-se a necessidade de obter algumas variáveis utilizadas pelo software ARQUITROP 3.0, relacionadas à condição de ocupação e ventilação das habitações de interesse social, isso com a intenção de obter informações mais precisas sobre o comportamento dos moradores. A partir dessa necessidade foi realizado um levantamento de dados comportamentais dos usuários de habitações de interesse social de dois conjuntos habitacionais da cidade de São Carlos $\mathrm{SP}$, levantamento esse que não estava previsto na metodologia original. Apesar das

\footnotetext{
${ }^{19}$ Projeto de pesquisa de Iniciação Científica: "Avaliação de desempenho térmico de painéis de vedação de concreto moldados in loco para habitações de interesse social: edificações térreas". Processo FAPESP n. 2006/56263-6.

${ }^{20}$ Projeto de pesquisa de Iniciação Científica: "Avaliação de desempenho de painéis de vedação de concreto moldados in loco para habitações de interesse social: edificações assobradadas e de múltiplos pavimentos".
} 
características de ocupação e ventilação serem específicas da cidade de São Carlos foi de extrema importância para a indicação de períodos representativos próximos à situação real para serem considerados nas simulações.

Dentre as informações coletadas nesse levantamento se encontram: o número médio de ocupantes por quarto; o horário de ocupação do quarto; a duração da ocupação do quarto; o horário de abertura da janela para ventilação; a duração da ventilação do quarto; e a utilização de equipamento de condicionamento térmico. Esse levantamento foi realizado também com a colaboração dos estudantes de Iniciação Científica José Irail de Rezende Neto e Fernanda Faria Graçon, por meio de entrevista a 70 moradores dos dois conjuntos habitacionais.

Posteriormente foram executas todas as simulações computacionais para as tipologias térreas e multipavimentos, para os painéis de referência e de concreto. Essa avaliação resultou num total de 1700 simulações computacionais, sendo 1020 para as tipologias térreas e 680 para a tipologia multipavimentos. As simulações computacionais são apresentadas nos Apêndices 3 e 4, e analisadas no Capítulo 7. Apresentação e Análise dos Resultados.

Após a execução das simulações computacionais e definição da espessura do painel e da massa específica do concreto adequadas de acordo com a região bioclimática, foi realizada a análise da produção do concreto: mistura, transporte, adensamento e cura; a especificação e caracterização dos materiais utilizados na dosagem dos concretos; a avaliação da resistência à compressão de corpos-de-prova das dosagens obtidas nas idades de 12 horas, 1, 7 e 28 dias e a análise do módulo de deformação de corpos-de-prova das dosagens obtidas na idade de 28 dias.

Foi realizado o estudo de dosagem dos concretos destinados às tipologias analisadas, com valor de massa específica de $2400 \mathrm{~kg} / \mathrm{m}^{3}$, definidas a partir dos resultados das simulações computacionais, atendendo os seguintes requisitos: relação a/c abaixo de 0,60 (Classe de agressividade II, em área urbana - NBR 6118); abatimento do tronco de cone (slump test) acima de $150 \mathrm{~mm}$; e resistência à compressão aos 28 dias acima de 25 MPa (Classe de agressividade II - NBR 6118). 


\subsection{Definição dos Critérios Iniciais de Estudo}

Os critérios iniciais de estudo foram definidos em conjunto com os outros dois membros do grupo de pesquisa, sendo eles os estudantes de Iniciação Científica José Irail de Rezende Neto $^{21}$ (tipologia térrea) e Fernanda Faria Graçon ${ }^{22}$ (tipologia multipavimentos), isso com o intuito de uniformizar a base de dados utilizada no prosseguimento dessas pesquisas.

A definição dos critérios iniciais de estudo compreendeu os dados utilizados nas simulações computacionais de desempenho térmico das habitações, entre eles: a definição das tipologias habitacionais, térrea e multipavimentos a serem analisadas, tendo como referência as empregadas atualmente pela Companhia de Desenvolvimento Habitacional e Urbano do Estado de São Paulo (CDHU) e pela Caixa Econômica Federal (CEF); determinação dos painéis de referência adotados para a análise comparativa de desempenho; definição da faixa de variação da espessura dos painéis de vedação em concreto e da faixa de variação da massa específica do concreto utilizado; determinação das propriedades térmicas, especificamente a condutividade térmica dos concretos de acordo com a massa específica; e por último a determinação das cidades a serem analisadas, representativas das 8 regiões bioclimáticas brasileiras de acordo com a NBR 15220 (ABNT, 2005).

\subsubsection{Definição das Tipologias Habitacionais Térrea e Multipavimentos}

A definição das tipologias das habitações térreas e multipavimentos a serem adotadas neste estudo foi realizada por meio de consulta aos departamentos técnicos da Companhia do Desenvolvimento Habitacional e Urbano do Estado de São Paulo (CDHU) (contato: Arquiteta Irene Borges Rizzo - Gerente de Projetos) e da Caixa Econômica Federal (CEF) (contato: Arquiteto Silmar Samis Fattori) com a finalidade de verificar quais as tipologias mais usadas atualmente na construção de habitações térreas e além disso quais delas disponibilizaria as informações mais completas em termos de projeto arquitetônico, necessárias para a execução das simulações computacionais. Nessa consulta verificou-se que atualmente a tipologia de habitação térrea unifamiliar mais executada pela CEF é a HM5 (Anexo 1) e pela CDHU é a TI24A (Anexo 2). Já para habitações multipavimentos a tipologia padrão determinada foi a V052H-01 (Antiga VI22B-V2) (Anexo 3). Para a tipologia térrea e multipavimentos o quarto foi adotado como ambiente padrão para análise do

\footnotetext{
${ }^{21}$ Projeto de pesquisa de Iniciação Científica: "Avaliação de desempenho térmico de painéis de vedação de concreto moldados in loco para habitações de interesse social: edificações térreas”. Processo FAPESP n. 2006/56263-6.

22 Projeto de pesquisa de Iniciação Científica: "Avaliação de desempenho de painéis de vedação de concreto moldados in loco para habitações de interesse social: edificações assobradadas e de múltiplos pavimentos".
} 
desempenho térmico das edificações, por ser o ambiente de maior permanência dos usuários.

As características dos quartos das tipologias térreas TI24A (CDHU) e HM5 (CEF) são apresentados nas Figuras 70 e 71, respectivamente. Observa-se nas mesmas que as dimensões dos quartos das duas tipologias são semelhantes. Além disso, as simulações iniciais indicaram grande semelhança nos resultados, por isso optou-se por simplificar o processo de avaliação do desempenho térmico das edificações e analisar um maior número de cidades utilizando apenas o projeto da CDHU. Com isso, adotou-se apenas uma tipologia construtiva térrea para análise por meio da simulação computacional, sendo ela a tipologia TI24A da CDHU (Figura 70).

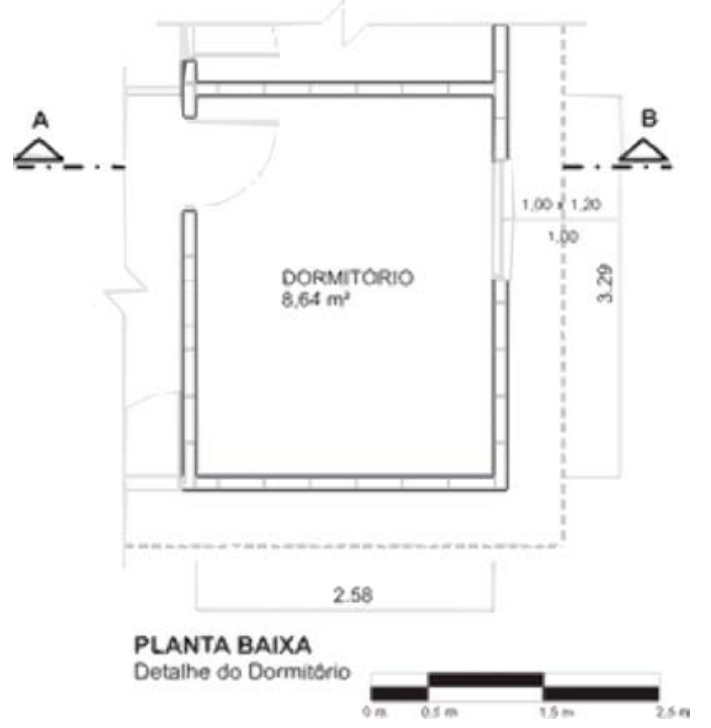

Figura 70. Detalhe do dormitório - Projeto CDHU - Padrão Habitacional TI24A.

Fonte: CDHU, 2007.

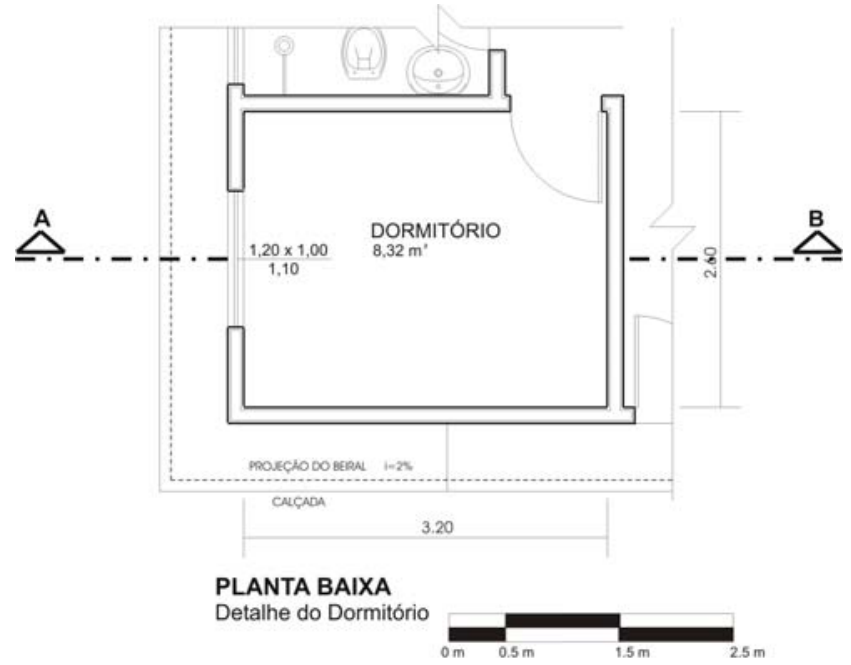

Figura 71. Detalhe do dormitório - Projeto CEF Padrão Habitacional HM5.

Fonte: CEF, 2007.

Para a tipologia térrea com relação à cobertura foram adotados três tipos ${ }^{23}$ : cobertura de telha cerâmica (Figura 72); cobertura de telha cerâmica e laje plana (Figura 73); e cobertura de telha cerâmica e laje inclinada (Figura 74). A laje adotada na simulação computacional foi a do tipo mista com espessura de $10 \mathrm{~cm}$, composta por elementos préfabricados de concreto, elementos cerâmicos de enchimento e capa de concreto.

\footnotetext{
${ }^{23}$ No Anexo 4 encontram-se as tabelas do software Arquitrop 3.0, com as características dos tipos de cobertura utilizados nas simulações computacionais.
} 


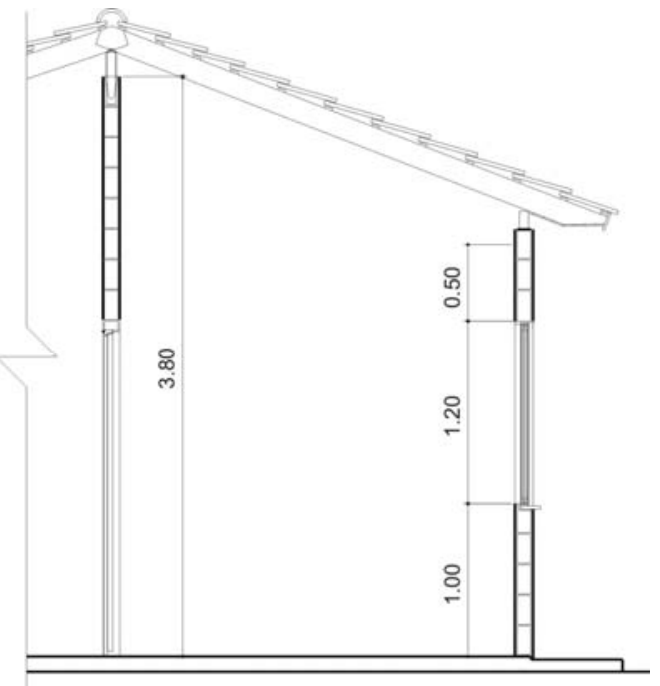

Figura 72. Tipologia TI24A-CDHU com cobertura de telha cerâmica.

Fonte: CDHU, 2007.

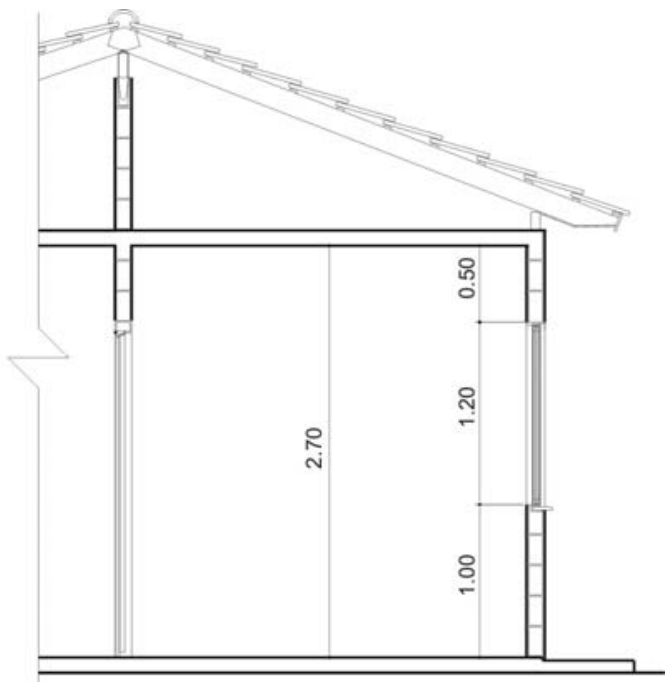

Figura 73. Tipologia TI24A-CDHU com cobertura de telha cerâmica e laje plana.

Fonte: CDHU, 2007.

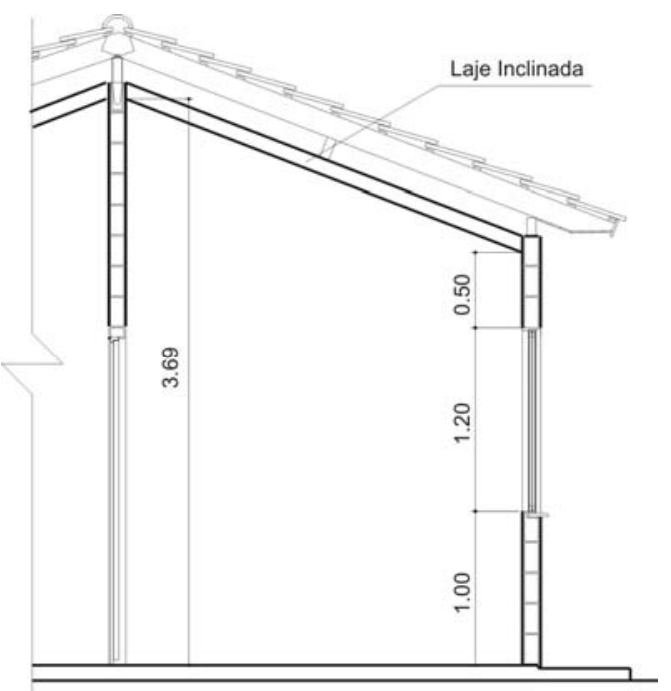

Figura 74. Tipologia TI24A-CDHU com cobertura de telha cerâmica e laje inclinada.

Fonte: CDHU, 2007.

As características dos quartos da tipologia multipavimentos são apresentadas nas Figuras 75 e 76, respectivamente. Observa-se na mesma a pouca diferença entre as dimensões desse ambiente e o ambiente da tipologia térrea, sendo que a diferença mais significativa é o posicionamento da abertura, que nesse caso em oposição ao anterior está na parede com a menor dimensão. Para a tipologia multipavimentos com relação à cobertura foi adotada cobertura de telha cerâmica e laje plana e além disso, também foi simulado um pavimento intermediário, no caso o segundo pavimento. A laje adotada na simulação computacional também foi a do tipo mista com espessura de $10 \mathrm{~cm}$, composta 
por elementos pré-fabricados de concreto, elementos cerâmicos de enchimento e capa de concreto.

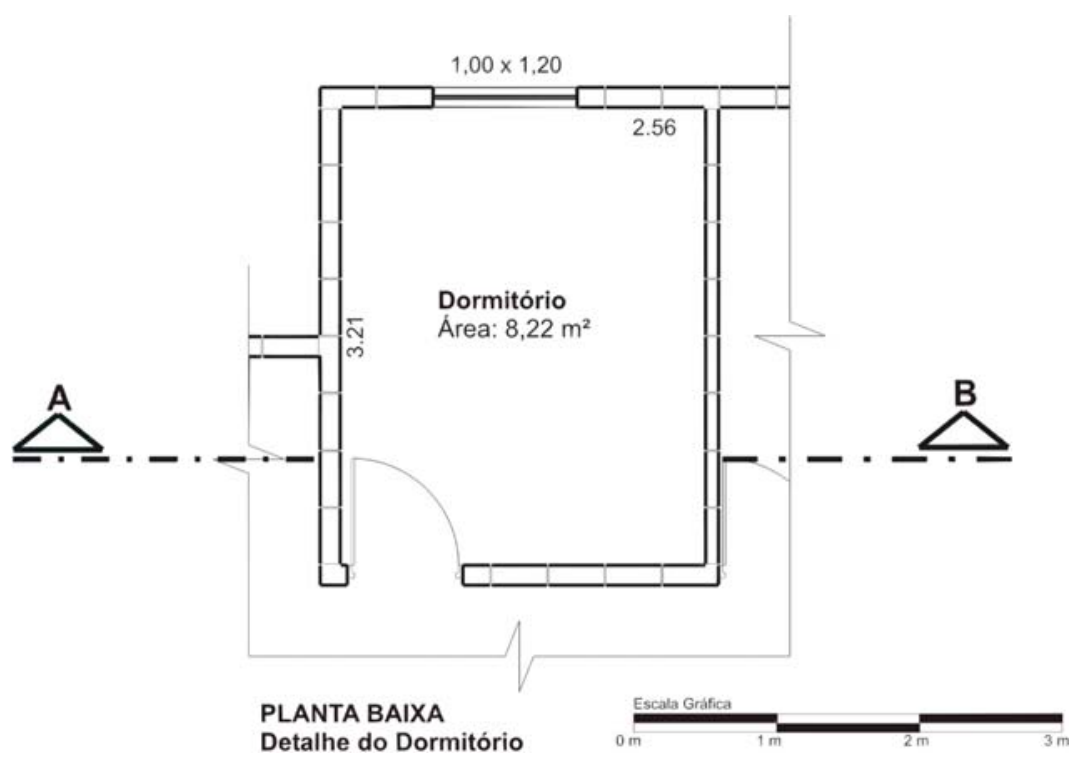

Figura 75. Detalhe do dormitório - Projeto CDHU - Padrão Habitacional V052H-01 (Antiga VI22B-V2).

Fonte: CDHU, 2007.

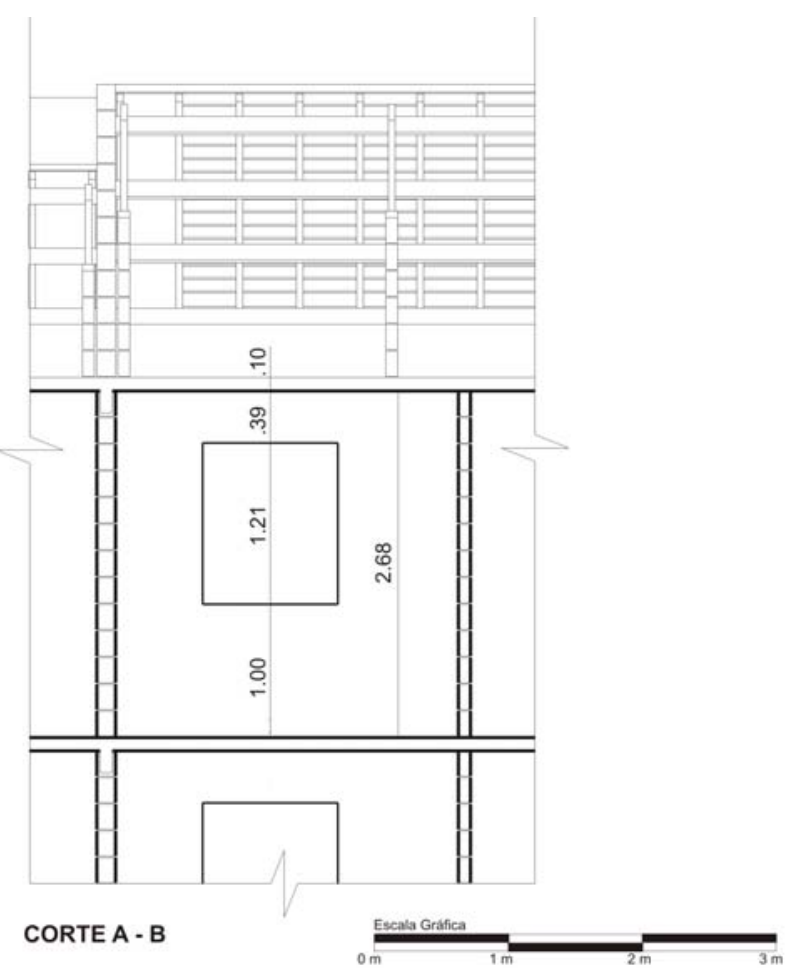

Figura 76. Corte $A B$ - Projeto $C D H U$ - Padrão Habitacional V052H01 (Antiga VI22B-V2).

Fonte: CDHU, 2007. 


\subsubsection{Características dos Painéis de Referência ${ }^{24}$}

Para análise comparativa de desempenho térmico com os painéis de concreto, foram adotados os painéis de alvenaria de bloco cerâmico e de bloco de concreto como referências por serem tradicionalmente empregados na execução de habitação de interesse social. Segundo as recomendações do memorial descritivo da tipologia TI24A da CDHU deve ser adotado o bloco cerâmico vazado com espessura de $9 \mathrm{~cm}$, argamassa de revestimento externo com espessura de $2 \mathrm{~cm}$ e de revestimento interno de $0,8 \mathrm{~cm}$; e para painel de bloco de concreto deve ser adotado bloco espessura de $9 \mathrm{~cm}$ e argamassa de revestimento externo e interno com $2 \mathrm{~cm}$ de espessura.

Para a tipologia multipavimentos V052H-01 (Antiga VI22B-V2) da CDHU as recomendações prescritas no memorial se referem ao uso de blocos de concreto ou cerâmicos de furos horizontais (não é especificado detalhadamente); a espessura do revestimento externo deve ser no mínimo de $2 \mathrm{~cm}$ e no máximo de $2,5 \mathrm{~cm}$ e a espessura do revestimento de paredes internas deve ser no mínimo de $1,5 \mathrm{~mm}$ e no máximo $2,0 \mathrm{~cm}$, a partir desses dados adotou-se $2 \mathrm{~cm}$ de espessura tanto para revestimento externo quanto para interno. Essas recomendações foram seguidas para as simulações dos painéis de referência, no que se refere aos tipos de vedações e revestimentos.

\subsubsection{Características dos Painéis de Concreto ${ }^{25}$}

\section{Faixa de Variação da Espessura dos Painéis de Vedação e da Massa Específica do Concreto}

Os valores da espessura dos painéis de vedação em concreto celular para habitações térreas usualmente variam entre 9 e $10 \mathrm{~cm}$. Neste estudo, para avaliar a influência do concreto com agregados leves no desempenho térmico das habitações térreas foram adotados três valores de espessura dos painéis, em uma faixa mais ampla do que a adotada para o concreto celular, sendo elas 8,10 e $12 \mathrm{~cm}$.

O concreto celular empregado na confecção dos painéis de vedação das habitações térreas geralmente apresenta massa específica em torno de $1700 \mathrm{~kg} / \mathrm{m}^{3}$. Já neste estudo, com a finalidade de realizar uma avaliação ampla da influência da massa específica de concreto das vedações no desempenho térmico das habitações, foram adotados valores de massa específica entre 1600 e $2400 \mathrm{~kg} / \mathrm{m}^{3}$, sendo eles: 1600, 1800, 2000, 2200 e $2400 \mathrm{~kg} / \mathrm{m}^{3}$.

\footnotetext{
${ }^{24}$ No Anexo 4 encontram-se as tabelas do software Arquitrop 3.0, com as características dos painéis de referência utilizados nas simulações computacionais.

${ }^{25}$ No Anexo 4 também se encontram as tabelas com as características dos painéis de concreto utilizados nas simulações computacionais.
} 


\section{Determinação da Condutividade Térmica $(\lambda)^{26}$ dos concretos}

Diante da possibilidade de aplicação do concreto leve anteriormente apresentada, mostra-se necessário conhecer suas propriedades térmicas para uma correta aplicação. Nessas propriedades se inclui a condutividade térmica, uma das propriedades físicas mais importantes do ponto de vista de cálculo térmico de um material. Os valores da mesma são fornecidos pela NBR 15220 (ABNT, 2005), porém a norma determina valores em intervalos de massa específica significativos (Tabela 7), sendo, portanto necessária a determinação exata desses valores, de forma a permitir uma maior precisão na execução de simulações computacionais de habitação de interesse social utilizando esses dados.

Tabela 7. Valores da condutividade térmica de acordo com a NBR 15220 (ABNT, 2005).

\begin{tabular}{|c|c|c|}
\hline Massa Especifica $\left(\mathrm{kg} / \mathrm{m}^{3}\right)$ & $\begin{array}{c}\text { Condutividade } \\
\text { Térmica }(\lambda) \\
(W / m K)\end{array}$ & OBS \\
\hline $2200-2400$ & 1,75 & - \\
\hline $1600-1800$ & 1.05 & \multirow{4}{*}{$\begin{array}{c}\text { Dosagem de } \\
\text { cimento }>300 \mathrm{~kg} / \mathrm{m}^{3} \\
\text { densidade de massa } \\
\text { aparente dos inertes } \\
>350 \mathrm{~kg} / \mathrm{m}^{3}\end{array}$} \\
\hline $1400-1600$ & 0,85 & \\
\hline $1200-1400$ & 0,70 & \\
\hline $1000-1200$ & 0,46 & \\
\hline
\end{tabular}

Fonte: ABNT, 2005.

A condutividade térmica $(\lambda)$ é a propriedade do material que determina o fluxo de calor por condução que passa, na unidade de tempo, através de uma espessura unitária e de uma unidade de área do material, através de um gradiente de temperatura. Assume-se que as temperaturas de ambos os lados do material, bem como a distribuição de temperatura em todo o material, são uniforme e constante com o tempo (condições estáveis) (GIVONI, 1976).

Diz respeito à capacidade que um dado material possui em transferir calor, estando relacionada ao fluxo de calor por condução (ANDRADE, 2007). É um parâmetro físico importante na Engenharia Civil, por meio dele é possível estimar, por exemplo, o fluxo de calor através de uma parede. Considerando dois ambientes separados por um elemento, o calor é transmitido do ambiente mais quente por condução externa e radiação para a superfície da parede, atravessando-a por condutividade externa e radiação para o ambiente mais frio (COSTA, 2003).

Essa propriedade está diretamente ligada à densidade do material, a matéria é sempre muito mais condutora que o ar contido em seus poros; à natureza química do material, os materiais amorfos são geralmente menos condutores que os cristalinos; e à

\footnotetext{
${ }^{26} \mathrm{O}$ ensaio de determinação da condutividade térmica pelo método do fio quente paralelo foi executado em parceria com o Departamento de Engenharia de Materiais (DEMa) da Universidade Federal de São Carlos (UFSCar).
} 
umidade do material. A condutividade térmica também varia com a temperatura, porém no caso das temperaturas que ocorrem na construção pode ser considerado como uma característica de cada material (FROTA et al, 2005).

A condutividade térmica $(\lambda)$ juntamente com o calor específico (c) e difusividade térmica ( $\alpha$ ) são as propriedades físicas mais importantes do ponto de vista de cálculo térmico de um material. A determinação experimental da condutividade térmica apresenta algumas dificuldades e requer alta precisão na determinação dos fatores necessários para o seu cálculo. O Método do Fio Quente Paralelo utilizado neste trabalho é o método de medida de condutividade térmica para materiais refratários mais usado hoje em todo o mundo, tanto nos centros de pesquisa, quanto nos laboratórios industriais, onde a condutividade térmica é calculada a partir do transiente de temperatura gerado por uma fonte de calor ideal, infinitamente longa e fina num meio material infinito (SANTOS, 2002).

\section{O Método do Fio Quente Paralelo}

O Método do Fio Quente Paralelo consiste no cálculo da condutividade térmica a partir do gradiente de temperatura gerado por uma fonte de calor (tida como ideal, infinitamente longa e fina) num meio material de dimensões infinitas. No equipamento do fio quente em paralelo há dois fios, um sendo o central o fio quente (resistência de khantal DS) e o outro a $1,6 \mathrm{~cm}$ do central o termopar tipo $\mathrm{K}$ (cromel-alumel). A condutividade térmica do material é obtida por meio da aplicação de uma corrente contínua ao fio quente e uma vez por segundo, aproximadamente, verifica-se o gradiente com o auxílio do termopar. Essa técnica foi utilizada pela primeira vez por Haupin (1960) na determinação da condutividade térmica de materiais cerâmicos, seu trabalho foi a base para todas as variantes do método utilizadas hoje em todo mundo (SANTOS, 1988). É muito utilizado na França, Japão e Alemanha e pouco utilizado nos Estados Unidos. No Brasil essa técnica foi introduzida por SANTOS (1988) na determinação das propriedades térmicas de cerâmicas refratárias. Com esse método é possível medir condutividades térmicas até aproximadamente o valor de 25 $\mathrm{W} / \mathrm{mK}$, o que cobre a maioria dos produtos refratários industriais (SANTOS, 2005).

Além disso, nessa técnica de medida o conceito de temperatura média entre a face quente e a face fria de uma amostra, utilizados nos cálculos dos métodos calorimétricos é eliminado, uma vez que o cálculo da condutividade é feito a uma dada temperatura fixa. Nesse método o gradiente de temperatura através da amostra é muito baixo, o que é sem dúvida outra virtude, uma vez que um método ideal de medida de condutividade térmica seria aquele capaz de medir essa propriedade segundo um gradiente de temperatura zero através da amostra. Entretanto, esse método tem duas limitações: materiais condutores elétricos, e materiais de alta condutividade térmica, o que não é o caso do concreto leve em 
questão. A técnica de fio quente paralelo foi normalizada em 1978 pela norma DIN 51046Parte 2 (SANTOS, 2002).

\section{Procedimentos Experimentais do Ensaio de Determinação da Condutividade Térmica}

Foi determinada a condutividade térmica dos concretos com agregados leves, com massa específica entre 1600 e $2400 \mathrm{~kg} / \mathrm{m}^{3}$, utilizando o método do fio quente paralelo. Esses dados foram utilizados para a realização de simulações computacionais para avaliação do desempenho térmico das edificações com vedações em paredes maciças de concreto, utilizando o software ARQUITROP 3.0.

Para a produção dos concretos leves foram utilizados os dados de pesquisas preliminares desenvolvidas no LCC/EESC/USP. Os materiais utilizados para produção dos concretos foram: cimento Portland composto com escória de alto forno (CPII E32), fabricado pela empresa CIMINAS S.A. (grupo Holdercim), com massa específica de 2,96 g/cm 3 e área específica Blaine de $4.023 \mathrm{~cm}^{2} / \mathrm{g}$; aditivo mineral Metacaulim, cuja massa específica é de $2,65 \mathrm{~g} / \mathrm{cm}^{3}$, área específica em torno de $327.000 \mathrm{~cm}^{2} / \mathrm{g}$ e teor de SiO2 de 51,6 \%; areia natural quartzosa, brita basáltica 01 e dois tipos de argila expandida, Cinexpan 0500 $($ Dmax $=5,0 \mathrm{~mm})$ e Cinexpan 1506 (Dmax=12,5mm) (Tabela 8) e o superplastificante do tipo Glenium 51 (policarboxilato) com massa específica entre 1,067 a $1,107 \mathrm{~g} / \mathrm{cm}^{3}$ e teor de sólidos entre 28,5 a $31,5 \%$. A Tabela 9 mostra a quantidade de materiais utilizada para a produção de $1 \mathrm{~m}^{3}$ de concreto.

Tabela 8. Características dos agregados

\begin{tabular}{|c|c|c|c|c|c|}
\hline \multirow[t]{2}{*}{ Agregado } & \multirow{2}{*}{$\begin{array}{c}D_{\max } \\
(\mathrm{mm}) \\
\text { NBR7211 }\end{array}$} & \multirow{2}{*}{$\begin{array}{c}\text { Massa } \\
\text { específica } \\
\left(\mathrm{g} / \mathrm{cm}^{3}\right) \\
\text { NBR9776 }\end{array}$} & \multirow{2}{*}{$\begin{array}{c}\text { Massa } \\
\text { unitária } \\
\left(\mathrm{g} / \mathrm{cm}^{3}\right) \\
\text { NBR7251 }\end{array}$} & \multicolumn{2}{|c|}{$\begin{array}{c}\text { Absorção de água } \\
\text { (\% em massa) }\end{array}$} \\
\hline & & & & $30 \mathrm{~min}$. & $24 \mathrm{hs}$ \\
\hline Areia & 2,4 & 2,63 & 1,49 & - & - \\
\hline Brita basáltica 01 & 19,0 & 2,87 & 1,32 & - & - \\
\hline $\begin{array}{l}\text { Argila expandida } 0500 \\
\text { (CINEXPAN 0500) }\end{array}$ & 5,0 & 1,51 & 0,86 & 1,8 & 6,0 \\
\hline $\begin{array}{l}\text { Argila expandida } 1506 \\
\text { (CINEXPAN 1506) }\end{array}$ & 12,5 & 1,11 & 0,59 & 2,7 & 7,0 \\
\hline
\end{tabular}


Tabela 9. Tabela quantitativa dos materiais utilizados para $1 \mathrm{~m}^{3}$ de concreto

\begin{tabular}{|c|c|c|c|c|c|c|c|c|c|c|}
\hline Traço & $\underset{32}{\text { CPII E }}$ & Metacaulin & Areia & Brita 01 & $\begin{array}{c}\text { Arg. } \\
\text { Expandida } \\
0500\end{array}$ & $\begin{array}{c}\text { Arg. } \\
\text { Expandida } \\
1506\end{array}$ & Glenium & Água & a/aglo & $\begin{array}{c}\text { Massa } \\
\text { Específica } \\
\text { Seca aos } \\
28 \text { dias } \\
\left(\mathbf{k g} / \mathrm{m}^{3}\right)\end{array}$ \\
\hline (1) & 310,68 & 31,07 & 894,77 & 1093,61 & 0,00 & 0,00 & 2,33 & 178 & 0,52 & 2364,0 \\
\hline (2) & 312,06 & 31,21 & 858,15 & 686,52 & 0,00 & 171,63 & 2,34 & 172 & 0,50 & 2014,0 \\
\hline (3) & 313,38 & 31,34 & 902,53 & 300,84 & 0,00 & 300,84 & 2,35 & 192 & 0,55 & 1781,0 \\
\hline (4) & 307,77 & 30,78 & 899,91 & 0,00 & 0,00 & 423,49 & 2,31 & 212 & 0,62 & 1589,0 \\
\hline (5) & 307,88 & 30,79 & 95,44 & 0,00 & 362,68 & 496,30 & 2,31 & 200 & 0,59 & 1216,0 \\
\hline \multicolumn{3}{|c|}{ Slump } & \multicolumn{8}{|c|}{$160 \pm 10 \mathrm{~mm}$} \\
\hline
\end{tabular}

Para cada dosagem foram moldados 3 corpos-de-prova prismáticos com $120 \mathrm{~mm}$ de largura, $230 \mathrm{~mm}$ de comprimento e $120 \mathrm{~mm}$ de altura para o ensaio de condutividade térmica e dois corpos-de-prova cilíndricos de $100 \mathrm{~mm}$ de diâmetro e $200 \mathrm{~mm}$ de altura foram utilizados para a determinação da massa específica (ABNT, 1987). O molde dos corpos-deprova prismáticos foi construído em madeira compensada desmontável especialmente para esta finalidade, com capacidade para produzir 3 blocos. Os fios foram posicionados nas fôrmas de acordo com o esquema da Figura 77. O termopar cromel-alumel foi montado por meio de soldagem tipo MIG (Metal Inert Gás), cuja região fundida é protegida por um gás inerte, no caso argônio. Os fios foram passados pelos furos, antes da moldagem, e presos por conectores até a desforma.

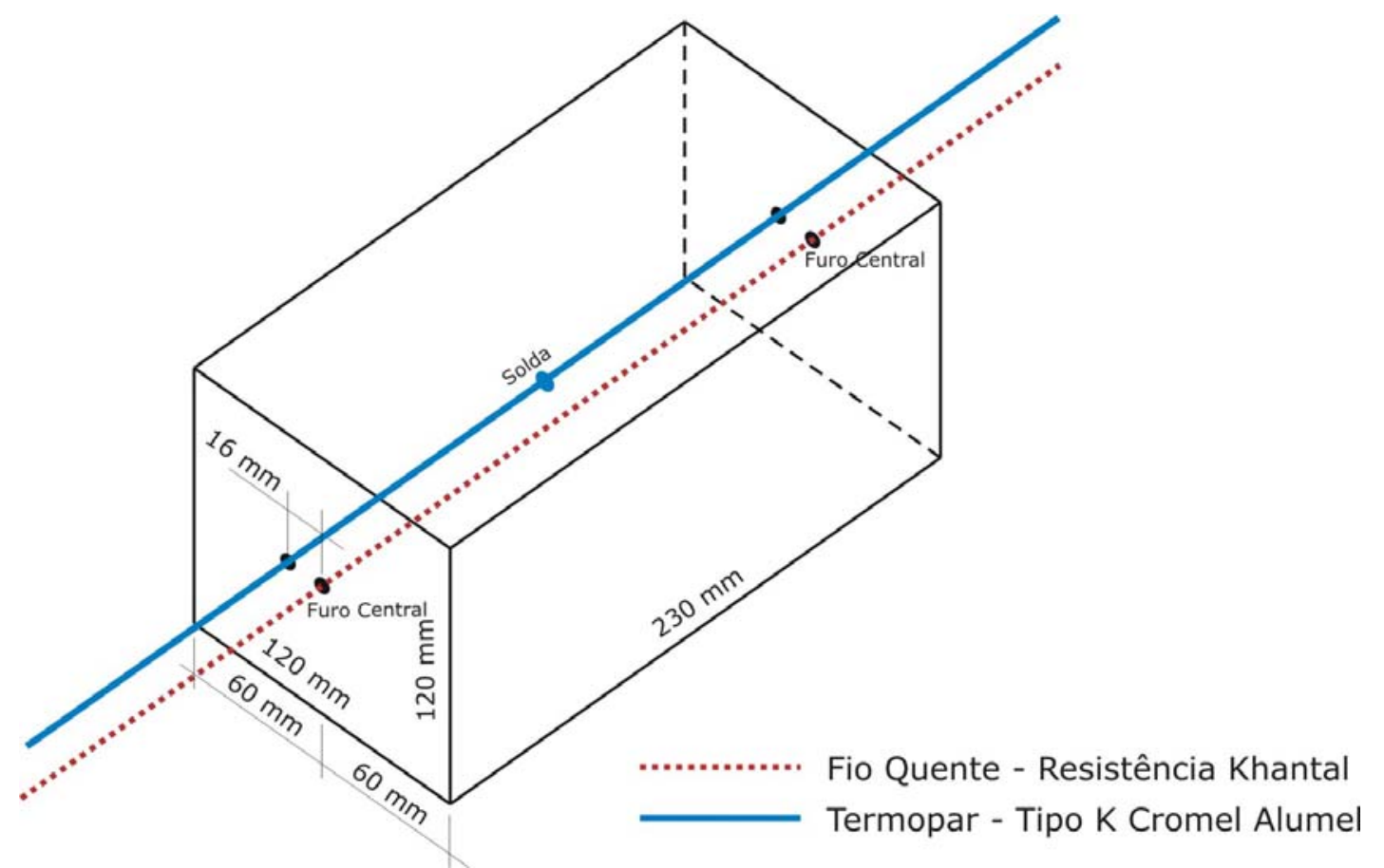

Figura 77. Arranjo dos corpos-de-prova: técnica do fio quente paralelo.

Após a preparação das formas e posicionamento dos fios foram então executados os conjuntos de amostras de acordo com os traços do concreto, cada conjunto com um total de 
3 corpos-de-prova. As amostras foram feitas adicionando-se inicialmente, água à mistura agregado e cimento, até obter a consistência desejada (slump $160 \pm 10 \mathrm{~mm}$ ). O concreto foi então colocado nas fôrmas de madeira e vibrado numa mesa vibratória por aproximadamente 90 segundos. Depois de vibrados, os corpos-de-prova foram cobertos com um plástico para evitar secagem rápida e deixados em repouso ao ar livre e à temperatura ambiente por 24 horas.

Após a desforma foram acondicionados em câmara úmida com temperatura de $25 \pm$ $2^{\circ} \mathrm{C}$ e com umidade relativa de $95 \%$ por um período de 7 dias. Após esse período, os corpos-de-prova foram expostos às condições ambientais do laboratório (temperatura de 25 $\pm 4^{\circ} \mathrm{C}$ e umidade relativa de $50 \pm 10 \%$ ) com a finalidade de aproximar o teor de umidade às condições reais dos painéis de vedação das habitações, até a realização das análises experimentais, sendo aos 28 dias para a massa específica e aos 56 dias para a condutividade térmica. No dia de realização do ensaio, um corpo-de-prova prismático de cada traço foi colocado em estufa a $100^{\circ} \mathrm{C}$ por um período de 72 horas, para verificar as condições de umidade das mesmas, característica esta que exerce influencia nos valores de condutividade térmica.

O arranjo experimental para a execução do ensaio de determinação da condutividade térmica obedeceu ao esquema da Figura 78, onde se lê "Amostra" foi inserido o corpo-de-prova mostrado na figura anterior (Figura 77). Os corpos-de-prova foram moldados com os fios quente (resistência de khantal DS) e termopar tipo K (cromelalumel) já posicionados no interior do corpo-de-prova, o que de certa forma facilitou para a obtenção dos resultados, apresentando uma melhor superfície de contato térmico (Figura 79).

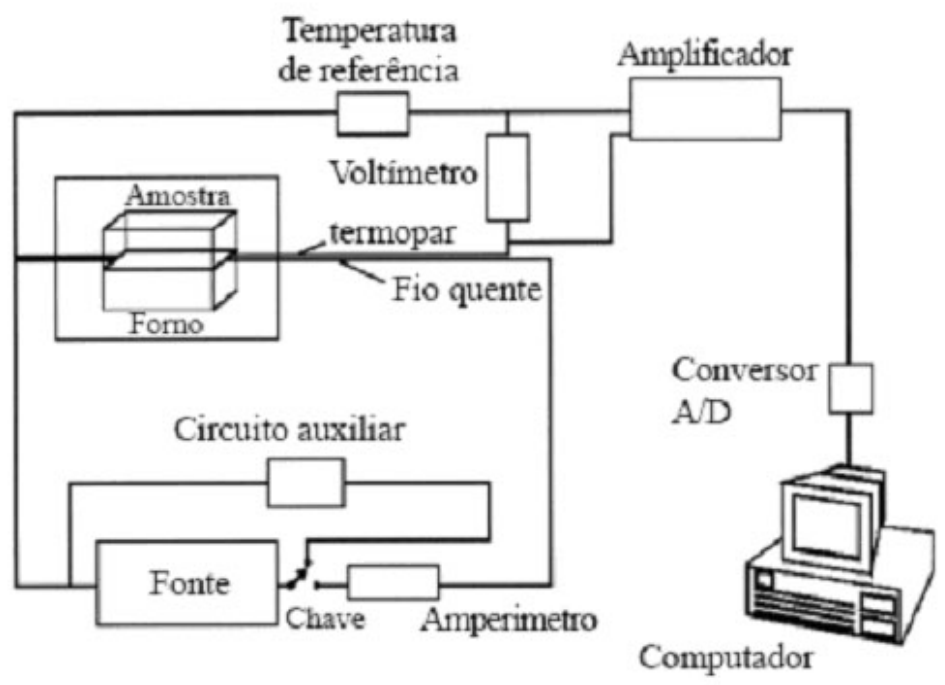

Figura 78. Diagrama esquemático do Método do Fio Quente Paralelo

Fonte: SANTOS, 1988. 
Inicialmente foram solicitados os seguintes dados preliminares pelo software: nome da amostra, interessado, tipo de material (isolante ou não); tempo de ensaio (min); temperatura ambiente e da amostra $\left({ }^{\circ} \mathrm{C}\right)$; tipo de termopar; resistência do fio (Ohms); densidade da amostra $\left(\mathrm{kg} / \mathrm{m}^{3}\right)$ e distância fio-termopar $(\mathrm{m})$. A condutividade térmica do material foi obtida por meio da aplicação de uma corrente contínua ao fio quente (resistência de khantal DS). No equipamento (Figura 80), uma vez por segundo aproximadamente, verifica-se o gradiente de temperatura com o auxílio do termopar tipo $\mathrm{K}$ (cromel-alumel). Ao final do ensaio foram obtidos os seguintes dados: corrente na amostra (A), estimativa inicial, intervalo de tempo (s); e Resultados: temperatura de ensaio $\left({ }^{\circ} \mathrm{C}\right)$, condutividade térmica $(\lambda)$, calor específico $(\mathrm{J} / \mathrm{kgK})$, difusividade térmica $\left(\mathrm{m}^{2} / \mathrm{s}\right)$ e coeficiente de correlação.

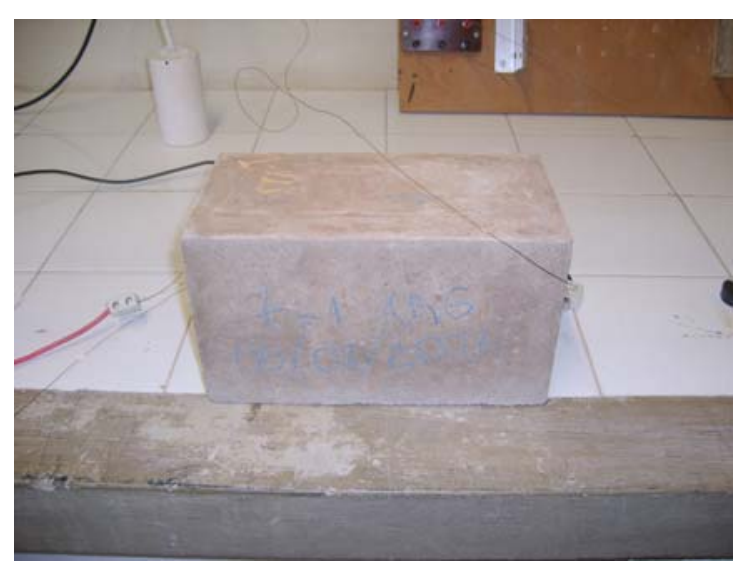

Figura 79. Corpo-de-prova sendo ensaiado.

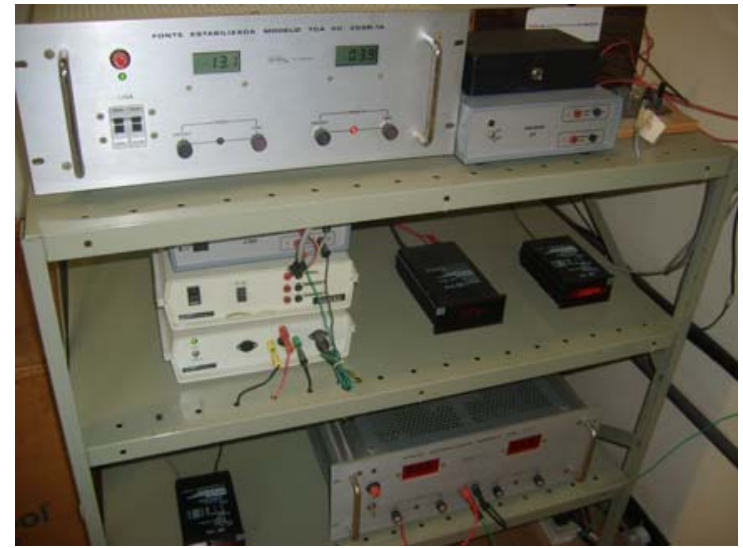

Figura 80. Aparelhagem para aquisição dos dados.

\subsubsection{Cidades Determinadas para a Execução das Simulações Computacionais}

No Quadro 7 encontram-se indicadas as cidades brasileiras adotadas para as simulações computacionais que foram realizadas nesta pesquisa, compreendendo as oito regiões bioclimáticas apresentadas na NBR 15220 (ABNT, 2005).

A escolha por 10 cidades justifica-se pelo fato de incluir, além de Santos e Presidente Prudente mais 2 cidades do Estado de São Paulo (São Paulo e São Carlos). Isso com a intenção de avaliar as quatro regiões bioclimáticas presentes nesse Estado e, além disso, analisar o comportamento das habitações localizadas em cidades que mesmo inseridas na mesma zona bioclimática apresentam características climáticas distintas. As cidades de São Paulo e Florianópolis, por exemplo, estão inseridas na zona bioclimática 3, mas possuem climas diferenciados, o mesmo ocorre com São Carlos e Brasília que se inserem na zona bioclimática 4. As demais cidades foram selecionadas de forma aleatória, de modo a localizar-se em diferentes estados. 
Quadro 7. Cidades adotadas para simulação do desempenho térmico das habitações.

\begin{tabular}{ll}
\hline \multicolumn{1}{c}{ Cidade } & Zona Bioclimática \\
\hline Caxias do Sul - RS & 1 \\
\hline Ponta Grossa - PR & 2 \\
\hline São Paulo - SP & 3 \\
\hline Florianópolis - SC & 3 \\
\hline São Carlos - SP & 4 \\
\hline Brasília - DF & 4 \\
\hline Santos - SP & 5 \\
\hline Presidente Prudente - SP & 6 \\
\hline Teresina - PI & 7 \\
\hline Belém - PA & 8 \\
\hline
\end{tabular}

\subsection{Avaliação do Desempenho Térmico das Edificações por meio de Simulação Computacional}

A norma NBR 15575-1 Edifícios habitacionais de até cinco pavimentos Desempenho (ABNT, 2008), apresenta dois procedimentos para avaliar o desempenho térmico de edificações, sendo a análise da edificação na fase de projeto, por meio de simulação computacional, e a avaliação da edificação já executada, por meio de medições in loco. Nesta pesquisa o procedimento utilizado foi a análise da edificação na fase de projeto, utilizando um software de simulação, com o objetivo de avaliar a influência da espessura do painel e do tipo de concreto utilizado no mesmo no desempenho térmico das habitações térreas e multipavimentos.

Segundo o mesma norma (ABNT, 2008), para edificações na fase de projeto, a avaliação de desempenho térmico deve ser feita nos dias considerados críticos de projeto para verão (22 de dezembro) e inverno (22 de junho), utilizando os dados climáticos da cidade. Caso os dados climáticos da cidade escolhida não constem no banco de dados do software, por exemplo, deve-se utilizar os dados climáticos da cidade mais próxima, dentro da mesma zona bioclimática, com altitude de mesma ordem de grandeza. Especificamente para as cidades analisadas nesta pesquisa, os dados climáticos já estavam inseridos na base de dados do software utilizado para a simulação (ARQUITROP 3.0), sendo eles: Altitude $(\mathrm{m})$; Pressão $(\mathrm{Pa})$; Latitude $\left({ }^{\circ}\right)$; Longitude $\left({ }^{\circ}\right)$; Temperatura máxima diária $\left({ }^{\circ} \mathrm{C}\right)$; Amplitude Diária da Temperatura $\left({ }^{\circ} \mathrm{C}\right)$; Temperatura de Bulbo Úmido $\left({ }^{\circ} \mathrm{C}\right)$; Radiação Solar $\left(\mathrm{Wh} / \mathrm{m}^{2}\right)$ e Nebulosidade (décimos). 


\subsubsection{Diretrizes para a Simulação Computacional (ABNT, 2008)}

Seguem no Quadro 8 algumas diretrizes a serem seguidas para a simulação computacional do desempenho térmico de edificações na fase de projeto (ABNT, 2008).

Quadro 8. Diretrizes para Simulação Computacional

\section{Diretrizes para Simulação Computacional}

1. Todos os recintos devem ser simulados, considerando trocas térmicas entre os ambientes. Neste projeto foi adotado apenas o quarto como cômodo padrão para análise, por ser o ambiente de maior permanência dos usuários e para simplificar o processo de análise;

2. Em paredes geminadas os respectivos recintos devem ser considerados na condição térmica mais próxima possível do ambiente que está sendo simulado;

3. As orientações das unidades habitacionais devem ser tais que haja pelo menos um dormitório ou sala com duas paredes expostas. As paredes expostas desse recinto devem ter orientação tal que no verão a janela do dormitório ou sala esteja voltada para oeste e a outra parede exposta voltada para norte; e no inverno que a janela do dormitório ou sala de estar esteja voltada para sul e a outra parede exposta voltada para leste.

4. Não deve haver obstrução por elementos externos, ou seja, a parede exposta e a janela devem estar desobstruídas (sem edificações ou vegetação nas proximidades) que modifiquem a incidência de sol e/ou vento;

5. A taxa de ventilação do ambiente de 3 ren/h e deve-se considerar a janela não sombreada;

6. A absortância à radiação solar das superfícies expostas: para a cobertura considerar o valor especificado no projeto; para as paredes a absortância à radiação solar deve ser de acordo com a cor definida no projeto. Caso não esteja definida: clara $=\alpha=0,3$; cor média $=\alpha=0,5$; e cor escura $=\alpha=0,7$;

7. Deve-se utilizar as propriedades térmicas dos materiais.

Fonte: Adaptado de ABNT (2008).

\subsubsection{Simulação Computacional da Tipologia Térrea e Multipavimentos}

$\mathrm{Na}$ execução das simulações computacionais foi adotado o software ARQUITROP 3.0 sendo que para a tipologia térrea TI24A - CDHU foram considerados três tipos de cobertura (cobertura de telha cerâmica, cobertura de telha cerâmica e laje plana e cobertura de telha cerâmica e laje inclinada); dois tipos de painéis de referência (alvenaria de bloco cerâmico e bloco de concreto) e os painéis com concreto, com variações na espessura do painel (8 a $12 \mathrm{~cm}$ ) e na massa específica do concreto (1600 a $2400 \mathrm{~kg} / \mathrm{m}^{3}$ ); isso para os dias críticos de projeto, também recomendados pela norma (ABNT, 2008), sendo para a estação de verão 22 de dezembro e de inverno 22 de junho, totalizando 1020 simulações.

Para a tipologia multipavimentos V052H-01 (Antiga VI22B-V2) - CDHU foi adotada cobertura de telha cerâmica e laje plana e, além disso, também foi simulado um pavimento intermediário, no caso o segundo pavimento. As simulações também foram feitas considerando dois tipos de painéis de referência (alvenaria de bloco cerâmico e bloco de concreto) e os painéis com concreto, com variações na espessura do painel (8 a $12 \mathrm{~cm}$ ) e na massa específica do concreto $\left(1600\right.$ a $\left.2400 \mathrm{~kg} / \mathrm{m}^{3}\right)$, isso considerando também os dias críticos de projeto, de acordo com as diretrizes da norma (ABNT, 2008), resultando em 680 simulações. 
Portanto, o total de simulações executados foram 1700 simulações computacionais, sendo 1020 simulações para a tipologia térrea (TI24A - CDHU) e 680 simulações para a tipologia multipavimentos (V052H-01 - Antiga VI22B-V2 - CDHU).

\section{Levantamento de dados comportamentos dos usuários das Habitações de Interesse Social da cidade de São Carlos - SP}

Durante as primeiras simulações observou-se a necessidade de adotar precisamente algumas variáveis solicitadas pelo software ARQUITROP 3.0, relacionadas à condição de ocupação e à ventilação das habitações de interesse social, isso com a intenção de obter informações mais precisas sobre o comportamento dos moradores, esse levantamento não estava previsto no projeto original, porém foi de grande importância para o andamento dos trabalhos. A partir dessa necessidade foi realizado um levantamento de dados comportamentais dos usuários de habitações de interesse social de conjuntos habitacionais da cidade de São Carlos - SP. Dentre as informações coletadas se encontram: o número médio de ocupantes por quarto (nos locais com dois quartos foram verificados dados sobre a ocupação dos dois); o horário de ocupação do quarto; duração da ocupação do quarto; horário de abertura da janela para ventilação; duração da ventilação do quarto; e a utilização de equipamento de condicionamento térmico.

Esse levantamento foi realizado também com a colaboração dos estudantes de Iniciação Científica José Irail de Rezende Neto $^{27}$ e Fernanda Faria Graçon ${ }^{28}$, por meio de entrevista a 70 moradores de dois conjuntos habitacionais, sendo 43 no Conjunto Valdomiro Lobbe Neto e 27 no Conjunto Romeo Santini, ambos na cidade de São Carlos-SP. As entrevistas foram realizadas nos dias 18 e 19 de dezembro de 2006 utilizando um questionário (Apêndice 1). Os resultados obtidos nessas entrevistas estão sintetizados nas Figuras 81 a 86 . Não foi observado o uso de equipamentos condicionadores de temperatura nas habitações analisadas.

O número predominante de ocupantes por quarto foram duas pessoas, tanto para o quarto do casal (65,7\%), quanto para o segundo quarto (40\%) (Figuras 81 e 82 ).

\footnotetext{
${ }^{27}$ Projeto de pesquisa de Iniciação Científica: "Avaliação de desempenho térmico de painéis de vedação de concreto moldados in loco para habitações de interesse social: edificações térreas". Processo FAPESP $n^{\circ}$. 2006/56263-6.

${ }^{28}$ Projeto de pesquisa de Iniciação Científica: "Avaliação de desempenho de painéis de vedação de concreto moldados in loco para habitações de interesse social: edificações assobradadas e de múltiplos pavimentos".
} 


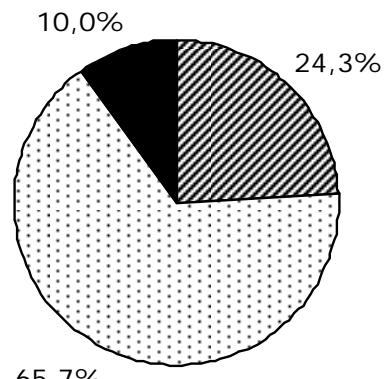

$65,7 \%$
1 Pessoa

ㄴ 2 Pessoas

- 3 Pessoas

Figura 81. Número de Pessoas por Quarto (Casal)

Fonte: Levantamento in loco em conjuntos habitacionais a partir de questionário.

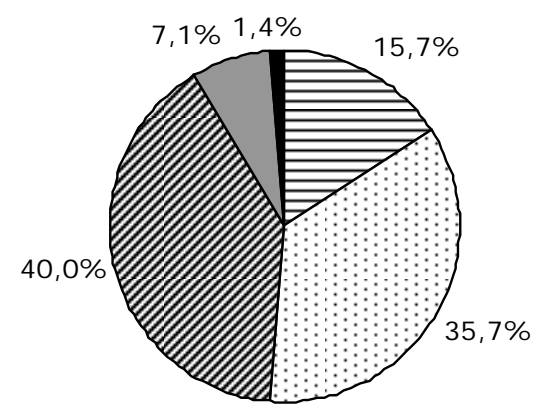

$$
\begin{aligned}
& \text { } 90 \text { Pessoa } \\
& \text { ㅁ } 1 \text { Pessoa } \\
& \checkmark 2 \text { Pessoas } \\
& \text { ㄱ Pessoas } \\
& \text { - } 4 \text { Pessoas }
\end{aligned}
$$

Figura 82. Número de Pessoas por Quarto

Fonte: Levantamento in loco em conjuntos habitacionais a partir de questionário

Devido à variação de respostas, para o gráfico período de ocupação os dados foram sintetizados por período (manhã, tarde, noite, fechado todo o dia, aberto todo o dia e sem resposta); e o gráfico duração de ocupação por intervalos de tempo (de 5:00 a 10:00; de 10:00 a 15:00; de 15:00 em diante e sem resposta). O período da noite predominou como período de ocupação e o intervalo de 5 a 10 horas para a duração da ocupação (Figuras 83 e 84). O período de início da ocupação e a duração da ocupação foram determinados com base em média ponderada, resultando no horário de 21:00 horas para início de ocupação e 9:00 horas para duração de ocupação. 


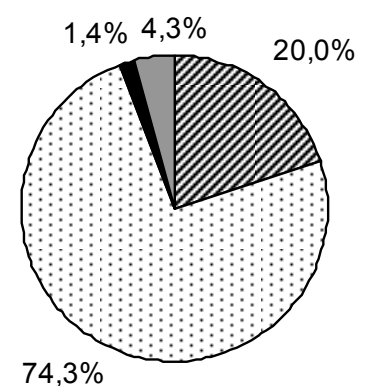

\ Manhã (Até 12:00)

$\square$ Noite (Após às 18:00)

- Todo o Dia

口 Sem Resposta

Figura 83. Período de Ocupação

Fonte: Levantamento in loco em conjuntos habitacionais a partir de questionário.

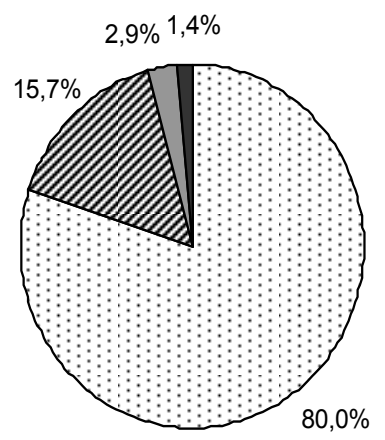

$$
\begin{aligned}
& \text { घDe 5:00 a 10:00 } \\
& \text { घ De 10:00 a 15:00 } \\
& \text { व De 15:00 em diante } \\
& \text { — Sem Resposta }
\end{aligned}
$$

Figura 84. Duração de Ocupação

Fonte: Levantamento in loco em conjuntos habitacionais a partir de questionário.

Para a determinação do período de ventilação, novamente devido à variação de respostas, os dados foram sintetizados em gráficos por período (manhã, tarde, noite, fechado todo o dia, aberto todo o dia e sem resposta). Nesse caso o período da manhã foi predominante como período de ventilação e o intervalo de 10 a 15 horas para a duração da ocupação (Figuras 85 e 86). A partir dos resultados foi calculada uma média ponderada utilizando toda a amostra para o início de abertura de ventilação (período de ventilação), o horário predominante foi 9:00 horas. Para a duração da ventilação também foi calculada 
uma média ponderada usando toda a amostra e o resultado obtido foi uma duração de $13: 30$ horas.

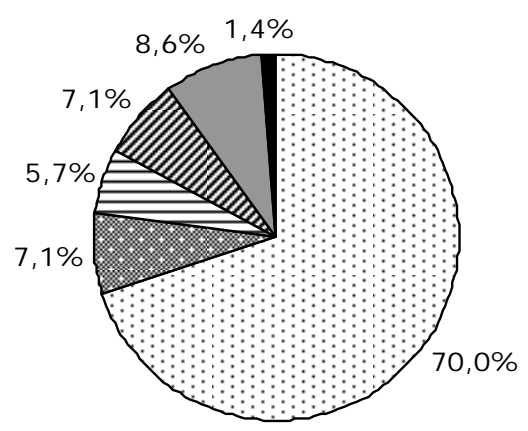

๑ Manhã (Até 12:00)

⿴囗十 Tarde (de 12:00 às 18:00)

曰 Noite (Após às 18:00)

$\checkmark$ Fechado Todo o Dia

$\square$ Aberto Todo o Dia

- Sem Resposta

Figura 85. Período de Ventilação

Fonte: Levantamento in loco em conjuntos habitacionais a partir de questionário.

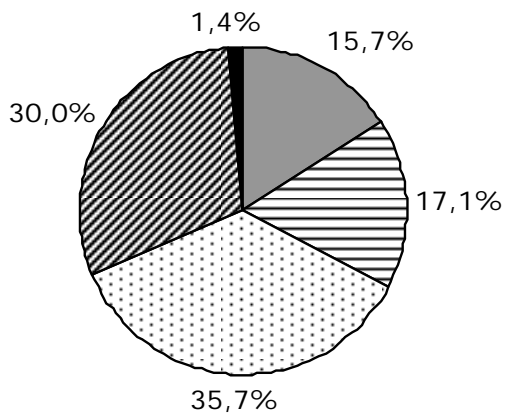

$\square$ De 0:00 a 5:00

घDe 5:00 a 10:00

$\square$ De 10:00 a 15:00

De 15:00 em diante

- Sem Resposta

Figura 86. Duração da Ventilação

Fonte: Levantamento in loco em conjuntos habitacionais a partir de questionário.

No Quadro 9 a seguir, são apresentados os dados utilizados para realização das simulações no ARQUITROP 3.0. 
Quadro 9. Dados para Simulação Computacional

\section{Dados para Simulação Computacional}

1. Título do Projeto - de acordo com a tipologia e cidade simulada;

2. Número de fachadas - duas fachadas expostas;

3. Área de ventilação - foi considerada apenas as áreas com efetiva possibilidade de serem abertas ao vento, ou seja, $50 \%$ da área da janela, o que corresponde a $0,6 \mathrm{~m}^{2}$ para ambas tipologias térrea e multipavimentos;

4. Período de ventilação - como mostrado anteriormente no levantamento realizado em dois conjuntos habitacionais na cidade de São Carlos, e o horário do início de abertura de ventilação obtido foi 9:00 hs e o tempo de duração da abertura foi de 13:30 hs.

5. Orientação das fachadas - As orientações das unidades habitacionais escolhidas foram tais que 0 dormitório de cada tipologia ficasse com duas paredes expostas. Sendo no verão a parede com a janela voltada para oeste e a outra para norte; e no inverno, a parede com a janela voltada para sul e a outra para leste;

6. Área envidraçada - as janelas foram consideradas envidraçadas em metade da área total $\left(0,6 \mathrm{~m}^{2}\right), \mathrm{com}$ vidro de $3 \mathrm{~mm}$ de espessura;

7. Número de Pavimentos - para as simulações da tipologia térrea foi considerado 1 pavimento (térreo) construído diretamente sobre o solo; e para a tipologia multipavimentos foi considerada 4 pavimentos, sendo o quarto e o segundo simulados.

8. Como o pavimento simulado considerado está diretamente sob a cobertura par a tipologia térrea e um dos casos isso também ocorre para a tipologia multipavimentos, a cor da face superior escolhida foi o valor 5 de uma escala de 1 a 5 do software, que corresponde a uma cor escura.

9. Pé direito - de acordo com as informações dos projetos da CDHU mostrados anteriormente (Figuras 70 e 72 a 76 );

10. Dimensões do ambiente (quarto) - de acordo com as informações dos projetos (Figuras 70 e 72 a 76);

11. Cores das fachadas - cor tipo 2, que corresponde à cor creme e cinzas claros;

12. Ocupação do ambiente - no levantamento mostrado anteriormente houve o predomínio de duas pessoas por quarto;

13. O período de início da ocupação e a duração da ocupação - esses dados também foram obtidos no levantamento mostrado anteriormente, resultando o horário de 21:00 hs para início de ocupação e 9:00 hs para duração de ocupação;

14. Calor produzido por equipamentos - não foram considerados equipamentos que geram calor nos locais simulados, somente para a Zona Bioclimática 1, pois foi exigido pela norma (ABNT, 2008);

15. Tipo de paredes - Foram adotadas, primeiramente paredes de alvenaria de bloco cerâmico e de bloco de concreto, utilizadas como referência na análise do desempenho, além de painéis maciços de concreto, com espessura variando entre 8,10 e $12 \mathrm{~cm}$ e concreto com massa específica variando entre 1600 e $2400 \mathrm{~kg} / \mathrm{m}^{3}$, os dados dos painéis foram complementados no software com a condutividade térmica determinada em ensaio anteriormente executado.

16. Piso - foi adotado piso de concreto armado com $10 \mathrm{~cm}$ de espessura (fundação do tipo radier);

17. Coberturas - para a tipologia térrea foi considerada a cobertura com telha cerâmica, porém com as variações: sem laje, com laje mista plana $(10 \mathrm{~cm}$ de espessura) e com laje mista inclinada $(10 \mathrm{~cm}$ de espessura); e para a tipologia multipavimentos foi considerada somente a cobertura com telha cerâmica e laje mista plana (10 cm de espessura), além da simulação de um pavimento intermediário no caso o segundo;

18. A taxa de ventilação do ambiente considerada foi de $3 \mathrm{ren} / \mathrm{h}^{29}$.

18. Cidades de Implantação - foram adotadas as cidades mostradas anteriormente no Quadro 7.

As orientações das unidades habitacionais são mostradas nas Figuras 87 a 90 e foram consideradas de forma que no verão a parede com a janela estivesse voltada para oeste e no inverno, a parede com a janela estivesse voltada para sul.

\footnotetext{
${ }^{29}$ Taxa considerada média para Habitação de Interesse Social, também indicada por ALLUCCI (1986).
} 


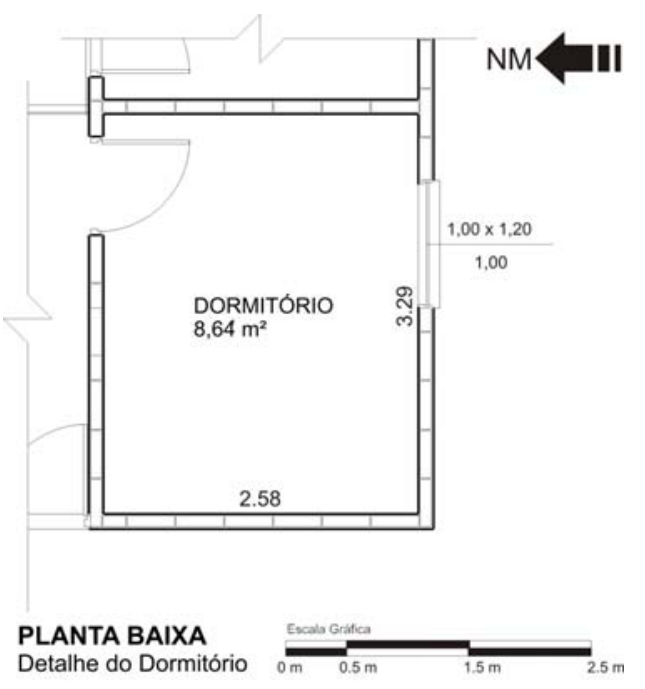

Figura 87. Orientação Padrão Habitacional TI24A (Tipologia Térrea) - Inverno.

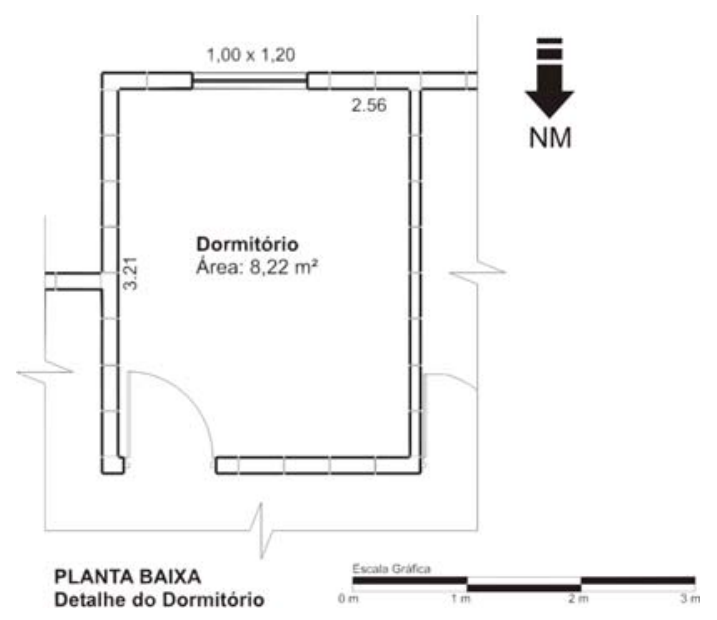

Figura 89. Orientação Padrão Habitacional V052H-01 (Tipologia Multipavimentos) - Inverno.

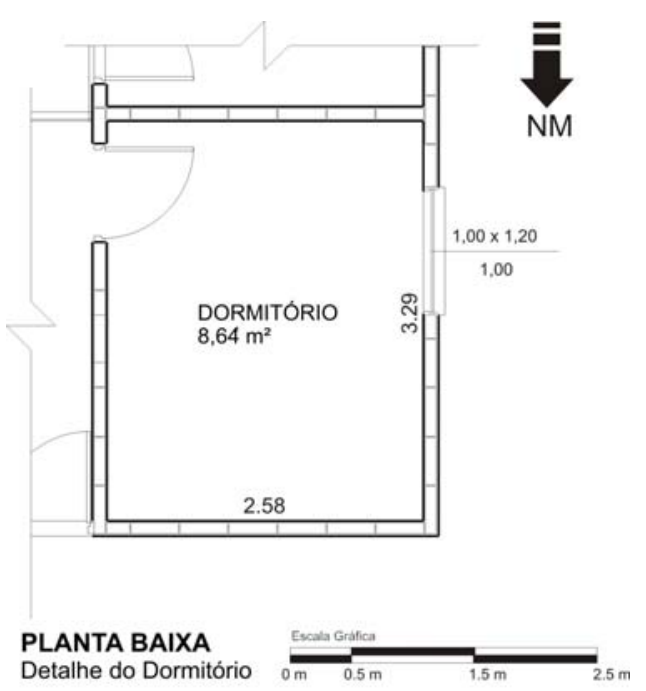

Figura 88. Orientação Padrão Habitacional TI24A (Tipologia Térrea) - Verão.

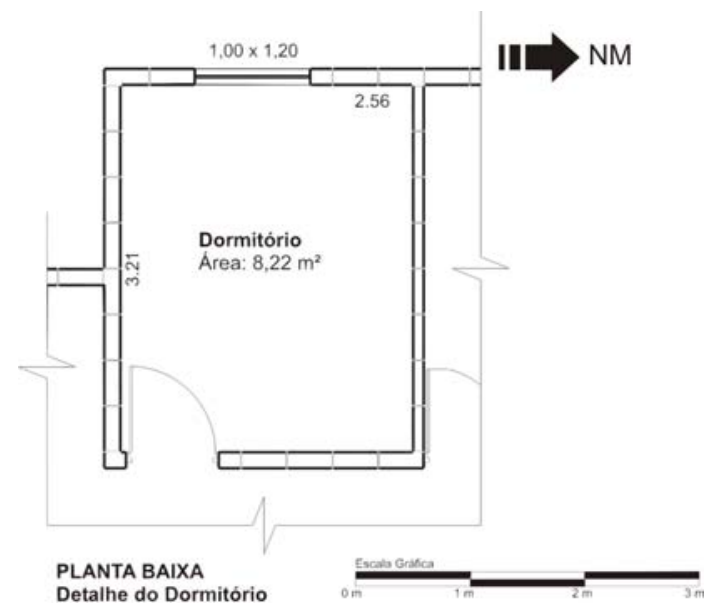

Figura 90. Orientação Padrão Habitacional V052H-01 (Tipologia Multipavimentos) - Verão. 


\subsection{Desenvolvimento de Concretos}

De acordo com os objetivos desta pesquisa, será apresentado o detalhamento do programa experimental adotado para a especificação dos concretos selecionados a partir dos resultados das simulações computacionais de desempenho térmico das tipologias térreas e multipavimentos que indicaram o concreto tradicional (massa específica em torno de $2400 \mathrm{~kg} / \mathrm{m}^{3}$ ) com melhor desempenho dentre os demais avaliados.

Esse programa experimental divide-se em quatro etapas, sendo: caracterização dos materiais constituintes; dosagem dos concretos; produção dos concretos e caracterização das propriedades dos concretos.

\subsubsection{Caracterização dos materiais constituintes}

\section{Cimento Portland}

$\mathrm{Na}$ produção dos concretos foram utilizados dois tipos de cimento Portland, sendo eles: CPII E 32 e CPIII 40 RS. O dois tipos de cimentos selecionados são fabricados pela empresa CIMINAS S.A. (grupo Holdercim) e facilmente encontrados na região de São Carlos SP. As Tabelas 10 e 11 apresentam as características e propriedades desses cimentos.

Tabela 10. Características e Propriedades do CPII E 32.

\begin{tabular}{|c|c|c|c|}
\hline \multicolumn{2}{|c|}{ Características e Propriedades } & Unidade & CPII E 32 \\
\hline \multicolumn{2}{|c|}{ Massa específica (NBR 6474) } & $\mathrm{kg} / \mathrm{dm}^{3}$ & 2,96 \\
\hline \multicolumn{2}{|c|}{ Massa unitária no estado solto (NBR 7251) } & $\mathrm{kg} / \mathrm{dm}^{3}$ & 0,96 \\
\hline \multirow{2}{*}{ Finura } & Resíduo \# 200 (NBR 11579) & $\%$ & 3,0 \\
\hline & Sup. Esp. Blaine (NBR 7224) & $\mathrm{cm}^{2} / \mathrm{g}$ & 4.023 \\
\hline \multirow{2}{*}{ Tempo de pega } & Início (NBR 11581) & Min & 171 \\
\hline & Fim (NBR 11581) & Min & 251 \\
\hline \multirow{3}{*}{$\begin{array}{l}\text { Resistência à } \\
\text { compressão (fcj) } \\
\text { (NBR 7215) }\end{array}$} & 3 dias & $\mathrm{MPa}$ & 22,9 \\
\hline & 7 dias & $\mathrm{MPa}$ & 29,1 \\
\hline & 28 dias & $\mathrm{MPa}$ & 37,7 \\
\hline
\end{tabular}

Fonte: Fabricante. 
Tabela 11. Características e Propriedades do CPIII 40 RS

\begin{tabular}{l|l|c|c}
\hline \multicolumn{1}{c|}{ Características e Propriedades } & Unidade & CPIII 40 RS \\
\hline \multicolumn{2}{l}{ Massa específica (NBR 6474) } & $\mathrm{kg} / \mathrm{dm}^{3}$ & 3,04 \\
\hline \multicolumn{2}{l}{ Massa unitária no estado solto (NBR 7251) } & $\mathrm{kg} / \mathrm{dm}^{3}$ & 1,00 \\
\hline \multirow{2}{*}{ Finura } & Resíduo \# 400 (NBR 11579) & $\%$ & 4,3 \\
\cline { 2 - 4 } & Sup. Esp. Blaine (NBR 7224) & $\mathrm{cm}^{2} / \mathrm{g}$ & 4.450 \\
\hline \multirow{2}{*}{ Tempo de pega } & Início (NBR 11581) & $\mathrm{Min}$ & 192 \\
\cline { 2 - 4 } & Fim (NBR 11581) & $\mathrm{Min}$ & 240 \\
\hline \multirow{2}{*}{$\begin{array}{l}\text { Resistência à } \\
\text { compressão (fcj) } \\
\text { (NBR 7215) }\end{array}$} & 3 dias & $\mathrm{MPa}$ & 29,7 \\
\cline { 2 - 4 } & 7 dias & $\mathrm{MPa}$ & 41,8 \\
\cline { 2 - 4 } & 28 dias & $\mathrm{MPa}$ & 53,0 \\
\hline
\end{tabular}

Fonte: Fabricante.

\section{Metacaulin HP}

Na produção dos concretos utilizou-se a adição mineral pozolânica Metacaulin HP, fornecida pela empresa METACAULIN DO BRASIL Ltda., que apresenta características (fornecidas pelo fabricante) de acordo com a Tabela 12.

Tabela 12. Características e Propriedades do Metacaulim HP

\begin{tabular}{|c|c|c|c|}
\hline \multicolumn{2}{|c|}{ Características e Propriedades } & Unidade & Metacaulin HP \\
\hline \multicolumn{2}{|c|}{ Massa Específica (NBR 6474) } & $\mathrm{kg} / \mathrm{dm}^{3}$ & 2,65 \\
\hline \multicolumn{2}{|c|}{ Massa Unitária } & $\mathrm{kg} / \mathrm{dm}^{3}$ & 0,24 \\
\hline \multicolumn{2}{|c|}{ Superfície Específica (BET) } & $\mathrm{cm}^{2} / \mathrm{g}$ & 327.000 \\
\hline \multicolumn{4}{|c|}{ Análise Química do Metacaulin HP } \\
\hline Composto & $\%$ & Composto & $\%$ \\
\hline PF & 2,62 & $\mathrm{MgO}$ & - \\
\hline $\mathrm{SiO}_{2}$ & 51,6 & $\mathrm{SO}_{3}$ & - \\
\hline $\mathrm{Al}_{2} \mathrm{O}_{3}$ & 40,5 & $\mathrm{~K}_{2} \mathrm{O}$ & 0,2 \\
\hline $\mathrm{Fe}_{2} \mathrm{O}_{3}$ & 2,8 & \multirow{2}{*}{$\mathrm{Na}_{2} \mathrm{O}$} & \multirow{2}{*}{0,1} \\
\hline $\mathrm{CaO}$ & - & & \\
\hline \multicolumn{2}{|c|}{ Total } & \multicolumn{2}{|c|}{97,8} \\
\hline
\end{tabular}

Fonte: Fabricante.

\section{Areia Natural Quartzosa ${ }^{30}$}

Foi utilizada a areia natural quartzosa proveniente do Rio Mogi-Guaçú, município de São Carlos, estado de São Paulo. A Tabela 13 e a Figura 91 apresentam a composição granulométrica da areia, que atendeu aos requisitos da NBR 7211 (ABNT, 1983) quanto à presença de substâncias nocivas aos concretos.

\footnotetext{
${ }^{30}$ Análises realizadas no Laboratório de Construção Civil EESC/USP.
} 
Tabela 13. Características da Areia Natural.

\begin{tabular}{|c|c|c|}
\hline Características e Propriedades & Unidade & Areia Natural \\
\hline Massa específica (NBR 9776) & $\mathrm{Kg} / \mathrm{dm}^{3}$ & 2,63 \\
\hline Massa unitária no estado solto e seco (NBR 7251) & $\mathrm{Kg} / \mathrm{dm}^{3}$ & 1,49 \\
\hline \multicolumn{3}{|c|}{ Granulometria da areia natural (NBR 7217) } \\
\hline Peneira \# (mm) & \multicolumn{2}{|c|}{$\%$ Retida acumulada } \\
\hline 4.8 & \multicolumn{2}{|c|}{0.0} \\
\hline 2.4 & \multicolumn{2}{|r|}{2.0} \\
\hline 1.2 & \multicolumn{2}{|r|}{9.0} \\
\hline 0.6 & \multicolumn{2}{|c|}{28.0} \\
\hline 0.3 & \multicolumn{2}{|r|}{62.0} \\
\hline 0.15 & \multicolumn{2}{|r|}{97.0} \\
\hline Resíduo & \multicolumn{2}{|c|}{100.0} \\
\hline \multicolumn{3}{|c|}{ Dimensão máxima característica: $\mathrm{D}_{\text {máx }}=2,4 \mathrm{~mm}(\mathrm{NBR} 7211)$} \\
\hline \multicolumn{3}{|c|}{ Módulo de finura: MF = 2,00 (NBR 7211) } \\
\hline \multicolumn{3}{|c|}{ Classificação NBR 7211: areia média (zona 2) } \\
\hline
\end{tabular}

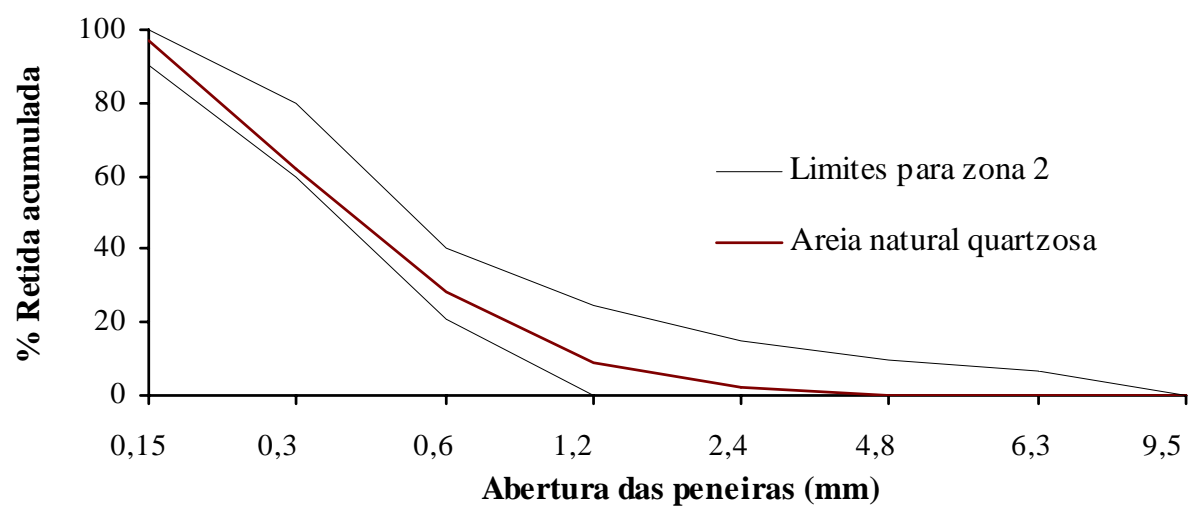

Figura 91. Curva Granulométrica da Areia Natural Quartzosa

\section{Brita Basáltica ${ }^{31}$}

O agregado graúdo utilizado na produção dos concretos foi a brita basáltica 01 (Tabela 14).

\footnotetext{
${ }^{31}$ Análises realizadas no Laboratório de Construção Civil EESC/USP.
} 
Tabela 14. Características e Propriedades da Brita Basáltica.

\begin{tabular}{l|c|c}
\hline \multicolumn{1}{c|}{ Características e Propriedades } & Unidade & Brita Basáltica 01 \\
\hline$D_{\max }$ (NBR 7211) & $\mathrm{mm}$ & 19,0 \\
\hline Massa específica (NBR 9776) & $\mathrm{g} / \mathrm{cm}^{3}$ & 2,87 \\
\hline Massa unitária (NBR 7251) & $\mathrm{g} / \mathrm{cm}^{3}$ & 1,32 \\
\hline Massa específica (NBR 9776) & $\mathrm{kg} / \mathrm{dm}^{3}$ & 2,63 \\
\hline Massa unitária no estado solto e seco (NBR 7251) & $\mathrm{kg} / \mathrm{dm}^{3}$ & 1,54 \\
\hline
\end{tabular}

\section{Aditivo Superplastificante}

$\mathrm{Na}$ produção dos concretos foi empregado um aditivo superplastificante fabricado pela empresa MBT Brasil Indústria e Comércio, com designação comercial de GLENIUM 51. A Tabela 15 apresenta as características do aditivo superplastificante.

Tabela 15. Características do Aditivo Superplastificante.

\begin{tabular}{l|c|c}
\hline \multicolumn{1}{c|}{ Características e Propriedades } & Unidade & Glenium 51 \\
\hline Massa Específica & $\mathrm{kg} / \mathrm{dm}^{3}$ & 1,08 \\
\hline $\mathrm{Ph}$ & - & 8,89 \\
\hline Teor de Sólidos & $\%$ & 19,8 \\
\hline Aspecto & - & Liq. Homogêneo \\
\hline Cor & - & Bege \\
\hline Base Química & - & $\begin{array}{c}\text { Éter Carboxílico } \\
\text { Modificado }\end{array}$ \\
\hline
\end{tabular}

Fonte: Fabricante

\subsubsection{Dosagem dos Concretos}

A dosagem do concreto destinado à execução dos painéis monolíticos moldados in loco foi inteiramente experimental, tendo como referência os estudos preliminares executados no Laboratório de Construção Civil (LCC) da EESC/ USP. De acordo com o resultado das simulações computacionais foram estudados concretos com massa específica em torno de $2400 \mathrm{~kg} / \mathrm{m}^{3}$. Nesses estudos foram determinados os seguintes parâmetros iniciais de dosagem:

- Relação água/aglomerante inferior a 0,60: concreto exposto à classe de agressividade II em área urbana prevista na NBR 6118 (ABNT, 2004);

- Resistência à compressão aos 28 dias acima de $25 \mathrm{MPa}$ : concreto exposto à classe de agressividade II prevista na NBR 6118 (ABNT, 2004);

- Resistência à compressão às 12 horas acima de 1,0 MPa: condição adequada para retirada das formas dos painéis; 
- Adição de $10 \%$ de Metacaulin (em substituição à massa de cimento): material pozolânico incorporado ao concreto com a intenção de reduzir a segregação dos agregados; proporcionar maior coesão; melhorar o acabamento superficial dos painéis e o desempenho das propriedades relacionadas à durabilidade;

- Abatimento do tronco de cone (ABNT, 1992 d) (slump test) de $160 \pm 10 \mathrm{~mm}$ : trabalhabilidade indicada para a moldagem dos painéis de concreto;

Foram utilizados dois tipos de cimento Portland comumente empregados no estado de São Paulo, sendo eles CPII E 32 e CPIII 40 RS. Para cada tipo de cimento foram estabelecidos três traços (rico, médio e pobre) (Tabelas 16 e 17) com a intenção de elaborar a curva de dosagem. Além disso, foi utilizado o teor de 0,75\% de aditivo superplastificante, em relação à massa de aglomerante (ver Anexo 5). As Tabelas 18 e 19 apresentam os valores de "m"32, relação agregados secos/cimento em massa (kg/kg), com $45 \%$ de areia e $55 \%$ de brita 01 , em massa, para os concretos com os dois tipos de cimento.

Tabela 16. Traços teóricos para concreto tradicional com CPII E $32\left(1 \mathrm{~m}^{3}\right)$.

\begin{tabular}{c|c|c|c|c|c|c|c|c|c}
\hline \multicolumn{2}{c|}{ Traços } & $\begin{array}{c}\text { Consumo } \\
\text { de Cimento } \\
(\mathbf{k g})\end{array}$ & CPII E 32 & Metacaulin & Areia & Brita 01 & Glenium 51 & Água & a/aglo \\
\hline \multirow{3}{*}{ CPII E32 } & Rico & 335,91 & 1 & 0,1 & 2,44 & 2,98 & 0,0075 & 0,49 & 0,45 \\
\cline { 2 - 10 } & Médio & 302,58 & 1 & 0,1 & 2,89 & 3,53 & 0,0075 & 0,49 & 0,45 \\
\cline { 2 - 10 } & Pobre & 271,82 & 1 & 0,1 & 3,34 & 4,08 & 0,0075 & 0,49 & 0,45 \\
\hline
\end{tabular}

Tabela 17. Traços teóricos para concreto tradicional com CPIII 40 RS (1 $\left.\mathrm{m}^{3}\right)$.

\begin{tabular}{|c|c|c|c|c|c|c|c|c|c|}
\hline \multicolumn{2}{|c|}{ Traços } & $\begin{array}{l}\text { Consumo } \\
\text { de Cimento }\end{array}$ & $\begin{array}{c}\text { CPIII } 40 \\
\text { RS }\end{array}$ & Metacaulin & Areia & Brita 01 & Glenium 51 & Água & a/aglo \\
\hline \multirow{3}{*}{$\begin{array}{c}\text { CPIII } 40 \\
\text { RS }\end{array}$} & Rico & 342,31 & 1 & 0,1 & 2,44 & 2,98 & 0,0075 & 0,49 & 0,45 \\
\hline & Médio & 303,46 & 1 & 0,1 & 2,89 & 3,53 & 0,0075 & 0,49 & 0,45 \\
\hline & Pobre & 272,54 & 1 & 0,1 & 3,34 & 4,08 & 0,0075 & 0,49 & 0,45 \\
\hline
\end{tabular}

Tabela 18. Valores de $\mathrm{m}$ (relação agregados secos/cimento em massa) para o concreto tradicional com CPII E $32\left(1 \mathrm{~m}^{3}\right)$.

\begin{tabular}{c|c}
\hline Traços & Valores de $\mathbf{m}$ (relação agregados secos/cimento em massa) \\
\hline Rico & 5,42 \\
\hline Médio & 6,42 \\
\hline Pobre & 7,42 \\
\hline
\end{tabular}

\footnotetext{
${ }^{32}$ Segundo Helene (1992) "m" é a "relação agregados secos/cimento em massa (kg/kg)".
} 
Tabela 19. Valores de $m$ (relação agregados secos/cimento em massa) para concreto tradicional com CPIII $40 \mathrm{RS}\left(1 \mathrm{~m}^{3}\right)$.

\begin{tabular}{c|c}
\hline Traços & Valores de $\mathbf{m}$ (relação agregados secos/cimento em massa) \\
\hline Rico & 5,42 \\
\hline Médio & 6,42 \\
\hline Pobre & 7,42 \\
\hline
\end{tabular}

\subsubsection{Produção dos Concretos}

\section{Mistura dos materiais}

Os materiais foram misturados em uma betoneira do tipo planetária, com capacidade de $320 \mathrm{dm}^{3}$, à temperatura de $24 \pm 2{ }^{\circ} \mathrm{C}$ e umidade relativa do ar de $70 \pm 15 \%$, até obter-se uma mistura homogênea, aproximadamente 5 minutos para $50 \mathrm{dm}^{3}$ de concreto (Figura 92 e 93). A inclusão dos materiais na betoneira obedeceu a seguinte ordem: $1^{\circ}$ ) areia, cimento, metacaulim, aditivo superplastificante e $50 \%$ da água; $2^{\circ}$ ) brita basáltica; e $3^{\circ}$ ) $50 \%$ restante da água.

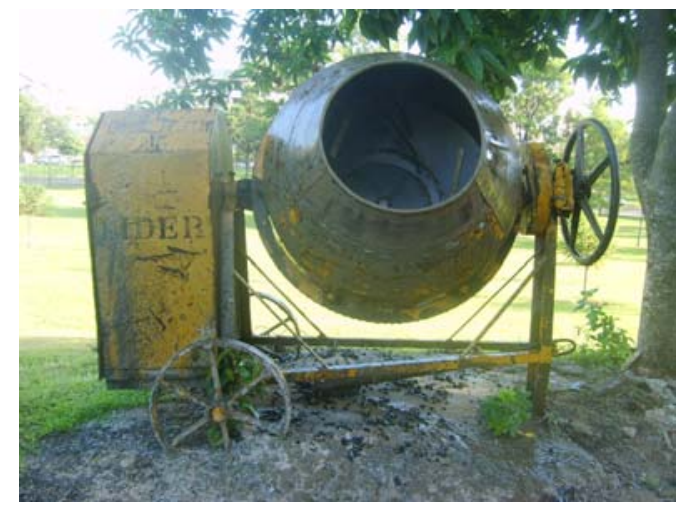

Figura 92. Ilustração do preparo dos concretos - betoneira utilizada.

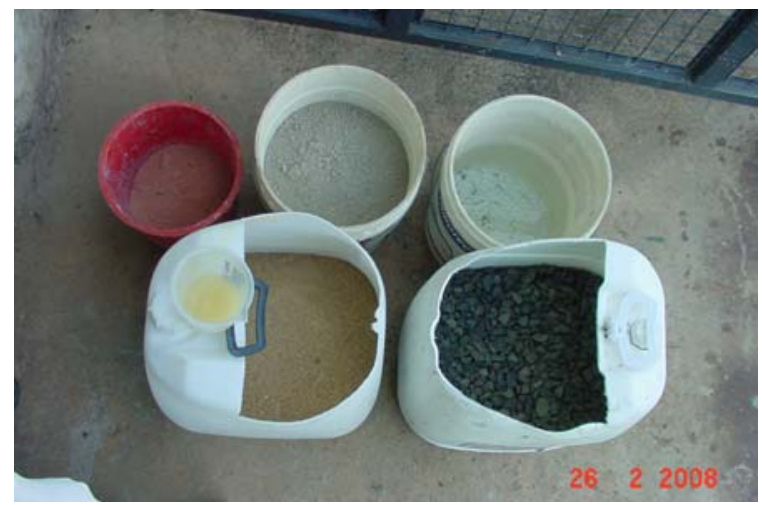

Figura 93. Ilustração do preparo dos concretos materiais.

\section{Adensamento}

Foram utilizadas fôrmas metálicas para a moldagem os corpos-de-prova cilíndricos, com $100 \mathrm{~mm}$ de diâmetro e $200 \mathrm{~mm}$ de altura; e para o adensamento utilizou-se mesa vibratória (Figura 94). 


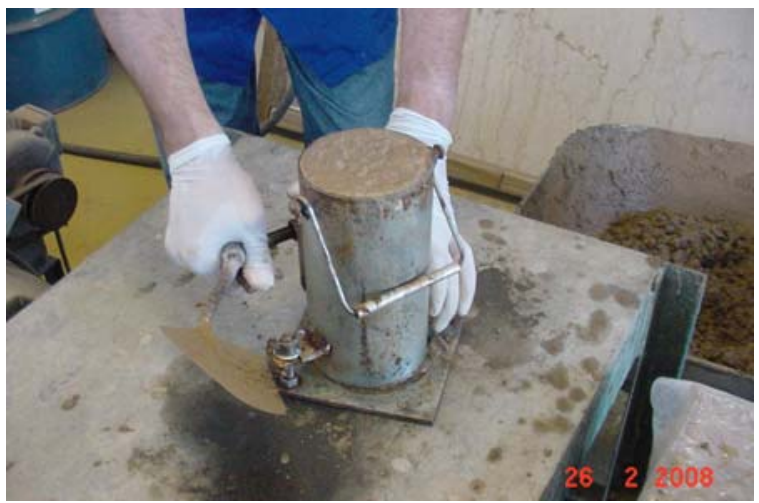

Figura 94. Adensamento em mesa vibratória.

\section{Procedimento de Cura}

Para a caracterização das propriedades dos concretos adotou-se a cura úmida ( $\mathrm{T}=$ $23 \pm 2^{\circ} \mathrm{C}$ e UR $=95 \%$ ) dos corpos-de-prova, durante 27 dias após a desmoldagem ou até a idade de análise, para o caso de idades inferiores (7 dias) (Figura 95).

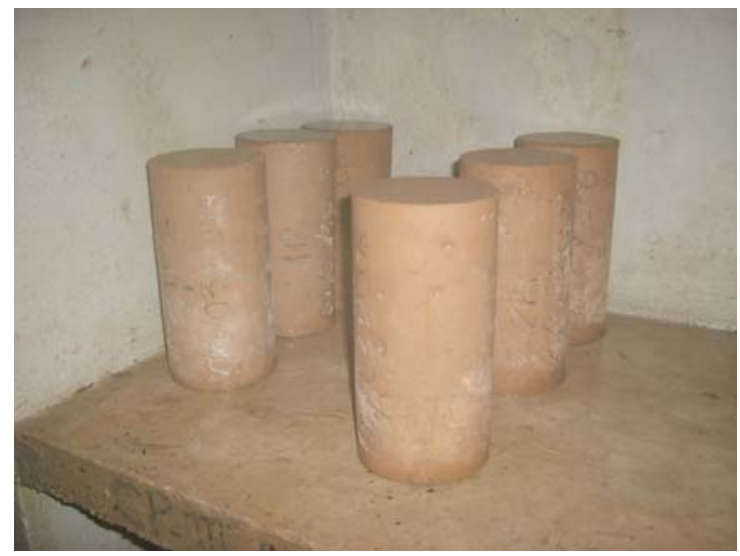

Figura 95. Corpos-de-prova sob cura úmida

\subsubsection{Caracterização das Propriedades dos Concretos}

O Quadro 10 apresenta os procedimentos utilizados na avaliação das propriedades dos concretos assim como as idades das análises. 
Quadro 10. Procedimentos experimentais normalizados.

\begin{tabular}{|c|c|c|}
\hline \multicolumn{3}{|c|}{ Procedimentos Experimentais } \\
\hline Item & Norma & Idade \\
\hline Abatimento do tronco de cone & $\begin{array}{l}\text { NBR 7223: Concreto - Determinação } \\
\text { da consistência pelo abatimento do } \\
\text { tronco de cone (ABNT, } 1992 \text { d). }\end{array}$ & Estado Fresco \\
\hline $\begin{array}{l}\text { Massa específica no estado } \\
\text { fresco e teor do ar incorporado }\end{array}$ & $\begin{array}{l}\text { NBR 9833: Concreto fresco - } \\
\text { Determinação da massa específica e } \\
\text { do teor de ar pelo método } \\
\text { gravimétrico (ABNT, } 1987 \mathrm{~d}) \text {. }\end{array}$ & Estado Fresco \\
\hline Resistência à compressão & $\begin{array}{l}\text { NBR 5739: Ensaio de compressão } \\
\text { de corpos-de-prova cilíndricos de } \\
\text { concreto (ABNT, } 1994 \text { c). }\end{array}$ & 12 horas, $1,7,28$ dias \\
\hline $\begin{array}{l}\text { Resistência à tração por } \\
\text { compressão diametral }\end{array}$ & $\begin{array}{l}\text { NBR 7222: Argamassa e concreto - } \\
\text { Determinação da resistência à tração } \\
\text { por compressão diametral de corpos- } \\
\text { de-prova cilíndricos (ABNT, } 1994 \text { d). }\end{array}$ & 28 dias \\
\hline Módulo de deformação & $\begin{array}{l}\text { NBR 8522: Concreto - Determinação } \\
\text { do módulo de deformação estática e } \\
\text { diagrama tensão-deformação (ABNT, } \\
\text { 2003). }\end{array}$ & 28 dias \\
\hline $\begin{array}{l}\text { Massa específica, índice de } \\
\text { vazios e absorção de água por } \\
\text { imersão }\end{array}$ & $\begin{array}{l}\text { NBR 9778: Argamassa e concreto } \\
\text { endurecidos - Determinação da } \\
\text { absorção de água por imersão, } \\
\text { índice de vazios e massa específica } \\
\text { (ABNT, } 1987 \text { c). }\end{array}$ & 28 dias \\
\hline
\end{tabular}

No próximo capítulo são apresentados e analisados os resultados obtidos no ensaio de determinação da condutividade térmica e nas simulações de desempenho térmico das tipologias térrea e multipavimentos, executadas para os painéis de referência e os painéis de concreto, além dos resultados dos experimentos de caracterização das propriedades dos concretos. 


\section{APRESENTAÇÃO E ANÁLISE DOS RESULTADOS}

\subsection{Resultados do Ensaio de Condutividade Térmica}

Os resultados obtidos no ensaio de condutividade térmica representaram maior precisão para as simulações computacionais, essa propriedade foi especificada no software de simulação de acordo com a massa específica dos concretos. A Tabela 20 apresenta os valores da condutividade térmica, obtidos pelo método do fio quente paralelo detalhado no capítulo anterior, assim como os valores da massa específica e do teor de umidade dos corpos-de-prova.

Tabela 20. Valores da condutividade térmica, massa especifica e teor de umidade.

\begin{tabular}{c|c|c|c}
\hline Traço & $\begin{array}{c}\text { Massa } \\
\text { Específica } \\
\text { Seca aos 28 } \\
\text { dias }\left(\mathbf{k g} / \mathbf{m}^{3}\right)\end{array}$ & $\begin{array}{c}\text { Teor de } \\
\text { Umidade dos } \\
\text { Corpos-de- } \\
\text { prova (\%) }\end{array}$ & $\begin{array}{c}\text { Condutividade } \\
\text { Térmica } \boldsymbol{\lambda}\end{array}$ \\
\hline $\mathbf{( 1 )}$ & 2364,0 & 2,06 & 1,80 \\
\hline $\mathbf{( 2 )}$ & 2014,0 & 2,17 & 1,39 \\
\hline $\mathbf{( 3 )}$ & 1781,0 & 2,84 & 1,06 \\
\hline $\mathbf{( 4 )}$ & 1589,0 & 4,56 & 0,94 \\
\hline $\mathbf{( 5 )}$ & 1216,0 & 4,69 & 0,54 \\
\hline
\end{tabular}

A Figura 96 mostra o aumento da condutividade térmica com o aumento de massa específica, ou seja, os valores da condutividade térmica são influenciados pelo valor da massa específica do concreto, especificamente pelo teor de argila expandida. Quanto maior o teor de argila expandida no concreto menores são os valores da condutividade térmica. Os valores de condutividade térmica, nesse caso, considerando o intervalo de dados, obedecem a uma função linear. A partir da linha de tendência traçada é possível determinar os valores de condutividade térmica para concretos leves com argila expandida que estão nesse intervalo de massa específica. Observa-se também que os valores encontrados no 
ensaio estão bem próximos aos valores indicados pela NBR 15220 (ABNT, 2005), apresentados no capítulo anterior (Tabela 7, pág. 117, Capítulo 6).

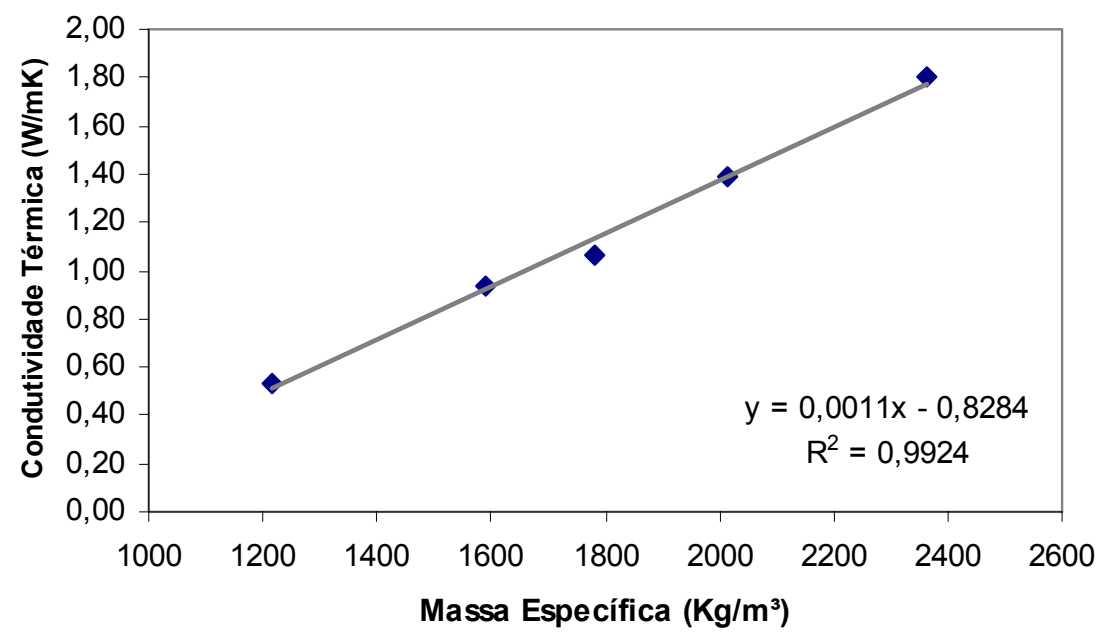

Figura 96. Relação entre condutividade térmica e massa específica dos concretos analisados.

\subsection{Resultados das Simulações Computacionais - Tipologia Térrea e Multipavimentos}

Todas as simulações computacionais previstas foram executadas e os respectivos resultados analisados, tanto para as habitações térreas quanto para as multipavimentos. Os resultados das simulações se encontram na forma de tabelas em apêndice (Apêndice 3 e 4), e foram analisados na forma de gráficos que serão mostrados a seguir.

Como apresentado no capítulo sobre conforto térmico, neste trabalho os níveis de desempenho foram adotados de acordo com a NBR 15575-1 Edifícios habitacionais de até cinco pavimentos - Desempenho (ABNT, 2008). Tanto para as condições de inverno quanto para as condições de verão, na análise dos dados o nível de desempenho deve ser entendido da seguinte maneira (Quadro 11 e 12): Nível de desempenho M: atende às exigências mínimas do usuário. Deve ser obrigatoriamente atendido; Nível de desempenho I: representa as exigências ideais do usuário, além das exigências mínimas, e não é obrigatório; Nível de desempenho S: excede o nível mínimo I, atende além das exigências mínimas do usuário, não é obrigatório. 
Quadro 11. Níveis de desempenho das edificações no inverno.

\begin{tabular}{|c|c|c|}
\hline \multirow{2}{*}{ Nível de Desempenho } & \multicolumn{2}{|c|}{ Critério } \\
\hline & Zonas Bioclimáticas 1 a $5^{1}$ & Zonas Bioclimáticas 6,7 e 8 \\
\hline $\mathbf{M}$ & $\mathrm{T}_{\mathrm{i}, \min } \geq\left(\mathrm{T}_{\mathrm{e}, \min }+3^{\circ} \mathrm{C}\right)$ & \multirow{3}{*}{$\begin{array}{l}\text { Nestas zonas, este critério não } \\
\text { precisa ser verificado. }\end{array}$} \\
\hline I & $T_{i, \min } \geq\left(T_{e, \min }+5^{\circ} \mathrm{C}\right)$ & \\
\hline $\mathbf{S}$ & $\mathrm{T}_{\mathrm{i}, \min } \geq\left(\mathrm{T}_{\mathrm{e}, \min }+7^{\circ} \mathrm{C}\right)$ & \\
\hline \multicolumn{3}{|c|}{$\begin{array}{l}T_{i, \text { min }} \text { é o valor mínimo diário da temperatura do ar no interior da edificação, em graus centígrados; } \\
T_{e, \text { min }} \text { é o valor mínimo diário da temperatura do ar exterior à edificação, em graus centígrados. } \\
\text { NOTA: Zonas Bioclimáticas de acordo com a ABNT NBR 15220-3. }\end{array}$} \\
\hline
\end{tabular}

Fonte: ABNT, 2008.

Quadro 12. Níveis de desempenho das edificações no verão.

\begin{tabular}{|c|c|c|}
\hline \multirow{2}{*}{ Nível de Desempenho } & \multicolumn{2}{|c|}{ Critério } \\
\hline & Zonas Bioclimáticas 1 a $7^{1}$ & Zona Bioclimática 8 \\
\hline M & $\mathrm{T}_{\mathrm{i}, \max } \leq \mathrm{T}_{\mathrm{e}, \max }$ & $\mathrm{T}_{\mathrm{i}, \max } \leq \mathrm{T}_{\mathrm{e}, \max }$ \\
\hline $\mathbf{I}$ & $\mathrm{T}_{\mathrm{i}, \max } \leq\left(\mathrm{T}_{\mathrm{e}, \max }-2^{\circ} \mathrm{C}\right)$ & $\mathrm{T}_{\mathrm{i}, \max } \leq\left(\mathrm{T}_{\mathrm{e}, \max }-1^{\circ} \mathrm{C}\right)$ \\
\hline $\mathbf{S}$ & $\mathrm{T}_{\mathrm{i}, \max } \leq\left(\mathrm{T}_{\mathrm{e}, \max }-4^{\circ} \mathrm{C}\right)$ & $\begin{array}{c}T_{i, \max } \leq\left(T_{e, \max }-2^{\circ} \mathrm{C}\right) \mathrm{e} \\
\mathrm{T}_{\mathrm{i}, \min } \leq\left(\mathrm{T}_{\mathrm{e}, \min }+1^{\circ} \mathrm{C}\right)\end{array}$ \\
\hline \multicolumn{3}{|c|}{$\begin{array}{l}\mathrm{T}_{\mathrm{i}, \text { max }} \text { é o valor máximo diário da temperatura do ar no interior da edificação, em graus centígrados; } \\
\mathrm{T}_{\mathrm{e}, \text { max }} \text { é o valor máximo diário da temperatura do ar exterior à edificação, em graus centígrados; } \\
\mathrm{T}_{\mathrm{i}, \text { min é o valor mínimo diário da temperatura do ar no interior da edificação, em graus centígrados; }} \\
\mathrm{T}_{\mathrm{e}, \text { min }} \text { é o valor mínimo diário da temperatura do ar exterior à edificação, em graus centígrados. }\end{array}$} \\
\hline
\end{tabular}

Fonte: ABNT, 2008.

As Figuras 97 a 116 apresentam os resultados das simulações de desempenho térmico para as habitações térrea e multipavimentos com o emprego de vedações em alvenaria de blocos cerâmicos e de blocos de concreto, denominadas neste trabalho de vedações de referência, assim como dos painéis em concreto com espessuras de 8, 10 e 12 $\mathrm{cm}$ e massa específica variando de 1600 a $2400 \mathrm{~kg} / \mathrm{m}^{3}$. Todos os gráficos apresentados possuem no canto inferior direito informações sobre os níveis de desempenho, de forma a facilitar a análise e entendimento. Além disso, as tipologias que apresentaram o melhor resultado em termos de desempenho estão destacadas por um contorno (linha pontilhada). 


\subsubsection{Zona Bioclimática 1 - Caxias do Sul}

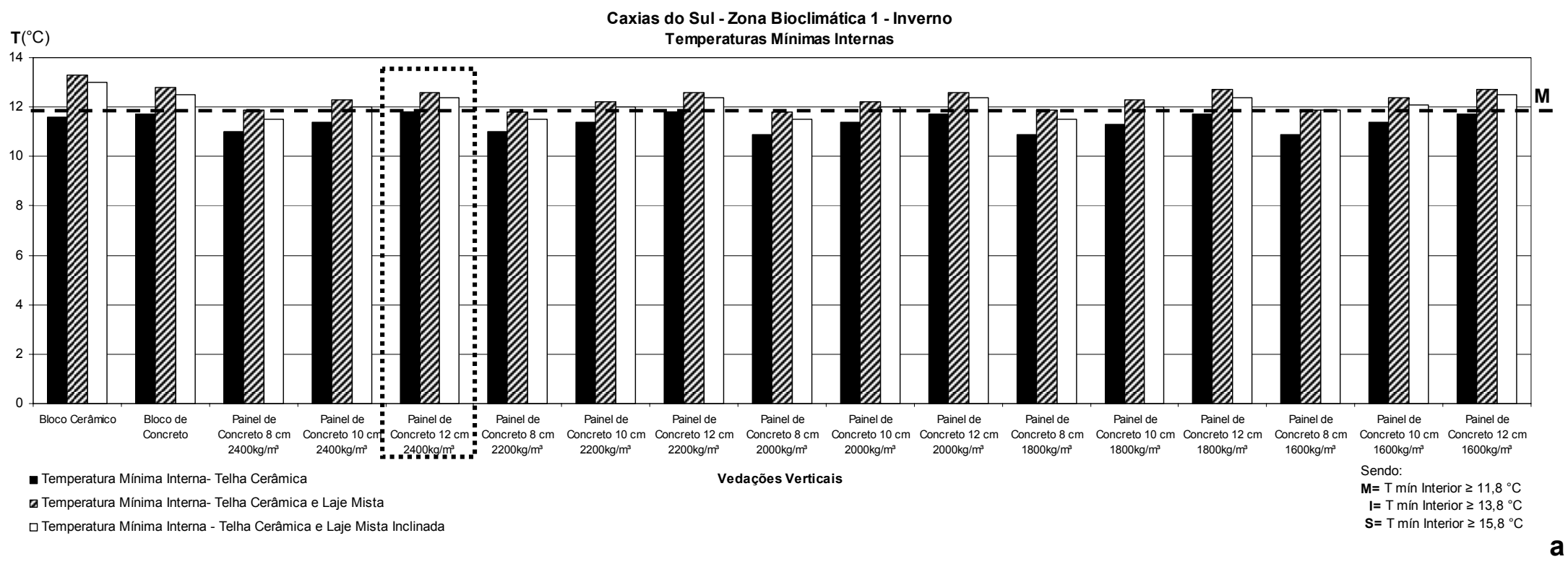

Caxias do Sul - Zona Bioclimática 1 - Verão

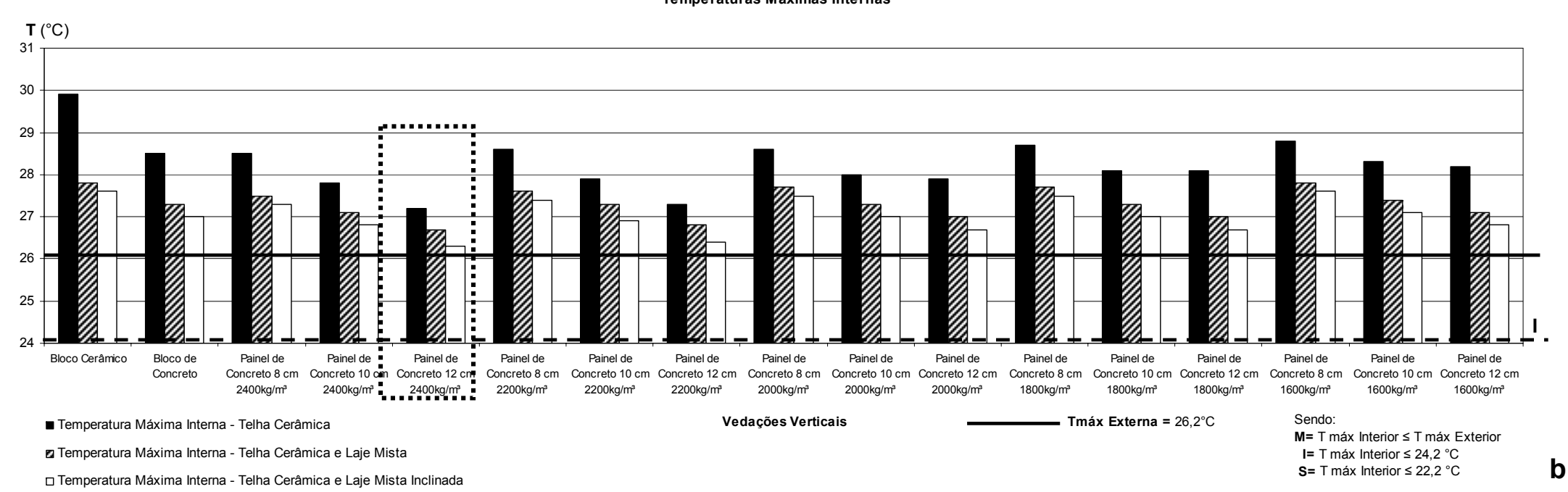

Figura 97 a-b. Tipologia Térrea - Temperaturas Internas - Zona Bioclimática 1 (Caxias do Sul) - a. Inverno. b. Verão 
Na Zona Bioclimática 1 para o inverno ${ }^{33}$, observou-se que para Caxias do Sul as temperaturas mínimas internas apresentaram-se modestamente superiores à temperatura mínima de $11,8^{\circ} \mathrm{C}$ determinada para esta localidade, de acordo com a NBR 15575-1 (ABNT, 2008), com exceção das tipologias sem laje.

Dentre as tipologias que atenderam ao nível mínimo de desempenho $(\mathrm{M})$, destacamse as tipologias compostas pelos painéis de referência (alvenaria de blocos cerâmicos e de blocos de concreto) que apresentaram para o inverno as temperaturas mínimas internas mais elevadas em relação às demais tipologias. A tipologia com painel de bloco cerâmico e com laje plana apresentou temperatura interna ligeiramente superior às demais, apesar da pouca variação das temperaturas para o inverno.

Já nas tipologias com painéis de concreto, as temperaturas mínimas internas das habitações permaneceram próximas à temperatura mínima recomendada $\left(11,8^{\circ} \mathrm{C}\right)$. Não foram observadas variações significativas nas temperaturas internas decorrentes das alterações de massa específica dos concretos dos painéis de vedação. Já em relação à variação de espessura, foi observado que as tipologias com painéis de concreto de 10 e 12 $\mathrm{cm}$ de espessura, para todas as massas específicas, atenderam ao nível mínimo (M) de desempenho para inverno, principalmente as tipologias com laje (plana ou inclinada). O mesmo não ocorreu para as tipologias com painéis de espessura $8 \mathrm{~cm}$, que em grande parte dos casos não atenderam ao nível mínimo de desempenho (M).

Observou-se que mesmo com a utilização da fonte de calor de $1000 \mathrm{~W}$ como previsto na NBR 15575-1 (ABNT, 2008), as tipologias sem laje não apresentaram temperatura interna acima de $11,8^{\circ} \mathrm{C}$. Salienta-se ainda que mesmo as temperaturas internas das tipologias analisadas estarem próximas do limite aceitável pela norma, de $11,8^{\circ} \mathrm{C}$, esse valor encontra-se abaixo do mínimo $\left(18^{\circ} \mathrm{C}\right)$ recomendado por algumas normas internacionais, como discutido no Capítulo 5. Conforto Térmico de Edificações.

Em relação ao tipo de cobertura, as tipologias com laje (plana e inclinada) atenderam aos requisitos mínimos de desempenho. Já as tipologias sem laje não atenderam ao nível mínimo (M) de desempenho para o inverno.

Para o verão nenhuma das tipologias térreas atendeu aos níveis de desempenho. A tipologia composta por alvenaria de blocos cerâmicos sem laje, apresentou a temperatura mais elevada em relação às demais (temperatura máxima interna acima de $29^{\circ} \mathrm{C}$ ).

As tipologias com painéis de referência apresentaram comportamento semelhante às tipologias com painéis de concreto com $8 \mathrm{~cm}$ de espessura incluindo todas as massas específicas.

\footnotetext{
${ }^{33}$ Devido às características climáticas dessa Zona Bioclimática no inverno, está prevista na norma NBR 15575-1 (ABNT, 2008) a inclusão de uma fonte de calor de 1000 W nos ambientes simulados para as localidades situadas na mesma.
} 
As tipologias térreas com painéis de concreto de $12 \mathrm{~cm}$ de espessura apresentaram no verão as menores temperaturas máximas internas (melhor desempenho) para todas as massas específicas analisadas, apesar de não atenderem a nenhum dos níveis de desempenho. As tipologias com painéis de concreto sem laje apresentaram as temperaturas internas mais elevadas no verão. Em relação ao tipo de cobertura, todas as tipologias sem laje apresentaram as temperaturas mais elevadas para o verão.

Dentre as tipologias com painéis de concreto analisadas para as condições críticas de inverno e de verão, apresentou melhor desempenho a com painel de concreto com espessura $12 \mathrm{~cm}$, massa específica de $2400 \mathrm{~kg} / \mathrm{m}^{3}$ e com laje plana (melhor desempenho no inverno) ou inclinada (melhor desempenho no verão). Os dados obtidos nesta pesquisa para esta cidade não indicam a necessidade de reduzir a massa específica do concreto para aplicação nos painéis de vedação, por isso recomenda-se o concreto tradicional, ou seja, com massa específica de $2400 \mathrm{~kg} / \mathrm{m}^{3}$. 
Caxias do Sul - Zona Bioclimática 1 - Inverno Temperaturas Mínimas Internas
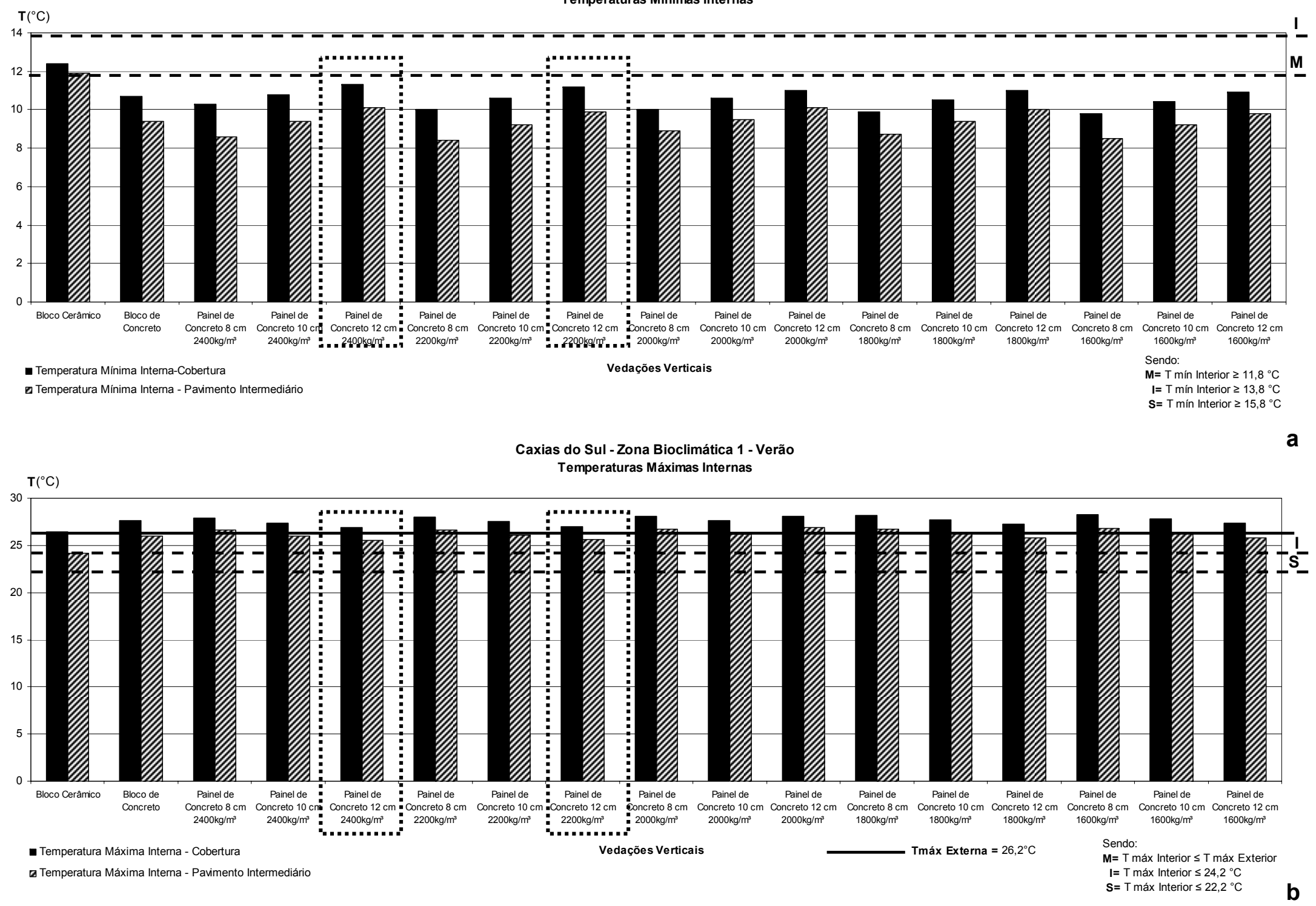

Figura 98 a-b. Tipologia Multipavimentos - Temperaturas Internas - Zona Bioclimática 1 (Caxias do Sul) - a. Inverno. b. Verão 
Na Zona Bioclimática 1 no inverno, observou-se que para Caxias do Sul somente as tipologias com alvenaria de blocos cerâmicos atenderam ao nível mínimo de desempenho, cuja temperatura mínima interna prevista na ABNT (2008) deve estar acima de $11,8^{\circ} \mathrm{C}$.

As tipologias com alvenaria de blocos de concreto apresentaram comportamento semelhante às tipologias com painéis de concreto de $10 \mathrm{~cm}$ de espessura, que não atenderam nem mesmo ao nível mínimo de desempenho. As tipologias com alvenaria de blocos cerâmicos apresentaram as temperaturas mais elevadas em relação às demais tipologias no inverno, ou seja, apresentaram o melhor desempenho.

As tipologias com painéis de concreto de espessura $12 \mathrm{~cm}$ e massa específica 2400 $\mathrm{kg} / \mathrm{m}^{3}$ apresentaram as temperaturas mínimas mais elevadas para o inverno, principalmente a tipologia da cobertura. Não foram observadas variações significativas nas temperaturas mínimas internas decorrentes das alterações de massa específica dos concretos, somente em relação à variação de espessura.

Com relação ao pavimento, as tipologias da cobertura apresentaram temperaturas internas mais elevadas que as do pavimento intermediário, em torno de $1^{\circ} \mathrm{C}$. Isso demonstra que apesar de não atingir aos níveis mínimos de desempenho em grande parte dos casos, as temperaturas das tipologias da cobertura encontraram-se mais próximas de $11,8^{\circ} \mathrm{C}$.

No verão, grande parte das tipologias do pavimento intermediário atingiu ao nível $M$ (temperaturas abaixo de $26,2^{\circ} \mathrm{C}$ ) de desempenho. Para as tipologias da cobertura nenhum dos níveis de desempenho foram atendidos.

Dentre as tipologias com painéis de referência, a alvenaria com blocos cerâmicos apresentou para o verão em termos de desempenho, as temperaturas menos elevadas tanto para o pavimento intermediário quanto para a cobertura. A tipologia com alvenaria de blocos cerâmicos do pavimento intermediário atendeu também ao nível I de desempenho (temperaturas abaixo de $24,2^{\circ} \mathrm{C}$ ). Já o comportamento das tipologias com alvenaria de blocos de concreto foi semelhante às tipologias com painéis de concreto de $12 \mathrm{~cm}$ de espessura e massa específica $2400 \mathrm{~kg} / \mathrm{m}^{3}$.

Nas tipologias com painéis de concreto apresentaram-se melhores em relação ao desempenho as tipologias com concreto de massa específica 2400 e $2200 \mathrm{~kg} / \mathrm{m}^{3}$ e espessura $12 \mathrm{~cm}$, principalmente para o pavimento intermediário, que atenderam ao nível mínimo de desempenho (temperaturas abaixo de $26,2^{\circ} \mathrm{C}$ ). Para o verão as tipologias do pavimento intermediário apresentaram temperaturas máximas internas abaixo das temperaturas das tipologias da cobertura, em cerca de $1,5^{\circ} \mathrm{C}$.

Diante das análises das tipologias multipavimentos com painéis de concreto para as condições críticas de inverno e de verão, apesar de dois tipos de painéis de concreto apresentarem o melhor desempenho $(12 \mathrm{~cm}$ de espessura e massa específica de $2200 \mathrm{e}$ 
$2400 \mathrm{~kg} / \mathrm{m}^{3}$ ) recomenda-se a utilização do painel com espessura $12 \mathrm{~cm}$ e massa específica $2400 \mathrm{~kg} / \mathrm{m}$ por questões de viabilidade econômica. 


\subsubsection{Zona Bioclimática 2 - Ponta Grossa}

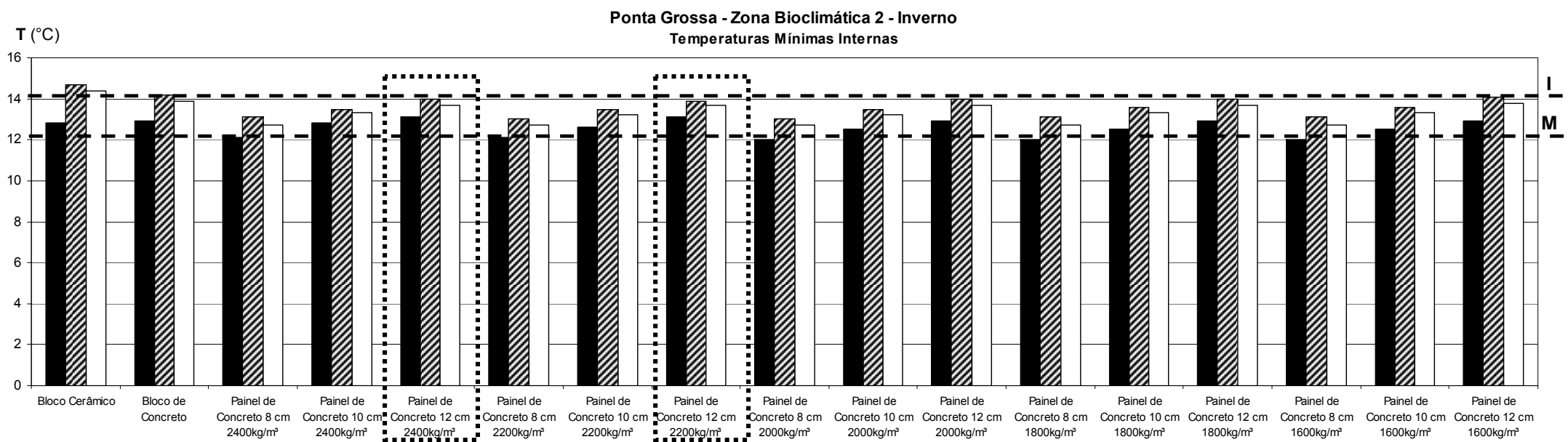

- Temperatura Minima Interna- Telha Cerâmica

Temperatura Minima Interna- Telha Cerâmica e Laje Mista

口Temperatura Minima Interna - Telha Cerâmica e Laje Mista Inclinada

Vedações Verticais

Sendo:

Ponta Grossa - Zona Bioclimática 2 - Verão

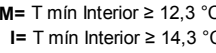

Temperaturas Máximas Internas

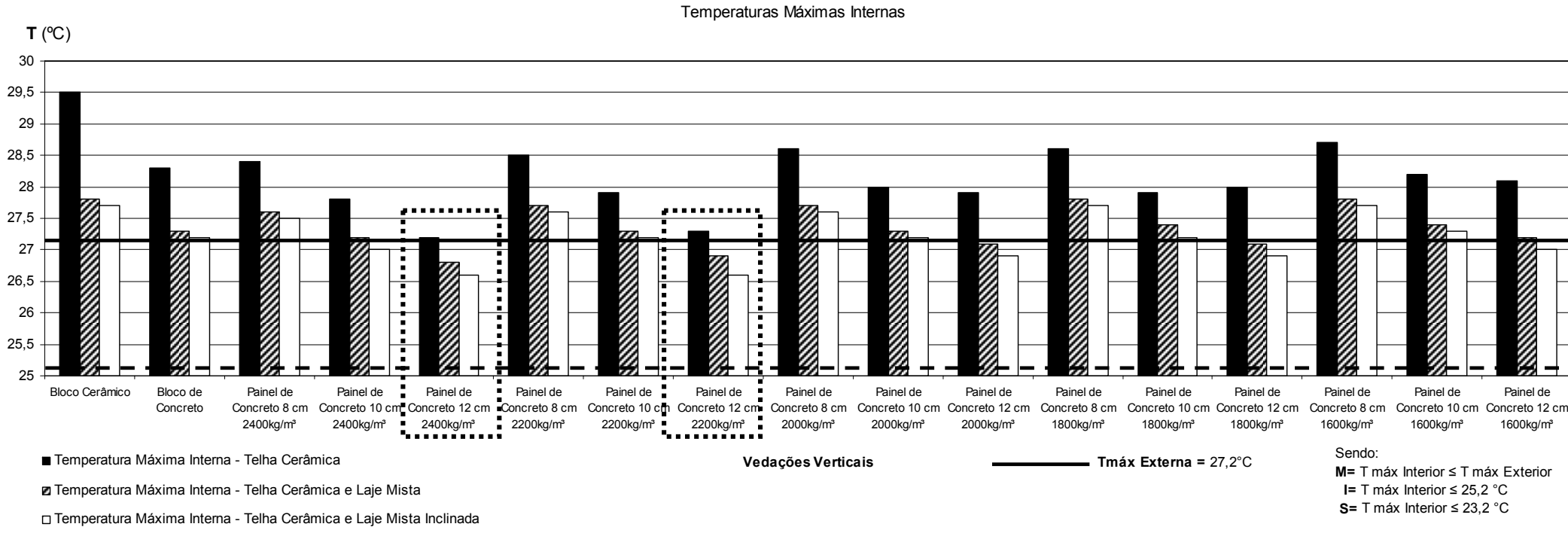

Figura 99 a-b. Tipologia Térrea - Temperaturas Internas - Zona Bioclimática 2 (Ponta Grossa) - a. Inverno. b. Verão 
Para a tipologia térrea no inverno na cidade de Ponta Grossa, observou-se que tanto os painéis de referência quanto os painéis de concreto atenderam ao nível mínimo de desempenho (M), ou seja, apresentaram as temperaturas mínimas internas superiores a $12,3^{\circ} \mathrm{C}$

As tipologias compostas pelos painéis de referência apresentaram uma sutil melhoria de desempenho para o inverno (maior temperatura mínima interna) em relação às tipologias com painéis de concreto. As tipologias com alvenaria de blocos cerâmicos apresentaram as temperaturas mínimas internas mais elevadas que as tipologias com todos os tipos de painéis, inclusive os de concreto, sendo as únicas a atender o nível I de desempenho (temperaturas internas acima de $14,3^{\circ} \mathrm{C}$, para as tipologias com laje). Já as tipologias com alvenaria de blocos de concreto apresentaram temperaturas semelhantes às tipologias com painéis de concreto de $12 \mathrm{~cm}$ de espessura de todas as massas específicas.

Nas tipologias com painéis de concreto, a variação de espessura de 8 para $12 \mathrm{~cm}$ promoveu em grande parte dos casos a elevação da temperatura mínima interna em $1^{\circ} \mathrm{C}$, porém a variação da massa específica não apresentou resultados significativos nas temperaturas mínimas internas. Dentre as tipologias com painéis de concreto, o melhor desempenho foi das tipologias com painéis de espessura $12 \mathrm{~cm}$ independentemente da massa específica e cobertura do tipo laje plana que atendeu ao nível mínimo de desempenho (M).

As tipologias com laje plana apresentaram melhor desempenho para o inverno.

Para o verão todas as tipologias com painéis de concreto de espessura $12 \mathrm{~cm}$ atenderam ao nível mínimo de desempenho (temperaturas máximas internas $\leq 12,3^{\circ} \mathrm{C}$ ), as demais tipologias não atenderam a nenhum dos níveis de desempenho.

As tipologias com vedações em alvenaria de blocos cerâmicos apresentaram as temperaturas máximas internas mais elevadas para o verão e se compararam às tipologias com painéis de concreto de $8 \mathrm{~cm}$ de espessura. Já as tipologias com blocos de concreto apresentaram comportamento semelhante às tipologias com painéis de concreto de $10 \mathrm{~cm}$ de espessura e apresentaram temperaturas máximas internas menores (em torno de $27^{\circ} \mathrm{C}$ ) para as tipologias com laje (plana ou inclinada) quando comparadas às tipologias com blocos cerâmicos.

Nas tipologias térreas com painéis de concreto de $12 \mathrm{~cm}$ de espessura e massa específica de 2400 e $2200 \mathrm{~kg} / \mathrm{m}^{3}$ foi atendido o nível mínimo de desempenho (M) para as tipologias com laje (plana ou inclinada), as mesmas apresentaram as temperaturas menos elevadas quando comparadas às demais.

Com relação ao tipo de cobertura, as tipologias sem laje apresentaram temperaturas máximas internas mais elevadas. Já a cobertura com laje inclinada apresentou temperaturas menos elevadas, sendo melhor em relação ao desempenho para o verão. 
Analisando as condições críticas de inverno e de verão, dentre as tipologias com painéis de concreto destacou-se o painel com $12 \mathrm{~cm}$ de espessura, massa específica 2400 $\mathrm{kg} / \mathrm{m}^{3}$ e laje inclinada apresentou desempenho térmico satisfatório (como no inverno os dois tipos de lajes apresentaram desempenho semelhante, a laje inclinada foi adotada por apresentar as menores temperaturas no verão). Apesar do concreto de massa específica $2200 \mathrm{~kg} / \mathrm{m}^{3}$ também ter apresentado desempenho satisfatório, por questões de viabilidade econômica indica-se o concreto tradicional $\left(2400 \mathrm{~kg} / \mathrm{m}^{3}\right)$. 
Ponta Grossa - Zona Bioclimática 2 - Inverno Temperaturas Mínimas Internas
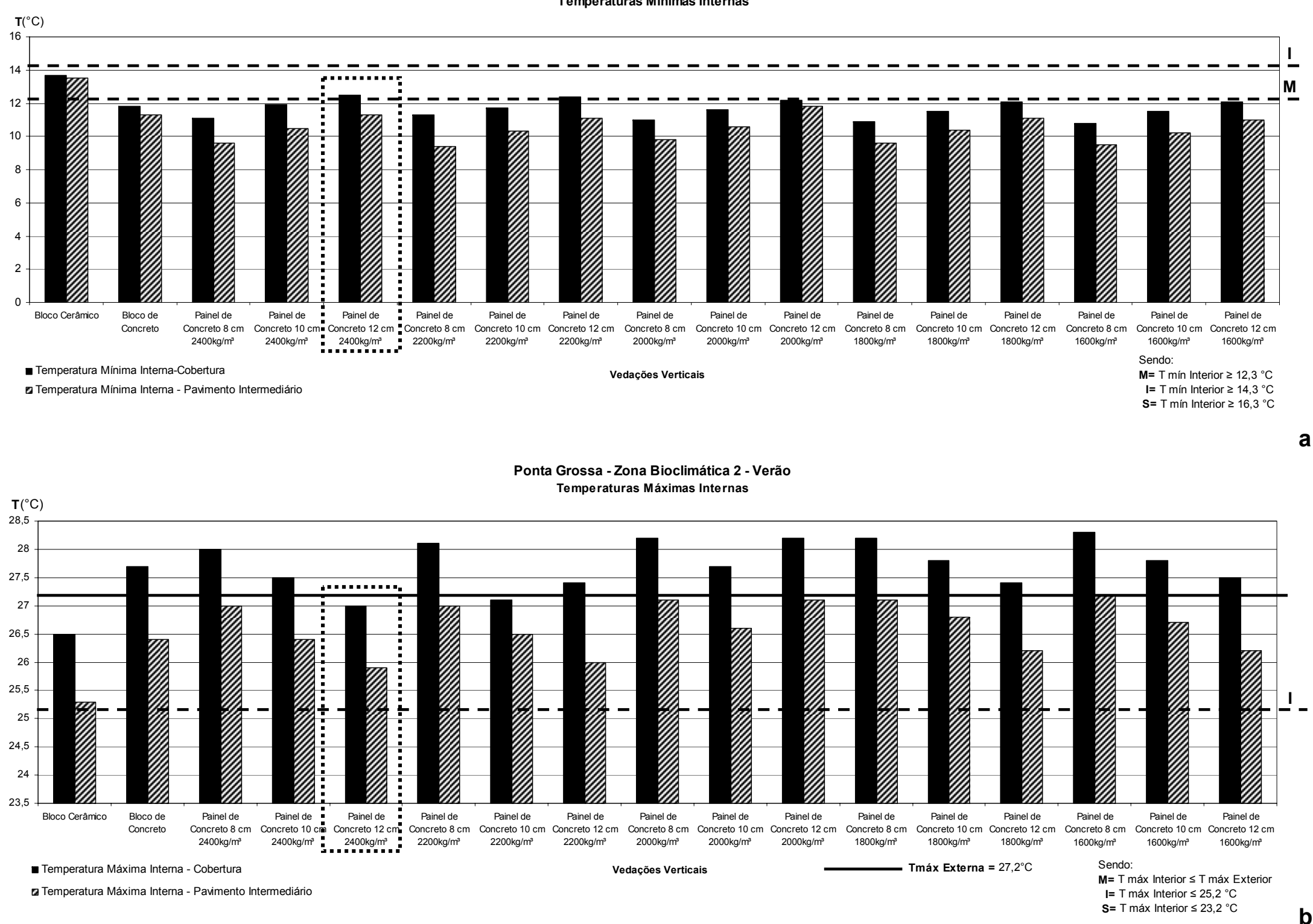

Figura 100 a-b. Tipologia Multipavimentos - Temperaturas Internas - Zona Bioclimática 2 (Ponta Grossa) - a. Inverno. b. Verão 
Observou-se nas tipologias multipavimentos para Ponta Grossa que no inverno foi atendido o nível mínimo de desempenho (M) (temperaturas mínimas internas $\geq 12,3{ }^{\circ} \mathrm{C}$ ) somente para as tipologias da cobertura com painéis de alvenaria de blocos cerâmicos e painéis de concreto com $12 \mathrm{~cm}$ de espessura e massa específica 2200 e $2400 \mathrm{~kg} / \mathrm{m}^{3}$. Já para o pavimento intermediário, nenhuma das tipologias atendeu ao nível mínimo de desempenho (M) somente a tipologia com alvenaria de blocos cerâmicos.

Dentre as tipologias com painéis de referência, somente a com alvenaria de blocos cerâmicos atendeu ao requisito mínimo de desempenho para o inverno, isso para ambos os pavimentos, esta apresentou um aumento de temperatura de $1^{\circ} \mathrm{C}$ aproximadamente em relação à temperatura máxima limite $\left(12,3^{\circ} \mathrm{C}\right)$.

As tipologias com painéis de concreto que apresentaram temperaturas mínimas internas superiores à $12,3^{\circ} \mathrm{C}$ foram as com $12 \mathrm{~cm}$ de espessura e massa específica 2400 , $2200 \mathrm{~kg} / \mathrm{m}^{3}$, situadas na cobertura. A variação de massa específica dos painéis de concreto pouco influenciou nos resultados, porém a variação de espessura ocasionou maior influência nas temperaturas.

Em relação à tipologia, se localizada na cobertura ou no pavimento intermediário, observou-se que não houve diferenças significativas entre os resultados das temperaturas mínimas internas para o inverno.

Para o verão todas as tipologias do pavimento intermediário atenderam ao nível mínimo de desempenho (temperaturas máximas internas $\leq 27,2^{\circ} \mathrm{C}$ ). As únicas tipologias da cobertura a atender ao nível mínimo de desempenho para o verão foram as tipologias com alvenaria de blocos cerâmicos e com painéis de concreto de $12 \mathrm{~cm}$ de espessura e massas específicas 2400 e $2200 \mathrm{~kg} / \mathrm{m}^{3}$.

A tipologia com alvenaria de blocos de concreto da cobertura apresentou desempenho inferior ao das tipologias com alvenaria de blocos cerâmicos. Apesar de ter atendido na tipologia do pavimento intermediário ao nível mínimo de desempenho apresentou temperaturas mais elevadas para o verão.

No verão as tipologias com vedação em painel de concreto com espessura $12 \mathrm{~cm}$ e massa específica de $2400 \mathrm{~kg} / \mathrm{m}^{3}$ apresentaram temperaturas máximas internas menores (em torno de 26 a $27^{\circ} \mathrm{C}$ ) em relação às demais vedações, isso para a cobertura e o pavimento intermediário, atendendo para ambos os nível mínimo de desempenho (M). Para as tipologias do pavimento intermediário com painéis de concreto todas as massas específicas atenderam também ao nível mínimo de desempenho.

Com relação ao pavimento, a tipologia da cobertura mostrou-se com as temperaturas máximas internas mais elevadas para o verão, chegando inclusive em alguns casos à diferença de $1,5^{\circ} \mathrm{C}$ acima da temperatura do pavimento intermediário. 
Diante das análises para as condições críticas de inverno e de verão, observou-se para ambas as estações, que dentre as tipologias com painéis de concreto a com $12 \mathrm{~cm}$ espessura e massa específica de $2400 \mathrm{~kg} / \mathrm{m}^{3}$ apresentou melhor desempenho, tanto para o pavimento intermediário quanto para a cobertura. 

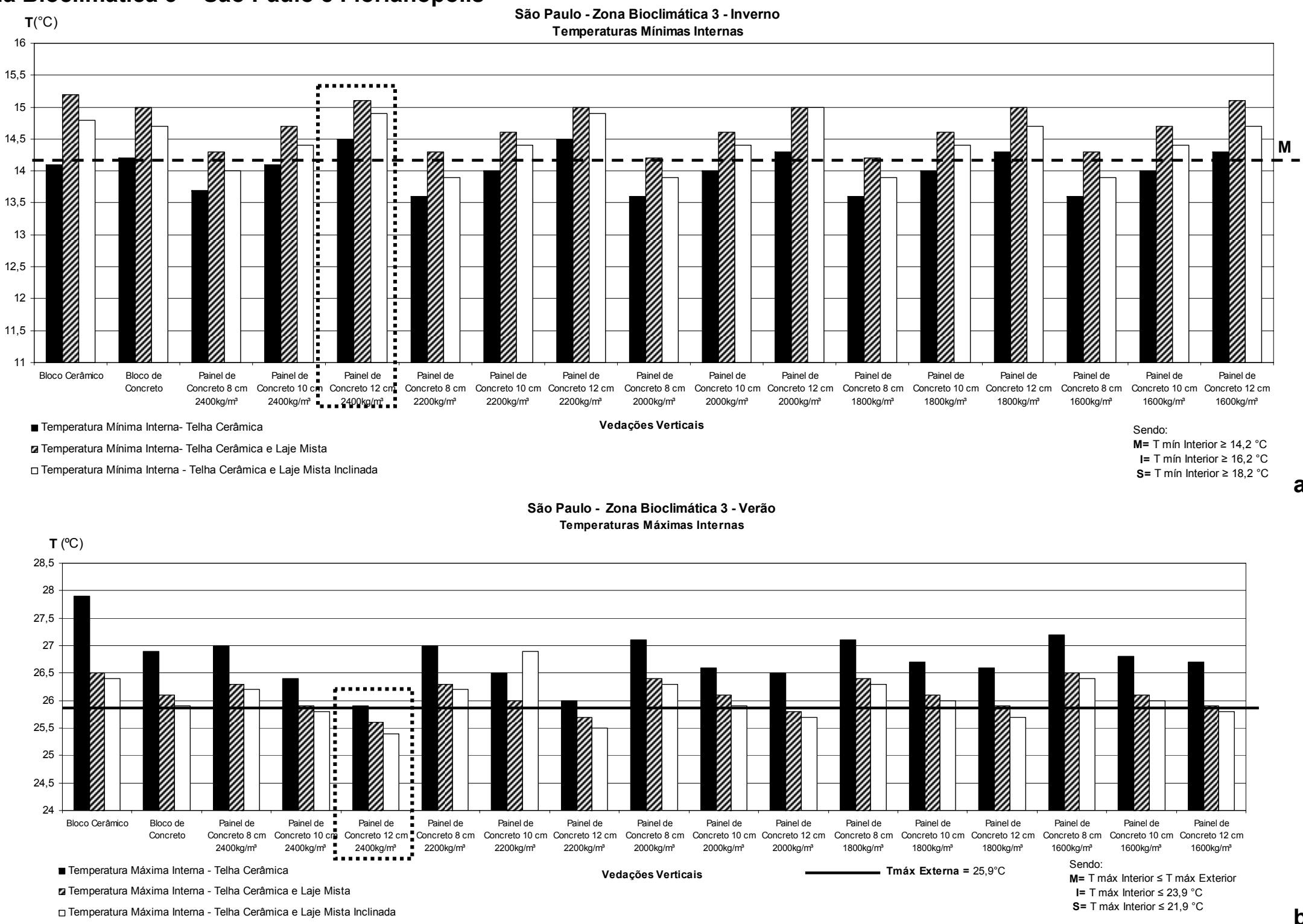

- Temperatura Máxima Interna - Telha Cerâmica e Lje Mista

$\mathbf{S}=\mathrm{T}$ máx Interior $\leq 21,9^{\circ} \mathrm{C}$

Figura 101 a-b. Tipologia Térrea - Temperaturas Internas - Zona Bioclimática 3 (São Paulo) - a. Inverno. b. Verão 
$\mathbf{T}\left({ }^{\circ} \mathrm{C}\right)$

Florianópolis - Zona Bioclimática 3 - Inverno

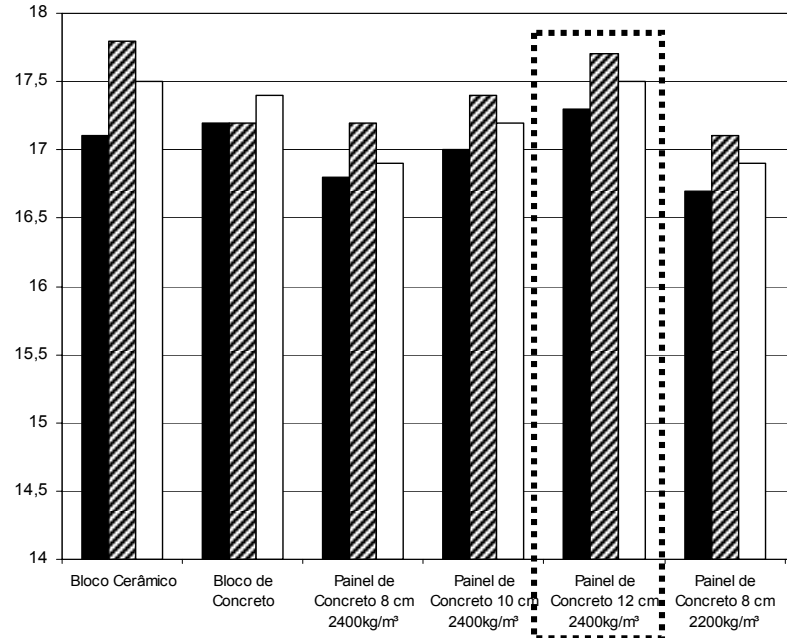

- Temperatura Mínima Interna- Telha Cerâmica

च Temperatura Minima Interna- Telha Cerâmica e Laje Mista

口 Temperatura Minima Interna - Telha Cerâmica e Laje Mista Inclinada

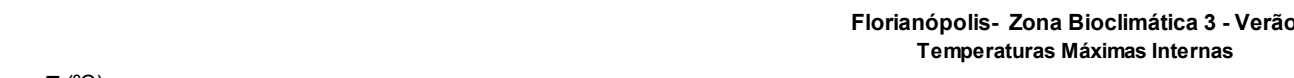

Temperaturas Mínimas Internas

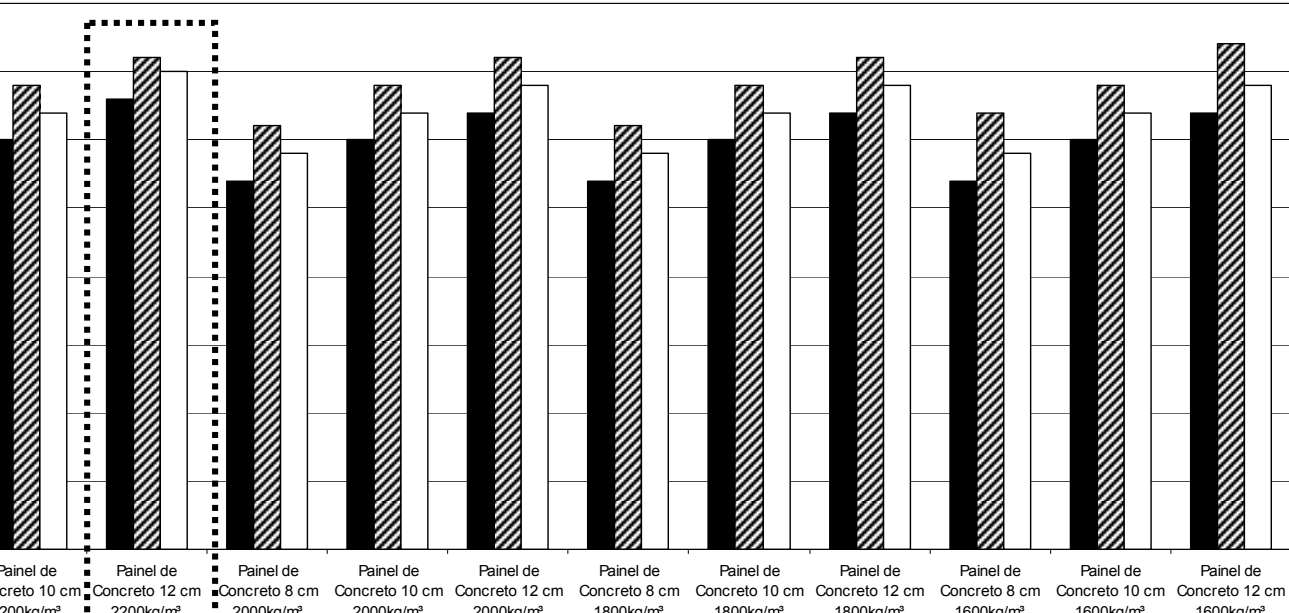

Sendo:

$\mathbf{M}=\mathrm{T}_{\min }$ Interior $218,2^{\circ} \mathrm{C}$ $\mathrm{S}=\mathrm{T}$ min Interior $\geq 22,2^{\circ} \mathrm{C}$

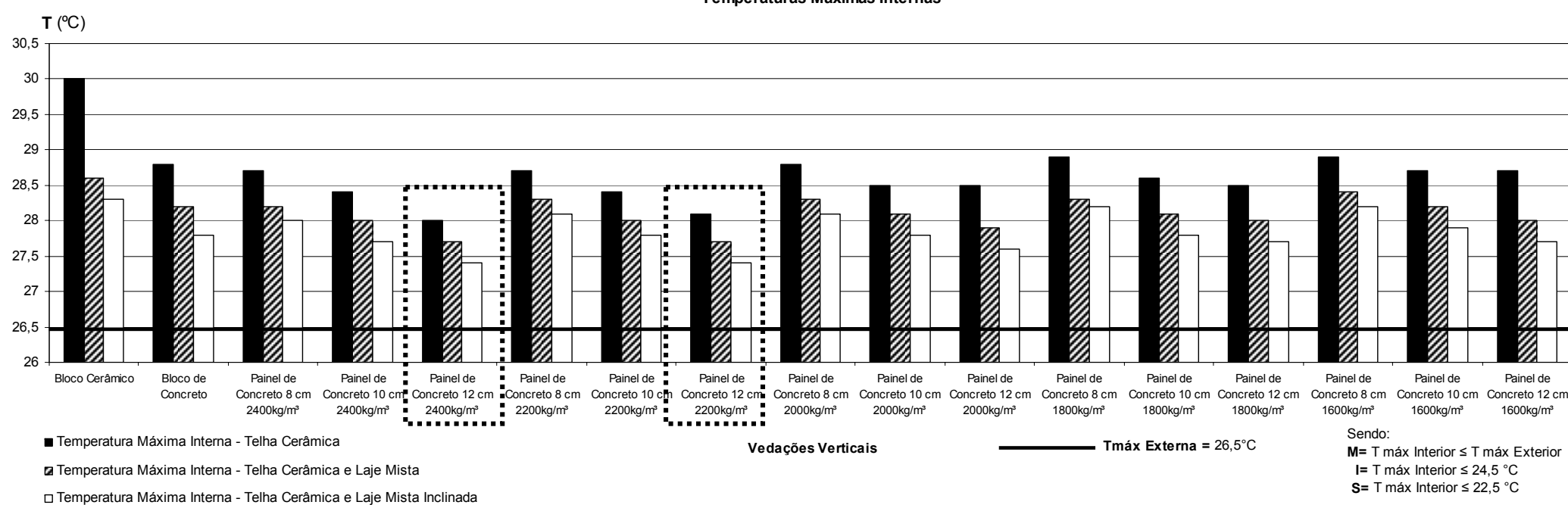

口 Temperatura Máxima Interna - Telha Cerâmica e Laje Mista Inclinada

Figura 102 a-b. Tipologia Térrea - Temperaturas Internas - Zona Bioclimática 3 (Florianópolis) - a. Inverno. b. Verão 
Observou-se no inverno, na cidade de São Paulo, que todas as tipologias analisadas com laje plana atenderam ao nível mínimo de desempenho (M), ou seja, apresentaram temperaturas superiores à temperatura mínima interna de $14,2^{\circ} \mathrm{C}$.

As tipologias com painéis de referência apresentaram temperaturas mínimas internas semelhantes entre si, sendo que a tipologia com alvenaria de blocos cerâmicos e laje plana apresentou a temperatura um pouco mais elevada. O desempenho das tipologias com painéis de referência foi semelhante às tipologias com painéis de concreto de $12 \mathrm{~cm}$ de espessura.

Já para nas tipologias compostas por painéis de concreto no inverno foram observadas as menores temperaturas mínimas internas para espessuras de $8 \mathrm{~cm}$ e as maiores temperaturas mínimas internas para $12 \mathrm{~cm}$ de espessura, ou seja, os painéis com maiores espessuras apresentaram-se mais adequados em relação ao desempenho. Para o inverno as tipologias com painéis de concreto de espessura $12 \mathrm{~cm}$, independente da massa específica e do tipo de cobertura, atenderam ao nível mínimo de desempenho (temperaturas internas acima de $\left.14,2^{\circ} \mathrm{C}\right)$.

De forma geral, as tipologias com laje plana apresentaram as temperaturas mínimas internas mais elevadas do que as tipologias sem laje e com laje inclinada.

Para o verão em São Paulo, algumas tipologias atenderam ao nível mínimo de desempenho (temperaturas máximas internas $\leq 25,9^{\circ} \mathrm{C}$ ), porém em grande parte dos casos nenhum dos níveis de desempenho foi atendido.

As tipologias com alvenaria de blocos de concreto apresentaram desempenho semelhante às vedações em concreto de espessura $8 \mathrm{~cm}$ apesar de não ter atendido a nenhum dos níveis de desempenho. Já a tipologia com alvenaria de blocos cerâmicos apresentou as temperaturas máximas internas mais elevadas dentre todos os demais painéis para a tipologia sem laje.

As tipologias com painéis de concreto com espessura $12 \mathrm{~cm}$ e massa específica $2400 \mathrm{~kg} / \mathrm{m}^{3}$ e $2200 \mathrm{~kg} / \mathrm{m}^{3}$, apresentaram as menores temperaturas máximas internas (aproximadamente $26^{\circ} \mathrm{C}$ ) em relação às demais, isso para os três tipos de cobertura, apresentando assim melhor desempenho. Todas as tipologias com painéis de concreto de $2400 \mathrm{~kg} / \mathrm{m}^{3}$ atenderam ao nível mínimo de desempenho. Igualmente para o inverno, no verão as variações de massa específica dos painéis de concreto também não ocasionaram variações significativas nas temperaturas máximas internas das tipologias.

As tipologias com laje (plana e inclinada) principalmente as com painéis de concreto de $12 \mathrm{~cm}$ de espessura apresentaram desempenho satisfatório para o verão.

Como a variação de massa específica dos concretos não ocasionou mudanças significativas nos resultados das temperaturas internas das tipologias, tanto para o inverno, 
quanto para o verão, a adoção de painéis de concreto de massa específica $2400 \mathrm{~kg} / \mathrm{m}^{3}$ implica em maior economia de recursos pelo fato de ser o menos oneroso dentre os demais.

Por meio da análise dos resultados para as condições críticas de inverno e de verão pode-se considerar que apresentaram melhor desempenho para a cidade de São Paulo as tipologias com painel de concreto de espessura $12 \mathrm{~cm}$ e massa específica de $2400 \mathrm{~kg} / \mathrm{m}^{3}$, apresentando desempenho satisfatório tipologias com laje plana para o inverno e ambas as lajes para o verão.

Para Florianópolis, também localizada na Zona Bioclimática 3, nenhum dos níveis de desempenho foram atendidos para o inverno, as temperaturas internas ficaram entre $16,5^{\circ} \mathrm{C}$ e $18^{\circ} \mathrm{C}$, sendo que o nível mínimo inclui temperaturas acima de $18,2^{\circ} \mathrm{C}$.

As tipologias com alvenaria de blocos cerâmicos apresentaram desempenho semelhante às tipologias com painéis de concreto com $12 \mathrm{~cm}$ de espessura. Já as tipologias com alvenaria de blocos de concreto apresentaram desempenho semelhante às tipologias com painéis de concreto de $10 \mathrm{~cm}$ de espessura.

Para as tipologias com painéis de concreto os de espessura $12 \mathrm{~cm}$ para todas as massas específicas apresentaram melhor desempenho para o inverno, mesmo não atendendo aos níveis de desempenho, seguidos das tipologias com painéis de $10 \mathrm{~cm}$ de desempenho.

As tipologias com laje plana apresentaram maiores temperaturas mínimas internas no inverno, o que significa um melhor desempenho para inverno.

Para o verão em Florianópolis as tipologias térreas de forma geral não atenderam a nenhum dos níveis de desempenho para o verão. A tipologia com alvenaria de blocos cerâmicos e sem laje apresentou a temperatura mais elevada em relação às demais estando próxima aos $30^{\circ} \mathrm{C}$, sendo, portanto a mais inadequada em relação aos requisitos de desempenho.

As tipologias com alvenaria de blocos de concreto apresentaram menores temperaturas máximas internas (abaixo de $29^{\circ} \mathrm{C}$ ) e desempenho semelhante às tipologias com painéis de concreto de $8 \mathrm{~cm}$ de espessura. As tipologias com alvenaria de blocos cerâmicos apresentaram as temperaturas máximas internas mais elevadas dente todos os painéis.

Em relação ao tipo de cobertura, as tipologias com laje inclinada apresentaram as menores temperaturas máximas internas, ou seja, temperaturas mais agradáveis no verão, sendo, portanto mais adequadas.

Analisando as tipologias térreas para Florianópolis nas condições críticas de inverno e de verão, observou-se que o uso de painéis de concreto com $12 \mathrm{~cm}$ destacou-se em relação ao desempenho, apesar de não terem atendido à nenhum dos níveis de desempenho, isso principalmente para a massa específica de $2400 \mathrm{~kg} / \mathrm{m}^{3} \mathrm{com}$ cobertura do 
tipo laje plana (inverno) e do tipo laje inclinada (verão). O painel de concreto da mesma espessura e massa específica $2200 \mathrm{~kg} / \mathrm{m}^{3}$ também apresentou desempenho semelhante, mas por motivos de viabilidade econômica recomenda-se o concreto de massa específica $2400 \mathrm{~kg} / \mathrm{m}^{3}$ para os painéis de vedação. 
São Paulo - Zona Bioclimática 3 - Inverno Temperaturas Mínimas Internas

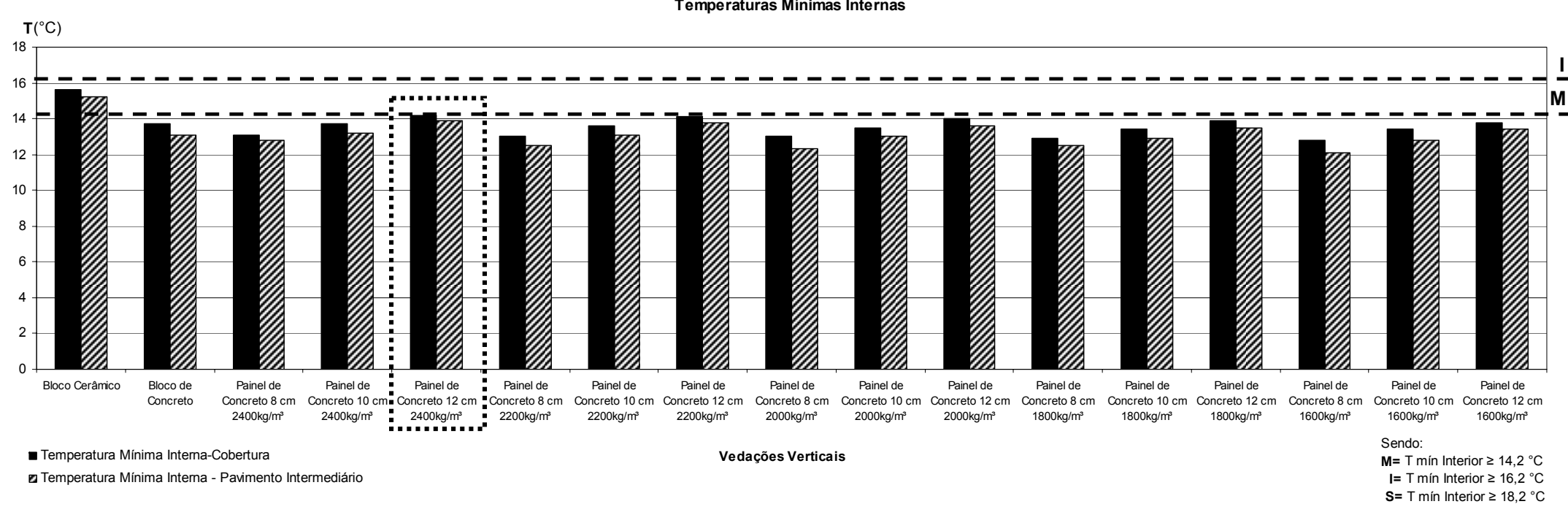

São Paulo - Zona Bioclimática 3 - Verão

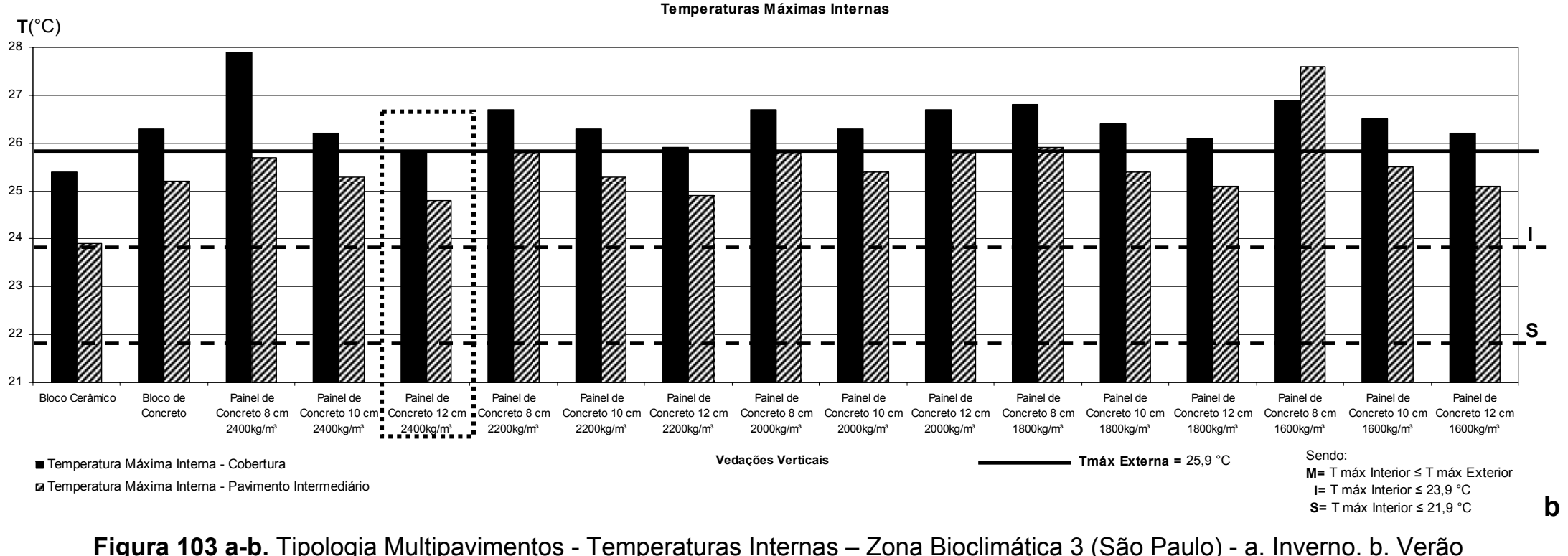

Figura 103 a-b. Tipologia Multipavimentos - Temperaturas Internas - Zona Bioclimática 3 (São Paulo) - a. Inverno. b. Verão 
Florianópolis - Zona Bioclimática 3 - Inverno Temperaturas Mínimas Internas
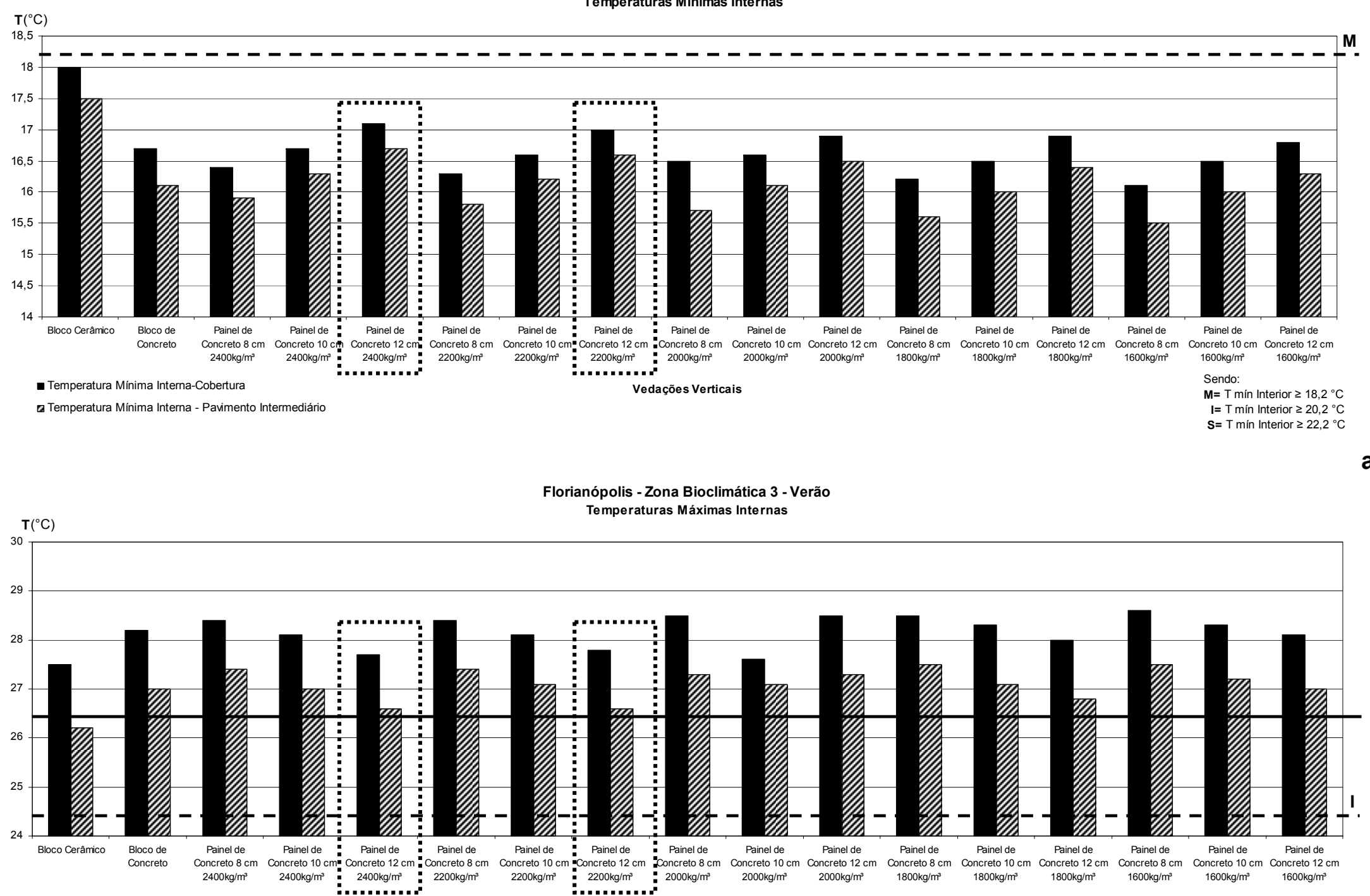

- Temperatura Máxima Interna - Cobertura

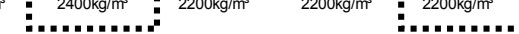

- Temperatura Máxima Interna - Pavimento Intermediário

Vedações Verticais

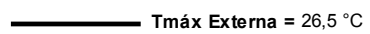

Sendo:
M= T máx Interior $\leq T$ máx Exterior
I $T$ T $l=T$ maxx Interior $\leq 24,5^{\circ} \mathrm{C}$
$\mathrm{S}=\mathrm{T}$ máx Interior $\leq 22,5^{\circ} \mathrm{C}$

Figura 104 a-b. Tipologia Multipavimentos - Temperaturas Internas - Zona Bioclimática 3 (Florianópolis) - a. Inverno. b. Verão 
Para a cidade de São Paulo, grande parte das tipologias multipavimentos não atenderam aos níveis de desempenho no inverno, com exceção das tipologias de alvenaria de blocos cerâmicos, tanto para o pavimento da cobertura quanto para o pavimento intermediário que atenderam ao nível mínimo de desempenho (M) (temperaturas mínimas internas $\geq 12,2^{\circ} \mathrm{C}$ ).

Dentre as tipologias com painéis de referência, as com painéis de alvenaria de blocos cerâmicos de ambos os pavimentos apresentaram temperaturas mínimas internas mais elevadas em relação às demais tipologias analisadas, ultrapassando os $15^{\circ} \mathrm{C}$. Já as tipologias com alvenaria de blocos de concreto apresentaram desempenho semelhante às tipologias com painéis de concreto de espessura $8 \mathrm{~cm}$, as quais não atenderam a nenhum dos níveis de desempenho.

As tipologias com painéis de concreto não apresentaram diferenças nas temperaturas mínimas internas decorrentes da variação de massa específica, porém a variação de espessura dos painéis promoveu uma diferença de aproximadamente $0,5^{\circ} \mathrm{C}$ para a mesma massa específica. Dentre os painéis de concreto destacaram-se as temperaturas das tipologias com painéis de massa específica $2400 \mathrm{~kg} / \mathrm{m}^{3}$ e espessura 12 $\mathrm{cm}$, pouco mais elevadas para o inverno quando comparadas às demais tipologias.

Em relação ao pavimento, não houve variação significativa para os resultados das temperaturas mínimas internas para as tipologias localizadas na cobertura e no pavimento intermediário.

Para o verão em São Paulo de forma geral foi atendido o nível mínimo de desempenho (temperatura máxima interna $\leq 25,9{ }^{\circ} \mathrm{C}$ ) para as tipologias do pavimento intermediário, com exceção das tipologias com painéis de concreto de $8 \mathrm{~cm}$ de espessura e massas específicas 1800 e $1600 \mathrm{~kg} / \mathrm{m}^{3}$. As tipologias da cobertura com painel de concreto de $8 \mathrm{~cm}$ de espessura de massa específica $2400 \mathrm{~kg} / \mathrm{m}^{3}$, e as tipologias da cobertura e do pavimento intermediário com painel de concreto de $8 \mathrm{~cm}$ de espessura e massa específica $1600 \mathrm{~kg} / \mathrm{m}^{3}$ apresentaram a temperatura máxima interna superior às demais, sendo, portanto mais quentes internamente no verão.

Dentre as tipologias multipavimentos com painéis de referência analisadas, a tipologia com alvenaria de blocos cerâmicos foi a única dentre todas que atendeu ao nível mínimo de desempenho para ambos os pavimentos, e apresentou as temperaturas menos elevadas para o verão, sendo melhor em termos de desempenho. Já as tipologias com alvenaria de blocos de concreto apresentaram desempenho semelhante às tipologias com painéis de concreto com $10 \mathrm{~cm}$ de espessura, nos quais a tipologia do pavimento intermediário atendeu ao nível mínimo de desempenho (temperatura máxima interna $\leq 25,9$ $\left.{ }^{\circ} \mathrm{C}\right)$. 
Nas tipologias com painéis de concreto de massa específica 2400 e $2200 \mathrm{~kg} / \mathrm{m}^{3}$ (principalmente de espessura $12 \mathrm{~cm}$ ) observou-se menores temperaturas máximas internas (em torno de 25 a $26^{\circ} \mathrm{C}$ ) em relação às demais, significando temperaturas mais agradáveis no verão. Destacou-se também a tipologia da cobertura com painel de concreto de $8 \mathrm{~cm}$ de espessura e massa específica $2400 \mathrm{~kg} / \mathrm{m}^{3}$ que apresentou a temperatura mais elevada para o verão dentre todas as tipologias analisadas.

Em relação ao pavimento houve variação de cerca de $1^{\circ} \mathrm{C}$ entre as temperaturas máximas internas das tipologias localizadas na cobertura e no pavimento intermediário.

Por meio da análise dos resultados para as condições críticas de inverno e de verão, dentre as tipologias com painéis de concreto, pode-se considerar que apresentaram melhor desempenho para a cidade de São Paulo as tipologias multipavimentos com painel de espessura $12 \mathrm{~cm}$ e massa específica de $2400 \mathrm{~kg} / \mathrm{m}^{3}$.

Para o inverno em Florianópolis, nenhuma das tipologias multipavimentos analisadas atenderam para o inverno nem mesmo o requisito mínimo de desempenho (M) (temperaturas mínimas internas $\geq 18,2^{\circ} \mathrm{C}$ ). As tipologias com alvenaria de blocos cerâmicos foram as que se encontraram mais próximas desse valor para o inverno.

Para as tipologias multipavimentos com painéis de referência, as com alvenaria de blocos cerâmicos apresentaram melhor desempenho dentre todas as tipologias e as tipologias com alvenaria de blocos de concreto apresentaram temperaturas mínimas internas menos elevadas em relação as com alvenaria de blocos cerâmicos.

Para a cidade de Florianópolis no inverno houve variação das temperaturas mínimas internas de cerca de $0,5^{\circ} \mathrm{C}$ entre as tipologias da cobertura e do pavimento intermediário.

Para o verão em Florianópolis todas as tipologias multipavimentos analisadas não atenderam aos níveis de desempenho, com exceção da tipologia do pavimento intermediário com alvenaria de blocos cerâmicos que foi a única a atender ao nível mínimo de desempenho (temperaturas máximas internas $\leq 26,5^{\circ} \mathrm{C}$ ).

Para as tipologias multipavimentos com painéis de referência analisadas, a tipologia com alvenaria de blocos cerâmicos apresentaram as temperaturas máximas internas menos elevadas para o verão. Já as tipologias com alvenaria de blocos de concreto apresentaram desempenho semelhante às tipologias com painéis de concreto com $10 \mathrm{~cm}$ de espessura, não atendendo aos níveis de desempenho.

Dentre as tipologias com painéis de concreto novamente a variação de massa específica dos painéis não apresentou mudanças significativas nas temperaturas máximas internas, somente a variação de espessura dos painéis. As tipologias com $12 \mathrm{~cm}$ de espessura e massa específica de $2400 \mathrm{~kg} / \mathrm{m}^{3}, 2200$ e $1800 \mathrm{~kg} / \mathrm{m}^{3}$, apresentaram menores temperaturas máximas internas em relação às demais, em torno de 26,5 para as tipologias do pavimento intermediário e entre 27,5 e $28{ }^{\circ} \mathrm{C}$ para as tipologias da cobertura. 
Em relação ao pavimento houve variação de cerca de $1^{\circ} \mathrm{C}$ entre as temperaturas máximas internas das tipologias localizadas na cobertura e no pavimento intermediário.

A partir das análises executadas para as condições críticas para cidade de Florianópolis, observou-se que tanto no inverno quanto no verão as tipologias multipavimentos com painel de concreto de espessura $12 \mathrm{~cm}$ e massa específica de 2400 $\mathrm{kg} / \mathrm{m}^{3}$ e $2200 \mathrm{~kg} / \mathrm{m}^{3}$ apresentaram o melhor desempenho, dentre as tipologias com painéis de concreto, mesmo diante do não atendimento aos níveis de desempenho. Porém por motivos de viabilidade econômica recomenda-se o uso de painéis de concreto de massa específica $2400 \mathrm{~kg} / \mathrm{m}^{3}$. 


\subsubsection{Zona Bioclimática 4 - São Carlos e Brasília} $T\left({ }^{\circ} \mathrm{C}\right)$

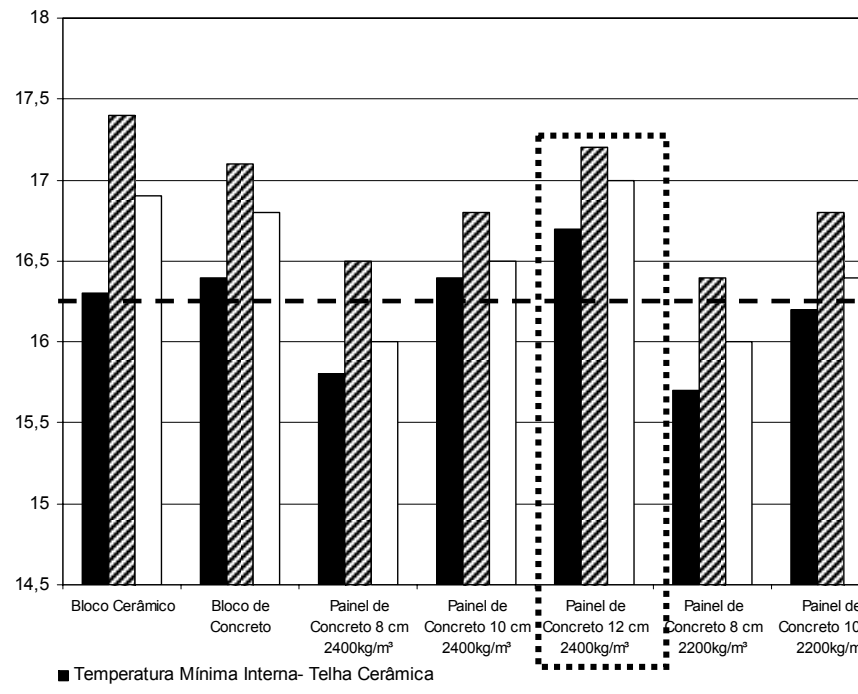

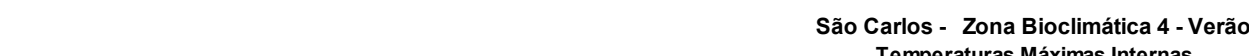

Temperaturas Máximas Internas

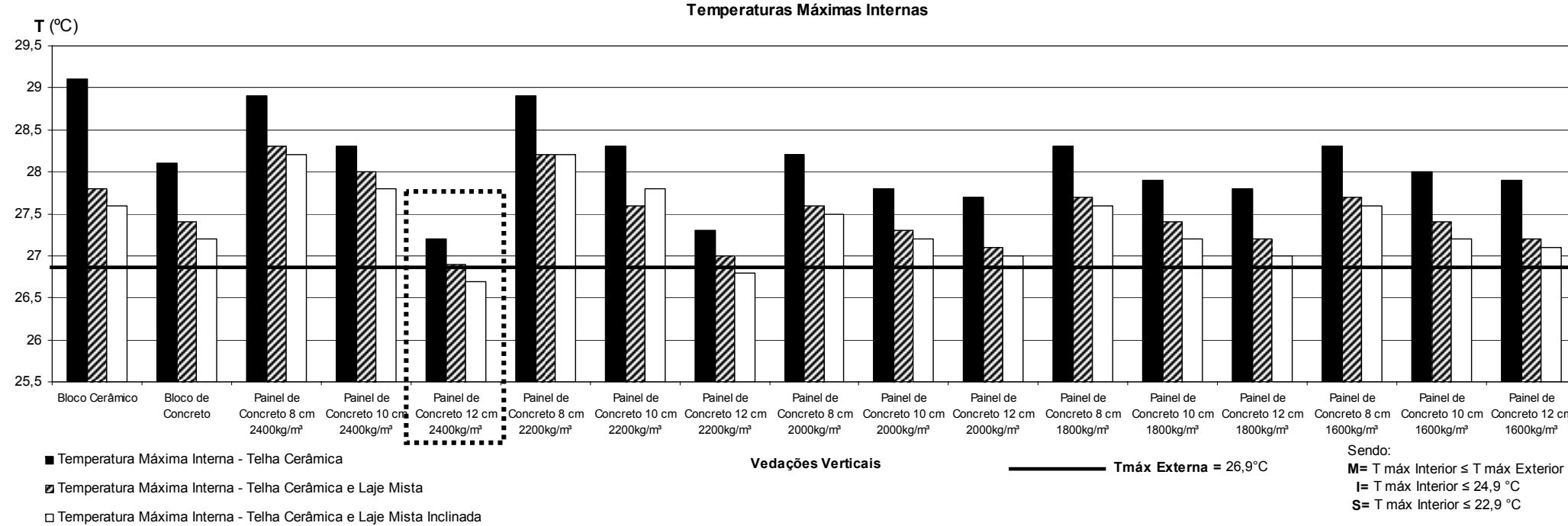

Figura 105 a-b. Tipologia Térrea - Temperaturas Internas - Zona Bioclimática 4 (São Carlos) - a. Inverno. b. Verão 
$\mathbf{T}\left({ }^{\circ} \mathrm{C}\right) \quad$ Brasilia - Zona Bioclimática 4 - Inverno

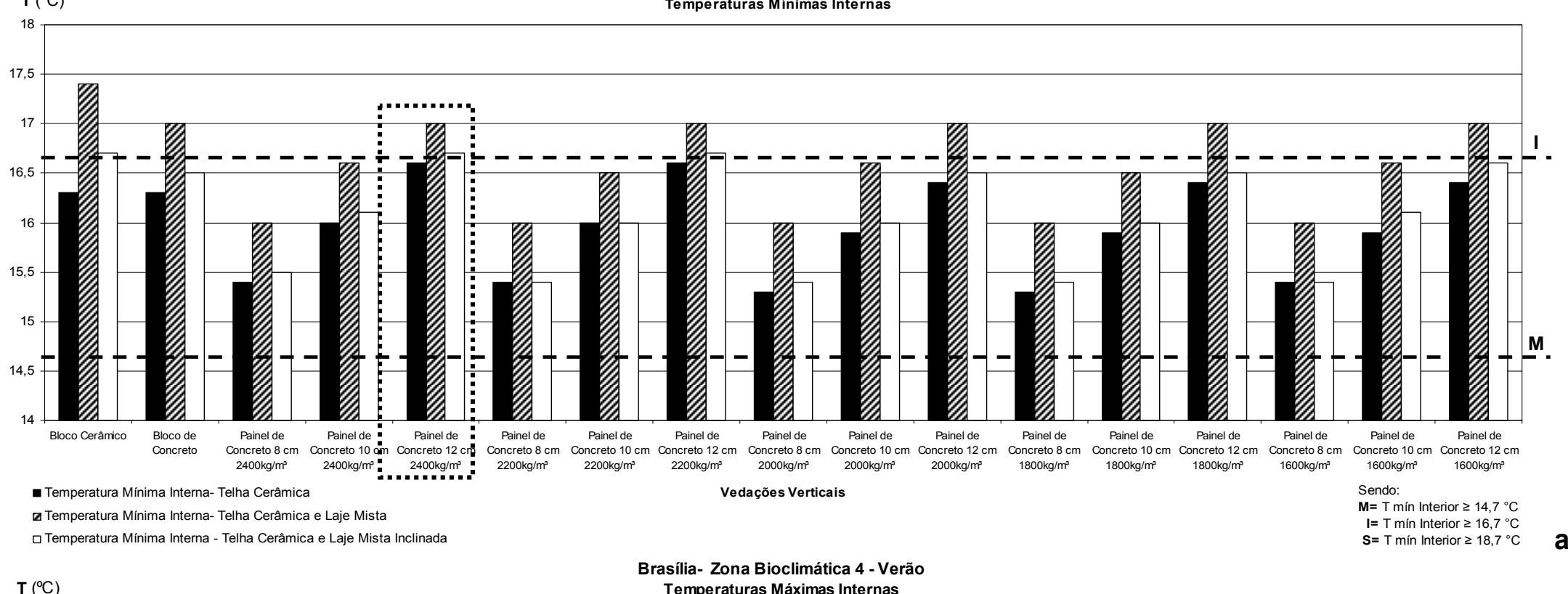

T $\left({ }^{\circ} \mathrm{C}\right) \quad$ Temperaturas Máximas Internas

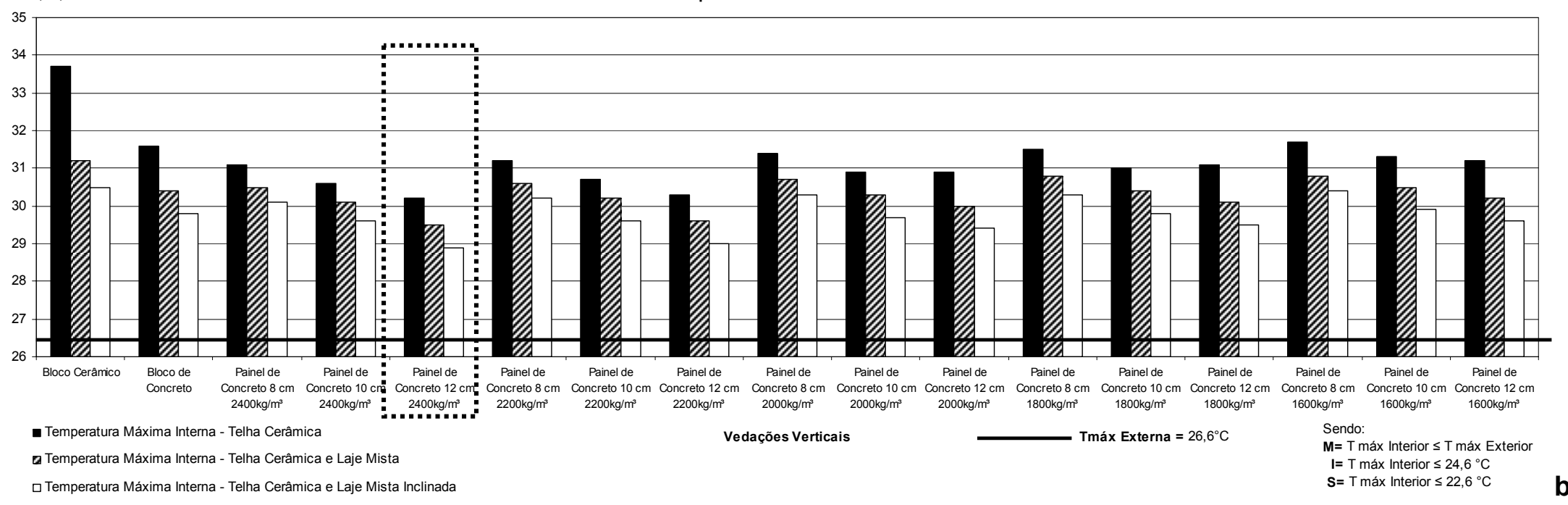

Figura 106 a-b. Tipologia Térrea - Temperaturas Internas - Zona Bioclimática 4 (Brasília) - a. Inverno. b. Verão 
Na Zona Bioclimática 4 para São Carlos observou-se em grande parte dos casos que para o inverno as tipologias atenderam somente ao nível $\mathrm{M}$ de desempenho (temperaturas mínimas internas $\geq 16,3^{\circ} \mathrm{C}$ ).

Dentre as tipologias com painéis de referência, a com blocos cerâmicos e cobertura de laje plana apresentou a temperatura mais elevada dentre todas as tipologias analisadas. As tipologias com laje (plana e inclinada) atenderam ao nível mínimo de desempenho (temperaturas mínimas internas $\geq 16,3{ }^{\circ} \mathrm{C}$ ). As tipologias com blocos de concreto apresentaram comportamento semelhante às tipologias com painéis de concreto de $12 \mathrm{~cm}$ de espessura, atendendo ao nível mínimo de desempenho para todos os tipos de cobertura.

As tipologias com painéis de concreto de espessura $12 \mathrm{~cm}$, para todas as massas específicas e com cobertura de laje plana, apresentaram as temperaturas mais elevadas (melhor desempenho) dentre as tipologias com painéis de concreto e atenderam ao nível mínimo de desempenho para o inverno. As tipologias com painéis de $8 \mathrm{~cm}$ de espessura apresentaram menores temperaturas mínimas internas para todas as massas específicas. A variação de espessura dos painéis de concreto promoveu cerca de $1^{\circ} \mathrm{C}$ de variação nas temperaturas mínimas internas das tipologias.

Em relação ao tipo de cobertura, as tipologias com laje plana apresentaram maiores temperaturas mínimas internas, mostrando-se com desempenho satisfatório no inverno; já as tipologias sem laje apresentaram menores temperaturas mínimas internas, mostrando-se inadequadas para o inverno.

Para a cidade de São Carlos no verão a maioria das tipologias não atendeu aos níveis de desempenho. As tipologias com painéis de concreto de $12 \mathrm{~cm}$ de espessura independente da massa específica apresentaram as menores temperaturas máximas internas (melhor desempenho).

Dentre as tipologias com painéis de referência, as com alvenaria de blocos cerâmicos apresentaram temperaturas mais elevadas do que as tipologias com alvenaria de blocos de concreto, apesar de não atender aos níveis de desempenho. A tipologia com alvenaria de blocos cerâmicos e sem laje apresentou um desempenho inferior quando comparada às demais tipologias.

As tipologias com painéis de concreto de $12 \mathrm{~cm}$ de espessura, massas específicas $2400 \mathrm{~kg} / \mathrm{m}^{3}$ e $2200 \mathrm{~kg} / \mathrm{m}^{3}$ e laje inclinada, destacaram-se em termos de desempenho para o verão dentre todas as tipologias, sendo as únicas a atender o nível mínimo de desempenho (temperaturas máximas internas $\leq 26,9^{\circ} \mathrm{C}$ ).

Em relação ao tipo de cobertura as tipologias com laje plana apresentaram melhor desempenho para o inverno e as tipologias com lajes inclinada apresentaram melhor desempenho para o verão. 
Diante das condições críticas de inverno e verão para a cidade de São Carlos, dentre as tipologias térreas com painéis de concreto de $12 \mathrm{~cm}$ de espessura e massa específica de $2400 \mathrm{~kg} / \mathrm{m}^{3}$ apresentou melhor desempenho térmico, isso para cobertura do tipo laje plana no inverno e laje inclinada para o verão. A determinação dessa massa específica se deu por questões de viabilidade econômica, pois as tipologias com painéis de concreto com massa específica $2200 \mathrm{~kg} / \mathrm{m}^{3}$ também apresentaram desempenho satisfatório.

Para Brasília, também da zona bioclimática 4 observou-se em grande parte dos casos que para o inverno as tipologias atenderam aos níveis $M$ (temperaturas mínimas internas $\geq 14,7^{\circ} \mathrm{C}$ ) e I (temperaturas mínimas internas $\geq 16,7^{\circ} \mathrm{C}$ ) de desempenho.

Dentre as tipologias com painéis de referência, a com blocos cerâmicos e cobertura de laje plana apresentou a temperatura mais elevada dentre todas as tipologias analisadas, inclusive as com painéis de concreto, atendendo aos níveis de desempenho $\mathrm{M}$ e I para o inverno.

As tipologias com painéis de concreto de espessura $12 \mathrm{~cm}$ para todas as massas específicas com cobertura de laje plana, apresentaram as temperaturas mais elevadas dentre as tipologias com painéis de concreto e atenderam aos níveis $\mathrm{M}$ e I de desempenho sendo, portanto mais adequados para aplicação no inverno. A variação de massa específica dos painéis pouco influenciou nos resultados das temperaturas mínimas internas das tipologias. Já a variação das espessuras em painéis da mesma massa específica ocasionou diferença nas temperaturas mínimas internas em torno de $0,5^{\circ} \mathrm{C}$.

As tipologias com laje plana apresentaram maiores temperaturas mínimas internas, significando melhor desempenho para o inverno; já as tipologias sem laje apresentaram menores temperaturas mínimas internas.

No verão para Brasília, as temperaturas máximas internas mostraram-se ainda mais elevadas do que para São Carlos. Grande parte das tipologias não atendeu a nenhum dos níveis de desempenho, diferente do que ocorreu para São Carlos, ou seja, não houve desempenho satisfatório para o verão.

Igualmente às demais tipologias, as com painéis de referência não atenderam a nenhum dos níveis de desempenho para o verão. As tipologias com alvenaria de blocos cerâmicos apresentaram as temperaturas máximas internas mais elevadas dentre todas as tipologias analisadas; já as tipologias com alvenaria de blocos de concreto apresentaram desempenho semelhante às tipologias com painéis de concreto de $8 \mathrm{~cm}$ de espessura de forma geral.

Novamente as tipologias térreas com painéis de concreto de $12 \mathrm{~cm}$ de espessura independente da massa específica apresentaram as menores temperaturas máximas internas, ou seja, temperaturas mais agradáveis no verão. Apenas as tipologias com painel 
de concreto com $12 \mathrm{~cm}$ de espessura, massa específica de 2400 e $2200 \mathrm{~kg} / \mathrm{m}^{3}$ e laje inclinada apresentaram as mínimas temperaturas no verão.

Em relação ao tipo de cobertura, as tipologias sem laje apresentaram maiores temperaturas máximas internas que as tipologias com laje plana ou inclinada.

Tem-se para a cidade de Brasília, considerando as condições críticas de inverno e verão que dentre as tipologias com painéis de concreto analisadas destacaram-se em termos de desempenho térmico, apesar do não atendimento aos níveis de desempenho, as tipologias térreas com painéis de concreto de $12 \mathrm{~cm}$ de espessura, massa específica de $2400 \mathrm{~kg} / \mathrm{m}^{3}$, isso para cobertura do tipo laje plana no inverno e laje inclinada para o verão. 
São Carlos - Zona Bioclimática 4 - Inverno Temperaturas Mínimas Internas

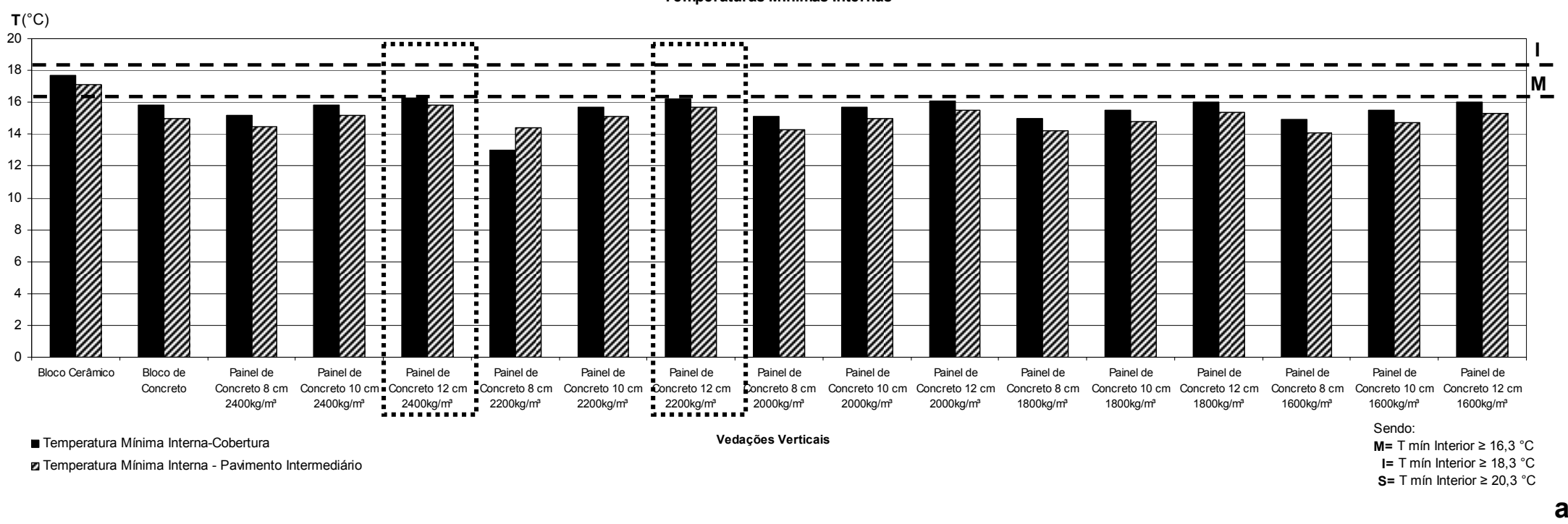

São Carlos- Zona Bioclimática 4 - Verão

$\mathbf{T}\left({ }^{\circ} \mathrm{C}\right)$ Temperaturas Máximas Internas

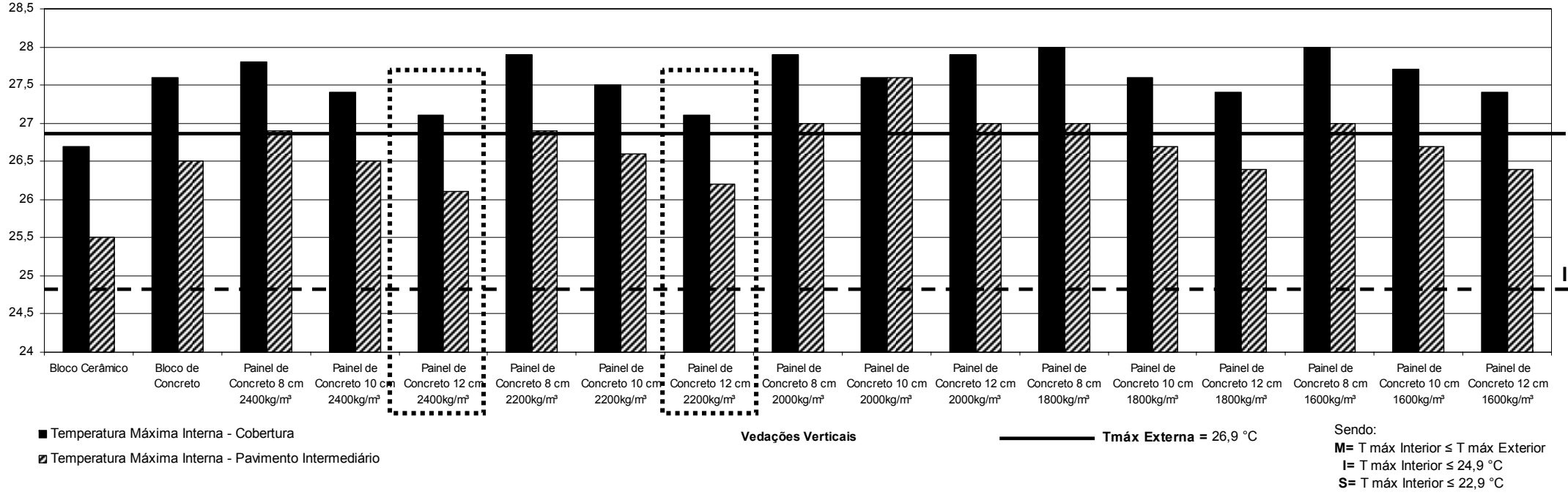

Figura 107 a-b. Tipologia Multipavimentos - Temperaturas Internas - Zona Bioclimática 4 (São Carlos) - a. Inverno. b. Verão 
Brasilia - Zona Bioclimática 4 - Inverno Temperaturas Mínimas Internas
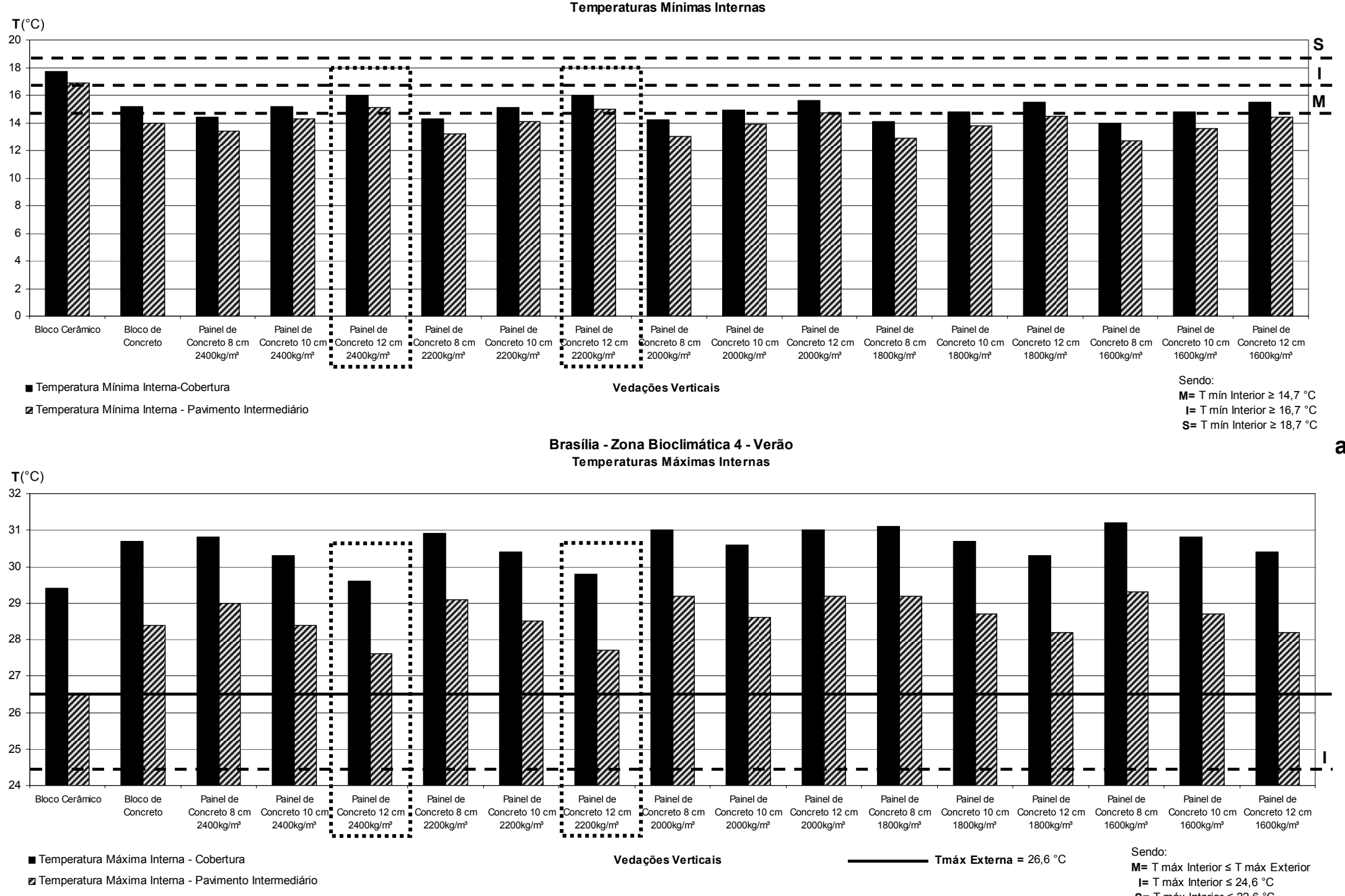

- Temperatura Máxima Interna - Pavimento Intermediário

Figura 108 a-b. Tipologia Multipavimentos - Temperaturas Internas - Zona Bioclimática 4 (Brasília) - a. Inverno. b. Verão 
Na Zona Bioclimática 4 para a cidade de São Carlos observou-se para o inverno que praticamente todas as tipologias analisadas não atenderam a nenhum dos níveis de desempenho, com exceção da tipologia com alvenaria de blocos cerâmicos.

Dentre todas as tipologias analisadas para São Carlos, as temperaturas mínimas internas mais elevadas observadas no inverno foram para as tipologias com alvenaria de blocos cerâmicos, isso para ambos os pavimentos, que atenderam ao nível mínimo de desempenho (temperaturas mínimas internas $\geq 16,3^{\circ} \mathrm{C}$ ). Já as tipologias com alvenaria de blocos de concreto apresentaram desempenho semelhante ao das tipologias com painéis de concreto com de $10 \mathrm{~cm}$ de espessura.

As tipologias com painéis de concreto não atenderam a nenhum dos níveis de desempenho, porém as tipologias com painéis de espessura 10 e $12 \mathrm{~cm}$ em grande parte das massas específicas estiveram mais próximas da temperatura limite para o nível mínimo, já as tipologias com painéis de concreto com $8 \mathrm{~cm}$ de espessura apresentaram menores temperaturas mínimas internas para todas as massas específicas, o que significa um desempenho insatisfatório.

Em relação ao pavimento no inverno as tipologias da cobertura apresentaram um aumento das temperaturas mínimas internas. Já nas tipologias do pavimento intermediário foram observadas temperaturas mínimas internas em torno de $1^{\circ} \mathrm{C}$ abaixo das temperaturas para as tipologias da cobertura.

No verão para a cidade de São Carlos a tipologia com alvenaria de blocos cerâmicos e a tipologia com painéis de concreto de $12 \mathrm{~cm}$ de espessura independente da massa específica apresentaram as menores temperaturas máximas internas, para ambos os pavimentos. Grande parte das tipologias do pavimento intermediário atendeu ao nível mínimo de desempenho $(\mathrm{M})$ (temperaturas máximas internas $\leq 26,9^{\circ} \mathrm{C}$ ). Dentre as tipologias da cobertura somente a tipologia com alvenaria de blocos cerâmicos atendeu ao nível mínimo de desempenho.

As tipologias com alvenaria de blocos cerâmicos apresentaram temperaturas máximas internas menos elevadas, isso para ambos os pavimentos. Igualmente ao que ocorreu para o inverno, no verão as tipologias com alvenaria de blocos de concreto apresentaram desempenho semelhante ao das tipologias com painéis de concreto com de $10 \mathrm{~cm}$ de espessura, os quais atenderam ao nível mínimo de desempenho (M) (temperaturas máximas internas $\leq 26,9^{\circ} \mathrm{C}$ ) para as tipologias do pavimento intermediário.

Dentre as tipologias com painéis de concreto observaram-se as menores temperaturas máximas internas para as tipologias com concreto de $12 \mathrm{~cm}$ de espessura e massa específica 2400 e $2200 \mathrm{~kg} / \mathrm{m}^{3}$, sendo que para essas tipologias localizadas no pavimento intermediário todos o nível mínimo de desempenho $(\mathrm{M})$ foi atendido para o verão. A variação de massa específica dos concretos não ocasionou diferenças significativas nas 
temperaturas máximas internas das tipologias, já a variação de espessura implicou em diferenças de menos de $0,5^{\circ} \mathrm{C}$ entre as temperaturas das tipologias de mesma massa específica.

Em relação ao pavimento as tipologias da cobertura apresentaram maiores temperaturas máximas internas que as tipologias do pavimento intermediário, em torno de $1^{\circ} \mathrm{C}$ de diferença.

Analisando os dados para as condições críticas de inverno e de verão, dentre as tipologias com painéis de concreto observou-se que se torna viável a utilização de painéis de concreto com massa específica de $2400 \mathrm{~kg} / \mathrm{m}^{3}$ e espessura $12 \mathrm{~cm}$ nas tipologias multipavimentos, por motivos econômicos e pelo fato do mesmo ter apresentado desempenho satisfatório para inverno e verão.

No inverno para Brasília algumas tipologias atenderam ao nível mínimo de desempenho (M) (temperaturas mínimas internas $\geq 14,7^{\circ} \mathrm{C}$ ), e ao nível I (temperaturas mínimas internas $\geq 16,7^{\circ} \mathrm{C}$ ).

Para Brasília igualmente a São Carlos, as temperaturas mínimas internas mais elevadas observadas no inverno foram para as tipologias com alvenaria de blocos cerâmicos, isso tanto para a tipologia da cobertura quanto para a tipologia do pavimento intermediário, nas quais os níveis de desempenho $\mathrm{M}$ e I foram atendidos para o inverno. Novamente as tipologias com alvenaria de blocos de concreto apresentaram desempenho semelhante ao das tipologias com painéis de concreto com de $10 \mathrm{~cm}$ de espessura, que atenderam ao nível mínimo de desempenho para a tipologia da cobertura.

As tipologias com painéis de concreto atenderam ao nível mínimo de desempenho (M) para os painéis de $12 \mathrm{~cm}$ de espessura e massa específica 2400 e $2200 \mathrm{~kg} / \mathrm{m}^{3}$, em ambos os pavimentos. Já as tipologias com painéis de concreto com $8 \mathrm{~cm}$ de espessura apresentaram menores temperaturas mínimas internas para todas as massas específicas, não atendendo a nenhum dos níveis de desempenho.

Em relação ao pavimento, igualmente a São Carlos em Brasília para o inverno, as tipologias da cobertura apresentaram temperaturas mínimas internas mais elevadas. Já nas tipologias do pavimento intermediário foram observadas temperaturas mínimas internas em torno de $1^{\circ} \mathrm{C}$ abaixo das temperaturas para as tipologias da cobertura.

Em relação ao pavimento, no inverno as tipologias da cobertura apresentaram um aumento das temperaturas mínimas internas, já para nas tipologias do pavimento intermediário foram observadas temperaturas mínimas internas em torno de $1^{\circ} \mathrm{C}$ abaixo das temperaturas para as tipologias da cobertura. 
No verão para a cidade de Brasília, as temperaturas máximas internas mostraram-se superiores as de São Carlos, novamente as tipologias com painéis de concreto de $12 \mathrm{~cm}$ de espessura independente da massa específica apresentaram as menores temperaturas máximas internas. Em grande parte dos casos nenhum nível de desempenho foi atendido para o verão com exceção da tipologia com alvenaria de blocos cerâmicos do pavimento intermediário.

As tipologias com alvenaria de blocos cerâmicos apresentaram as temperaturas máximas internas menos elevadas, sendo que a tipologia da cobertura foi a única que atendeu a um dos níveis de desempenho, no caso o nível mínimo de desempenho (M) (temperaturas máximas internas $\leq 26,6^{\circ} \mathrm{C}$ ) para o verão. As tipologias com alvenaria de blocos de concreto apresentaram desempenho semelhante ao das tipologias com painéis de concreto com de $10 \mathrm{~cm}$ de espessura.

Dentre as tipologias com painéis de concreto observaram-se as menores temperaturas máximas internas para as tipologias com concreto de $12 \mathrm{~cm}$ de espessura e massas específicas 2400 e $2200 \mathrm{~kg} / \mathrm{m}^{3}$, sendo que nenhum dos níveis de desempenho foi atendido para o verão. A variação de massa específica dos concretos não ocasionou diferenças significativas nas temperaturas máximas internas das tipologias, já a variação de espessura implicou em diferenças de $0,5^{\circ} \mathrm{C}$ entre as temperaturas das tipologias de mesma massa específica.

Para Brasília em relação ao pavimento, as tipologias da cobertura apresentaram as temperaturas máximas internam elevadas em cerca de $2^{\circ} \mathrm{C}$ em relação ao pavimento intermediário.

Analisando os dados para as condições críticas de inverno e de verão observou-se que para Brasília, dentre as tipologias com painéis de concreto, as tipologias com painel de massa específica de $2400 \mathrm{~kg} / \mathrm{m}^{3}$ e espessura $12 \mathrm{~cm}$ apresentaram o melhor desempenho para o inverno e o verão. 


\subsubsection{Zona Bioclimática 5 - Santos} $\mathrm{T}\left({ }^{\circ} \mathrm{C}\right)$

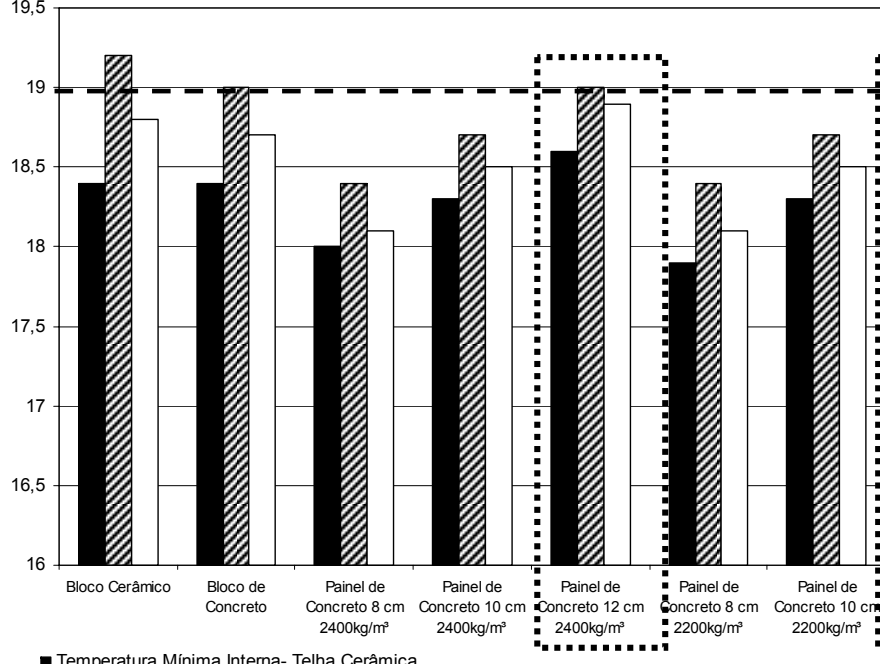

- Temperatura Minima Intema- Teha Cerâmica

- Temperatura Minima Interna- Telha Cerâmica e Laje Mista

口 Temperatura Minima Interna - Telha Cerâmica e Laje Mista Inclinada

$$
\begin{gathered}
\text { Santos - Zona Bioclimática } 5 \text { - Verão } \\
\text { Temperaturas Máximas Internas }
\end{gathered}
$$

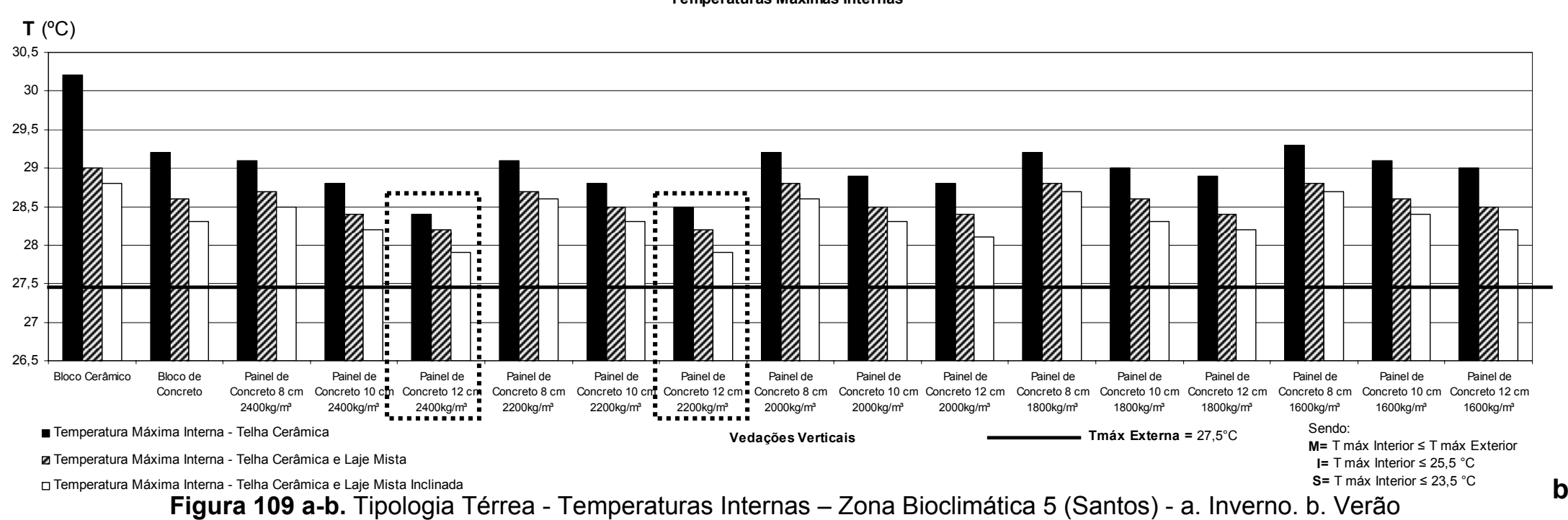

Santos - Zona Bioclimática 5 - Inverno

Temperaturas Minimas Internas

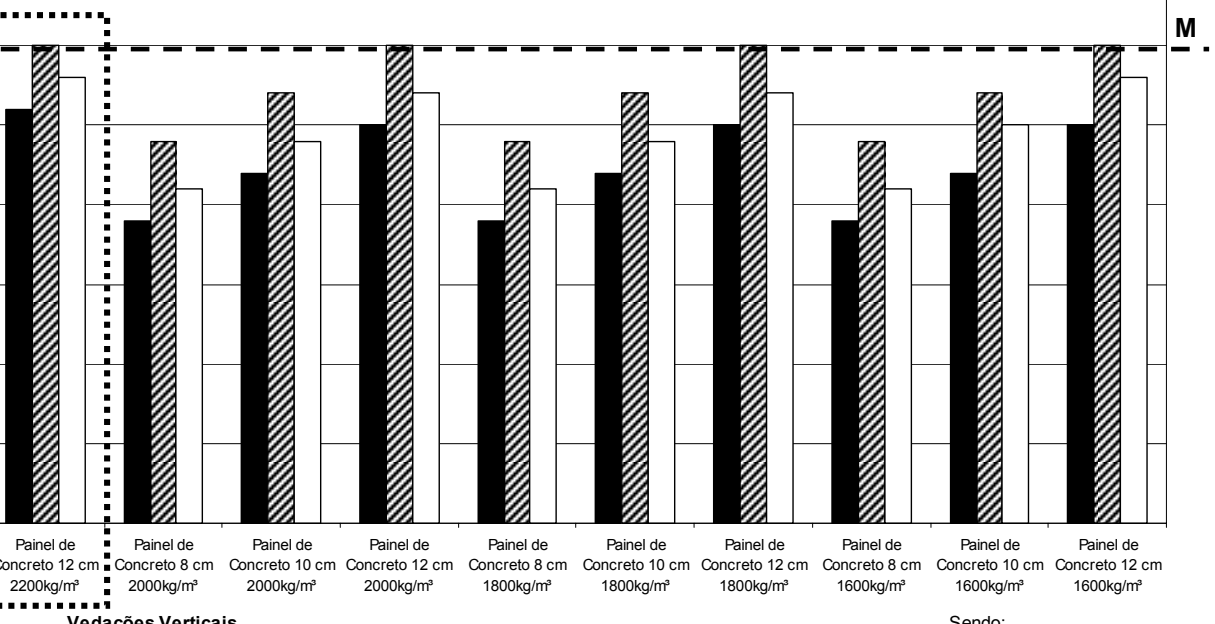

Sendo:

$M=T$ min Interior $\geq 19^{\circ} \mathrm{C}$
$I=T$ min $\ln$ terior $\geq 21^{\circ} \mathrm{C}$ $\quad=T$ min Interior $\geq 21^{\circ} \mathrm{C}$
$\mathrm{S}=\mathrm{T}$ min Interior $\geq 23^{\circ} \mathrm{C}$ 
$\mathrm{Na}$ Zona Bioclimática 5 que nesse caso compreende a cidade de Santos, para o inverno somente uma das tipologias térreas atendeu aos requisitos de desempenho para o inverno. As temperaturas mínimas internas das tipologias em todos os casos ultrapassaram $17,5^{\circ} \mathrm{C}$

As tipologias com painéis de referência (blocos cerâmicos e blocos de concreto) apresentaram comportamento semelhante entre si para as tipologias, com exceção da tipologia com laje plana e alvenaria de blocos cerâmicos que apresentou temperatura mínima interna pouco elevada em relação à tipologia com alvenaria de blocos de concreto, atendendo ao nível mínimo de desempenho (M) (temperaturas mínimas internas $\geq 19^{\circ} \mathrm{C}$ ).

Dentre as tipologias com painéis de concreto as com $12 \mathrm{~cm}$ de espessura de todas as massas específicas apresentaram temperaturas mínimas internas mais elevadas. As temperaturas mínimas internas das tipologias com painéis de concreto de $12 \mathrm{~cm}$ de espessura foram semelhantes às temperaturas das tipologias com painéis de referência. Como observado em grande parte das Zonas Bioclimáticas analisadas anteriormente, a variação de massa específica para os painéis de concreto não implicou em variações das temperaturas mínimas internas das tipologias térreas. Já a variação da espessura dos painéis representou uma diferença de cerca de $0,7{ }^{\circ} \mathrm{C}$ entre as tipologias para a mesma massa específica, quanto maior a espessura maior a temperatura mínima interna para o inverno.

Em relação à cobertura, as tipologias sem laje apresentaram as temperaturas mínimas internas menos elevadas. Para as tipologias térreas com cobertura do tipo laje plana observou-se maiores temperaturas mínimas internas, o que significa desempenho satisfatório para o inverno, apesar de apenas uma tipologia ter atendido a um dos níveis de desempenho.

Para o verão nenhuma das tipologias atendeu aos níveis de desempenho, nem mesmo ao nível mínimo (temperaturas máximas internas $\leq 27,5^{\circ} \mathrm{C}$ ).

As tipologias com alvenaria de blocos de concreto apresentaram comportamento muito semelhante às tipologias com painéis de concreto com $8 \mathrm{~cm}$ de espessura, independente da massa específica. Já as tipologias com alvenaria de blocos cerâmicos apresentaram comportamento semelhante às tipologias com painéis de concreto de $12 \mathrm{~cm}$ de espessura. A tipologia com alvenaria de blocos cerâmicos sem laje apresentou a temperatura máxima interna acima de $30^{\circ} \mathrm{C}$, a mais elevada dentre todas as tipologias analisadas.

As tipologias com painéis de concreto de $12 \mathrm{~cm}$ de espessura e massa específica 2400 e $2200 \mathrm{~kg} / \mathrm{m}^{3}$ apresentaram temperaturas máximas internas menos elevadas, em torno de $28^{\circ} \mathrm{C}$ ficando próximos aos valores estabelecidos para o atendimento ao nível mínimo de desempenho para o verão (temperatura máxima interna $\leq 27,5^{\circ} \mathrm{C}$ ). Nenhuma das tipologias 
com painéis de concreto de $8 \mathrm{~cm}$ de espessura e sem laje atendeu aos níveis de desempenho, estas apresentaram as temperaturas mais elevadas dentre as tipologias com painéis de concreto. A variação da espessura dos painéis de concreto para as tipologias representou uma pequena diferença nas temperaturas máximas internas de mesma massa específica, quanto maior a espessura menor as temperaturas máximas internas para o verão.

Em relação ao tipo de cobertura as tipologias sem laje apresentaram as temperaturas máximas internas mais elevadas do que os demais. Já as coberturas com laje (plana ou inclinada) apresentaram temperaturas máximas internas menos elevadas, o que indica um melhor desempenho para o verão.

Diante da análise de desempenho das tipologias, dentre as tipologias com painéis de concreto, observou-se que para o verão a tipologia térrea com painel de concreto de $12 \mathrm{~cm}$ de espessura e massa específica de $2400 \mathrm{~kg} / \mathrm{m}^{3}$ com laje inclinada foi a que apresentou o melhor desempenho, ou seja, as menores temperaturas máximas internas para o verão. A mesma tipologia mostra-se adequada para o inverno, porém com a cobertura do tipo laje plana. A escolha por essa massa específica para o painel de concreto deu-se por questões de viabilidade econômica, visto que o painel de concreto com massa específica de 2200 $\mathrm{kg} / \mathrm{m}^{3}$ também apresentou desempenho semelhante. 
Santos - Zona Bioclimática 5 - Inverno
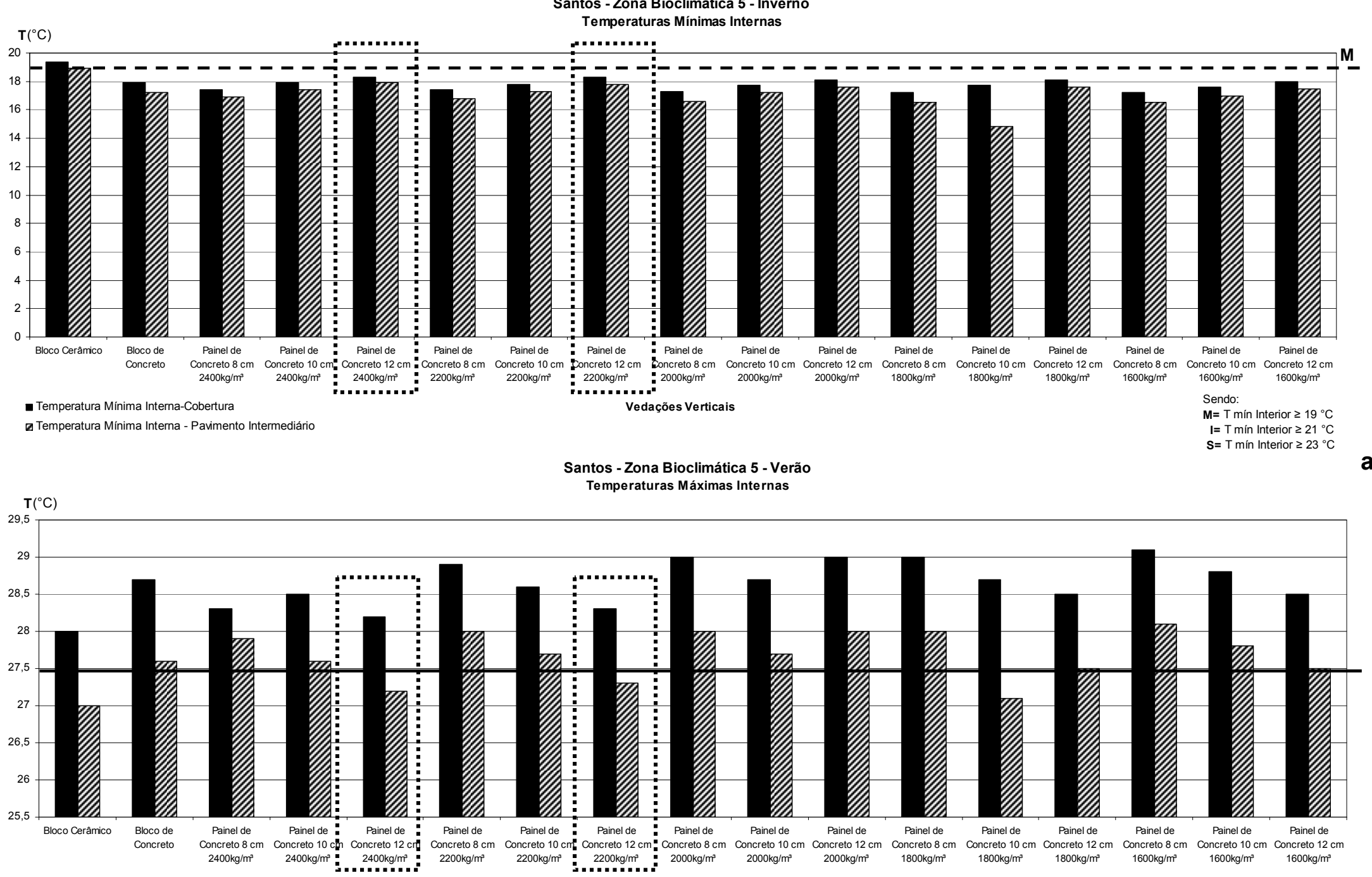

- Temperatura Máxima Interna - Cobertura

Vedaçöes Verticais

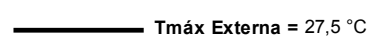

\section{Sendo:}

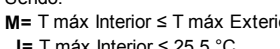

I $=$ T máx Interior $\leq 25,5^{\circ} \mathrm{C}$
$\mathrm{S}=\mathrm{T}$ máx Interior $\leq 23,5^{\circ} \mathrm{C}$

Figura 110 a-b. Tipologia Multipavimentos - Temperaturas Internas - Zona Bioclimática 5 (Santos) - a. Inverno. b. Verão 
Para a cidade de Santos, observou-se que no inverno as temperaturas mínimas internas apresentaram poucas variações para a tipologia multipavimentos. A maior parte das tipologias não atendeu aos níveis de desempenho, com exceção da tipologia da cobertura com alvenaria de blocos cerâmicos.

As tipologias com alvenaria de blocos cerâmicos apresentaram as temperaturas mínimas internas mais elevadas dentre todas as tipologias e foram as únicas a atender ao nível mínimo de desempenho (M) (temperaturas mínimas internas $\geq 19^{\circ} \mathrm{C}$ ). Já as tipologias com alvenaria de blocos de concreto apresentaram desempenho semelhante às tipologias com painéis de concreto de $8 \mathrm{~cm}$ de espessura.

As tipologias com painéis de concreto não atenderam a nenhum dos níveis de desempenho para o inverno. A variação da massa específica dos painéis pouco influenciou nos resultados das temperaturas mínimas internas, já a variação das espessuras dos painéis representou uma pequena diferença nas temperaturas mínimas internas para as tipologias de mesma massa específica, em torno de $0,5^{\circ} \mathrm{C}$.

Em relação ao pavimento, as tipologias apresentaram diferenças entre as temperaturas mínimas internas inferiores a $1{ }^{\circ} \mathrm{C}$, entre as tipologias do pavimento intermediário e as tipologias da cobertura.

Para o verão, algumas tipologias multipavimentos atenderam ao nível mínimo de desempenho (temperaturas máximas internas $\leq 27,5^{\circ} \mathrm{C}$ ), principalmente para o pavimento intermediário. Houve algumas tipologias com painéis de concreto também atenderam ao nível mínimo de desempenho.

A tipologia do pavimento intermediário com alvenaria de blocos cerâmicos foi a única dentre os painéis de referência que atendeu ao nível mínimo de desempenho (M) para o verão. Esta tipologia apresentou a temperatura máxima interna menos elevada. Já as tipologias com alvenaria de blocos de concreto apresentaram desempenho semelhante às tipologias com painéis de concreto de $10 \mathrm{~cm}$ de espessura.

As tipologias com painéis de concreto de espessura $12 \mathrm{~cm}$ e massas específicas $2400 \mathrm{~kg} / \mathrm{m}^{3}$ e $2200 \mathrm{~kg} / \mathrm{m}^{3}$ do pavimento intermediário apresentaram as temperaturas máximas internas menos elevadas em relação às demais tipologias com painéis de concreto, atendendo para a tipologia do pavimento intermediário ao nível mínimo de desempenho (M) para o verão. As tipologias com painéis de concreto de espessura $8 \mathrm{~cm}$ apresentaram temperaturas máximas internas mais elevadas, principalmente para a tipologia da cobertura. As variações tanto nas massas específicas quanto nas espessuras dos painéis de concreto pouco influenciaram nas temperaturas internas das tipologias de mesma massa específica.

Em relação ao pavimento, as tipologias da cobertura temperaturas máximas internas de cerca de $1^{\circ} \mathrm{C}$ acima das temperaturas das tipologias do pavimento intermediário. 
Após as análises das tipologias multipavimentos, tendo em vista as condições criticas para o verão e para inverno observou-se que dentre as tipologias com painéis de concreto, o de espessura $12 \mathrm{~cm}$ e massa específica $2400 \mathrm{~kg} / \mathrm{m}^{3}$ mostrou-se viável em termos de desempenho. Como ocorreu para tipologia térrea, a escolha por essa massa específica para o painel de concreto deu-se por questões de viabilidade econômica, visto que o painel de concreto com massa específica de $2200 \mathrm{~kg} / \mathrm{m}^{3}$ apresentou desempenho semelhante. 
$T\left({ }^{\circ} \mathrm{C}\right)$

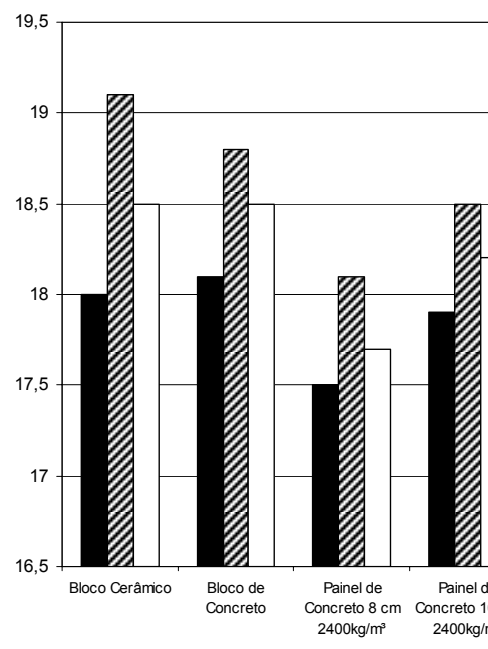

- Temperatura Minima Interna- Telha Cerâmica

v Temperatura Minima Interna- Telha Cerâmica e Laje Mista

口 Temperatura Minima Interna - Telha Cerâmica e Laje Mista Inclinada

$$
\mathbf{T}\left({ }^{\circ} \mathrm{C}\right)
$$

Presidente Prudente- Zona Bioclimática 6 - Verão Temperaturas Máximas Internas

Presidente Prudente - Zona Bioclimática 6 - Inverno Temperaturas Mínimas Internas

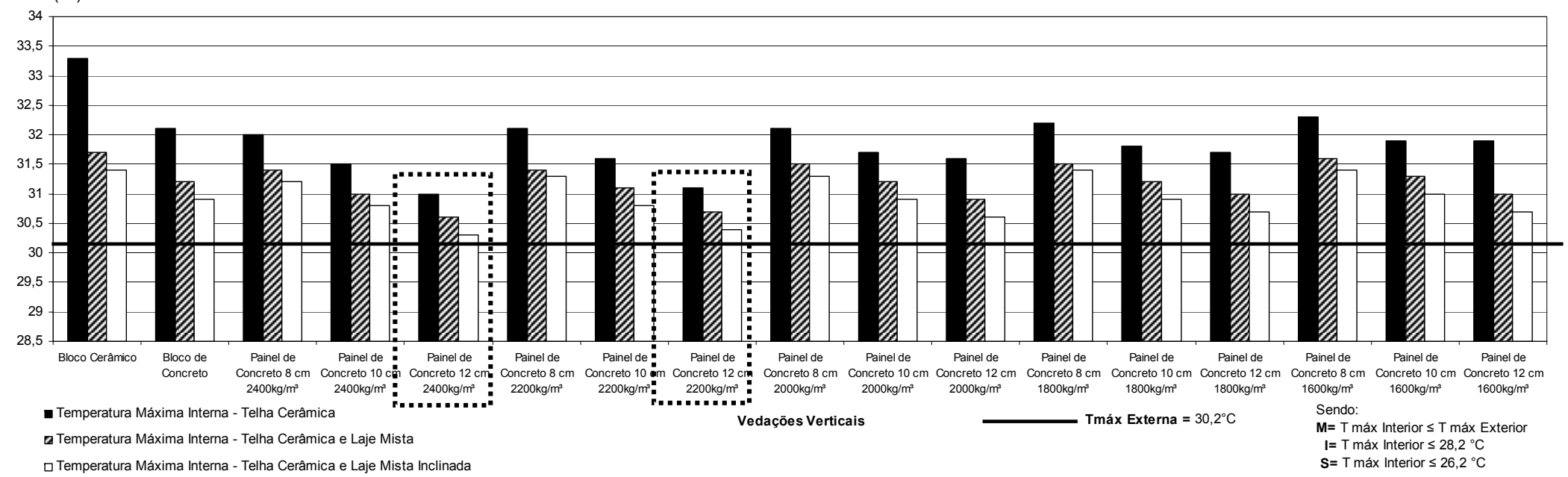

口 Temperatura Máxima Interna - Telha Cerâmica e Laje Mista Inclinada

Figura 111 a-b. Tipologia Térrea - Temperaturas Internas - Zona Bioclimática 6 (Presidente Prudente) - a. Inverno. b. Verão 
Para essa Zona Bioclimática como é o caso de Presidente Prudente é dispensada a verificação de desempenho térmico para o inverno, segundo a NBR 15575-1 (ABNT, 2008). Essa condição explica-se, pois, as temperaturas mínimas internas em todos os casos estão acima de $17,8^{\circ} \mathrm{C}$, valor esse que já abrange pelo menos o nível mínimo de desempenho.

Apesar de não necessitar de verificação de desempenho térmico, observou-se que no inverno dentre as tipologias analisadas, as que apresentaram temperaturas mínimas internas mais elevadas (melhor desempenho) foram as com os painéis de referência e as com os painéis de concreto com $12 \mathrm{~cm}$ de espessura, independente da massa específica, ambas com laje plana, as quais apresentaram desempenho semelhante entre si.

As tipologias com painéis de referência (blocos cerâmicos e blocos de concreto) apresentaram temperaturas mínimas internas semelhantes, com exceção da tipologia com laje plana, onde a temperatura mínima interna foi superior para a tipologia com alvenaria de blocos cerâmicos.

As tipologias térreas com painéis de concreto com $12 \mathrm{~cm}$ de espessura independente da massa específica apresentaram temperaturas mínimas internas mais elevadas para o inverno e as tipologias com painéis de concreto de espessura de $8 \mathrm{~cm}$ apresentaram temperaturas mínimas internas menores.

Em relação ao tipo de cobertura observaram-se para Presidente Prudente temperaturas mínimas internas mais elevadas para a tipologia térrea com laje plana, já as tipologias sem laje apresentaram menores temperaturas mínimas internas.

No verão para Presidente Prudente nenhum dos níveis de desempenho (M, I ou S) foi atendido para as tipologias térreas, as temperaturas ultrapassaram os $30^{\circ} \mathrm{C}$, sendo que o limite máximo estabelecido para o atendimento aos requisitos de desempenho no verão é temperaturas internas abaixo de $30,2^{\circ} \mathrm{C}$. Apesar disso observou-se que as tipologias com painéis de concreto de $12 \mathrm{~cm}$ de espessura e massas específicas de 2400 e $2200 \mathrm{~kg} / \mathrm{m}^{3}$ apresentaram as temperaturas máximas internas menos elevadas em relação às demais tipologias.

As tipologias com alvenaria de blocos cerâmicos apresentaram as temperaturas máximas internas mais elevadas em relação às demais tipologias. Já as tipologias com alvenaria de blocos de concreto apresentaram temperaturas semelhantes às tipologias com painéis de concreto de espessura $8 \mathrm{~cm}$, independente da massa específica.

Observou-se, ainda, que no verão as tipologias com painéis de concreto de $12 \mathrm{~cm}$ de espessura, apesar de terem apresentado temperaturas máximas internas entre 30 e $31^{\circ} \mathrm{C}$ apresentaram desempenho superior às demais tipologias, em especial as tipologias com painéis em concreto com massa específica de 2400 e $2200 \mathrm{~kg} / \mathrm{m}^{3}$, com cobertura do tipo laje inclinada. 
Em relação à cobertura para o verão, observou-se que as tipologias sem laje apresentaram as temperaturas máximas internas mais elevadas, e as tipologias com laje inclinada apresentaram as temperaturas máximas internas menos elevadas, sendo, portanto melhores em termos de desempenho.

Após as análises das tipologias térreas nas condições críticas de inverno e de verão, observou-se que dentre as tipologias com painéis de concreto, o uso de painéis com espessura $12 \mathrm{~cm}$ e massa específica $2400 \mathrm{~kg} / \mathrm{m}^{3}$ tanto pro inverno quanto para o verão apresentou o melhor desempenho, porém com laje inclinada para o verão e com laje plana para o inverno. A escolha por essa massa específica para o painel de concreto deu-se por questões de viabilidade econômica, visto que as tipologias com o painel de concreto com massa específica de $2200 \mathrm{~kg} / \mathrm{m}^{3}$ apresentaram desempenho semelhante. 
Presidente Prudente-Zona Bioclimática 6 - Inverno Temperaturas Mínimas Internas

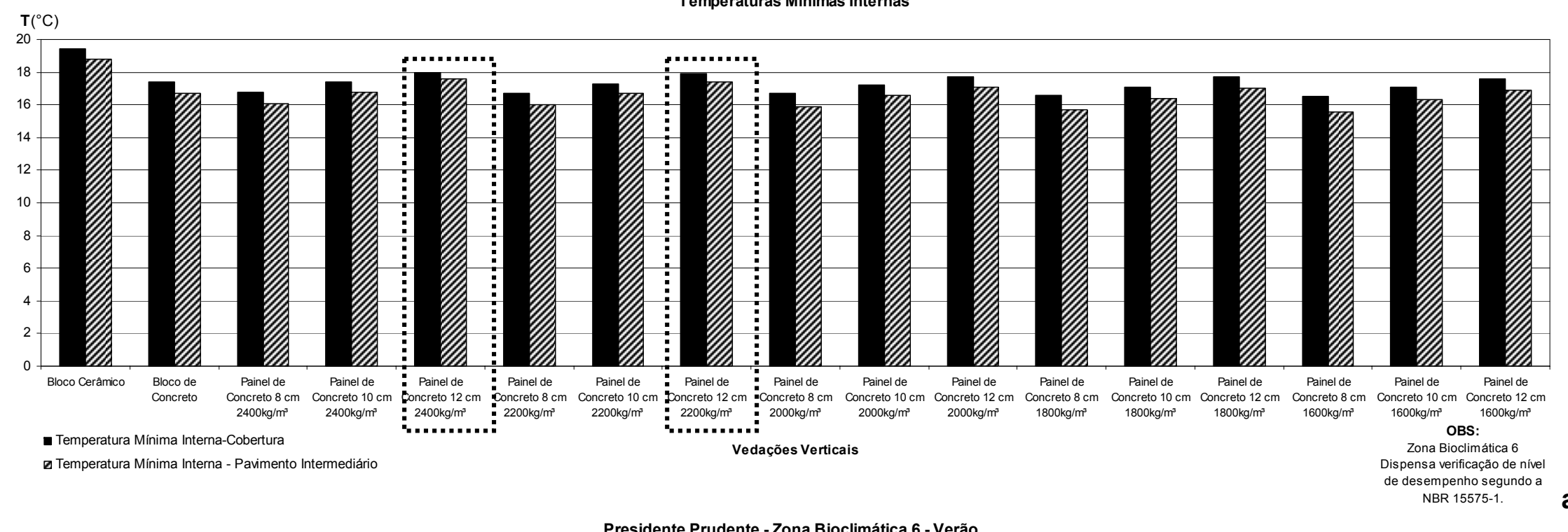

Presidente Prudente - Zona Bioclimática 6 - Verão

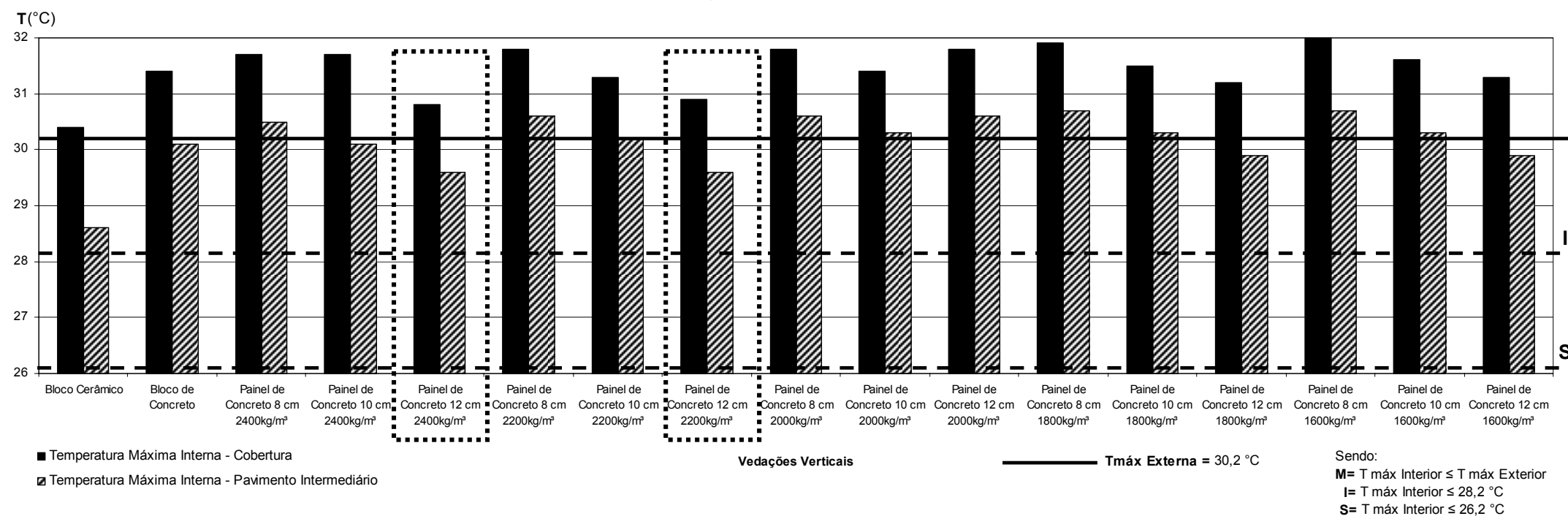

Figura 112 a-b. Tipologia Multipavimentos - Temperaturas Internas - Zona Bioclimática 6 (Presidente Prudente) - a. Inverno. b. Verão 
Para essa Zona Bioclimática é dispensada a verificação de desempenho térmico para o inverno, segundo a NBR 15575-1 (ABNT, 2008). Essa condição explica-se, pois as temperaturas mínimas internas em boa parte dos casos estão acima de $17,8^{\circ} \mathrm{C}$, valores esses que abrangem pelo menos o nível mínimo de desempenho.

Embora seja dispensada a verificação de desempenho térmico, observou-se que no inverno dentre as tipologias analisadas, as que apresentaram temperaturas mínimas internas mais elevadas foram as com os painéis em alvenaria de blocos cerâmicos e as com os painéis de concreto com $12 \mathrm{~cm}$ de espessura, independente da massa específica.

As tipologias com alvenaria de blocos cerâmicos apresentaram temperaturas mínimas internas mais elevadas (acima de $18^{\circ} \mathrm{C}$ ) em relação às demais tipologias, já as tipologias com alvenaria de blocos de concreto apresentaram temperaturas mínimas internas semelhantes às tipologias com painéis de concreto de $8 \mathrm{~cm}$.

As tipologias multipavimentos com painéis de concreto com $12 \mathrm{~cm}$ de espessura independente da massa específica apresentaram temperaturas mínimas internas mais elevadas para o inverno e as tipologias com painéis de concreto de espessura de $8 \mathrm{~cm}$ apresentaram temperaturas mínimas internas menores. A variação da massa específica dos concretos pouco influenciou nas temperaturas mínimas internas, já a variação das espessuras para a mesma massa específica apresentou uma diferença de cerca de $0,5^{\circ} \mathrm{C}$ entre as temperaturas mínimas internas das tipologias.

Em relação ao pavimento, as temperaturas mínimas internas das tipologias da cobertura ficaram acima das temperaturas mínimas internas das tipologias do pavimento intermediário em torno de $1^{\circ} \mathrm{C}$.

No verão em algumas tipologias do pavimento intermediário foi atendido somente o nível mínimo $(M)$ de desempenho (temperaturas máximas internas $\leq 30,2$ ), isso para as tipologias com painéis de referência (blocos cerâmicos e blocos de concreto) e para as tipologias com painéis de concreto de $12 \mathrm{~cm}$ de espessura (massas específicas 2400, 2200, 1800 e $\left.1600 \mathrm{~kg} / \mathrm{m}^{3}\right)$.

A tipologia com alvenaria de blocos cerâmicos do pavimento intermediário destacouse dentre as demais com a menor temperatura máxima interna para o verão (em torno de $28,5^{\circ} \mathrm{C}$ ), atendendo ao nível mínimo de desempenho (temperaturas máximas internas $\leq$ $30,2^{\circ} \mathrm{C}$ ). A tipologia com alvenaria de blocos de concreto do pavimento intermediário atendeu igualmente ao nível mínimo de desempenho, esta apresentou temperaturas máximas internas semelhantes às da tipologia com painéis de concreto com $10 \mathrm{~cm}$.

As tipologias com painéis de concreto de espessura $12 \mathrm{~cm}$ e massa específica 2400 e $2200 \mathrm{~kg} / \mathrm{m}^{3}$, apresentaram as temperaturas máximas internas menos elevadas, ou seja, 
melhores em relação ao desempenho. Essas tipologias atenderam para o pavimento intermediário o nível $\mathrm{M}$ de desempenho para o verão.

Em relação ao pavimento, as tipologias da cobertura apresentaram as temperaturas máximas internas em torno de $1^{\circ} \mathrm{C}$ mais elevadas em relação às temperaturas das tipologias do pavimento intermediário.

Em termos de desempenho, analisando as condições críticas para inverno e verão, dentre as tipologias com painéis de concreto destacaram-se as com painéis de $12 \mathrm{~cm}$ de espessura e massa específica $2400 \mathrm{~kg} / \mathrm{m}^{3}$. A adoção desse tipo de concreto implica em adequação em relação ao desempenho e maior economia de recursos pelo fato de ser o menos oneroso quando comparado ao concreto com massa específica $2200 \mathrm{~kg} / \mathrm{m}^{3}$. 
7.2.7 Zona Bioclimática 7 - Teresina

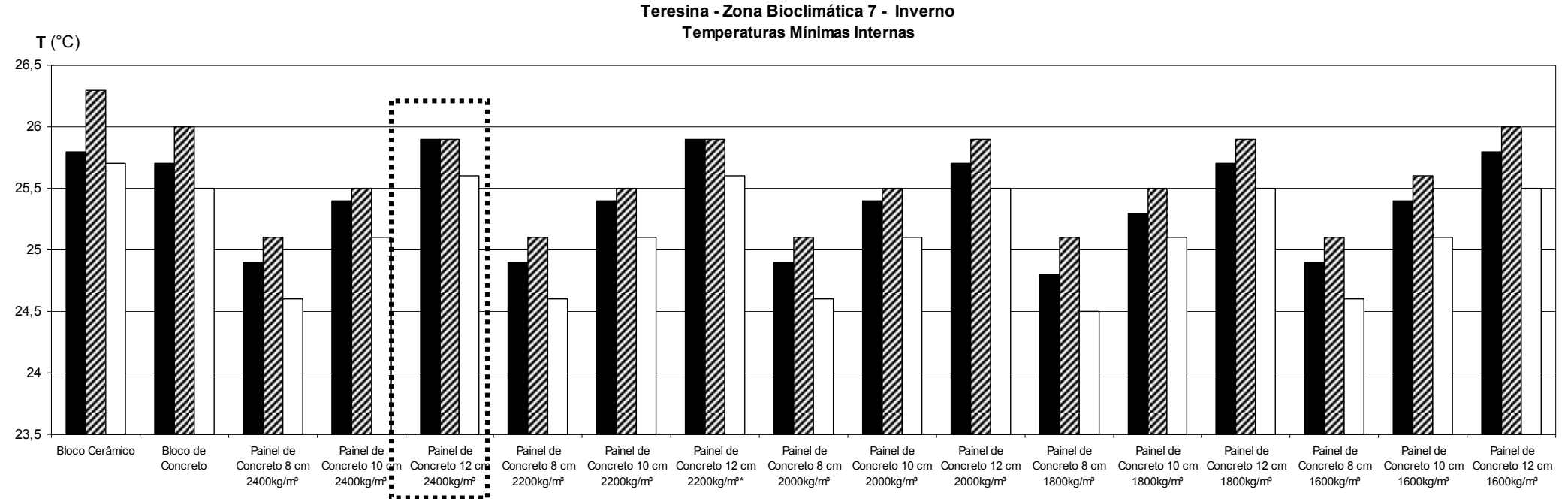

- Temperatura Minima Interna- Telha Cerámica

口 Temperatura Minima Interma - Telha Cerâmica e Laje Mista Inclinada

$\begin{array}{cc}\text { T }\left({ }^{\circ} \mathrm{C}\right) & \begin{array}{c}\text { Teresina - Zona Bioclimática 7- Verão } \\ \text { Temperaturas Máximas Internas }\end{array}\end{array}$

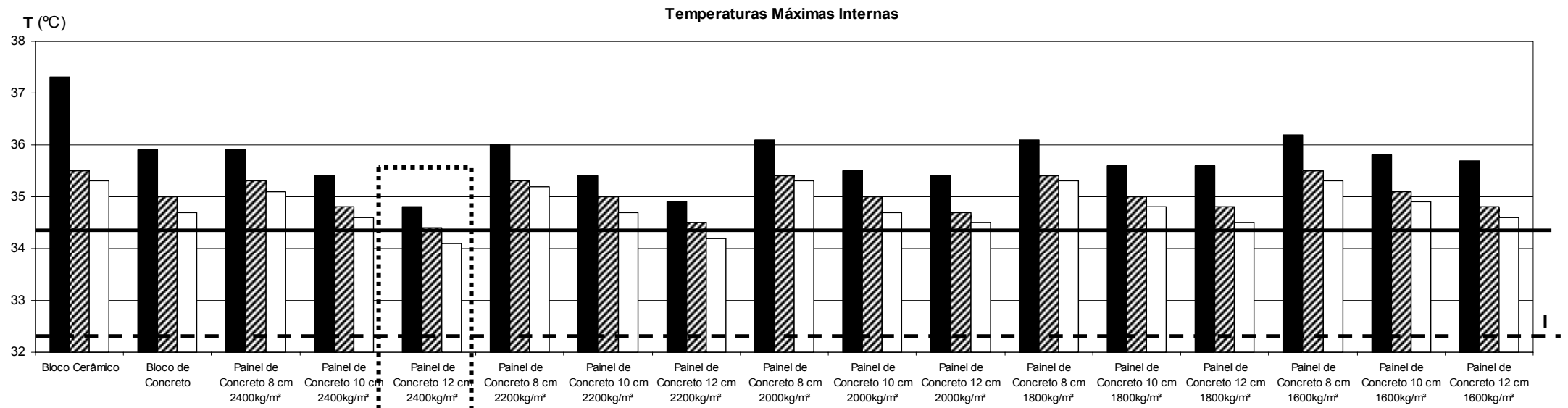

- Temperatura Máxima Interna - Telha Cerâmica

Vedações Verticais

Tmáx Externa $=34,4^{\circ} \mathrm{C}$

Sendo:
M= T máx Interior $\leq T$ máx Exterio I $=$ T máx Interior $\leq 32,4{ }^{\circ} \mathrm{C}$
$\mathrm{S}=$ T máx Interior $\leq 30,4{ }^{\circ} \mathrm{C}$

TTemperatura Máxima Interna - Telha Cerâmica e Laje Mista Inclinada

Figura 113 a-b. Tipologia Térrea - Temperaturas Internas - Zona Bioclimática 7 (Teresina) - a. Inverno. b. Verão 
Para essa zona bioclimática também é dispensada a verificação de desempenho térmico para o inverno, segundo a NBR 15575-1 (ABNT, 2008). Essa condição explica-se, pois as temperaturas mínimas internas estão acima de $24,4^{\circ} \mathrm{C}$, ou seja, estão elevadas se comparadas às demais zonas bioclimáticas e abrangem pelo menos o nível mínimo de desempenho para o inverno.

Apesar de não ter necessidade de verificação de desempenho térmico, observou-se que no inverno dentre as tipologias analisadas, as que apresentaram temperaturas mínimas internas mais elevadas foram as com os painéis de referência e as com os painéis de concreto com $12 \mathrm{~cm}$ de espessura, independente da massa específica, ambas com laje plana.

As tipologias com painéis de referência (blocos cerâmicos e blocos de concreto) apresentaram temperaturas mínimas internas semelhantes variando entre 25,5 e $26^{\circ} \mathrm{C}$, com exceção da tipologia com laje plana, onde a temperatura mínima interna foi superior para a tipologia com alvenaria de blocos cerâmicos.

Dentre as tipologias com painéis de concreto, as com $12 \mathrm{~cm}$ de espessura independente da massa específica apresentaram temperaturas mínimas internas mais elevadas no inverno, variando entre 25,5 e $26^{\circ} \mathrm{C}$; já as tipologias com painéis de concreto de espessura de $8 \mathrm{~cm}$ apresentaram temperaturas mínimas internas menores, sendo, portanto inferiores em termos de desempenho para o inverno.

Em relação ao tipo de cobertura foram observadas temperaturas mínimas internas mais elevadas no inverno para as tipologias com laje plana, já as tipologias com laje inclinada apresentaram menores temperaturas mínimas internas.

No verão observou-se que para Teresina todas as temperaturas máximas internas ficaram acima de $34^{\circ} \mathrm{C}$. Somente duas tipologias com painéis de concreto com $12 \mathrm{~cm}$ de espessura atenderam ao nível $\mathrm{M}$ de desempenho (temperaturas máximas internas $\leq 34,4$ ).

As tipologias com alvenaria de blocos cerâmicos apresentaram as temperaturas máximas internas mais elevadas dentre todas as tipologias analisadas. Já as tipologias com alvenaria de blocos de concreto apresentaram desempenho semelhante às tipologias com painéis de concreto de $10 \mathrm{~cm}$ de espessura.

As tipologias com painéis de concreto de $12 \mathrm{~cm}$ de espessura e massa específica $2400 \mathrm{~kg} / \mathrm{m}^{3}$ com laje plana e laje inclinada; e também a tipologia com painel de concreto com $12 \mathrm{~cm}$ de espessura e massa específica $2200 \mathrm{~kg} / \mathrm{m}^{3} \mathrm{com}$ laje inclinada atenderam ao nível mínimo de desempenho $(\mathrm{M})$ para o verão. Dentre as tipologias com painéis de concreto, a variação das espessuras dos painéis tampouco da massa específica ocasionaram grandes diferenças nas temperaturas máximas internas para o verão. 
Em relação ao tipo de cobertura foram observadas temperaturas máximas internas mais elevadas no verão para as tipologias sem laje, já as tipologias com laje tanto plana quanto inclinada apresentaram menores temperaturas máximas internas.

Diante das análises para as condições críticas de inverno e verão, observou-se dentre as tipologias térreas com painéis de concreto, que o uso de painéis de concreto com $12 \mathrm{~cm}$ de espessura e massa específica $2400 \mathrm{~kg} / \mathrm{m}^{3}$ apresentou melhor desempenho em ambas as estações. Sendo a laje plana mais adequada para o inverno e a laje inclinada para o verão. 
Teresina - Zona Bioclimática 7 - Inverno Temperaturas Minimas Internas
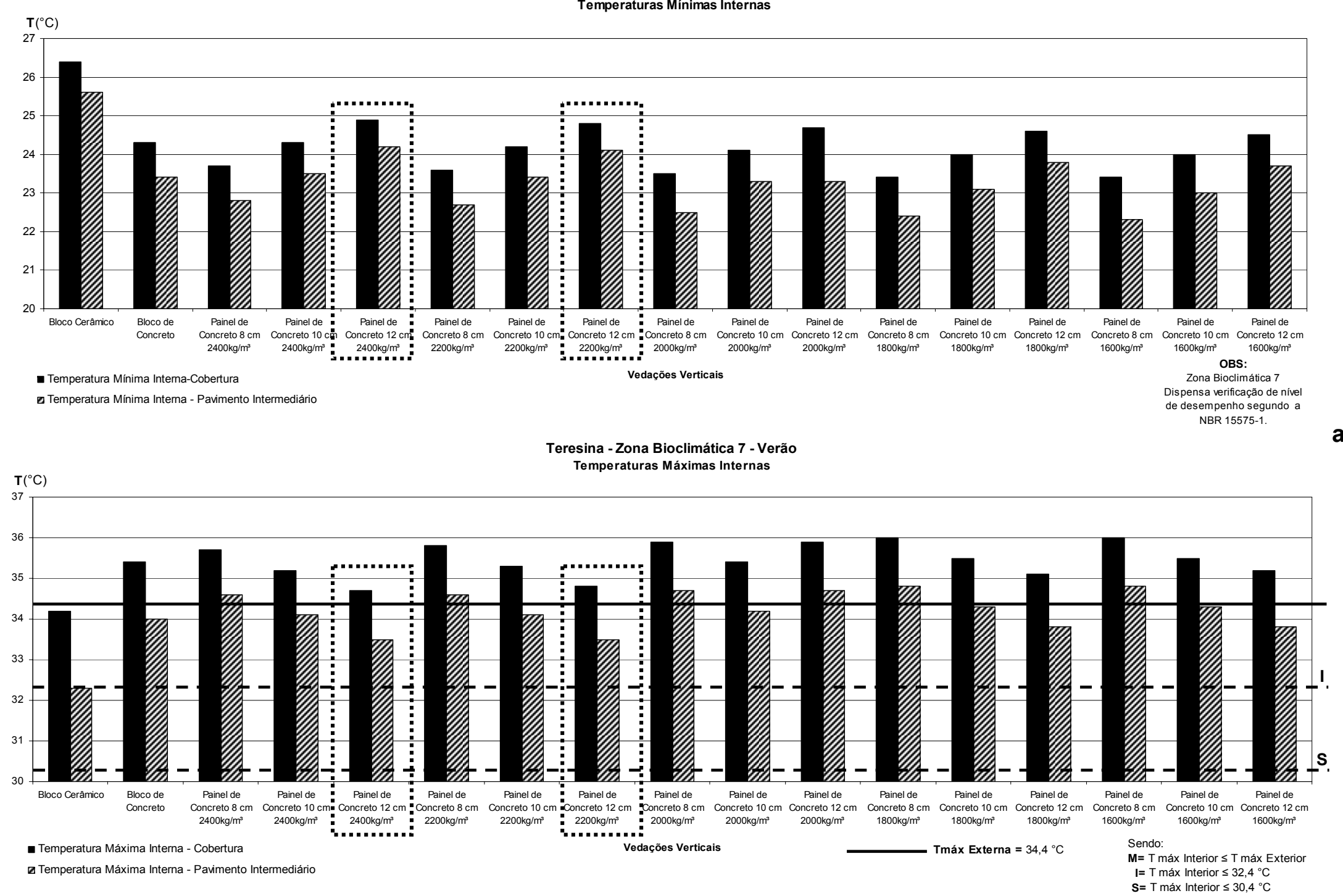

Figura 114 a-b. Tipologia Multipavimentos- Temperaturas Internas - Zona Bioclimática 7 (Teresina) - a. Inverno. b. Verão 
Como dito anteriormente, é dispensada a verificação de desempenho térmico para o inverno para essa zona bioclimática, segundo a NBR 15575-1 (ABNT, 2008). Essa condição explica-se, pois as temperaturas mínimas internas para o inverno nesta localidade são elevadas se comparadas às demais zonas bioclimáticas.

Apesar de não ter necessidade de verificação de desempenho térmico, observou-se que no inverno dentre as tipologias analisadas, as que apresentaram temperaturas mínimas internas mais elevadas foram as com alvenaria de blocos cerâmicos e as com os painéis de concreto com $12 \mathrm{~cm}$ de espessura, independente da massa específica. Em comparação à tipologia térrea as temperaturas mínimas internas das tipologias multipavimentos mostraram-se pouco menos elevadas no inverno.

As tipologias com alvenaria de blocos cerâmicos apresentaram as temperaturas mínimas internas mais elevadas dentre todas as tipologias analisadas; já as tipologias com alvenaria de blocos de concreto apresentaram temperaturas mínimas internas semelhantes às das tipologias com painéis de concreto de $8 \mathrm{~cm}$ de espessura.

As tipologias com painéis de concreto de $12 \mathrm{~cm}$ de espessura, independente da massa específica, apresentaram temperaturas mínimas internas mais elevadas; Dentre as tipologias com painéis de concreto, a variação da massa específica não ocasionou grandes diferenças nas temperaturas mínimas internas para o inverno. Já a variação das espessuras dos painéis ocasionou diferenças de $0,5^{\circ} \mathrm{C}$ entre as temperaturas mínimas internas das tipologias para a mesma massa específica.

Em relação ao pavimento, foram observadas no inverno diferenças entre 0,5 e $0,9^{\circ} \mathrm{C}$ nas temperaturas mínimas internas das tipologias da cobertura e do pavimento intermediário.

Para o verão grande parte das tipologias não atendeu aos níveis de desempenho, com exceção de algumas tipologias do pavimento intermediário que atenderam somente ao nível mínimo de desempenho (M) (temperaturas máximas internas $\leq 34,4^{\circ} \mathrm{C}$ ).

As tipologias com alvenaria de blocos cerâmicos apresentaram as temperaturas máximas internas menos elevadas dentre todas as tipologias analisadas, e atenderam o nível mínimo de desempenho (M) para ambos os pavimentos. Já as tipologias com alvenaria de blocos de concreto apresentaram temperaturas máximas internas semelhantes às das tipologias com painéis de concreto de $10 \mathrm{~cm}$ de espessura, que atenderam ao nível mínimo de desempenho (M) para a tipologia do pavimento intermediário.

Dentre as tipologias com painéis de concreto, as com massa específica 2400, 2200 , 1800 e $1600 \mathrm{~kg} / \mathrm{m}^{3}$ (espessuras 10 e $12 \mathrm{~cm}$ ) e as tipologias com painéis de concreto de massa específica $2000 \mathrm{~kg} / \mathrm{m}^{3}$ (espessura $10 \mathrm{~cm}$ ) atenderam ao nível mínimo de desempenho (M) para a tipologia do pavimento intermediário. As diferenças nas 
temperaturas máximas internas observadas para as tipologias ocorreram principalmente devido à variação das espessuras dos painéis de concreto utilizados.

Em relação ao pavimento foram observadas diferenças nas temperaturas máximas interna entre as tipologias dos dois pavimentos em cerca de $1^{\circ} \mathrm{C}$, sendo que a tipologia da cobertura apresentou em todos os casos as temperaturas mais elevadas.

Diante das análises para as condições críticas de inverno e verão, observou-se dentre as tipologias multipavimentos com painéis de concreto, que o uso de concreto com $12 \mathrm{~cm}$ de espessura e massas específicas 2400 e $2200 \mathrm{~kg} / \mathrm{m}^{3}$ representou um melhor desempenho em ambas as estações. Porém, apesar das tipologias com painéis de concreto de massa específica $2200 \mathrm{~kg} / \mathrm{m}^{3}$ terem apresentado desempenho semelhante, a escolha de concreto de massa específica $2400 \mathrm{~kg} / \mathrm{m}^{3}$, torna-se viável por questões econômicas. 
7.2.8 Zona Bioclimática 8 - Belém

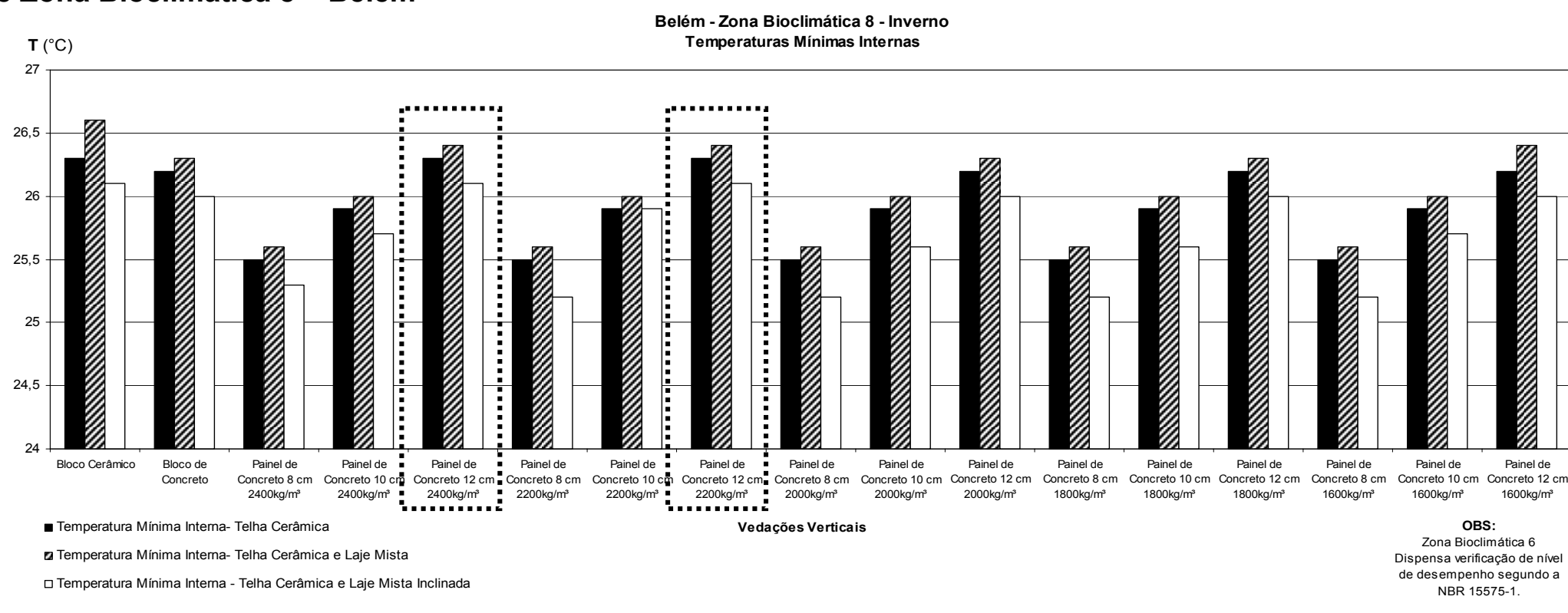

Belém - Zona Bioclimática 8 - Verão Temperaturas Máximas Internas

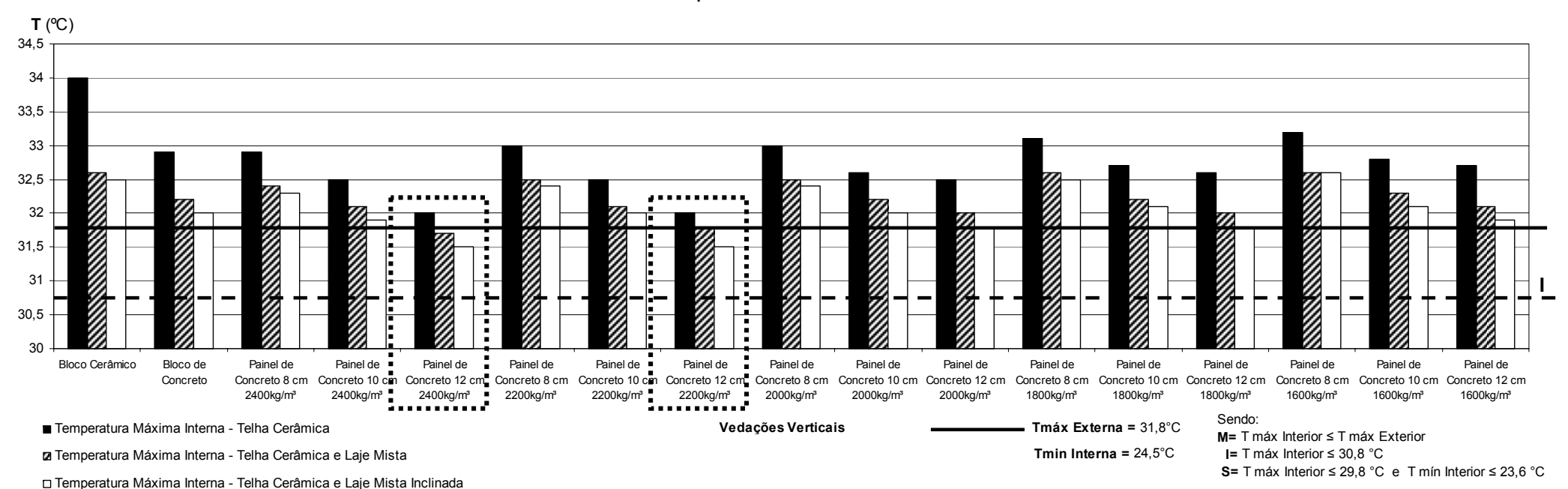

Figura 115 a-b. Tipologia Térrea - Temperaturas Internas - Zona Bioclimática 8 (Belém) - a. Inverno. b. Verão 
Para a zona bioclimática 8 também é dispensada a verificação de desempenho térmico para o inverno, segundo a NBR 15575-1 (ABNT, 2008). Essa condição explica-se, pois as temperaturas mínimas internas estão acima de $25,7^{\circ} \mathrm{C}$ em grande parte dos casos, ou seja, estão elevadas se comparadas às demais zonas bioclimáticas e abrangem o nível mínimo de desempenho para o inverno.

Apesar de não haver a necessidade de verificação de desempenho térmico, observou-se que no inverno dentre as tipologias analisadas, as que apresentaram temperaturas mínimas internas mais elevadas foram as com os painéis de referência e as com os painéis de concreto com $12 \mathrm{~cm}$ de espessura, independente da massa específica, ambas com laje plana, igualmente ao que ocorreu para a cidade de Teresina da zona bioclimática 7 .

As tipologias com painéis de referência (blocos cerâmicos e blocos de concreto) apresentaram temperaturas mínimas internas semelhantes variando entre 26 e $26,5^{\circ} \mathrm{C}$, com exceção da tipologia com laje plana, onde a temperatura mínima interna foi superior para a tipologia com alvenaria de blocos cerâmicos.

As tipologias térreas com painéis de espessura de $12 \mathrm{~cm}$ independente da massa específica apresentaram temperaturas mínimas internas mais elevadas; já as tipologias com painéis de concreto de espessura de $8 \mathrm{~cm}$ apresentaram menores temperaturas mínimas internas. Observou-se pouca influência da variação de massa específica dos concretos nas temperaturas mínimas internas das tipologias. Já a variação de espessura influenciou numa diferença em grande parte dos casos inferior a $0,5^{\circ} \mathrm{C}$ para tipologias da mesma massa específica.

Observou-se que no inverno ocorreram as temperaturas mínimas internas mais elevadas para as tipologias com laje plana, e as temperaturas menos elevadas para as tipologias com laje inclinada.

No verão todas as temperaturas máximas internas ficaram acima de $31^{\circ} \mathrm{C}$. Somente algumas tipologias com painéis de concreto com $12 \mathrm{~cm}$ de espessura atenderam ao nível mínimo de desempenho $(M)$ (temperaturas máximas internas $\leq 31,8^{\circ} \mathrm{C}$ ).

As tipologias com alvenaria de blocos cerâmicos apresentaram as temperaturas máximas internas mais elevadas dentre todas as tipologias analisadas. Já as tipologias com alvenaria de blocos de concreto apresentaram desempenho semelhante às tipologias com painéis de concreto de $10 \mathrm{~cm}$ de espessura.

Percebe-se que as tipologias com painéis de concreto de espessura de $12 \mathrm{~cm}$, para todas as massas específicas do intervalo estudado, apresentaram temperaturas máximas internas menos elevadas, sendo, portanto melhores em relação ao desempenho no verão. Dentre as tipologias com painéis de concreto que atenderam o nível mínimo de desempenho (M) estão as tipologias com $12 \mathrm{~cm}$ de espessura, massa específica entre 2400 e $1600 \mathrm{~kg} / \mathrm{m}^{3}$ 
e laje inclinada. Também atenderam ao nível mínimo de desempenho (M) as tipologias com painéis de concreto de $12 \mathrm{~cm}$ de espessura e massa específica de 2400 e $2200 \mathrm{~kg} / \mathrm{m}^{3}$, com laje plana.

Em relação à cobertura, as tipologias sem laje apresentaram as temperaturas máximas internas mais elevadas para o verão e as tipologias com laje (plana e inclinada) apresentaram as temperaturas máximas internas menos elevadas.

Diante das análises para as condições críticas de inverno e verão, observou-se que dentre as tipologias com painéis de concreto que as tipologias com painéis de $12 \mathrm{~cm}$ de espessura, massa específica $2400 \mathrm{~kg} / \mathrm{m}^{3}$ e laje plana ou inclinada, mostraram-se adequadas em relação ao desempenho principalmente para verão. 
Belém - Zona Bioclimática 8 - Inverno Temperaturas Mínimas Internas

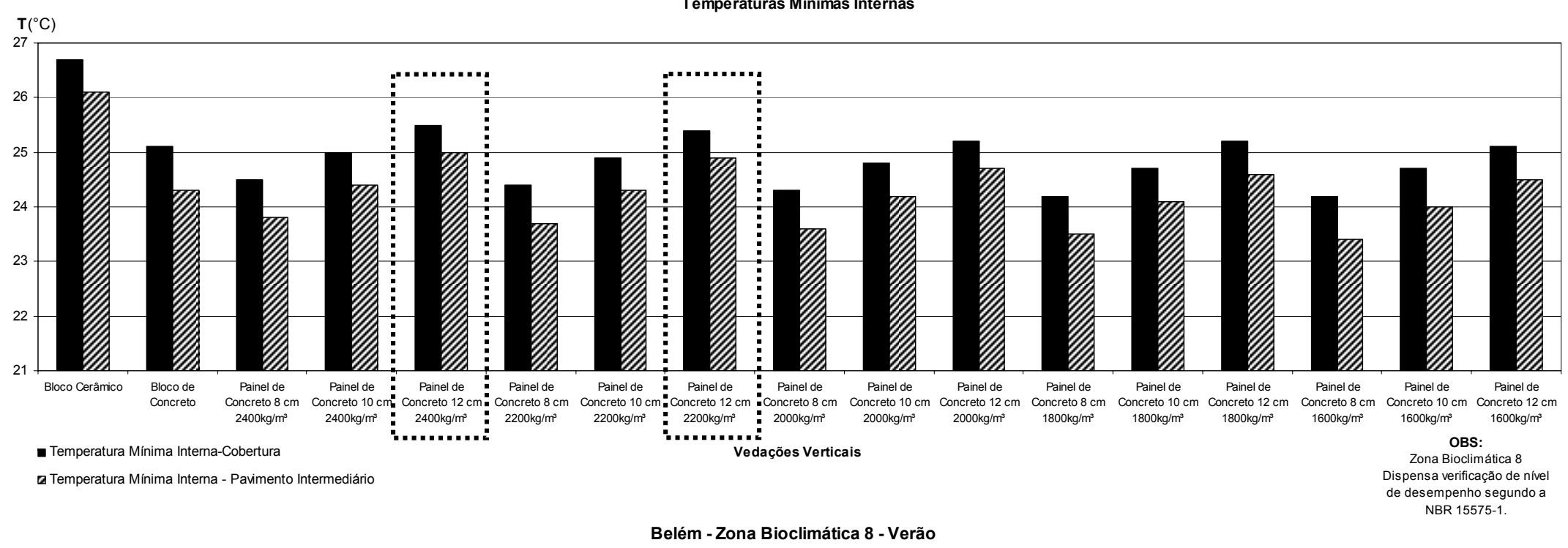

Belém - Zona Bioclimática 8 - Verão

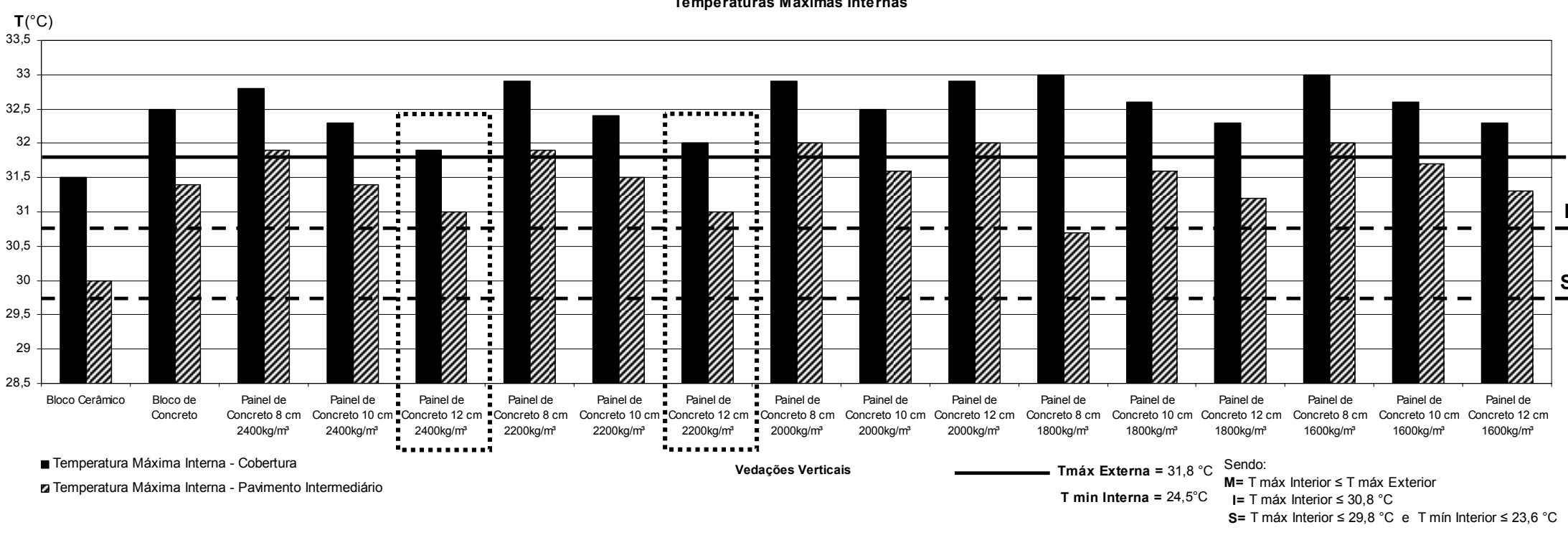

Figura 116 a-b. Tipologia Multipavimentos - Temperaturas Internas - Zona Bioclimática 8 (Belém) - a. Inverno. b. Verão 
A verificação de desempenho térmico para o inverno é dispensada para essa zona bioclimática, segundo a NBR 15575-1 (ABNT, 2008). Essa condição explica-se, pois as temperaturas mínimas internas estão elevadas se comparadas às demais zonas bioclimáticas.

Apesar de não haver a necessidade de verificação de desempenho térmico, observou-se que no inverno dentre as tipologias analisadas, as que apresentaram temperaturas mínimas internas mais elevadas foram as com alvenaria de blocos cerâmicos e as com os painéis de concreto com $12 \mathrm{~cm}$ de espessura, independente da massa específica. Em comparação à tipologia térrea as temperaturas mínimas internas das tipologias multipavimentos mostraram-se pouco menos elevadas no inverno.

As tipologias com alvenaria de blocos cerâmicos apresentaram as temperaturas mínimas internas mais elevadas dentre todas as tipologias analisadas, acima de $26^{\circ} \mathrm{C}$; já as tipologias com alvenaria de blocos de concreto apresentaram temperaturas mínimas internas semelhantes às das tipologias com painéis de concreto de $10 \mathrm{~cm}$ de espessura.

Observou-se que para as tipologias com painéis de concreto com $12 \mathrm{~cm}$ de espessura, independente da massa específica as temperaturas mínimas internas apresentaram-se mais elevadas; já para as tipologias com painéis de concreto de espessura $8 \mathrm{~cm}$ foram observadas temperaturas mínimas internas menos elevadas. A variação da massa específica dos painéis de concreto não ocasionou grandes diferenças nas temperaturas mínimas internas para o inverno. Já a variação das espessuras dos painéis ocasionou diferenças de $0,5^{\circ} \mathrm{C}$ entre as temperaturas mínimas internas das tipologias para a mesma massa específica.

Em relação ao pavimento, foram observadas no inverno diferenças entre 0,5 e $0,9{ }^{\circ} \mathrm{C}$ nas temperaturas mínimas internas das tipologias da cobertura e do pavimento intermediário.

Para o verão grande parte das tipologias do pavimento intermediário atendeu ao nível mínimo de desempenho $(\mathrm{M})$ (temperaturas máximas internas $\leq 31,8^{\circ} \mathrm{C}$ ), isso incluindo as tipologias com painéis de referência e as tipologias com painéis de concreto de espessuras de 10 e $12 \mathrm{~cm}$, para grande parte das massas específicas.

As tipologias com alvenaria de blocos cerâmicos apresentaram as temperaturas máximas internas menos elevadas dentre todas as tipologias analisadas, e atenderam o nível mínimo de desempenho (M) para ambos os pavimentos e inclusive o nível I de desempenho (temperaturas máximas internas $\leq 30,8^{\circ} \mathrm{C}$ ) para o pavimento intermediário. Já as tipologias com alvenaria de blocos de concreto apresentaram temperaturas máximas internas semelhantes às das tipologias com painéis de concreto de $10 \mathrm{~cm}$ de espessura, 
que atenderam ao nível mínimo de desempenho (M) para a tipologia do pavimento intermediário.

Dentre as tipologias com painéis de concreto, as com massa específica 2400, 2200, 1800 e $1600 \mathrm{~kg} / \mathrm{m}^{3}$ (espessuras 10 e $12 \mathrm{~cm}$ ) e as tipologias com painéis de concreto de massa específica $2000 \mathrm{~kg} / \mathrm{m}^{3}$ (espessura $10 \mathrm{~cm}$ ) atenderam ao nível mínimo de desempenho (M) para a tipologia do pavimento intermediário. As diferenças nas temperaturas máximas internas observadas para as tipologias ocorreram principalmente devido à variação das espessuras dos painéis de concreto utilizados.

Em relação ao pavimento foram observadas diferenças na temperatura máxima interna entre as tipologias dos dois pavimentos em cerca de $1^{\circ} \mathrm{C}$, sendo que a tipologia da cobertura apresentou em todos os casos as temperaturas mais elevadas.

Diante das análises para as condições críticas de inverno e verão, observou-se dentre as tipologias multipavimentos com painéis de concreto, que o uso de concreto com $12 \mathrm{~cm}$ de espessura e massas específicas 2400 e $2200 \mathrm{~kg} / \mathrm{m}^{3}$ representou um melhor desempenho em ambas as estações. Porém, apesar das tipologias com painéis de concreto de massa específica $2200 \mathrm{~kg} / \mathrm{m}^{3}$ terem apresentado desempenho semelhante, a escolha de concreto de massa específica $2400 \mathrm{~kg} / \mathrm{m}^{3}$, torna-se viável por questões econômicas.

\subsubsection{Análise Geral do Desempenho Térmico das Tipologias}

\section{Habitação Térrea}

Diante da análise geral das tipologias térreas localizadas nas cidades de Caxias do Sul (Zona Bioclimática 1), Florianópolis (Zona Bioclimática 3), Brasília (Zona Bioclimática 4), Santos (Zona Bioclimática 5) e Presidente Prudente (Zona Bioclimática 6), observou-se que durante o verão para as habitações térreas executadas para essas localidades não foi atendido nenhum dos níveis de desempenho de acordo com a norma (ABNT, 2008).

Especificamente sobre o resultado das simulações computacionais para as tipologias térreas com os painéis de referência (alvenaria de blocos cerâmicos e blocos de concreto), de forma geral observou-se que o desempenho térmico esteve bastante próximo para os dois tipos de blocos utilizados, especialmente para as tipologias com laje (plana ou inclinada). As tipologias com alvenaria de blocos cerâmicos apresentaram desempenho térmico modestamente superior às com bloco de concreto no inverno. Já no verão, as tipologias com blocos de concreto apresentaram desempenho modestamente superior. Além disso, de maneira geral, as tipologias com painéis de referência apresentaram desempenho térmico semelhante às com painéis de concreto de 10 e $12 \mathrm{~cm}$ de espessura, para todos os valores de massa específica. Para as tipologias analisadas, os resultados obtidos indicam 
que o bloco cerâmico mostra-se mais indicado em regiões mais frias e o bloco de concreto para regiões com temperaturas mais elevadas.

Para as tipologias térreas com painéis de concreto no intervalo de dados analisados (massa específica do concreto variando de 1600 a $2400 \mathrm{~kg} / \mathrm{m}^{3}$ e espessuras dos painéis de $8 \mathrm{~cm}, 10 \mathrm{~cm}$ e $12 \mathrm{~cm}$ ), a espessura apresentou maior influência sobre os resultados das simulações do que a alteração de massa específica. O aumento de massa específica dos concretos pouco influenciou os resultados das temperaturas internas; já a variação de espessura, juntamente com o tipo de cobertura foram os aspectos determinantes nos resultados. Especificamente as tipologias térreas com painéis de concreto de $12 \mathrm{~cm}$ de espessura e massas específicas 2400 e $2200 \mathrm{~kg} / \mathrm{m}^{3}$ atenderam para algumas localidades aos requisitos de desempenho tanto para inverno quanto para verão.

Observou-se, ainda, que dentre os três tipos de cobertura, consideradas nas simulações, as sem laje apresentaram, em média, redução de $1^{\circ} \mathrm{C}$ na temperatura mínima interna no inverno e aumento de $2^{\circ} \mathrm{C}$ na temperatura máxima interna no verão, em relação às habitações com laje. Pode-se verificar também que a posição da laje, plana ou inclinada, de forma geral, não promoveu alterações significativas no valor da temperatura das tipologias analisadas para uma mesma massa específica. Porém, observou-se que as habitações com laje plana apresentaram melhor desempenho para inverno e as com laje inclinada para verão. Para o inverno percebeu-se a pouca influência das vedações, nesse caso a cobertura se destaca como fator determinante dos níveis de desempenho.

O Quadro 13 apresenta uma síntese das características das tipologias térreas com melhor desempenho térmico para as cidades analisadas, tanto para inverno quanto para verão, mesmo em casos onde não são atendidos os níveis de desempenho estabelecidos por norma (ABNT, 2008). 
Quadro 13. Quadro resumo dos resultados das simulações computacionais para a tipologia térrea.

\begin{tabular}{|c|c|c|c|c|c|c|}
\hline \multicolumn{7}{|c|}{ Tipologia Térrea } \\
\hline \multirow{2}{*}{$\begin{array}{c}\text { Zona } \\
\text { Bioclimática }\end{array}$} & \multirow{2}{*}{ Cidade } & \multicolumn{2}{|c|}{ Painel } & \multicolumn{2}{|c|}{$\begin{array}{c}\text { Nível de } \\
\text { Desempenho } \\
\text { (ABNT, 2008) }\end{array}$} & \multirow[t]{2}{*}{ Cobertura } \\
\hline & & $\begin{array}{l}\text { Espessura } \\
(\mathrm{cm})\end{array}$ & $\begin{array}{c}\text { Massa } \\
\text { Específica }\left(\mathrm{kg} / \mathrm{m}^{3}\right)\end{array}$ & Inverno & Verão & \\
\hline 1 & Caxias do Sul - RS & 12 & 2400 & $M$ & - & \multirow{15}{*}{$\begin{array}{l}\text { Inverno } \\
\text { Laje Plana }\end{array}$} \\
\hline \multirow{2}{*}{2} & \multirow{2}{*}{ Ponta Grossa - PR } & \multirow{2}{*}{12} & 2200 & $\mathrm{M}$ & $\mathrm{M}$ & \\
\hline & & & 2400 & $M$ & $M$ & \\
\hline 3 & São Paulo - SP & 12 & 2400 & $M$ & $M$ & \\
\hline \multirow{2}{*}{3} & \multirow{2}{*}{ Florianópolis - SC } & \multirow{2}{*}{12} & 2200 & - & - & \\
\hline & & & 2400 & - & - & \\
\hline 4 & São Carlos - SP & 12 & 2400 & M & $M$ & \\
\hline 4 & Brasília - DF & 12 & 2400 & M & - & \\
\hline \multirow{2}{*}{5} & \multirow{2}{*}{ Santos - SP } & \multirow{2}{*}{12} & 2200 & - & - & \\
\hline & & & 2400 & - & - & \\
\hline \multirow{2}{*}{6} & \multirow{2}{*}{$\begin{array}{l}\text { Presidente } \\
\text { Prudente - SP }\end{array}$} & \multirow{2}{*}{12} & 2200 & M & - & \\
\hline & & & 2400 & $M$ & - & \\
\hline 7 & Teresina $-\mathrm{PI}$ & 12 & 2400 & $M$ & $M$ & \\
\hline \multirow{2}{*}{8} & \multirow{2}{*}{ Belém - PA } & \multirow{2}{*}{12} & 2200 & $M$ & $M$ & \\
\hline & & & 2400 & $M$ & $M$ & \\
\hline
\end{tabular}

\section{Habitação Multipavimentos}

Para a tipologia multipavimentos foram observadas algumas características que se repetem na maioria dos casos. Para todas as zonas bioclimáticas, observou-se que durante o verão, considerando as simulações tanto para as tipologias do pavimento intermediário quanto da cobertura, executados com todos os tipos de painéis, pelo menos o nível mínimo de desempenho foi atendido de acordo com a norma para algumas localidades (ABNT, 2008). Observa-se ainda que para todas as zonas bioclimáticas com exceção da terceira (Florianópolis) e das zonas que dispensam verificação (Presidente Prudente, Teresina e Belém), o nível de desempenho mínimo (M) (temperaturas mínimas internas $\geq$ temperaturas mínimas externas + 3) para o inverno foi atendido. No verão as temperaturas máximas internas das tipologias multipavimentos mostraram-se menos elevadas do que as temperaturas das tipologias térreas para a mesma localidade.

Para as tipologias multipavimentos com painéis de referência (alvenaria de blocos cerâmicos e blocos de concreto), entre os tipos de bloco, de forma geral, não foram observadas alterações significativas nas temperaturas internas para o inverno e verão. Porém, quando atendido algum nível de desempenho, em grande parte dos casos o painel de alvenaria de blocos cerâmicos estava entre os painéis adequados de acordo com os 
níveis de desempenho estabelecidos pela NBR 15575-1 (ABNT, 2008). Principalmente para as zonas bioclimáticas mais quentes (zonas bioclimáticas 6,7 e 8 ), as tipologias com alvenaria de blocos cerâmicos destacaram-se com desempenho satisfatório para verão e inverno. Já as tipologias com alvenaria de blocos de concreto apresentaram em grande parte dos casos desempenho semelhante ao das tipologias com painéis de concreto de 10 $\mathrm{cm}$ de espessura.

Para todas as tipologias multipavimentos analisadas, igualmente ao que ocorreu para as tipologias térreas, dentre as características dos painéis de concreto (massa específica do concreto variando de 1600 a $2400 \mathrm{~kg} / \mathrm{m}^{3}$ e espessuras de $8 \mathrm{~cm}, 10 \mathrm{~cm}$ e $12 \mathrm{~cm}$ ), a espessura dos mesmos exerceu maior influência sobre os resultados das temperaturas internas do que a variação de massa específica dos concretos.

No inverno as tipologias com painéis de $8 \mathrm{~cm}$ de espessura apresentaram menores temperaturas mínimas internas para todas as massas específicas e as tipologias com painéis de $12 \mathrm{~cm}$ de espessura, principalmente para os concretos com massas específicas 2400 e $2200 \mathrm{~kg} / \mathrm{m}^{3}$, apresentaram temperaturas mínimas internas mais elevadas; já para o verão ocorreu o inverso, as tipologias com painéis de $8 \mathrm{~cm}$ de espessura apresentaram temperaturas máximas internas mais elevadas e os painéis com espessura de $12 \mathrm{~cm}$ apresentaram temperaturas máximas internas menores.

Semelhante aos resultados para a tipologia térrea, na tipologia multipavimentos, os painéis de concreto de $12 \mathrm{~cm}$ de espessura e massa específica 2400 e $2200 \mathrm{~kg} / \mathrm{m}^{3}$, destacaram-se em relação ao atendimento dos níveis de desempenho, tanto para as tipologias da cobertura quanto para as do pavimento intermediário, em ambas as estações. Porém, a adoção de concreto com massa específica $2400 \mathrm{~kg} / \mathrm{m}^{3} \mathrm{em}$ grande parte dos casos explica-se por maior viabilidade econômica pelo fato desse tipo de concreto ser o menos oneroso dentre os demais.

Em relação ao pavimento, tanto no verão quanto no inverno as tipologias da cobertura apresentaram temperaturas mínimas internas (inverno) e máximas internas (verão) mais elevadas quando comparadas às tipologias do pavimento intermediário, sendo que a diferença entre as mesmas chega à $1^{\circ} \mathrm{C}$ em grande parte dos casos. $\mathrm{O}$ comportamento das tipologias da cobertura assemelhou-se ao comportamento da tipologia térrea sem laje.

O Quadro 14 apresenta uma síntese das características das tipologias multipavimentos com melhor desempenho térmico para as cidades analisadas, tanto para inverno quanto para verão, mesmo em casos onde não são atendidos os níveis de desempenho estabelecidos por norma (ABNT, 2008). 
Quadro 14. Quadro resumo dos resultados das simulações computacionais para a tipologia multipavimentos.

\begin{tabular}{|c|c|c|c|c|c|c|}
\hline \multicolumn{7}{|c|}{ Tipologia Multipavimentos } \\
\hline \multirow{2}{*}{$\begin{array}{c}\text { Zona } \\
\text { Bioclimática }\end{array}$} & \multirow{2}{*}{ Cidade } & \multicolumn{2}{|c|}{ Painel } & \multicolumn{2}{|c|}{$\begin{array}{c}\text { Nível de } \\
\text { Desempenho } \\
\text { (ABNT, 2008) } \\
\end{array}$} & \multirow[t]{2}{*}{ Cobertura } \\
\hline & & $\begin{array}{l}\text { Espessura } \\
\qquad(\mathrm{cm})\end{array}$ & $\begin{array}{c}\text { Massa } \\
\text { Específica }\left(\mathrm{kg} / \mathrm{m}^{3}\right)\end{array}$ & Inverno & Verão & \\
\hline \multirow{2}{*}{1} & \multirow{2}{*}{ Caxias do Sul - RS } & \multirow{2}{*}{12} & 2200 & - & M & \multirow{18}{*}{$\begin{array}{c}\text { Inverno } \\
\text { Laje Plana } \\
\text { Verão } \\
\text { Laje Plana } 2^{\circ} \text {.Pav }\end{array}$} \\
\hline & & & 2400 & - & $\mathrm{M}$ & \\
\hline 2 & Ponta Grossa - PR & 12 & 2400 & M & M & \\
\hline 3 & São Paulo - SP & 12 & 2400 & - & M & \\
\hline \multirow{2}{*}{3} & \multirow{2}{*}{ Florianópolis - SC } & \multirow{2}{*}{12} & 2200 & - & - & \\
\hline & & & 2400 & - & - & \\
\hline \multirow{2}{*}{4} & \multirow{2}{*}{ São Carlos - SP } & \multirow{2}{*}{12} & 2200 & - & M & \\
\hline & & & 2400 & - & M & \\
\hline \multirow{2}{*}{4} & \multirow{2}{*}{ Brasília - DF } & \multirow{2}{*}{12} & 2200 & $M$ & - & \\
\hline & & & 2400 & M & - & \\
\hline \multirow{2}{*}{5} & \multirow{2}{*}{ Santos - SP } & \multirow{2}{*}{12} & 2200 & - & $\mathrm{M}$ & \\
\hline & & & 2400 & - & $\mathrm{M}$ & \\
\hline \multirow{2}{*}{6} & \multirow{2}{*}{$\begin{array}{l}\text { Presidente } \\
\text { Prudente - SP }\end{array}$} & \multirow{2}{*}{12} & 2200 & $\mathrm{M}$ & $\mathrm{M}$ & \\
\hline & & & 2400 & $\mathrm{M}$ & $\mathrm{M}$ & \\
\hline \multirow{2}{*}{7} & \multirow{2}{*}{ Teresina - PI } & \multirow{2}{*}{12} & 2200 & $\mathrm{M}$ & $\mathrm{M}$ & \\
\hline & & & 2400 & $\mathrm{M}$ & $\mathrm{M}$ & \\
\hline \multirow{2}{*}{8} & \multirow{2}{*}{ Belém - PA } & \multirow{2}{*}{12} & 2200 & $\mathrm{M}$ & $\mathrm{M}$ & \\
\hline & & & 2400 & $M$ & $M$ & \\
\hline
\end{tabular}

\subsection{Desenvolvimento de Concretos}

Com base no resultado das simulações computacionais de desempenho térmico para habitações térreas e multipavimentos, as quais indicaram que o concreto com massa específica em torno de $2400 \mathrm{~kg} / \mathrm{m}^{3}$ apresentou o melhor desempenho térmico, e nas características a ser atendidas pelos concretos estabelecidas anteriormente, foram determinados três traços de concreto para cada tipo de cimento portland (CPII E 32 e CPIII $40 \mathrm{RS}$ ), sendo um traço rico, um médio e um pobre. As Tabelas 21 e 22 apresentam as dosagens finais dos seis tipos de concretos analisados. No fim deste item, são apresentados os traços finais indicados e suas propriedades (Tabelas 31 e 32 ).

Tabela 21. Dosagem para concreto tradicional com CPII E $32\left(1 \mathrm{~m}^{3}\right)$.

\begin{tabular}{c|c|c|c|c|c|c|c|c|}
\hline \multicolumn{2}{|c|}{ Traços } & CPII E 32 & Metacaulin & Areia & Brita 01 & Glenium 51 & Água & a/aglo \\
\hline \multirow{3}{*}{ CPII E 32 } & Rico & 346,76 & 34,68 & 845,76 & 1033,70 & 2,60 & 160,90 & 0,42 \\
\cline { 2 - 9 } & Médio & 296,71 & 29,67 & 857,21 & 1047,70 & 2,23 & 182,18 & 0,56 \\
\cline { 2 - 9 } & Pobre & 263,84 & 26,38 & 880,96 & 1076,73 & 1,98 & 183,10 & 0,63 \\
\hline \multicolumn{7}{c}{ Slump } & $160 \pm \mathbf{1 0} \mathbf{~ m m}$ \\
\hline
\end{tabular}


Tabela 22. Dosagem para concreto tradicional com CPIII $40 \mathrm{RS}\left(1 \mathrm{~m}^{3}\right)$.

\begin{tabular}{c|c|c|c|c|c|c|c|c}
\hline \multicolumn{2}{c|}{ Traços } & CPIII 40 RS & Metacaulin & Areia & Brita 01 & Glenium 51 & Água & a/aglo \\
\hline \multirow{2}{*}{$\begin{array}{c}\text { CPIII 40 } \\
\text { RS }\end{array}$} & Rico & 349,70 & 34,97 & 852,91 & 1042,44 & 2,62 & 162,26 & 0,42 \\
\cline { 2 - 9 } & Médio & 297,66 & 29,77 & 859,93 & 1051,03 & 2,23 & 179,78 & 0,55 \\
\cline { 2 - 9 } & Pobre & 259,33 & 25,93 & 865,90 & 1058,32 & 1,94 & 177,38 & 0,62 \\
\hline \multicolumn{7}{c|}{ Slump } & \multicolumn{6}{c|}{$\mathbf{1 6 0 \pm 1 0 ~} \mathbf{~ m m}$} \\
\hline
\end{tabular}

A Figura 117 apresenta a relação entre o consumo de cimento $\left(\mathrm{kg} / \mathrm{m}^{3}\right)$ e $\mathrm{m}$ (relação agregados secos/cimento em massa).

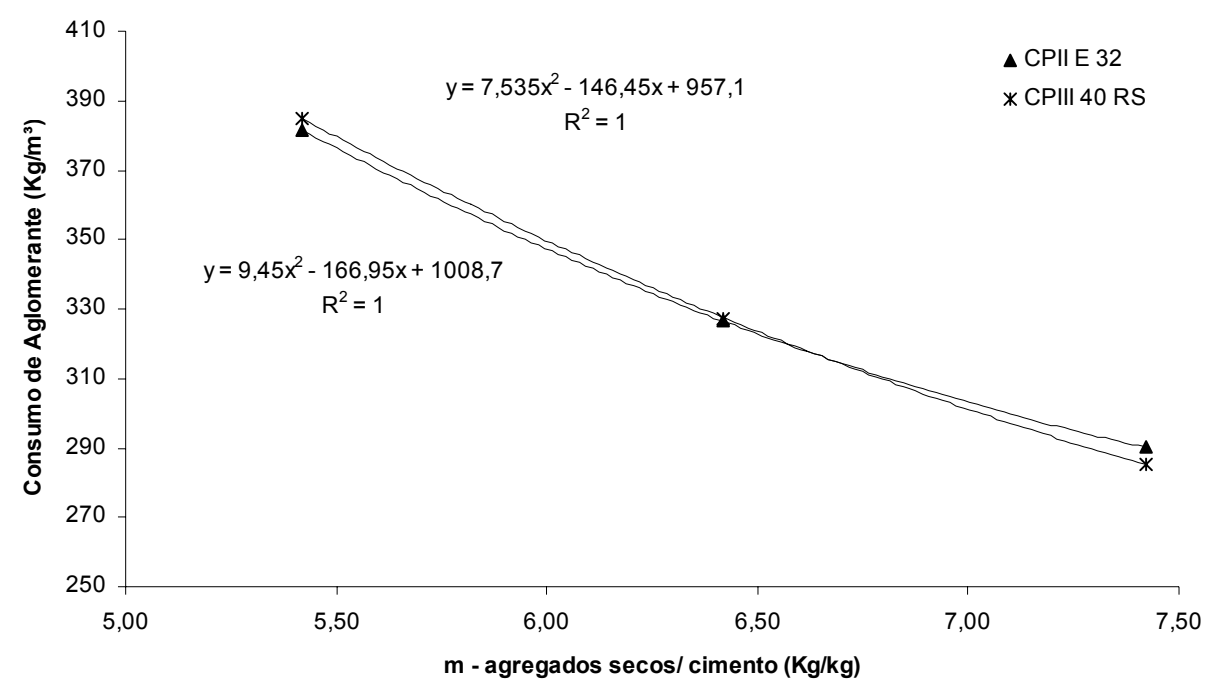

Figura 117. Comportamento do consumo de cimento dos concretos em função de $\mathrm{m}$ (agregados secos/cimento em massa).

A Figura 118 apresenta a relação entre m (agregados secos/cimento em massa) e a relação água/aglomerante (a/aglo).

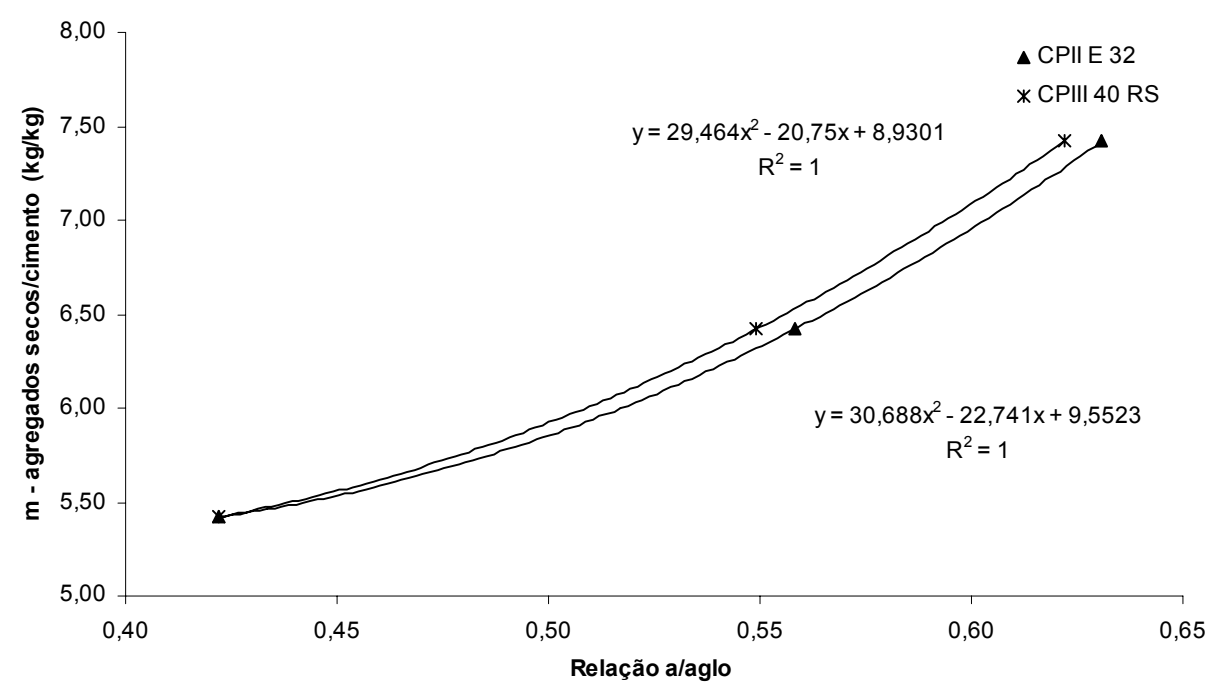

Figura 118. Comportamento de $m$ (relação agregados secos/cimento em massa) em função da relação água/aglo efetiva. 


\subsubsection{Propriedades no Estado Fresco}

\section{Ensaio de abatimento de tronco de cone}

O ensaio de abatimento de tronco de cone foi realizado segundo as recomendações da NBR 7223 (ABNT, 1992 d) e repetidos até que a consistência necessária fosse obtida. Os concretos analisados apresentaram trabalhabilidade e coesão adequadas para a moldagem dos corpos-de-prova. Não foi observada a ocorrência de exsudação ou segregação dos agregados nos concretos em estudo. Os valores de abatimento do tronco de cone (slump test) para os seis traços analisados estiveram na faixa pré-estabelecida de $160 \pm 10 \mathrm{~mm}$ (Figura 119).

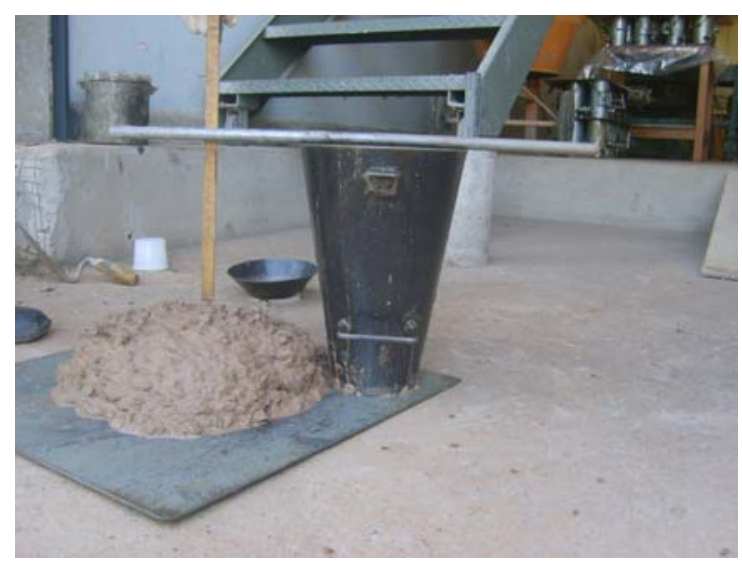

Figura 119. Ensaio de abatimento de tronco de cone.

Massa específica fresca e teor de ar incorporado

A massa específica fresca e o teor de ar incorporado dos concretos foram determinados segundo as recomendações de NBR 9833 (ABNT, 1987 d) (Tabela 23). A massa específica no estado fresco variou entre 2388,8 e $2444,9 \mathrm{~kg} / \mathrm{m}^{3}$.

Observa-se que os valores de teor de ar incorporado nos concretos variaram entre 0,6 e 2,8\%. O teor de ar incorporado para os concretos com CPIII 40 RS médio e pobre apresentaram valores mais elevados. Segundo Neville (1997) o volume total de vazios de um dado volume de concreto interfere na resistência do concreto, sendo que o teor ótimo de ar incorporado para concretos com agregado de tamanho máximo $19 \mathrm{~mm}$ e consumo de cimento de $307 \mathrm{~kg} / \mathrm{m}^{3}$ é de $6 \%$; o mesmo autor cita a $\mathrm{ACl} 20.2 \mathrm{R}-92$ na qual o teor de ar recomendado para concretos com agregado com tamanho máximo $19 \mathrm{~mm}$, em nível de exposição moderada e severa são respectivamente, 5 e $6 \%$. 
Tabela 23. Valores da massa específica fresca e do teor de ar incorporado dos concretos.

\begin{tabular}{c|c|c|c}
\hline \multicolumn{3}{c}{ Massa Específica Fresca e Teor de Ar Incorporado } \\
\hline \multirow{2}{*}{ Traços } & $\begin{array}{c}\text { Massa } \\
\text { Específica } \\
\text { Fresca }\left(\mathbf{k g} / \mathbf{m}^{3}\right)\end{array}$ & $\begin{array}{c}\text { Ar Incorporado } \\
(\%)\end{array}$ \\
\hline \multirow{3}{*}{ CPII E 32 } & Rico & 2424,6 & 2,4 \\
\cline { 2 - 4 } & Médio & 2415,7 & 1,3 \\
\cline { 2 - 4 } & Pobre & 2433,0 & 0,6 \\
\hline \multirow{3}{*}{ CPIII 40 RS } & Rico & 2444,9 & 2,0 \\
\cline { 2 - 4 } & Médio & 2420,4 & 1,6 \\
\cline { 2 - 4 } & Pobre & 2388,8 & 2,8 \\
\hline
\end{tabular}

\subsubsection{Propriedades no Estado Endurecido}

\section{Resistência à compressão}

A resistência à compressão dos concretos foi determinada segundo as recomendações da NBR 5739 (ABNT, 1994 c) (Figura 120), utilizando-se corpos-de-prova cilíndricos, com $100 \mathrm{~mm}$ de diâmetro e $200 \mathrm{~mm}$ de altura, nas idades de 12 horas, 1,7 e 28 dias. Foram utilizados 3 corpos-de-prova por idade para as idades de 12 horas, 1 e 7 dias e para a idade de 28 dias foram moldados 5 corpos-de-prova. As Tabelas 24 e 25 apresentam os resultados da resistência à compressão dos concretos.

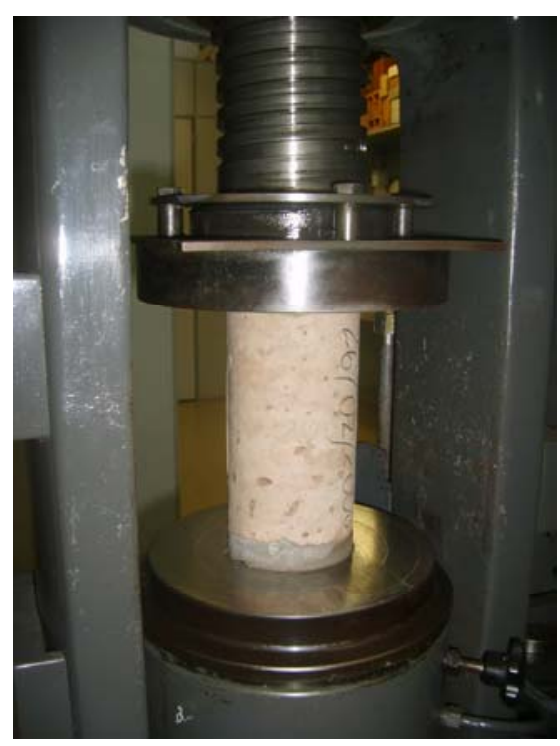

Figura 120. Execução do ensaio de resistência à compressão. 
Tabela 24. Valores da resistência à compressão dos concretos com CPII E 32.

\begin{tabular}{l|c|c|c|c|c}
\hline \multicolumn{4}{c}{ Resistência à Compressão - Concretos com CPII E 32} \\
\hline \multirow{2}{*}{ Traços } & \multicolumn{4}{c}{ Resistência à Compressão (MPa) } \\
\cline { 3 - 6 } & & 12 hrs & 1 Dia & 7 Dias & 28 Dias \\
\hline \multirow{3}{*}{ CPII E 32 } & Rico & 2,6 & 9,9 & 39,5 & 51,3 \\
\cline { 2 - 6 } & Médio & 1,4 & 6,1 & 26,5 & 36,0 \\
\cline { 2 - 6 } & Pobre & 0,9 & 3,9 & 21,2 & 28,6 \\
\hline
\end{tabular}

Tabela 25. Valores da resistência à compressão dos concretos com CPIII 40 RS.

\begin{tabular}{l|c|c|c|c|c}
\hline \multicolumn{5}{c}{ Resistência à Compressão - Concretos com CPIII 40 RS } \\
\hline \multirow{2}{*}{ Traços } & \multicolumn{4}{c}{ Resistência à Compressão (MPa) } \\
\cline { 3 - 6 } & & $\mathbf{1 2} \mathbf{h}$ & 1 Dia & 7 Dias & 28 Dias \\
\hline \multirow{3}{*}{ CPIII 40 RS } & Rico & 2,5 & 8,0 & 37,6 & 48,7 \\
\cline { 2 - 6 } & Médio & 1,4 & 4,4 & 22,8 & 31,6 \\
\cline { 2 - 6 } & Pobre & 0,9 & 2,4 & 18,7 & 23,7 \\
\hline
\end{tabular}

Nos corpos-de-prova com os dois tipos de cimento Portland analisados (CPII E 32 e CPIII 40 RS), foi possível realizar a desmoldagem para a avaliação da resistência à compressão às 12 horas. Observou-se que para essa idade os valores de resistência à compressão foram semelhantes (Tabelas 24 e 25) para os dois tipos de cimento. Já para as demais idades (1, 7 e 28 dias) os valores foram mais elevados para os traços com CPII $E$ 32.

A Figura 121 apresenta os valores de resistência à compressão às 12 horas de acordo com a relação água/aglomerante.

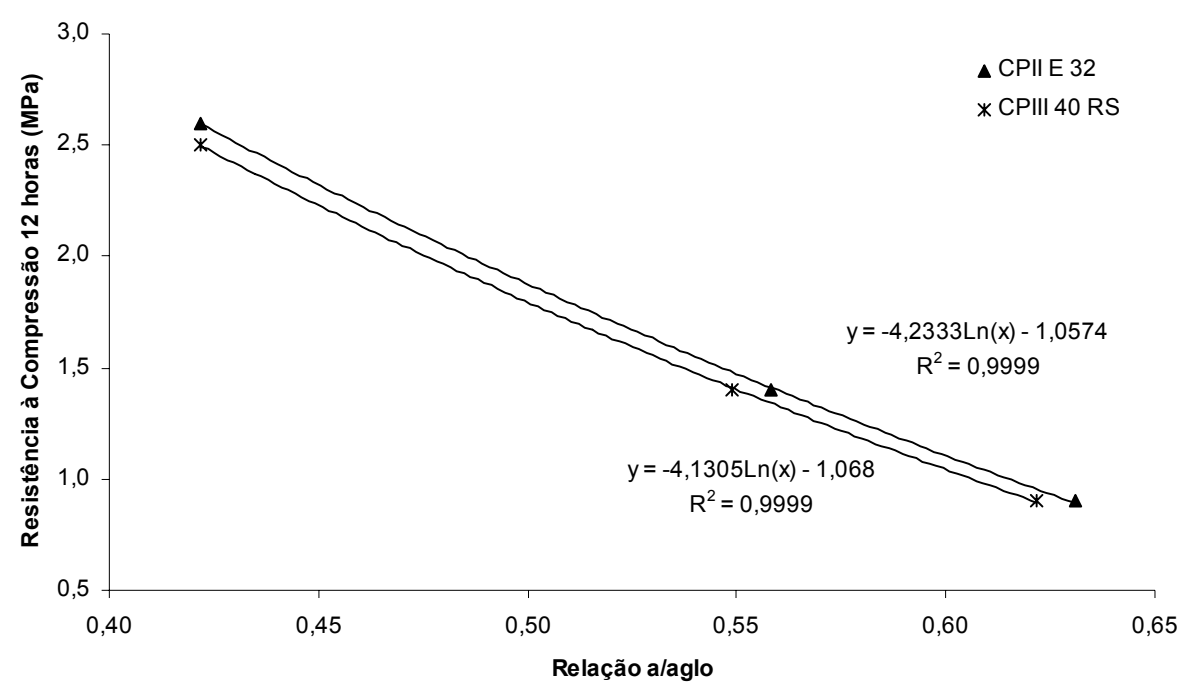

Figura 121. Comportamento da resistência à compressão às 12 horas dos concretos em função da relação a/aglo efetiva. 
As Figuras 122 e 123 apresentam respectivamente a relação entre a resistência à compressão a 1 e 7 dias de idade e a relação água/aglomerante (a/aglo). Os valores da relação água/aglomerante foram semelhantes para os concretos com ambos os cimentos. Os valores de resistência à compressão para a idade de 1 dia foram superiores em cerca de $30 \%$ em média para os concretos com CPII E 32; e para a idade de 7 dias foi observado um aumento de $10 \%$ em média para os concretos com esse tipo de cimento.

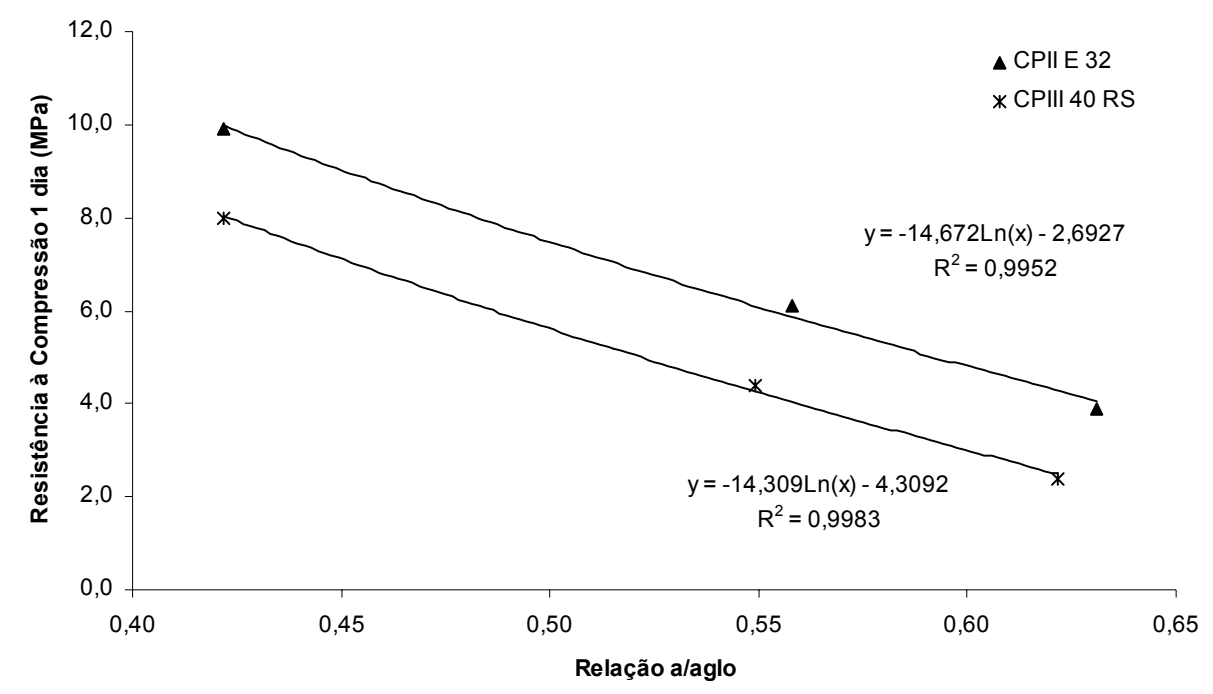

Figura 122. Comportamento da resistência à compressão a 1 dia dos concretos em função da relação a/ aglo efetiva.

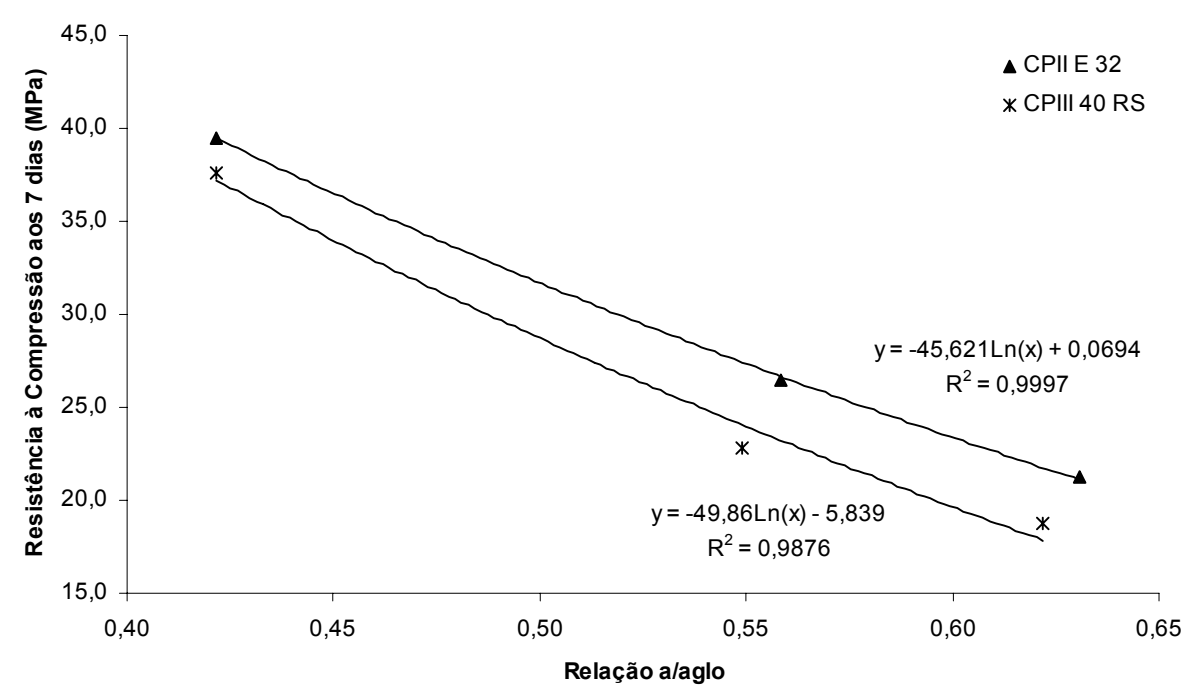

Figura 123. Comportamento da resistência à compressão aos 7 dias dos concretos em função da relação a/aglo efetiva. 
A Figura 124 apresenta a relação entre a resistência à compressão aos 28 dias e a relação água/aglomerante (a/aglo), na qual se observou níveis próximos dos valores da relação água/aglomerante para os concretos analisados.

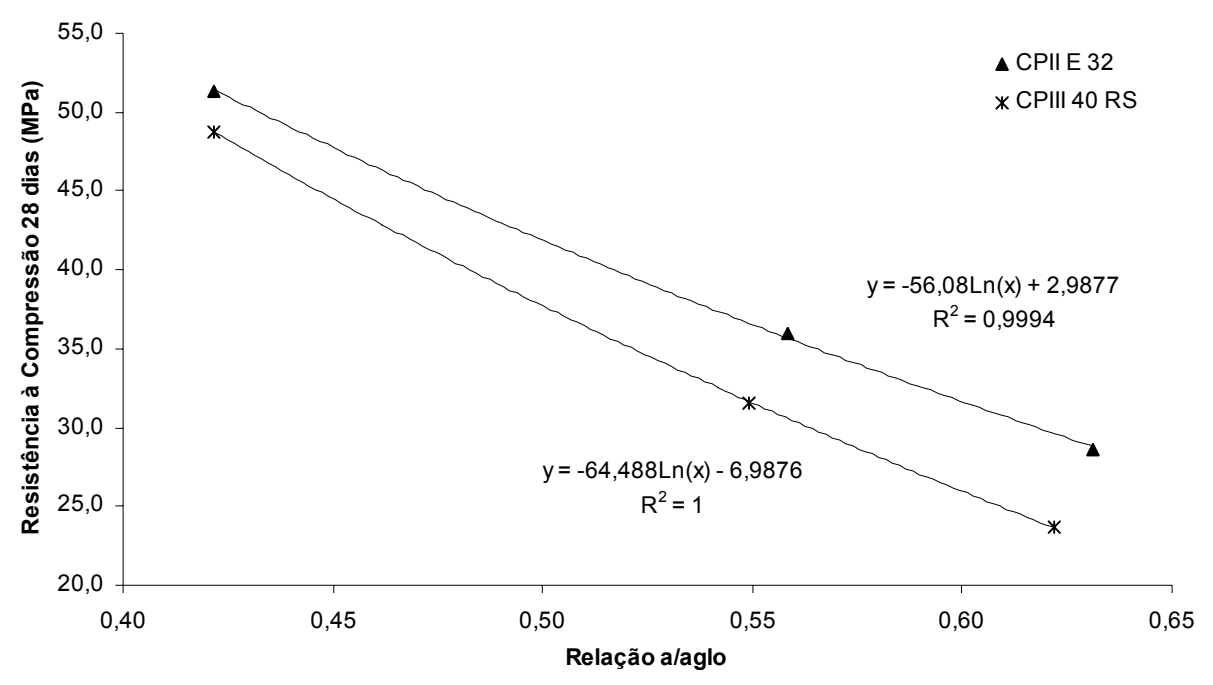

Figura 124. Comportamento da resistência à compressão aos 28 dias dos concretos em função da relação a/aglo efetiva.

As Figuras 125 e 126 apresentam uma síntese do comportamento da resistência à compressão para todas as idades (12 horas, 1, 7 e 28 dias) dos concretos com CPII E 32 e CPIII 40 RS em função da relação água/aglomerante efetiva.

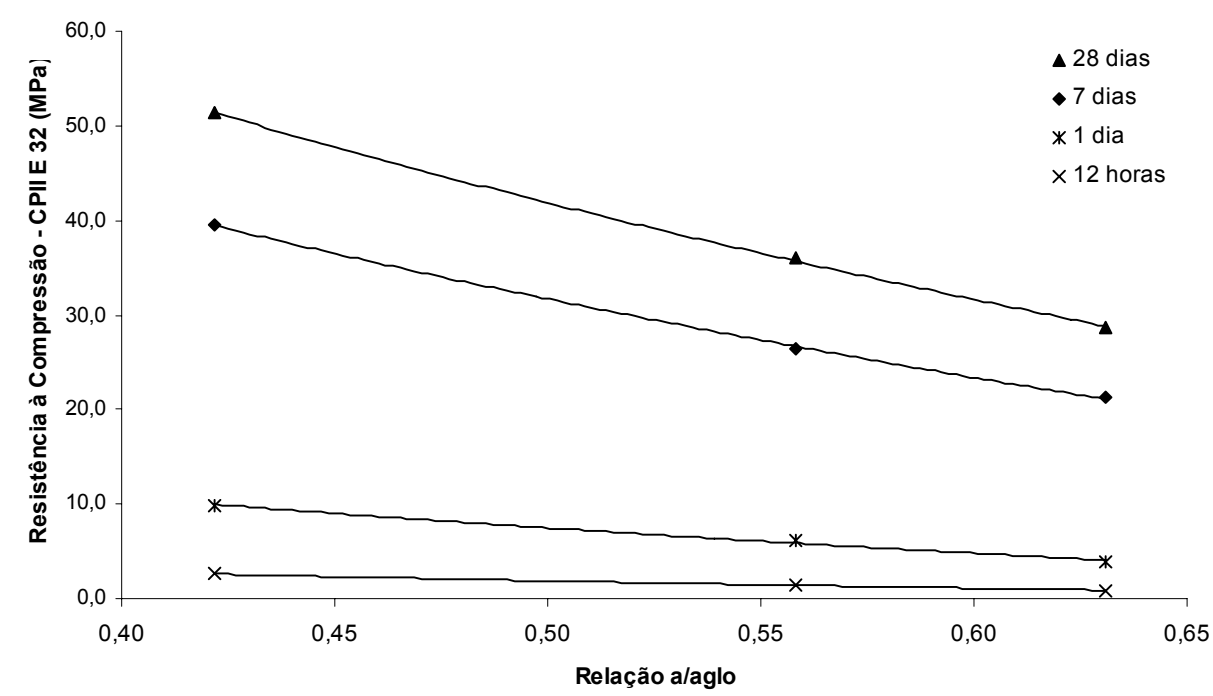

Figura 125. Comportamento da resistência à compressão (todas as idades) dos concretos com CPII E 32 em função da relação a/aglo efetiva. 


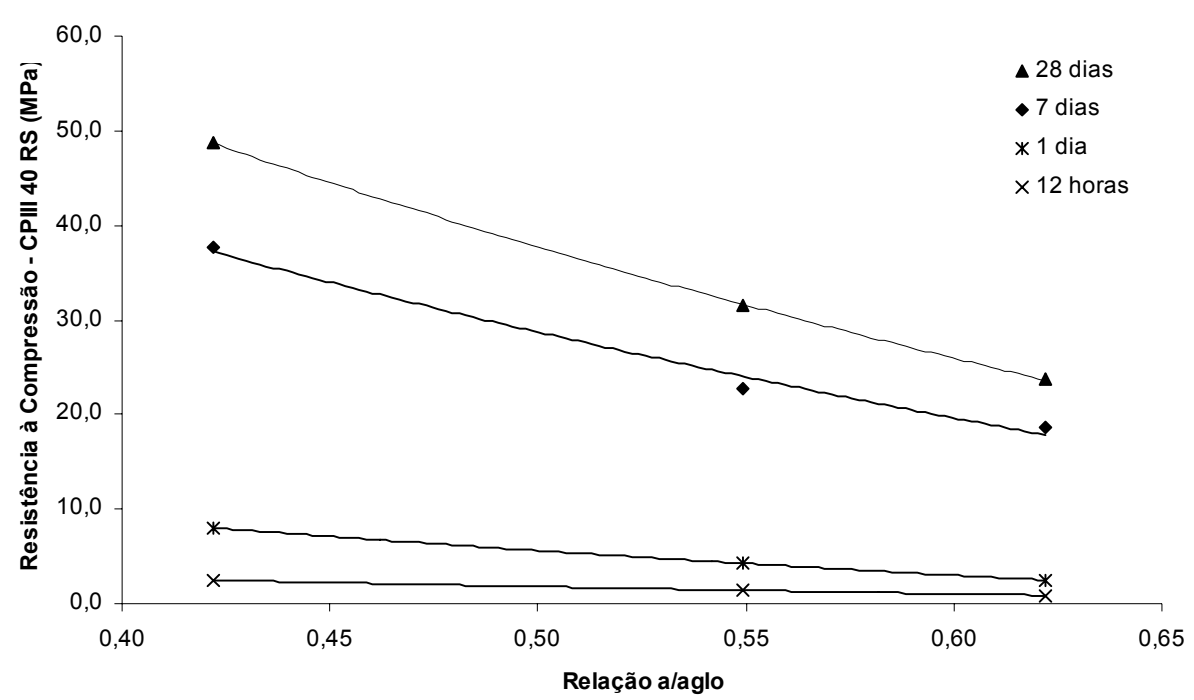

Figura 126. Comportamento da resistência à compressão (todas as idades) dos concretos com CPIII 40 RS em função da relação a/aglo efetiva.

Resistência à tração por compressão diametral

A resistência à tração por compressão diametral foi determinada segundo as recomendações da NBR 7222 (ABNT, 1994 d) (Figura 127). Foram determinados os valores para concretos com idades de 28 dias através do ensaio de 5 corpos-de-prova cilíndricos com $100 \mathrm{~mm}$ de diâmetro e $200 \mathrm{~mm}$ de altura para cada dosagem. Os valores da resistência à tração por compressão diametral dos concretos (Tabela 26 e Figura 128) foram em média $8,72 \%$ (relação Rt/Rc (\%)) dos valores da resistência à compressão obtidos aos 28 dias.

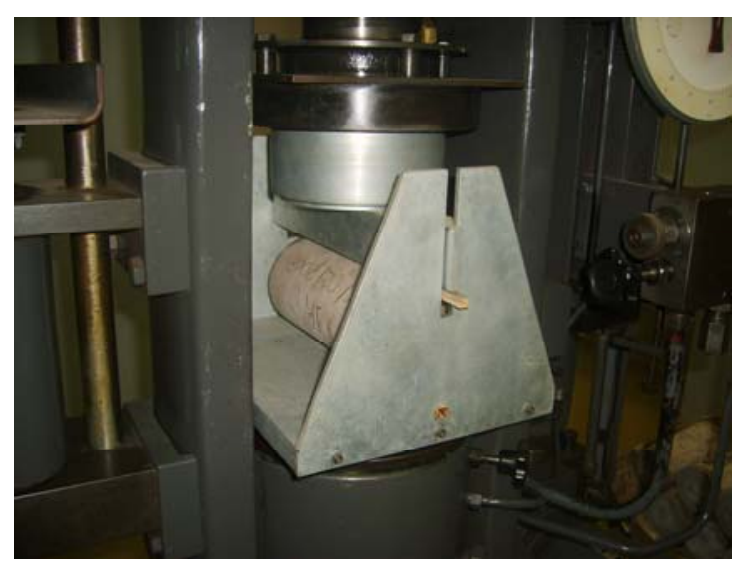

Figura 127. Execução do ensaio de resistência à tração por compressão diametral. 
Tabela 26. Valores da resistência à tração por compressão diametral.

\begin{tabular}{c|c|c|c}
\hline \multicolumn{4}{c}{ Resistência à Tração por Compressão Diametral } \\
\hline \multirow{2}{*}{ Traços } & $\begin{array}{c}\text { Resistência à Tração por } \\
\text { Compressão Diametral (MPa) } \\
\text { 28 dias }\end{array}$ & $\begin{array}{c}\text { \% Rt/ Rc } \\
\text { (28 dias) }\end{array}$ \\
\hline \multirow{3}{*}{ CPII E 32 } & Rico & 3,79 & 7,38 \\
\cline { 2 - 4 } & Médio & 2,79 & 8,16 \\
\cline { 2 - 4 } & Pobre & 2,63 & 9,62 \\
\hline \multirow{3}{*}{ CPIII 40 RS } & Rico & 3,43 & 7,27 \\
\cline { 2 - 4 } & Médio & 2,93 & 9,42 \\
\cline { 2 - 4 } & Pobre & 2,48 & 10,45 \\
\hline
\end{tabular}

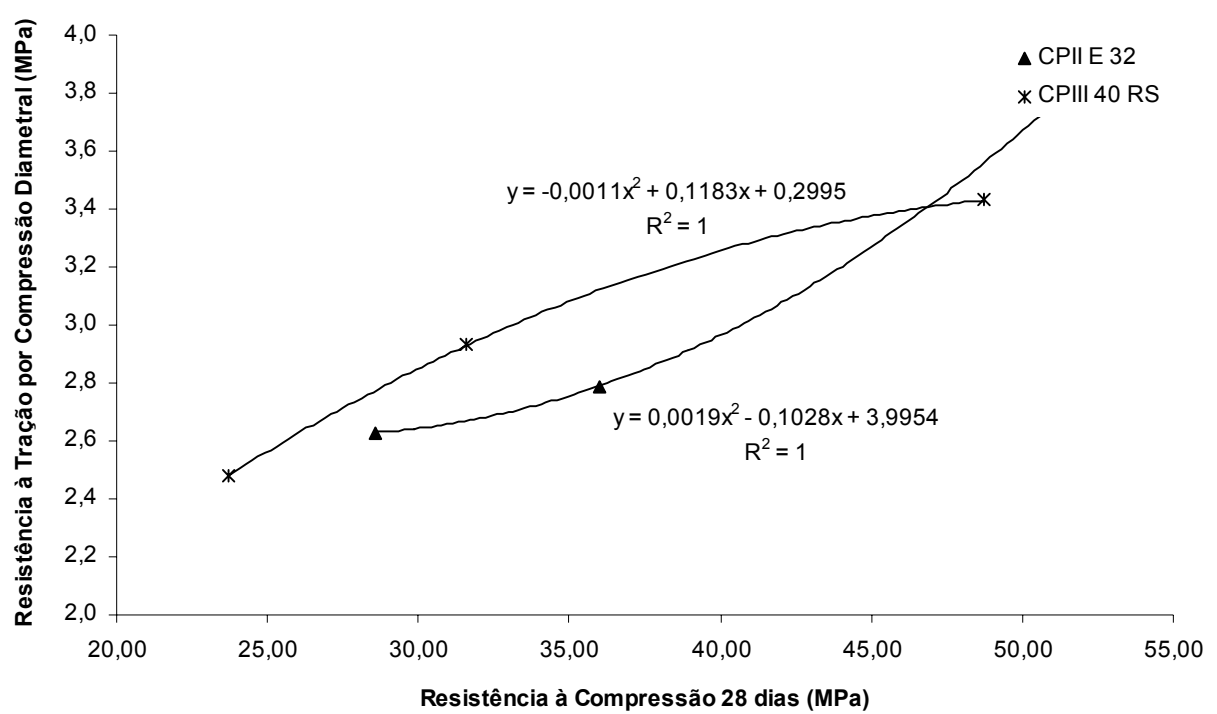

Figura 128. Comportamento da resistência à tração por compressão diametral dos concretos com CPII E 32 e CPIII 40 RS em função da resistência à compressão aos 28 dias.

Segundo Mehta; Monteiro (1994) a razão resistência à tração/compressão depende do nível geral da resistência à compressão, quanto maior a resistência à compressão, menor será a relação. A razão entre a resistência à tração direta/compressão é de 10 a 11\% para concreto de baixa resistência, 8 a $9 \%$ para concreto de média resistência e $7 \%$ para concreto de alta resistência.

\section{Modulo de elasticidade}

Os valores do módulo de deformação dos concretos analisados variaram entre 31,7 e 44,1 GPa (Tabelas 27 e 28). 
Tabela 27. Módulo de Deformação, Concretos com CPII E 32.

\begin{tabular}{c|c|c|c}
\hline \multicolumn{4}{c}{ Módulo de Deformação } \\
\hline \multirow{2}{*}{ Traços } & $\begin{array}{c}\text { Módulo de } \\
\text { Elasticidade (GPa) } \\
\text { (28 dias) }\end{array}$ & $\begin{array}{c}\text { Módulo de } \\
\text { Elasticidade (GPa) } \\
\text { (28 dias) NBR 6118 }\end{array}$ \\
\hline \multirow{3}{*}{ CPII E 32 } & Rico & 43,3 & 40,1 \\
\cline { 2 - 4 } & Médio & 37,8 & 33,6 \\
\cline { 2 - 4 } & Pobre & 32,3 & 30,0 \\
\hline
\end{tabular}

Tabela 28. Módulo de Deformação, Concretos com CPIII 40 RS.

\begin{tabular}{c|c|c|c}
\hline \multicolumn{4}{c}{ Módulo de Deformação } \\
\hline \multirow{2}{*}{ Traços } & $\begin{array}{c}\text { Módulo de } \\
\text { Elasticidade (GPa) } \\
\text { (28 dias) }\end{array}$ & $\begin{array}{c}\text { Módulo de } \\
\text { Elasticidade (GPa) } \\
\text { (28 dias) NBR 6118 }\end{array}$ \\
\hline \multirow{3}{*}{ CPIII 40 RS } & Rico & 44,1 & 39,1 \\
\cline { 2 - 4 } & Médio & 35,1 & 31,2 \\
\cline { 2 - 4 } & Pobre & 31,7 & 27,8 \\
\hline
\end{tabular}

Tendo como referência a NBR 6118 (2004), pode-se estimar o valor do módulo de elasticidade aos 28 dias por meio da expressão:

$$
\begin{aligned}
& \qquad E_{c i}=5600 f c k^{1 / 2} \\
& E_{c i}=\text { módulo de elasticidade } \\
& f c k=\text { resistência característica do concreto } \\
& \text { Onde } E_{c i} \text { e } f c k \text { são dados em MPa. }
\end{aligned}
$$

Por meio da expressão foram determinados os valores estimados para o módulo de elasticidade para os concretos estudados. Todos os valores encontrados estão próximos aos recomendados por norma (ABNT, 2004).

As Figuras 129 e 130 apresentam o comportamento da resistência à compressão aos 28 dias em relação ao módulo de deformação para os concretos com CPII E 32 e CPIII 40 RS respectivamente. 


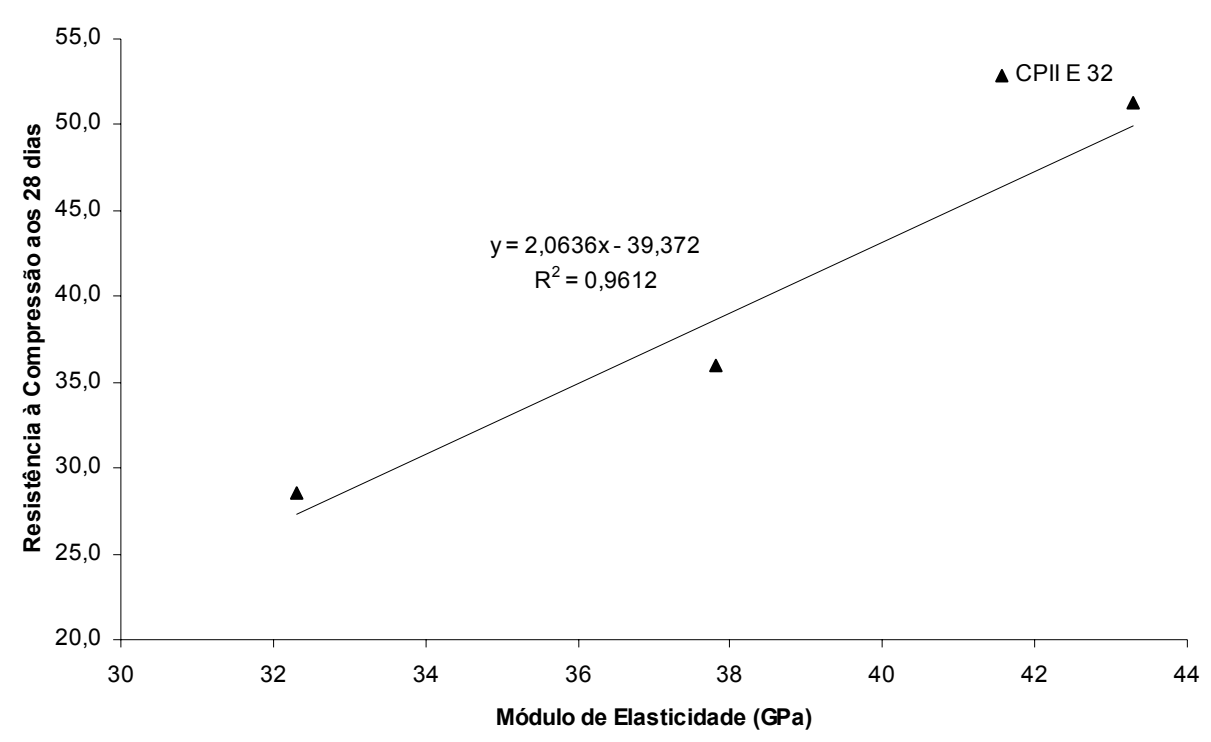

Figura 129. Comportamento da resistência à compressão aos 28 dias em relação ao módulo de elasticidade para os concretos com CPII E 32.

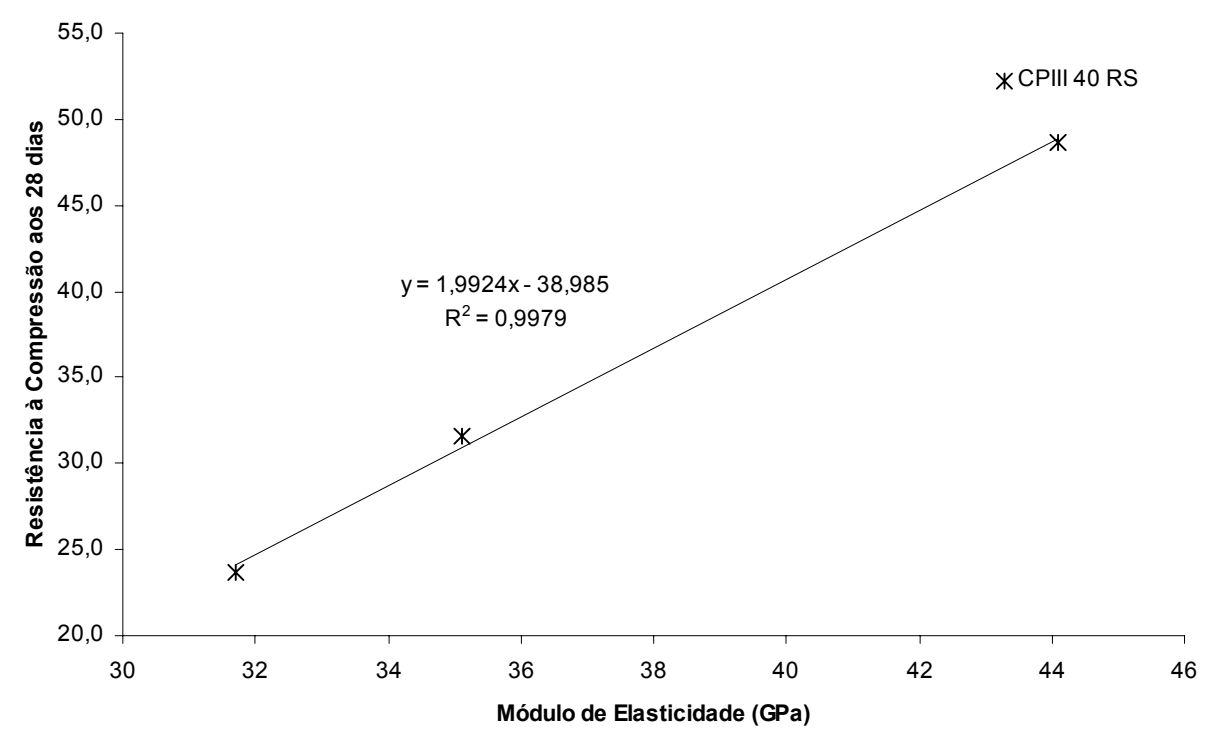

Figura 130. Comportamento da resistência à compressão aos 28 dias em relação ao módulo de elasticidade para os concretos com CPII 40 RS.

Absorção de água por imersão e índice de vazios

A determinação dos valores de absorção de água por imersão e índice de vazios dos concretos foi realizada segundo as recomendações da NBR 9778 (ABNT, 1987 c) (Figura 131) para os concretos com idade de 28 dias, utilizando-se 3 corpos-de-prova cilíndricos com 100 mm de diâmetro e 200 mm de altura para cada tipo de concreto (Tabela 29 e 30). 


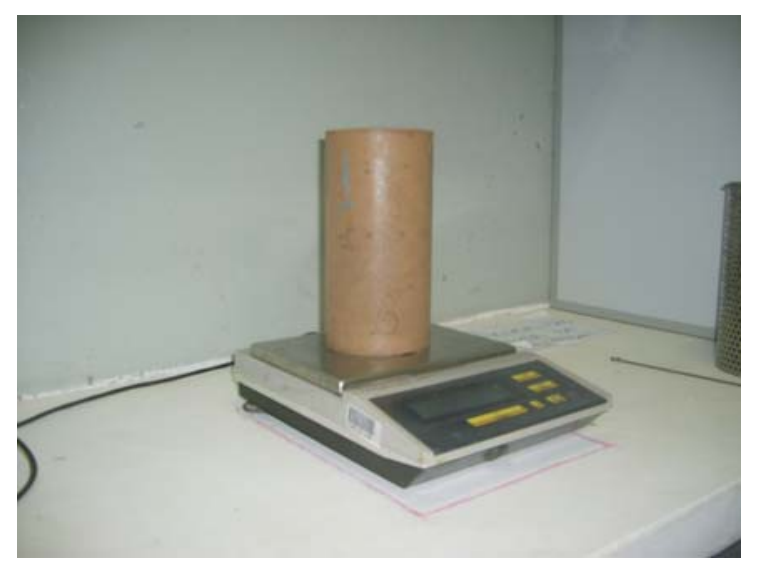

Figura 131. Ensaio de absorção de água por imersão e índice de vazios - Pesagem do corpode-prova saturado.

Tabela 29. Valores de absorção de água por imersão e índice de vazios, concretos com CPII E 32.

\begin{tabular}{c|c|c|c}
\hline \multicolumn{4}{c}{ Absorção de água por imersão e índice de vazios } \\
\hline \multirow{2}{*}{ Traços } & $\begin{array}{c}\text { Absorção de } \\
\text { água por } \\
\text { imersão (\%) }\end{array}$ & $\begin{array}{c}\text { Índice de Vazios } \\
\text { (\%) }\end{array}$ \\
\hline \multirow{3}{*}{ CPII E 32 } & Rico & 2,4 & 5,7 \\
\cline { 2 - 4 } & Médio & 2,9 & 6,8 \\
\cline { 2 - 4 } & Pobre & 3,3 & 7,8 \\
\hline
\end{tabular}

Tabela 30. Valores de absorção de água por imersão e índice de vazios, concretos com CPIII 40 RS.

\begin{tabular}{l|c|c|c}
\hline \multicolumn{4}{c}{ Absorção de água por imersão e índice de vazios } \\
\hline \multirow{2}{*}{ Traços } & $\begin{array}{c}\text { Absorção de } \\
\text { água por } \\
\text { imersão (\%) }\end{array}$ & $\begin{array}{c}\text { Índice de Vazios } \\
\text { (\%) }\end{array}$ \\
\hline \multirow{3}{*}{ CPIII 40 RS } & Rico & 1,6 & 3,9 \\
\cline { 2 - 4 } & Médio & 2,4 & 5,7 \\
\cline { 2 - 4 } & Pobre & 2,8 & 6,6 \\
\hline
\end{tabular}

Nos resultados apresentados nas Tabelas 29 e $\mathbf{3 0}$ observou-se que os concretos ricos apresentaram redução dos valores de absorção de água por imersão em relação aos demais concretos, especialmente nos concretos com CPIII 40 RS. O mesmo ocorreu para o índice de vazios que aumentou para os concretos pobres. Porém ambos os valores (absorção de água por imersão e índice de vazios) foram menos elevados para os concretos com CPIII 40 RS (Figura 132). 


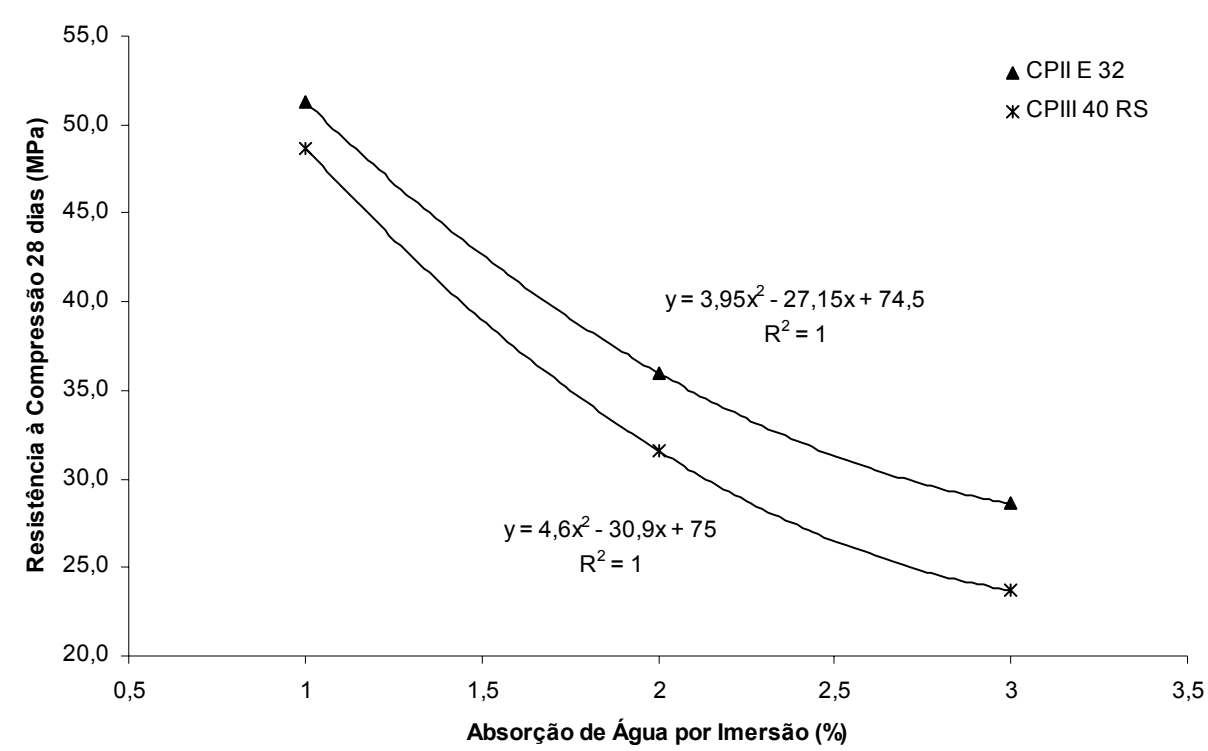

Figura 132. Comportamento da absorção de água por imersão (28 dias) dos concretos com CPII E 32 e CPIII 40 RS em função da resistência à compressão aos 28 dias.

Os valores de absorção de água por imersão dos concretos analisados estiveram abaixo do valor estabelecido pela NBR 11173 (ABNT, 1990) que se limita a 8\%.

\subsubsection{Especificação da dosagem de concretos para aplicação nos painéis moldados in loco}

De acordo com os resultados da avaliação de desempenho térmico, executadas para as tipologias térreas e multipavimentos que indicaram o concreto com massa específica de $2400 \mathrm{~kg} / \mathrm{m}^{3}$ com desempenho satisfatório para grande parte das localidades, apresenta-se uma síntese das propriedades de dois traços de concretos sugeridos (Tabelas 31 e 32), sendo um deles com CPII E 32 e outro com CPIII 40 RS.

Tabela 31. Dosagens recomendadas para aplicação $\left(1 \mathrm{~m}^{3}\right)$.

\begin{tabular}{|c|c|c|c|c|c|c|c|c|}
\hline & $\operatorname{Traços}^{1}$ & $\begin{array}{c}\text { Consumo } \\
\text { de } \\
\text { Cimento } \\
\text { (kg) }\end{array}$ & $\begin{array}{l}\text { Metacaulim } \\
(\mathbf{k g})\end{array}$ & Areia $(\mathbf{k g})$ & $\begin{array}{c}\text { Brita } 01 \\
\text { (kg) }\end{array}$ & $\begin{array}{c}\text { Aditivo } \\
\text { Superplast. } \\
\text { (kg) }\end{array}$ & Água & $\begin{array}{l}\text { Relação } \\
\text { a/aglom }\end{array}$ \\
\hline CPII E 32 & $1: 0,1: 3,13: 3,83: 0,0075: 0,60^{2}$ & 272,8 & 27,3 & 853,9 & 1044,8 & 2,05 & 180,0 & 0,60 \\
\hline CPIII 40 RS & $1: 0,1: 3,19: 3,90: 0,0075: 0,60^{2}$ & 267,4 & 26,7 & 853,0 & 1042,9 & 2,01 & 176,5 & 0,60 \\
\hline
\end{tabular}

${ }^{1}$ Os valores de "m" foram obtidos na Figura 118, para o valor limite da relação a/aglo $(0,6)$.

2 Traço: cimento:metacaulim: areia:brita:aditivo:relação a/aglo;

Tabela 32. Propriedades dos Concretos.

\begin{tabular}{|c|c|c|c|c|c|c|c|}
\hline \multirow{2}{*}{ Traços } & \multicolumn{4}{|c|}{$\begin{array}{c}\text { Resistência à Compressão } \\
(\mathrm{MPa})\end{array}$} & \multirow{2}{*}{$\begin{array}{c}\text { Resistência á Tração } \\
\text { por Compressão } \\
\text { Diametral } 28 \text { dias } \\
\text { (MPa) }\end{array}$} & \multirow{2}{*}{$\begin{array}{l}\text { Módulo de } \\
\text { Deformação } \\
\text { (E) } 28 \text { dias } \\
\text { (GPa) }\end{array}$} & \multirow{2}{*}{$\begin{array}{c}\text { Absorção de Água } \\
\text { por Imersão } 28 \text { dias } \\
\text { (\%) }\end{array}$} \\
\hline & $12 \mathrm{hrs}$ & 1dia & 7dias & 28dias & & & \\
\hline CPII E 32 & 1,1 & 4,8 & 23,4 & 31,6 & 2,6 & 34,4 & 3,1 \\
\hline CPIII 40 RS & 1,0 & 3,0 & 19,6 & 26,0 & 2,6 & 32,6 & 2,7 \\
\hline
\end{tabular}




\section{CONSIDERAÇÕES RNAIS}

Diante dos resultados finais desta pesquisa, percebe-se a importância da definição dos parâmetros inicias de estudo, do contato com os arquitetos das diretorias técnicas da Caixa Econômica Federal (CEF) e da Companhia de Desenvolvimento Habitacional e Urbano (CDHU), que possibilitou a verificação das tipologias de habitações térreas e multipavimentos mais utilizadas atualmente (Anexos 1, 2 e 3). Apesar de não estar previsto inicialmente nesta pesquisa, o levantamento de dados comportamentais realizados nos dois conjuntos habitacionais da cidade de São Carlos-SP proporcionou um importante ganho de informações em termos de ocupação e ventilação para uso na simulação do desempenho térmico das habitações.

Os valores de condutividade térmica dos concretos obtidos pelo Método do Fio Quente Paralelo estão próximos aos recomendados pela NBR 15220 (ABNT, 2005). Observou-se que a partir da diminuição dos valores de massa específica do concreto, devido à substituição de brita basáltica por argila expandida, houve um decréscimo da condutividade térmica. Isso se explica principalmente devido ao ar aprisionado na estrutura celular dos agregados leves fazendo com que seja reduzida a transferência e a absorção de calor.

Com a determinação dos valores de condutividade térmica $(\lambda)$, foi possível para esse intervalo de massa específica, avaliar de forma mais precisa o comportamento dos painéis executados com concreto nos aspectos referentes ao conforto térmico. Esse estudo foi importante tanto para o conhecimento das características térmicas dos concretos leves produzidos com argila expandida, quanto para a sua utilização nas simulações computacionais do conforto térmico das habitações de interesse social.

Analisando os resultados das simulações computacionais para as tipologias térreas observou-se que durante o verão para grande parte das localidades (Caxias do Sul, Florianópolis, Brasília, Santos e Presidente Prudente) não foi atendido nenhum dos níveis de desempenho de acordo com a norma (ABNT, 2008). Já para a tipologia multipavimentos 
em todas as zonas bioclimáticas, observou-se que durante o verão, considerando as simulações tanto para as tipologias do pavimento intermediário quanto da cobertura, executados com todos os tipos de painéis, pelo menos o nível mínimo de desempenho foi atendido de acordo com a norma. As temperaturas máximas internas das tipologias multipavimentos mostraram-se menos elevadas do que as temperaturas das tipologias térreas para a mesma localidade (ABNT, 2008).

Especificamente sobre o resultado das simulações computacionais para as tipologias térreas e multipavimentos com os painéis de referência (alvenaria de blocos cerâmicos e blocos de concreto), de forma geral observou-se que o desempenho térmico esteve próximo para os dois tipos de blocos utilizados. As tipologias com alvenaria de blocos cerâmicos apresentaram desempenho térmico modestamente superior às com bloco de concreto para ambas as estações. Já as tipologias com alvenaria de blocos de concreto apresentaram em grande parte dos casos desempenho semelhante ao das tipologias com painéis de concreto de $10 \mathrm{~cm}$ de espessura, para todos os valores de massa específica.

Para todas as tipologias térreas e multipavimentos analisadas, dentre as características dos painéis de concreto (massa específica do concreto variando entre 1600 e $2400 \mathrm{~kg} / \mathrm{m}^{3}$ e espessuras de $8 \mathrm{~cm}, 10 \mathrm{~cm}$ e $12 \mathrm{~cm}$ ), a espessura exerceu maior influência sobre os resultados das temperaturas internas do que a variação de massa específica dos concretos. O aumento de massa específica dos concretos pouco influenciou os resultados das temperaturas internas; já a variação de espessura, juntamente com o tipo de cobertura (no caso das tipologias térreas) foram os aspectos determinantes nos resultados.

No inverno as tipologias com painéis de $8 \mathrm{~cm}$ de espessura apresentaram menores temperaturas mínimas internas para todas as massas específicas e as tipologias com painéis de $12 \mathrm{~cm}$ de espessura, principalmente para os concretos com massas específicas 2400 e $2200 \mathrm{~kg} / \mathrm{m}^{3}$, apresentaram temperaturas mínimas internas mais elevadas. Já para o verão ocorreu o inverso, as tipologias com painéis de $8 \mathrm{~cm}$ de espessura apresentaram temperaturas máximas internas mais elevadas e os painéis com espessura de $12 \mathrm{~cm}$ apresentaram temperaturas máximas internas menores. Grande parte das tipologias com painéis de concreto de $12 \mathrm{~cm}$ de espessura e massas específicas 2400 e $2200 \mathrm{~kg} / \mathrm{m}^{3}$ atenderam aos requisitos de desempenho tanto para inverno quanto para verão.

Em relação ao tipo de cobertura da tipologia térrea, destacaram-se em termos de desempenho para o inverno as tipologias com laje plana e para o verão as tipologias com laje inclinada. $\mathrm{Na}$ tipologia multipavimentos apresentaram melhor desempenho para o inverno as unidades posicionadas na cobertura e para o verão as tipologias do pavimento intermediário ( $2^{\circ}$. pavimento).

Apesar da predominância da adequação em termos de desempenho térmico das tipologias com painéis de concreto de massa específica de 2200 e $2400 \mathrm{~kg} / \mathrm{m}^{3}$ e $12 \mathrm{~cm}$ de 
espessura, a adoção de concreto com massa específica $2400 \mathrm{~kg} / \mathrm{m}^{3}$ explica-se por maior viabilidade econômica pelo fato desse tipo de concreto ser o menos oneroso dentre os dois, mesmo em termos estruturais, pois no caso da tipologia térrea especificamente a fundação do tipo radier suportaria as cargas.

Os resultados desta pesquisa indicam que, apesar de alguns órgãos financiadores de habitação de interesse social (CEF e CDHU) especificar o concreto leve para a execução das vedações das habitações térreas, este material não foi ideal em grande parte dos casos em termos de desempenho térmico. Para as tipologias analisadas neste trabalho, observouse que os painéis em concreto tradicional apresentaram melhor desempenho térmico que os com concreto leve, podendo ser aplicado com bons resultados nesse sistema construtivo.

Durante a realização desta pesquisa foi possível acompanhar o desenvolvimento da recente NBR 15575 Edifícios habitacionais de até 5 pavimentos - Desempenho (ABNT, 2008), especificamente a Parte 1: Requisitos Gerais, norma que estará em vigor a partir de 2010. Foi possível observar, a partir dos resultados das simulações computacionais, que os requisitos da versão final dessa norma (maio de 2007) ficaram mais rigorosos que a versão inicial (outubro de 2002). Ocorreram mudanças nos parâmetros de desempenho, especificamente nas temperaturas mínimas (inverno) e máximas (verão) internas, tornando esses parâmetros mais rigorosos. Essa aplicação foi de extrema importância, por ser uma norma atual (aprovada em maio de 2008), sendo que provavelmente esta pesquisa é uma das primeiras aplicações. É importante salientar também as dificuldades de utilização desta norma que podem surgir, principalmente em relação à obtenção das temperaturas para fazer a avaliação dos níveis de desempenho, que neste trabalho foram obtidas por simulação computacional, ferramenta esta que pode não estar acessível aos profissionais.

Observou-se que para o inverno em alguns casos o parâmetro para a temperatura interna adequada esteve abaixo dos valores normalmente encontrados na literatura, por exemplo, estariam adequadas de acordo com a norma, para as tipologias localizadas na zona bioclimática 1 (Caxias do Sul): temperaturas acima de $11,8^{\circ} \mathrm{C}$; para a zona bioclimática 2 (Ponta Grossa): temperaturas acima de $12,3^{\circ} \mathrm{C}$ e para a zona bioclimática 3 (São Paulo): temperaturas acima de $14,3^{\circ} \mathrm{C}$; sendo que de acordo com estudos realizados por Givoni (1992) esse valor deveria estar acima de $18^{\circ} \mathrm{C}$.

Diante dos resultados desta pesquisa, ressalta-se que o fato de determinada tipologia não atender aos níveis de desempenho estabelecidos por norma não implica exatamente em inadequação para aplicação em determinados locais de acordo com a zona bioclimática, pois para contornar tais problemas podem ser utilizados recursos adicionais, principalmente soluções passivas de adequação climática quando possível, por tratar-se de habitação de interesse social, na qual soluções complexas implicam em gastos adicionais. $E$ 
em relação ao desempenho diferenciados de acordo com a estação do ano, recomenda-se a adequação climática para a estação mais rigorosa que ocorra na localidade.

\subsection{Conclusões}

Com base na metodologia de trabalho utilizada em termos gerais destaca-se que: Dentre todas as tipologias térreas e multipavimentos analisadas, o uso de painéis de massa específica $2400 \mathrm{~kg} / \mathrm{m}^{3}$ e espessura de $12 \mathrm{~cm}$ apresentou um melhor desempenho térmico aliado à viabilidade técnica e econômica; $\mathrm{O}$ aumento de massa específica dos concretos pouco influenciou nos resultados, sendo a espessura a característica determinante; Os níveis de desempenho térmico da NBR 15575 (ABNT, 2008) tornaram-se mais rigorosos em relação às versões iniciais, principalmente em relação aos parâmetros de temperaturas para inverno.

\subsection{Continuidade da Pesquisa}

A metodologia de trabalho mostrou-se eficaz em relação aos objetivos propostos, porém, salienta-se para esse tipo de pesquisa a importância de incorporar à metodologia dados precisos. Como foi o caso da determinação de massa específica e condutividade térmica dos concretos e das características de ocupação e ventilação das habitações por meio da execução do levantamento comportamental dos moradores de habitação de interesse social, isso com o objetivo de buscar variáveis mais concretas para inserção no software de simulação.

Pelo número de cidades analisadas, algumas características das habitações não foram variadas, como é o caso da cor, considerada no software como cor tipo 2, que corresponde à cor creme e cinzas claros. Sugere-se para trabalhos futuros a execução de simulações considerando também o uso de cores mais claras, no caso o branco, que provavelmente promoveria um aumento no número de tipologias a atender os requisitos de desempenho de acordo com a NBR 15575 (ABNT, 2008). 


\section{REERÊNCIAS}

ABIKO, A. K. (1995). Introdução à gestão habitacional. Texto técnico da Escola Politécnica da USP, Departamento de Engenharia de Construção Civil, TT/PCC/12. São Paulo, EPUSP.

AïTICIN, P. C. (2000). Concreto de Alto Desempenho. Trad. Geraldo G. Serra. São Paulo: Pini.

AL-KHAIAT, H.; HAQUE, M. N. (1998). Effect of initial curing on early strength and physical properties of lightweight concrete. Cement e Concrete Research, v. 26, n. 6, p. 859-866.

ALUCCI, M. P. (1986). Implantação de conjuntos habitacionais: recomendações para adequação climática e acústica. São Paulo : IPT, 95 p.

AMERICAN CONCRETE INSTITUTE (ACI). (1995). ACI 213R-87. Guide for Structural Lightweight Aggregate Concrete, 1995.

AMERICAN CONCRETE INSTITUTE (ACI). (1992). ACI 318-02 Building code requirements for structural concrete.

AMERICAN CONCRETE INSTITUTE (ACI). (2004). ACI 332R-04. Guide to Residential Cast-in-Place Concrete Construction.

AMERICAN SOCIETY FOR TESTING AND MATERIALS (ASTM). (1993). ASTM C 125. Definitions of terms relating to concrete and concrete aggregates. In: ANNUAL BOOK OF ASTM STANDARDS. Philadelphia, USA.

ANDRADE, J. J. O. (2007). Propriedades Físicas e Mecânicas dos Materiais. In: Materiais de Construção Civil e princípios de Ciências e Engenharia de Materiais. Ed. G. C. Isaia. São Paulo: IBRACON, v. 1

ARMELIN, H. S.; LIMA, M. G.; SELMO, S. M. S. (1994). Alta resistência com argila expandida. Revista Ibracon, n. 09, p. 42-47.

ARRUDA, M. P. (2000). Diretrizes para Projeto Arquitetônico de Habitação Social em Pinus Realizada por Mutirão. Dissertação (Mestrado) - Universidade de São Paulo, São Carlos.

ASSOCIAÇÃO BRASILEIRA DE CIMENTO PORTLAND (ABCP). (2002). Manual Técnico para Implementação: Habitação 1.0: Bairro saudável. $1^{\text {a }}$ Ed. São Paulo: ABCP. 
ASSOCIAÇÃO BRASILEIRA DE NORMAS TÉCNICAS (ABNT) (1992). NBR 11581: Cimento Portland - Determinação dos tempos de pega. Rio de Janeiro.

ASSOCIAÇÃO BRASILEIRA DE NORMAS TÉCNICAS (ABNT). (1974). NBR 5739: Ensaio de compressão de corpos-de-prova cilíndricos de concreto. Rio de Janeiro.

ASSOCIAÇÃO BRASILEIRA DE NORMAS TÉCNICAS (ABNT). (1983). (1982 a). NBR 7211: Agregado para concreto. Rio de Janeiro.

ASSOCIAÇÃO BRASILEIRA DE NORMAS TÉCNICAS (ABNT). (1982 b). NBR 7251: Agregado em estado solto: determinação da massa unitária. Rio de Janeiro.

ASSOCIAÇÃO BRASILEIRA DE NORMAS TÉCNICAS (ABNT). (1983). NBR 8522: Concreto: Determinação do módulo de deformação estática e diagrama tensão-deformação. Rio de Janeiro.

ASSOCIAÇÃO BRASILEIRA DE NORMAS TÉCNICAS (ABNT). (1984). NBR 7224: Cimento Portland e outros materiais em pó - Determinação da área específica. Rio de Janeiro.

ASSOCIAÇÃO BRASILEIRA DE NORMAS TÉCNICAS (ABNT). (1987 a). NBR 7217: Determinação da composição granulométrica dos agregados. Rio de Janeiro.

ASSOCIAÇÃO BRASILEIRA DE NORMAS TÉCNICAS (ABNT). (1987b). NBR 9776 : Agregados - Determinação da massa específica por meio do Frasco Chapman. Rio de Janeiro.

ASSOCIAÇÃO BRASILEIRA DE NORMAS TÉCNICAS (ABNT). (1987 c). NBR 9778: Argamassa e concreto endurecidos - Determinação da absorção de água por imersão Índice de vazios e massa específica. Rio de Janeiro.

ASSOCIAÇÃO BRASILEIRA DE NORMAS TÉCNICAS (ABNT). (1987 d). NBR 9833: Concreto fresco - Determinação da massa específica e do teor de ar pelo método gravimétrico. Rio de Janeiro.

ASSOCIAÇÃO BRASILEIRA DE NORMAS TÉCNICAS (ABNT). (1990). NBR 11173: Projeto e execução de argamassa armada. Rio de Janeiro.

ASSOCIAÇÃO BRASILEIRA DE NORMAS TÉCNICAS (ABNT). (1991 a). NBR 11579 - MB 3432: Cimento Portland - Determinação da finura por meio da peneira $75 \mu m$ ( $\left.n^{\circ} 200\right)$. Rio de Janeiro.

ASSOCIAÇÃO BRASILEIRA DE NORMAS TÉCNICAS (ABNT). (1991b). NBR 11581: Cimento Portland - Determinação dos tempos de pega. Rio de Janeiro.

ASSOCIAÇÃO BRASILEIRA DE NORMAS TÉCNICAS (ABNT). (1991c). NBR 7215: Cimento Portland: Determinação da resistência à compressão. Rio de Janeiro.

ASSOCIAÇÃO BRASILEIRA DE NORMAS TÉCNICAS (ABNT). (1992 a). NBR 11768: Aditivos para concreto de cimento Portland. Rio de Janeiro.

ASSOCIAÇÃO BRASILEIRA DE NORMAS TÉCNICAS (ABNT). (1992 b). NBR 12645: Execução de paredes de concreto celular espumoso moldadas no local. Rio de Janeiro.

ASSOCIAÇÃO BRASILEIRA DE NORMAS TÉCNICAS (ABNT). (1992 c). NBR 12646: Paredes de concreto celular espumoso moldadas no local. Rio de Janeiro. 
ASSOCIAÇÃO BRASILEIRA DE NORMAS TÉCNICAS (ABNT). (1992 d). NBR 7223: Concreto: Determinação da Consistência pelo Abatimento do Tronco de Cone. Rio de Janeiro.

ASSOCIAÇÃO BRASILEIRA DE NORMAS TÉCNICAS (ABNT). (1992 e). NBR 7224 (NM76): Cimento Portland: Determinação da finura pelo método de permeabilidade ao ar (método do Blaine). Rio de Janeiro.

ASSOCIAÇÃO BRASILEIRA DE NORMAS TÉCNICAS (ABNT). (1994 a). NBR 12821: Preparação de Concreto em Laboratório - Procedimento. Rio de Janeiro.

ASSOCIAÇÃO BRASILEIRA DE NORMAS TÉCNICAS (ABNT). (1994 b). NBR 5738: Moldagem e cura de corpos-de-prova cilíndricos ou prismáticos de concreto - Procedimento. Rio de Janeiro.

ASSOCIAÇÃO BRASILEIRA DE NORMAS TÉCNICAS (ABNT). (1994 c). NBR 5739: Ensaio de compressão de corpos-de-prova cilíndricos de concreto. Rio de Janeiro.

ASSOCIAÇÃO BRASILEIRA DE NORMAS TÉCNICAS (ABNT). (1994 d). NBR 7222: Argamassa e Concreto - Determinação da resistência a tração por compressão diametral de corpos-de-prova cilíndricos. Rio de Janeiro.

ASSOCIAÇÃO BRASILEIRA DE NORMAS TÉCNICAS (ABNT). (1995). NM35: Agregados leves para concreto estrutural - Especificações. Rio de Janeiro.

ASSOCIAÇÃO BRASILEIRA DE NORMAS TÉCNICAS (ABNT). (1996). NBR 12655: Concreto - Preparo, controle e recebimento. Rio de Janeiro.

ASSOCIAÇÃO BRASILEIRA DE NORMAS TÉCNICAS (ABNT). (2000). NBR 6474 - NM 23: Cimento Portland e outros materiais em pó - Determinação da massa específica. Rio de Janeiro.

ASSOCIAÇÃO BRASILEIRA DE NORMAS TÉCNICAS (ABNT). (2003). NBR 8522: Concreto - Determinação do módulo de deformação estática e diagrama tensãodeformação. Rio de Janeiro.

ASSOCIAÇÃO BRASILEIRA DE NORMAS TÉCNICAS (ABNT). (2004). NBR 6118: Projeto de estruturas de concreto. Rio de Janeiro.

ASSOCIAÇÃO BRASILEIRA DE NORMAS TÉCNICAS (ABNT). (2005). NBR 15220: Desempenho térmico de edificações. Rio de Janeiro.

ASSOCIAÇÃO BRASILEIRA DE NORMAS TÉCNICAS (ABNT). (2005). NBR 15220: Desempenho térmico de edificações. Parte 3: Zoneamento Bioclimático Brasileiro e Diretrizes para Habitações Unifamiliares de Interesse Social. Rio de Janeiro.

ASSOCIAÇÃO BRASILEIRA DE NORMAS TÉCNICAS (ABNT). (2008). NBR 15575-1: Edifícios habitacionais de até 5 pavimentos - Desempenho - Parte 1: Requisitos Gerais. Rio de Janeiro.

AURÉLIO. (2004): dicionário eletrônico. Rio de Janeiro: Positivo Informática. 1 cd-rom.

BARBOSA, M. G. (1994). Uma Metodologia para Avaliação e Especificação do Desempenho Térmico de Edificações Térreas Unifamiliares. Dissertação (Mestrado em Engenharia de Produção), Departamento de Engenharia de Produção e Sistemas - Universidade Federal de Santa Catarina. Florianópolis. 
BARBOSA, M. G. (1997). Desenvolvimento de uma Metodologia para Avaliação e Especificação do Desempenho Térmico de Edificações Térreas Unifamiliares. Tese (Doutorado em Engenharia de Produção), Departamento de Engenharia de Produção e Sistemas - Universidade Federal de Santa Catarina. Florianópolis.

BARBOSA, M. J.; LAMBERTS, R. (1997). Aplicação de uma metodologia para especificar e avaliar o desempenho térmico em edificações residenciais unifamiliares ao clima de Londrina-PR. In: IV ENCONTRO NACIONAL DE CONFORTO NO AMBIENTE CONSTRUÍDO. Anais... Salvador. p. 205-210.

BARROS, M. M. B. B. (1998). O processo de produção das alvenarias racionalizadas. In: CONGRESSO LATINO AMERICANO TECNOLOGIA E GESTÃO NA PRODUÇÃO DE EDIFÍCIOS - SOLUÇÕES PARA O TERCEIRO MILÊNIO. Escola Politécnica, Universidade de São Paulo - Departamento de Engenharia Civil - PCC. São Paulo: Nov.

BERNER D.E. (1991). High Ductility, High Strength, lightweight aggregate concrete. In: ACI SYMPOSIUM ON PERFORMANCE OF STRUCTURAL LIGHTWEIGHT CONCRETE. Dallas, Texas.

BLAY, E. A. (1985). Eu não tenho onde morar: Vilas Operárias na Cidade de São Paulo. São Paulo: Nobel.

BOECHAT, Y. (2008). Para ganhar rapidez, construtoras industrializam canteiros de obras. Disponível em: <http://www.fiepr.org.br/sindicatos/sinduscon_nortepr/News3961content32761.shtml> Acesso em Jul. 2008.

BONDUKI, N. (1998). Origens da habitação social no Brasil: arquitetura moderna, lei do inquilinato e difusão da casa própria. São Paulo: Estação Liberdade/FAPESP.

BOTTURA, M. M. S.; FERREIRA, O. P.; SILVA, L. F. (1986). Concreto leve, aplicação com função estrutural. Universidade de São Paulo Escola Politécnica.

BUCHER, H.R.E. (1988). Desempenho de aditivos redutores de água de alta eficiência em pastas, argamassas e concretos. In: $30^{\circ}$. CONGRESSO BRASILEIRO DO CONCRETO. Rio de Janeiro.

US DEPARTAMENT OF ENERGY. Energy Efficiency and Renewable Energy. Building Energy Software Tools Directory, 2008. Disponível em: < http://apps1.eere.energy.gov/buildings/tools_directory/ > Acesso em ago. 2008.

CAIXA ECONÔMICA FEDERAL (CEF). (2003). Relatório DCT.T.15.005.2003 - R1 Avaliações de Sistemas Construtivos e Estabelecimento de Requisitos para Edificações Térreas com Paredes de Concreto Celular. Departamento de Apoio e Controle Técnico de FURNAS Centrais Elétricas S. A., Brasília/DF.

CARDOSO, J. C. M. (2002). Estratégias visando eficiência energética e conforto térmico incorporados aos projetos de edificações residenciais em Maringá-PR. 225 p. Dissertação (Mestrado em Engenharia Civil), Departamento de Engenharia Civil - Universidade Federal de Santa Catarina. Florianópolis. 225 p.

CARRASQUILLO, R. L.; NILSON, A. H.; SLATE, F. O. (1981). Properties of high strenght concrete subject to short term loads. Journal of American Concrete Institute, v. 78, n. 3, p. 171-178. 
COMPANHIA DE DESENVOLVIMENTO HABITACIONAL E URBANO (CDHU). (2006). Atuação em Favelas e Áreas de Risco. Disponível em <http://www.cdhu.sp.gov.br> Acesso em jan. 2006.

(CDHU). (1998). Manual Técnico de Projetos. São Paulo.

CORREIA, T. B. (2004). A construção do Habitat Moderno no Brasil - 1870 - 1950. São Carlos: Rima. 109 p.

COSTA, E. C. (2003). Física Aplicada à Construção: Conforto Térmico. São Paulo: Edgard Blücher. $265 \mathrm{p}$.

DANTAS, F. A. S. (2003). Agregados leves e concretos alternativos. In: FREIRE, W. J. BERALDO, A. L. (coord.). Tecnologias e materiais alternativos de construção, Campinas, SP: Editora da UNICAMP.

DÉFICIT habitacional no Brasil 2005. (2006). Fundação João Pinheiro, Centro de Estatística e Informações. Belo Horizonte. 200p. Projeto PNUD-BRA-00/019 - Habitar Brasil - BID. Disponível em: <http://www.cidades.gov.br/media/Deficit2005.pdf> Acesso em abr. 2007.

EUROLHIGHTCON. (1998). Project BE96-3942/R2. LWAC Material Properties, State-of-theArt. 111 p. Disponível em:<www.sintef.no> Acesso em jun. 2007.

EUROLHIGHTCON. (2000). Project BE96-3942/R11. Pumping of lightweight aggregate concrete based on expanded clay in Europe. 67p. Disponível em:<www.sintef.no $>$ Acesso em jun. 2007.

EVANGELISTA, A. C. J.; SHEHATA, L. C. D.; ALMEIDA, I. R. (1996). Características mecânicas de concretos leves de alta resistência com argila expandida, produzidos no Brasil. In: INTERNATIONAL CONGRESS ON HIGH-PERFORMANCE CONCRETE, AND PERFORMANCE AND QUALITY OF CONCRETE STRUCTURES. Florianopolis. p. 170189.

FABRICIO, M. M.; MELHADO, S. B.; BAÍA, J. L. (2000). Formalização e implantação de procedimentos de projeto e a gestão da qualidade nos escritórios. In: NUTAU - Tecnologia e Desenvolvimento.

FABRÍCIO, M. M.; MELHADO, S.B. (2002). Impactos da tecnologia da informação nos conhecimentos e métodos projetuais. In: SEMINÁRIO DE TECNOLOGIA DA INFORMAÇÃO E COMUNICAÇÃO NA CONSTRUÇÃO CIVIL - Oportunidades e Futuro. 2002, Curitiba, Anais... Curitiba: Construbusiness Paraná.

FERRARI, C. (2006). Desenvolvimento de concreto leve estrutural para execução de habitações de interesse social. Processo $n^{\circ}$ 05/00261-2, Relatório de Iniciação Científica. São Carlos: EESC-USP, FAPESP.

FINEP/GAP HABITAÇÃO POPULAR. (1985). Inventário da Ação Governamental. [S.L.]: FINEP/GAP.

FOLZ. R.R. (2004). Habitações Econômicas Paulistas:análise dos projetos das unidades dos atuais programas habitacionais. Monografia apresentada na disciplina SAP-5846 Habitação metrópoles modos de vida. Universidade de São Paulo, São Carlos. Disponível em:<http://www.eesc.usp.br/nomads/SAP5846/mono_Folz.pdf> Acesso em: maio 2007.

FOLZ. R.R. (2003). Mobiliário na Habitação Popular. São Carlos: Rima. 183 p. 
FORSA FORMALETAS. (2007). Proceso Constructivo. Disponível em: <http://www.forsa.com.co/index.php?p=sections\&plnt_sec=proceso> Acesso em: jun. 2007.

FREIRE, W. J., BERALDO. A. L. (coord.). (2003). Tecnologias e materiais alternativos de construção, Campinas, SP: Editora da UNICAMP.

FROTA, A. B; SCHIFFER, S. R. (1995). Manual de conforto térmico. São Paulo: Nobel. 228 p.

FUNDAÇÃO JOÃO PINHEIRO Déficit Habitacional no Brasil 2000. (2001). Belo Horizonte.

GETHAL. (2006). Sistemas Construtivos Gethal: São Paulo. Disponível em: $<$ http://www.gethal.com.br/concretocelular/imagens/modoconstrutivo.pdf> Acesso em jun. 2007.

GETHAL. (2006). Concreto Celular. Sistema Gethal para execução de paredes moldadas "in loco". Gethal: São Paulo. Disponível em: <http://www.gethal.com.br/concretocelular/imagens/modoconstrutivo.pdf> Acesso em jun. 2007.

GIVONI, B. (1992). Comfort Climate Analysis and Building Design Guidelines. Energy and Buildings, v. 18, n. 1, p. 11-23.

GIVONI, B. (1976). Man climate and architecture. 2 ed. London: Applied Science. 483 p.

GOMES NETO, D. P. (1998). Dosagem de microconcretos leves de alto desempenho para produção de pré-fabricados de pequena espessura - Estudo de Caso. Dissertação (Mestrado) - Escola de Engenharia de São Carlos, Universidade de São Paulo. São Carlos. $156 \mathrm{p}$.

GOMES, R.J. (1967). Condicionamentos Climáticos da envolvente para edifícios para habitação. Lisboa, Laboratório Nacional de Engenharia Civil - LNEC.

GONÇALVES, J. C. S.; DUARTE, SILVA, D. H. (2006). Arquitetura sustentável: uma integração entre ambiente, projeto e tecnologia em experiências de pesquisa, prática e ensino. Ambiente Construído, Revista on line da ANTAC. Porto Alegre. v. 6, n. 4. Disponível em: <http://www.antac.org.br/ambienteconstruido/pdf/revista/artigos/Doc126168.pdf> Acesso em: maio 2007.

GOSCH, S. R.; LAMBERTS, R. (2004). Simulação Térmica e Energética de Edificações. Relatório de Iniciação Científica do Departamento de Engenharia Civil da Universidade Federal de Santa Catarina (PIBIC). UFSC, Florianópolis.

GOSCH, S. R.; WESTPHAL, F. S.; LAMBERTS, R. (2004). Análise energética de edificações através da simulação de células. In: ENCIT 2004 - 10TH BRAZILIAN CONGRESS OF THERMAL SCIENCES AND ENGINEERING,2004, Rio de Janeiro. Anais eletrônicos... Santa Catarina: UFSC-LabEEE. Disponível em: $<$ http://www.labeee.ufsc.br/arquivos/publicacoes/Encit2004_Simulação_Celulas_samuel.pdf >. Acesso em abr. 2007.

GOULART, S.; BARBOSA, M. J.; PIETROBON, C. E.; BOGO, A.; PITTA, T. (1994). Bioclimatologia aplicada ao projeto de edificações visando o conforto térmico. Florianópolis: UFSC. Relatório interno - 02 / 94 NPCC mimeo.

GRANJA, A. D.; LABAKI, L. C. (2004). Paredes orientadas a leste e a oeste: uma abordagem crítica em relação ao conforto e à eficiência energética. In: ENCONTRO 
NACIONAL SOBRE CONFORTO NO AMBIENTE CONSTRUÍDO, Porto Alegre, Rio Grande do Sul. v. 4, n. 4, p. 65-75.

GRIMER, F. J.; HEWITT, R. E. (1969). The form of the stress-strain curve of concrete interpreted with a diaphase concept of material behavior. In: INTERNATIONAL CONFERENCE IN CIVIL ENGINEERING MATERIALS. Southampton.

HABITAR. (199?). Banco de dados de sistemas construtivos destinados à habitação de interesse social. COHAB-MG - Sistema Industrializado. Universidade Federal de Minas Gerais. Disponível em: <http://www.arquitetura.ufmg.br/habitar/sis3.html> Acesso em: maio 2007.

HABITAR. (199?).Banco de dados de sistemas construtivos destinados à habitação de interesse social. SISTEMA COHAB - Forma Metálical Concreto Celular. Universidade Federal de Minas Gerais. Disponível em: <http://www.arquitetura.ufmg.br/habitar/sis3.html> Acesso em: maio 2007.

HELENE, P. R.L. \& TERZIAN, P. R. (1993). Manual de Dosagem e Controle do Concreto. São Paulo, PINI/SENAI.

HOLM T. A.; BREMNER. T. W. (1994). High strength lightweight aggregate concrete. In: SHAH S. P. AHAMAD S. H. High performance concrete: Properties and Aplications. Great Britain, McGraw-Hill. p. 341-374.

HOLM T. A.; BREMNER. T. W. (2000). State-of-the-art report on high-strength, high durability structural low-density concrete for applications in severe marine environments. US Army Corps of Engineers - Engineer Research Development Center. ERDC/SL TR-00-3. $116 \mathrm{p}$.

IHL DO BRASIL. (2007). Sistema Contech. Disponível em: <http://www.ihldobrasil.com.br > Acesso em: jun. 2007.

INPAR. (2007). Tecnologia, Parede de concreto moldada in loco Disponível em: <http://www.inpar.com.br/institucional/empresa_tecnologia.asp\#07> Acesso em: jun. 2007.

INSTITUTO DE PESQUISAS TÉCNICAS (IPT). (2007). Relatório Técnico RT-025A Sistema Construtivo Sergus com Fôrmas tipo Banche, Sergus Construções e Comércio Ltda. São Paulo: IPT. Disponível em: <http://www.ipt.br/atividades/servicos/rt/files/rt025Asergus formasbanche.pdf > Acesso em jun. 2007.

INSTITUTTO DE PESQUISAS TECNOLÓGICAS DO ESTADO DE SÃO PAULO (IPT). (1998). Catálogo de processos e sistemas construtivos para habitação. Publicação IPT; n.2515.

KANTRO, D. L. (1980). Influence of Water-Reducing Admixtures on Porperties of Cement Paste - A Miniature Slump Test. Cement, Concrete and Aggregate, v.2, n.2, p.95-102.

KOWALTOWSKI, D. C. C. K. et al. (1998). A visualização do conforto ambiental no projeto arquitetônico. VII ENCONTRO NACIONAL DE TECNOLOGIA DO AMBIENTE CONSTRUÍDO. FLORIANÓPOLIS. p. 371-379. v. 1.

LAMBERTS, R. (2005). Desempenho Térmico de Edificações. Disciplina: ECV 5161 Universidade Federal de Santa Catarina, Departamento de Engenharia Civil, LABEEE. Florianópolis.

LAMBERTS, R.; DUTRA, L.; PEREIRA, F. O. R. (1997). Eficiência energética na arquitetura São Paulo: PW Editores. 188 p. 
LARCHE, J. V. M. (2005). Diretrizes visando a melhoria de projetos e soluções Construtivas na expansão de habitações de interesse social. Dissertação de Mestrado Pós-Graduação em Construção Civil, do Setor de Tecnologia da Universidade Federal do Paraná. Curitiba. Disponível em: <http://www.ppgcc.ufpr.br/dissertacoes/1d0068.pdf> Acesso em: maio 2007.

LIGHTWEIGHT. (1971). Concrete - History - Applications - Economics. 43 p. Disponível em: <http://www.escsi.org/pdfdoc1/General Info Sheet 7600.1.pdf.> Acesso em nov. 2006.

LORDSLEEM JUNIOR, A. C. et al. (1998a). Estágio atual do uso de paredes maciças moldadas no local em São Paulo. In: CONGRESSO LATINO AMERICANO TECNOLOGIA E GESTÃO NA PRODUÇÃO DE EDIFÍCIOS - SOLUÇÕES PARA O TERCEIRO MILÊNIO. São Paulo. Anais... São Paulo: Escola Politécnica, Universidade de São Paulo Departamento de Engenharia Civil - PCC. nov, 1998.

LORDSLEEM JÚNIOR, A. C. (1998b). O processo de produção das paredes maciças. In: SEMINÁRIO TECNOLOGIA E GESTÃO NA PRODUÇÃO DE EDIFÍCIOS VEDAÇÕES VERTICIAS - TECNOLOGIA E GESTÃO NA PRODUÇÃO DE EDIFÍCIOS, 1998, São Paulo. Anais... São Paulo: Escola Politécnica da Universidade de São Paulo, Departamento de Engenharia de Construção Civil - PCC.

MACIEL, A. A. (2006). Integração de conceitos bioclimáticos ao projeto arquitetônico. Tese (Doutorado em Engenharia Civil), Departamento de Engenharia Civil - Universidade Federal de Santa Catarina. Florianópolis.

MAGNAVITA, L. A. S. (1994). COHAB/SP - Capital, 1965 - 1990: Processos Construtivos/ Análise de uma Questão sem Resposta: a Habitação Social. Dissertação (Mestrado) Universidade de São Paulo, São Carlos.

MANGE, E. R. C. (1956). A função abrigo em arquitetura. Tese (Doutorado em Arquitetura e Urbanismo) - Faculdade de Arquitetura e Urbanismo, Universidade de São Paulo. São Paulo.

MARTIN, J.F. (2005). Aditivos para concreto. In: ISAIA, G. C. (Org.). Concreto: Ensino, Pesquisa e Realizações. Vol. 1, p. 381-406.

MARTUCCI, R. (1999). Porque Analisar e Avaliar Habitações e Tecnologias para Sistemas Construtivos Habitacionais. In: Habitação 2: tecnologias em debate. Anais... Brasília: Starprint. $132 \mathrm{p}$.

MAWAKDIYE, A. (2006). Casa própria: tragédia anunciada. In: Revista Problemas Brasileiros. Revista Bimestral n.378, ano 44. São Paulo: SESC/SENAC. Disponível em: $<$ http://www.sescsp.org.br/sesc/revistas_sesc/pb/artigo.cfm?Edicao_ld=260\&breadcrumb=1 \&Artigo_ID=4083\&IDCategoria=4579\&reftype=1> Acesso em: abr. 2007.

MEHTA, K; MONTEIRO, J.M. (1994). Concreto: estrutura, propriedades e materiais. São Paulo: PINI.

MENDES, M. R. et al. (1998). Uso de resíduos para obtenção de agregados leves para a construção civil. In: Anais ENTAC, VII Encontro Nacional de Tecnologia do Ambiente Construído Qualidade no Processo Construtivo. Florianópolis.

MENDES, N. et al. (2005). Uso de instrumentos computacionais para análise do desempenho térmico e energético de edificações no Brasil. Ambiente Construído, Porto Alegre, $\quad$ v. 5, n. 4, p. 47-68. Disponível em: <http://www.labeee.ufsc.br/arquivos/publicacoes/Antac_Doc122144.pdf> Acesso em abr. 2007. 
NATIONAL READY MIXED CONCRETE ASSOCIATION (NRMCA). (2003). What, why \& how? Structural Lightweight Concrete. CIP 36 Structural Lightweight Concrete. Maryland. Disponível em: <http://www.escsi.org/pdfdoc1/StructurallnfoSheet4600.13.pdf.> Acesso em nov. 2006.

NEVILLE, A. M. (1997); Tradução Salvador E. Giammusso. Propriedades do Concreto. São Paulo: Pini.

NOUMOWÉ. A.; AGGOUN, S.; CABRILLAC, R. (2000). Mechanical properties of lightweight aggregate concrete after exposure at high temperature. In: INTERNATIONAL SYMPOSIUM ON STRUCTURAL LIGHTWEIGHT AGGREGATE CONCRETE, Kristiansand, Norway. p. 641-649.

OLGYAY, V. (1963). Design with Climate. Princeton University Press, New Jersey.

ORNSTEIN, S. W. (1992). Avaliação Pós-ocupação (APO) do ambiente construído. (Colab. Marcelo Romero). São Paulo: Studio Nobel/EDUSP.

OUTINORD. (2007). Tunnel Forms. Disponível em: <http://www.outinordamericas.com/tech_tunnelform.htm> Acesso em jun. 2007.

PIETROBON, C. E. (2000). Conforto na edificação: conforto térmico. In: VII SEMANA DA ENGENHARIA. LABCON/ARQ. Anais... Maringá.

PIETROBON, C. E., LAMBERTS R., PEREIRA, F. O. R. (2001). Estratégias bioclimáticas para o projeto de edificações: conceituação e aplicação para maringá, $P R$. In: VI ENCONTRO NACIONAL E III ENCONTRO LATINO-AMERICANO SOBRE CONFORTO NO AMBIENTE CONSTRUÍDO. São Pedro. Disponível em: $<$ http://www.labeee.ufsc.br/arquivos/publicacoes/ENCAC01_pietrobon.pdf> Acesso em: maio 2007.

PORTO, A; PONTE, C. F. (2003). Vacinas e campanhas: imagens de uma história a ser contada. In: História, Ciências, Saúde - Manguinhos, vol. 10 (suplemento 2): 725-42. Disponível em: <http://www.scielo.br/pdf/hcsm/v10s2/a13v10s2.pdf. Acesso em: maio 2007.

PRECISE FORMS. (2007). Precise Aluminum Forming Disponível em: < http://www.theconcretesource.com/images/ConcreteSourceSponsorship/Concrete.pdf/Precis e\%20Forms\%20Catalog.pdf> Acesso em: jun. 2007.

RABHA, N. M. C. E.(Coordenadora) (2007). Planos de Governo Rodrigues Alves/Pereira Passos 1902/1906 Parte 1. In: Rio Estudos, n. 249. Rio de Janeiro: IPP - Instituto Municipal Pereira Passos, Disponível em: <http://www.rio.rj.gov.br/ipp/> Acesso em:maio 2007.

ROMERO, M. A. (1998). Legislação energética em edifícios: a análise do caso de Portugal. In: Cadernos Técnicos AUT n. 5. São Paulo: FAU.

RORIZ, M. (Programação); BASSO, A. (Dados). (1989). ARQUITROP Versão 3.0: Conforto térmico e economia de energia nas edificações. Sistema integrado de rotinas e bancos de dados para apoio às atividades de projeto em Arquitetura e Engenharia Civil. São Paulo: UFSCAR.

RORIZ, M.; BASSO, A. (1991). Comparação entre dez critérios para a definição da zona de conforto térmico. ENCONTRO DE NORMALIZAÇÃO LIGADA AO USO RACIONAL DE ENERGIA E AO CONFORTO AMBIENTAL EM EDIFICAÇÕES, Florianópolis. Anais... Florianópolis: UFSC. p. 145-149. 
RORIZ, M. (1987). Zona de conforto térmico: um estudo comparativo de diferentes abordagens. Dissertação (Mestrado em Arquitetura e Urbanismo). Departamento de Arquitetura e Planejamento, Universidade de São Paulo. São Carlos.

RORIZ, M., GHISI, E.; LAMBERTS, R. (1999). Uma proposta de norma técnica brasileira sobre o desempenho térmico de habitações populares. In: V ENCONTRO NACIONAL DE CONFORTO NO AMBIENTE CONSTRUÍDO \& II ENCONTRO LATINO AMERICANO DE CONFORTO NO AMBIENTE CONSTRUÍDO. Fortaleza.

ROSSIGNOLO, J. A.; AGNESINI M. V. C. (2002). Mechanical Properties of polymer-modified lightweight aggregate concrete. Cement and Concrete Research. Vol. 32, n. 3, p.329-334.

ROSSIGNOLO, J. A.; PAULON, V. A., AGNESINI M. V. C. (2001). Concreto leve de elevado desempenho. Revista Engenharia e Construção, n. 56, p. 24-30.

ROSSIGNOLO, J. A.; PEREIRA, J. R. L. (2005). Influencia do agregado no desempenho da resistência à compressão do concreto: comparação entre basalto e argila expandida. In: $V$ Encontro Tecnológico da Engenharia Civil e Arquitetura - ENTECA 2005.

ROSSIGNOLO, J. A. (2003). Concreto leve de alto desempenho modificado com sb para pré-fabricados esbeltos - dosagem, produção, propriedades e microestrutura. Tese de Doutorado. Interunidades Ciência e Engenharia de Materiais. Universidade de São Paulo. São Carlos.

ROSSIGNOLO, J. A. e AGNESINI, M.V.C. (2005). Concreto estrutural leve. In: ISAIA, G. C. (Org.). Concreto: Ensino, Pesquisa e Realizações. Vol. 2, p. 1331-1362.

SANTOS. W. N. (1988). Contribuição ao estudo da condutividade térmica do material cerâmico concreto refratário utilizando a técnica de fio quente com ajuste por regressão não linear. 1988. 149 p. Tese (Doutorado em Tecnologia Nuclear), Instituto de Pesquisas Energéticas e Nuclerares, Universidade de São Paulo, São Paulo.

SANTOS. W. N. (2002). O método do fio quente: técnica em paralelo e técnica de superfície. Cerâmica 48 (306) Abr/Mai/Jun 86-91.

SANTOS. W. N.; CINTRA FILHO, J. S. (2005). Aplicação da técnica do fio quente na determinação das propriedades térmicas de polímeros. Polímeros: Ciência e Tecnologia, vol. $15, \mathrm{n}^{\circ} 4$, p. 289-295.

SEGRE, R. (1991). America latina, fim de milênio : raízes e perspectivas de sua arquitetura. Tradução por: Luis Eduardo de Lima Brandão. São Paulo: Studio Nobel. 326p.

SLATE, F.O.; NILSON, A.H.; MARTINEZ, S. (1986). Mechanical properties of high-strength lightweight concrete. ACI Materials Journal, vol. 83, n. 4, p. 606-613.

SOBRAL. H. S. (1996). ET-86 Concretos leves: tipos e comportamento estrutural. São Paulo: ABCP.

TECNOLOGIA DO CONCRETO ARMADO (TCA). (2004b). Sistema racionalizado em habitação popular, $n^{\circ}$ 20, p. 12. Informativo técnico ABCP, ABESC, IBRACON e IBTS.

TECNOLOGIA DO CONCRETO ARMADO (TCA). (2000). Condomínio em Ribeirão Preto utiliza concreto celular, $n^{\circ} 8$, p. 16. Informativo técnico ABCP, ABESC, IBRACON e IBTS. 
TECNOLOGIA DO CONCRETO ARMADO (TCA). (2004a) Tecnologia agiliza construção de empreendimento de alto padrão, $n^{\circ} 19$, p. 16. Informativo técnico ABCP, ABESC, IBRACON e IBTS.

TEZUKA, Y. (1973). Concreto leve à base de argila expandida. Dissertação (mestrado). Escola Politécnica da Universidade de São Paulo, São Paulo.

TODESCHINI M.; BETTI, R. (2008). Casas populares com pequenos luxos: eis a fórmula encontrada pela Rodobens para tornar-se a construtora que mais cresce no país. Disponível em: <http://veja.abril.com.br/040608/p_162.shtml> Acesso em jul. 2008.

VIEIRA, C.C. (2005). Desempenho térmico de painéis de concreto leve. São Paulo: USP. Monografia apresentada à disciplina SAP 5820 A utilização de novos materiais na tecnologia do concreto. Departamento de Arquitetura e Planejamento - EESC, Universidade Federal de São Paulo.

WERNA, E. et al. (2001). Pluralismo na Habitação. São Paulo: Annablume/EPUSP. 300 p.

ZHANG, M.H.; GJ $\phi R V$, O.E. (1991). Mechanical properties of high-strength lightweight concrete. ACl Materials Journal, v.88, n.3, p.240-247. 


\section{REFERÊNCIAS ICONOGRÁFICAS}

ROSSIGNOLO, João Adriano. Analândia - SP, 2005. Fotografia digital.

ROSSIGNOLO, João Adriano. Monte Mor - SP, 2005. Fotografia digital.

ROSSIGNOLO, João Adriano. Santa Maria da Serra - SP, 2006. Fotografia digital.

ROSSIGNOLO, João Adriano. São Paulo - SP, 2005. Fotografia digital. 
APÊNDICES 
APÊNDICE 1. Questionário Ocupação e Ventilação

\begin{tabular}{|c|c|c|c|c|c|c|c|}
\hline \multicolumn{3}{|l|}{ Local: } & \multicolumn{3}{|c|}{$N^{\circ}$. Residência: } & \multicolumn{2}{|l|}{ Data: } \\
\hline \multirow[b]{2}{*}{$\mathbf{N}^{\circ}$. DE PESSOAS } & \multicolumn{2}{|c|}{ PERÍODO DE OCUPAÇÃO } & \multicolumn{3}{|c|}{ EQUIPAMENTOS } & \multicolumn{2}{|c|}{ PERÍODO DE VENTILAÇÃO } \\
\hline & $\begin{array}{l}\text { Início } \\
\text { (Horas) }\end{array}$ & $\begin{array}{c}\text { Duração } \\
\text { (Horas) }\end{array}$ & Tipo & $\begin{array}{c}\text { Calor } \\
\text { produzido } \\
\text { (watts) }\end{array}$ & $\begin{array}{c}\text { Período de } \\
\text { Funcionamento } \\
\text { (Horas) }\end{array}$ & $\begin{array}{c}\text { Hora de } \\
\text { abertura } \\
\text { (Horas) }\end{array}$ & $\begin{array}{c}\text { Tempo de } \\
\text { abertura } \\
\text { (Horas) }\end{array}$ \\
\hline \multicolumn{3}{|l|}{ Local: } & \multicolumn{3}{|c|}{$N^{\circ}$. Residência: } & \multicolumn{2}{|l|}{ Data: } \\
\hline \multirow[b]{2}{*}{$\mathbf{N}^{\circ}$. DE PESSOAS } & \multicolumn{2}{|c|}{ PERÍODO DE OCUPAÇÃO } & \multicolumn{3}{|c|}{ EQUIPAMENTOS } & \multicolumn{2}{|c|}{ PERÍODO DE VENTILAÇÃO } \\
\hline & $\begin{array}{l}\text { Início } \\
\text { (Horas) }\end{array}$ & $\begin{array}{c}\text { Duração } \\
\text { (Horas) }\end{array}$ & Tipo & $\begin{array}{l}\text { Calor } \\
\text { produzido } \\
\text { (watts) }\end{array}$ & $\begin{array}{c}\text { Período de } \\
\text { Funcionamento } \\
\text { (Horas) }\end{array}$ & $\begin{array}{c}\text { Hora de } \\
\text { abertura } \\
\text { (Horas) }\end{array}$ & $\begin{array}{c}\text { Tempo de } \\
\text { abertura } \\
\text { (Horas) }\end{array}$ \\
\hline \multicolumn{3}{|l|}{ Local: } & \multicolumn{3}{|c|}{$N^{\circ}$. Residência: } & \multicolumn{2}{|l|}{ Data: } \\
\hline \multirow[b]{2}{*}{$\mathbf{N}^{\circ}$. DE PESSOAS } & \multicolumn{2}{|c|}{ PERÍODO DE OCUPAÇÃO } & \multicolumn{3}{|c|}{ EQUIPAMENTOS } & \multicolumn{2}{|c|}{ PERÍODO DE VENTILAÇÃO } \\
\hline & $\begin{array}{l}\text { Início } \\
\text { (Horas) }\end{array}$ & $\begin{array}{l}\text { Duração } \\
\text { (Horas) }\end{array}$ & Tipo & $\begin{array}{c}\text { Calor } \\
\text { produzido } \\
\text { (watts) }\end{array}$ & $\begin{array}{c}\text { Período de } \\
\text { Funcionamento } \\
\text { (Horas) }\end{array}$ & $\begin{array}{l}\text { Hora de } \\
\text { abertura } \\
\text { (Horas) }\end{array}$ & $\begin{array}{c}\text { Tempo de } \\
\text { abertura } \\
\text { (Horas) }\end{array}$ \\
\hline \multicolumn{3}{|l|}{ Local: } & \multicolumn{3}{|c|}{$\mathbf{N}^{\circ}$. Residência: } & \multicolumn{2}{|l|}{ Data: } \\
\hline \multirow[b]{2}{*}{$N^{\circ}$. DE PESSOAS } & \multicolumn{2}{|c|}{ PERÍODO DE OCUPAÇÃO } & \multicolumn{3}{|c|}{ EQUIPAMENTOS } & \multicolumn{2}{|c|}{ PERÍODO DE VENTILAÇÃO } \\
\hline & $\begin{array}{c}\text { Início } \\
\text { (Horas) }\end{array}$ & $\begin{array}{c}\text { Duração } \\
\text { (Horas) }\end{array}$ & Tipo & $\begin{array}{c}\text { Calor } \\
\text { produzido } \\
\text { (watts) }\end{array}$ & $\begin{array}{c}\text { Período de } \\
\text { Funcionamento } \\
\text { (Horas) }\end{array}$ & $\begin{array}{c}\text { Hora de } \\
\text { abertura } \\
\text { (Horas) }\end{array}$ & $\begin{array}{c}\text { Tempo de } \\
\text { abertura } \\
\text { (Horas) }\end{array}$ \\
\hline \multicolumn{3}{|l|}{ Local: } & \multicolumn{3}{|c|}{$N^{\circ}$. Residência: } & \multicolumn{2}{|l|}{ Data: } \\
\hline \multirow[b]{2}{*}{$N^{\circ}$. DE PESSOAS } & \multicolumn{2}{|c|}{ PERÍODO DE OCUPAÇÃO } & \multicolumn{3}{|c|}{ EQUIPAMENTOS } & PERÍODO & ENTILAÇÃO \\
\hline & $\begin{array}{l}\text { Início } \\
\text { (Horas) }\end{array}$ & $\begin{array}{c}\text { Duração } \\
\text { (Horas) }\end{array}$ & Tipo & $\begin{array}{l}\text { Calor } \\
\text { produzido } \\
\text { (watts) }\end{array}$ & $\begin{array}{c}\text { Período de } \\
\text { Funcionamento } \\
\text { (Horas) }\end{array}$ & $\begin{array}{l}\text { Hora de } \\
\text { abertura } \\
\text { (Horas) }\end{array}$ & $\begin{array}{l}\text { Tempo de } \\
\text { abertura } \\
\text { (Horas) }\end{array}$ \\
\hline Local: & & & $N^{\circ} \cdot \operatorname{Res}$ & ia: & & Data: & \\
\hline & PERÍODO & CUPAÇÃO & & EQUIPAME & & PERÍODO & ENTILAÇÃO \\
\hline $\mathrm{N}^{\circ}$. DE PESSOAS & $\begin{array}{l}\text { Início } \\
\text { (Horas) }\end{array}$ & $\begin{array}{c}\text { Duração } \\
\text { (Horas) }\end{array}$ & Tipo & $\begin{array}{c}\text { Calor } \\
\text { produzido } \\
\text { (watts) } \\
\end{array}$ & $\begin{array}{c}\text { Período de } \\
\text { Funcionamento } \\
\text { (Horas) }\end{array}$ & $\begin{array}{l}\text { Hora de } \\
\text { abertura } \\
\text { (Horas) } \\
\end{array}$ & $\begin{array}{l}\text { Tempo de } \\
\text { abertura } \\
\text { (Horas) }\end{array}$ \\
\hline Local: & & & $N^{\circ} \cdot \operatorname{Res}$ & ia: & & Data: & \\
\hline & PERÍODO & CUPAÇÃO & & EQUIPAME & & PERÍODO & ENTILAÇÃO \\
\hline $\mathbf{N}^{\circ}$. DE PESSOAS & $\begin{array}{c}\text { Início } \\
\text { (Horas) }\end{array}$ & $\begin{array}{l}\text { Duração } \\
\text { (Horas) }\end{array}$ & Tipo & $\begin{array}{c}\text { Calor } \\
\text { produzido } \\
\text { (watts) }\end{array}$ & $\begin{array}{c}\text { Período de } \\
\text { Funcionamento } \\
\text { (Horas) }\end{array}$ & $\begin{array}{l}\text { Hora de } \\
\text { abertura } \\
\text { (Horas) } \\
\end{array}$ & $\begin{array}{l}\text { Tempo de } \\
\text { abertura } \\
\text { (Horas) }\end{array}$ \\
\hline & & & & & & & \\
\hline
\end{tabular}


APÊNDICE 2. Tabelas - Resultados das Simulações Térreas

\subsection{Simulações de Referência}

\begin{tabular}{|c|c|c|c|c|c|c|}
\hline \multicolumn{7}{|c|}{ Simulações para o Verão - 22 de Dezembro } \\
\hline Cidade & Zona Bioclimática & Tipo de Cobertura & Vedações & Temp. Máxima Interna & Temp. Máxima Externa & Desempenho \\
\hline \multirow{3}{*}{ Caxias do Sul } & \multirow{3}{*}{1} & Telha Cerâmica & \multirow{3}{*}{ Bloco Cerâmico } & & 26,2 & Não Atende \\
\hline & & \multirow{2}{*}{\begin{tabular}{|l|} 
Telha Cerâamica e Laje Mista \\
Telha Cerâmica e Laje Mista Inclinada \\
Telha Cerâmica
\end{tabular}} & & 27,8 & 26,2 & Não Atende \\
\hline & & & & $\frac{27,6}{28,5}$ & $\frac{26,2}{262}$ & Não Atende \\
\hline \multirow{2}{*}{ Caxias do Sul } & \multirow{2}{*}{1} & $\begin{array}{l}\text { lelna Ceramica } \\
\text { Telha Cerâmica e Laje Mista } \\
\end{array}$ & \multirow{2}{*}{ Bloco de Concreto } & $\frac{20,5}{27,3}$ & 26,2 & Não Atende \\
\hline & & Telha Cerâmica e Laje Mista Inclinada & & 27 & $\frac{26,2}{26,2}$ & Não Atende \\
\hline \multirow{2}{*}{ Ponta Grossa } & \multirow{3}{*}{2} & Telha Cerâmica & \multirow[b]{2}{*}{ Bloco Cerâmico } & 29,5 & & Não Atende \\
\hline & & Telha Cerâmica e Laje Mista & & 27,8 & 27,2 & Não Atende \\
\hline \multirow{3}{*}{ Ponta Grossa } & & $\begin{array}{l}\text { Telha Cerâmica e Laje Mista Inclinada } \\
\text { Telha Cerâmica }\end{array}$ & \multirow{3}{*}{ Bloco de Concreto } & $\frac{27,7}{28,3}$ & $\frac{27,2}{27,2}$ & $\frac{\text { Não Atende }}{\text { Não Atende }}$ \\
\hline & \multirow[t]{2}{*}{2} & \begin{tabular}{|l|l} 
Telha Cerâmica e Laje Mista \\
\end{tabular} & & 27,3 & 27,2 & Não Atende \\
\hline & & Telha Cerâmica e Laje Mista Inclinada & & 27,2 & & \\
\hline \multirow{2}{*}{ São Paulo } & \multirow{2}{*}{3} & \begin{tabular}{|l|} 
Telha Cerâmica \\
Tolha Cômica \\
\end{tabular} & \multirow{2}{*}{ Bloco Cerâmico } & 27,9 & $\frac{25,9}{259}$ & Não Atende \\
\hline & & \begin{tabular}{|l} 
Telha Cerâmica e Laje Mista \\
Telha Cerâmica e Laje Mista Inclinada
\end{tabular} & & $\frac{26,5}{26,4}$ & $\frac{25,9}{25,9}$ & $\begin{array}{l}\text { Năo Atende } \\
\text { Não Atende }\end{array}$ \\
\hline \multirow{3}{*}{ São Paulo } & \multirow{3}{*}{3} & Telha Cerâmica & & 26,9 & 25,9 & Não Atende \\
\hline & & Telha Cerâmica e Laje Mista & Bloco de Concreto & 26,1 & 25,9 & Não Atende \\
\hline & & Telha Cerâmica e Laje Mista Inclinada & & $\frac{25,9}{30}$ & $\frac{25,9}{265}$ & $\frac{\mathrm{M}}{\mathrm{N} \tilde{\mathrm{n}} \mathrm{A} \operatorname{conde}}$ \\
\hline Florianópolis & 3 & $\begin{array}{l}\text { Telha Cerâmica } \\
\text { Telha Cerâmica e Laie Mista }\end{array}$ & Bloco Cerâmico & $\frac{30}{28,6}$ & $\frac{26,5}{26,5}$ & Não Atende \\
\hline & & Telha Cerâmica e Laje Mista Inclinada & & & $\frac{20,5}{26,5}$ & Não Atende \\
\hline & & & & $\frac{26,8}{28,8}$ & 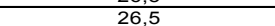 & Não Atende \\
\hline Florianópolis & 3 & \begin{tabular}{|l|} 
Telha Cerâmica e Laje Mista \\
\end{tabular} & Bloco de Concreto & $\frac{26,2}{28,2}$ & 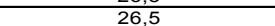 & Não Atende \\
\hline & & Telha Cerâmica e Laje Mista Inclinada & & 27,8 & 26,5 & Não Atende \\
\hline & & Telha Cerâmica & & 29,1 & 26,9 & Não Atende \\
\hline São Carlos & 4 & Telha Cerâmica e Laje Mista & Bloco Cerâmico & 27,8 & 26,9 & Não Atende \\
\hline & & Telha Cerâmica e Laje Mista Inclinada & & $\frac{27,6}{28,1}$ & $\frac{26,9}{26,9}$ & Não Atende \\
\hline São Carlos & 4 & $\begin{array}{l}\text { Tehla Cerămica } \\
\text { Telha Cerâmica e Laje Mista }\end{array}$ & Bloco de Concreto & $\frac{28,1}{27,4}$ & $\frac{26,9}{26,9}$ & Não Atende \\
\hline sao carios & 4 & a e Laie Mista Inclinada & 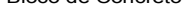 & $\frac{27,4}{27.2}$ & $\begin{array}{ll}26,5 \\
269\end{array}$ & 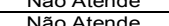 \\
\hline & & 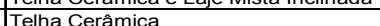 & & 33.7 & 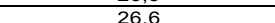 & Năo Atende \\
\hline Brasilia & 4 & Telha Cerâmica e Laje Mista & Bloco Cerâmico & 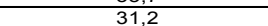 & $\frac{26,6}{26,6}$ & Năo Atende \\
\hline & & Telha Cerâmica e Laje Mista Inclinada & & 30,5 & 26,6 & Não Atende \\
\hline & & Telha Cerâmica & 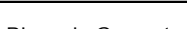 & 31,6 & 26,6 & Não Atende \\
\hline Brasília & 4 & \begin{tabular}{|l|} 
Telha Cerâmica e Laje Mista \\
\end{tabular} & Bloco de Concreto & 30,4 & 26,6 & Não Atende \\
\hline & & $\begin{array}{l}\text { lelha Ceramica e Laje Mista Inclinada } \\
\text { Telha Cerâmica }\end{array}$ & & $\frac{29,8}{30,2}$ & $\frac{26,6}{27,5}$ & $\begin{array}{l}\text { Nao Atende } \\
\text { Não Atende }\end{array}$ \\
\hline Santos & 5 & Telha Cerâmica e Laje Mista & Bloco Cerâmico & 29 & 27,5 & Não Atende \\
\hline & & Telha Cerâmica e Laje Mista Inclinada & & 28,8 & 27,5 & Não Atende \\
\hline Santos & 5 & Telha Cerâmica & Bloce de Concreto & $\frac{29,2}{286}$ & $\frac{27,5}{27,5}$ & Não Atende \\
\hline Santos & & $\begin{array}{l}\text { Telha Cerâmica e Laje Mista } \\
\text { Telha Cerâmica e Laie Mista Inclinada }\end{array}$ & Bloco de Concreto & $\frac{28,6}{28,3}$ & $\frac{27,5}{27,5}$ & $\frac{\text { Năo Atende }}{\text { Não Atende }}$ \\
\hline & & Telha Cerâm & & $\frac{20,0}{33,3}$ & $\frac{21,0}{30,2}$ & Năo Atende \\
\hline Presidente Prudente & 6 & Telha Cerâm & Bloco Cerâmico & $\frac{3,17}{317}$ & $\frac{30}{302}$ & Nad Atende \\
\hline & & e Laie Mista Inclinada & & $\frac{3,1}{31.4}$ & 302 & $\frac{\text { Atende }}{\text { Atende }}$ \\
\hline & & Telha Cerâm & & $\frac{1,4}{32,1}$ & 30,2 & $\frac{\text { Nao Atende }}{\text { Não Atende }}$ \\
\hline Presidente Prudente & 6 & e Laje Mista & Bloco de Concreto & 31,2 & 30,2 & Não Atende \\
\hline & & e Laje Mista Inclinada & & 30,9 & 30,2 & Não Atende \\
\hline 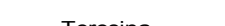 & 7 & Telh & 20 & 37,3 & 34,4 & Não Atende \\
\hline Teresina & 7 & e Laje Mista & Bloco Cerâmico & 35,5 & 34,4 & Não Atende \\
\hline & & a e Laje Mista Inclinada & & 35,3 & 34,4 & Não Atende \\
\hline Teresina & 7 & Telha Ce & Bloce de Concrete $\mathrm{C} \mathrm{C}$ & $\frac{3,9}{35}$ & $\begin{array}{l}34,4 \\
3,4\end{array}$ & Não Aten \\
\hline & & $\begin{array}{l}\text { lelha Ceramica e Laje Mista } \\
\text { Telha Cerâmica e Laje Mista Inclinada }\end{array}$ & & $\frac{35}{34,7}$ & $\frac{34,4}{34,4}$ & $\frac{\text { Nao Atende }}{\text { Não Atende }}$ \\
\hline & & & & & 31,8 & Não Atende \\
\hline Belém & 8 & e Laje Mista & Bloco Cerâmico & 32,6 & 31,8 & Não Atende \\
\hline & & e Laje Mista Inclinada & & $\begin{array}{l}32,5 \\
329\end{array}$ & $\frac{31,8}{31,8}$ & Não Atende \\
\hline Belém & 8 & $\begin{array}{l}\text { Telha Cerâmica } \\
\text { Telha Cerâmica e Laje Mista }\end{array}$ & Bloco de Concreto & $\frac{32,9}{32,2}$ & $\frac{31,8}{31,8}$ & $\begin{array}{l}\text { Naoo Atende } \\
\text { Não Atende }\end{array}$ \\
\hline & & Telha Cerâmica e Laje Mista lı & & & & Não Atende \\
\hline
\end{tabular}




\begin{tabular}{|c|c|c|c|c|c|}
\hline \multicolumn{6}{|c|}{ Simulações para o Inverno - 22 de Junho } \\
\hline Cidade & Zona Bioclimática & Tipo de Cobertura & Vedações & Temp. Mínima Interna & Desempenho \\
\hline \multirow{3}{*}{ Caxias do Sul } & \multirow[t]{3}{*}{ 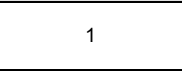 } & Telha Cerâmica & \multirow{3}{*}{ Bloco Cerâmico } & 11,1 & Não Atende \\
\hline & & Telha Cerâmica e Laje Mista & & 12,2 & $\mathrm{M}$ \\
\hline & & Telha Cerâmica e Laje Mista Inclinada & & 11,8 & $\mathrm{M}$ \\
\hline \multirow{3}{*}{ Caxias do Sul } & \multirow{3}{*}{1} & Telha Cerâmica & \multirow{3}{*}{ Bloco de Concreto } & 11,3 & Não Atende \\
\hline & & Telha Cerâmica e Laje Mista & & 11,9 & $\mathrm{M}$ \\
\hline & & Telha Cerâmica e Laje Mista Inclinada & & 11,7 & Não Atende \\
\hline \multirow{3}{*}{ Ponta Grossa } & \multirow{3}{*}{2} & Telha Cerâmica & & 12,3 & $\mathrm{M}$ \\
\hline & & Telha Cerâmica e Laje Mista & Bloco Cerâmico & 13,5 & $\mathrm{M}$ \\
\hline & & Telha Cerâmica e Laje Mista Inclinada & & 13,1 & $\bar{M}$ \\
\hline & & Telha Cerâmica & & 12,5 & $\mathrm{M}$ \\
\hline Ponta Grossa & 2 & Telha Cerâmica e Laje Mista & Bloco de Concreto & 13,3 & $\mathrm{M}$ \\
\hline & & Telha Cerâmica e Laje Mista Inclinada & & 13 & M \\
\hline & & Telha Cerâmica & & 14,1 & Não Atende \\
\hline São Paulo & 3 & Telha Cerâmica e Laje Mista & Bloco Cerâmico & 15,2 & $\mathrm{M}$ \\
\hline & & Telha Cerâmica e Laje Mista Inclinada & & 14,8 & M \\
\hline & & Telha Cerâmica & & 14,2 & $\mathrm{M}$ \\
\hline São Paulo & 3 & Telha Cerâmica e Laje Mista & Bloco de Concreto & 15 & M \\
\hline & & Telha Cerâmica e Laje Mista Inclinada & & 14,7 & $\mathrm{M}$ \\
\hline & & Telha Cerâmica & & 17,1 & Não Atende \\
\hline Florianópolis & 3 & Telha Cerâmica e Laje Mista & Bloco Cerâmico & 17,8 & Não Atende \\
\hline & & Telha Cerâmica e Laje Mista Inclinada & & 17,5 & Não Atende \\
\hline & & Telha Cerâmica & & 17,2 & Não Atende \\
\hline Florianópolis & 3 & Telha Cerâmica e Laje Mista & Bloco de Concreto & 17,6 & Não Atende \\
\hline & & Telha Cerâmica e Laje Mista Inclinada & & 17,4 & Não Atende \\
\hline & & Telha Cerâmica & & 16,3 & $M$ \\
\hline São Carlos & 4 & Telha Cerâmica e Laje Mista & Bloco Cerâmico & 17,4 & $\mathrm{M}$ \\
\hline & & Telha Cerâmica e Laje Mista Inclinada & & 16,9 & $\mathrm{M}$ \\
\hline & & Telha Cerâmica & & 16,4 & $\mathrm{M}$ \\
\hline São Carlos & 4 & Telha Cerâmica e Laje Mista & Bloco de Concreto & 17,1 & $\mathrm{M}$ \\
\hline & & Telha Cerâmica e Laje Mista Inclinada & & 16,8 & M \\
\hline & & Telha Cerâmica & & 16,3 & $\mathrm{M}$ \\
\hline Brasília & 4 & Telha Cerâmica e Laje Mista & Bloco Cerâmico & 17,4 & $\mathrm{M} / \mathrm{I}$ \\
\hline & & Telha Cerâmica e Laje Mista Inclinada & & 16,7 & $\mathrm{M} / \mathrm{I}$ \\
\hline & & Telha Cerâmica & & 16,3 & $\mathrm{M}$ \\
\hline Brasilia & 4 & Telha Cerâmica e Laje Mista & Bloco de Concreto & 17 & $\mathrm{M} / \mathrm{I}$ \\
\hline & & Telha Cerâmica e Laje Mista Inclinada & & 16,5 & $\mathrm{M}$ \\
\hline & & Telha Cerâmica & & 18,4 & Não Atende \\
\hline Santos & 5 & Telha Cerâmica e Laje Mista & Bloco Cerâmico & 19,2 & $\mathrm{M}$ \\
\hline & & Telha Cerâmica e Laje Mista Inclinada & & 18,8 & Não Atende \\
\hline & & Telha Cerâmica & & 18,4 & Não Atende \\
\hline Santos & 5 & Telha Cerâmica e Laje Mista & Bloco de Concreto & 19 & $M$ \\
\hline & & Telha Cerâmica e Laje Mista Inclinada & & 18,7 & Não Atende \\
\hline & & Telha Cerâmica & & 18 & \\
\hline Presidente Prudente & 6 & Telha Cerâmica e Laje Mista & Bloco Cerâmico & 19,1 & \\
\hline & & Telha Cerâmica e Laje Mista Inclinada & & 18,6 & Dispensa Verificacão \\
\hline & & Telha Cerâmica & & 18,1 & Dispensa Veriticaçao \\
\hline Presidente Prudente & 6 & Telha Cerâmica e Laje Mista & Bloco de Concreto & 18,8 & \\
\hline & & Telha Cerâmica e Laje Mista Inclinada & & 18,5 & \\
\hline & & Telha Cerâmica & & 25,8 & \\
\hline Teresina & 7 & Telha Cerâmica e Laje Mista & Bloco Cerâmico & 26,3 & \\
\hline & & Telha Cerâmica e Laje Mista Inclinada & & 25,7 & Dispensa Verificacão \\
\hline & & Telha Cerâmica & & 25,7 & \\
\hline Teresina & 7 & Telha Cerâmica e Laje Mista & Bloco de Concreto & 26 & \\
\hline & & Telha Cerâmica e Laje Mista Inclinada & & 25,5 & \\
\hline & & Telha Cerâmica & & 26,3 & \\
\hline Belém & 8 & Telha Cerâmica e Laje Mista & Bloco Cerâmico & 26,6 & \\
\hline & & Telha Cerâmica e Laje Mista Inclinada & & 26,1 & \\
\hline & & Telha Cerâmica & & 26,2 & Dispensa verificaçao \\
\hline Belém & 8 & Telha Cerâmica e Laje Mista & Bloco de Concreto & 26,3 & \\
\hline & & Telha Cerâmica e Laje Mista Inclinada & & 26 & \\
\hline & & Telha Cerâmica & & 11,6 & Não Atende \\
\hline Caxias do Sul ${ }^{*}$ & 1 & Telha Cerâmica e Laje Mista & Bloco Cerâmico & 13,3 & Não Atende \\
\hline & & Telha Cerâmica e Laje Mista Inclinada & & 13 & Não Atende \\
\hline & & Telha Cerâmica & & 11,7 & Não Atende \\
\hline Caxias do Sul* & 1 & Telha Cerâmica e Laje Mista & Bloco de Concreto & 12,8 & Não Atende \\
\hline & & Telha Cerâmica e Laje Mista Inclinada & & 12,5 & Não Atende \\
\hline & & Telha Cerâmica & & 12,8 & $M$ \\
\hline Ponta Grossa* & 2 & Telha Cerâmica e Laje Mista & Bloco Cerâmico & 14,7 & $\mathrm{M} / \mathrm{I}$ \\
\hline & & Telha Cerâmica e Laje Mista Inclinada & & 14,4 & $\mathrm{M} / \mathrm{I}$ \\
\hline & & Telha Cerâmica & & 12,9 & $M$ \\
\hline Ponta Grossa* & 2 & Telha Cerâmica e Laje Mista & Bloco de Concreto & 14,2 & $\mathrm{M}$ \\
\hline & & Telha Cerâmica e Laje Mista Inclinada & & 13,9 & $\mathrm{M}$ \\
\hline
\end{tabular}




\subsection{Simulações dos Painéis de Concreto}

\begin{tabular}{|c|c|c|c|c|c|c|}
\hline \multicolumn{7}{|c|}{ Simulações para o Verão - 22 de Dezembro } \\
\hline Cidade & Zona Bioclimática & \begin{tabular}{|c|} 
Tipos de Cobertura \\
\end{tabular} & Vedações & Temp. Máxima Interna & Temp. Máxima Externa & Desempenho \\
\hline \multirow{3}{*}{ Caxias do Sul } & \multirow{3}{*}{1} & Telha Cerâmica & \multirow{3}{*}{$\mathrm{P} 08 \mathrm{~cm} / \mathrm{conc} 2400$} & 28,5 & 26,2 & Não Atende \\
\hline & & Telha Cerâmica e Laje Mista Plana & & 27,5 & 26,2 & Não Atende \\
\hline & & Telha Cerâmica e Laje Mista Inclinada & & 27,3 & 26,2 & Não Atende \\
\hline \multirow{3}{*}{ Caxias do Sul } & \multirow{3}{*}{1} & Telha Cerâmica & \multirow{3}{*}{$\mathrm{P} 08 \mathrm{~cm} / \mathrm{conc} 2200$} & 28,6 & 26,2 & Não Atende \\
\hline & & Telha Cerâmica e Laje Mista Plana & & 27,6 & 26,2 & Não Atende \\
\hline & & Telha Cerâmica e Laje Mista Inclinada & & 27,4 & 26,2 & Não Atende \\
\hline \multirow{3}{*}{ Caxias do Sul } & \multirow{3}{*}{1} & Telha Cerâmica & \multirow{3}{*}{ P $08 \mathrm{~cm} /$ conc 2000} & 28,6 & 26,2 & Não Atende \\
\hline & & Telha Cerâmica e Laje Mista Plana & & 27,7 & 26,2 & Não Atende \\
\hline & & Telha Cerâmica e Laje Mista Inclinada & & 27,5 & 26,2 & Não Atende \\
\hline \multirow{3}{*}{ Caxias do Sul } & \multirow{3}{*}{1} & Telha Cerâmica & \multirow{3}{*}{$\mathrm{P} 08 \mathrm{~cm} /$ conc 1800} & 28,7 & 26,2 & Não Atende \\
\hline & & Telha Cerâmica e Laje Mista Plana & & 27,7 & 26,2 & Não Atende \\
\hline & & Telha Cerâmica e Laje Mista Inclinada & & 27,5 & 26,2 & Não Atende \\
\hline \multirow{3}{*}{ Caxias do Sul } & \multirow{3}{*}{1} & Telha Cerâmica & \multirow{3}{*}{$\mathrm{P} 08 \mathrm{~cm} /$ conc 1600} & 28,8 & 26,2 & Não Atende \\
\hline & & Telha Cerâmica e Laje Mista Plana & & 27,8 & 26,2 & Não Atende \\
\hline & & Telha Cerâmica e Laje Mista Inclinada & & 27,6 & 26,2 & Não Atende \\
\hline \multirow{3}{*}{ Caxias do Sul } & \multirow{3}{*}{1} & Telha Cerâmica & \multirow{3}{*}{ P $10 \mathrm{~cm} /$ conc 2400} & 27,8 & 26,2 & Não Atende \\
\hline & & Telha Cerâmica e Laje Mista Plana & & 27,1 & 26,2 & Não Atende \\
\hline & & Telha Cerâmica e Laje Mista Inclinada & & 26,8 & 26,2 & Não Atende \\
\hline \multirow{3}{*}{ Caxias do Sul } & \multirow{3}{*}{1} & Telha Cerâmica & \multirow{3}{*}{ P $10 \mathrm{~cm} /$ conc 2200} & 27,9 & 26,2 & Não Atende \\
\hline & & \begin{tabular}{|l|l|} 
Telha Cerâmica e Laje Mista Plana \\
\end{tabular} & & 27,3 & 26,2 & Não Atende \\
\hline & & Telha Cerâmica e Laje Mista Inclinada & & 26,9 & 26,2 & Não Atende \\
\hline & & Telha Cerâmica & & 28 & 26,2 & Não Atende \\
\hline Caxias do Sul & 1 & Telha Cerâmica e Laje Mista Plana & P $10 \mathrm{~cm} /$ conc 2000 & 27,3 & 26,2 & Não Atende \\
\hline & & Telha Cerâmica e Laje Mista Inclinada & & 27 & 26,2 & Não Atende \\
\hline & & Telha Cerâmica & & 28,1 & 26,2 & Não Atende \\
\hline Caxias do Sul & 1 & Telha Cerâmica e Laje Mista Plana & P $10 \mathrm{~cm} /$ conc 1800 & 27,3 & 26,2 & Não Atende \\
\hline & & Telha Cerâmica e Laje Mista Inclinada & & 27 & 26,2 & Não Atende \\
\hline & & Telha Cerâmica & & 28,3 & 26,2 & Não Atende \\
\hline Caxias do Sul & 1 & Telha Cerâmica e Laje Mista Plana & P $10 \mathrm{~cm} /$ conc 1600 & 27,4 & 26,2 & Não Atende \\
\hline & & Telha Cerâmica e Laje Mista Inclinada & & 27,1 & 26,2 & Não Atende \\
\hline & & Telha Cerâmica & & 27,2 & 26,2 & Não Atende \\
\hline Caxias do Sul & 1 & Telha Cerâmica e Laje Mista Plana & P $12 \mathrm{~cm} /$ conc 2400 & 26,7 & 26,2 & Não Atende \\
\hline & & Telha Cerâmica e Laje Mista Inclinada & & 26,3 & 26,2 & Não Atende \\
\hline & & Telha Cerâmica & & 27,3 & 26,2 & Não Atende \\
\hline Caxias do Sul & 1 & Telha Cerâmica e Laje Mista Plana & P $12 \mathrm{~cm} /$ conc 2200 & 26,8 & 26,2 & Não Atende \\
\hline & & Telha Cerâmica e Laje Mista Inclinada & & 26,4 & 26,2 & Não Atende \\
\hline & & Telha Cerâmica & & 27,9 & 26,2 & Não Atende \\
\hline Caxias do Sul & 1 & Telha Cerâmica e Laje Mista Plana & P $12 \mathrm{~cm} /$ conc 2000 & 27 & 26,2 & Não Atende \\
\hline & & Telha Cerâmica e Laje Mista Inclinada & & 26,7 & 26,2 & Não Atende \\
\hline & & Telha Cerâmica & & 28,1 & 26,2 & Não Atende \\
\hline Caxias do Sul & 1 & Telha Cerâmica e Laje Mista Plana & $\mathrm{P} 12 \mathrm{~cm} /$ conc 1800 & 27 & 26,2 & Não Atende \\
\hline & & Telha Cerâmica e Laje Mista Inclinada & & 26,7 & 26,2 & Não Atende \\
\hline & & Telha Cerâmica & & 28,2 & 26,2 & Não Atende \\
\hline Caxias do Sul & 1 & Telha Cerâmica e Laje Mista Plana & P $12 \mathrm{~cm} /$ conc 1600 & 27,1 & 26,2 & Não Atende \\
\hline & & Telha Cerâmica e Laje Mista Inclinada & & 26,8 & 26,2 & Não Atende \\
\hline
\end{tabular}




\begin{tabular}{|c|c|c|c|c|c|c|}
\hline \multicolumn{7}{|c|}{ Simulações para o Verão - 22 de Dezembro } \\
\hline Cidade & Zona Bioclimática & Tipos de Cobertura & Vedações & Temp. Máxima Interna & Temp. Máxima Externa & Desempenho \\
\hline \multirow{3}{*}{ Ponta Grossa } & \multirow{3}{*}{ 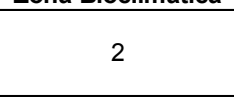 } & Telha Cerâmica & \multirow{3}{*}{$\mathrm{P} 08 \mathrm{~cm} /$ conc 2400} & 28,4 & 27,2 & Não Atende \\
\hline & & Telha Cerâmica e Laje Mista Plana & & 27,6 & 27,2 & Não Atende \\
\hline & & Telha Cerâmica e Laje Mista Inclinada & & 27,5 & 27,2 & Não Atende \\
\hline \multirow{3}{*}{ Ponta Grossa } & \multirow{3}{*}{2} & Telha Cerâmica & \multirow{3}{*}{$\mathrm{P} 08 \mathrm{~cm} /$ conc 2200} & 28,5 & 27,2 & Não Atende \\
\hline & & \begin{tabular}{|l|l|} 
Telha Cerâmica e Laje Mista Plana \\
\end{tabular} & & 27,7 & 27,2 & Não Atende \\
\hline & & Telha Cerâmica e Laje Mista Inclinada & & 27,6 & 27,2 & Não Atende \\
\hline \multirow{3}{*}{ Ponta Grossa } & \multirow{3}{*}{2} & Telha Cerâmica & \multirow{3}{*}{ P $08 \mathrm{~cm} /$ conc 2000} & 28,6 & 27,2 & Não Atende \\
\hline & & Telha Cerâmica e Laje Mista Plana & & 27,7 & 27,2 & Não Atende \\
\hline & & Telha Cerâmica e Laje Mista Inclinada & & 27,6 & 27,2 & Não Atende \\
\hline \multirow{3}{*}{ Ponta Grossa } & \multirow{3}{*}{2} & Telha Cerâmica & \multirow{3}{*}{$\mathrm{P} 08 \mathrm{~cm} /$ conc 1800} & 28,6 & 27,2 & Não Atende \\
\hline & & Telha Cerâmica e Laje Mista Plana & & 27,8 & 27,2 & Não Atende \\
\hline & & Telha Cerâmica e Laje Mista Inclinada & & 27,7 & 27,2 & Não Atende \\
\hline \multirow{3}{*}{ Ponta Grossa } & \multirow{3}{*}{2} & Telha Cerâmica & \multirow{3}{*}{$\mathrm{P} 08 \mathrm{~cm} /$ conc 1600} & 28,7 & 27,2 & Não Atende \\
\hline & & Telha Cerâmica e Laje Mista Plana & & 27,8 & 27,2 & Não Atende \\
\hline & & Telha Cerâmica e Laje Mista Inclinada & & 27,7 & 27,2 & Não Atende \\
\hline \multirow{3}{*}{ Ponta Grossa } & \multirow{3}{*}{2} & Telha Cerâmica & \multirow{3}{*}{ P $10 \mathrm{~cm} /$ conc 2400} & 27,8 & 27,2 & Não Atende \\
\hline & & Telha Cerâmica e Laje Mista Plana & & 27,2 & 27,2 & $\mathrm{M}$ \\
\hline & & Telha Cerâmica e Laje Mista Inclinada & & 27 & 27,2 & $\mathrm{M}$ \\
\hline \multirow{3}{*}{ Ponta Grossa } & \multirow{3}{*}{2} & Telha Cerâmica & \multirow{3}{*}{ P $10 \mathrm{~cm} /$ conc 2200} & 27,9 & 27,2 & Não Atende \\
\hline & & Telha Cerâmica e Laje Mista Plana & & 27,3 & 27,2 & Não Atende \\
\hline & & Telha Cerâmica e Laje Mista Inclinada & & 27,2 & 27,2 & $M$ \\
\hline & & Telha Cerâmica & & 28 & 27,2 & Não Atende \\
\hline Ponta Grossa & 2 & Telha Cerâmica e Laje Mista Plana & P $10 \mathrm{~cm} /$ conc 2000 & 27,3 & 27,2 & Não Atende \\
\hline & & Telha Cerâmica e Laje Mista Inclinada & & 27,2 & 27,2 & $\mathrm{M}$ \\
\hline & & Telha Cerâmica & & 27,9 & 27,2 & Não Atende \\
\hline Ponta Grossa & 2 & Telha Cerâmica e Laje Mista Plana & P $10 \mathrm{~cm} /$ conc 1800 & 27,4 & 27,2 & Não Atende \\
\hline & & Telha Cerâmica e Laje Mista Inclinada & & 27,2 & 27,2 & $\mathrm{M}$ \\
\hline & & Telha Cerâmica & & 28,2 & 27,2 & Não Atende \\
\hline Ponta Grossa & 2 & Telha Cerâmica e Laje Mista Plana & P $10 \mathrm{~cm} /$ conc 1600 & 27,4 & 27,2 & Não Atende \\
\hline & & Telha Cerâmica e Laje Mista Inclinada & & 27,3 & 27,2 & Não Atende \\
\hline & & Telha Cerâmica & & 27,2 & 27,2 & $\mathrm{M}$ \\
\hline Ponta Grossa & 2 & Telha Cerâmica e Laje Mista Plana & P $12 \mathrm{~cm} /$ conc 2400 & 26,8 & 27,2 & $\mathrm{M}$ \\
\hline & & Telha Cerâmica e Laje Mista Inclinada & & 26,6 & 27,2 & $\mathrm{M}$ \\
\hline & & Telha Cerâmica & & 27,3 & 27,2 & Não Atende \\
\hline Ponta Grossa & 2 & Telha Cerâmica e Laje Mista Plana & P $12 \mathrm{~cm} /$ conc 2200 & 26,9 & 27,2 & $\mathrm{M}$ \\
\hline & & Telha Cerâmica e Laje Mista Inclinada & & 26,6 & 27,2 & $\mathrm{M}$ \\
\hline & & Telha Cerâmica & & 27,9 & 27,2 & Não Atende \\
\hline Ponta Grossa & 2 & Telha Cerâmica e Laje Mista Plana & P $12 \mathrm{~cm} /$ conc 2000 & 27,1 & 27,2 & $\mathrm{M}$ \\
\hline & & Telha Cerâmica e Laje Mista Inclinada & & 26,9 & 27,2 & $\mathrm{M}$ \\
\hline & & Telha Cerâmica & & 28 & 27,2 & Não Atende \\
\hline Ponta Grossa & 2 & Telha Cerâmica e Laje Mista Plana & P $12 \mathrm{~cm} /$ conc 1800 & 27,1 & 27,2 & $\mathrm{M}$ \\
\hline & & Telha Cerâmica e Laje Mista Inclinada & & 26,9 & 27,2 & $\mathrm{M}$ \\
\hline & & Telha Cerâmica & & 28,1 & 27,2 & Não Atende \\
\hline Ponta Grossa & 2 & Telha Cerâmica e Laje Mista Plana & P $12 \mathrm{~cm} /$ conc 1600 & 27,2 & 27,2 & $\mathrm{M}$ \\
\hline & & Telha Cerâmica e Laje Mista Inclinada & & 27 & 27,2 & $\mathrm{M}$ \\
\hline
\end{tabular}




\begin{tabular}{|c|c|c|c|c|c|c|}
\hline \multicolumn{7}{|c|}{ Simulações para o Verão - 22 de Dezembro } \\
\hline Cidade & Zona Bioclimática & Tipos de Cobertura & Vedações & Temp. Máxima Interna & Temp. Máxima Externa & Desempenho \\
\hline \multirow{3}{*}{ São Paulo } & \multirow{3}{*}{ 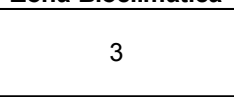 } & Telha Cerâmica & \multirow{3}{*}{ P $08 \mathrm{~cm} /$ conc 2400} & 27 & 25,9 & Não Atende \\
\hline & & Telha Cerâmica e Laje Mista & & 26,3 & 25,9 & Não Atende \\
\hline & & Telha Cerâmica e Laje Mista Inclinada & & 26,2 & 25,9 & Não Atende \\
\hline \multirow{3}{*}{ São Paulo } & \multirow{3}{*}{3} & Telha Cerâmica & \multirow{3}{*}{$\mathrm{P} 08 \mathrm{~cm} /$ conc 2200} & 27 & 25,9 & Não Atende \\
\hline & & Telha Cerâmica e Laje Mista & & 26,3 & 25,9 & Não Atende \\
\hline & & Telha Cerâmica e Laje Mista Inclinada & & 26,2 & 25,9 & Não Atende \\
\hline \multirow{3}{*}{ São Paulo } & \multirow{3}{*}{3} & Telha Cerâmica & \multirow{3}{*}{$\mathrm{P} 08 \mathrm{~cm} /$ conc 2000} & 27,1 & 25,9 & Não Atende \\
\hline & & Telha Cerâmica e Laje Mista Plana & & 26,4 & 25,9 & Não Atende \\
\hline & & Telha Cerâmica e Laje Mista Inclinada & & 26,3 & 25,9 & Não Atende \\
\hline \multirow{3}{*}{ São Paulo } & \multirow{3}{*}{3} & Telha Cerâmica & \multirow{3}{*}{$\mathrm{P} 08 \mathrm{~cm} /$ conc 1800} & 27,1 & 25,9 & Não Atende \\
\hline & & Telha Cerâmica e Laje Mista Plana & & 26,4 & 25,9 & Não Atende \\
\hline & & Telha Cerâmica e Laje Mista Inclinada & & 26,3 & 25,9 & Não Atende \\
\hline \multirow{3}{*}{ São Paulo } & \multirow{3}{*}{3} & Telha Cerâmica & \multirow{3}{*}{$\mathrm{P} 08 \mathrm{~cm} /$ conc 1600} & 27,2 & 25,9 & Não Atende \\
\hline & & Telha Cerâmica e Laje Mista Plana & & 26,5 & 25,9 & Não Atende \\
\hline & & Telha Cerâmica e Laje Mista Inclinada & & 26,4 & 25,9 & Não Atende \\
\hline \multirow{3}{*}{ São Paulo } & \multirow{3}{*}{3} & Telha Cerâmica & \multirow{3}{*}{ P $10 \mathrm{~cm} /$ conc 2400} & 26,4 & 25,9 & Não Atende \\
\hline & & Telha Cerâmica e Laje Mista & & 25,9 & 25,9 & $\mathrm{M}$ \\
\hline & & Telha Cerâmica e Laje Mista Inclinada & & 25,8 & 25,9 & $\mathrm{M}$ \\
\hline \multirow{3}{*}{ São Paulo } & \multirow{3}{*}{3} & Telha Cerâmica & \multirow{3}{*}{ P $10 \mathrm{~cm} /$ conc 2200} & 26,5 & 25,9 & Não Atende \\
\hline & & Telha Cerâmica e Laje Mista & & 26 & 25,9 & Não Atende \\
\hline & & Telha Cerâmica e Laje Mista Inclinada & & 25,9 & 25,9 & $\mathrm{M}$ \\
\hline & & Telha Cerâmica & & 26,6 & 25,9 & Não Atende \\
\hline São Paulo & 3 & Telha Cerâmica e Laje Mista Plana & P $10 \mathrm{~cm} /$ conc 2000 & 26,1 & 25,9 & Não Atende \\
\hline & & Telha Cerâmica e Laje Mista Inclinada & & 25,9 & 25,9 & $\mathrm{M}$ \\
\hline & & Telha Cerâmica & & 26,7 & 25,9 & Não Atende \\
\hline São Paulo & 3 & Telha Cerâmica e Laje Mista Plana & P $10 \mathrm{~cm} /$ conc 1800 & 26,1 & 25,9 & Não Atende \\
\hline & & Telha Cerâmica e Laje Mista Inclinada & & 26 & 25,9 & Não Atende \\
\hline & & Telha Cerâmica & & 26,8 & 25,9 & Não Atende \\
\hline São Paulo & 3 & Telha Cerâmica e Laje Mista Plana & P $10 \mathrm{~cm} /$ conc 1600 & 26,1 & 25,9 & Não Atende \\
\hline & & Telha Cerâmica e Laje Mista Inclinada & & 26 & 25,9 & Não Atende \\
\hline & & Telha Cerâmica & & 25,9 & 25,9 & $\mathrm{M}$ \\
\hline São Paulo & 3 & Telha Cerâmica e Laje Mista Plana & P $12 \mathrm{~cm} /$ conc 2400 & 25,6 & 25,9 & $\mathrm{M}$ \\
\hline & & Telha Cerâmica e Laje Mista Inclinada & & 25,4 & 25,9 & $\mathrm{M}$ \\
\hline & & Telha Cerâmica & & 26 & 25,9 & Não Atende \\
\hline São Paulo & 3 & Telha Cerâmica e Laje Mista Plana & P $12 \mathrm{~cm} /$ conc 2200 & 25,7 & 25,9 & $\mathrm{M}$ \\
\hline & & Telha Cerâmica e Laje Mista Inclinada & & 25,5 & 25,9 & $\mathrm{M}$ \\
\hline & & Telha Cerâmica & & 26,5 & 25,9 & Não Atende \\
\hline São Paulo & 3 & Telha Cerâmica e Laje Mista Plana & P $12 \mathrm{~cm} /$ conc 2000 & 25,8 & 25,9 & $\mathrm{M}$ \\
\hline & & Telha Cerâmica e Laje Mista Inclinada & & 25,7 & 25,9 & $\mathrm{M}$ \\
\hline & & Telha Cerâmica & & 26,6 & 25,9 & Não Atende \\
\hline São Paulo & 3 & Telha Cerâmica e Laje Mista Plana & P $12 \mathrm{~cm} /$ conc 1800 & 25,9 & 25,9 & $\mathrm{M}$ \\
\hline & & Telha Cerâmica e Laje Mista Inclinada & & 25,7 & 25,9 & $\mathrm{M}$ \\
\hline & & Telha Cerâmica & & 26,7 & 25,9 & Não Atende \\
\hline São Paulo & 3 & Telha Cerâmica e Laje Mista Plana & P $12 \mathrm{~cm} /$ conc 1600 & 25,9 & 25,9 & $\mathrm{M}$ \\
\hline & & Telha Cerâmica e Laje Mista Inclinada & & 25,8 & 25,9 & $\mathrm{M}$ \\
\hline
\end{tabular}


Simulações para o Verão - 22 de Dezembro

\begin{tabular}{|c|c|c|c|c|c|c|}
\hline \multicolumn{7}{|c|}{ Simulações para o Verão - 22 de Dezembro } \\
\hline Cidade & Zona Bioclimática & $\begin{array}{l}\text { Tipos de Cobertura } \\
\end{array}$ & Vedações & Temp. Máxima Interna & Temp. Máxima Externa & Desempenho \\
\hline \multirow{3}{*}{ Florianópolis } & \multirow[t]{3}{*}{ Cuira Diociniratica } & Telha Cerâmica & \multirow{3}{*}{$\mathrm{P} 08 \mathrm{~cm} /$ conc 2400} & 28,7 & 26,5 & Não Atende \\
\hline & & Telha Cerâmica e Laje Mista & & 28,2 & 26,5 & Não Atende \\
\hline & & Telha Cerâmica e Laje Mista Inclinada & & 28 & 26,5 & Não Atende \\
\hline \multirow{3}{*}{ Florianópolis } & \multirow{3}{*}{3} & $\begin{array}{l}\text { Telha Cerâmica } \\
\end{array}$ & \multirow{3}{*}{$\mathrm{P} 08 \mathrm{~cm} /$ conc 2200} & 28,7 & 26,5 & Não Atende \\
\hline & & Telha Cerâmica e Laje Mista & & 28,3 & 26,5 & Não Atende \\
\hline & & Telha Cerâmica e Laje Mista Inclinada & & 28,1 & 26,5 & Não Atende \\
\hline \multirow{3}{*}{ Florianópolis } & \multirow{3}{*}{3} & $\begin{array}{l}\text { Telha Cerâmica } \\
\end{array}$ & \multirow{3}{*}{ P $08 \mathrm{~cm} /$ conc 2000} & 28,8 & 26,5 & Não Atende \\
\hline & & Telha Cerâmica e Laje Mista Plana & & 28,3 & 26,5 & Não Atende \\
\hline & & Telha Cerâmica e Laje Mista Inclinada & & 28,1 & 26,5 & Não Atende \\
\hline \multirow{3}{*}{ Florianópolis } & \multirow{3}{*}{3} & Telha Cerâmica & \multirow{3}{*}{$\mathrm{P} 08 \mathrm{~cm} /$ conc 1800} & 28,9 & 26,5 & Não Atende \\
\hline & & Telha Cerâmica e Laje Mista Plana & & 28,3 & 26,5 & Não Atende \\
\hline & & Telha Cerâmica e Laje Mista Inclinada & & 28,2 & 26,5 & Não Atende \\
\hline \multirow{3}{*}{ Florianópolis } & \multirow{3}{*}{3} & Telha Cerâmica & \multirow{3}{*}{$\mathrm{P} 08 \mathrm{~cm} /$ conc 1600} & 28,9 & 26,5 & Não Atende \\
\hline & & Telha Cerâmica e Laje Mista Plana & & 28,4 & 26,5 & Não Atende \\
\hline & & Telha Cerâmica e Laje Mista Inclinada & & 28,2 & 26,5 & Não Atende \\
\hline \multirow{3}{*}{ Florianópolis } & \multirow{3}{*}{3} & Telha Cerâmica & \multirow{3}{*}{ P $10 \mathrm{~cm} /$ conc 2400} & 28,4 & 26,5 & Não Atende \\
\hline & & Telha Cerâmica e Laje Mista & & 28 & 26,5 & Não Atende \\
\hline & & Telha Cerâmica e Laje Mista Inclinada & & 27,7 & 26,5 & Não Atende \\
\hline \multirow{3}{*}{ Florianópolis } & \multirow{3}{*}{3} & Telha Cerâmica & \multirow{3}{*}{ P $10 \mathrm{~cm} /$ conc 2200} & 28,4 & 26,5 & Não Atende \\
\hline & & Telha Cerâmica e Laje Mista & & 28 & 26,5 & Não Atende \\
\hline & & Telha Cerâmica e Laje Mista Inclinada & & 27,8 & 26,5 & Não Atende \\
\hline & & Telha Cerâmica & & 28,5 & 26,5 & Não Atende \\
\hline Florianópolis & 3 & Telha Cerâmica e Laje Mista Plana & P $10 \mathrm{~cm} /$ conc 2000 & 28,1 & 26,5 & Não Atende \\
\hline & & Telha Cerâmica e Laje Mista Inclinada & & 27,8 & 26,5 & Não Atende \\
\hline & & Telha Cerâmica & & 28,6 & 26,5 & Não Atende \\
\hline Florianópolis & 3 & Telha Cerâmica e Laje Mista Plana & P $10 \mathrm{~cm} /$ conc 1800 & 28,1 & 26,5 & Não Atende \\
\hline & & Telha Cerâmica e Laje Mista Inclinada & & 27,8 & 26,5 & Não Atende \\
\hline & & Telha Cerâmica & & 28,7 & 26,5 & Não Atende \\
\hline Florianópolis & 3 & Telha Cerâmica e Laje Mista Plana & P $10 \mathrm{~cm} /$ conc 1600 & 28,2 & 26,5 & Não Atende \\
\hline & & Telha Cerâmica e Laje Mista Inclinada & & 27,9 & 26,5 & Não Atende \\
\hline & & Telha Cerâmica & & 28 & 26,5 & Não Atende \\
\hline Florianópolis & 3 & Telha Cerâmica e Laje Mista Plana & P $12 \mathrm{~cm} /$ conc 2400 & 27,7 & 26,5 & Não Atende \\
\hline & & Telha Cerâmica e Laje Mista Inclinada & & 27,4 & 26,5 & Não Atende \\
\hline & & $\begin{array}{l}\text { Telha Cerâmica } \\
\end{array}$ & & 28,1 & 26,5 & Não Atende \\
\hline Florianópolis & 3 & Telha Cerâmica e Laje Mista Plana & P $12 \mathrm{~cm} /$ conc 2200 & 27,7 & 26,5 & Não Atende \\
\hline & & Telha Cerâmica e Laje Mista Inclinada & & 27,4 & 26,5 & Não Atende \\
\hline & & Telha Cerâmica & & 28,5 & 26,5 & Não Atende \\
\hline Florianópolis & 3 & Telha Cerâmica e Laje Mista Plana & P $12 \mathrm{~cm} /$ conc 2000 & 27,9 & 26,5 & Não Atende \\
\hline & & Telha Cerâmica e Laje Mista Inclinada & & 27,6 & 26,5 & Não Atende \\
\hline & & Telha Cerâmica & & 28,5 & 26,5 & Não Atende \\
\hline Florianópolis & 3 & Telha Cerâmica e Laje Mista Plana & P $12 \mathrm{~cm} /$ conc 1800 & 28 & 26,5 & Não Atende \\
\hline & & Telha Cerâmica e Laje Mista Inclinada & & 27,7 & 26,5 & Não Atende \\
\hline & & Telha Cerâmica & & 28,7 & 26,5 & Não Atende \\
\hline Florianópolis & 3 & Telha Cerâmica e Laje Mista Plana & P $12 \mathrm{~cm} /$ conc 1600 & 28 & 26,5 & Não Atende \\
\hline & & Telha Cerâmica e Laje Mista Inclinada & & 27,7 & 26,5 & Não Atende \\
\hline
\end{tabular}




\begin{tabular}{|c|c|c|c|c|c|c|}
\hline \multicolumn{7}{|c|}{ Simulações para o Verão - 22 de Dezembro } \\
\hline Cidade & Zona Bioclimática & Tipos de Cobertura & Vedações & Temp. Máxima Interna & Temp. Máxima Externa & Desempenho \\
\hline \multirow{3}{*}{ São Carlos } & \multirow[t]{3}{*}{ Luira Diociniratica } & Telha Cerâmica & \multirow{3}{*}{$\mathrm{P} 08 \mathrm{~cm} /$ conc 2400} & 28,1 & 26,9 & Não Atende \\
\hline & & Telha Cerâmica e Laje Mista & & 27,5 & 26,9 & Não Atende \\
\hline & & Telha Cerâmica e Laje Mista Inclinada & & 27,4 & 26,9 & Não Atende \\
\hline \multirow{3}{*}{ São Carlos } & \multirow{3}{*}{4} & Telha Cerâmica & \multirow{3}{*}{$\mathrm{P} 08 \mathrm{~cm} /$ conc 2200} & 28,1 & 26,9 & Não Atende \\
\hline & & Telha Cerâmica e Laje Mista & & 27,4 & 26,9 & Não Atende \\
\hline & & Telha Cerâmica e Laje Mista Inclinada & & 27,5 & 26,9 & Não Atende \\
\hline \multirow{3}{*}{ São Carlos } & \multirow{3}{*}{4} & Telha Cerâmica & \multirow{3}{*}{ P 08cm / conc 2000} & 28,2 & 26,9 & Não Atende \\
\hline & & Telha Cerâmica e Laje Mista Plana & & 27,6 & 26,9 & Não Atende \\
\hline & & Telha Cerâmica e Laje Mista Inclinada & & 27,5 & 26,9 & Não Atende \\
\hline \multirow{3}{*}{ São Carlos } & \multirow{3}{*}{4} & Telha Cerâmica & \multirow{3}{*}{$\mathrm{P} 08 \mathrm{~cm} /$ conc 1800} & 28,3 & 26,9 & Não Atende \\
\hline & & Telha Cerâmica e Laje Mista Plana & & 27,7 & $\frac{26,5}{26,9}$ & Não Atende \\
\hline & & Telha Cerâmica e Laje Mista Inclinada & & 27,6 & 26,9 & Não Atende \\
\hline \multirow{3}{*}{ São Carlos } & \multirow{3}{*}{4} & Telha Cerâmica & \multirow{3}{*}{$\mathrm{P} 08 \mathrm{~cm} /$ conc 1600} & 28,3 & 26,9 & Não Atende \\
\hline & & Telha Cerâmica e Laje Mista Plana & & 27,7 & 26,9 & Não Atende \\
\hline & & Telha Cerâmica e Laje Mista Inclinada & & 27,6 & 26,9 & Não Atende \\
\hline \multirow{3}{*}{ São Carlos } & \multirow{3}{*}{4} & Telha Cerâmica & \multirow{3}{*}{ P $10 \mathrm{~cm} /$ conco 2400} & 27,7 & 26,9 & Não Atende \\
\hline & & Telha Cerâmica e Laje Mista & & 27,2 & 26,9 & Não Atende \\
\hline & & Telha Cerâmica e Laje Mista Inclinada & & 27,1 & 26,9 & Não Atende \\
\hline \multirow{3}{*}{ São Carlos } & \multirow{3}{*}{4} & Telha Cerâmica & \multirow{3}{*}{ P $10 \mathrm{~cm} /$ conco 2200} & 27,6 & 26,9 & Não Atende \\
\hline & & Telha Cerâmica e Laje Mista & & 26,9 & 26,9 & $M$ \\
\hline & & Telha Cerâmica e Laje Mista Inclinada & & 27,1 & 26,9 & Não Atende \\
\hline & & Telha Cerâmica & & 27,8 & 26,9 & Não Atende \\
\hline São Carlos & 4 & Telha Cerâmica e Laje Mista Plana & P $10 \mathrm{~cm} /$ conc 2000 & 27,3 & 26,9 & Não Atende \\
\hline & & Telha Cerâmica e Laje Mista Inclinada & & 27,2 & 26,9 & Não Atende \\
\hline & & Telha Cerâmica & & 27,9 & 26,9 & Não Atende \\
\hline São Carlos & 4 & Telha Cerâmica e Laje Mista Plana & $\mathrm{P} 10 \mathrm{~cm} /$ conc 1800 & 27,4 & 26,9 & Não Atende \\
\hline & & Telha Cerâmica e Laje Mista Inclinada & & 27,2 & 26,9 & Não Atende \\
\hline & & Telha Cerâmica & & 28 & 26,9 & Não Atende \\
\hline São Carlos & 4 & Telha Cerâmica e Laje Mista Plana & P $10 \mathrm{~cm} /$ conc 1600 & 27,4 & 26,9 & Não Atende \\
\hline & & Telha Cerâmica e Laje Mista Inclinada & & 27,2 & 26,9 & Não Atende \\
\hline & & Telha Cerâmica & & 27,2 & 26,9 & Não Atende \\
\hline São Carlos & 4 & Telha Cerâmica e Laje Mista Plana & P $12 \mathrm{~cm} /$ conc 2400 & 26,9 & 26,9 & $\mathrm{M}$ \\
\hline & & Telha Cerâmica e Laje Mista Inclinada & & 26,7 & 26,9 & $\mathrm{M}$ \\
\hline & & Telha Cerâmica & & 27,3 & 26,9 & Não Atende \\
\hline São Carlos & 4 & Telha Cerâmica e Laje Mista Plana & P $12 \mathrm{~cm} /$ conc 2200 & 27 & 26,9 & Não Atende \\
\hline & & Telha Cerâmica e Laje Mista Inclinada & & 26,8 & 26,9 & $M$ \\
\hline & & Telha Cerâmica & & 27,7 & 26,9 & Não Atende \\
\hline São Carlos & 4 & Telha Cerâmica e Laje Mista Plana & P $12 \mathrm{~cm} /$ conc 2000 & 27,1 & 26,9 & Não Atende \\
\hline & & Telha Cerâmica e Laje Mista Inclinada & & 27 & 26,9 & Não Atende \\
\hline & & Telha Cerâmica & & 27,8 & 26,9 & Não Atende \\
\hline São Carlos & 4 & Telha Cerâmica e Laje Mista Plana & $\mathrm{P} 12 \mathrm{~cm} /$ conc 1800 & 27,2 & 26,9 & Não Atende \\
\hline & & Telha Cerâmica e Laje Mista Inclinada & & 27 & 26,9 & Não Atende \\
\hline & & Telha Cerâmica & & 27,9 & 26,9 & Não Atende \\
\hline São Carlos & 4 & Telha Cerâmica e Laje Mista Plana & $\mathrm{P} 12 \mathrm{~cm} /$ conc 1600 & 27,2 & 26,9 & Não Atende \\
\hline & & Telha Cerâmica e Laje Mista Inclinada & & 27,1 & 26,9 & Não Atende \\
\hline
\end{tabular}




\begin{tabular}{|c|c|c|c|c|c|c|}
\hline \multicolumn{7}{|c|}{ Simulações para o Verão - 22 de Dezembro } \\
\hline Cidade & Zona Bioclimática & Tipos de Cobertura & Vedações & Temp. Máxima Interna & Temp. Máxima Externa & Desempenho \\
\hline \multirow{3}{*}{ Brasília } & \multirow{3}{*}{ 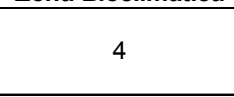 } & Telha Cerâmica & \multirow{3}{*}{$\mathrm{P} 08 \mathrm{~cm} /$ conc 2400} & 31,1 & 26,6 & Não Atende \\
\hline & & Telha Cerâmica e Laje Mista & & 30,5 & 26,6 & Não Atende \\
\hline & & Telha Cerâmica e Laje Mista Inclinada & & 30,1 & 26,6 & Não Atende \\
\hline \multirow{3}{*}{ Brasília } & \multirow{3}{*}{4} & Telha Cerâmica & \multirow{3}{*}{$\mathrm{P} 08 \mathrm{~cm} /$ conc 2200} & 31,2 & 26,6 & Não Atende \\
\hline & & Telha Cerâmica e Laje Mista & & 30,6 & 26,6 & Não Atende \\
\hline & & Telha Cerâmica e Laje Mista Inclinada & & 30,2 & 26,6 & Não Atende \\
\hline \multirow{3}{*}{ Brasília } & \multirow{3}{*}{4} & Telha Cerâmica & \multirow{3}{*}{$\mathrm{P} 08 \mathrm{~cm} /$ conc 2000} & 31,4 & 26,6 & Não Atende \\
\hline & & Telha Cerâmica e Laje Mista Plana & & 30,7 & 26,6 & Não Atende \\
\hline & & Telha Cerâmica e Laje Mista Inclinada & & 30,3 & 26,6 & Não Atende \\
\hline \multirow{3}{*}{ Brasília } & \multirow{3}{*}{4} & Telha Cerâmica & \multirow{3}{*}{$\mathrm{P} 08 \mathrm{~cm} /$ conc 1800} & 31,5 & 26,6 & Não Atende \\
\hline & & Telha Cerâmica e Laje Mista Plana & & 30,8 & 26,6 & Não Atende \\
\hline & & Telha Cerâmica e Laje Mista Inclinada & & 30,3 & 26,6 & Não Atende \\
\hline \multirow{3}{*}{ Brasília } & \multirow{3}{*}{4} & Telha Cerâmica & \multirow{3}{*}{$\mathrm{P} 08 \mathrm{~cm} /$ conc 1600} & 31,7 & 26,6 & Não Atende \\
\hline & & Telha Cerâmica e Laje Mista Plana & & 30,8 & 26,6 & Não Atende \\
\hline & & Telha Cerâmica e Laje Mista Inclinada & & 30,4 & 26,6 & Não Atende \\
\hline \multirow{3}{*}{ Brasília } & \multirow{3}{*}{4} & Telha Cerâmica & \multirow{3}{*}{ P $10 \mathrm{~cm} /$ conco 2400} & 30,6 & 26,6 & Não Atende \\
\hline & & Telha Cerâmica e Laje Mista & & 30,1 & 26,6 & Não Atende \\
\hline & & Telha Cerâmica e Laje Mista Inclinada & & 29,6 & 26,6 & Não Atende \\
\hline \multirow{3}{*}{ Brasília } & \multirow{3}{*}{4} & Telha Cerâmica & \multirow{3}{*}{ P $10 \mathrm{~cm} /$ conco 2200} & 30,7 & 26,6 & Não Atende \\
\hline & & \begin{tabular}{|l|l|} 
Telha Cerâmica e Laje Mista \\
\end{tabular} & & 30,2 & 26,6 & Não Atende \\
\hline & & Telha Cerâmica e Laje Mista Inclinada & & 29,6 & 26,6 & Não Atende \\
\hline & & Telha Cerâmica & & 30,9 & 26,6 & Não Atende \\
\hline Brasília & 4 & Telha Cerâmica e Laje Mista Plana & P $10 \mathrm{~cm} /$ conc 2000 & 30,3 & 26,6 & Não Atende \\
\hline & & Telha Cerâmica e Laje Mista Inclinada & & 29,7 & 26,6 & Não Atende \\
\hline & & Telha Cerâmica & & 31 & 26,6 & Não Atende \\
\hline Brasília & 4 & Telha Cerâmica e Laje Mista Plana & P $10 \mathrm{~cm} /$ conc 1800 & 30,4 & 26,6 & Não Atende \\
\hline & & Telha Cerâmica e Laje Mista Inclinada & & 29,8 & 26,6 & Não Atende \\
\hline & & Telha Cerâmica & & 31,3 & 26,6 & Não Atende \\
\hline Brasília & 4 & Telha Cerâmica e Laje Mista Plana & P $10 \mathrm{~cm} /$ conc 1600 & 30,5 & 26,6 & Não Atende \\
\hline & & Telha Cerâmica e Laje Mista Inclinada & & 29,9 & 26,6 & Não Atende \\
\hline & & Telha Cerâmica & & 30,2 & 26,6 & Não Atende \\
\hline Brasília & 4 & Telha Cerâmica e Laje Mista Plana & P $12 \mathrm{~cm} /$ conc 2400 & 29,5 & 26,6 & Não Atende \\
\hline & & Telha Cerâmica e Laje Mista Inclinada & & 28,9 & 26,6 & Não Atende \\
\hline & & Telha Cerâmica & & 30,3 & 26,6 & Não Atende \\
\hline Brasília & 4 & Telha Cerâmica e Laje Mista Plana & P $12 \mathrm{~cm} /$ conc 2200 & 29,6 & 26,6 & Não Atende \\
\hline & & Telha Cerâmica e Laje Mista Inclinada & & 29 & 26,6 & Não Atende \\
\hline & & Telha Cerâmica & & 30,9 & 26,6 & Não Atende \\
\hline Brasília & 4 & Telha Cerâmica e Laje Mista Plana & P $12 \mathrm{~cm} /$ conc 2000 & 30 & 26,6 & Não Atende \\
\hline & & Telha Cerâmica e Laje Mista Inclinada & & 29,4 & 26,6 & Não Atende \\
\hline & & Telha Cerâmica & & 31,1 & 26,6 & Não Atende \\
\hline Brasília & 4 & Telha Cerâmica e Laje Mista Plana & P $12 \mathrm{~cm} /$ conc 1800 & 30,1 & 26,6 & Não Atende \\
\hline & & Telha Cerâmica e Laje Mista Inclinada & & 29,5 & 26,6 & Não Atende \\
\hline & & Telha Cerâmica & & 31,2 & 26,6 & Não Atende \\
\hline Brasília & 4 & Telha Cerâmica e Laje Mista Plana & P $12 \mathrm{~cm} /$ conc 1600 & 30,2 & 26,6 & Não Atende \\
\hline & & Telha Cerâmica e Laje Mista Inclinada & & 29,6 & 26,6 & Não Atende \\
\hline
\end{tabular}




\begin{tabular}{|c|c|c|c|c|c|c|}
\hline \multicolumn{7}{|c|}{ Simulações para o Verão - 22 de Dezembro } \\
\hline Cidade & Zona Bioclimática & Tipos de Cobertura & Vedações & Temp. Máxima Interna & Temp. Máxima Externa & Desempenho \\
\hline \multirow{3}{*}{ Santos } & \multirow{3}{*}{ 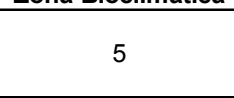 } & Telha Cerâmica & \multirow{3}{*}{$\mathrm{P} 08 \mathrm{~cm} /$ conc 2400} & 29,1 & 27,5 & Não Atende \\
\hline & & Telha Cerâmica e Laje Mista & & 28,7 & 27,5 & Não Atende \\
\hline & & Telha Cerâmica e Laje Mista Inclinada & & 28,5 & 27,5 & Não Atende \\
\hline \multirow{3}{*}{ Santos } & \multirow{3}{*}{5} & Telha Cerâmica & \multirow{3}{*}{$\mathrm{P} 08 \mathrm{~cm} /$ conc 2200} & 29,1 & 27,5 & Não Atende \\
\hline & & Telha Cerâmica e Laje Mista & & 28,7 & 27,5 & Não Atende \\
\hline & & Telha Cerâmica e Laje Mista Inclinada & & 28,6 & 27,5 & Não Atende \\
\hline \multirow{3}{*}{ Santos } & \multirow{3}{*}{5} & Telha Cerâmica & \multirow{3}{*}{$\mathrm{P} 08 \mathrm{~cm} /$ conc 2000} & 29,2 & 27,5 & Não Atende \\
\hline & & Telha Cerâmica e Laje Mista Plana & & 28,8 & 27,5 & Não Atende \\
\hline & & Telha Cerâmica e Laje Mista Inclinada & & 28,6 & 27,5 & Não Atende \\
\hline \multirow{3}{*}{ Santos } & \multirow{3}{*}{5} & Telha Cerâmica & \multirow{3}{*}{$\mathrm{P} 08 \mathrm{~cm} /$ conc 1800} & 29,2 & 27,5 & Não Atende \\
\hline & & \begin{tabular}{|l|l} 
Telha Cerâmica e Laje Mista Plana \\
\end{tabular} & & 28,8 & 27,5 & Não Atende \\
\hline & & Telha Cerâmica e Laje Mista Inclinada & & 28,7 & 27,5 & Não Atende \\
\hline \multirow{3}{*}{ Santos } & \multirow{3}{*}{5} & Telha Cerâmica & \multirow{3}{*}{$\mathrm{P} 08 \mathrm{~cm} /$ conc 1600} & 29,3 & 27,5 & Não Atende \\
\hline & & Telha Cerâmica e Laje Mista Plana & & 28,8 & 27,5 & Não Atende \\
\hline & & Telha Cerâmica e Laje Mista Inclinada & & 28,7 & 27,5 & Não Atende \\
\hline \multirow{3}{*}{ Santos } & \multirow{3}{*}{5} & Telha Cerâmica & \multirow{3}{*}{ P $10 \mathrm{~cm} /$ conco 2400} & 28,8 & 27,5 & Não Atende \\
\hline & & Telha Cerâmica e Laje Mista & & 28,4 & 27,5 & Não Atende \\
\hline & & Telha Cerâmica e Laje Mista Inclinada & & 28,2 & 27,5 & Não Atende \\
\hline \multirow{3}{*}{ Santos } & \multirow{3}{*}{5} & Telha Cerâmica & \multirow{3}{*}{ P $10 \mathrm{~cm} /$ conco 2200} & 28,8 & 27,5 & Não Atende \\
\hline & & Telha Cerâmica e Laje Mista & & 28,5 & 27,5 & Não Atende \\
\hline & & Telha Cerâmica e Laje Mista Inclinada & & 28,3 & 27,5 & Não Atende \\
\hline & & Telha Cerâmica & & 28,9 & 27,5 & Não Atende \\
\hline Santos & 5 & Telha Cerâmica e Laje Mista Plana & P $10 \mathrm{~cm} /$ conc 2000 & 28,5 & 27,5 & Não Atende \\
\hline & & Telha Cerâmica e Laje Mista Inclinada & & 28,3 & 27,5 & Não Atende \\
\hline & & Telha Cerâmica & & 29 & 27,5 & Não Atende \\
\hline Santos & 5 & Telha Cerâmica e Laje Mista Plana & P $10 \mathrm{~cm} /$ conc 1800 & 28,6 & 27,5 & Não Atende \\
\hline & & Telha Cerâmica e Laje Mista Inclinada & & 28,3 & 27,5 & Não Atende \\
\hline & & Telha Cerâmica & & 29,1 & 27,5 & Não Atende \\
\hline Santos & 5 & Telha Cerâmica e Laje Mista Plana & P $10 \mathrm{~cm} / \mathrm{conc} 1600$ & 28,6 & 27,5 & Não Atende \\
\hline & & Telha Cerâmica e Laje Mista Inclinada & & 28,4 & 27,5 & Não Atende \\
\hline & & Telha Cerâmica & & 28,4 & 27,5 & Não Atende \\
\hline Santos & 5 & Telha Cerâmica e Laje Mista Plana & P $12 \mathrm{~cm} /$ conc 2400 & 28,2 & 27,5 & Não Atende \\
\hline & & Telha Cerâmica e Laje Mista Inclinada & & 27,9 & 27,5 & Não Atende \\
\hline & & Telha Cerâmica & & 28,5 & 27,5 & Não Atende \\
\hline Santos & 5 & Telha Cerâmica e Laje Mista Plana & P $12 \mathrm{~cm} /$ conc 2200 & 28,2 & 27,5 & Não Atende \\
\hline & & Telha Cerâmica e Laje Mista Inclinada & & 27,9 & 27,5 & Não Atende \\
\hline & & Telha Cerâmica & & 28,8 & 27,5 & Não Atende \\
\hline Santos & 5 & Telha Cerâmica e Laje Mista Plana & P $12 \mathrm{~cm} /$ conc 2000 & 28,4 & 27,5 & Não Atende \\
\hline & & Telha Cerâmica e Laje Mista Inclinada & & 28,1 & 27,5 & Não Atende \\
\hline & & Telha Cerâmica & & 28,9 & 27,5 & Não Atende \\
\hline Santos & 5 & Telha Cerâmica e Laje Mista Plana & P $12 \mathrm{~cm} /$ conc 1800 & 28,4 & 27,5 & Não Atende \\
\hline & & Telha Cerâmica e Laje Mista Inclinada & & 28,2 & 27,5 & Não Atende \\
\hline & & Telha Cerâmica & & 29 & 27,5 & Não Atende \\
\hline Santos & 5 & Telha Cerâmica e Laje Mista Plana & P $12 \mathrm{~cm} /$ conc 1600 & 28,5 & 27,5 & Não Atende \\
\hline & & Telha Cerâmica e Laje Mista Inclinada & & 28,2 & 27,5 & Não Atende \\
\hline
\end{tabular}




\begin{tabular}{|c|c|c|c|c|c|c|}
\hline \multicolumn{7}{|c|}{ Simulações para o Verão - 22 de Dezembro } \\
\hline Cidade & Zona Bioclimática & Tipos de Cobertura & Vedações & Temp. Máxima Interna & Temp. Máxima Externa & Desempenho \\
\hline \multirow{3}{*}{ Presidente Prudente } & \multirow[t]{3}{*}{ 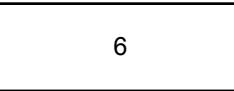 } & Telha Cerâmica & \multirow{3}{*}{$\mathrm{P} 08 \mathrm{~cm} /$ conc 2400} & 32 & 30,2 & Não Atende \\
\hline & & \begin{tabular}{|l|l|} 
Telha Cerâmica e Laje Mista \\
\end{tabular} & & 31,4 & 30,2 & Não Atende \\
\hline & & Telha Cerâmica e Laje Mista Inclinada & & 31,2 & 30,2 & Não Atende \\
\hline \multirow{3}{*}{ Presidente Prudente } & \multirow{3}{*}{6} & Telha Cerâmica & \multirow{3}{*}{$\mathrm{P} 08 \mathrm{~cm} /$ conc 2200} & 32,1 & 30,2 & Não Atende \\
\hline & & \begin{tabular}{|l|l|} 
Telha Cerâmica e Laje Mista \\
\end{tabular} & & 31,4 & 30,2 & Não Atende \\
\hline & & Telha Cerâmica e Laje Mista Inclinada & & 31,3 & 30,2 & Não Atende \\
\hline \multirow{3}{*}{ Presidente Prudente } & \multirow{3}{*}{6} & Telha Cerâmica & \multirow{3}{*}{$\mathrm{P} 08 \mathrm{~cm} /$ conc 2000} & 32,1 & 30,2 & Não Atende \\
\hline & & Telha Cerâmica e Laje Mista Plana & & 31,5 & 30,2 & Não Atende \\
\hline & & Telha Cerâmica e Laje Mista Inclinada & & 31,3 & 30,2 & Não Atende \\
\hline \multirow{3}{*}{ Presidente Prudente } & \multirow{3}{*}{6} & Telha Cerâmica & \multirow{3}{*}{$\mathrm{P} 08 \mathrm{~cm} /$ conc 1800} & 32,2 & 30,2 & Não Atende \\
\hline & & Telha Cerâmica e Laje Mista Plana & & 31,5 & 30,2 & Não Atende \\
\hline & & Telha Cerâmica e Laje Mista Inclinada & & 31,4 & 30,2 & Não Atende \\
\hline \multirow{3}{*}{ Presidente Prudente } & \multirow{3}{*}{6} & Telha Cerâmica & \multirow{3}{*}{$\mathrm{P} 08 \mathrm{~cm} /$ conc 1600} & 32,3 & 30,2 & Não Atende \\
\hline & & Telha Cerâmica e Laje Mista Plana & & 31,6 & 30,2 & Não Atende \\
\hline & & Telha Cerâmica e Laje Mista Inclinada & & 31,4 & 30,2 & Não Atende \\
\hline \multirow{3}{*}{ Presidente Prudente } & \multirow{3}{*}{6} & Telha Cerâmica & \multirow{3}{*}{ P $10 \mathrm{~cm} /$ conco 2400} & 31,5 & 30,2 & Não Atende \\
\hline & & Telha Cerâmica e Laje Mista & & 31 & 30,2 & Não Atende \\
\hline & & Telha Cerâmica e Laje Mista Inclinada & & 30,8 & 30,2 & Não Atende \\
\hline \multirow{3}{*}{ Presidente Prudente } & \multirow{3}{*}{6} & Telha Cerâmica & \multirow{3}{*}{ P $10 \mathrm{~cm} /$ conco 2200} & 31,6 & 30,2 & Não Atende \\
\hline & & Telha Cerâmica e Laje Mista & & 31,1 & 30,2 & Não Atende \\
\hline & & Telha Cerâmica e Laje Mista Inclinada & & 30,8 & 30,2 & Não Atende \\
\hline & & Telha Cerâmica & & 31,7 & 30,2 & Não Atende \\
\hline Presidente Prudente & 6 & Telha Cerâmica e Laje Mista Plana & P $10 \mathrm{~cm} /$ conc 2000 & 31,2 & 30,2 & Não Atende \\
\hline & & Telha Cerâmica e Laje Mista Inclinada & & 30,9 & 30,2 & Não Atende \\
\hline & & Telha Cerâmica & & 31,8 & 30,2 & Não Atende \\
\hline Presidente Prudente & 6 & Telha Cerâmica e Laje Mista Plana & P $10 \mathrm{~cm} /$ conc 1800 & 31,2 & 30,2 & Não Atende \\
\hline & & Telha Cerâmica e Laje Mista Inclinada & & 30,9 & 30,2 & Não Atende \\
\hline & & Telha Cerâmica & & 31,9 & 30,2 & Não Atende \\
\hline Presidente Prudente & 6 & Telha Cerâmica e Laje Mista Plana & P $10 \mathrm{~cm} /$ conc 1600 & 31,3 & 30,2 & Não Atende \\
\hline & & Telha Cerâmica e Laje Mista Inclinada & & 31 & 30,2 & Não Atende \\
\hline & & Telha Cerâmica & & 31 & 30,2 & Não Atende \\
\hline Presidente Prudente & 6 & Telha Cerâmica e Laje Mista Plana & P $12 \mathrm{~cm} /$ conc 2400 & 30,6 & 30,2 & Não Atende \\
\hline & & Telha Cerâmica e Laje Mista Inclinada & & 30,3 & 30,2 & Não Atende \\
\hline & & Telha Cerâmica & & 31,1 & 30,2 & Não Atende \\
\hline Presidente Prudente & 6 & Telha Cerâmica e Laje Mista Plana & P $12 \mathrm{~cm} /$ conc 2200 & 30,7 & 30,2 & Não Atende \\
\hline & & Telha Cerâmica e Laje Mista Inclinada & & 30,4 & 30,2 & Não Atende \\
\hline & & Telha Cerâmica & & 31,6 & 30,2 & Não Atende \\
\hline Presidente Prudente & 6 & Telha Cerâmica e Laje Mista Plana & P $12 \mathrm{~cm} /$ conc 2000 & 30,9 & 30,2 & Não Atende \\
\hline & & Telha Cerâmica e Laje Mista Inclinada & & 30,6 & 30,2 & Não Atende \\
\hline & & Telha Cerâmica & & 31,7 & 30,2 & Não Atende \\
\hline Presidente Prudente & 6 & Telha Cerâmica e Laje Mista Plana & P $12 \mathrm{~cm} /$ conc 1800 & 31 & 30,2 & Não Atende \\
\hline & & Telha Cerâmica e Laje Mista Inclinada & & 30,7 & 30,2 & Não Atende \\
\hline & & Telha Cerâmica & & 31,9 & 30,2 & Não Atende \\
\hline Presidente Prudente & 6 & Telha Cerâmica e Laje Mista Plana & P $12 \mathrm{~cm} /$ conc 1600 & 31 & 30,2 & Não Atende \\
\hline & & Telha Cerâmica e Laje Mista Inclinada & & 30,7 & 30,2 & Não Atende \\
\hline
\end{tabular}




\begin{tabular}{|c|c|c|c|c|c|c|}
\hline \multicolumn{7}{|c|}{ Simulações para o Verão - 22 de Dezembro } \\
\hline Cidade & Zona Bioclimática & Tipos de Cobertura & Vedações & Temp. Máxima Interna & Temp. Máxima Externa & Desempenho \\
\hline \multirow{3}{*}{ Teresina } & \multirow[t]{3}{*}{ 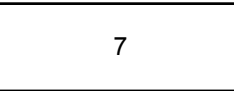 } & Telha Cerâmica & \multirow{3}{*}{$\mathrm{P} 08 \mathrm{~cm} /$ conc 2400} & 35,9 & 34,4 & Não Atende \\
\hline & & \begin{tabular}{|l|l|} 
Telha Cerâmica e Laje Mista \\
\end{tabular} & & 35,3 & 34,4 & Não Atende \\
\hline & & Telha Cerâmica e Laje Mista Inclinada & & 35,1 & 34,4 & Não Atende \\
\hline \multirow{3}{*}{ Teresina } & \multirow{3}{*}{7} & Telha Cerâmica & \multirow{3}{*}{ P $08 \mathrm{~cm} /$ conc 2200} & 36 & 34,4 & Não Atende \\
\hline & & Telha Cerâmica e Laje Mista & & 35,3 & 34,4 & Não Atende \\
\hline & & Telha Cerâmica e Laje Mista Inclinada & & 35,2 & 34,4 & Não Atende \\
\hline \multirow{3}{*}{ Teresina } & \multirow{3}{*}{7} & Telha Cerâmica & \multirow{3}{*}{ P $08 \mathrm{~cm} /$ conc 2000} & 36,1 & 34,4 & Não Atende \\
\hline & & Telha Cerâmica e Laje Mista Plana & & 35,4 & 34,4 & Não Atende \\
\hline & & Telha Cerâmica e Laje Mista Inclinada & & 35,3 & 34,4 & Não Atende \\
\hline \multirow{3}{*}{ Teresina } & \multirow{3}{*}{7} & Telha Cerâmica & \multirow{3}{*}{$\mathrm{P} 08 \mathrm{~cm} /$ conc 1800} & 36,1 & 34,4 & Não Atende \\
\hline & & Telha Cerâmica e Laje Mista Plana & & 35,4 & 34,4 & Não Atende \\
\hline & & Telha Cerâmica e Laje Mista Inclinada & & 35,3 & 34,4 & Não Atende \\
\hline \multirow{3}{*}{ Teresina } & \multirow{3}{*}{7} & Telha Cerâmica & \multirow{3}{*}{$\mathrm{P} 08 \mathrm{~cm} /$ conc 1600} & 36,2 & 34,4 & Não Atende \\
\hline & & Telha Cerâmica e Laje Mista Plana & & 35,5 & 34,4 & Não Atende \\
\hline & & Telha Cerâmica e Laje Mista Inclinada & & 35,3 & 34,4 & Não Atende \\
\hline \multirow{3}{*}{ Teresina } & \multirow{3}{*}{7} & Telha Cerâmica & \multirow{3}{*}{ P $10 \mathrm{~cm} /$ conco 2400} & 35,4 & 34,4 & Não Atende \\
\hline & & Telha Cerâmica e Laje Mista & & 34,8 & 34,4 & Não Atende \\
\hline & & Telha Cerâmica e Laje Mista Inclinada & & 34,6 & 34,4 & Não Atende \\
\hline \multirow{3}{*}{ Teresina } & \multirow{3}{*}{7} & Telha Cerâmica & \multirow{3}{*}{ P $10 \mathrm{~cm} /$ conco 2200} & 35,4 & 34,4 & Não Atende \\
\hline & & Telha Cerâmica e Laje Mista & & 35 & 34,4 & Não Atende \\
\hline & & Telha Cerâmica e Laje Mista Inclinada & & 34,7 & 34,4 & Não Atende \\
\hline & & Telha Cerâmica & & 35,5 & 34,4 & Não Atende \\
\hline Teresina & 7 & Telha Cerâmica e Laje Mista Plana & P $10 \mathrm{~cm} /$ conc 2000 & 35 & 34,4 & Não Atende \\
\hline & & Telha Cerâmica e Laje Mista Inclinada & & 34,7 & 34,4 & Não Atende \\
\hline & & Telha Cerâmica & & 35,6 & 34,4 & Não Atende \\
\hline Teresina & 7 & Telha Cerâmica e Laje Mista Plana & P $10 \mathrm{~cm} /$ conc 1800 & 35 & 34,4 & Não Atende \\
\hline & & Telha Cerâmica e Laje Mista Inclinada & & 34,8 & 34,4 & Não Atende \\
\hline & & Telha Cerâmica & & 35,8 & 34,4 & Não Atende \\
\hline Teresina & 7 & Telha Cerâmica e Laje Mista Plana & P $10 \mathrm{~cm} /$ conc 1600 & 35,1 & 34,4 & Não Atende \\
\hline & & Telha Cerâmica e Laje Mista Inclinada & & 34,9 & 34,4 & Não Atende \\
\hline & & Telha Cerâmica & & 34,8 & 34,4 & Não Atende \\
\hline Teresina & 7 & Telha Cerâmica e Laje Mista Plana & P $12 \mathrm{~cm} /$ conc 2400 & 34,4 & 34,4 & $\mathrm{M}$ \\
\hline & & Telha Cerâmica e Laje Mista Inclinada & & 34,1 & 34,4 & $\mathrm{M}$ \\
\hline & & Telha Cerâmica & & 34,9 & 34,4 & Não Atende \\
\hline Teresina & 7 & Telha Cerâmica e Laje Mista Plana & P $12 \mathrm{~cm} /$ conc 2200 & 34,5 & 34,4 & Não Atende \\
\hline & & Telha Cerâmica e Laje Mista Inclinada & & 34,2 & 34,4 & $M$ \\
\hline & & Telha Cerâmica & & 35,4 & 34,4 & Não Atende \\
\hline Teresina & 7 & Telha Cerâmica e Laje Mista Plana & P $12 \mathrm{~cm} /$ conc 2000 & 34,7 & 34,4 & Não Atende \\
\hline & & Telha Cerâmica e Laje Mista Inclinada & & 34,5 & 34,4 & Não Atende \\
\hline & & Telha Cerâmica & & 35,6 & 34,4 & Não Atende \\
\hline Teresina & 7 & Telha Cerâmica e Laje Mista Plana & P $12 \mathrm{~cm} /$ conc 1800 & 34,8 & 34,4 & Não Atende \\
\hline & & Telha Cerâmica e Laje Mista Inclinada & & 34,5 & 34,4 & Não Atende \\
\hline & & Telha Cerâmica & & 35,7 & 34,4 & Não Atende \\
\hline Teresina & 7 & Telha Cerâmica e Laje Mista Plana & P $12 \mathrm{~cm} /$ conc 1600 & 34,8 & 34,4 & Não Atende \\
\hline & & Telha Cerâmica e Laje Mista Inclinada & & 34,6 & 34,4 & Não Atende \\
\hline
\end{tabular}




\begin{tabular}{|c|c|c|c|c|c|c|}
\hline \multicolumn{7}{|c|}{ Simulações para o Verão - 22 de Dezembro } \\
\hline Cidade & Zona Bioclimática & Tipos de Cobertura & Vedações & Temp. Máxima Interna & Temp. Máxima Externa & Desempenho \\
\hline \multirow{3}{*}{ Belém } & \multirow{3}{*}{ - } & Telha Cerâmica & \multirow{3}{*}{$\mathrm{P} 08 \mathrm{~cm} /$ conc 2400} & 32,9 & 31,8 & Não Atende \\
\hline & & Telha Cerâmica e Laje Mista & & 32,4 & 31,8 & Não Atende \\
\hline & & Telha Cerâmica e Laje Mista Inclinada & & 32,3 & 31,8 & Não Atende \\
\hline \multirow{3}{*}{ Belém } & \multirow{3}{*}{8} & Telha Cerâmica & \multirow{3}{*}{ P $08 \mathrm{~cm} /$ conc 2200} & 33 & 31,8 & Não Atende \\
\hline & & Telha Cerâmica e Laje Mista & & 32,5 & 31,8 & Não Atende \\
\hline & & Telha Cerâmica e Laje Mista Inclinada & & 32,4 & 31,8 & Não Atende \\
\hline \multirow{3}{*}{ Belém } & \multirow{3}{*}{8} & Telha Cerâmica & \multirow{3}{*}{ P $08 \mathrm{~cm} /$ conc 2000} & 33 & 31,8 & Não Atende \\
\hline & & \begin{tabular}{|l|l|} 
Telha Cerâmica e Laje Mista Plana \\
\end{tabular} & & 32,5 & 31,8 & Não Atende \\
\hline & & Telha Cerâmica e Laje Mista Inclinada & & 32,4 & 31,8 & Não Atende \\
\hline \multirow{3}{*}{ Belém } & \multirow{3}{*}{8} & Telha Cerâmica & \multirow{3}{*}{$\mathrm{P} 08 \mathrm{~cm} /$ conc 1800} & 33,1 & 31,8 & Não Atende \\
\hline & & Telha Cerâmica e Laje Mista Plana & & 32,6 & 31,8 & Não Atende \\
\hline & & Telha Cerâmica e Laje Mista Inclinada & & 32,5 & 31,8 & Não Atende \\
\hline \multirow{3}{*}{ Belém } & \multirow{3}{*}{8} & Telha Cerâmica & \multirow{3}{*}{$\mathrm{P} 08 \mathrm{~cm} /$ conc 1600} & 33,2 & 31,8 & Não Atende \\
\hline & & Telha Cerâmica e Laje Mista Plana & & 32,6 & 31,8 & Não Atende \\
\hline & & Telha Cerâmica e Laje Mista Inclinada & & 32,6 & 31,8 & Não Atende \\
\hline \multirow{3}{*}{ Belém } & \multirow{3}{*}{8} & Telha Cerâmica & \multirow{3}{*}{ P $10 \mathrm{~cm} /$ conc 2400} & 32,5 & 31,8 & Não Atende \\
\hline & & Telha Cerâmica e Laje Mista & & 32,1 & 31,8 & Não Atende \\
\hline & & Telha Cerâmica e Laje Mista Inclinada & & 31,9 & 31,8 & Não Atende \\
\hline \multirow{3}{*}{ Belém } & \multirow{3}{*}{8} & Telha Cerâmica & \multirow{3}{*}{ P $10 \mathrm{~cm} /$ conc 2200} & 32,5 & 31,8 & Não Atende \\
\hline & & Telha Cerâmica e Laje Mista & & 32,1 & 31,8 & Não Atende \\
\hline & & \begin{tabular}{|l|l} 
Telha Cerâmica e Laje Mista Inclinada \\
\end{tabular} & & 32 & 31,8 & Não Atende \\
\hline & & $\begin{array}{l}\text { Telha Cerâmica } \\
\end{array}$ & & 32,6 & 31,8 & Não Atende \\
\hline Belém & 8 & Telha Cerâmica e Laje Mista Plana & P $10 \mathrm{~cm} /$ conc 2000 & 32,2 & 31,8 & Não Atende \\
\hline & & Telha Cerâmica e Laje Mista Inclinada & & $\frac{3,2}{32}$ & 31,8 & Não Atende \\
\hline & & Telha Cerâmica & & 32,7 & 31,8 & Não Atende \\
\hline Belém & 8 & Telha Cerâmica e Laje Mista Plana & P $10 \mathrm{~cm} /$ conc 1800 & 32,2 & $\begin{array}{ll}31,0 \\
31,8\end{array}$ & Não Atende \\
\hline & & Telha Cerâmica e Laje Mista Inclinada & & 32,1 & 31,8 & Não Atende \\
\hline & & Telha Cerâmica & & 32,8 & 31,8 & Não Atende \\
\hline Belém & 8 & Telha Cerâmica e Laje Mista Plana & P $10 \mathrm{~cm} /$ conc 1600 & 32,3 & 31,8 & Não Atende \\
\hline & & Telha Cerâmica e Laje Mista Inclinada & & 32,1 & 31,8 & Não Atende \\
\hline & & Telha Cerâmica & & 32 & 31,8 & Não Atende \\
\hline Belém & 8 & Telha Cerâmica e Laje Mista Plana & P $12 \mathrm{~cm} /$ conc 2400 & 31,7 & 31,8 & $\mathrm{M}$ \\
\hline & & Telha Cerâmica e Laje Mista Inclinada & & 31,5 & 31,8 & $\mathrm{M}$ \\
\hline & & $\begin{array}{l}\text { Telha Cerâmica } \\
\end{array}$ & & 32 & $\frac{3,0}{31,8}$ & Não Atende \\
\hline Belém & 8 & Telha Cerâmica e Laje Mista Plana & P $12 \mathrm{~cm} /$ conc 2200 & 31,8 & 31,8 & $\mathrm{M}$ \\
\hline & & Telha Cerâmica e Laje Mista Inclinada & & 31,5 & 31,8 & $M$ \\
\hline & & Telha Cerâmica & & 32,5 & 31,8 & Não Atende \\
\hline Belém & 8 & Telha Cerâmica e Laje Mista Plana & P $12 \mathrm{~cm} /$ conc 2000 & 32 & 31,8 & Não Atende \\
\hline & & Telha Cerâmica e Laje Mista Inclinada & & 31,8 & 31,8 & $\mathrm{M}$ \\
\hline & & Telha Cerâmica & & 32,6 & 31,8 & Não Atende \\
\hline Belém & 8 & Telha Cerâmica e Laje Mista Plana & P $12 \mathrm{~cm} /$ conc 1800 & 32 & 31,8 & Não Atende \\
\hline & & Telha Cerâmica e Laje Mista Inclinada & & 31,8 & 31,8 & $\mathrm{M}$ \\
\hline & & Telha Cerâmica & & 32,7 & 31,8 & Não Atende \\
\hline Belém & 8 & Telha Cerâmica e Laje Mista Plana & P $12 \mathrm{~cm} /$ conc 1600 & 32,1 & 31,8 & Não Atende \\
\hline & & Telha Cerâmica e Laje Mista Inclinada & & 31,9 & 31,8 & Não Atende \\
\hline
\end{tabular}




\begin{tabular}{|c|c|c|c|c|c|}
\hline \multicolumn{6}{|c|}{ Simulações para o Inverno - 22 de Junho } \\
\hline Cidade & Zona Bioclimática & \begin{tabular}{|c|} 
Tipos de Cobertura \\
\end{tabular} & Vedações & Temp. Mínima Interna & Desempenho \\
\hline \multirow{3}{*}{ Caxias do Sul } & \multirow{3}{*}{1} & Telha Cerâmica & \multirow{3}{*}{$\mathrm{P} 08 \mathrm{~cm} /$ conc 2400} & 11 & Não Atende \\
\hline & & Telha Cerâmica e Laje Mista Plana & & 11,9 & $\mathrm{M}$ \\
\hline & & Telha Cerâmica e Laje Mista Inclinada & & 11,5 & Não Atende \\
\hline \multirow{3}{*}{ Caxias do Sul } & \multirow{3}{*}{1} & Telha Cerâmica & \multirow{3}{*}{$\mathrm{P} 08 \mathrm{~cm} /$ conc 2200} & 11 & Não Atende \\
\hline & & Telha Cerâmica e Laje Mista Plana & & 11,8 & $\mathrm{M}$ \\
\hline & & Telha Cerâmica e Laje Mista Inclinada & & 11,5 & Não Atende \\
\hline \multirow{3}{*}{ Caxias do Sul } & \multirow{3}{*}{1} & Telha Cerâmica & \multirow{3}{*}{ P 08cm / conc 2000} & 10,9 & Não Atende \\
\hline & & Telha Cerâmica e Laje Mista Plana & & 11,8 & $\mathrm{M}$ \\
\hline & & Telha Cerâmica e Laje Mista Inclinada & & 11,5 & Não Atende \\
\hline \multirow{3}{*}{ Caxias do Sul } & \multirow{3}{*}{1} & Telha Cerâmica & \multirow{3}{*}{ P 08cm / conc 1800} & 10,9 & Não Atende \\
\hline & & Telha Cerâmica e Laje Mista Plana & & 11,9 & $\mathrm{M}$ \\
\hline & & Telha Cerâmica e Laje Mista Inclinada & & 11,5 & Não Atende \\
\hline \multirow{3}{*}{ Caxias do Sul } & \multirow{3}{*}{1} & Telha Cerâmica & \multirow{3}{*}{$\mathrm{P} 08 \mathrm{~cm} /$ conc 1600} & 10,9 & Não Atende \\
\hline & & \begin{tabular}{|l|l|} 
Telha Cerâmica e Laje Mista Plana \\
\end{tabular} & & 11,9 & $\mathrm{M}$ \\
\hline & & Telha Cerâmica e Laje Mista Inclinada & & 11,6 & Não Atende \\
\hline \multirow{3}{*}{ Caxias do Sul } & \multirow{3}{*}{1} & Telha Cerâmica & \multirow{3}{*}{ P $10 \mathrm{~cm} /$ conc 2400} & 11,4 & Não Atende \\
\hline & & Telha Cerâmica e Laje Mista Plana & & 12,3 & $\mathrm{M}$ \\
\hline & & Telha Cerâmica e Laje Mista Inclinada & & 12 & $\mathrm{M}$ \\
\hline \multirow{3}{*}{ Caxias do Sul } & \multirow{3}{*}{1} & Telha Cerâmica & \multirow{3}{*}{ P $10 \mathrm{~cm} /$ conc 2200} & 11,4 & Não Atende \\
\hline & & Telha Cerâmica e Laje Mista Plana & & 12,2 & $\mathrm{M}$ \\
\hline & & Telha Cerâmica e Laje Mista Inclinada & & 12 & $\mathrm{M}$ \\
\hline \multirow{3}{*}{ Caxias do Sul } & & Telha Cerâmica & & 11,4 & Não Atende \\
\hline & 1 & Telha Cerâmica e Laje Mista Plana & P $10 \mathrm{~cm} /$ conc 2000 & 12,2 & $\mathrm{M}$ \\
\hline & & Telha Cerâmica e Laje Mista Inclinada & & 12 & $\mathrm{M}$ \\
\hline & & Telha Cerâmica & & 11,3 & Não Atende \\
\hline Caxias do Sul & 1 & Telha Cerâmica e Laje Mista Plana & P $10 \mathrm{~cm} /$ conc 1800 & 12,3 & $\mathrm{M}$ \\
\hline & & Telha Cerâmica e Laje Mista Inclinada & & 12 & $\mathrm{M}$ \\
\hline & & Telha Cerâmica & & 11,4 & Não Atende \\
\hline Caxias do Sul & 1 & Telha Cerâmica e Laje Mista Plana & P $10 \mathrm{~cm} /$ conc 1600 & 12,4 & $\mathrm{M}$ \\
\hline & & Telha Cerâmica e Laje Mista Inclinada & & 12,1 & $\mathrm{M}$ \\
\hline & & Telha Cerâmica & & 11,8 & $\mathrm{M}$ \\
\hline Caxias do Sul & 1 & Telha Cerâmica e Laje Mista Plana & P $12 \mathrm{~cm} /$ conc 2400 & 12,6 & $\mathrm{M}$ \\
\hline & & Telha Cerâmica e Laje Mista Inclinada & & 12,4 & $\mathrm{M}$ \\
\hline & & Telha Cerâmica & & 11,8 & $\mathrm{M}$ \\
\hline Caxias do Sul & 1 & Telha Cerâmica e Laje Mista Plana & P $12 \mathrm{~cm} /$ conc 2200 & 12,6 & M \\
\hline & & Telha Cerâmica e Laje Mista Inclinada & & 12,4 & $\mathrm{M}$ \\
\hline & & Telha Cerâmica & & 11,7 & Não Atende \\
\hline Caxias do Sul & 1 & Telha Cerâmica e Laje Mista Plana & P $12 \mathrm{~cm} /$ conc 2000 & 12,6 & $M$ \\
\hline & & Telha Cerâmica e Laje Mista Inclinada & & 12,4 & $\mathrm{M}$ \\
\hline & & Telha Cerâmica & & 11,7 & Não Atende \\
\hline Caxias do Sul & 1 & Telha Cerâmica e Laje Mista Plana & P $12 \mathrm{~cm} /$ conc 1800 & 12,7 & $M$ \\
\hline & & Telha Cerâmica e Laje Mista Inclinada & & 12,4 & $\mathrm{M}$ \\
\hline & & Telha Cerâmica & & 11,7 & Não Atende \\
\hline Caxias do Sul & 1 & Telha Cerâmica e Laje Mista Plana & P $12 \mathrm{~cm} /$ conc 1600 & 12,7 & $\mathrm{M}$ \\
\hline & & Telha Cerâmica e Laje Mista Inclinada & & 12,5 & $\mathrm{M}$ \\
\hline
\end{tabular}




\begin{tabular}{|c|c|c|c|c|c|}
\hline \multicolumn{6}{|c|}{ Simulações para o Inverno - 22 de Junho } \\
\hline Cidade & Zona Bioclimática & Tipos de Cobertura & Vedações & Temp. Mínima Interna & Desempenho \\
\hline \multirow{3}{*}{ Ponta Grossa } & \multirow{3}{*}{ Luila biocintiatica } & Telha Cerâmica & \multirow{3}{*}{ P $08 \mathrm{~cm} /$ conc 2400} & 12,1 & Não Atende \\
\hline & & Telha Cerâmica e Laje Mista Plana & & 13,1 & $\mathrm{M}$ \\
\hline & & Telha Cerâmica e Laje Mista Inclinada & & 12,7 & $\mathrm{M}$ \\
\hline \multirow{3}{*}{ Ponta Grossa } & \multirow{3}{*}{2} & Telha Cerâmica & \multirow{3}{*}{$\mathrm{P} 08 \mathrm{~cm} /$ conc 2200} & 12,1 & Não Atende \\
\hline & & Telha Cerâmica e Laje Mista Plana & & 13 & $\mathrm{M}$ \\
\hline & & Telha Cerâmica e Laje Mista Inclinada & & 12,7 & $\mathrm{M}$ \\
\hline \multirow{3}{*}{ Ponta Grossa } & \multirow{3}{*}{2} & Telha Cerâmica & \multirow{3}{*}{ P 08cm / conc 2000} & 12 & Não Atende \\
\hline & & Telha Cerâmica e Laje Mista Plana & & 13 & $\mathrm{M}$ \\
\hline & & Telha Cerâmica e Laje Mista Inclinada & & 12,7 & $\mathrm{M}$ \\
\hline \multirow{3}{*}{ Ponta Grossa } & \multirow{3}{*}{2} & Telha Cerâmica & \multirow{3}{*}{$\mathrm{P} 08 \mathrm{~cm} /$ conc 1800} & 12 & Não Atende \\
\hline & & Telha Cerâmica e Laje Mista Plana & & 13,1 & $\mathrm{M}$ \\
\hline & & Telha Cerâmica e Laje Mista Inclinada & & 12,7 & $\mathrm{M}$ \\
\hline \multirow{3}{*}{ Ponta Grossa } & \multirow{3}{*}{2} & Telha Cerâmica & \multirow{3}{*}{$\mathrm{P} 08 \mathrm{~cm} /$ conc 1600} & 12 & Não Atende \\
\hline & & Telha Cerâmica e Laje Mista Plana & & 13,1 & $\mathrm{M}$ \\
\hline & & Telha Cerâmica e Laje Mista Inclinada & & 12,7 & $\mathrm{M}$ \\
\hline \multirow{3}{*}{ Ponta Grossa } & \multirow{3}{*}{2} & Telha Cerâmica & \multirow{3}{*}{ P $10 \mathrm{~cm} /$ conc 2400} & 12,6 & $\mathrm{M}$ \\
\hline & & Telha Cerâmica e Laje Mista Plana & & 13,5 & M \\
\hline & & Telha Cerâmica e Laje Mista Inclinada & & 13,3 & $\mathrm{M}$ \\
\hline \multirow{3}{*}{ Ponta Grossa } & \multirow{3}{*}{2} & Telha Cerâmica & \multirow{3}{*}{ P $10 \mathrm{~cm} /$ conc 2200} & 12,6 & $\mathrm{M}$ \\
\hline & & Telha Cerâmica e Laje Mista Plana & & 13,5 & M \\
\hline & & Telha Cerâmica e Laje Mista Inclinada & & 13,2 & $\mathrm{M}$ \\
\hline \multirow{3}{*}{ Ponta Grossa } & & Telha Cerâmica & & 12,5 & $\mathrm{M}$ \\
\hline & 2 & Telha Cerâmica e Laje Mista Plana & P $10 \mathrm{~cm} /$ conc 2000 & 13,5 & $M$ \\
\hline & & Telha Cerâmica e Laje Mista Inclinada & & 13,2 & $\mathrm{M}$ \\
\hline & & Telha Cerâmica & & 12,5 & $M$ \\
\hline Ponta Grossa & 2 & Telha Cerâmica e Laje Mista Plana & P $10 \mathrm{~cm} /$ conc 1800 & 13,6 & $\mathrm{M}$ \\
\hline & & Telha Cerâmica e Laje Mista Inclinada & & 13,3 & $\mathrm{M}$ \\
\hline & & Telha Cerâmica & & 12,5 & $\mathrm{M}$ \\
\hline Ponta Grossa & 2 & Telha Cerâmica e Laje Mista Plana & P $10 \mathrm{~cm} /$ conc 1600 & 13,6 & $\mathrm{M}$ \\
\hline & & Telha Cerâmica e Laje Mista Inclinada & & 13,3 & M \\
\hline & & Telha Cerâmica & & 13,1 & $\mathrm{M}$ \\
\hline Ponta Grossa & 2 & Telha Cerâmica e Laje Mista Plana & P $12 \mathrm{~cm} / \mathrm{conc} 2400$ & 14 & M \\
\hline & & Telha Cerâmica e Laje Mista Inclinada & & 13,7 & $\mathrm{M}$ \\
\hline & & Telha Cerâmica & & 13,1 & $\mathrm{M}$ \\
\hline Ponta Grossa & 2 & Telha Cerâmica e Laje Mista Plana & P $12 \mathrm{~cm} /$ conc 2200 & 13,9 & $\mathrm{M}$ \\
\hline & & Telha Cerâmica e Laje Mista Inclinada & & 13,7 & M \\
\hline & & Telha Cerâmica & & 12,9 & $\mathrm{M}$ \\
\hline Ponta Grossa & 2 & Telha Cerâmica e Laje Mista Plana & P $12 \mathrm{~cm} /$ conc 2000 & 14 & $\mathrm{M}$ \\
\hline & & Telha Cerâmica e Laje Mista Inclinada & & 13,7 & M \\
\hline & & Telha Cerâmica & & 12,9 & $\mathrm{M}$ \\
\hline Ponta Grossa & 2 & Telha Cerâmica e Laje Mista Plana & $\mathrm{P} 12 \mathrm{~cm} / \mathrm{conc} 1800$ & 14 & $\mathrm{M}$ \\
\hline & & Telha Cerâmica e Laje Mista Inclinada & & 13,7 & $M$ \\
\hline & & Telha Cerâmica & & 12,9 & $\mathrm{M}$ \\
\hline Ponta Grossa & 2 & Telha Cerâmica e Laje Mista Plana & P $12 \mathrm{~cm} /$ conc 1600 & 14,1 & $\mathrm{M}$ \\
\hline & & Telha Cerâmica e Laje Mista Inclinada & & 13,8 & $\mathrm{M}$ \\
\hline
\end{tabular}




\begin{tabular}{|c|c|c|c|c|c|}
\hline \multicolumn{6}{|c|}{ Simulações para o Inverno - 22 de Junho } \\
\hline Cidade & Zona Bioclimática & Tipos de Cobertura & Vedações & Temp. Mínima Interna & Desempenhc \\
\hline \multirow{3}{*}{ São Paulo } & \multirow{3}{*}{ Loria biovimation } & Telha Cerâmica & \multirow{3}{*}{$\mathrm{P} 08 \mathrm{~cm} /$ conc 2400} & 13,7 & Não Atende \\
\hline & & Telha Cerâmica e Laje Mista Plana & & 14,3 & $M$ \\
\hline & & Telha Cerâmica e Laje Mista Inclinada & & 14 & Não Atende \\
\hline \multirow{3}{*}{ São Paulo } & \multirow{3}{*}{3} & Telha Cerâmica & \multirow{3}{*}{ P $08 \mathrm{~cm} /$ conc 2200} & 13,6 & Não Atende \\
\hline & & Telha Cerâmica e Laje Mista Plana & & 14,3 & $\mathrm{M}$ \\
\hline & & Telha Cerâmica e Laje Mista Inclinada & & 13,9 & Não Atende \\
\hline \multirow{3}{*}{ São Paulo } & \multirow{3}{*}{3} & Telha Cerâmica & \multirow{3}{*}{ P $08 \mathrm{~cm} /$ conc 2000} & 13,6 & Não Atende \\
\hline & & Telha Cerâmica e Laje Mista Plana & & 14,2 & $\mathrm{M}$ \\
\hline & & Telha Cerâmica e Laje Mista Inclinada & & 13,9 & Não Atende \\
\hline \multirow{3}{*}{ São Paulo } & \multirow{3}{*}{3} & Telha Cerâmica & \multirow{3}{*}{$\mathrm{P} 08 \mathrm{~cm} /$ conc 1800} & 13,6 & Não Atende \\
\hline & & Telha Cerâmica e Laje Mista Plana & & 14,2 & $\mathrm{M}$ \\
\hline & & Telha Cerâmica e Laje Mista Inclinada & & 13,9 & Não Atende \\
\hline \multirow{3}{*}{ São Paulo } & \multirow{3}{*}{3} & Telha Cerâmica & \multirow{3}{*}{$\mathrm{P} 08 \mathrm{~cm} /$ conc 1600} & 13,6 & Não Atende \\
\hline & & Telha Cerâmica e Laje Mista Plana & & 14,3 & $\mathrm{M}$ \\
\hline & & Telha Cerâmica e Laje Mista Inclinada & & 13,9 & Não Atende \\
\hline \multirow{3}{*}{ São Paulo } & \multirow{3}{*}{3} & Telha Cerâmica & \multirow{3}{*}{ P $10 \mathrm{~cm} /$ conc 2400} & 14,1 & Não Atende \\
\hline & & Telha Cerâmica e Laje Mista Plana & & 14,7 & $\mathrm{M}$ \\
\hline & & Telha Cerâmica e Laje Mista Inclinada & & 14,4 & $\mathrm{M}$ \\
\hline \multirow{3}{*}{ São Paulo } & \multirow{3}{*}{3} & Telha Cerâmica & \multirow{3}{*}{ P $10 \mathrm{~cm} /$ conc 2200} & 14 & Não Atende \\
\hline & & Telha Cerâmica e Laje Mista Plana & & 14,6 & $M$ \\
\hline & & Telha Cerâmica e Laje Mista Inclinada & & 14,4 & $\mathrm{M}$ \\
\hline \multirow{3}{*}{ São Paulo } & & Telha Cerâmica & & 14 & Não Atende \\
\hline & 3 & Telha Cerâmica e Laje Mista Plana & P $10 \mathrm{~cm} / \mathrm{conc} 2000$ & 14,6 & $M$ \\
\hline & & Telha Cerâmica e Laje Mista Inclinada & & 14,4 & $\mathrm{M}$ \\
\hline & & Telha Cerâmica & & 14 & Não Atende \\
\hline São Paulo & 3 & Telha Cerâmica e Laje Mista Plana & P $10 \mathrm{~cm} /$ conc 1800 & 14,6 & $\mathrm{M}$ \\
\hline & & Telha Cerâmica e Laje Mista Inclinada & & 14,4 & $\mathrm{M}$ \\
\hline & & Telha Cerâmica & & 14 & Não Atende \\
\hline São Paulo & 3 & Telha Cerâmica e Laje Mista Plana & P $10 \mathrm{~cm} / \mathrm{conc} 1600$ & 14,7 & $\mathrm{M}$ \\
\hline & & Telha Cerâmica e Laje Mista Inclinada & & 14,4 & $M$ \\
\hline & & Telha Cerâmica & & 14,5 & $M$ \\
\hline São Paulo & 3 & Telha Cerâmica e Laje Mista Plana & P $12 \mathrm{~cm} /$ conc 2400 & 15,1 & $M$ \\
\hline & & Telha Cerâmica e Laje Mista Inclinada & & 14,9 & $\mathrm{M}$ \\
\hline & & Telha Cerâmica & & 14,5 & $\mathrm{M}$ \\
\hline São Paulo & 3 & Telha Cerâmica e Laje Mista Plana & P $12 \mathrm{~cm} /$ conc 2200 & 15 & $M$ \\
\hline & & Telha Cerâmica e Laje Mista Inclinada & & 14,9 & $\mathrm{M}$ \\
\hline & & Telha Cerâmica & & 14,3 & $\mathrm{M}$ \\
\hline São Paulo & 3 & Telha Cerâmica e Laje Mista Plana & P $12 \mathrm{~cm} /$ conc 2000 & 15 & $M$ \\
\hline & & Telha Cerâmica e Laje Mista Inclinada & & 15 & $\mathrm{M}$ \\
\hline & & Telha Cerâmica & & 14,3 & $\mathrm{M}$ \\
\hline São Paulo & 3 & Telha Cerâmica e Laje Mista Plana & P $12 \mathrm{~cm} /$ conc 1800 & 15 & $\mathrm{M}$ \\
\hline & & Telha Cerâmica e Laje Mista Inclinada & & 14,7 & $\mathrm{M}$ \\
\hline & & Telha Cerâmica & & 14,3 & $\mathrm{M}$ \\
\hline São Paulo & 3 & Telha Cerâmica e Laje Mista Plana & P $12 \mathrm{~cm} /$ conc 1600 & 15,1 & $\mathrm{M}$ \\
\hline & & Telha Cerâmica e Laje Mista Inclinada & & 14,7 & $\mathrm{M}$ \\
\hline
\end{tabular}




\begin{tabular}{|c|c|c|c|c|c|}
\hline \multicolumn{6}{|c|}{ Simulações para o Inverno - 22 de Junho } \\
\hline Cidade & Zona Bioclimática & \begin{tabular}{|l|} 
Tipos de Cobertura \\
\end{tabular} & Vedações & Temp. Mínima Interna & Desempenho \\
\hline \multirow{3}{*}{ Florianópolis } & \multirow{3}{*}{3} & Telha Cerâmica & \multirow{3}{*}{ P $08 \mathrm{~cm} /$ conc 2400} & 16,8 & Não Atende \\
\hline & & Telha Cerâmica e Laje Mista Plana & & 17,2 & Não Atende \\
\hline & & Telha Cerâmica e Laje Mista Inclinada & & 16,9 & Não Atende \\
\hline \multirow{3}{*}{ Florianópolis } & \multirow{3}{*}{3} & Telha Cerâmica & \multirow{3}{*}{ P $08 \mathrm{~cm} /$ conc 2200} & 16,7 & Não Atende \\
\hline & & Telha Cerâmica e Laje Mista Plana & & 17,1 & Não Atende \\
\hline & & Telha Cerâmica e Laje Mista Inclinada & & 16,9 & Não Atende \\
\hline \multirow{3}{*}{ Florianópolis } & \multirow{3}{*}{3} & Telha Cerâmica & \multirow{3}{*}{ P $08 \mathrm{~cm} /$ conc 2000} & 16,7 & Não Atende \\
\hline & & Telha Cerâmica e Laje Mista Plana & & 17,1 & Não Atende \\
\hline & & Telha Cerâmica e Laje Mista Inclinada & & 16,9 & Não Atende \\
\hline \multirow{3}{*}{ Florianópolis } & \multirow{3}{*}{3} & Telha Cerâmica & \multirow{3}{*}{ P $08 \mathrm{~cm} /$ conc 1800} & 16,7 & Não Atende \\
\hline & & Telha Cerâmica e Laje Mista Plana & & 17,1 & Não Atende \\
\hline & & Telha Cerâmica e Laje Mista Inclinada & & 16,9 & Não Atende \\
\hline \multirow{3}{*}{ Florianópolis } & \multirow{3}{*}{3} & Telha Cerâmica & \multirow{3}{*}{$\mathrm{P} 08 \mathrm{~cm} /$ conc 1600} & 16,7 & Não Atende \\
\hline & & Telha Cerâmica e Laje Mista Plana & & 17,2 & Não Atende \\
\hline & & Telha Cerâmica e Laje Mista Inclinada & & 16,9 & Não Atende \\
\hline \multirow{3}{*}{ Florianópolis } & \multirow{3}{*}{3} & Telha Cerâmica & \multirow{3}{*}{ P $10 \mathrm{~cm} /$ conc 2400} & 17 & Não Atende \\
\hline & & Telha Cerâmica e Laje Mista Plana & & 17,4 & Não Atende \\
\hline & & Telha Cerâmica e Laje Mista Inclinada & & 17,2 & Não Atende \\
\hline \multirow{3}{*}{ Florianópolis } & \multirow{3}{*}{3} & Telha Cerâmica & \multirow{3}{*}{ P $10 \mathrm{~cm} /$ conc 2200} & 17 & Não Atende \\
\hline & & Telha Cerâmica e Laje Mista Plana & & 17,4 & Não Atende \\
\hline & & Telha Cerâmica e Laje Mista Inclinada & & 17,2 & Não Atende \\
\hline \multirow{3}{*}{ Florianópolis } & & Telha Cerâmica & & 17 & Não Atende \\
\hline & 3 & Telha Cerâmica e Laje Mista Plana & P $10 \mathrm{~cm} /$ conc 2000 & 17,4 & Não Atende \\
\hline & & Telha Cerâmica e Laje Mista Inclinada & & 17,2 & Não Atende \\
\hline & & Telha Cerâmica & & 17 & Não Atende \\
\hline Florianópolis & 3 & Telha Cerâmica e Laje Mista Plana & P $10 \mathrm{~cm} /$ conc 1800 & 17,4 & Não Atende \\
\hline & & Telha Cerâmica e Laje Mista Inclinada & & 17,2 & Não Atende \\
\hline & & Telha Cerâmica & & 17 & Não Atende \\
\hline Florianópolis & 3 & Telha Cerâmica e Laje Mista Plana & P $10 \mathrm{~cm} /$ conc 1600 & 17,4 & Não Atende \\
\hline & & Telha Cerâmica e Laje Mista Inclinada & & 17,2 & Não Atende \\
\hline & & Telha Cerâmica & & 17,3 & Não Atende \\
\hline Florianópolis & 3 & Telha Cerâmica e Laje Mista Plana & P $12 \mathrm{~cm} /$ conc 2400 & 17,7 & Não Atende \\
\hline & & Telha Cerâmica e Laje Mista Inclinada & & 17,5 & Não Atende \\
\hline & & Telha Cerâmica & & 17,3 & Não Atende \\
\hline Florianópolis & 3 & Telha Cerâmica e Laje Mista Plana & P $12 \mathrm{~cm} /$ conc 2200 & 17,6 & Não Atende \\
\hline & & Telha Cerâmica e Laje Mista Inclinada & & 17,5 & Não Atende \\
\hline & & Telha Cerâmica & & 17,2 & Não Atende \\
\hline Florianópolis & 3 & Telha Cerâmica e Laje Mista Plana & P $12 \mathrm{~cm} /$ conc 2000 & 17,6 & Não Atende \\
\hline & & Telha Cerâmica e Laje Mista Inclinada & & 17,4 & Não Atende \\
\hline & & Telha Cerâmica & & 17,2 & Não Atende \\
\hline Florianópolis & 3 & Telha Cerâmica e Laje Mista Plana & P $12 \mathrm{~cm} /$ conc 1800 & 17,6 & Não Atende \\
\hline & & Telha Cerâmica e Laje Mista Inclinada & & 17,4 & Não Atende \\
\hline & & Telha Cerâmica & & 17,2 & Não Atende \\
\hline Florianópolis & 3 & Telha Cerâmica e Laje Mista Plana & P $12 \mathrm{~cm} /$ conc 1600 & 17,7 & Não Atende \\
\hline & & Telha Cerâmica e Laje Mista Inclinada & & 17,4 & Não Atende \\
\hline
\end{tabular}




\begin{tabular}{|c|c|c|c|c|c|}
\hline \multicolumn{6}{|c|}{ Simulações para o Inverno - 22 de Junho } \\
\hline Cidade & Zona Bioclimática & $\begin{array}{l}\text { Tipos de Cobertura } \\
\end{array}$ & Vedações & Temp. Mínima Interna & Desempenhc \\
\hline \multirow{3}{*}{ São Carlos } & \multirow[t]{3}{*}{ Loria biovimation } & Telha Cerâmica & \multirow{3}{*}{ P $8 \mathrm{~cm} /$ conc 2400} & 15,8 & Não Atende \\
\hline & & Telha Cerâmica e Laje Mista Plana & & 16,5 & $M$ \\
\hline & & Telha Cerâmica e Laje Mista Inclinada & & 16 & Não Atende \\
\hline \multirow{3}{*}{ São Carlos } & \multirow{3}{*}{4} & Telha Cerâmica & \multirow{3}{*}{ P $8 \mathrm{~cm} /$ conc 2200} & 15,7 & Não Atende \\
\hline & & Telha Cerâmica e Laje Mista Plana & & 16,4 & $M$ \\
\hline & & Telha Cerâmica e Laje Mista Inclinada & & 16 & Não Atende \\
\hline \multirow{3}{*}{ São Carlos } & \multirow{3}{*}{4} & Telha Cerâmica & \multirow{3}{*}{ P $08 \mathrm{~cm} /$ conc 2000} & 15,8 & Não Atende \\
\hline & & Telha Cerâmica e Laje Mista Plana & & 16,4 & $\mathrm{M}$ \\
\hline & & Telha Cerâmica e Laje Mista Inclinada & & 16 & Não Atende \\
\hline \multirow{3}{*}{ São Carlos } & \multirow{3}{*}{4} & Telha Cerâmica & \multirow{3}{*}{ P $08 \mathrm{~cm} /$ conc 1800} & 15,7 & Não Atende \\
\hline & & Telha Cerâmica e Laje Mista Plana & & 16,4 & $\mathrm{M}$ \\
\hline & & Telha Cerâmica e Laje Mista Inclinada & & 16 & Não Atende \\
\hline \multirow{3}{*}{ São Carlos } & \multirow{3}{*}{4} & Telha Cerâmica & \multirow{3}{*}{$\mathrm{P} 08 \mathrm{~cm} /$ conc 1600} & 15,8 & Não Atende \\
\hline & & Telha Cerâmica e Laje Mista Plana & & 16,4 & $\mathrm{M}$ \\
\hline & & Telha Cerâmica e Laje Mista Inclinada & & 16 & Não Atende \\
\hline \multirow{3}{*}{ São Carlos } & \multirow{3}{*}{4} & Telha Cerâmica & \multirow{3}{*}{ P $10 \mathrm{~cm} /$ conc 2400} & 16,4 & $\mathrm{M}$ \\
\hline & & Telha Cerâmica e Laje Mista Plana & & 16,8 & $\mathrm{M}$ \\
\hline & & Telha Cerâmica e Laje Mista Inclinada & & 16,5 & $\mathrm{M}$ \\
\hline \multirow{3}{*}{ São Carlos } & \multirow{3}{*}{4} & Telha Cerâmica & \multirow{3}{*}{ P $10 \mathrm{~cm} /$ conc 2200} & 16,2 & Não Atende \\
\hline & & Telha Cerâmica e Laje Mista Plana & & 16,8 & $M$ \\
\hline & & Telha Cerâmica e Laje Mista Inclinada & & 16,4 & $\mathrm{M}$ \\
\hline \multirow{3}{*}{ São Carlos } & & Telha Cerâmica & & 16,2 & Não Atende \\
\hline & 4 & Telha Cerâmica e Laje Mista Plana & P $10 \mathrm{~cm} /$ conc 2000 & 16,7 & $\mathrm{M}$ \\
\hline & & Telha Cerâmica e Laje Mista Inclinada & & 16,4 & $\mathrm{M}$ \\
\hline & & Telha Cerâmica & & 16,2 & Não Atende \\
\hline São Carlos & 4 & Telha Cerâmica e Laje Mista Plana & P $10 \mathrm{~cm} /$ conc 1800 & 16,7 & $M$ \\
\hline & & Telha Cerâmica e Laje Mista Inclinada & & 16,4 & $\mathrm{M}$ \\
\hline & & Telha Cerâmica & & 16,2 & Não Atende \\
\hline São Carlos & 4 & Telha Cerâmica e Laje Mista Plana & P $10 \mathrm{~cm} / \mathrm{conc} 1600$ & 16,8 & $\mathrm{M}$ \\
\hline & & Telha Cerâmica e Laje Mista Inclinada & & 16,5 & $\mathrm{M}$ \\
\hline & & Telha Cerâmica & & 16,7 & $\mathrm{M}$ \\
\hline São Carlos & 4 & Telha Cerâmica e Laje Mista Plana & P $12 \mathrm{~cm} /$ conc 2400 & 17,2 & $M$ \\
\hline & & Telha Cerâmica e Laje Mista Inclinada & & 17 & $\mathrm{M}$ \\
\hline & & Telha Cerâmica & & 16,7 & $\mathrm{M}$ \\
\hline São Carlos & 4 & Telha Cerâmica e Laje Mista Plana & P $12 \mathrm{~cm} /$ conc 2200 & 17,2 & $\mathrm{M}$ \\
\hline & & Telha Cerâmica e Laje Mista Inclinada & & 17 & $\mathrm{M}$ \\
\hline & & Telha Cerâmica & & 16,5 & $\mathrm{M}$ \\
\hline São Carlos & 4 & Telha Cerâmica e Laje Mista Plana & P $12 \mathrm{~cm} /$ conc 2000 & 17,1 & $M$ \\
\hline & & Telha Cerâmica e Laje Mista Inclinada & & 16,8 & $\mathrm{M}$ \\
\hline & & Telha Cerâmica & & 16,5 & $\mathrm{M}$ \\
\hline São Carlos & 4 & Telha Cerâmica e Laje Mista Plana & $\mathrm{P} 12 \mathrm{~cm} / \mathrm{conc} 1800$ & 17,1 & M \\
\hline & & Telha Cerâmica e Laje Mista Inclinada & & 16,8 & $\mathrm{M}$ \\
\hline & & Telha Cerâmica & & 16,5 & $\mathrm{M}$ \\
\hline São Carlos & 4 & Telha Cerâmica e Laje Mista Plana & P $12 \mathrm{~cm} /$ conc 1600 & 17,1 & $\mathrm{M}$ \\
\hline & & Telha Cerâmica e Laje Mista Inclinada & & 16,8 & $\mathrm{M}$ \\
\hline
\end{tabular}




\begin{tabular}{|c|c|c|c|c|c|}
\hline \multicolumn{6}{|c|}{ Simulações para o Inverno - 22 de Junho } \\
\hline Cidade & Zona Bioclimática & Tipos de Cobertura & Vedações & Temp. Mínima Interna & Desempenho \\
\hline \multirow[t]{2}{*}{ Brasília } & \multirow{2}{*}{ 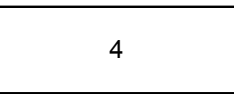 } & Telha Cerâmica e Laje Mista Plana & \multirow[t]{2}{*}{$\mathrm{P} 08 \mathrm{~cm} /$ conc 2400} & 16 & $\mathrm{M}$ \\
\hline & & Telha Cerâmica e Laje Mista Inclinada & & 15,5 & $\mathrm{M}$ \\
\hline \multirow[t]{2}{*}{ Brasilia } & \multirow[t]{2}{*}{4} & Telha Cerâmica e Laje Mista Plana & \multirow[t]{2}{*}{$\mathrm{P} 08 \mathrm{~cm} /$ conc 2200} & 16 & $\mathrm{M}$ \\
\hline & & Telha Cerâmica e Laje Mista Inclinada & & 15,4 & $\mathrm{M}$ \\
\hline \multirow{3}{*}{ Brasilia } & \multirow{3}{*}{4} & Telha Cerâmica & \multirow{3}{*}{$\mathrm{P} 08 \mathrm{~cm} /$ conc 2000} & 15,3 & $\mathrm{M}$ \\
\hline & & Telha Cerâmica e Laje Mista Plana & & 16 & $\mathrm{M}$ \\
\hline & & Telha Cerâmica e Laje Mista Inclinada & & 15,4 & $\mathrm{M}$ \\
\hline Brasilia & 4 & Telha Cerâmica e Laje Mista Inclinada & $\mathrm{P} 08 \mathrm{~cm} /$ conc 1800 & 15,4 & $\mathrm{M}$ \\
\hline \multirow{3}{*}{ Brasilia } & \multirow{3}{*}{4} & Telha Cerâmica & \multirow{3}{*}{$\mathrm{P} 08 \mathrm{~cm} /$ conc 1600} & 15,4 & $\mathrm{M}$ \\
\hline & & Telha Cerâmica e Laje Mista Plana & & 16 & $\mathrm{M}$ \\
\hline & & Telha Cerâmica e Laje Mista Inclinada & & 15,4 & $\mathrm{M}$ \\
\hline \multirow{3}{*}{ Brasilia } & \multirow{3}{*}{4} & Telha Cerâmica & \multirow{3}{*}{ P $10 \mathrm{~cm} /$ conco 2400} & 16 & $\mathrm{M}$ \\
\hline & & Telha Cerâmica e Laje Mista Plana & & 16,6 & $\mathrm{M}$ \\
\hline & & Telha Cerâmica e Laje Mista Inclinada & & 16,1 & $\mathrm{M}$ \\
\hline Brasília & 4 & Telha Cerâmica & P $10 \mathrm{~cm} /$ conco 2200 & 16 & $\mathrm{M}$ \\
\hline Brasilia & 4 & Telha Cerâmica e Laje Mista Plana & P $10 \mathrm{~cm} /$ conc 1800 & 16,5 & $\mathrm{M}$ \\
\hline & & Telha Cerâmica e Laje Mista Inclinada & & 16 & $\mathrm{M}$ \\
\hline & & Telha Cerâmica & & 15,9 & $\mathrm{M}$ \\
\hline Brasilia & 4 & Telha Cerâmica e Laje Mista Plana & P $10 \mathrm{~cm} /$ conc 1600 & 16,6 & $\mathrm{M}$ \\
\hline & & Telha Cerâmica e Laje Mista Inclinada & & 16,1 & $\mathrm{M}$ \\
\hline & & Telha Cerâmica & & 16,6 & $\mathrm{M}$ \\
\hline Brasília & 4 & Telha Cerâmica e Laje Mista Plana & P $12 \mathrm{~cm} /$ conc 2400 & 17 & $\mathrm{M} / \mathrm{I}$ \\
\hline & & Telha Cerâmica e Laje Mista Inclinada & & 16,7 & $\mathrm{M} / \mathrm{I}$ \\
\hline & & Telha Cerâmica & & 16,6 & $\mathrm{M}$ \\
\hline Brasília & 4 & Telha Cerâmica e Laje Mista Plana & P $12 \mathrm{~cm} /$ conc 2200 & 17 & $\mathrm{M} / \mathrm{I}$ \\
\hline & & Telha Cerâmica e Laje Mista Inclinada & & 16,7 & $\mathrm{M} / \mathrm{I}$ \\
\hline & & Telha Cerâmica & & 16,4 & $\mathrm{M}$ \\
\hline Brasília & 4 & Telha Cerâmica e Laje Mista Plana & P $12 \mathrm{~cm} /$ conc 2000 & 17 & $\mathrm{M} / \mathrm{I}$ \\
\hline & & Telha Cerâmica e Laje Mista Inclinada & & 16,5 & $\mathrm{M}$ \\
\hline & & Telha Cerâmica & & 16,4 & $\mathrm{M}$ \\
\hline Brasilia & 4 & Telha Cerâmica e Laje Mista Plana & P $12 \mathrm{~cm} /$ conc 1800 & 17 & $\mathrm{M} / \mathrm{I}$ \\
\hline & & Telha Cerâmica e Laje Mista Inclinada & & 16,5 & $\mathrm{M}$ \\
\hline
\end{tabular}




\begin{tabular}{|c|c|c|c|c|c|}
\hline \multicolumn{6}{|c|}{ Simulações para o Inverno - 22 de Junho } \\
\hline Cidade & Zona Bioclimática & Tipos de Cobertura & Vedações & Temp. Mínima Interna & Desempenho \\
\hline \multirow{3}{*}{ Santos } & \multirow[t]{3}{*}{ 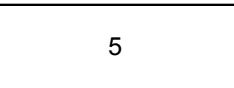 } & Telha Cerâmica & \multirow{3}{*}{$\mathrm{P} 08 \mathrm{~cm} /$ conc 2400} & 18 & Não Atende \\
\hline & & Telha Cerâmica e Laje Mista Plana & & 18,4 & Não Atende \\
\hline & & Telha Cerâmica e Laje Mista Inclinada & & 18,1 & Não Atende \\
\hline \multirow{3}{*}{ Santos } & \multirow{3}{*}{5} & Telha Cerâmica & \multirow{3}{*}{ P $08 \mathrm{~cm} /$ conc 2200} & 17,9 & Não Atende \\
\hline & & Telha Cerâmica e Laje Mista Plana & & 18,4 & Não Atende \\
\hline & & Telha Cerâmica e Laje Mista Inclinada & & 18,1 & Não Atende \\
\hline \multirow{3}{*}{ Santos } & \multirow{3}{*}{5} & Telha Cerâmica & \multirow{3}{*}{$\mathrm{P} 08 \mathrm{~cm} /$ conc 2000} & 17,9 & Não Atende \\
\hline & & Telha Cerâmica e Laje Mista Plana & & 18,4 & Não Atende \\
\hline & & Telha Cerâmica e Laje Mista Inclinada & & 18,1 & Não Atende \\
\hline \multirow{3}{*}{ Santos } & \multirow{3}{*}{5} & Telha Cerâmica & \multirow{3}{*}{ P $08 \mathrm{~cm} /$ conc 1800} & 17,9 & Não Atende \\
\hline & & Telha Cerâmica e Laje Mista Plana & & 18,4 & Não Atende \\
\hline & & Telha Cerâmica e Laje Mista Inclinada & & 18,1 & Não Atende \\
\hline \multirow{3}{*}{ Santos } & \multirow{3}{*}{5} & Telha Cerâmica & \multirow{3}{*}{$\mathrm{P} 08 \mathrm{~cm} /$ conc 1600} & 17,9 & Não Atende \\
\hline & & Telha Cerâmica e Laje Mista Plana & & 18,4 & Não Atende \\
\hline & & Telha Cerâmica e Laje Mista Inclinada & & 18,1 & Não Atende \\
\hline \multirow{3}{*}{ Santos } & \multirow{3}{*}{5} & Telha Cerâmica & \multirow{3}{*}{ P $10 \mathrm{~cm} /$ conco 2400} & 18,3 & Não Atende \\
\hline & & Telha Cerâmica e Laje Mista Plana & & 18,7 & Não Atende \\
\hline & & Telha Cerâmica e Laje Mista Inclinada & & 18,5 & Não Atende \\
\hline \multirow{3}{*}{ Santos } & \multirow{3}{*}{5} & Telha Cerâmica & \multirow{3}{*}{ P $10 \mathrm{~cm} /$ conco 2200} & 18,3 & Não Atende \\
\hline & & Telha Cerâmica e Laje Mista Plana & & 18,7 & Não Atende \\
\hline & & Telha Cerâmica e Laje Mista Inclinada & & 18,5 & Não Atende \\
\hline \multirow{3}{*}{ Santos } & & Telha Cerâmica & & 18,2 & Não Atende \\
\hline & 5 & Telha Cerâmica e Laje Mista Plana & P $10 \mathrm{~cm} /$ conc 2000 & 18,7 & Não Atende \\
\hline & & Telha Cerâmica e Laje Mista Inclinada & & 18,4 & Não Atende \\
\hline & & Telha Cerâmica & & 18,2 & Não Atende \\
\hline Santos & 5 & Telha Cerâmica e Laje Mista Plana & P $10 \mathrm{~cm} /$ conc 1800 & 18,7 & Não Atende \\
\hline & & Telha Cerâmica e Laje Mista Inclinada & & 18,4 & Não Atende \\
\hline & & Telha Cerâmica & & 18,2 & Não Atende \\
\hline Santos & 5 & Telha Cerâmica e Laje Mista Plana & P $10 \mathrm{~cm} /$ conc 1600 & 18,7 & Não Atende \\
\hline & & Telha Cerâmica e Laje Mista Inclinada & & 18,5 & Não Atende \\
\hline & & Telha Cerâmica & & 18,6 & Não Atende \\
\hline Santos & 5 & Telha Cerâmica e Laje Mista Plana & P $12 \mathrm{~cm} /$ conc 2400 & 19 & $\mathrm{M}$ \\
\hline & & Telha Cerâmica e Laje Mista Inclinada & & 18,9 & Não Atende \\
\hline & & Telha Cerâmica & & 18,6 & Não Atende \\
\hline Santos & 5 & Telha Cerâmica e Laje Mista Plana & P $12 \mathrm{~cm} /$ conc 2200 & 19 & $M$ \\
\hline & & Telha Cerâmica e Laje Mista Inclinada & & 18,8 & Não Atende \\
\hline & & Telha Cerâmica & & 18,5 & Não Atende \\
\hline Santos & 5 & Telha Cerâmica e Laje Mista Plana & P $12 \mathrm{~cm} /$ conc 2000 & 19 & $M$ \\
\hline & & Telha Cerâmica e Laje Mista Inclinada & & 18,7 & Não Atende \\
\hline & & Telha Cerâmica & & 18,5 & Não Atende \\
\hline Santos & 5 & Telha Cerâmica e Laje Mista Plana & P $12 \mathrm{~cm} /$ conc 1800 & 19 & $\mathrm{M}$ \\
\hline & & Telha Cerâmica e Laje Mista Inclinada & & 18,7 & Não Atende \\
\hline & & Telha Cerâmica & & 18,5 & Não Atende \\
\hline Santos & 5 & Telha Cerâmica e Laje Mista Plana & P $12 \mathrm{~cm} /$ conc 1600 & 19 & $\mathrm{M}$ \\
\hline & & Telha Cerâmica e Laje Mista Inclinada & & 18,8 & Não Atende \\
\hline
\end{tabular}




\begin{tabular}{|c|c|c|c|c|c|}
\hline \multicolumn{6}{|c|}{ Simulações para o Inverno - 22 de Junho } \\
\hline Cidade & Zona Bioclimática & \begin{tabular}{|l|} 
Tipos de Cobertura \\
\end{tabular} & Vedações & Temp. Mínima Interna & Desempenho \\
\hline \multirow{3}{*}{ Presidente Prudente } & \multirow[t]{3}{*}{ 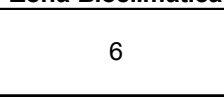 } & Telha Cerâmica & \multirow{3}{*}{$\mathrm{P} 08 \mathrm{~cm} /$ conc 2400} & 17,5 & \multirow{3}{*}{ Dispensa Verificação } \\
\hline & & Telha Cerâmica e Laje Mista Plana & & 18,1 & \\
\hline & & Telha Cerâmica e Laje Mista Inclinada & & 17,7 & \\
\hline \multirow{3}{*}{ Presidente Prudente } & \multirow{3}{*}{6} & Telha Cerâmica & \multirow{3}{*}{$\mathrm{P} 08 \mathrm{~cm} /$ conc 2200} & 17,4 & \multirow{3}{*}{ Dispensa Verificação } \\
\hline & & Telha Cerâmica e Laje Mista Plana & & 18 & \\
\hline & & Telha Cerâmica e Laje Mista Inclinada & & 17,6 & \\
\hline \multirow{3}{*}{ Presidente Prudente } & \multirow{3}{*}{6} & Telha Cerâmica & \multirow{3}{*}{ P 08cm / conc 2000} & 17,4 & \multirow{3}{*}{ Dispensa Verificação } \\
\hline & & Telha Cerâmica e Laje Mista Plana & & 18 & \\
\hline & & Telha Cerâmica e Laje Mista Inclinada & & 17,6 & \\
\hline \multirow{3}{*}{ Presidente Prudente } & \multirow{3}{*}{6} & Telha Cerâmica & \multirow{3}{*}{ P 08cm / conc 1800} & 17,4 & \multirow{3}{*}{ Dispensa Verificação } \\
\hline & & Telha Cerâmica e Laje Mista Plana & & 18 & \\
\hline & & Telha Cerâmica e Laje Mista Inclinada & & 17,6 & \\
\hline \multirow{3}{*}{ Presidente Prudente } & \multirow{3}{*}{6} & Telha Cerâmica & \multirow{3}{*}{$\mathrm{P} 08 \mathrm{~cm} /$ conc 1600} & 17,4 & \multirow{3}{*}{ Dispensa Verificação } \\
\hline & & Telha Cerâmica e Laje Mista Plana & & 18,1 & \\
\hline & & Telha Cerâmica e Laje Mista Inclinada & & 17,6 & \\
\hline \multirow{3}{*}{ Presidente Prudente } & \multirow{3}{*}{6} & Telha Cerâmica & & 17,9 & \\
\hline & & Telha Cerâmica e Laje Mista Plana & P $10 \mathrm{~cm} /$ conco 2400 & 18,5 & Dispensa Verificação \\
\hline & & Telha Cerâmica e Laje Mista Inclinada & & 18,2 & \\
\hline & & Telha Cerâmica & & 17,9 & \\
\hline Presidente Prudente & 6 & Telha Cerâmica e Laje Mista Plana & P $10 \mathrm{~cm} /$ conco 2200 & 18,4 & Dispensa Verificação \\
\hline & & Telha Cerâmica e Laje Mista Inclinada & & 18,1 & \\
\hline & & Telha Cerâmica & & 17,8 & \\
\hline Presidente Prudente & 6 & Telha Cerâmica e Laje Mista Plana & P $10 \mathrm{~cm} /$ conc 2000 & 18,4 & Dispensa Verificação \\
\hline & & Telha Cerâmica e Laje Mista Inclinada & & 18,1 & \\
\hline & & Telha Cerâmica & & 17,8 & \\
\hline Presidente Prudente & 6 & Telha Cerâmica e Laje Mista Plana & P $10 \mathrm{~cm} /$ conc 1800 & 18,4 & Dispensa Verificação \\
\hline & & Telha Cerâmica e Laje Mista Inclinada & & 18,1 & \\
\hline & & Telha Cerâmica & & 17,8 & \\
\hline Presidente Prudente & 6 & Telha Cerâmica e Laje Mista Plana & P $10 \mathrm{~cm} /$ conc 1600 & 18,5 & Dispensa Verificação \\
\hline & & Telha Cerâmica e Laje Mista Inclinada & & 18,1 & \\
\hline & & Telha Cerâmica & & 18,4 & \\
\hline Presidente Prudente & 6 & Telha Cerâmica e Laje Mista Plana & P $12 \mathrm{~cm} /$ conc 2400 & 18,9 & Dispensa Verificação \\
\hline & & Telha Cerâmica e Laje Mista Inclinada & & 18,7 & \\
\hline & & Telha Cerâmica & & 18,3 & \\
\hline Presidente Prudente & 6 & Telha Cerâmica e Laje Mista Plana & P $12 \mathrm{~cm} /$ conc 2200 & 18,8 & Dispensa Verificação \\
\hline & & Telha Cerâmica e Laje Mista Inclinada & & 18,6 & \\
\hline & & Telha Cerâmica & & 18,2 & \\
\hline Presidente Prudente & 6 & Telha Cerâmica e Laje Mista Plana & P $12 \mathrm{~cm} /$ conc 2000 & 18,8 & Dispensa Verificação \\
\hline & & Telha Cerâmica e Laje Mista Inclinada & & 18,5 & \\
\hline & & Telha Cerâmica & & 18,1 & \\
\hline Presidente Prudente & 6 & Telha Cerâmica e Laje Mista Plana & P $12 \mathrm{~cm} /$ conc 1800 & 18,8 & Dispensa Verificação \\
\hline & & Telha Cerâmica e Laje Mista Inclinada & & 18,5 & \\
\hline & & Telha Cerâmica & & 18,2 & \\
\hline Presidente Prudente & 6 & Telha Cerâmica e Laje Mista Plana & P $12 \mathrm{~cm} /$ conc 1600 & 18,8 & Dispensa Verificação \\
\hline & & Telha Cerâmica e Laje Mista Inclinada & & 18,5 & \\
\hline
\end{tabular}




\begin{tabular}{|c|c|c|c|c|c|}
\hline \multicolumn{6}{|c|}{ Simulações para o Inverno - 22 de Junho } \\
\hline Cidade & Zona Bioclimática & \begin{tabular}{|c|} 
Tipos de Cobertura \\
\end{tabular} & Vedações & Temp. Mínima Interna & Desempenho \\
\hline \multirow{3}{*}{ Teresina } & \multirow[t]{3}{*}{ - } & Telha Cerâmica & \multirow{3}{*}{$\mathrm{P} 08 \mathrm{~cm} /$ conc 2400} & 24,9 & \multirow{3}{*}{ Dispensa Verificação } \\
\hline & & Telha Cerâmica e Laje Mista Plana & & 25,1 & \\
\hline & & Telha Cerâmica e Laje Mista Inclinada & & 24,6 & \\
\hline \multirow{3}{*}{ Teresina } & \multirow{3}{*}{7} & Telha Cerâmica & \multirow{3}{*}{$\mathrm{P} 08 \mathrm{~cm} /$ conc 2200} & 24,9 & \multirow{3}{*}{ Dispensa Verificação } \\
\hline & & Telha Cerâmica e Laje Mista Plana & & 25,1 & \\
\hline & & Telha Cerâmica e Laje Mista Inclinada & & 24,6 & \\
\hline \multirow{3}{*}{ Teresina } & \multirow{3}{*}{7} & Telha Cerâmica & \multirow{3}{*}{$\mathrm{P} 08 \mathrm{~cm} /$ conc 2000} & 24,8 & \multirow{3}{*}{ Dispensa Verificação } \\
\hline & & Telha Cerâmica e Laje Mista Plana & & 25,1 & \\
\hline & & Telha Cerâmica e Laje Mista Inclinada & & 24,5 & \\
\hline \multirow{3}{*}{ Teresina } & \multirow{3}{*}{7} & Telha Cerâmica & \multirow{3}{*}{$\mathrm{P} 08 \mathrm{~cm} /$ conc 1800} & 24,8 & \multirow{3}{*}{ Dispensa Verificação } \\
\hline & & Telha Cerâmica e Laje Mista Plana & & 25,1 & \\
\hline & & Telha Cerâmica e Laje Mista Inclinada & & 24,5 & \\
\hline \multirow{3}{*}{ Teresina } & \multirow{3}{*}{7} & Telha Cerâmica & \multirow{3}{*}{$\mathrm{P} 08 \mathrm{~cm} /$ conc 1600} & 24,9 & \multirow{3}{*}{ Dispensa Verificação } \\
\hline & & Telha Cerâmica e Laje Mista Plana & & 25,1 & \\
\hline & & Telha Cerâmica e Laje Mista Inclinada & & 24,6 & \\
\hline \multirow{3}{*}{ Teresina } & \multirow{3}{*}{7} & Telha Cerâmica & & 25,4 & \\
\hline & & Telha Cerâmica e Laje Mista Plana & P $10 \mathrm{~cm} /$ conco 2400 & 25,5 & Dispensa Verificação \\
\hline & & Telha Cerâmica e Laje Mista Inclinada & & 25,1 & \\
\hline & & Telha Cerâmica & & 25,4 & \\
\hline Teresina & 7 & Telha Cerâmica e Laje Mista Plana & P $10 \mathrm{~cm} /$ conco 2200 & 25,5 & Dispensa Verificação \\
\hline & & Telha Cerâmica e Laje Mista Inclinada & & 25,1 & \\
\hline & & Telha Cerâmica & & 25,3 & \\
\hline Teresina & 7 & Telha Cerâmica e Laje Mista Plana & P $10 \mathrm{~cm} /$ conc 2000 & 25,5 & Dispensa Verificação \\
\hline & & Telha Cerâmica e Laje Mista Inclinada & & 25,1 & \\
\hline & & Telha Cerâmica & & 25,3 & \\
\hline Teresina & 7 & Telha Cerâmica e Laje Mista Plana & P $10 \mathrm{~cm} /$ conc 1800 & 25,5 & Dispensa Verificação \\
\hline & & Telha Cerâmica e Laje Mista Inclinada & & 25,1 & \\
\hline & & Telha Cerâmica & & 25,4 & \\
\hline Teresina & 7 & Telha Cerâmica e Laje Mista Plana & P $10 \mathrm{~cm} /$ conc 1600 & 25,6 & Dispensa Verificação \\
\hline & & Telha Cerâmica e Laje Mista Inclinada & & 25,1 & \\
\hline & & Telha Cerâmica & & 25,9 & \\
\hline Teresina & 7 & Telha Cerâmica e Laje Mista Plana & P $12 \mathrm{~cm} /$ conc 2400 & 25,9 & Dispensa Verificação \\
\hline & & Telha Cerâmica e Laje Mista Inclinada & & 25,6 & \\
\hline & & $\begin{array}{l}\text { Telha Cerâmica } \\
\end{array}$ & & 25,9 & \\
\hline Teresina & 7 & Telha Cerâmica e Laje Mista Plana & P $12 \mathrm{~cm} /$ conc 2200 & 25,9 & Dispensa Verificação \\
\hline & & Telha Cerâmica e Laie Mista Inclinada & & $\frac{20,0}{25,6}$ & \\
\hline & & Telha Cerâmica & & 25,7 & \\
\hline Teresina & 7 & Telha Cerâmica e Laje Mista Plana & P $12 \mathrm{~cm} /$ conc 2000 & 25,9 & Dispensa Verificação \\
\hline & & Telha Cerâmica e Laje Mista Inclinada & & 25,5 & \\
\hline & & Telha Cerâmica & & 25,7 & \\
\hline Teresina & 7 & Telha Cerâmica e Laje Mista Plana & P $12 \mathrm{~cm} /$ conc 1800 & 25,9 & Dispensa Verificação \\
\hline & & Telha Cerâmica e Laje Mista Inclinada & & 25,5 & \\
\hline & & Telha Cerâmica & & 25,8 & \\
\hline Teresina & 7 & Telha Cerâmica e Laje Mista Plana & P $12 \mathrm{~cm} /$ conc 1600 & 26 & Dispensa Verificação \\
\hline & & Telha Cerâmica e Laje Mista Inclinada & & 25,5 & \\
\hline
\end{tabular}




\begin{tabular}{|c|c|c|c|c|c|}
\hline \multicolumn{6}{|c|}{ Simulações para o Inverno - 22 de Junho } \\
\hline Cidade & Zona Bioclimática & Tipos de Cobertura & Vedações & Temp. Mínima Interna & Desempenho \\
\hline \multirow{3}{*}{ Belém } & \multirow{3}{*}{8} & Telha Cerâmica & \multirow{3}{*}{$\mathrm{P} 08 \mathrm{~cm} /$ conc 2400} & 25,5 & \multirow{3}{*}{ Dispensa Verificação } \\
\hline & & Telha Cerâmica e Laje Mista Plana & & 25,6 & \\
\hline & & Telha Cerâmica e Laje Mista Inclinada & & 25,3 & \\
\hline \multirow{3}{*}{ Belém } & \multirow{3}{*}{8} & Telha Cerâmica & \multirow{3}{*}{$\mathrm{P} 08 \mathrm{~cm} /$ conc 2200} & 25,5 & \multirow{3}{*}{ Dispensa Verificação } \\
\hline & & Telha Cerâmica e Laje Mista Plana & & 25,6 & \\
\hline & & Telha Cerâmica e Laje Mista Inclinada & & 25,2 & \\
\hline \multirow{3}{*}{ Belém } & \multirow{3}{*}{8} & Telha Cerâmica & \multirow{3}{*}{ P $08 \mathrm{~cm} /$ conc 2000} & 25,5 & \multirow{3}{*}{ Dispensa Verificação } \\
\hline & & Telha Cerâmica e Laje Mista Plana & & 25,6 & \\
\hline & & Telha Cerâmica e Laje Mista Inclinada & & 25,2 & \\
\hline \multirow{3}{*}{ Belém } & \multirow{3}{*}{8} & Telha Cerâmica & \multirow{3}{*}{$\mathrm{P} 08 \mathrm{~cm} /$ conc 1800} & 25,5 & \multirow{3}{*}{ Dispensa Verificação } \\
\hline & & Telha Cerâmica e Laje Mista Plana & & 25,6 & \\
\hline & & Telha Cerâmica e Laje Mista Inclinada & & 25,2 & \\
\hline \multirow{3}{*}{ Belém } & \multirow{3}{*}{8} & Telha Cerâmica & \multirow{3}{*}{$\mathrm{P} 08 \mathrm{~cm} /$ conc 1600} & 25,5 & \multirow{3}{*}{ Dispensa Verificação } \\
\hline & & Telha Cerâmica e Laje Mista Plana & & 25,6 & \\
\hline & & Telha Cerâmica e Laje Mista Inclinada & & 25,2 & \\
\hline \multirow{3}{*}{ Belém } & \multirow{3}{*}{8} & Telha Cerâmica & & 25,9 & \\
\hline & & Telha Cerâmica e Laje Mista Plana & P $10 \mathrm{~cm} /$ conc 2400 & 26 & Dispensa Verificação \\
\hline & & Telha Cerâmica e Laje Mista Inclinada & & 25,7 & \\
\hline & & Telha Cerâmica & & 25,9 & \\
\hline Belém & 8 & Telha Cerâmica e Laje Mista Plana & P $10 \mathrm{~cm} /$ conc 2200 & 26 & Dispensa Verificação \\
\hline & & Telha Cerâmica e Laje Mista Inclinada & & 25,9 & \\
\hline & & Telha Cerâmica & & 25,9 & \\
\hline Belém & 8 & Telha Cerâmica e Laje Mista Plana & P $10 \mathrm{~cm} /$ conc 2000 & 26 & Dispensa Verificação \\
\hline & & Telha Cerâmica e Laje Mista Inclinada & & 25,6 & \\
\hline & & Telha Cerâmica & & 25,9 & \\
\hline Belém & 8 & Telha Cerâmica e Laje Mista Plana & P $10 \mathrm{~cm} /$ conc 1800 & 26 & Dispensa Verificação \\
\hline & & Telha Cerâmica e Laje Mista Inclinada & & 25,6 & \\
\hline & & Telha Cerâmica & & 25,9 & \\
\hline Belém & 8 & Telha Cerâmica e Laje Mista Plana & P $10 \mathrm{~cm} /$ conc 1600 & 26 & Dispensa Verificação \\
\hline & & Telha Cerâmica e Laje Mista Inclinada & & 25,7 & \\
\hline & & Telha Cerâmica & & 26,3 & \\
\hline Belém & 8 & Telha Cerâmica e Laje Mista Plana & P $12 \mathrm{~cm} /$ conc 2400 & 26,4 & Dispensa Verificação \\
\hline & & Telha Cerâmica e Laje Mista Inclinada & & 26,1 & \\
\hline & & Telha Cerâmica & & 26,3 & \\
\hline Belém & 8 & Telha Cerâmica e Laje Mista Plana & P $12 \mathrm{~cm} /$ conc 2200 & 26,4 & Dispensa Verificação \\
\hline & & Telha Cerâmica e Laje Mista Inclinada & & 26,1 & \\
\hline & & Telha Cerâmica & & 26,2 & \\
\hline Belém & 8 & Telha Cerâmica e Laje Mista Plana & P $12 \mathrm{~cm} /$ conc 2000 & 26,3 & Dispensa Verificação \\
\hline & & Telha Cerâmica e Laje Mista Inclinada & & 26 & \\
\hline & & Telha Cerâmica & & 26,2 & \\
\hline Belém & 8 & Telha Cerâmica e Laje Mista Plana & P $12 \mathrm{~cm} /$ conc 1800 & 26,3 & Dispensa Verificação \\
\hline & & Telha Cerâmica e Laje Mista Inclinada & & 26 & \\
\hline & & Telha Cerâmica & & 26,2 & \\
\hline Belém & 8 & Telha Cerâmica e Laje Mista Plana & $\mathrm{P} 12 \mathrm{~cm} /$ conc 1600 & 26,4 & Dispensa Verificação \\
\hline & & Telha Cerâmica e Laje Mista Inclinada & & 26 & \\
\hline
\end{tabular}




\subsection{Simulações de Referência}

APÊNDICE 3. Tabelas - Resultados das Simulações Multipavimentos

\begin{tabular}{|c|c|c|c|c|c|c|}
\hline \multicolumn{7}{|c|}{ Simulações para o Verão - 22 de Dezembro } \\
\hline Cidade & Zona Bioclimática & Tipo de Cobertura & Vedações & Temp. Máxima Interna & Temp. Máxima Externa & Desempenho \\
\hline \multirow{2}{*}{ Caxias do Sul } & \multirow[t]{2}{*}{ ( } & Cobertura & \multirow{2}{*}{ Bloco Cerâmico } & 26,4 & 26,2 & Não Atende \\
\hline & & Laje Intermediária & & 24,2 & 26,2 & $\mathrm{M} / \mathrm{I}$ \\
\hline \multirow{2}{*}{ Caxias do Sul } & \multirow{2}{*}{1} & Cobertura & \multirow{2}{*}{ Bloco de Concreto } & 27,6 & 26,2 & Não Atende \\
\hline & & Laje Intermediária & & 26 & 26,2 & $\mathrm{M}$ \\
\hline \multirow{2}{*}{ Ponta Grossa } & \multirow{2}{*}{2} & Cobertura & \multirow{2}{*}{ Bloco Cerâmico } & 26,5 & 27,2 & $\mathrm{M}$ \\
\hline & & Laje Intermediária & & 25,3 & 27,2 & $\mathrm{M}$ \\
\hline \multirow{2}{*}{ Ponta Grossa } & \multirow{2}{*}{2} & Cobertura & \multirow{2}{*}{ Bloco de Concreto } & 27,7 & 27,2 & Não Atende \\
\hline & & Laje Intermediária & & 26,4 & 27,2 & $\mathrm{M}$ \\
\hline \multirow{2}{*}{ São Paulo } & \multirow{2}{*}{3} & Cobertura & \multirow{2}{*}{ Bloco Cerâmico } & 25,4 & 25,9 & $\mathrm{M}$ \\
\hline & & Laje Intermediária & & 23,9 & 25,9 & $\mathrm{M} / \mathrm{I}$ \\
\hline \multirow{2}{*}{ São Paulo } & \multirow{2}{*}{3} & Cobertura & \multirow{2}{*}{ Bloco de Concreto } & 26,3 & 25,9 & Não Atende \\
\hline & & Laje Intermediária & & 25,2 & 25,9 & $\mathrm{M}$ \\
\hline \multirow{2}{*}{ Florianópolis } & \multirow{2}{*}{3} & Cobertura & \multirow{2}{*}{ Bloco Cerâmico } & 27,5 & 26,5 & Não Atende \\
\hline & & \begin{tabular}{|l|} 
Laje Intermediária \\
\end{tabular} & & 26,2 & 26,5 & $M$ \\
\hline \multirow{2}{*}{ Florianópolis } & \multirow{2}{*}{3} & \begin{tabular}{|l|} 
Cobertura \\
\end{tabular} & \multirow{2}{*}{ Bloco de Concreto } & 28,2 & 26,5 & Não Atende \\
\hline & & Laje Intermediária & & 27 & 26,5 & Não Atende \\
\hline & 4 & Cobertura & & 26,7 & 26,9 & $M$ \\
\hline sao carios & 4 & \begin{tabular}{|l|} 
Laje Intermediária \\
\end{tabular} & Bloco ceramico & 25,5 & 26,9 & $\mathrm{M}$ \\
\hline & 4 & Cobertura & Bloco de Concreto & 27,6 & 26,9 & Não Atende \\
\hline sao carios & 4 & \begin{tabular}{|l|} 
Laje Intermediária \\
\end{tabular} & Bloco de Concreto & 26,5 & 26,9 & $M$ \\
\hline Brasília & 4 & Cobertura & Bloco Cerâmico & 29,4 & 26,6 & Não Atende \\
\hline Brasind & 4 & \begin{tabular}{|l|} 
Laje Intermediária \\
\end{tabular} & Bloco Ceramico & 26,5 & 26,6 & $M$ \\
\hline Rracília & 4 & Cobertura & Bloco de Concreto & 30,7 & 26,6 & Não Atende \\
\hline Brasind & 4 & Laje Intermediária & & 28,4 & 26,6 & Não Atende \\
\hline Santos & 5 & Cobertura & Bloco Cerâmico & 28 & 27,5 & Não Atende \\
\hline Sántos & 0 & \begin{tabular}{|l|} 
Laje Intermediária \\
\end{tabular} & Dioco Ceramico & 27 & 27,5 & $M$ \\
\hline & & Cobertura & Bloco de Concreto & 28,7 & 27,5 & Não Atende \\
\hline Santos & 5 & Laje Intermediária & Bloco de Concreto & 27,6 & 27,5 & Não Atende \\
\hline Presidente Prudente & 6 & Cobertura & Bloco Cerâmico & 30,4 & 30,2 & Não Atende \\
\hline Presidente Prudente & b & Laje Intermediária & Bloco ceramico & 28,6 & 30,2 & $M$ \\
\hline & & Cobertura & & 31,4 & 30,2 & Não Atende \\
\hline Presidente Prudente & 6 & \begin{tabular}{|l|} 
Laje Intermediária \\
\end{tabular} & Bloco de Concreto & 30,1 & 30,2 & $M$ \\
\hline Teresina & 7 & Cobertura & Bloco Cerâmico & 34,2 & 34,4 & $\mathrm{M}$ \\
\hline Ieresina & $r$ & \begin{tabular}{|l|} 
Laje Intermediária \\
\end{tabular} & Bloco ceramico & 32,3 & 34,4 & $\mathrm{M} / \mathrm{I}$ \\
\hline Teresina & 7 & Cobertura & Bloco de Concreto & 35,4 & 34,4 & Não Atende \\
\hline Ieresina & $r$ & Laje Intermediária & Bloco de Concreto & 34 & 34,4 & $M$ \\
\hline Relém & 8 & Cobertura & Bloco Cerâmico & 31,5 & 31,8 & $\mathrm{M}$ \\
\hline Berem & 8 & \begin{tabular}{|l|} 
Laje Intermediária \\
\end{tabular} & Bioco Ceramico & 30 & 31,8 & $\mathrm{M} / \mathrm{I}$ \\
\hline Belém & 8 & Cobertura & & 32,5 & 31,8 & Não Atende \\
\hline & & \begin{tabular}{|l|l|c|} 
Laje Interméria \\
\end{tabular} & Bloco de Concreto & 31,4 & 31,8 & \\
\hline
\end{tabular}




\begin{tabular}{|c|c|c|c|c|c|}
\hline \multicolumn{6}{|c|}{ Simulações para o Inverno - 22 de Junho } \\
\hline Cidade & Zona Bioclimática & Tipo de Cobertura & Vedações & Temp. Mínima Interna & Desempenho \\
\hline \multirow{2}{*}{ Caxias do Sul } & \multirow{2}{*}{ 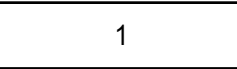 } & Cobertura & \multirow{2}{*}{ Bloco Cerâmico } & 12,4 & $\mathrm{M}$ \\
\hline & & \begin{tabular}{|l} 
Laje Intermediária \\
\end{tabular} & & 11,9 & $M$ \\
\hline \multirow{2}{*}{ Caxias do Sul } & \multirow{2}{*}{1} & Cobertura & \multirow{2}{*}{ Bloco de Concreto } & 10,7 & Não Atende \\
\hline & & \begin{tabular}{|l} 
Laje Intermediária \\
\end{tabular} & & 9,4 & Não Atende \\
\hline \multirow{2}{*}{ Ponta Grossa } & \multirow{2}{*}{2} & Cobertura & \multirow{2}{*}{ Bloco Cerâmico } & 13,7 & $M$ \\
\hline & & Laje Intermediária & & 13,5 & $\mathrm{M}$ \\
\hline \multirow{2}{*}{ Ponta Grossa } & \multirow{2}{*}{2} & Cobertura & \multirow{2}{*}{ Bloco de Concreto } & 11,8 & Não Atende \\
\hline & & Laje Intermediária & & 11,3 & Não Atende \\
\hline \multirow{2}{*}{ São Paulo } & \multirow{2}{*}{3} & Cobertura & \multirow{2}{*}{ Bloco Cerâmico } & 15,6 & $M$ \\
\hline & & Laje Intermediária & & 15,2 & $\mathrm{M}$ \\
\hline \multirow{2}{*}{ São Paulo } & \multirow{2}{*}{3} & Cobertura & \multirow{2}{*}{ Bloco de Concreto } & 13,7 & Não Atende \\
\hline & & Laje Intermediária & & 13,1 & Não Atende \\
\hline \multirow{2}{*}{ Florianópolis } & \multirow{2}{*}{3} & Cobertura & \multirow{2}{*}{ Bloco Cerâmico } & 18 & Não Atende \\
\hline & & Laje Intermediária & & 17,5 & Não Atende \\
\hline \multirow{2}{*}{ Florianópolis } & \multirow{2}{*}{3} & Cobertura & \multirow{2}{*}{ Bloco de Concreto } & 16,7 & Não Atende \\
\hline & & Laje Intermediária & & 16,1 & Não Atende \\
\hline & 4 & \begin{tabular}{|l|} 
Cobertura \\
\end{tabular} & Bloco Cerâmico & 17,7 & $M$ \\
\hline sao carios & 4 & \begin{tabular}{|l} 
Laje Intermediária \\
\end{tabular} & Dioco erialmico & 17,1 & $M$ \\
\hline & & Cobertura & & 15,8 & Não Atende \\
\hline Sao Carlos & 4 & Laje Intermediária & Bloco de Concreto & 15 & Não Atende \\
\hline Brasília & 4 & Cobertura & Bloco Cerâmico & 17,7 & $\mathrm{M} / \mathrm{I}$ \\
\hline Didsilid & & Laje Intermediária & 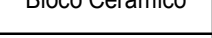 & 16,9 & $\mathrm{M} / \mathrm{I}$ \\
\hline & & Cobertura & & 15,2 & $\mathrm{M}$ \\
\hline Brasilla & 4 & Laje Intermediária & Bloco de Loncrelo & 14 & Não Atende \\
\hline Santos & 5 & Cobertura & Bloco Cerâmico & 19,4 & $M$ \\
\hline Salitus & 3 & \begin{tabular}{|l} 
Laje Intermediária \\
\end{tabular} & Dioco erianitico & 18,9 & Não Atende \\
\hline & 5 & Cobertura & Bloco de Concreto & 17,9 & Não Atende \\
\hline Santos & 5 & Laje Intermediária & Bloco de Concreto & 17,2 & Não Atende \\
\hline Presidente Prudente & 6 & Cobertura & Bloco Cerâmico & 19,4 & \\
\hline 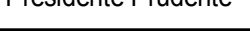 & 0 & \begin{tabular}{|l} 
Laje Intermediária \\
\end{tabular} & tiver & 18,8 & Dispensa Verificacão \\
\hline Presidente Prudente & 6 & Cobertura & Bloco de Concreto & 17,4 & ispelisd vermilaḑada \\
\hline residente prudente & 0 & Laje Intermediária & Bloco de Concreto & 16,7 & \\
\hline Teresina & 7 & \begin{tabular}{|l} 
Cobertura \\
\end{tabular} & Bloco Cerâmico & 26,4 & \\
\hline Elesilia & $r$ & Laje Intermediária & & 25,6 & Dispensa Verificacão \\
\hline Teresina & 7 & Cobertura & Bloco de Concreto & 24,3 & Lisperisd verintiçau \\
\hline 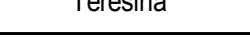 & $t$ & Laje Intermediária & Dioco de Conicreto & 23,4 & \\
\hline Belém & 8 & Cobertura & Bloco Cerâmico & 26,7 & \\
\hline Delem & 0 & Laje Intermediária & Dioco elatrico & 26,1 & Dispensa Verificacão \\
\hline Belém & 8 & Cobertura & Bloco de Concreto & 25,1 & 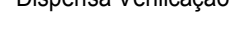 \\
\hline DelenII & 0 & Laje Intermediária & & 24,3 & \\
\hline
\end{tabular}


3.2 Simulações dos Painéis de Concreto

\begin{tabular}{|c|c|c|c|c|c|c|}
\hline \multirow{2}{*}{\multicolumn{7}{|c|}{ Simulações para o Verão - 22 de Dezembro }} \\
\hline & Zona Bioclimática & Tipo de Cobertura & Vedações & Temp. Máxima Interna & Temp. Máxima Externa & Desempenho \\
\hline Caxias do Sul & 1 & Cobertura & $\mathrm{P} 08 \mathrm{~cm} /$ conc 1600 & $\begin{array}{l}28,3 \\
68\end{array}$ & 26,2 & Não Atende \\
\hline Caxias do Sul & 1 & $\begin{array}{l}\text { Laje mermediarla } \\
\text { Cobertura }\end{array}$ & & $\frac{26,8}{27,8}$ & $\frac{26,2}{26,2}$ & $\begin{array}{l}\text { Năo Atende } \\
\text { Não Atende }\end{array}$ \\
\hline & & Laje Intermediária & P $10 \mathrm{~cm} / \operatorname{conc} 1600$ & 26,3 & 26,2 & Não Atende \\
\hline Caxias do Sul & 1 & \begin{tabular}{|l} 
Cobertura \\
Laje Intermediária
\end{tabular} & P $12 \mathrm{~cm} /$ conc 1600 & $\frac{27,4}{25,8}$ & $\frac{26,2}{262}$ & Não Atende \\
\hline Ponta Grossa & 2 & 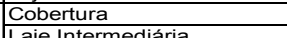 & $\mathrm{P} 08 \mathrm{~cm} / \mathrm{conc} 1600$ & 28,3 & 27,2 & Não Atende \\
\hline Donto $\mathrm{Crg}$ & & $\begin{array}{l}\text { Laje Intermediária } \\
\text { Cobertura }\end{array}$ & & & & $\mathrm{M}$ \\
\hline Ponta Grossa & 2 & \begin{tabular}{|l} 
Cobertura Intermediária \\
\end{tabular} & P $10 \mathrm{~cm} /$ conc 1600 & $\frac{27,8}{26.7}$ & $\frac{27,2}{27,2}$ & $\frac{\text { Não Atende }}{M}$ \\
\hline Ponta Grossa & 2 & \begin{tabular}{|l|} 
Cobertura \\
\end{tabular} & P $12 \mathrm{~cm} /$ conc 1600 & 27,5 & 27,2 & Não Atende \\
\hline São Рaulo & $=$ & \begin{tabular}{|l} 
Laje Intermediaria \\
Cobertura \\
\end{tabular} & 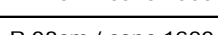 & $\frac{26,2}{26,9}$ & $\frac{27,2}{25,9}$ & $\frac{\mathrm{M}}{\text { Não Atende }}$ \\
\hline Săo Paulo & 3 & Laje Intermediária & P $08 \mathrm{~cm} / \mathrm{conc} 1600$ & 27,6 & 25,9 & Não Atende \\
\hline São Paulo & 3 & \begin{tabular}{|l|} 
Cobertura \\
Laie Intermediária
\end{tabular} & P $10 \mathrm{~cm} /$ conc 1600 & $\frac{26,5}{25 .}$ & 25,9 & Não Atende \\
\hline São Paulo & 3 & Cobertura & P $12 \mathrm{~cm} /$ conc 1600 & 26,2 & 25,9 & Não Atende \\
\hline Florianópolis & 3 & Cobertura & $\mathrm{P} 08 \mathrm{~cm} / \mathrm{conc} 1600$ & 28,6 & 26,5 & Não Atende \\
\hline & & Laje Intermediária & P $08 \mathrm{~cm} / \mathrm{conc}$ Tou & 27,5 & 26,5 & Não Atende \\
\hline Florianópolis & 3 & \begin{tabular}{|l|} 
Cobertura \\
Laje Intermediária
\end{tabular} & P $10 \mathrm{~cm} /$ conc 1600 & $\frac{28,3}{272}$ & $\frac{26,5}{265}$ & Não Atende \\
\hline Florianónolis & 3 & Cobertura & $\mathrm{P} 12 \mathrm{~cm} / \mathrm{conc} 1600$ & 28,1 & 26,5 & Não Atende \\
\hline & & \begin{tabular}{|l} 
Laje Intermediária \\
Sje
\end{tabular} & $\mathrm{P} / \mathrm{T} 2 \mathrm{~cm} / \mathrm{conc} 1600$ & 29,9 & 26,5 & Não Atende \\
\hline Brasília & 4 & \begin{tabular}{|l|} 
Cobertura \\
Laie Intermediária
\end{tabular} & $\mathrm{P} 08 \mathrm{~cm} /$ conc 1600 & $\frac{31,2}{293}$ & 26,6 & Não Atende \\
\hline Brasília & 4 & Cobertura & P $10 \mathrm{~cm} /$ conc 1600 & $\frac{2,5}{30,8}$ & $\frac{26,0}{26,6}$ & Não Atende \\
\hline Brasma & 4 & Laje Intermediária & T $10 \mathrm{~cm} / \mathrm{con}$ c 1000 & 28,7 & 26,6 & Não Atende \\
\hline Brasília & 4 & \begin{tabular}{|l|} 
Cobertura \\
Laje Intermediária
\end{tabular} & P $12 \mathrm{~cm} /$ conc 1600 & $\frac{30,4}{28,2}$ & $\frac{26,6}{26,6}$ & $\begin{array}{l}\text { Não Atende } \\
\text { Não Atende }\end{array}$ \\
\hline São Carlos & 4 & \begin{tabular}{|l|} 
Cobertura \\
Laieltoremíria \\
\end{tabular} & P 08cm / conc 1600 & 28 & 26,9 & Não Atende \\
\hline São Carlos & 4 & Cobertura & P $10 \mathrm{~cm} / \mathrm{conc} 1600$ & 27,7 & 26,9 & $\begin{array}{l}\text { Năo Atende } \\
\text { Năo Atende }\end{array}$ \\
\hline & & \begin{tabular}{|l} 
Laje Intermediária \\
Cobertura
\end{tabular} & & $\frac{26,7}{274}$ & $\frac{26,9}{26,9}$ & $\frac{M}{M}$ \\
\hline São Carlos & 4 & Laje Intermediária & P $12 \mathrm{~cm} /$ conc 1600 & $\frac{2,4}{26,4}$ & $\frac{26,5}{26,9}$ & $\begin{array}{l}\text { Năo Atende } \\
M\end{array}$ \\
\hline Santos & 5 & \begin{tabular}{|l|} 
Cobertura \\
\end{tabular} & $\mathrm{P} 08 \mathrm{~cm} /$ conc 1600 & 29,1 & 27,5 & Não Atende \\
\hline Santos & 5 & Cobertura & P $10 \mathrm{~cm} / \mathrm{conc} 1600$ & 20,1 & 27,5 & Não Atende \\
\hline & & Laje Intermediária & & 278 & 27,5 & Não Atende \\
\hline Santos & 5 & \begin{tabular}{|l|} 
Cobertura \\
\end{tabular} & $\mathrm{P} 12 \mathrm{~cm} /$ conc 1600 & $\frac{28,5}{275}$ & $\frac{27,5}{275}$ & Não Atende \\
\hline Presidente Prudente & 6 & Cobertura & P $08 \mathrm{~cm} /$ conc 1600 & 32 & 30,2 & Não Atende \\
\hline & & Laje Intermediária & & $\frac{30,7}{31,6}$ & & Não Atende \\
\hline Presidente Prudente & 6 & \begin{tabular}{|l} 
Laje Intermediária \\
\end{tabular} & P $10 \mathrm{~cm} /$ conc 1600 & $\frac{31,6}{30,3}$ & $\frac{30,2}{30,2}$ & $\begin{array}{l}\text { Nao Atende } \\
\text { NãoAtende }\end{array}$ \\
\hline Presidente Prudente & 6 & Cobertura & P $12 \mathrm{~cm} /$ conc 1600 & 31,3 & 30,2 & Não Atende \\
\hline & & Laje Intermediária & & 29,9 & 30,2 & $M$ \\
\hline Teresina & 7 & \begin{tabular}{|l} 
Cobertura \\
Laje Intermiária
\end{tabular} & P $08 \mathrm{~cm} /$ conc 1600 & $\begin{array}{r}36 \\
348 \\
\end{array}$ & $\frac{34,4}{34,4}$ & $\begin{array}{l}\text { NAo Atende } \\
\text { Não Atende }\end{array}$ \\
\hline Teresina & 7 & Cobertura & P $10 \mathrm{~cm} /$ conc 1600 & 35,5 & 34,4 & Não Atende \\
\hline Teresing & 7 & \begin{tabular}{|l} 
Laje Intermediária \\
Cobertura
\end{tabular} & 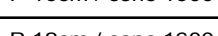 & $\begin{array}{l}34,3 \\
352\end{array}$ & $\frac{34,4}{34,4}$ & $\begin{array}{l}\text { M } \\
\text { Não Atende }\end{array}$ \\
\hline Teresina & 7 & Laje Intermediária & P $12 \mathrm{~cm} /$ conc 1600 & 33,8 & 34,4 & $M$ \\
\hline Belém & 8 & \begin{tabular}{|l|} 
Cobertura \\
ajie Itermiári
\end{tabular} & $\mathrm{P} 08 \mathrm{~cm} /$ conc 1600 & 33 & 31,8 & Não Atende \\
\hline Belém & 8 & Cobertura & P $10 \mathrm{~cm} /$ conc 1600 & 32,6 & 31,8 & Não Atende \\
\hline Belém & 8 & $\begin{array}{l}\text { Cobertura } \\
\end{array}$ & P $12 \mathrm{~cm} /$ conc 1600 & $\begin{array}{l}3,, 1 \\
32,3 \\
\end{array}$ & $\begin{array}{l}31,0 \\
31,8 \\
\end{array}$ & $\begin{array}{l}\mathrm{M} \\
\text { Năo Atende }\end{array}$ \\
\hline Belém & & & & $\frac{31,3}{31,3}, 0,0$ & 31,8 & M \\
\hline
\end{tabular}




\begin{tabular}{|c|c|c|c|c|c|c|}
\hline \multicolumn{7}{|c|}{ Simulações para o Verão - 22 de Dezembro } \\
\hline Cidade & Zona Bioclimática & Tipo de Cobertura & Vedações & Temp. Máxima Interna & Temp. Máxima Externa & Desempenho \\
\hline Caxias do Sul & 1 & \begin{tabular}{|l|l} 
Cobertura \\
\end{tabular} & $\mathrm{P} 08 \mathrm{~cm} / \mathrm{conc} 1800$ & $\frac{28,2}{26,7}$ & 26,2 & Não Atende \\
\hline & & $\begin{array}{l}\text { Laje Intermediária } \\
\text { Cobertura }\end{array}$ & & $\frac{26,7}{27,7}$ & $\frac{26,2}{266}$ & $\begin{array}{l}\text { Năo Atende } \\
\text { Năo Atende }\end{array}$ \\
\hline Caxias do Sul & 1 & Laje Intermediária & $\mathrm{P} 10 \mathrm{~cm} / \mathrm{conc} 1800$ & $\frac{2,1}{26,3}$ & $\frac{20,2}{26,2}$ & Não Atende \\
\hline Caxias do Sul & 1 & $\begin{array}{ll}\text { Cobertura } \\
\text { Laiellntermediária }\end{array}$ & $\mathrm{P} 12 \mathrm{~cm} / \mathrm{conc} 1800$ & $\frac{27,3}{258}$ & $\frac{26,2}{26,2}$ & Não Atende \\
\hline Ponta Grossa & 2 & Cobertura & $\mathrm{P} 08 \mathrm{~cm} /$ conc 1800 & 28,2 & 27,2 & Não Atende \\
\hline & & Laje Intermediária & & 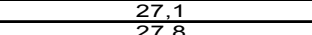 & 27,2 & $\mathrm{M}$ \\
\hline Ponta Grossa & 2 & $\begin{array}{l}\text { Cobertura } \\
\text { Laje Intermediária } \\
\end{array}$ & P $10 \mathrm{~cm} /$ conc 1800 & $\frac{27,8}{26,7}$ & $\frac{27,2}{27,2}$ & $\begin{array}{l}\text { Não Atende } \\
M\end{array}$ \\
\hline Ponta Grossa & 2 & \begin{tabular}{|l|} 
Cobertura \\
Laj Intermediária \\
\end{tabular} & $\mathrm{P} 12 \mathrm{~cm} /$ conc 1800 & $\frac{27,4}{26,2}$ & $\frac{27,2}{272}$ & Não Atende \\
\hline São Paulo & 3 & \begin{tabular}{|l|} 
Cobertura \\
\end{tabular} & $\mathrm{P} 08 \mathrm{~cm} /$ conc 1800 & $\frac{26,8}{25,8}$ & $\frac{25,2}{25,9}$ & Não Atende \\
\hline São Paulo & 3 & Cobertura & P $10 \mathrm{~cm} /$ conc 1800 & 26,4 & $\frac{25,5}{25,9}$ & Não Atende \\
\hline vaver aure & & Laje Intermediária & & 25,4 & 25,9 & $\mathrm{M}$ \\
\hline São Paulo & 3 & $\begin{array}{l}\text { Cobertura } \\
\text { Laje Intermediária }\end{array}$ & $\mathrm{P} 12 \mathrm{~cm} /$ conc 1800 & $\frac{26,1}{25,1}$ & $\begin{array}{l}25,9 \\
25,9\end{array}$ & $\frac{\text { Năo Atende }}{M}$ \\
\hline Florianópolis & 3 & 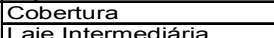 & P $08 \mathrm{~cm} /$ conc 1800 & $\frac{28,5}{275}$ & $\frac{26,5}{265}$ & $\begin{array}{l}\text { Não Atende } \\
\text { Não Atende. }\end{array}$ \\
\hline Florianópolis & 3 & 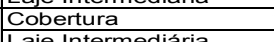 & P $10 \mathrm{~cm} /$ conc 1800 & 28,3 & 26,5 & Näo Atende \\
\hline Florianópolis & 3 & Cobertura & $\mathrm{P} 12 \mathrm{~cm} / \mathrm{conc} 1800$ & 28 & $\frac{26,5}{26,5}$ & Não Atende \\
\hline Fiorianopoils & 3 & Laje Intermediária & P. $12 \mathrm{~cm} /$ conc 1800 & 26,8 & 26,5 & Não Atende \\
\hline Brasília & 4 & \begin{tabular}{|l|} 
Cobertura \\
Laje Intermediária
\end{tabular} & P $08 \mathrm{~cm} /$ conc 1800 & $\frac{31,1}{29,2}$ & $\frac{26,6}{26,6}$ & $\frac{\text { Não Atende }}{\text { Não Atende }}$ \\
\hline Brasília & 4 & \begin{tabular}{|l|} 
Cobertura \\
Laielnterméíria \\
\end{tabular} & P $10 \mathrm{~cm} /$ conc 1800 & $\frac{30,7}{287}$ & $\frac{26,6}{26,6}$ & Não Atende \\
\hline Brasilia & 4 & Cobertura & P $12 \mathrm{~cm} /$ conc 1800 & 30,3 & 26,6 & Não Atende \\
\hline & & Laje Intermediária & & $\frac{28,2}{29}$ & 26,6 & Não Atende \\
\hline São Carlos & 4 & $\begin{array}{l}\text { Cobertura } \\
\text { Laje Intermediária }\end{array}$ & $\mathrm{P} 08 \mathrm{~cm} /$ conc 1800 & $\frac{28}{27}$ & $\frac{26,9}{26,9}$ & $\begin{array}{l}\text { Năo Atende } \\
\text { Năo Atende }\end{array}$ \\
\hline São Carlos & 4 & \begin{tabular}{|l} 
Cobertura \\
Laje Intermediária
\end{tabular} & P $10 \mathrm{~cm} /$ conc 1800 & $\frac{27,6}{26,7}$ & $\begin{array}{l}26,9 \\
26,9\end{array}$ & $\begin{array}{l}\text { Não Atende } \\
M\end{array}$ \\
\hline São Carlos & 4 & 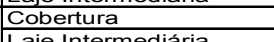 & P $12 \mathrm{~cm} /$ conc 1800 & $\frac{27,4}{2764}$ & $\frac{26,9}{26,9}$ & Não Atende \\
\hline Santos & 5 & Cobertura & $\mathrm{P} 08 \mathrm{~cm} /$ conc 1800 & $\frac{20,4}{29}$ & 27,5 & Não Atende \\
\hline Santos & & Laje Intermediária & Poom t conc 1000 & 28 & 27,5 & Não Atende \\
\hline Santos & 5 & \begin{tabular}{|l|} 
Cobertura \\
Laje Intermediária
\end{tabular} & P $10 \mathrm{~cm} /$ conc 1800 & $\frac{28,7}{27,1}$ & $\frac{27,5}{27,5}$ & Não Atende \\
\hline Santos & 5 & Cobertura & P $12 \mathrm{~cm} /$ conc 1800 & 28,5 & 27,5 & Não Atende \\
\hline Santos & 5 & Laje Intermediária & $\mathrm{P} / 12 \mathrm{~cm} / \mathrm{conc} 1800$ & 27,5 & 27,5 & $M$ \\
\hline Presidente Prudente & 6 & \begin{tabular}{|l|} 
Cobertura \\
Laje Intermediária
\end{tabular} & $\mathrm{P} 08 \mathrm{~cm} /$ conc 1800 & $\begin{array}{l}\frac{31,9}{30,7} \\
\end{array}$ & $\frac{30,2}{30,2}$ & $\begin{array}{l}\text { Não Atende } \\
\text { Não Atende }\end{array}$ \\
\hline Presidente Prudente & 6 & \begin{tabular}{|l|} 
Cobertura \\
Laiellnterméária
\end{tabular} & P $10 \mathrm{~cm} /$ conc 1800 & $\frac{31,5}{303}$ & $\frac{30,2}{30}$ & Não Atende \\
\hline Presidente Prudente & 6 & Cobertura & $\mathrm{P} 12 \mathrm{~cm} /$ conc 1800 & 31,2 & 30,2 & $\begin{array}{l}\text { Nao Atende } \\
\text { Não Atende }\end{array}$ \\
\hline & & Laje Intermediária & & $\frac{29,9}{36}$ & $\frac{30,2}{344}$ & $\frac{M}{M}$ \\
\hline Teresina & 7 & $\begin{array}{l}\text { Cobertura } \\
\text { Laje Intermediária }\end{array}$ & P $08 \mathrm{~cm} /$ conc 1800 & $\begin{array}{l}36 \\
34,8 \\
\end{array}$ & $\frac{34,4}{34,4}$ & $\begin{array}{l}\text { NAo Atende } \\
\text { Não Atende }\end{array}$ \\
\hline Teresina & 7 & \begin{tabular}{|l} 
Cobertura \\
Laje Intermediária
\end{tabular} & P $10 \mathrm{~cm} /$ conc 1800 & $\begin{array}{l}35,5 \\
34,3 \\
\end{array}$ & $\begin{array}{l}34,4 \\
34,4\end{array}$ & $\begin{array}{l}\text { Não Atende } \\
M\end{array}$ \\
\hline Teresina & 7 & Cobertura & P $12 \mathrm{~cm} /$ conc 1800 & 35,1 & 34,4 & Não Atende \\
\hline Belém & 8 & Cobertura & $P 08 \mathrm{~cm} /$ conc 1800 & 33 & $\begin{array}{l}34,4 \\
31,8\end{array}$ & Atende \\
\hline Belem & 8 & Laje Intermediária & - & 30,7 & 31 & M \\
\hline Belém & 8 & $\begin{array}{l}\text { Cobertura } \\
\text { Laje Intermediária }\end{array}$ & P $10 \mathrm{~cm} /$ conc 1800 & $\begin{array}{l}32,6 \\
31,6\end{array}$ & $\begin{array}{l}31,8 \\
31,8\end{array}$ & $\frac{\text { Năo Atende }}{M}$ \\
\hline Belém & 8 & Cobertura & P $12 \mathrm{~cm} /$ conc 1800 & 32,3 & 31,8 & Não Atende \\
\hline
\end{tabular}




\begin{tabular}{|c|c|c|c|c|c|c|}
\hline \multicolumn{7}{|c|}{ Simulações para o Verão - 22 de Dezembro } \\
\hline Cidade & Zona Bioclimática & Tipo de Cobertura & Vedações & Temp. Máxima Interna & Temp. Máxima Externa & Desempenho \\
\hline Caxias do Sul & 1 & \begin{tabular}{|l} 
Cobertura \\
Laie Intermediária
\end{tabular} & $\mathrm{P} 08 \mathrm{~cm} /$ conc 2000 & $\begin{array}{c}28,1 \\
267 \\
\end{array}$ & $\frac{26,2}{262}$ & $\begin{array}{ll}\text { Não Atende } \\
\text { Năo Atende } \\
\end{array}$ \\
\hline & 1 & Cobertura & P $10 \mathrm{~cm} / \mathrm{conc} 2000$ & $\frac{20,1}{27,6}$ & $\frac{26,2}{26,2}$ & Não Atende \\
\hline Caxias do Sul & 1 & Laje Intermediária & P $10 \mathrm{~cm} / \mathrm{conc} 2000$ & $\frac{21,0}{26,2}$ & $\frac{26,2}{26,2}$ & $\mathrm{M}$ \\
\hline Caxias do Sul & 1 & \begin{tabular}{|l|l|l} 
Cobertura \\
Laie Intermediária \\
\end{tabular} & P $12 \mathrm{~cm} /$ conc 2000 & $\frac{28,1}{26,9}$ & $\frac{26,2}{26,2}$ & $\begin{array}{l}\text { Não Atende } \\
\text { Năo Atende }\end{array}$ \\
\hline Ponta Grossa & 2 & Cobertura & P $08 \mathrm{~cm} /$ conc 2000 & 28,2 & $\frac{27,2}{27,2}$ & Não Atende \\
\hline Ponta Groses & 2 & $\begin{array}{l}\text { Laje Intermediária } \\
\text { Cobertura }\end{array}$ & & $\frac{27,1}{27,7}$ & $\frac{27,2}{27,2}$ & $\begin{array}{l}\mathrm{M} \\
\text { Não Atende }\end{array}$ \\
\hline Ponta Grossa & 2 & Laje Intermediária & P $10 \mathrm{~cm} /$ conc 2000 & 26,6 & 27,2 & $\mathrm{M}$ \\
\hline Ponta Grossa & 2 & \begin{tabular}{|l|} 
Cobertura \\
Laje Intermediária
\end{tabular} & P $12 \mathrm{~cm} /$ conc 2000 & $\frac{28,2}{27,1}$ & $\frac{27,2}{27,2}$ & $\frac{\text { Não Atende }}{M}$ \\
\hline São Paulo & 3 & \begin{tabular}{|l} 
Cobertura \\
Laje Intermediária
\end{tabular} & $\mathrm{P} 08 \mathrm{~cm} / \mathrm{conc} 2000$ & $\frac{26,7}{26,7}$ & $\frac{25,9}{259}$ & $\begin{array}{c}\text { Não Atende } \\
M\end{array}$ \\
\hline São Paulo & 3 & Cobertura & P $10 \mathrm{~cm} /$ conc 2000 & $\frac{25,8}{26,3}$ & 25,9 & Não Atende \\
\hline & & \begin{tabular}{|l} 
Laje Intermediária \\
Cobertura
\end{tabular} & D & $\frac{25,4}{267}$ & $\begin{array}{l}25,9 \\
25,9\end{array}$ & $\begin{array}{c}M \\
\end{array}$ \\
\hline São Paulo & 3 & $\begin{array}{l}\text { Lojertura } \\
\text { Laje Intermediária }\end{array}$ & P $12 \mathrm{~cm} /$ conc 2000 & $\frac{25, r}{25,8}$ & $\begin{array}{l}25,9 \\
25,9\end{array}$ & $\frac{\text { Naoo Atende }}{\mathrm{M}}$ \\
\hline Florianópolis & 3 & \begin{tabular}{|l|} 
Cobertura \\
Laje Intermediária
\end{tabular} & P $08 \mathrm{~cm} /$ conc 2000 & $\frac{28,5}{27,3}$ & $\begin{array}{l}26,5 \\
26,5\end{array}$ & $\begin{array}{l}\text { Não Atende } \\
\text { Não Atende }\end{array}$ \\
\hline Florianópolis & 3 & \begin{tabular}{|l|} 
Cobertura \\
Laie Intermediária
\end{tabular} & P $10 \mathrm{~cm} / \mathrm{conc} 2000$ & $\frac{27,6}{27,6}$ & $\frac{26,5}{26,5}$ & $\begin{array}{l}\text { Não Atende } \\
\text { NãAtede }\end{array}$ \\
\hline Florianópolis & 3 & Cobertura & P $12 \mathrm{~cm} /$ conc 2000 & 28,5 & 26,5 & Não Atende \\
\hline & & Laje Intermediária & & $\frac{27,3}{31}$ & $\frac{26,5}{266}$ & Não Atende \\
\hline Brasília & 4 & \begin{tabular}{|l|l|} 
Cajerertura Intermediária \\
Laje
\end{tabular} & P 08cm / conc 2000 & $\frac{31}{29,2}$ & $\frac{26,6}{26,6}$ & $\begin{array}{l}\text { Nao Atende } \\
\text { Não Atende }\end{array}$ \\
\hline Brasília & 4 & \begin{tabular}{|l|} 
Cobertura \\
Laje Intermediária
\end{tabular} & P $10 \mathrm{~cm} / \mathrm{conc} 2000$ & $\frac{30,6}{28,6}$ & $\frac{26,6}{26,6}$ & $\begin{array}{l}\text { Não Atende } \\
\text { Năo Atende }\end{array}$ \\
\hline Brasilia & 4 & \begin{tabular}{|l|} 
Cobertura \\
\end{tabular} & P $12 \mathrm{~cm} /$ conc 2000 & 31 & 26,6 & Não Atende \\
\hline & & \begin{tabular}{|l} 
Laje Intermediária \\
Cobertura
\end{tabular} & & $\frac{29,2}{279}$ & $\frac{26,6}{26,9}$ & Não Atende \\
\hline São Carlos & 4 & \begin{tabular}{|l|} 
Cobertura \\
Laje Intermediária
\end{tabular} & P 08cm / conc 2000 & $\frac{27,9}{27}$ & $\frac{26,9}{26,9}$ & $\frac{\text { Nao Atende }}{\text { Não Atende }}$ \\
\hline São Carlos & 4 & Cobertura & P $10 \mathrm{~cm} / \mathrm{conc} 2000$ & 27,6 & 26,9 & Não Atende \\
\hline São Carlos & 4 & Cobertura & P $12 \mathrm{~cm} /$ conc 2000 & 27,9 & 26,9 & Não Atende \\
\hline & 4 & Laje Intermediária & & 27 & 26,9 & Não Atende \\
\hline Santos & 5 & \begin{tabular}{|l|} 
Cobertura \\
Laje Intermediária
\end{tabular} & P $08 \mathrm{~cm} /$ conc 2000 & $\frac{29}{28}$ & $\frac{27,5}{27,5}$ & $\begin{array}{l}\text { Não Atende } \\
\text { Não Atende }\end{array}$ \\
\hline Santos & 5 & \begin{tabular}{|l|} 
Cobertura \\
Laie Intermediária
\end{tabular} & P $10 \mathrm{~cm} / \mathrm{conc} 2000$ & 28,7 & 27,5 & Não Atende \\
\hline Santos & 5 & Cobertura & P $12 \mathrm{~cm} / \mathrm{conc} 2000$ & 29 & 27,5 & Não Atende \\
\hline & & Laje Intermediária & & $\frac{28}{318}$ & $\begin{array}{l}27,5 \\
302\end{array}$ & Não Atende \\
\hline Presidente Prudente & 6 & \begin{tabular}{|l} 
Cobertura \\
Laje Intermediária
\end{tabular} & P 08cm / conc 2000 & $\frac{31,8}{30,6}$ & $\frac{30,2}{302}$ & $\begin{array}{l}\text { Năo Atende } \\
\text { Não Atende }\end{array}$ \\
\hline Presidente Prudente & 6 & Cobertura & P $10 \mathrm{~cm} / \mathrm{conc} 2000$ & 31,4 & 30,2 & Não Atende \\
\hline & & Laje Intermediária & & & $\frac{30,2}{302}$ & Não Atende \\
\hline Presidente Prudente & 6 & \begin{tabular}{|l} 
Cobertura \\
Laje Intermediária
\end{tabular} & P $12 \mathrm{~cm} /$ conc 2000 & $\frac{31,8}{30,6}$ & $\frac{3,2}{30,2}$ & $\begin{array}{l}\text { Nao Atende } \\
\text { Não Atende }\end{array}$ \\
\hline Teresina & 7 & \begin{tabular}{|l|} 
Cobertura \\
Lie Intermíria
\end{tabular} & $\mathrm{P} 08 \mathrm{~cm} / \mathrm{conc} 2000$ & $\frac{35,9}{347}$ & $\frac{34,4}{34,}$ & Não Atende \\
\hline Teresina & 7 & Cobertura & P $10 \mathrm{~cm} /$ conc 2000 & 24,1 & $\frac{34,4}{34,4}$ & $\begin{array}{c}\text { Nao Atende } \\
\text { M/l/S }\end{array}$ \\
\hline & & Cobertura & & $\frac{23,3}{35,9}$ & $\frac{34,4}{34,4}$ & $\begin{array}{l}\mathrm{M} / / \mathrm{S} \\
\text { Năo Atende }\end{array}$ \\
\hline Teresina & 7 & Laje Intermediária & P $12 \mathrm{~cm} /$ conc 2000 & 34,7 & 34,4 & Não Atende \\
\hline Belém & 8 & \begin{tabular}{|l} 
Cobertura \\
\end{tabular} & $\mathrm{P} 08 \mathrm{~cm} /$ conc 2000 & 32,9 & 31,8 & Não Atende \\
\hline Rolóm & 8 & ertura & P $10 \mathrm{~cm} / \mathrm{cons} 200$ & 24,8 & $\begin{array}{l}3,0 \\
31,8\end{array}$ & M/I/S \\
\hline Belem & 8 & Laje Intermediária & $\mathrm{P} 10 \mathrm{~cm} / \mathrm{conc} 2000$ & 24,2 & 31,8 & $\mathrm{M} / \mathrm{I} / \mathrm{S}$ \\
\hline Belém & 8 & \begin{tabular}{|l|} 
Cobertura \\
Laje Intermediária
\end{tabular} & P $12 \mathrm{~cm} /$ conc 2000 & $\frac{32,9}{32}$ & $\begin{array}{l}31,8 \\
331,8\end{array}$ & $\begin{array}{l}\text { Năo Atende } \\
\text { Não Atende }\end{array}$ \\
\hline
\end{tabular}




\begin{tabular}{|c|c|c|c|c|c|c|}
\hline \multicolumn{7}{|c|}{ Simulações para o Verão - 22 de Dezembro } \\
\hline Cidade & Zona Bioclimática & Tipo de Cobertura & Vedações & Temp. Máxima Interna & Temp. Máxima Externa & Desempenho \\
\hline Caxias do Sul & 1 & Cobertura & $\mathrm{P} 08 \mathrm{~cm} /$ conc 2200 & $\begin{array}{c}28 \\
266 \\
\end{array}$ & $\frac{26,2}{262}$ & $\begin{array}{l}\text { Não Atende } \\
\text { Năo Atende } \\
\end{array}$ \\
\hline Caxias do Sul & 1 & Cobertura & & $\frac{26,0}{27,5}$ & $\frac{26,2}{26,2}$ & Năo Atende \\
\hline Carias de cut & 1 & \begin{tabular}{|l} 
Laje Intermediaria \\
Cobertura
\end{tabular} & P $70 \mathrm{~cm} /$ conc 2200 & $\frac{26,1}{27}$ & $\frac{26,2}{26,2}$ & $\begin{array}{l}\mathrm{M} \\
\text { Não Atende }\end{array}$ \\
\hline Caxias do Sul & 1 & Laje Intermediária & $\mathrm{P} 12 \mathrm{~cm} /$ conc 2200 & 25,6 & 26,2 & $\mathrm{M}$ \\
\hline Ponta Grossa & 2 & $\begin{array}{l}\text { Cobertura } \\
\text { Laje Intermediária } \\
\end{array}$ & $\mathrm{P} 08 \mathrm{~cm} / \mathrm{conc} 2200$ & $\frac{28,1}{27}$ & $\frac{27,2}{27,2}$ & $\begin{array}{c}\text { Não Atende } \\
\mathrm{M}\end{array}$ \\
\hline Ponta Grossa & 2 & Cobertura & P $10 \mathrm{~cm} /$ conc 2200 & $\frac{27,1}{265}$ & $\frac{27,2}{272}$ & $\mathrm{M}$ \\
\hline Ponta Grossa & 2 & Cobertura & P $12 \mathrm{~cm} / \operatorname{conc} 2200$ & 27,4 & 27,2 & Não Atende \\
\hline & & $\begin{array}{l}\text { Laje Intermediária } \\
\text { Cobertura }\end{array}$ & & $\frac{26}{267}$ & $\frac{27,2}{25,9}$ & $\frac{\mathrm{M}}{\mathrm{M}}$ \\
\hline São Paulo & 3 & \begin{tabular}{|l|} 
Lajere Intermediária \\
\end{tabular} & P $08 \mathrm{~cm} /$ conc 2200 & $\frac{26,1}{25,8}$ & $\frac{25,9}{25,9}$ & $\frac{\text { Nào Atende }}{M}$ \\
\hline São Paulo & 3 & \begin{tabular}{|l} 
Cobbertura \\
Laie Intermediária
\end{tabular} & P $10 \mathrm{~cm} / \mathrm{conc} 2200$ & 26,3 & 25,9 & Não Atende \\
\hline São Paulo & 3 & Cobertura & P $12 \mathrm{~cm} / \mathrm{conc} 230$ & $\frac{25,3}{25,9}$ & $\frac{25,9}{25,9}$ & $\mathrm{M}$ \\
\hline Sad ridu & & Laje Intermediária & 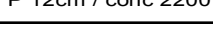 & 24,9 & 25,9 & $\mathrm{M}$ \\
\hline Florianópolis & 3 & \begin{tabular}{|l} 
Cobertura \\
Laje Intermediária \\
\end{tabular} & P 08cm / conc 2200 & $\frac{28,4}{27,4}$ & $\frac{26,5}{26,5}$ & $\begin{array}{l}\text { Não Atende } \\
\text { Não Atende }\end{array}$ \\
\hline Florianópolis & 3 & \begin{tabular}{|l|} 
Cobertura \\
Laie Intermediária
\end{tabular} & P $10 \mathrm{~cm} /$ conc 2200 & 28,1 & $\frac{26,5}{265}$ & Não Atende \\
\hline Florianónolis & 3 & Cobertura & P $12 \mathrm{~cm} / \mathrm{com} 230$ & 27,8 & $\frac{2,5}{26,5}$ & Não Atende \\
\hline & & Laje Intermediária & $\mathrm{P} 12 \mathrm{~cm} / \mathrm{conc} 2200$ & 26,6 & $\frac{26,5}{26,}>0$ & Não Atende \\
\hline Brasília & 4 & Cobertura & $\mathrm{P} 08 \mathrm{~cm} / \mathrm{conc} 2200$ & $\frac{30,9}{201}$ & 26,6 & Não Atende \\
\hline Brasilia & 4 & Cobertura & P $10 \mathrm{~cm} /$ conc 2200 & 30,4 & 26,6 & Não Atende \\
\hline & & Laje Intermediária & & $\frac{28,5}{298}$ & $\frac{26,6}{26,6}$ & Não Atende \\
\hline Brasília & 4 & \begin{tabular}{|l} 
Cobertura \\
Laje Intermediária
\end{tabular} & P $12 \mathrm{~cm} /$ conc 2200 & $\frac{29,8}{27,7}$ & $\frac{26,6}{26,6}$ & $\frac{\text { Nao Atende }}{\text { Não Atende }}$ \\
\hline São Carlos & 4 & \begin{tabular}{|l|} 
Cobertura \\
Laie Intermediária
\end{tabular} & P $08 \mathrm{~cm} /$ conc 2200 & $\frac{27,9}{269}$ & $\frac{26,9}{269}$ & $\frac{\text { Não Atende }}{M}$ \\
\hline São Carlos & 4 & $\begin{array}{l}\text { Cobertura } \\
\end{array}$ & P $10 \mathrm{~cm} /$ conc 2200 & $\frac{23,5}{27,5}$ & 26,9 & Não Atende \\
\hline Sก̃ก Carlos & 4 & \begin{tabular}{|l} 
Laje Intermediaria \\
Cobertura
\end{tabular} & $2120 m$ & 20,0 & 20,9 & Não Atende \\
\hline Sao Carios & 4 & Laje Intermediária & P $12 \mathrm{~cm} /$ conc 2200 & 26,2 & 26,9 & $\mathrm{M}$ \\
\hline Santos & 5 & \begin{tabular}{|l|} 
Cobertura \\
Laie Intermediária
\end{tabular} & $\mathrm{P} 08 \mathrm{~cm} / \mathrm{conc} 2200$ & 28,9 & 27,5 & Não Atende \\
\hline Santos & 5 & Cobertura & P $10 \mathrm{~cm}$ & 28,6 & 27,5 & $\begin{array}{l}\text { Nao Atende } \\
\text { Não Atende }\end{array}$ \\
\hline Santos & כ & Laje Intermediária & $510 \mathrm{~cm} / \mathrm{cone} 2200$ & & 27,5 & Não Atende \\
\hline Santos & 5 & \begin{tabular}{|l} 
Cobertura \\
Laje Inteŕáia
\end{tabular} & P $12 \mathrm{~cm} /$ conc 2200 & $\frac{28,3}{27,3}$ & $\begin{array}{r}27,5 \\
27,5 \\
-1\end{array}$ & Não Atende \\
\hline Presidente Prudente & 6 & Cobertura & $\mathrm{P} 08 \mathrm{~cm} / \mathrm{conc} 2200$ & 31,8 & 30,2 & Não Atende \\
\hline Presidente Prudente & 6 & & P $10 \mathrm{~cm} /$ conc 2200 & 31,3 & 30,2 & $\begin{array}{l}\text { Nao Atende } \\
\text { Não Atende }\end{array}$ \\
\hline & & & & $\frac{30,2}{30,9}$ & $\frac{30,2}{30 ?}$ & $\frac{M}{M}$ \\
\hline Presidente Prudente & 6 & \begin{tabular}{|l} 
Cobertura \\
Laje Interméria \\
\end{tabular} & P $12 \mathrm{~cm} /$ conc 2200 & $\frac{30,9}{29,6}$ & $\frac{30,2}{30,2}$ & \\
\hline Teresina & 7 & \begin{tabular}{|l|} 
Cobertura \\
\end{tabular} & $\mathrm{P} 08 \mathrm{~cm} /$ conc 2200 & $\frac{35,8}{34,6}$ & $\frac{34,4}{34,4}$ & NÄo Atende \\
\hline Teresina & 7 & Cobertura & P $10 \mathrm{~cm} /$ conc 2200 & $\begin{array}{l}35,3 \\
35,3\end{array}$ & $\begin{array}{ll}34,4 \\
34,4\end{array}$ & Não Atende \\
\hline Teresina & 7 & \begin{tabular}{|l} 
Cobertura \\
\end{tabular} & P $12 \mathrm{~cm} / \mathrm{con} 2200$ & 34,8 & 34,4 & $\frac{M}{\text { Não Atende }}$ \\
\hline Teresma & $r$ & Laje Intermediária & 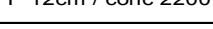 & 33,5 & 34,4 & $\mathrm{M}$ \\
\hline Belém & 8 & \begin{tabular}{|l} 
Cobertura \\
Laje Intermediária \\
\end{tabular} & P 08cm / conc 2200 & $\begin{array}{l}32,9 \\
31,9\end{array}$ & $\begin{array}{ll}31,8 \\
31,8\end{array}$ & $\begin{array}{l}\text { Não Atende } \\
\text { Não Atende }\end{array}$ \\
\hline Belém & 8 & \begin{tabular}{|l|} 
Cobertura \\
\end{tabular} & P $10 \mathrm{~cm} / \mathrm{conc} 2200$ & 32,4 & 31,8 & Não Atende \\
\hline Belém & 8 & Cobertura & P $12 \mathrm{~cm} /$ conc 2200 & 32 & 31,8 & Não Atende \\
\hline & & Laje Intermediária & 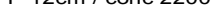 & 31 & 31,8 & $\mathrm{M}$ \\
\hline
\end{tabular}




\begin{tabular}{|c|c|c|c|c|c|c|}
\hline \multicolumn{7}{|c|}{ Simulações para o Verão - 22 de Dezembro } \\
\hline Cidade & Zona Bioclimática & Tipo de Cobertura & Vedações & Temp. Máxima Interna & Temp. Máxima Externa & Desempenho \\
\hline Caxias do Sul & 1 & Cobertura & $\mathrm{P} 08 \mathrm{~cm} / \mathrm{conc} 2400$ & $\begin{array}{c}27,9 \\
266 \\
\end{array}$ & $\frac{26,2}{26,2}$ & $\begin{array}{ll}\text { Não Atende } \\
\text { Năo Atende }\end{array}$ \\
\hline Caxias do Sul & 1 & 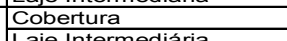 & P $10 \mathrm{~cm} /$ conc 2400 & $\frac{27,4}{27,4}$ & $\frac{26,2}{26,2}$ & Não Atende \\
\hline Caxias de sut & 1 & \begin{tabular}{|l|l|l|l|l|l} 
Laje Intermediária \\
Cobertura
\end{tabular} & & $\frac{26}{26,9}$ & $\frac{26,2}{26,2}$ & Não Atende \\
\hline Caxias do Sul & 1 & Laje Intermediária & P $12 \mathrm{~cm} /$ conc 2400 & 25,5 & $\frac{26,2}{26,2}$ & $\mathrm{M}$ \\
\hline Ponta Grossa & 2 & \begin{tabular}{|l|} 
Cobertura \\
Laje Intermediária
\end{tabular} & $\mathrm{P} 08 \mathrm{~cm} / \mathrm{conc} 2400$ & $\begin{array}{l}28 \\
27\end{array}$ & $\frac{27,2}{27,2}$ & $\frac{\text { Não Atende }}{M}$ \\
\hline Ponta Grossa & 2 & \begin{tabular}{|l} 
Cobertura \\
Laie Intermediária \\
\end{tabular} & P $10 \mathrm{~cm} /$ conc 2400 & $\frac{27,5}{264}$ & $\frac{27,2}{272}$ & Não Atende \\
\hline & & Cobertura & & $\frac{20,4}{27}$ & $\frac{27,2}{27,2}$ & $\mathrm{M}$ \\
\hline Ponta Grossa & 2 & Laje Intermediária & P $12 \mathrm{~cm} /$ conc 2400 & 25,9 & 27,2 & $M$ \\
\hline São Paulo & 3 & \begin{tabular}{|l|} 
Cobertura \\
Lajie Intermediária \\
\end{tabular} & P $08 \mathrm{~cm} /$ conc 2400 & $\frac{27,9}{259}$ & $\frac{25,9}{259}$ & Não Atende \\
\hline São Paulo & 3 & Cobertura & P $10 \mathrm{~cm} /$ conc 2400 & 26,2 & $\frac{25,9}{25,9}$ & Não Atende \\
\hline São Paulo & 3 & Cobertura & $\mathrm{P} 12 \mathrm{~cm} / \mathrm{conc} 2400$ & $\frac{25,3}{25,8}$ & $\begin{array}{l}25,9 \\
25,9\end{array}$ & $M$ \\
\hline Sao Paulo & & Laje Intermediária & $\mathrm{P} 72 \mathrm{~cm} / \mathrm{conc} 2400$ & 24,8 & 25,9 & $\mathrm{M}$ \\
\hline Florianópolis & 3 & \begin{tabular}{|l|} 
Caberertura \\
Laje Intermediária \\
\end{tabular} & P $08 \mathrm{~cm} /$ conc 2400 & $\frac{28,4}{27,4}$ & $\frac{26,5}{26,5}$ & $\frac{\text { Não Atende }}{\text { Não Atende }}$ \\
\hline Florianópolis & 3 & \begin{tabular}{|l|} 
Cobertura \\
Laie Intermediária
\end{tabular} & P $10 \mathrm{~cm} /$ conc 2400 & $\frac{28,1}{27}$ & 26,5 & Não Atende \\
\hline Florianópolis & 3 & Cobertura & P $12 \mathrm{~cm} /$ conc 2400 & 27,7 & 26,5 & Não Atende \\
\hline & & $\begin{array}{l}\text { Laje Intermediária } \\
\text { Cobertura }\end{array}$ & & $\frac{26,6}{30,8}$ & $\frac{26,5}{26,6}$ & Não Atende \\
\hline Brasília & 4 & Laje Intermediária & $\mathrm{P} 08 \mathrm{~cm} /$ conc 2400 & $\frac{30,0}{30}$ & $\frac{26,6}{26,6}$ & $\begin{array}{l}\text { Naoo Atende } \\
\text { Não Atende }\end{array}$ \\
\hline Brasília & 4 & \begin{tabular}{|l} 
Cobertura \\
Laje Intermediária
\end{tabular} & P $10 \mathrm{~cm} / \mathrm{conc} 2400$ & $\frac{30,3}{28.4}$ & $\frac{26,6}{26,6}$ & $\begin{array}{l}\text { Não Atende } \\
\text { Não Atende }\end{array}$ \\
\hline Brasília & 4 & Cobertura & P $12 \mathrm{~cm} /$ conc 2400 & 29,6 & 26,6 & Não Atende \\
\hline Drastira & & Laje Intermediária & $\mathrm{P} 12 \mathrm{~cm} / \mathrm{conc} 2400$ & 27,6 & 26,6 & Não Atende \\
\hline São Carlos & 4 & \begin{tabular}{|l|} 
Cobertura \\
Laje Intermediária
\end{tabular} & P $08 \mathrm{~cm} /$ conc 2400 & $\frac{27,8}{269}$ & $\frac{26,9}{269}$ & Não Atende \\
\hline São Carlos & 4 & Cobertura & P $10 \mathrm{~cm} /$ conc 2400 & 27,4 & $\frac{26,9}{26,9}$ & Não Atende \\
\hline São Carlos & 4 & Cobertura & P $12 \mathrm{~cm} /$ conc 2400 & 27,1 & 26,9 & $\begin{array}{l}\text { Năo Atende } \\
\text { Năo Atende }\end{array}$ \\
\hline Sao Carios & 4 & Laje Intermediária & 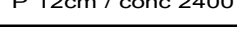 & 26,1 & 26,9 & $\mathrm{M}$ \\
\hline Santos & 5 & \begin{tabular}{|l|} 
Cobertura \\
Laje Intermediária
\end{tabular} & P $08 \mathrm{~cm} /$ conc 2400 & $\frac{28,3}{27,9}$ & $\frac{27,5}{27,5}$ & $\frac{\text { Não Atende }}{\text { Não Atende }}$ \\
\hline Santos & 5 & \begin{tabular}{|l|} 
Cobertura \\
Laie Intermediária
\end{tabular} & P $10 \mathrm{~cm} / \mathrm{conc} 2400$ & 28,5 & 27,5 & Não Atende \\
\hline Santos & 5 & Cobertura & P $12 \mathrm{~cm} /$ conc 2400 & 28,2 & 27,5 & Não Atende \\
\hline & & & & $\frac{27,2}{317}$ & $\frac{2,5}{30,2}$ & Mão Atende \\
\hline Presidente Prudente & 6 & \begin{tabular}{|l} 
Cobertura \\
Laje Intermediária
\end{tabular} & $\mathrm{P} 08 \mathrm{~cm} / \mathrm{conc} 2400$ & $\frac{3,1}{30,5}$ & $\frac{30,2}{30,2}$ & $\begin{array}{l}\text { Nao Atende } \\
\text { Não Atende }\end{array}$ \\
\hline Presidente Prudente & 6 & Cobertura & P $10 \mathrm{~cm} /$ conc 2400 & 31,7 & 30,2 & Não Atende \\
\hline & & $\begin{array}{l}\text { Laje Intermediaria } \\
\text { Cobertura }\end{array}$ & R190m & $\frac{30,1}{30,8}$ & $\frac{30,2}{30,2}$ & $\begin{array}{c}\mathrm{M} \\
\text { Não Atende }\end{array}$ \\
\hline Presidente Prudente & 6 & Laje Intermediária & $12 \mathrm{~cm} /$ conc 2400 & 29,6 & 30,2 & $\mathrm{M}$ \\
\hline Teresina & 7 & Cobertura & $\mathrm{P} 08 \mathrm{~cm} / \mathrm{conc} 2400$ & $\frac{35,7}{346}$ & $\frac{34,4}{34,}$ & $\begin{array}{l}\text { Não Atende } \\
\text { Nãatendo }\end{array}$ \\
\hline Teresina & 7 & Cobertura & P $10 \mathrm{~cm} / \mathrm{conc} 2400$ & 35,2 & $\begin{array}{ll}34,4 \\
34,4\end{array}$ & Não Atende \\
\hline Teresina & 7 & Cobertura & $\mathrm{P} 12 \mathrm{~cm} / \mathrm{conc} 2400$ & 34,7 & 34,4 & Não Atende \\
\hline 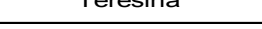 & $r$ & Laje Intermediária & 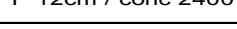 & 33,5 & 34,4 & $M$ \\
\hline Belém & 8 & \begin{tabular}{|l} 
Cobertura \\
Laje Intermediária
\end{tabular} & $\mathrm{P} 08 \mathrm{~cm} /$ conc 2400 & $\begin{array}{l}32,8 \\
31,9\end{array}$ & $\begin{array}{l}31,8 \\
31,8\end{array}$ & $\frac{\text { Não Atende }}{\text { Não Atende }}$ \\
\hline Belém & 8 & \begin{tabular}{|l} 
Cobertura \\
\end{tabular} & P $10 \mathrm{~cm} / \mathrm{conc} 2400$ & 32,3 & 31,8 & Não Atende \\
\hline Belém & 8 & Cobertura & P $12 \mathrm{~cm} /$ conc 2400 & 31,9 & 31,8 & Não Atende \\
\hline Berem & 8 & Laje Intermediária & $\mathrm{F} / 2 \mathrm{~cm} / \mathrm{conc} 2400$ & & 31,8 & $\mathrm{M}$ \\
\hline
\end{tabular}




\begin{tabular}{|c|c|c|c|c|c|}
\hline \multicolumn{6}{|c|}{ Simulações para o Inverno - 22 de Junho } \\
\hline Cidade & Zona Bioclimática & Tipo de Cobertura & Vedações & Temp. Mínima Interna & Desempenho \\
\hline \multirow{2}{*}{ Caxias do Sul } & \multirow[t]{2}{*}{ 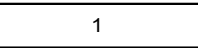 } & \multirow{2}{*}{\begin{tabular}{|l|} 
Cobertura \\
Laje intermediária \\
\end{tabular}} & \multirow{2}{*}{$\mathrm{P} 08 \mathrm{~cm} /$ conc 1600} & 9,8 & Não Atende \\
\hline & & & & 8,5 & Não Atende \\
\hline \multirow{2}{*}{ Caxias do Sul } & \multirow{2}{*}{1} & Cobertura & \multirow{2}{*}{ P $10 \mathrm{~cm} /$ conc 1600} & 10,4 & Não Atende \\
\hline & & Laje intermediária & & 9,2 & Não Atende \\
\hline \multirow{2}{*}{ Caxias do Sul } & \multirow{2}{*}{1} & Cobertura & \multirow{2}{*}{ P $12 \mathrm{~cm} /$ conc 1600} & 10,9 & Não Atende \\
\hline & & Laje intermediária & & 9,8 & Não Atende \\
\hline \multirow{2}{*}{ Ponta Grossa } & \multirow{2}{*}{2} & Cobertura & \multirow{2}{*}{ P $08 \mathrm{~cm} /$ conc 1600} & 10,8 & Não Atende \\
\hline & & Laje intermediária & & 9,5 & Não Atende \\
\hline \multirow{2}{*}{ Ponta Grossa } & \multirow{2}{*}{2} & Cobertura & & 11,5 & Não Atende \\
\hline & & Laje intermediária & 5 Tucm / conc 1600 & 10,2 & Não Atende \\
\hline & 2 & Cobertura & P $12 \mathrm{~cm} /$ conc 1600 & 12,1 & Não Atende \\
\hline Ponta Grossa & 2 & Laje intermediária & $\mathrm{P} 72 \mathrm{~cm} / \mathrm{conc} 1600$ & 11 & Não Atende \\
\hline SãoPaulo & 3 & Cobertura & P $08 \mathrm{~cm} /$ conc 1600 & 12,8 & Não Atende \\
\hline Sao Paulo & 3 & Laje intermediária & 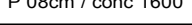 & 12,1 & Não Atende \\
\hline & & Cobertura & & 13,4 & Não Atende \\
\hline São Paulo & 3 & Laje intermediária & P $10 \mathrm{~cm} /$ conc 1600 & 12,8 & Não Atende \\
\hline & 3 & Cobertura & P $12 \mathrm{~cm} /$ conc 1600 & 13,8 & Não Atende \\
\hline Sao Paulo & 3 & Laje intermediária & P $12 \mathrm{~cm} / \mathrm{conc}$ Touo & 13,4 & Não Atende \\
\hline & & Cobertura & & 16,1 & Não Atende \\
\hline Florlanopolis & 3 & Laje intermediária & P $08 \mathrm{~cm} /$ conc 1600 & 15,5 & Não Atende \\
\hline & 3 & Cobertura & P $10 \mathrm{~cm} / \mathrm{conc} 1600$ & 16,5 & Não Atende \\
\hline Fiorlanopolis & 3 & Laje intermediária & $P$ T $10 \mathrm{~cm} / \mathrm{conc} 1600$ & 16 & Não Atende \\
\hline Florianópolis & 3 & Cobertura & P $12 \mathrm{~cm} /$ conc 1600 & 16,8 & Não Atende \\
\hline Fiorlanopoils & & Laje intermediária & P $12 \mathrm{~cm} / \mathrm{conc} 1000$ & 16,3 & Não Atende \\
\hline & & Cobertura & $\mathrm{P} 08 \mathrm{~cm} /$ conc 1600 & 14 & Não Atende \\
\hline Brasilia & 4 & Laje intermediária & P $08 \mathrm{~cm} /$ conc 1600 & 12,7 & Não Atende \\
\hline Brasília & 4 & Cobertura & P $10 \mathrm{~cm} /$ conc 1600 & 14,8 & $\mathrm{M}$ \\
\hline Brasina & 4 & Laje intermediária & $P$ Tocm / conc 1000 & 13,6 & Não Atende \\
\hline & 4 & Cobertura & P $12 \mathrm{~cm} /$ conc 1600 & 15,5 & $\mathrm{M}$ \\
\hline Brasilia & 4 & Laje intermediária & $\mathrm{P} / \mathrm{T2 \textrm {cm }} / \mathrm{conc} 1600$ & 14,4 & Não Atende \\
\hline & & Cobertura & & 14,9 & Não Atende \\
\hline Sao Carlos & 4 & Laje intermediária & P $08 \mathrm{~cm} /$ conc 7600 & 14,1 & Não Atende \\
\hline & 4 & Cobertura & P $10 \mathrm{~cm} /$ conc 1600 & 15,5 & Não Atende \\
\hline Sao Carlos & 4 & Laje intermediária & P $10 \mathrm{~cm} / \mathrm{conc} 1600$ & 14,7 & Não Atende \\
\hline & & Cobertura & & 16 & Não Atende \\
\hline São Carlos & 4 & Laje intermediária & P 12cm / conc 1600 & 15,3 & Não Atende \\
\hline & & Cobertura & & 17,2 & Não Atende \\
\hline Santos & 5 & Laje intermediária & $\mathrm{P} 08 \mathrm{~cm} /$ conc 1600 & 16,5 & Não Atende \\
\hline Santos & 5 & Cobertura & P $10 \mathrm{~cm} / \mathrm{conc} 1600$ & 17,6 & Não Atende \\
\hline Santos & 5 & Laje intermediária & P $10 \mathrm{~cm} /$ conc 1600 & 17 & Não Atende \\
\hline & 5 & Cobertura & P $12 \mathrm{~cm} /$ conc 1600 & 18 & Não Atende \\
\hline Santos & 5 & Laje intermediária & P 12cm / conc 1600 & 17,5 & Não Atende \\
\hline & & Cobertura & & 16,5 & \\
\hline Presidente Prudente & 6 & Laje intermediária & P 08cm / conc 1600 & 15,6 & \\
\hline Presidente Prudente & 6 & $\begin{array}{l}\text { Cobertura } \\
\end{array}$ & $\mathrm{P} 10 \mathrm{~cm} /$ conc 1600 & 17,1 & Dispensa Verificação \\
\hline Presidente Prudente & 6 & Laje intermediária & 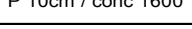 & 16,3 & Uispensa verticaçac \\
\hline Presidente Prudente & 6 & Cobertura & P $12 \mathrm{~cm} /$ conc 1600 & 17,6 & \\
\hline Presıdente Prudente & 6 & Laje intermediária & $\mathrm{P}$ 12cm / conc 1600 & 16,9 & \\
\hline & & Cobertura & & 23,4 & \\
\hline Teresina & 7 & Laje intermediária & P 08cm / conc 1800 & 22,3 & \\
\hline Teresina & 7 & Cobertura & P $10 \mathrm{~cm} / \mathrm{conc} 1800$ & 24 & Dispensa Verificacão \\
\hline Teresina & $t$ & Laje intermediária & $\mathrm{P} 10 \mathrm{~cm} / \mathrm{conc} 1800$ & 23 & Dispensa Verificaçăo \\
\hline & 7 & Cobertura & P $12 \mathrm{~cm} /$ conc 1600 & 24,5 & \\
\hline Teresina & $r$ & Laje intermediária & $5 / 2 \mathrm{~cm} / \mathrm{cone}+1000$ & 23,7 & \\
\hline & & \begin{tabular}{|l} 
Cobertura \\
\end{tabular} & & 24,2 & \\
\hline Belém & 8 & Laje intermediária & P 08cm / conc 1800 & 23,4 & \\
\hline Belém & 8 & Cobertura & P $10 \mathrm{~cm} / \mathrm{conc} 1600$ & 24,7 & Dispensa Verificacão \\
\hline Berem & 8 & \begin{tabular}{|l} 
Laje intermediária \\
\end{tabular} & $P T 0 \mathrm{~cm} / \mathrm{conc} 1600$ & 24 & Uispensa verticaçac \\
\hline Belém & 8 & \begin{tabular}{|l|} 
Cobertura \\
Laje intermediária
\end{tabular} & P $12 \mathrm{~cm} /$ conc 1600 & $\begin{array}{l}25,1 \\
245\end{array}$ & \\
\hline
\end{tabular}




\begin{tabular}{|c|c|c|c|c|c|}
\hline \multicolumn{6}{|c|}{ Simulações para o Inverno - 22 de Junho } \\
\hline Cidade & Zona Bioclimática & Tipo de Cobertura & \begin{tabular}{|l|} 
Vedações \\
\end{tabular} & Temp. Mínima Interna & Desempenho \\
\hline \multirow{2}{*}{ Caxias do Sul } & \multirow[t]{2}{*}{ - } & Cobertura & \multirow{2}{*}{$\mathrm{P} 08 \mathrm{~cm} /$ conc 1800} & 9,9 & Não Atende \\
\hline & & Laje intermediária & & 8,7 & Não Atende \\
\hline \multirow{2}{*}{ Caxias do Sul } & \multirow{2}{*}{1} & Cobertura & \multirow{2}{*}{$\mathrm{P} 10 \mathrm{~cm} /$ conc 1800} & 10,5 & Não Atende \\
\hline & & Laje intermediária & & 9,4 & Não Atende \\
\hline \multirow{2}{*}{ Caxias do Sul } & \multirow{2}{*}{1} & Cobertura & \multirow{2}{*}{$\mathrm{P} 12 \mathrm{~cm} /$ conc 1800} & 11 & Não Atende \\
\hline & & Laje intermediária & & 10 & Não Atende \\
\hline \multirow{2}{*}{ Ponta Grossa } & \multirow{2}{*}{2} & Cobertura & \multirow{2}{*}{$\mathrm{P} 08 \mathrm{~cm} /$ conc 1800} & 10,9 & Não Atende \\
\hline & & Laje intermediária & & 9,6 & Não Atende \\
\hline \multirow{2}{*}{ Ponta Grossa } & \multirow{2}{*}{2} & Cobertura & P $10 \mathrm{~cm} / \mathrm{sonc} 1800$ & 11,5 & Não Atende \\
\hline & & Laje intermediária & $5 / 10 \mathrm{~cm} / \mathrm{cone} 1800$ & 10,4 & Não Atende \\
\hline & & Cobertura & P $12 \mathrm{~cm} / \mathrm{conc} 1800$ & 12,1 & Não Atende \\
\hline Ponta Grossa & 2 & Laje intermediária & $\mathrm{P} 72 \mathrm{~cm} / \mathrm{conc} 1800$ & 11,1 & Não Atende \\
\hline São Paulo & 3 & Cobertura & $\mathrm{P} 08 \mathrm{~cm} /$ conc 1800 & 12,9 & Não Atende \\
\hline Sá rauto & & Laje intermediária & P $00 \mathrm{~cm} / \mathrm{CONC} / 800$ & 12,5 & Não Atende \\
\hline São Pauln & 3 & Cobertura & P $10 \mathrm{~cm} / \mathrm{cons} 1800$ & 13,4 & Não Atende \\
\hline Sá rauto & 3 & Laje intermediária & 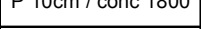 & 12,9 & Não Atende \\
\hline & 3 & Cobertura & P $12 \mathrm{~cm} / \mathrm{conc} 1800$ & 13,9 & Não Atende \\
\hline sao raulo & 3 & Laje intermediária & $5 / 2 \mathrm{~cm} / \mathrm{cone} 1800$ & 13,5 & Não Atende \\
\hline Elorianónolis & 3 & Cobertura & & 16,2 & Não Atende \\
\hline Florianopolis & 3 & \begin{tabular}{|l|} 
Laje intermediária \\
\end{tabular} & P 08cm / conc 1800 & 15,6 & Não Atende \\
\hline & 3 & Cobertura & P $10 \mathrm{~cm} / \mathrm{cons} 1800$ & 16,5 & Não Atende \\
\hline Florlanopolis & 3 & \begin{tabular}{|l|} 
Laje intermediária \\
\end{tabular} & $P 70 \mathrm{~cm} / \mathrm{conc} 1800$ & 16 & Não Atende \\
\hline & & Cobertura & & 16,9 & Não Atende \\
\hline Florianópolis & 3 & Laje intermediária & P $12 \mathrm{~cm} /$ conc 1800 & 16,4 & Não Atende \\
\hline Rracilia & 4 & Cobertura & & 14,1 & Não Atende \\
\hline Brasilla & 4 & Laje intermediária & P 08cm / conc 1800 & 12,9 & Não Atende \\
\hline & 4 & Cobertura & P $10 \mathrm{~cm} /$ conc 1800 & 14,8 & $\mathrm{M}$ \\
\hline Brasilla & 4 & \begin{tabular}{|l|} 
Laje intermediária \\
\end{tabular} & $5 / 10 \mathrm{~cm} / \mathrm{cone} 1800$ & 13,8 & Não Atende \\
\hline Rracilia & 4 & Cobertura & P $12 \mathrm{~cm} / \mathrm{conc} 1800$ & 15,5 & $M$ \\
\hline Drastind & 4 & Laje intermediária & 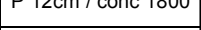 & 14,5 & Não Atende \\
\hline & 4 & Cobertura & P $08 \mathrm{~cm} / \mathrm{conc} 1800$ & 15 & Não Atende \\
\hline Sao Carlos & 4 & \begin{tabular}{|l|} 
Laje intermediária \\
\end{tabular} & P 08cm / conc 1800 & 14,2 & Não Atende \\
\hline São Carlos & 4 & \begin{tabular}{|l|} 
Cobertura \\
\end{tabular} & P $10 \mathrm{~cm} / \operatorname{conc} 1800$ & 15,5 & Não Atende \\
\hline sao Carios & & Laje intermediária & $5 / 10 \mathrm{~cm} / \mathrm{cone} 1800$ & 14,8 & Não Atende \\
\hline & & Cobertura & & 16 & Não Atende \\
\hline São Carlos & 4 & \begin{tabular}{|l|} 
Laje intermediária \\
\end{tabular} & $\mathrm{P} 12 \mathrm{~cm} / \mathrm{conc} 1800$ & 15,4 & Não Atende \\
\hline Santos & 5 & Cobertura & P $08 \mathrm{~cm} / \mathrm{conc} 1800$ & 17,2 & Não Atende \\
\hline Santos & 5 & Laje intermediária & P $08 \mathrm{~cm} / \mathrm{conc} 1800$ & 16,5 & Não Atende \\
\hline Santoc & 5 & Cobertura & P $10 \mathrm{~cm} / \mathrm{cons} 1800$ & 17,7 & Não Atende \\
\hline Sallutus & 5 & Laje intermediária & P $10 \mathrm{~cm} /$ conc 1800 & 14,8 & Não Atende \\
\hline & 5 & Cobertura & & 18,1 & Não Atende \\
\hline Santos & 5 & Laje intermediária & $\mathrm{P} 12 \mathrm{~cm} / \mathrm{conc} 1800$ & 17,6 & Não Atende \\
\hline Presidente Prudente & 6 & Cobertura & P $08 \mathrm{~cm} / \mathrm{conc} 1800$ & 16,6 & \\
\hline Presidente Prudente & 6 & Laje intermediária & P $08 \mathrm{~cm} /$ conc 1800 & 15,7 & \\
\hline Presidente Prudente & 6 & Cobertura & $\mathrm{P} 10 \mathrm{~cm} / \operatorname{conc} 1800$ & 17,1 & Disnensa Verificacão \\
\hline & & Laje intermediária & $P 70 \mathrm{~cm} / \mathrm{conc} 1800$ & 16,4 & Dispensa verritcaçao \\
\hline Presidente Prudente & 6 & Cobertura & P $12 \mathrm{~cm} / \operatorname{conc} 1800$ & 17,7 & \\
\hline Presıdente Prudente & 6 & Laje intermediária & $\mathrm{P} 72 \mathrm{~cm} / \mathrm{conc} 1800$ & 17 & \\
\hline Teresina & 7 & \begin{tabular}{|l|} 
Cobertura \\
\end{tabular} & P $08 \mathrm{~cm} /$ conc 1800 & 23,4 & \\
\hline Ieresina & $r$ & Laje intermediária & & 22,4 & \\
\hline Terecing & 7 & Cobertura & P $10 \mathrm{~cm} / \mathrm{conc} 1800$ & 24 & \\
\hline leresina & 7 & Laje intermediária & $\mathrm{P} 10 \mathrm{~cm} / \mathrm{conc} 1800$ & 23,1 & Dispensa Verificaçäo \\
\hline Teresina & 7 & Cobertura & P $12 \mathrm{~cm} / \mathrm{conc} 1800$ & 24,6 & \\
\hline Ieresina & $r$ & Laje intermediária & $5 / 2 \mathrm{~cm} / \mathrm{cone} 1800$ & 23,8 & \\
\hline Belém & 8 & Cobertura & P $08 \mathrm{~cm} /$ conc 1800 & 24,2 & \\
\hline Belem & 8 & Laje intermediária & P U8cm / conc 1800 & 23,5 & \\
\hline Belém & 8 & Cobertura & P $10 \mathrm{~cm} / \mathrm{conc} 1800$ & 24,7 & Disnensa Verificacão \\
\hline Delem & & Laje intermediária & P Tucint conciouo & 24,1 & Dispensa verimiedça \\
\hline Belém & 8 & Cobertura & P $12 \mathrm{~cm} / \operatorname{conc} 1800$ & 25,2 & \\
\hline Belem & 8 & Laje intermediária & $5 / 2 \mathrm{~cm} / \mathrm{cone} 1800$ & 24,6 & \\
\hline
\end{tabular}




\begin{tabular}{|c|c|c|c|c|c|}
\hline \multicolumn{6}{|c|}{ Simulações para o Inverno - 22 de Junho } \\
\hline Cidade & Zona Bioclimática & Tipo de Cobertura & Vedações & Temp. Mínima Interna & Nível de Desempenho \\
\hline \multirow{2}{*}{ Caxias do Sul } & \multirow{2}{*}{ 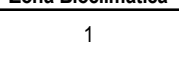 } & Cobertura & \multirow{2}{*}{ conc.2000/p8 } & 10 & Não Atende \\
\hline & & Laje intermediária & & 8,9 & Não Atende \\
\hline \multirow{2}{*}{ Caxias do Sul } & \multirow{2}{*}{1} & Cobertura & \multirow{2}{*}{ conc.2000/p10 } & 10,6 & Não Atende \\
\hline & & Laje intermediária & & 9,5 & Não Atende \\
\hline \multirow{2}{*}{ Caxias do Sul } & \multirow{2}{*}{1} & Cobertura & \multirow{2}{*}{ conc.2000/p12 } & 11 & Não Atende \\
\hline & & Laje intermediária & & 10,1 & Não Atende \\
\hline \multirow{2}{*}{ Ponta Grossa } & \multirow{2}{*}{2} & Cobertura & \multirow{2}{*}{ conc.2000/p8 } & 11 & Não Atende \\
\hline & & Laje intermediária & & 9,8 & Não Atende \\
\hline \multirow{2}{*}{ Ponta Grossa } & \multirow{2}{*}{2} & Cobertura & \multirow{2}{*}{ conc.2000/p10 } & 11,6 & Não Atende \\
\hline & & Laje intermediária & & 10,6 & Não Atende \\
\hline & & Cobertura & 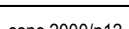 & 12,2 & $M$ \\
\hline Ponta Grossa & 2 & \begin{tabular}{|l|} 
Laje intermediária \\
\end{tabular} & conc.2000/p12 & 11,8 & Não Atende \\
\hline & & Cobertura & & 13 & $M$ \\
\hline São Paulo & 3 & Laje intermediária & conc.2000/p8 & 12,3 & M \\
\hline S̃̃̊ Poul & 3 & Cobertura & song $2000 / n 10$ & 13,5 & M \\
\hline Sao Paulo & 3 & Laje intermediária & conc.2000/pio & 13 & M \\
\hline c̃̃n Doul & 3 & Cobertura & 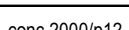 & 14 & M \\
\hline Sao Paulo & 3 & Laje intermediária & conc.2000/p12 & 13,6 & M \\
\hline & & Cobertura & & 12,2 & $\mathrm{M}$ \\
\hline Florianópolis & 3 & \begin{tabular}{|l|} 
Laje intermediária \\
\end{tabular} & conc.2000/p8 & 15,7 & $\mathrm{M} / \mathrm{I}$ \\
\hline Eloriań́ndlic & 3 & Cobertura & song $2000 / n 10$ & 16,6 & $\mathrm{M} / \mathrm{l}$ \\
\hline Florianópolis & 3 & \begin{tabular}{|l|} 
Laje intermediária \\
\end{tabular} & conc. $2000 / p 10$ & 16,1 & $\mathrm{M} / \mathrm{l}$ \\
\hline & & Cobertura & cong $2000 / 412$ & 16,9 & $\mathrm{M} / \mathrm{I}$ \\
\hline Florianópolis & 3 & \begin{tabular}{|l|} 
Laje intermediária \\
\end{tabular} & conc.2000/p12 & 16,5 & $\mathrm{M} / \mathrm{I}$ \\
\hline Rracilia & 4 & Cobertura & & 14,2 & $\mathrm{M}$ \\
\hline Brasilla & 4 & \begin{tabular}{|l} 
Laje intermediária \\
\end{tabular} & conc.2000/p8 & 13 & $\mathrm{M}$ \\
\hline & & Cobertura & conc $2000 / n 10$ & 14,9 & $\mathrm{M}$ \\
\hline Brasilia & 4 & \begin{tabular}{|l} 
Laje intermediária \\
\end{tabular} & conc.2000/p10 & 13,9 & $M$ \\
\hline Rrocilip & 4 & Cobertura & 200902012 & 15,6 & $\mathrm{M} / \mathrm{I}$ \\
\hline Brasilla & 4 & Laje intermediária & conc.2000/p12 & 14,7 & $M$ \\
\hline & & Cobertura & & 15,1 & $\mathrm{M} / \mathrm{I}$ \\
\hline São Carlos & 4 & \begin{tabular}{|l} 
Laje intermediária \\
\end{tabular} & conc.2000/p8 & 14,3 & $\mathrm{M}$ \\
\hline & 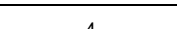 & Cobertura & (1) $2000 / n 10$ & 15,7 & $\mathrm{M} / \mathrm{I}$ \\
\hline São Carlos & 4 & \begin{tabular}{|l|} 
Laje intermediária \\
\end{tabular} & conc.2000/p10 & 15 & $\mathrm{M} / \mathrm{l}$ \\
\hline SãnCarlos & 4 & \begin{tabular}{|l|} 
Cobertura \\
\end{tabular} & (conc $2000 / \ln ^{2} 2$ & 16,1 & $\mathrm{M} / \mathrm{I}$ \\
\hline Sao Carlos & 4 & \begin{tabular}{|l|} 
Laje intermediária \\
\end{tabular} & conc.2000/p12 & 15,5 & $\mathrm{M} / \mathrm{I}$ \\
\hline Contor 10 & 5 & Cobertura & 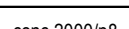 & 17,3 & $\mathrm{M} / / \mathrm{S}$ \\
\hline Santos & 5 & \begin{tabular}{|l} 
Laje intermediária \\
\end{tabular} & conc.2000/p8 & 16,6 & $\mathrm{M} / \mathrm{I}$ \\
\hline Santos & 5 & Cobertura & conc $2000 / n 10$ & 17,7 & $\mathrm{M} / / \mathrm{S}$ \\
\hline Santos & 5 & \begin{tabular}{|l} 
Laje intermediária \\
\end{tabular} & conc.2000/p10 & 17,2 & $\mathrm{M} / / \mathrm{S}$ \\
\hline Contos & 5 & Cobertura & $20002000 / 412$ & 18,1 & $\mathrm{M} / / \mathrm{S}$ \\
\hline Santos & 5 & \begin{tabular}{|l} 
Laje intermediária \\
\end{tabular} & conc.2000/p12 & 17,6 & $\mathrm{M} / / \mathrm{S}$ \\
\hline Precidente Prudent & 6 & Cobertura & 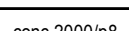 & 16,7 & \\
\hline Presidente Prudente & 6 & \begin{tabular}{|l|} 
Laje intermediária \\
\end{tabular} & conc.2000/p8 & 15,9 & \\
\hline Presidente Prudente & & Cobertura & & 17,2 & Disnensa Verificacão \\
\hline Presidente Prudente & 6 & \begin{tabular}{|l} 
Laje intermediária \\
\end{tabular} & conc.2000/p10 & 16,6 & Dispensa Verficaçaoo \\
\hline Procidonte Prudont & 6 & Cobertura & $2000 / n 12$ & & \\
\hline Presidente Prudente & 6 & \begin{tabular}{|l} 
Laje intermediária \\
\end{tabular} & conc.2000/p12 & 17,1 & \\
\hline & 7 & \begin{tabular}{|l|} 
Cobertura \\
\end{tabular} & 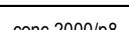 & 23,5 & \\
\hline Teresina & 7 & \begin{tabular}{|l|} 
Laje intermediária \\
\end{tabular} & conc.2000/p8 & 22,5 & \\
\hline Torecing & 7 & Cobertura & (non $2000 / n 10$ & 24,1 & Disnonç Vorifiçõ̃ \\
\hline Teresina & 7 & \begin{tabular}{|l|} 
Laje intermediária \\
\end{tabular} & conc.2000/pio & 23,3 & Dispensa Verficaçao \\
\hline Terecing & 7 & \begin{tabular}{|l|} 
Cobertura \\
\end{tabular} & $2000 / n 12$ & & \\
\hline Teresina & 7 & Laje intermediária & conc.2000/p12 & 23,3 & \\
\hline Rolóm & 8 & Cobertura & (onp $2000 / 28$ & 24,3 & \\
\hline Belém & 8 & Laje intermediária & conc.2000/p8 & 23,6 & \\
\hline & & Cobertura & conc $2000 / p 10$ & 24,8 & Dispensa Verificacão \\
\hline Belém & 8 & \begin{tabular}{|l} 
Laje intermediária \\
\end{tabular} & conc.2000/p10 & 24,2 & Dispensa Veriticação \\
\hline Belém & 8 & Cobertura & conc.2000/p12 & 247 & \\
\hline
\end{tabular}




\begin{tabular}{|c|c|c|c|c|c|}
\hline \multicolumn{6}{|c|}{ Simulações para o Inverno - 22 de Junho } \\
\hline Cidade & Zona Bioclimática & Tipo de Cobertura & Vedações & Temp. Mínima Interna & Desempenho \\
\hline \multirow{2}{*}{ Caxias do Sul } & \multirow[t]{2}{*}{ 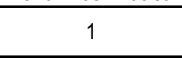 } & Cobertura & \multirow{2}{*}{ P $08 \mathrm{~cm} /$ conc 2200} & 10 & Não Atende \\
\hline & & Laje intermediária & & 8,4 & Não Atende \\
\hline \multirow{2}{*}{ Caxias do Sul } & \multirow{2}{*}{1} & Cobertura & \multirow{2}{*}{ P $10 \mathrm{~cm} /$ conc 2200} & 10,6 & Não Atende \\
\hline & & Laje intermediária & & 9,2 & Não Atende \\
\hline \multirow{2}{*}{ Caxias do Sul } & \multirow{2}{*}{1} & Cobertura & \multirow{2}{*}{ P $12 \mathrm{~cm} /$ conc 2200} & 11,2 & Não Atende \\
\hline & & Laje intermediária & & 9,9 & Não Atende \\
\hline \multirow{2}{*}{ Ponta Grossa } & \multirow{2}{*}{2} & Cobertura & \multirow{2}{*}{$\mathrm{P} 08 \mathrm{~cm} /$ conc 2200} & 11,3 & Não Atende \\
\hline & & Laje intermediária & & 9,4 & Não Atende \\
\hline \multirow{2}{*}{ Ponta Grossa } & \multirow{2}{*}{2} & Cobertura & P $10 \mathrm{~cm} / \mathrm{conc} 2200$ & 11,7 & Não Atende \\
\hline & & Laje intermediária & T $10 \mathrm{~cm} / \mathrm{cone} \angle 200^{2}$ & 10,3 & Não Atende \\
\hline & & Cobertura & P $12 \mathrm{~cm} /$ conc 2200 & 12,4 & $\mathrm{M}$ \\
\hline Ponta Grossa & 2 & \begin{tabular}{|l|} 
Laje intermediária \\
\end{tabular} & $P 12 \mathrm{~cm} /$ conc $2200^{\circ}$ & 11,1 & Não Atende \\
\hline Sãn Pauln & 3 & Cobertura & $\mathrm{P} 08 \mathrm{~cm} / \mathrm{conc} 2200$ & 13 & Não Atende \\
\hline Sao raulo & 3 & Laje intermediária & F Vocm/ conic $\angle 200$ & 12,5 & Não Atende \\
\hline Sãn Pauln & 3 & Cobertura & P $10 \mathrm{~cm} / \mathrm{conc} 2200$ & 13,6 & Não Atende \\
\hline Sá raulo & 3 & Laje intermediária & 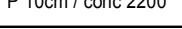 & 13,1 & Não Atende \\
\hline & & Cobertura & P $12 \mathrm{~cm} / \mathrm{conc} 2200$ & 14,1 & Não Atende \\
\hline sao raulo & 3 & Laje intermediária & F $12 \mathrm{~cm} / \mathrm{cone} \angle 200^{2}$ & 13,8 & Não Atende \\
\hline Florianónolis & 3 & Cobertura & $\mathrm{P} 08 \mathrm{~cm} / \mathrm{conc} 2200$ & 16,3 & Não Atende \\
\hline Florianopolis & 3 & Laje intermediária & P $08 \mathrm{~cm} /$ conc 2200 & 15,8 & Não Atende \\
\hline & 3 & Cobertura & & 16,6 & Não Atende \\
\hline Florianopolis & 3 & Laje intermediária & $P 10 \mathrm{~cm} /$ conc 2200 & 16,2 & Não Atende \\
\hline Florianónolis & 3 & Cobertura & $\mathrm{P} 12 \mathrm{~cm} / \mathrm{conc} 2200$ & 17 & Não Atende \\
\hline Florlanopolis & 3 & Laje intermediária & 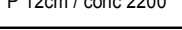 & 16,6 & Não Atende \\
\hline Brasília & 4 & Cobertura & $\mathrm{P} 08 \mathrm{~cm} / \mathrm{conc} 2200$ & 14,3 & Não Atende \\
\hline Brasilla & 4 & Laje intermediária & 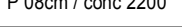 & 13,2 & Não Atende \\
\hline & 4 & Cobertura & P $10 \mathrm{~cm} / \operatorname{conc} 2200$ & 15,1 & $M$ \\
\hline Brasilla & 4 & Laje intermediária & I $10 \mathrm{~cm} / \mathrm{cone} \angle 200^{2}$ & 14,1 & Não Atende \\
\hline Brasilia & 4 & Cobertura & $\mathrm{P} 12 \mathrm{~cm} / \mathrm{conc} 2200$ & 16 & $M$ \\
\hline Drasilla & 4 & Laje intermediária & 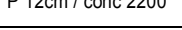 & 15 & $\mathrm{M}$ \\
\hline & & Cobertura & $\mathrm{P} 08 \mathrm{~cm} / \mathrm{conc} 2200$ & 13 & Não Atende \\
\hline Sao Carlos & 4 & Laje intermediária & P 08cm / conc 2200 & 14,4 & Não Atende \\
\hline Sãn Carlos & 4 & Cobertura & P $10 \mathrm{~cm} / \mathrm{coc} \cdot 2200$ & 15,7 & Não Atende \\
\hline Sao Carios & 4 & Laje intermediária & I $10 \mathrm{~cm} / \mathrm{cone} \angle 200^{2}$ & 15,1 & Não Atende \\
\hline Sãก Carloc & 4 & Cobertura & $\mathrm{P} 12 \mathrm{~cm} / \mathrm{conc} 2200$ & 16,2 & Não Atende \\
\hline Salo Callus & 4 & Laje intermediária & 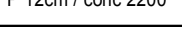 & 15,7 & Não Atende \\
\hline Santos & 5 & Cobertura & $\mathrm{P} 08 \mathrm{~cm} /$ conc 2200 & 17,4 & Não Atende \\
\hline Santos & 5 & Laje intermediária & $P 08 \mathrm{~cm} /$ conc 2200 & 16,8 & Não Atende \\
\hline Santos & 5 & Cobertura & P $10 \mathrm{~cm} / \mathrm{conc} 2200$ & 17,8 & Não Atende \\
\hline Santos & 5 & Laje intermediária & $P 10 \mathrm{~cm} / \mathrm{conc} 2200$ & 17,3 & Não Atende \\
\hline & 5 & Cobertura & & 18,3 & Não Atende \\
\hline Santos & 5 & Laje intermediária & P 12cm / conc 2200 & 17,8 & Não Atende \\
\hline Presidente Prudente & 6 & Cobertura & $\mathrm{P} 08 \mathrm{~cm} /$ conc 2200 & 16,7 & \\
\hline Presidente Prudente & 6 & Laje intermediária & P U8cm / conc Z200 & 16 & \\
\hline Presidente Prudente & 6 & Cobertura & P $10 \mathrm{~cm} / \mathrm{conc} 2200$ & 17,3 & Disnenş Verificacão \\
\hline & 6 & Laje intermediária & $P 10 \mathrm{~cm} / \mathrm{conc} 2200$ & 16,7 & Dispensa verticaçao \\
\hline Presidente Prudente & 6 & Cobertura & P $12 \mathrm{~cm} / \mathrm{conc} 2200$ & 17,9 & \\
\hline Prestaente pruaente & 6 & Laje intermediária & 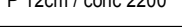 & 17,4 & \\
\hline Teresina & 7 & Cobertura & $\mathrm{P} 08 \mathrm{~cm} /$ conc 2200 & 23,6 & \\
\hline Teresina & $T$ & Laje intermediária & 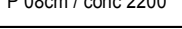 & 22,7 & \\
\hline & 7 & Cobertura & P $10 \mathrm{~cm} / \mathrm{conc} 2200$ & 24,2 & \\
\hline Teresina & 7 & \begin{tabular}{|l|} 
Laje intermediária \\
\end{tabular} & P $10 \mathrm{~cm} /$ conc 2200 & 23,4 & Dispensa Veriticaçăo \\
\hline Teresina & 7 & Cobertura & P $12 \mathrm{~cm} / \mathrm{conc}_{2} 200$ & 24,8 & \\
\hline Ieresina & 1 & Laje intermediária & F $12 \mathrm{~cm} / \mathrm{cone} \angle 200^{\circ}$ & 24,1 & \\
\hline Belém & 8 & Cobertura & $\mathrm{P} 08 \mathrm{~cm} / \operatorname{conc} 2200$ & 24,4 & \\
\hline Belem & 8 & Laje intermediária & P 08cm / conc Z200 & 23,7 & \\
\hline Belém & 8 & \begin{tabular}{|l|} 
Cobertura \\
\end{tabular} & P $10 \mathrm{~cm} /$ conc 2200 & 24,9 & Dispensa Verificacão \\
\hline Belem & 8 & Laje intermediária & $P$ Tucm / conc 2200 & 24,3 & Dispensa verriccaçao \\
\hline Belém & 8 & Cobertura & P $12 \mathrm{~cm} /$ conc 2200 & 25,4 & \\
\hline & 8 & Laje intermediária & F $12 \mathrm{~cm} / \mathrm{cone} \angle 200$ & 24,9 & \\
\hline
\end{tabular}




\begin{tabular}{|c|c|c|c|c|c|}
\hline \multicolumn{6}{|c|}{ Simulações para o Inverno - 22 de Junho } \\
\hline Cidade & Zona Bioclimática & Tipo de Cobertura & Vedações & Temp. Mínima Interna & Desempenho \\
\hline \multirow{2}{*}{ Caxias do Sul } & \multirow[t]{2}{*}{ 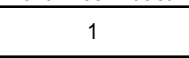 } & Cobertura & \multirow{2}{*}{ conc.2400/p8 } & 10,3 & Não Atende \\
\hline & & Laje intermediária & & 8,6 & Não Atende \\
\hline \multirow{2}{*}{ Caxias do Sul } & \multirow{2}{*}{1} & Cobertura & \multirow{2}{*}{ conc.2400/p10 } & 10,8 & Não Atende \\
\hline & & Laje intermediária & & 9,4 & Não Atende \\
\hline \multirow{2}{*}{ Caxias do Sul } & \multirow{2}{*}{1} & Cobertura & \multirow{2}{*}{ conc.2400/p12 } & 11,3 & Não Atende \\
\hline & & Laje intermediária & & 10,1 & Não Atende \\
\hline \multirow{2}{*}{ Ponta Grossa } & \multirow{2}{*}{2} & Cobertura & \multirow{2}{*}{ conc.2400/p8 } & 11,1 & Não Atende \\
\hline & & \begin{tabular}{|l} 
Laje intermediária \\
\end{tabular} & & 9,6 & Não Atende \\
\hline \multirow{2}{*}{ Ponta Grossa } & \multirow{2}{*}{2} & Cobertura & conc $2400 / n 10$ & 11,9 & Não Atende \\
\hline & & \begin{tabular}{|l} 
Laje intermediária \\
\end{tabular} & conc. 24001 ipto & 10,5 & Não Atende \\
\hline & & Cobertura & conc $2400 / 012$ & 12,5 & $\mathrm{M}$ \\
\hline Ponta Grossa & 2 & \begin{tabular}{|l} 
Laje intermediária \\
\end{tabular} & conc.2400/p12 & 11,3 & Não Atende \\
\hline Sãn Paun & 3 & Cobertura & $2400 / \mathrm{n} 8$ & 13,1 & Não Atende \\
\hline sau ráluo & 3 & Laje intermediária & comic. $2400 / 100$ & 12,8 & Não Atende \\
\hline & & Cobertura & & 13,7 & Não Atende \\
\hline Sao Paulo & 3 & Laje intermediária & conc. $2400 / p 10$ & 13,2 & Não Atende \\
\hline & & Cobertura & $\operatorname{conc} 2400 / n 12$ & 14,2 & $\mathrm{M}$ \\
\hline sao Paulo & 3 & Laje intermediária & conc. $\angle 400 / p 12$ & 13,9 & Não Atende \\
\hline Florianónolic & 3 & Cobertura & $2400 / n 8$ & 16,4 & Não Atende \\
\hline Florianopolis & 3 & \begin{tabular}{|l|} 
Laje intermediária \\
\end{tabular} & conc.2400/p8 & 15,9 & Não Atende \\
\hline & 3 & Cobertura & & 16,7 & Não Atende \\
\hline Florianopolis & 3 & \begin{tabular}{|l|} 
Laje intermediária \\
\end{tabular} & conc.2400/pio & 16,3 & Não Atende \\
\hline & & Cobertura & & 17,1 & Não Atende \\
\hline Florianópolis & 3 & Laje intermediária & conc. $2400 / p 12$ & 16,7 & Não Atende \\
\hline Brasilia & 4 & Cobertura & $\operatorname{conc} 2400 / \mathrm{p} 8$ & 14,4 & Não Atende \\
\hline Brasilla & 4 & \begin{tabular}{|l|} 
Laje intermediária \\
\end{tabular} & conc.2400/p8 & 13,4 & Não Atende \\
\hline Brasilia & 4 & Cobertura & $\operatorname{conc} 2400 / p 10$ & 15,2 & $M$ \\
\hline Brasilla & 4 & \begin{tabular}{|l|} 
Laje intermediária \\
\end{tabular} & conc. 24001 pio & 14,3 & Não Atende \\
\hline & & Cobertura & & 16 & $M$ \\
\hline Brasilla & 4 & \begin{tabular}{|l|} 
Laje intermediária \\
\end{tabular} & conc.2400/p12 & 15,1 & $\mathrm{M}$ \\
\hline & 4 & Cobertura & $2400 / n 8$ & 15,2 & Não Atende \\
\hline Sao Carlos & 4 & \begin{tabular}{|l} 
Laje intermediária \\
\end{tabular} & conc.2400/p8 & 14,5 & Não Atende \\
\hline Sãn Carlos & 4 & Cobertura & (anc $2400 / n 10$ & 15,8 & Não Atende \\
\hline Sao Carios & 4 & Laje intermediária & conc. 24001 pio & 15,2 & Não Atende \\
\hline & & \begin{tabular}{|l|} 
Cobertura \\
\end{tabular} & & 16,3 & $M$ \\
\hline Sáo Carlos & 4 & Laje intermediária & conc.2400/p12 & 15,8 & Não Atende \\
\hline Santos & 5 & Cobertura & $\operatorname{conc} 2400 / \mathrm{p} 8$ & 17,4 & Não Atende \\
\hline Santos & 5 & \begin{tabular}{|l} 
Laje intermediária \\
\end{tabular} & conc. $2400 / p 8$ & 16,9 & Não Atende \\
\hline Santoc & 5 & Cobertura & (nonc $2400 / n 10$ & 17,9 & Não Atende \\
\hline Sallus & 5 & \begin{tabular}{|l} 
Laje intermediária \\
\end{tabular} & conc.2400/p10 & 17,4 & Não Atende \\
\hline & 5 & Cobertura & & 18,3 & Não Atende \\
\hline Santos & 5 & \begin{tabular}{|l} 
Laje intermediária \\
\end{tabular} & conc.2400/p12 & 17,9 & Não Atende \\
\hline Presidente Prudente & 6 & Cobertura & conc $2400 / 08$ & 16,8 & \\
\hline Presidente Prudente & 6 & \begin{tabular}{|l} 
Laje intermediária \\
\end{tabular} & conc. $2400 / p 8$ & 16,1 & \\
\hline Presidente Prudente & 6 & Cobertura & conc $2400 / 010$ & 17,4 & Disnensa Verificacão \\
\hline Presidente Prudente & 6 & Laje intermediária & conc.2400/p10 & 16,8 & Dispensa Verificaçäo \\
\hline Presidente Prudente & 6 & Cobertura & conc. $2400 / p 12$ & 18 & \\
\hline Presidente Prudente & 6 & Laje intermediária & conc.2400/p12 & 17,6 & \\
\hline & & Cobertura & conc $2400 / p 8$ & 23,7 & \\
\hline leresina & 7 & Laje intermediária & conc.2400/p8 & 22,8 & \\
\hline & 7 & Cobertura & (nonc $2400 / n 10$ & 24,3 & \\
\hline leresina & 7 & Laje intermediária & conc.2400/p10 & 23,5 & Dispensa Veriticaçăo \\
\hline Teresina & 7 & Cobertura & conc $2400 / 012$ & 24,9 & \\
\hline Ieresina & 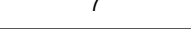 & \begin{tabular}{|l} 
Laje intermediária \\
\end{tabular} & conc. 24001 pil & 24,2 & \\
\hline Belém & 8 & Cobertura & conc $2400 / p 8$ & 24,5 & \\
\hline Belem & 8 & Laje intermediária & conc.2400/p8 & 23,8 & \\
\hline Relém & 8 & Cobertura & $\operatorname{conc} 2400 / n 10$ & 25 & Disnensa Verificacão \\
\hline Belem & 8 & Laje intermediária & conc.2400/pio & 24,4 & Dispensa verticaçąa \\
\hline Belém & 8 & Cobertura & conc.2400/p12 & 25,5 & \\
\hline Belem & 8 & Laje intermediária & conc. $24001 \mathrm{p} 12$ & 25 & \\
\hline
\end{tabular}


ANEXOS 
ANEXO 1. Projeto Tipologia Térrea HM5 - Caixa Econômica Federal - CEF

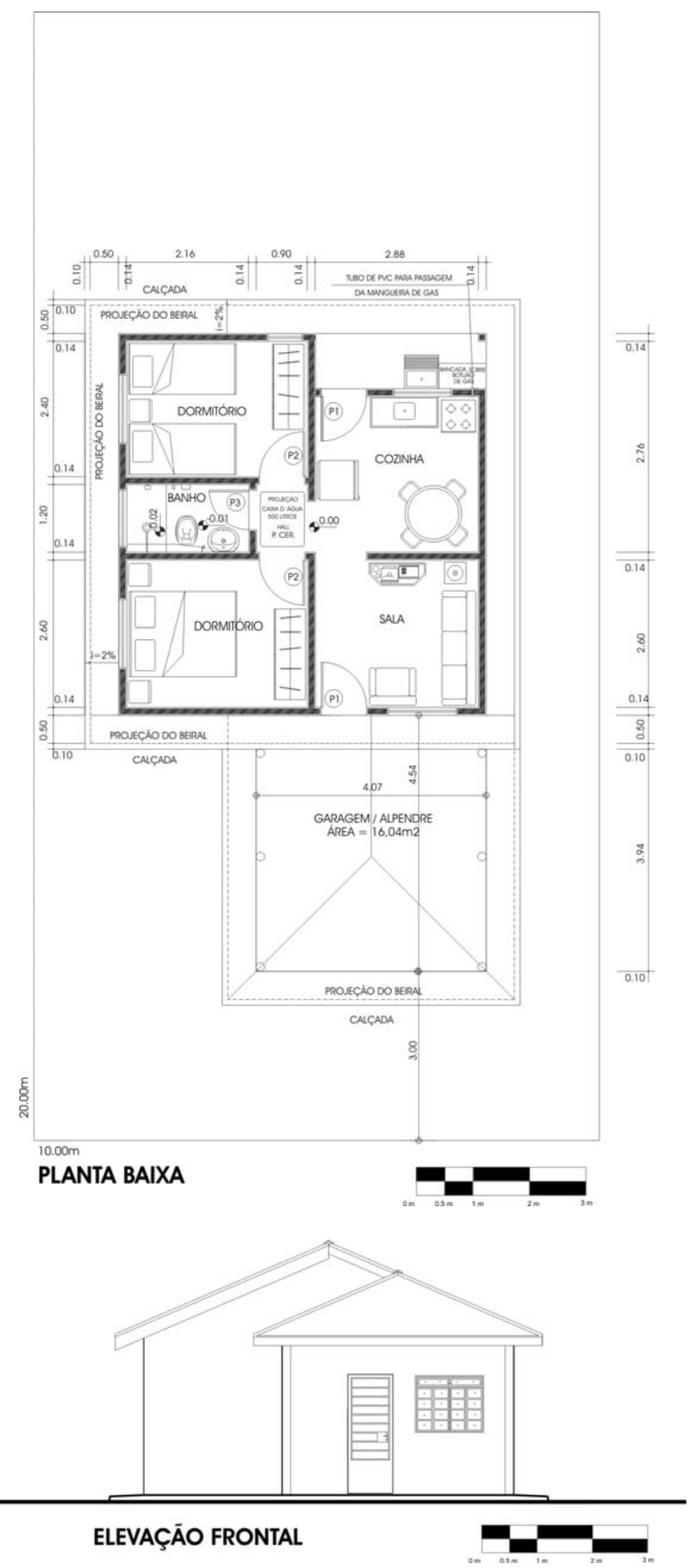


ANEXO 2. Projeto Tipologia Térrea TI $24 \mathrm{~A}$ - Companhia do Desenvolvimento Urbano e Habitacional do Estado de São Paulo - CDHU

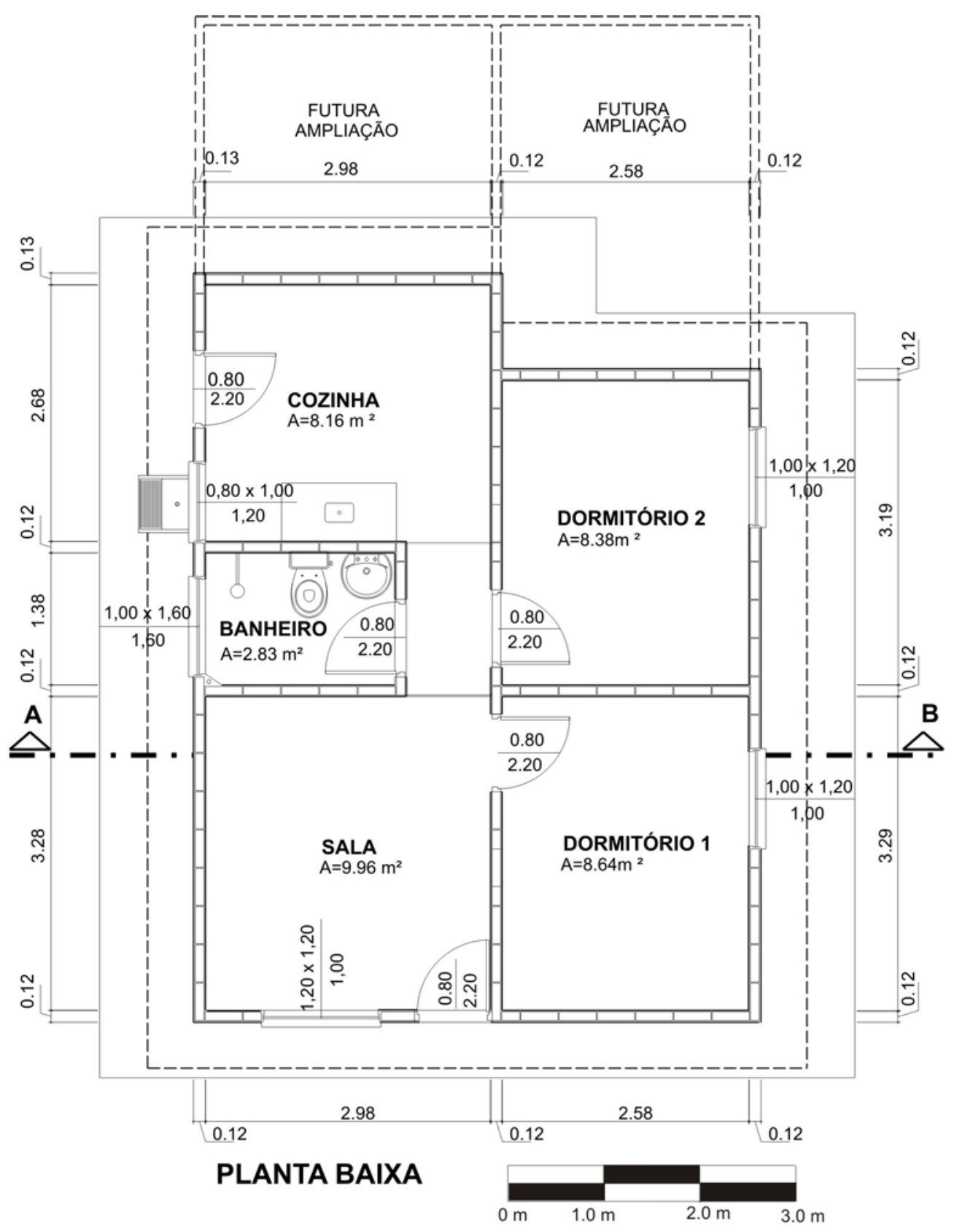




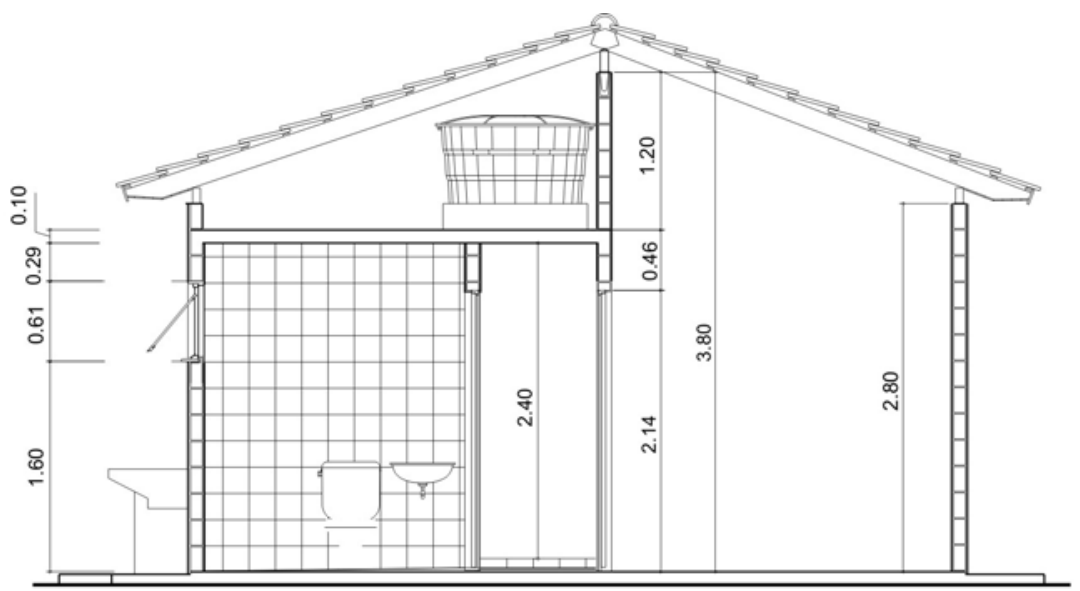

CORTE AB

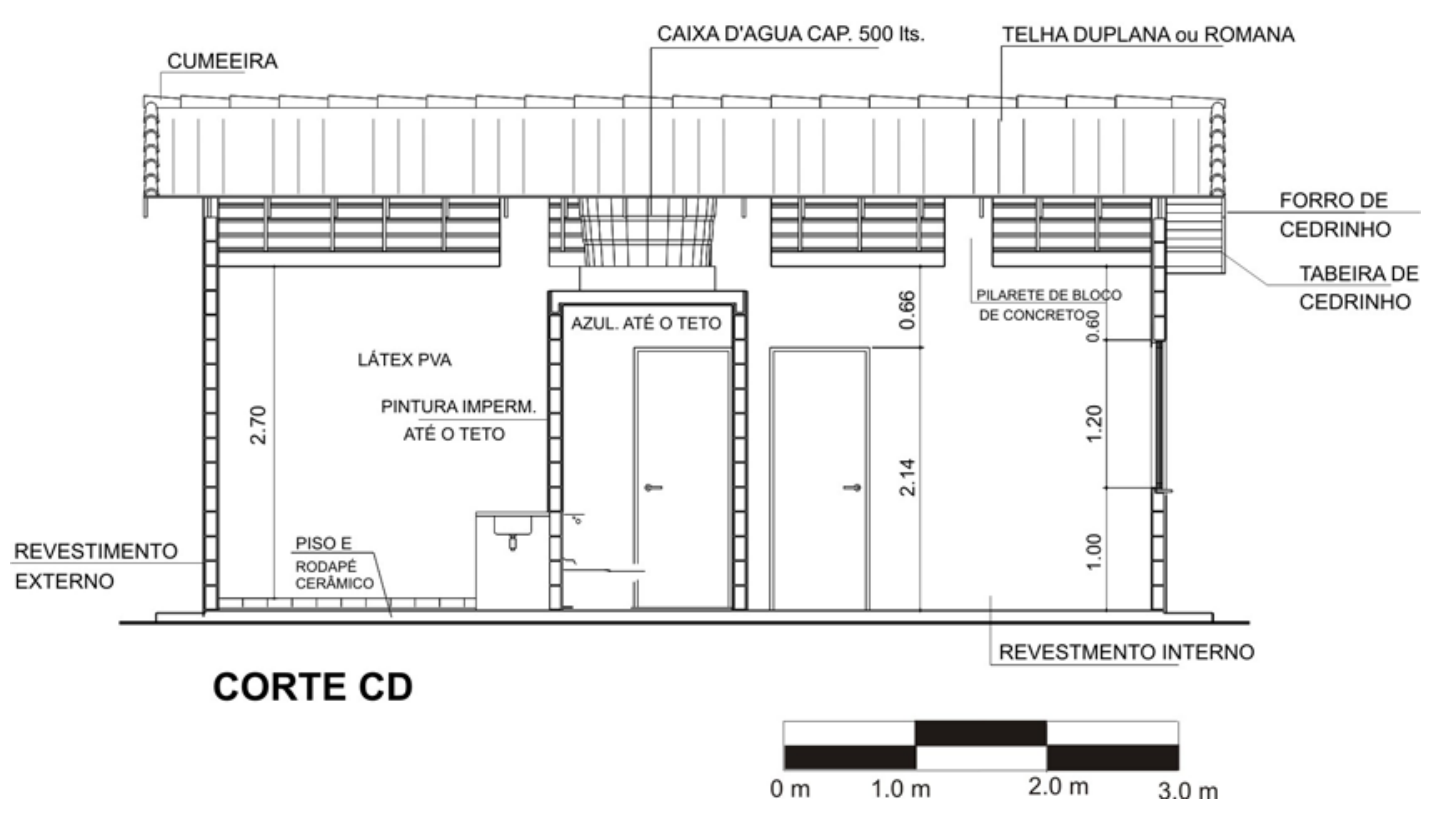




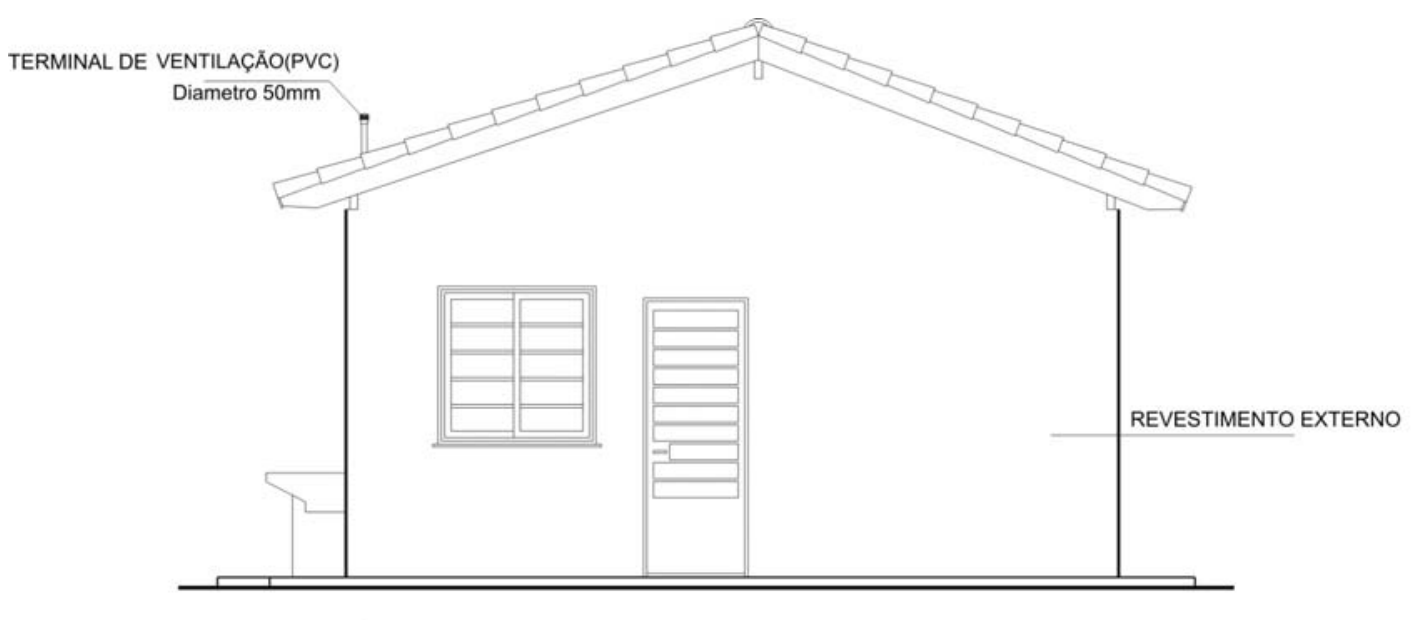

FACHADA FRONTAL

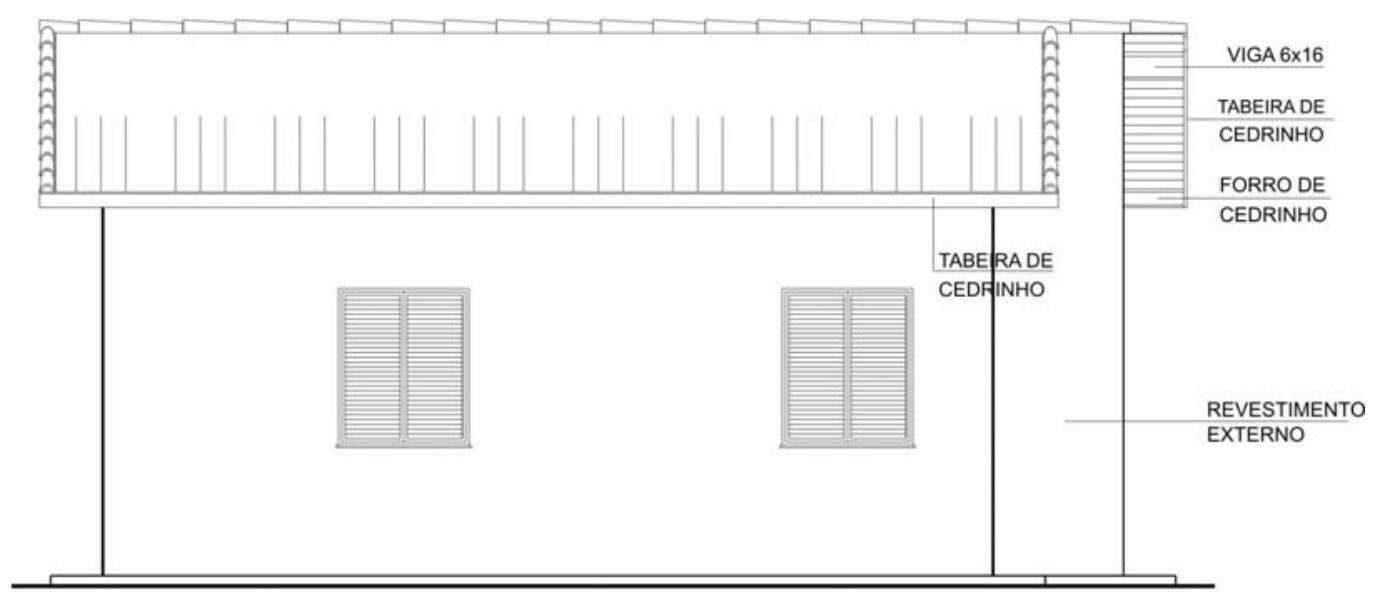

FACHADA LATERAL DIREITA

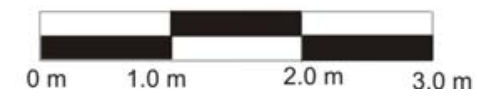


Anexo 2. Projeto Tipologia Térrea TI24A - CDHU 271

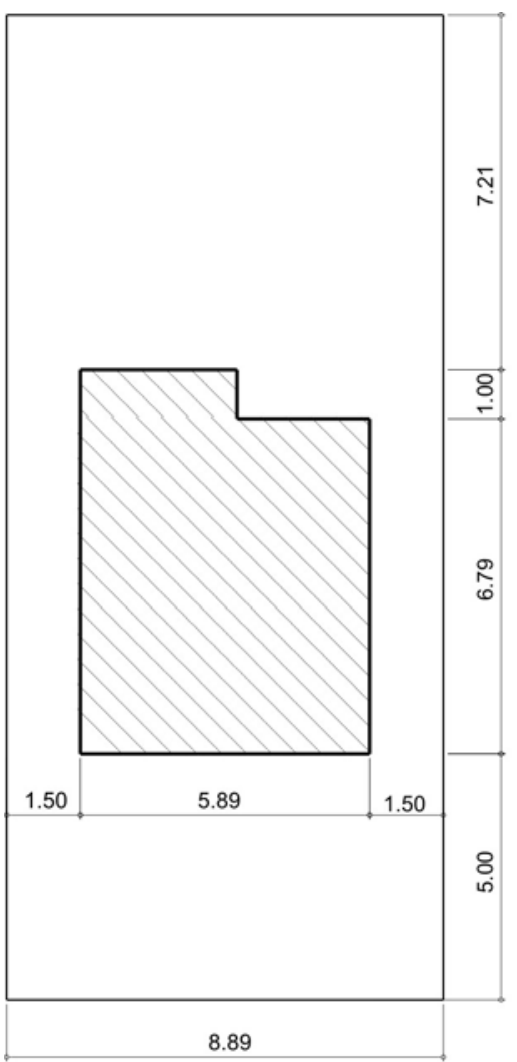

IMPLANTAÇÃO

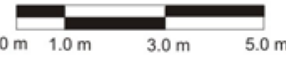


ANEXO 3. Projeto Tipologia Multipavimentos V052H-01 (Antiga VI22B-V2) - Companhia do Desenvolvimento Urbano e Habitacional do Estado de São Paulo - CDHU

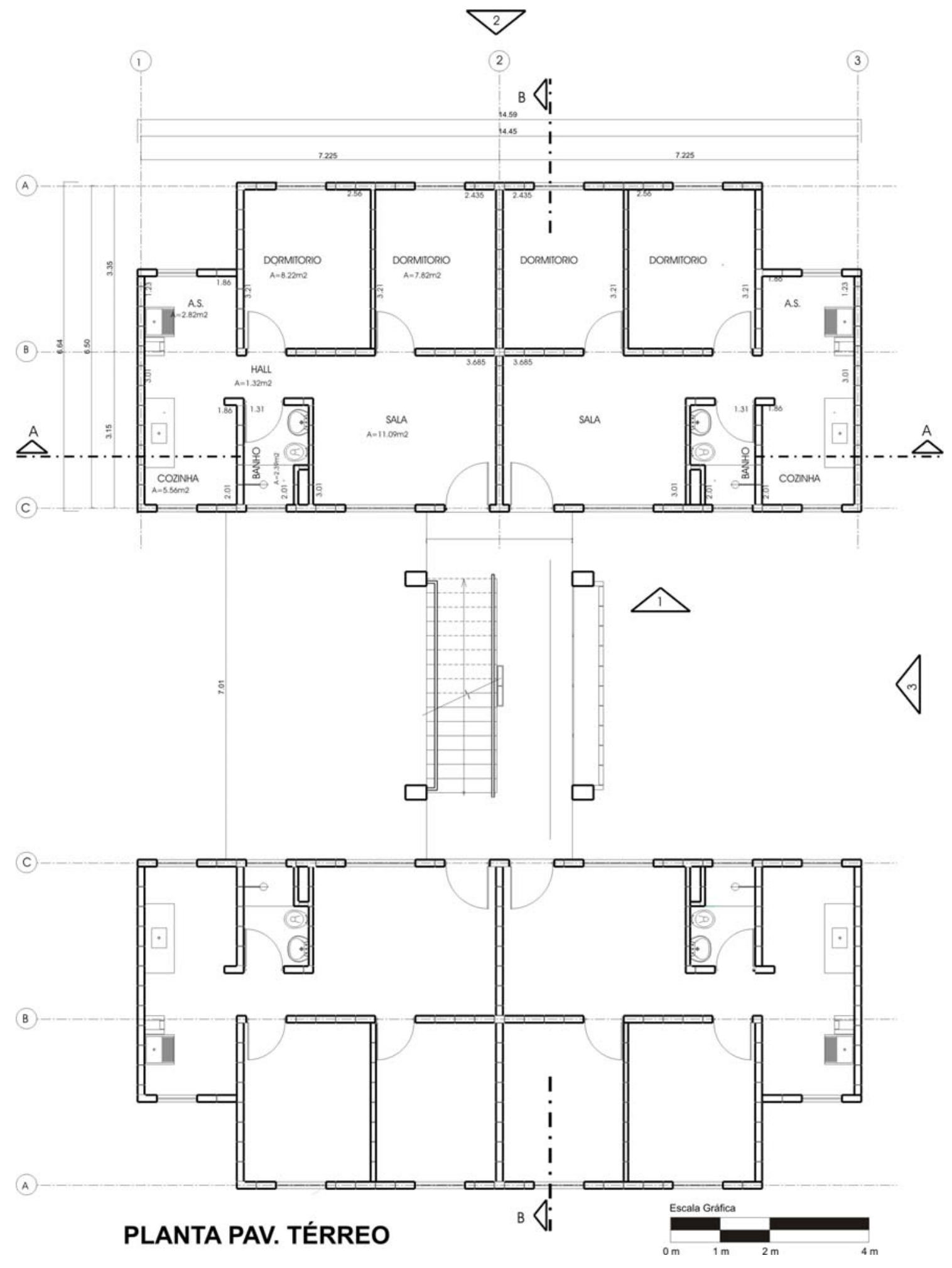




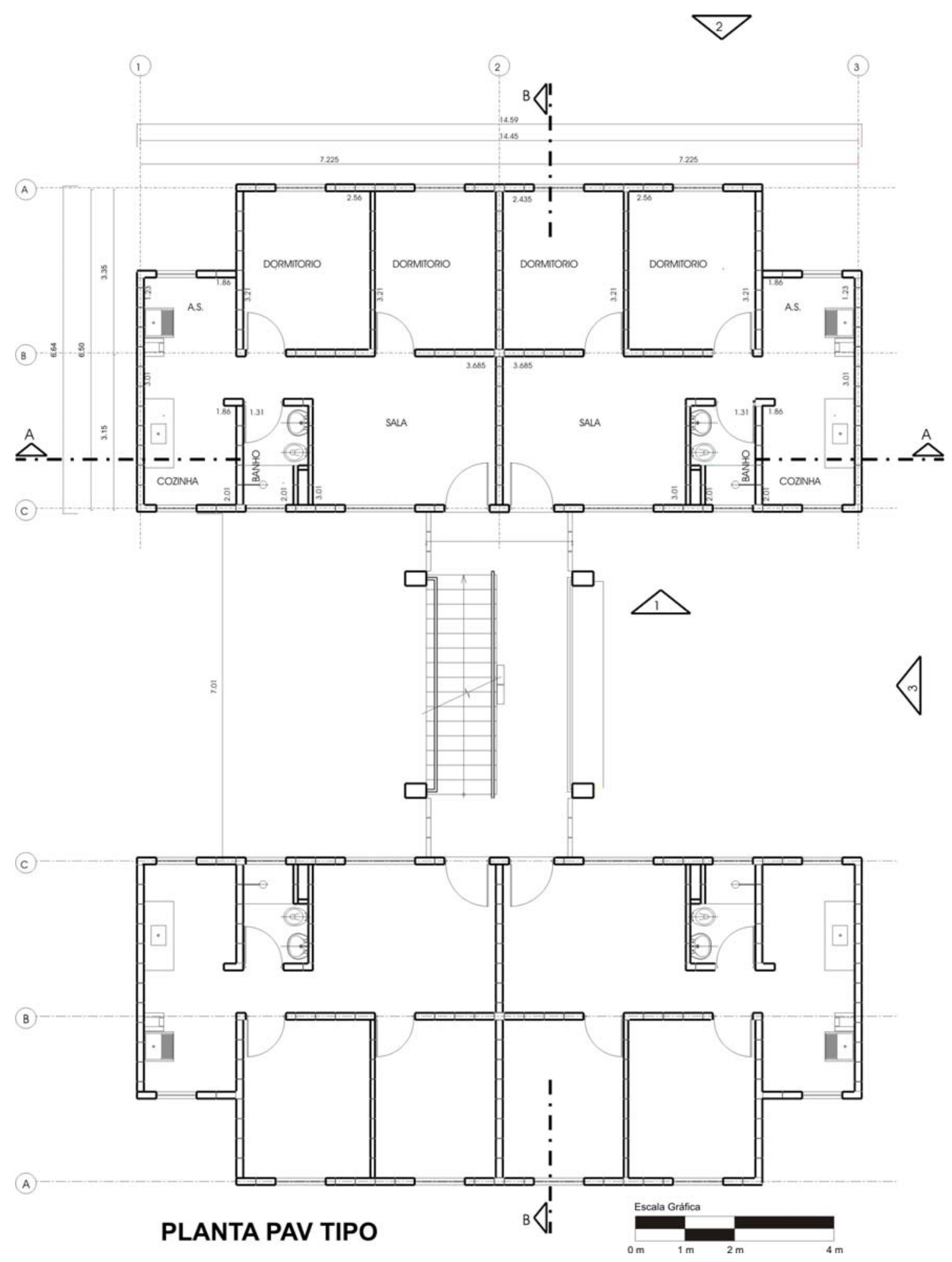



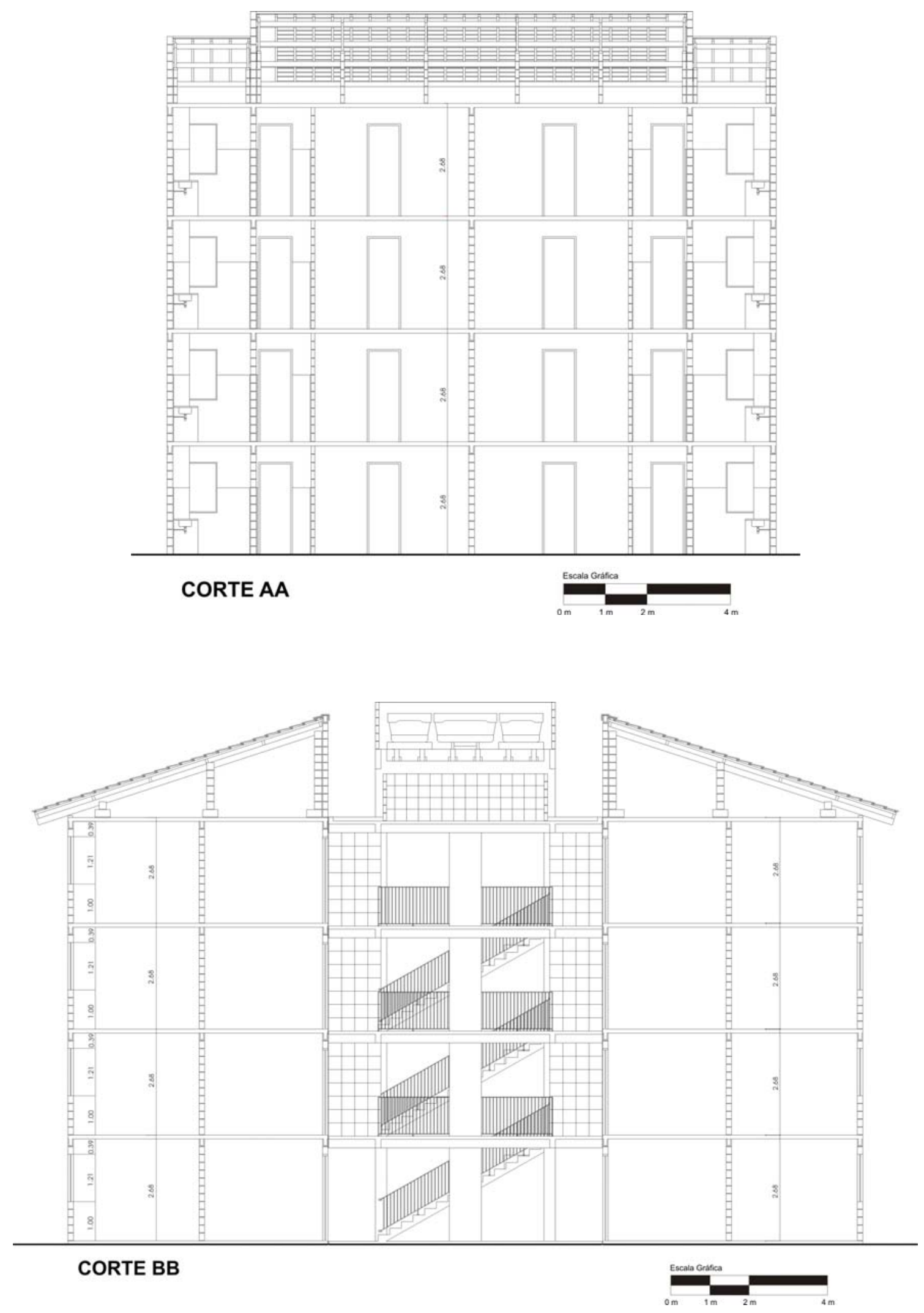

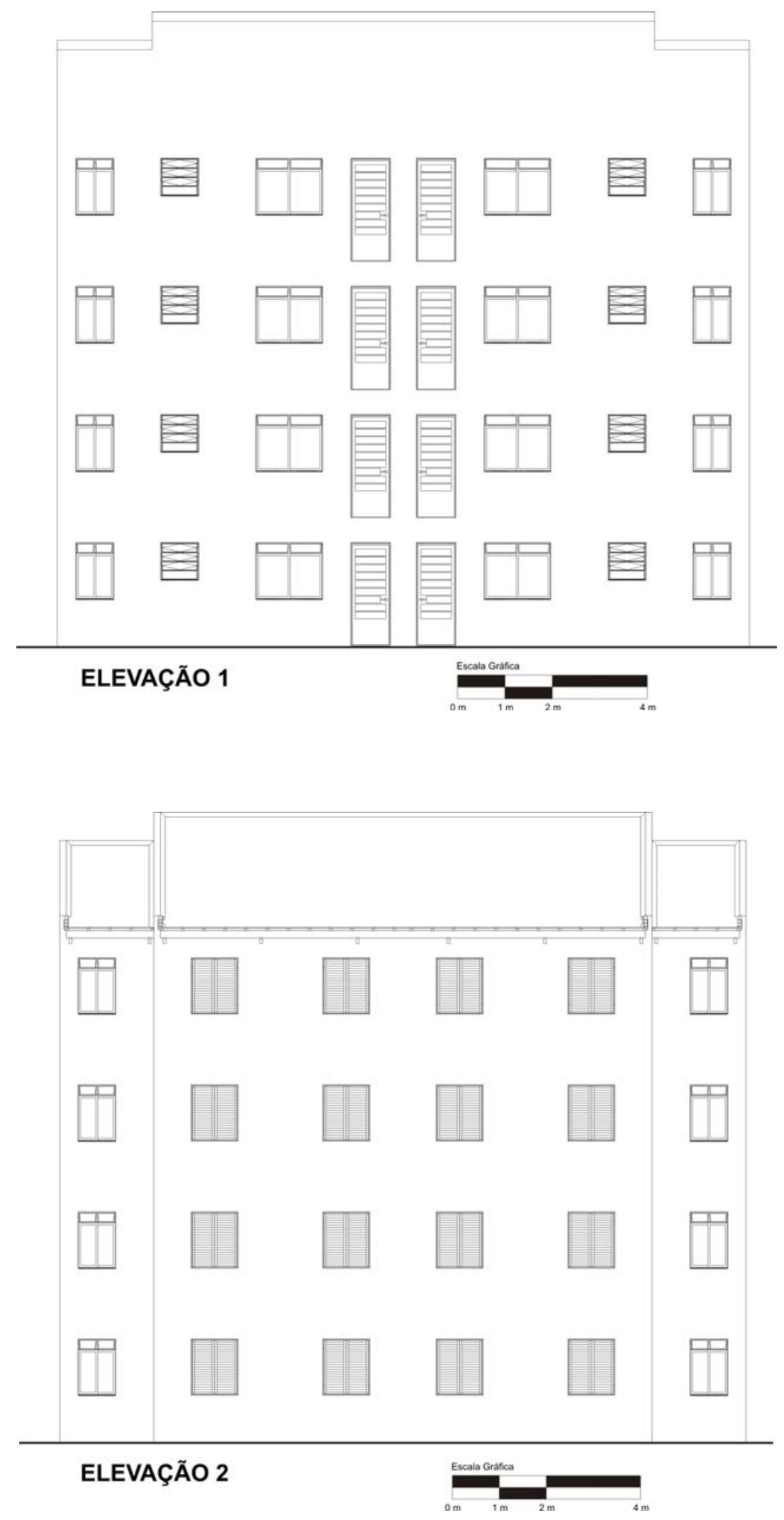


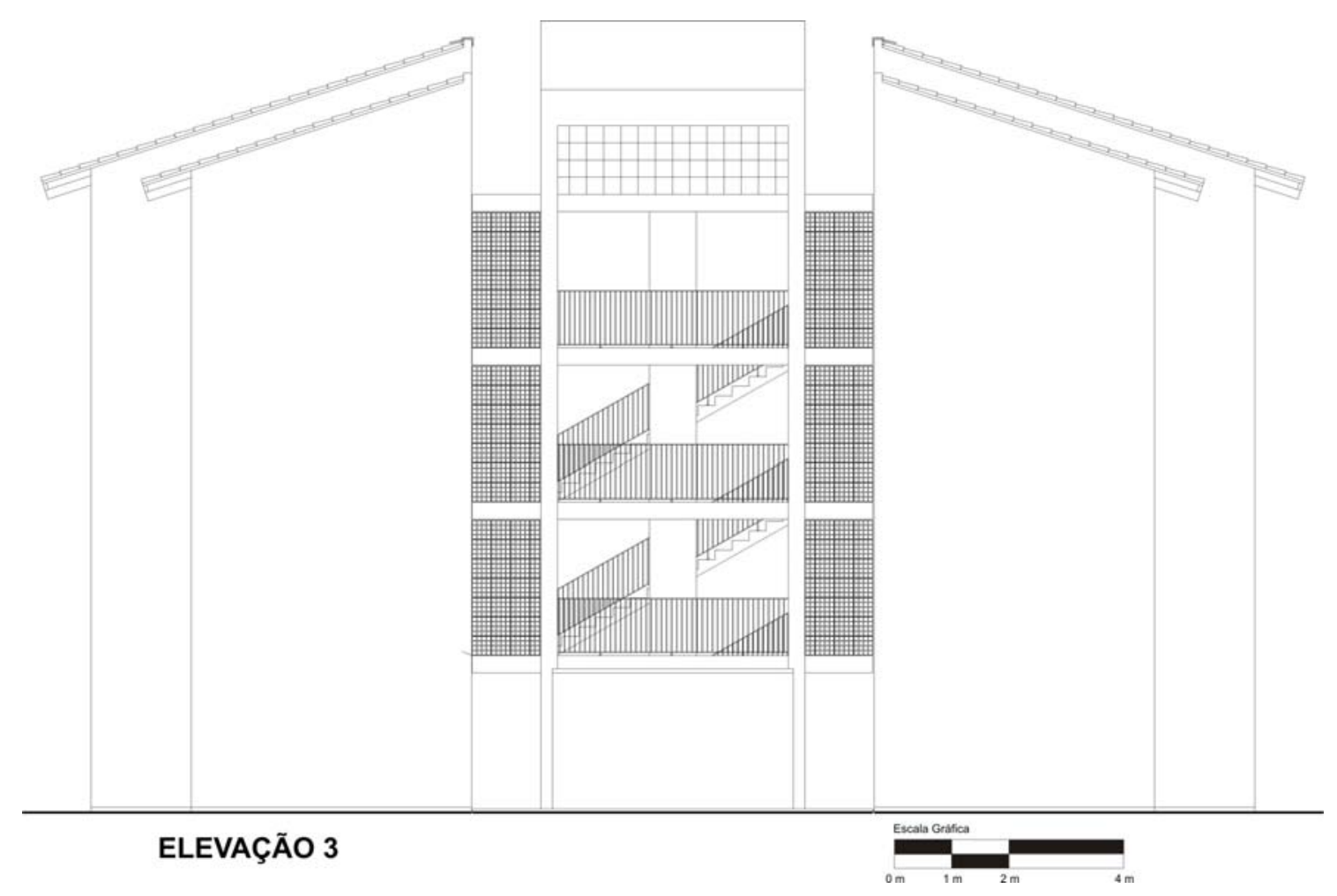


ANEXO 4. Características dos Painéis e Tipos de Cobertura

\subsection{Painéis de Referência}

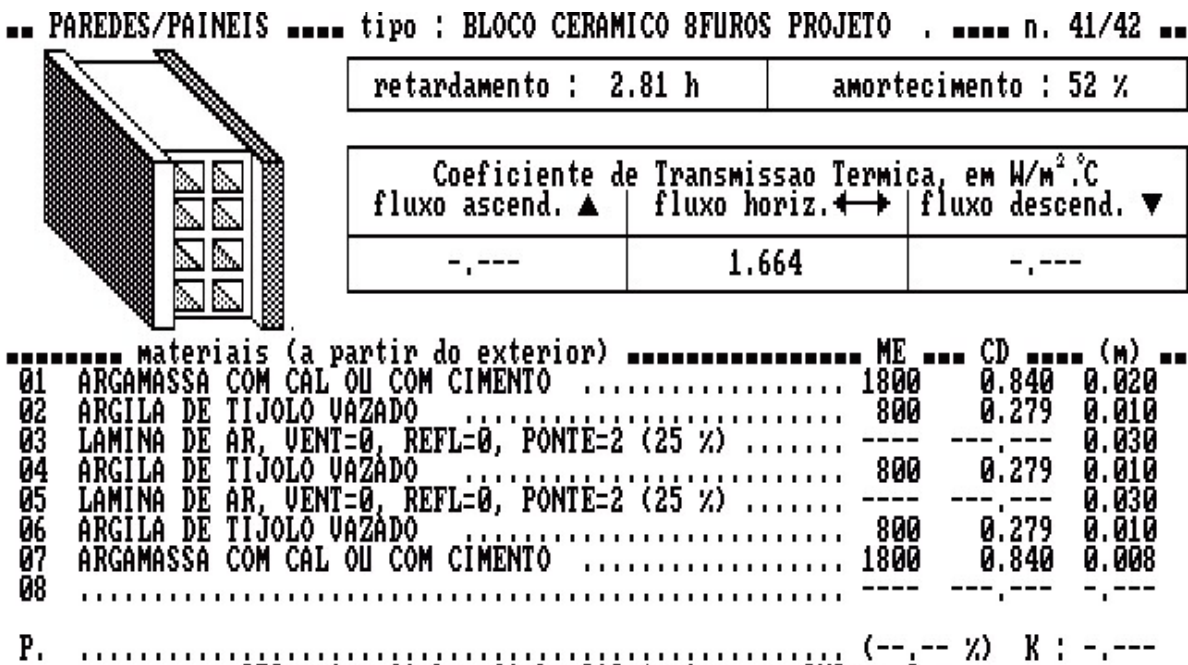

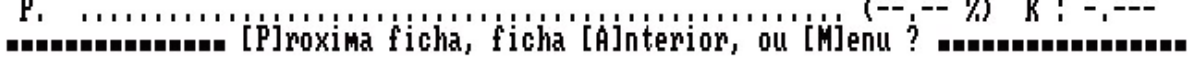

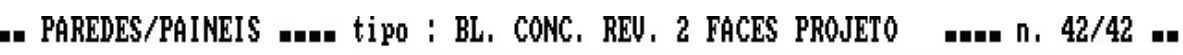

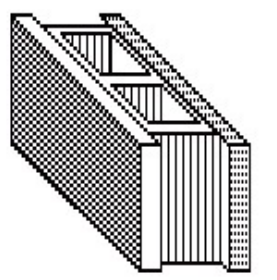

\begin{tabular}{|l|l|} 
retardamento $: 3.36 \mathrm{~h}$ & amortecimento $: 58 \%$ \\
\hline
\end{tabular}

\begin{tabular}{|c|c|c|}
\hline \multicolumn{2}{|c|}{ Coeficiente de Transmissao Termica, en $\mathrm{W} / \mathrm{m}^{2} \mathrm{i} C$} \\
fluxo ascend. $\boldsymbol{A}$ & fluxo horiz, & fluxo descend, $\mathbf{\nabla}$ \\
\hline,---- & 2.883 &,---- \\
\hline
\end{tabular}

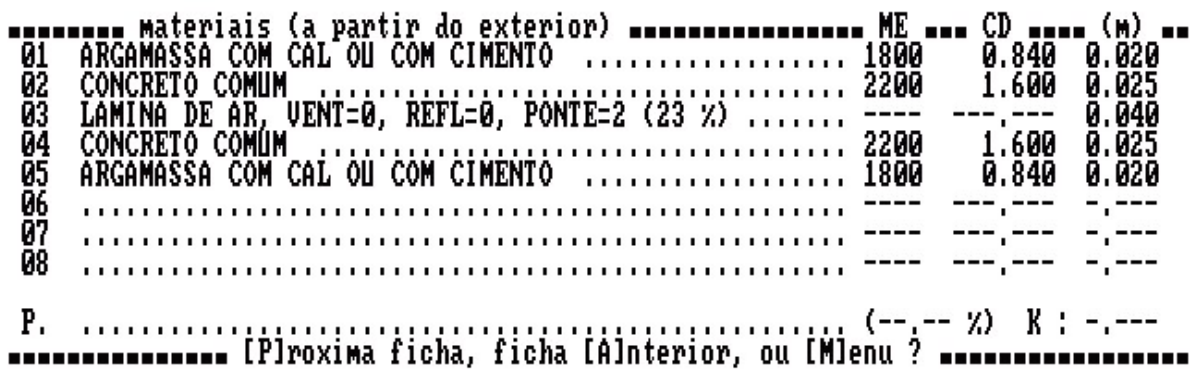




\subsection{Painéis de Concreto}

- PAREDES/PAINEIS an. tipo : PAINEL 8CM CONC 2400

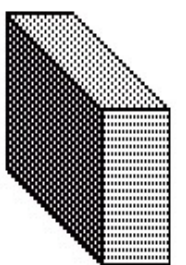

retardamen to : $2.12 \mathrm{~h} \quad$ amortecimento : $43 \%$

\begin{tabular}{|c|c|c|}
\hline \multicolumn{2}{|c|}{ Coeficiente de Transmissao Termica, em $\mathrm{W} / \mathrm{m}^{2}{ }^{\circ} \mathrm{C}$} \\
fluxo ascend, $\boldsymbol{A}$ & fluxo horiz, & fluxo descend, $\mathbf{\nabla}$ \\
\hline,---- & 4,095 &,---- \\
\hline
\end{tabular}

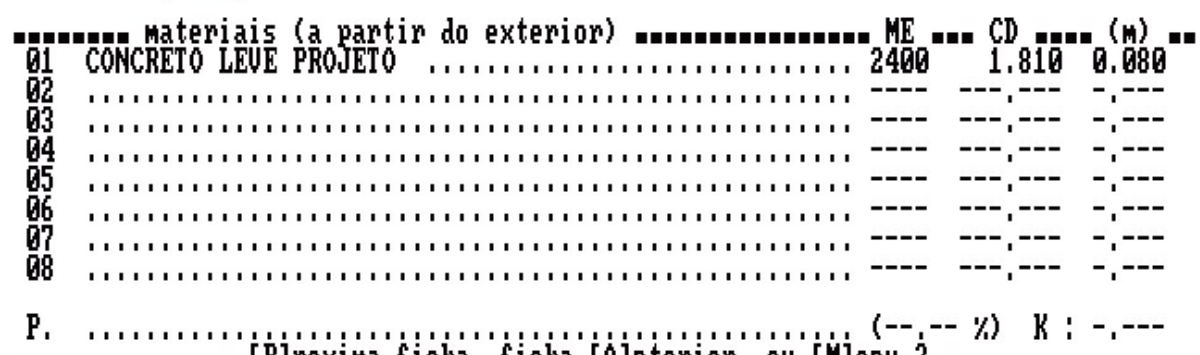

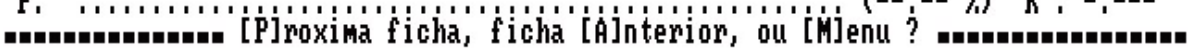

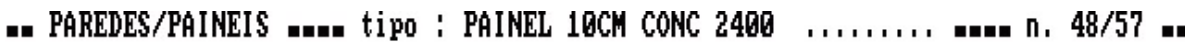

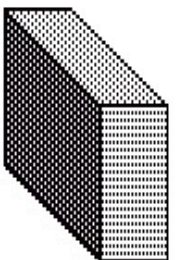
retardamento : $2.65 \mathrm{~h} \quad$ amortecimento : $50 \%$

\begin{tabular}{|c|c|c|}
\hline \multicolumn{2}{|c|}{ Coeficiente de Transmissao Termica, em $\mathrm{W} / \mathrm{m}^{2}, \mathrm{C}$} \\
fluxo ascend, $\boldsymbol{\Delta}$ & fluxo horiz. & flluxo descend, $\mathbf{\nabla}$ \\
\hline,---- & 3.918 &,---- \\
\hline
\end{tabular}

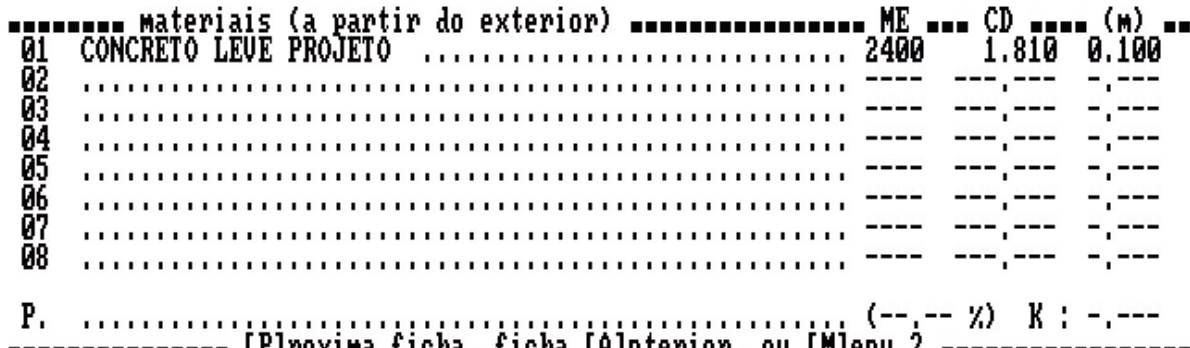

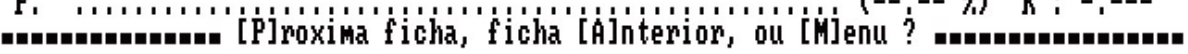
- PaREdes/PainEIS -... tipo : PáINEL 12CM CONC 2400 ก. $53 / 57$.

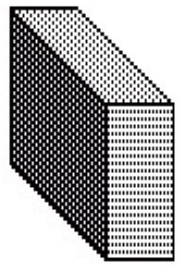
retardamento : $3.18 \mathrm{~h} \quad$ amortecimento : $57 \%$

\begin{tabular}{|c|c|c|}
\hline \multicolumn{2}{|c|}{ Coeficiente de Transmissao Termica, em $\mathrm{W} / \mathrm{m}^{2}{ }^{\circ} \mathrm{C}$} \\
fluxo ascend, $\boldsymbol{\Delta}$ & fluxo horiz, & fluxo descend, $\mathbf{\nabla}$ \\
\hline,---- & 3.755 &,---- \\
\hline
\end{tabular}

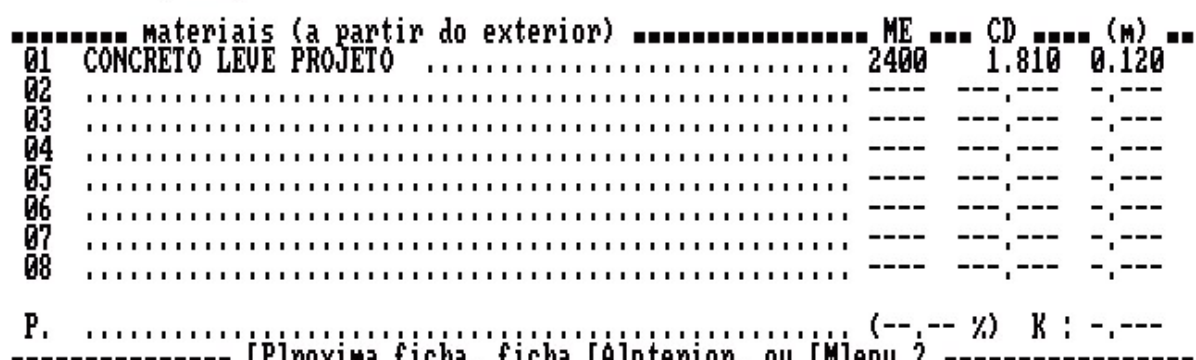

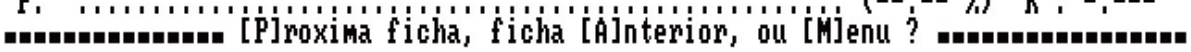




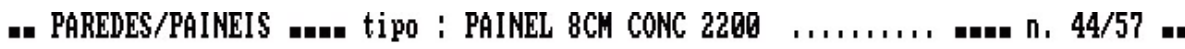

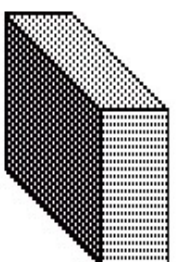
retardamento: $2.17 \mathrm{~h} \quad$ amortecimento : $43 \%$

\begin{tabular}{|c|c|c|}
\hline \multicolumn{2}{|c|}{ Coeficiente de Transmissao Termica, em $\mathrm{W} / \mathrm{m}^{2}{ }^{\circ} \mathrm{C}$} \\
fluxo ascend, $\boldsymbol{\Delta}$ & fluxo horiz, & fluxo descend, $\mathbf{\nabla}$ \\
\hline,---- & 3.995 &,---- \\
\hline
\end{tabular}

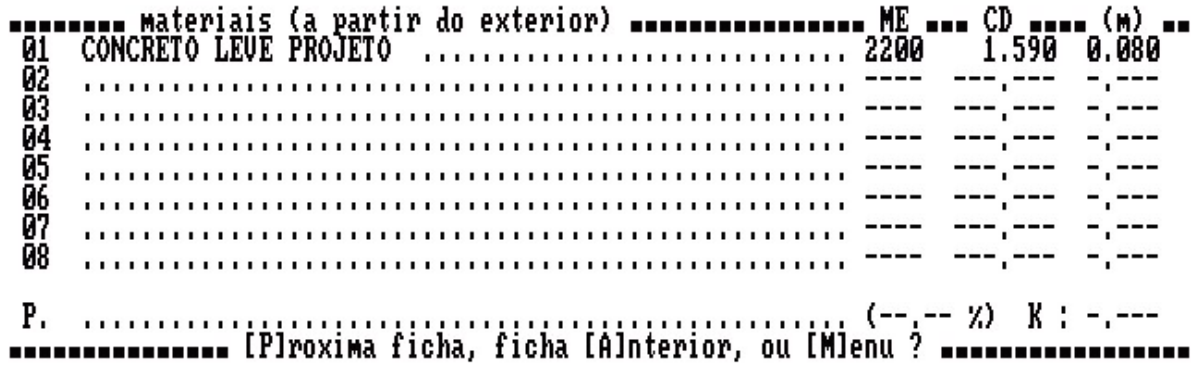

- PAREDES/PaINEIS an. tipo : PAINEL 10CM CONC 2200

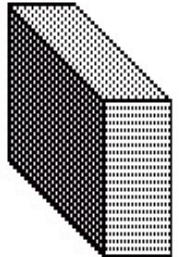
\begin{tabular}{|l|l|}
\hline retardamento $: 2.71 \mathrm{~h}$ & amortecimento $: 51 \%$ \\
\hline
\end{tabular}

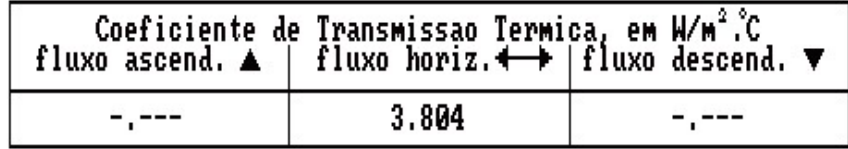

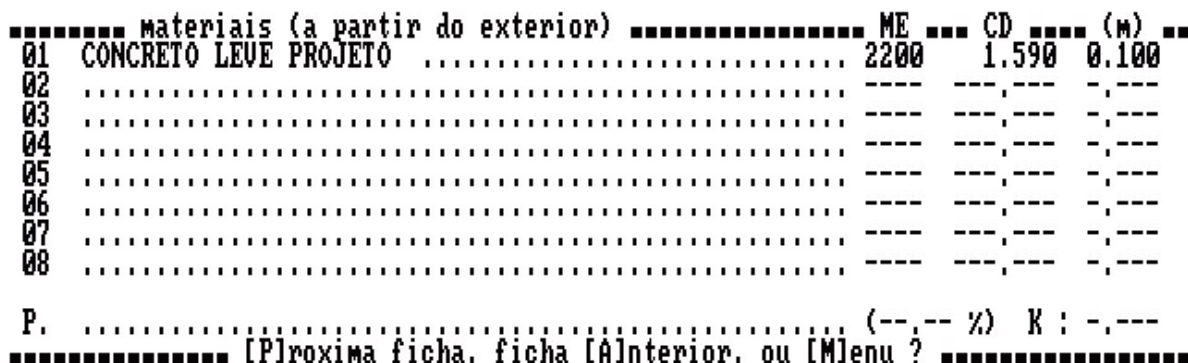

- PAREDES/PaINEIS -... tipo : PaINEL 12CM CONC 2200

-

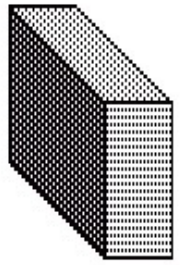

retardamento: $3.25 \mathrm{~h} \quad$ amortecimento : $57 \%$

\begin{tabular}{|c|c|c|}
\hline \multicolumn{2}{|c|}{ Coeficiente de Transmissao Termica, en $\mathrm{W} / \mathrm{m}^{2}{ }^{\circ} \mathrm{C}$} \\
fluxo ascend. $\Delta$ & fluxo horiz, $\longleftrightarrow$ & fluxo descend, $\nabla$ \\
\hline,---- & 3.630 &,---- \\
\hline
\end{tabular}

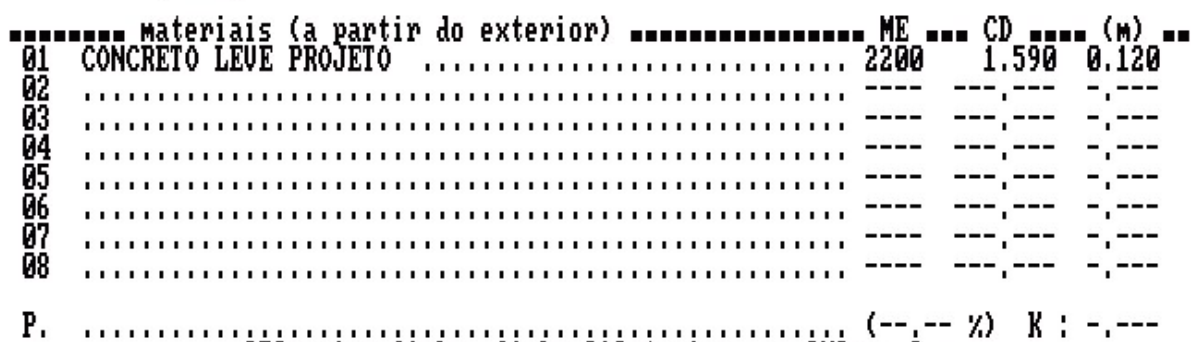

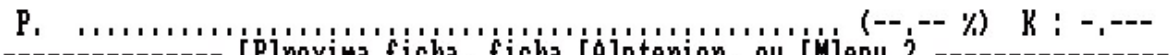

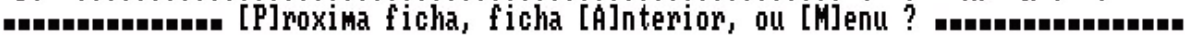




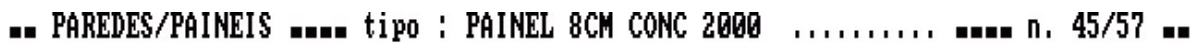

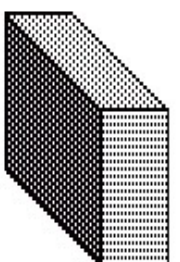

retardamento: $2.23 \mathrm{~h} \quad$ amortecimento : $44 \%$

\begin{tabular}{|c|c|c|}
\hline \multicolumn{2}{|c|}{ Coeficiente de Transmissao Termica, em $\mathrm{W} / \mathrm{m}^{2}{ }^{\circ} \mathrm{C}$} \\
fluxo ascend, $\boldsymbol{\Delta}$ & fluxo horiz, & fluxo descend, $\mathbf{\nabla}$ \\
\hline,---- & 3.870 &,---- \\
\hline
\end{tabular}

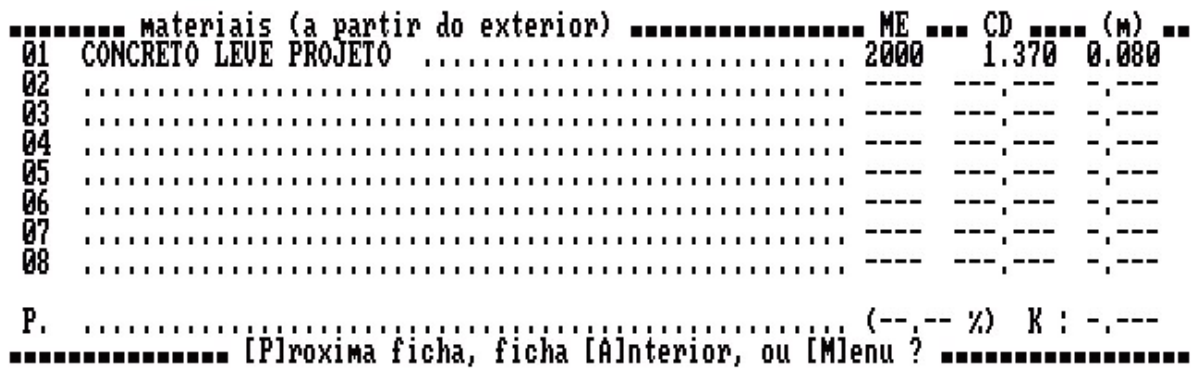

- PAREDES/PaINEIS an. tipo : PAINEL 10CM CONC 2000

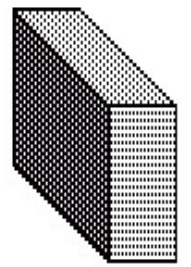

retardamento : $2.78 \mathrm{~h} \quad$ amortecimento : $52 \%$

\begin{tabular}{|c|c|c|}
\hline \multicolumn{2}{|c|}{ Coeficiente de Transmissao Termica, em $W / \mathrm{m}^{2} \mathrm{i} C$} \\
fluxo ascend, $\boldsymbol{\Delta}$ & fluxo horiz, & fluxo descend, $\boldsymbol{\nabla}$ \\
\hline,---- & 3.663 &,---- \\
\hline
\end{tabular}

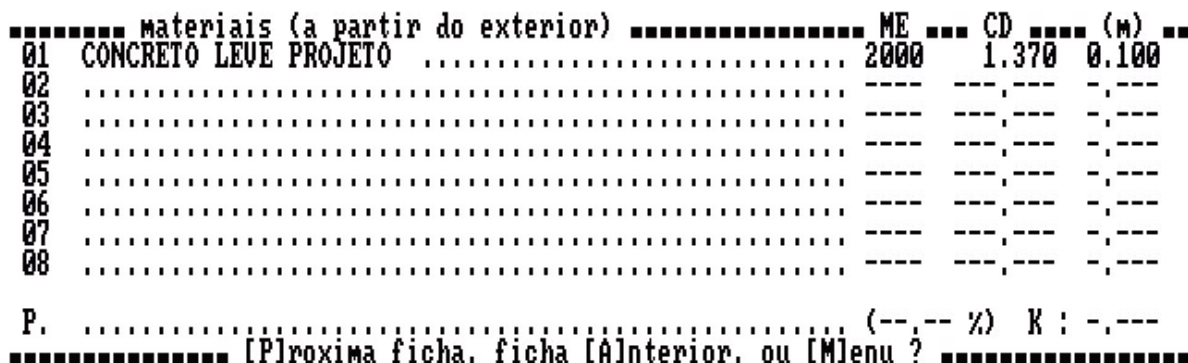

- PAREDES/PaineIS nn tipo： PaINEL 12CM CONC 2000

anan $n, 55 / 57$.

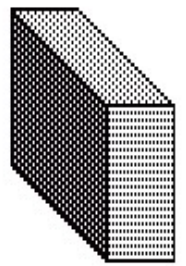

retardamento: $3.34 \mathrm{~h} \quad$ amortecimento : $58 \%$

\begin{tabular}{|c|c|c|}
\hline \multicolumn{2}{|c|}{ Coeficiente de Transmissao Termica, en $\mathrm{W} / \mathrm{m}^{2}{ }^{\circ} \mathrm{C}$} \\
fluxo ascend. $\Delta$ & fluxo horiz, $\longleftrightarrow$ & fluxo descend, $\mathbf{\nabla}$ \\
\hline,---- & 3.477 &,---- \\
\hline
\end{tabular}

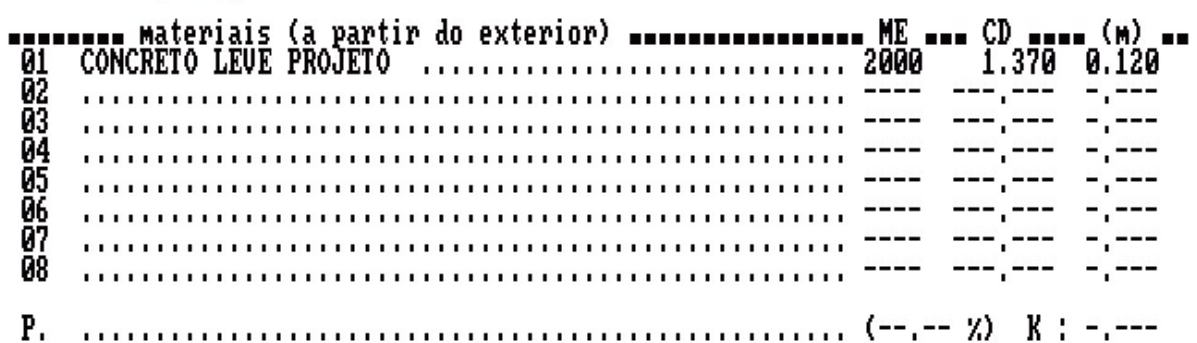

P. ……...

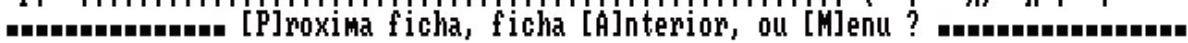




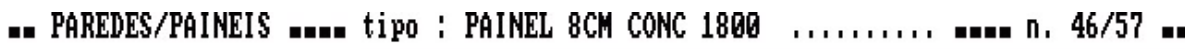

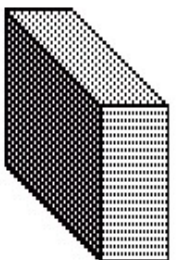
retardamento: $2.31 \mathrm{~h} \quad$ amortecimento : $45 \%$

\begin{tabular}{|c|c|c|}
\hline \multicolumn{2}{|c|}{ Coeficiente de Transmissao Termica, em $\mathrm{W} / \mathrm{m}^{2}{ }^{\circ} \mathrm{C}$} \\
fluxo ascend, $\boldsymbol{\Delta}$ & fluxo horiz, & fluxo descend, $\mathbf{\nabla}$ \\
\hline,---- & 3.710 &,---- \\
\hline
\end{tabular}

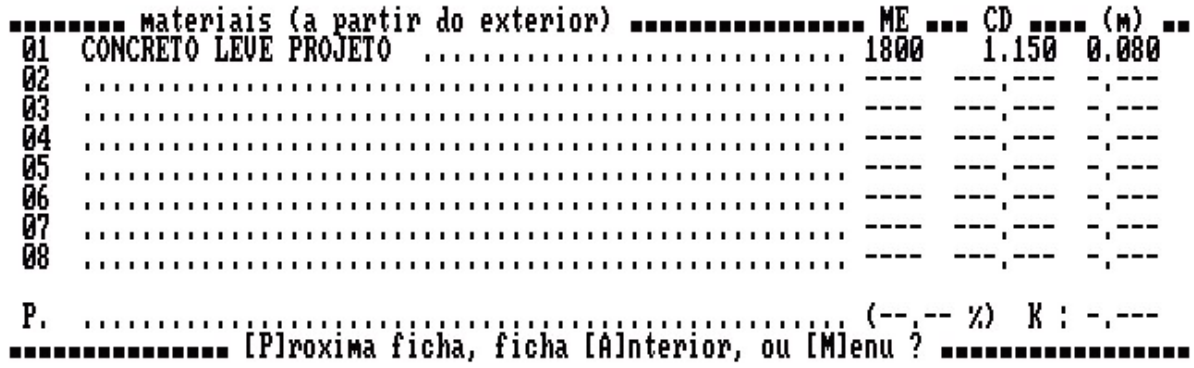

- PAREDES/PAINEIS m. tipo i PAINEL 10CM CONC 1800

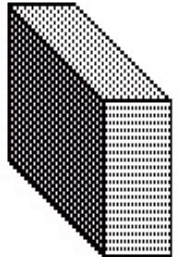

retardamento : $2.88 \mathrm{~h} \quad$ amortecimento : $53 \%$

\begin{tabular}{|c|c|c|}
\hline \multicolumn{2}{|c|}{ Coeficiente de Transmissao Termica, em $\mathrm{W} / \mathrm{m}^{2} \mathrm{iC}$} \\
fluxo ascend, $\boldsymbol{A}$ & fluxo horiz, & fluxo descend, $\boldsymbol{\nabla}$ \\
\hline,---- & 3.485 &,---- \\
\hline
\end{tabular}

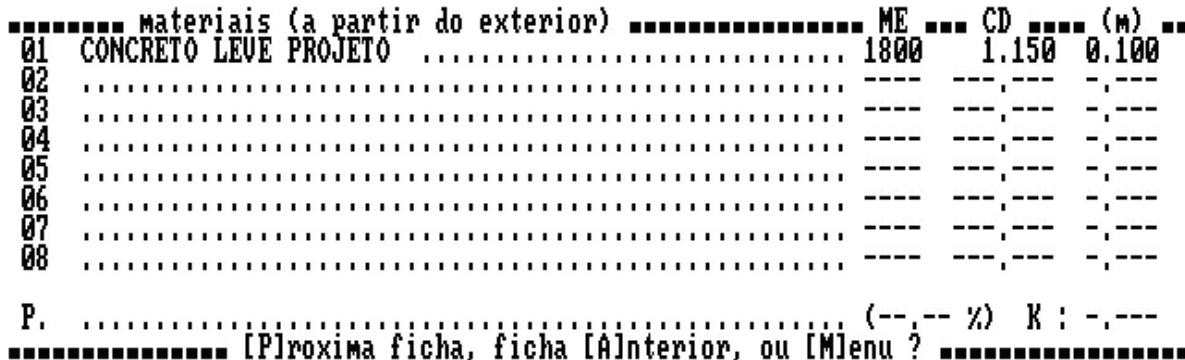

- PaREDES/PaineIS m tipo i PaINEL 12CM CONC 1800

anan $n, 56 / 57$ m

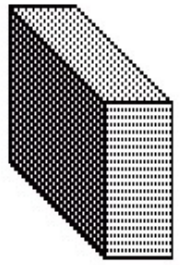

retardamento: $3.46 \mathrm{~h} \quad$ amortecimento : $60 \%$

\begin{tabular}{|c|c|c|}
\hline \multicolumn{2}{|c|}{ Coeficiente de Transmissao Termica, en $\mathrm{W} / \mathrm{m}^{2}{ }^{\circ} \mathrm{C}$} \\
fluxo ascend. $\Delta$ & fluxo horiz, $\longleftrightarrow$ & fluxo descend, $\nabla$ \\
\hline,---- & 3.286 &,---- \\
\hline
\end{tabular}

materiais (a partir do exterior) CONCRETO LEUE PROJETO

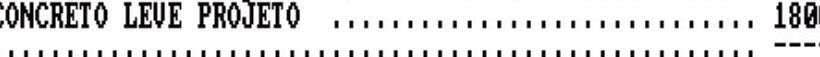

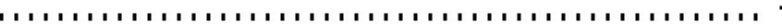

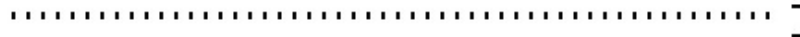

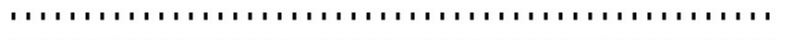

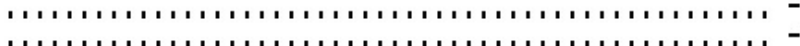

4י

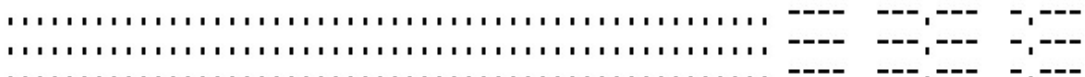

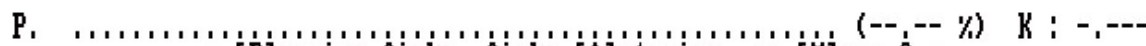

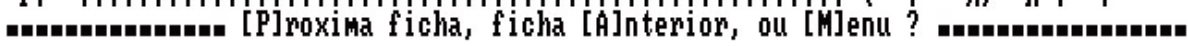


- PAREDES/PaINEIS - n... tipo i PaINEL 8CM CONC 1600

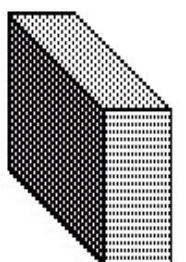

retardamento : $2.42 \mathrm{~h} \quad$ amortecimento : $47 \%$

\begin{tabular}{|c|c|c|}
\hline \multicolumn{2}{|c|}{ Coeficiente de Transmissao Termica, em $\mathrm{W} / \mathrm{m}^{2}, \mathrm{C}$} \\
fluxo ascend, $\boldsymbol{A}$ & fluxo horiz, $\longleftrightarrow$ fluxo descend, $\mathbf{\nabla}$ \\
\hline,---- & 3.496 &,---- \\
\hline
\end{tabular}

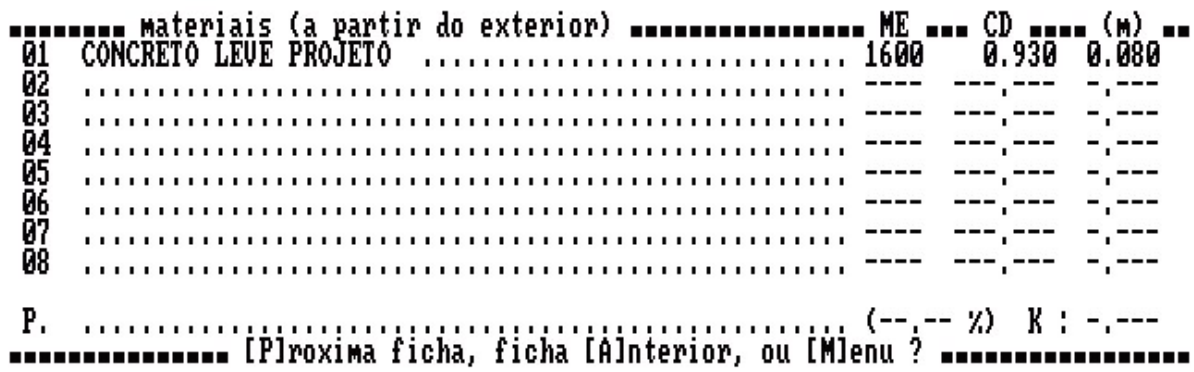

- PAREDES/PaINEIS an. tipo： PAINEL 10CM CONC 1600

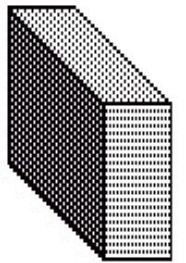

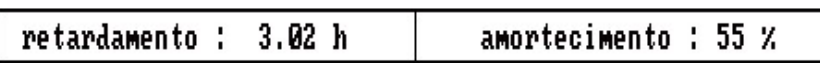

\begin{tabular}{|c|c|c|}
\hline \multicolumn{2}{|c|}{ Coeficiente de Transmissao Termica, em $\mathrm{W} / \mathrm{m}^{2} \mathrm{i} \mathrm{C}$} \\
fluxo ascend, $\boldsymbol{A}$ & fluxo horiz, & fluxo descend, $\mathbf{\nabla}$ \\
\hline,---- & 3.252 &,---- \\
\hline
\end{tabular}

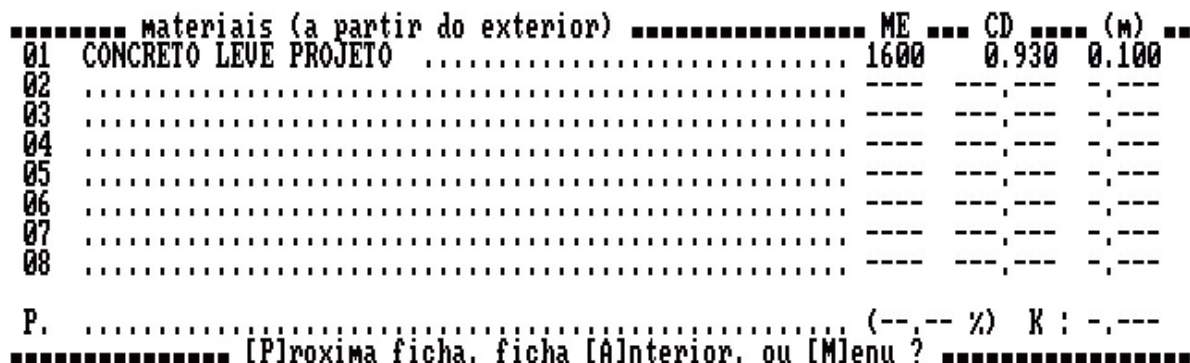

- PaREDES/PAINEIS n. tipo i PAINEL 12CM CONC 1600

-

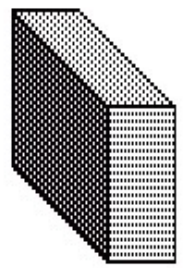

retardamento : $3.63 \mathrm{~h} \quad$ amortecimento : $61 \%$

\begin{tabular}{|c|c|c|}
\hline \multicolumn{2}{|c|}{ Coeficiente de Transmissao Termica, en $\mathrm{W} / \mathrm{m}^{2} \mathrm{i} \mathrm{C}$} \\
fluxo ascend, $\boldsymbol{\Delta}$ & fluxo horiz, & fluxo descend, $\mathbf{\nabla}$ \\
\hline,---- & 3.039 &,---- \\
\hline
\end{tabular}

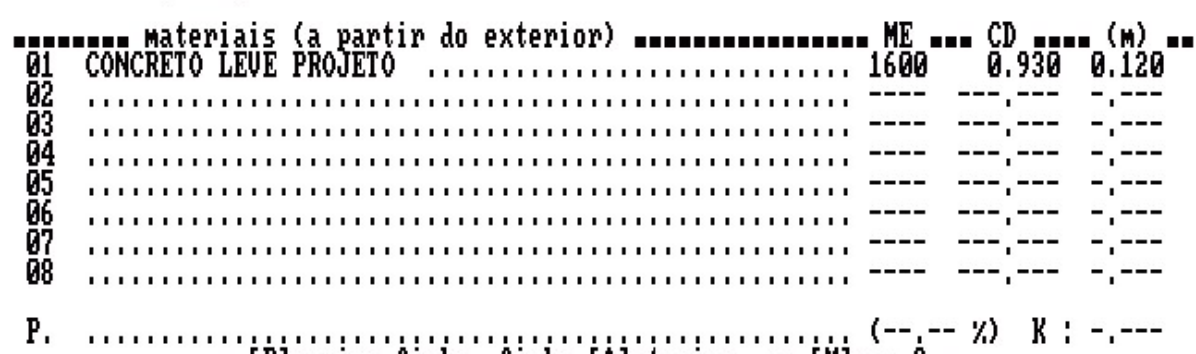

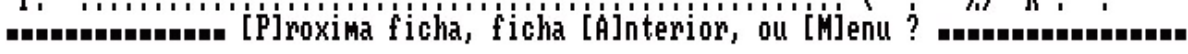




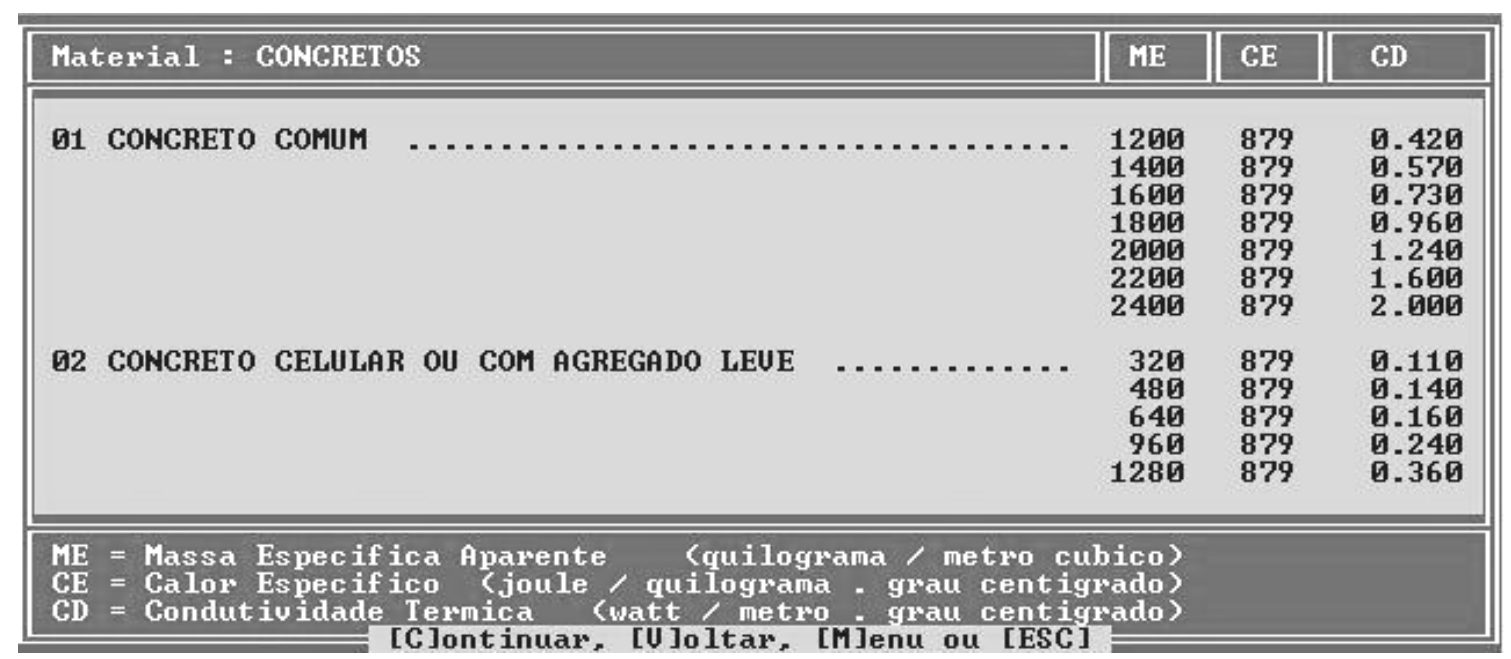




\subsection{Tipos de Cobertura}

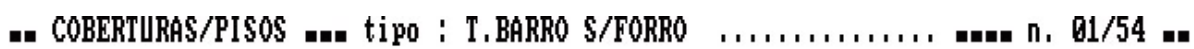

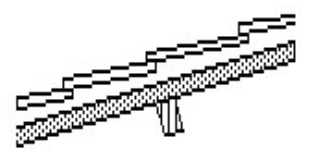

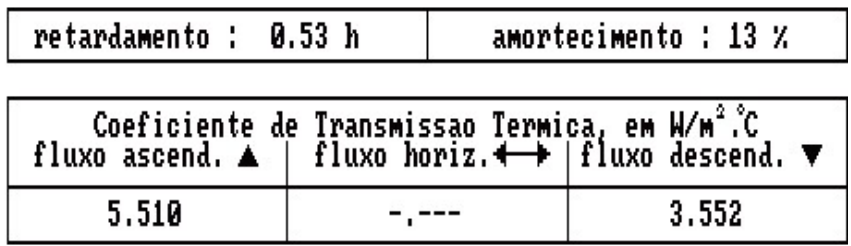

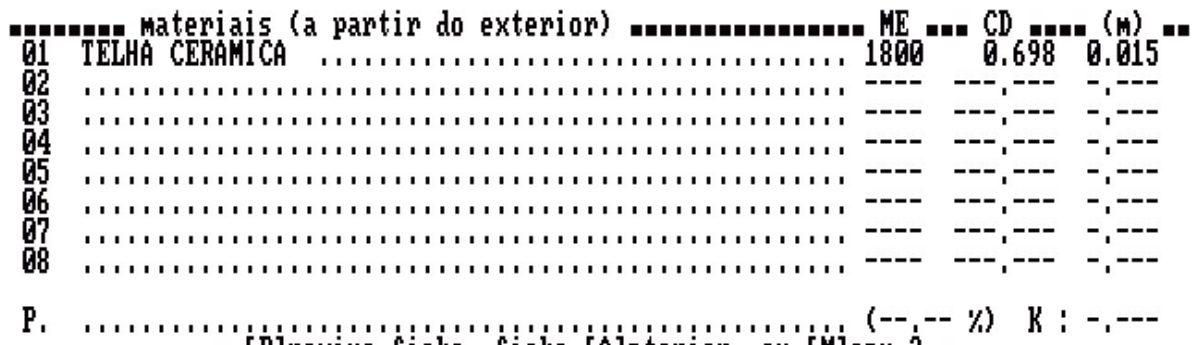

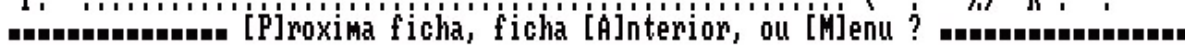

.. COBERTURAS/PISOS ... tipo : T,BARRO L.MISTA VEN

\begin{tabular}{|l|l|}
\hline retardamento : $2.25 \mathrm{~h}$ & amortecimento $: 44 \%$ \\
\hline
\end{tabular}

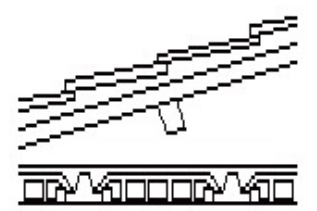

\begin{tabular}{|c|c|c|}
\hline \multicolumn{2}{|c|}{ Coeficiente de Transmissao Termica, em $W / \mathrm{m}^{2} \mathrm{i} C$} \\
fluxo ascend. $\boldsymbol{A}$ & fluxo horiz. & fluxo descend, $\mathbf{\nabla}$ \\
\hline 2.425 &,---- & 1.951 \\
\hline
\end{tabular}

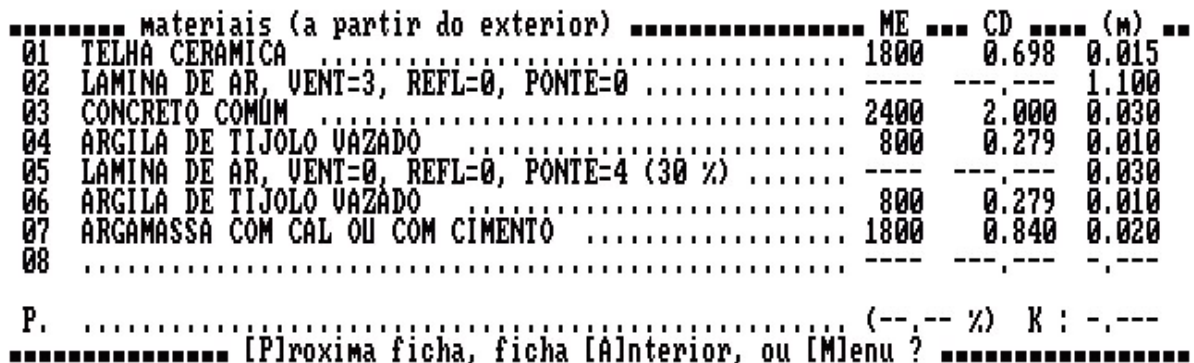

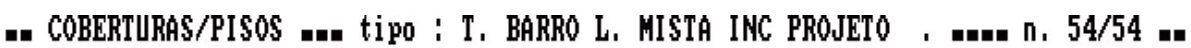

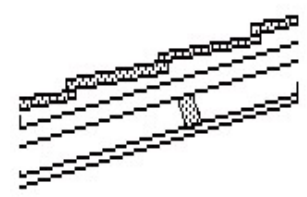

\begin{tabular}{|c|c|c|}
\hline \multicolumn{2}{|c|}{ retardamento : $4.71 \mathrm{~h}$} & amortecimento : $71 \%$ \\
\hline $\begin{array}{l}\text { Coeficiente de } \\
\text { fluxo ascend. } \boldsymbol{A}\end{array}$ & $\begin{array}{l}\text { Transmissão Termi } \\
\text { fluxo horiz. }\end{array}$ & 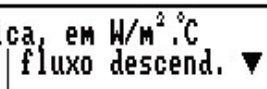 \\
\hline 1.894 &,---- & 1.593 \\
\hline
\end{tabular}

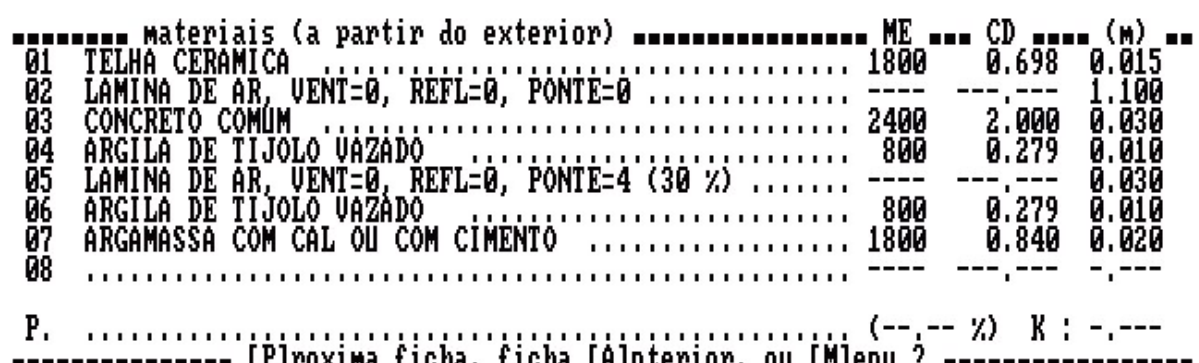

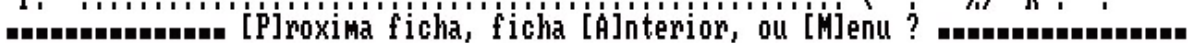


ANEXO 5. Avaliação do Teor Ótimo de Aditivo Superplastificante

O processo proposto por KANTRO (1980), também denominado de "mini-slump", é uma das formas de avaliar o desempenho do aditivo redutor de água. Esse processo avalia o efeito do aditivo sobre o cimento sem a interferência dos agregados. O método consiste na comparação da fluidez de pastas de cimento em ensaios de "mini-slump", de forma similar ao slump test, com as dimensões do cone reduzidas.
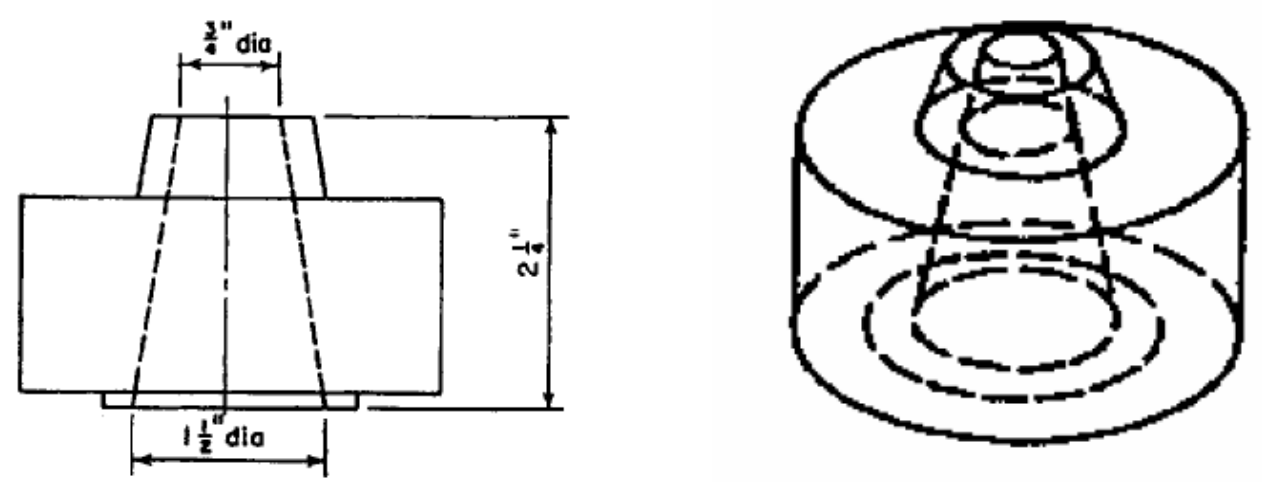

Seção transversal e vista geral do tronco de cone para ensaio de "mini-slump"

Fonte: KANTRO, 1980

O procedimento desse ensaio consiste em colocar o tronco de cone sobre uma placa de vidro plano liso, nivelado horizontalmente. Após seu preenchimento com a pasta de cimento e posterior arrasamento, o tronco-cônico é levantado, permitindo que a pasta se deforme desimpedida até seu equilíbrio em estado de repouso. A área que a projeção vertical do corpo-de-prova nesta condição ocupa sobre a placa é medida com planímetro ou outro procedimento equivalente. As áreas dos corpos-de-prova experimentais de pastas de cimento, medidas pela projeção após a retirada do molde, se estendem de $12,6 \mathrm{~cm}^{2}$ (área da base do molde) até, aproximadamente, $200 \mathrm{~cm}^{2}$ (BUCHER, 1988; KANTRO, 1980). Esse método utiliza a área do espalhamento correspondente à relação água/cimento de 0,36 como referência ou comparação do efeito reológico instantâneo ou deferido de uma pasta de cimento Portland. As demais pastas são preparadas com teores variados do aditivo analisado, mantendo-se fixa a relação água/cimento igual a 0,36, levando-se em conta a água presente no aditivo. $O$ desempenho do aditivo é avaliado em função da comparação da área de espalhamento das diferentes pastas

No estudo realizado por Ferrari (2006) foram utilizados os teores de 0,25, 0,5, 0,75, $1,00,1,25$ e 1,5\% de aditivo, em relação à massa de aglomerante, e os resultados são apresentados no gráfico a seguir. Tendo como referência os resultados apresentados foi adotado o teor de $0,75 \%$ de aditivo superplastificante para a dosagem de concretos leves utilizando os dois tipos de cimento Portland analisados. Nesse teor, os valores de 
espalhamento das pastas apresentam estabilização no valor máximo, indicando assim ser o valor mais adequado.

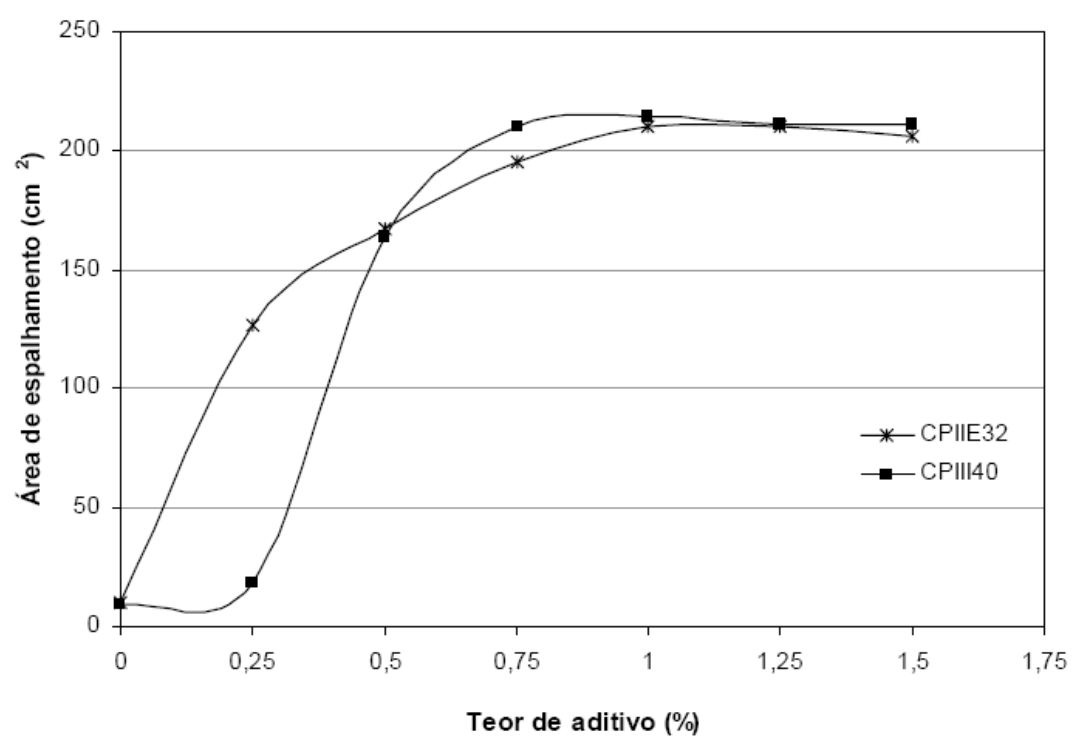

Ilustração do desempenho do aditivo superplastificante utilizando o método proposto por KANTRO (1980).

Fonte: FERRARI, 2006. 